MARIA THEREZA WAISBERG

\title{
O QUE EU ME TORNEI PARA MIM MESMO? \\ O HOMEM SEM QUALIDADES, E O CARÁTER PREDATÓRIO \\ DA MODERNIDADE TARDIA
}

Tese apresentada ao Instituto de

Psicologia da Universidade de São Paulo, como parte dos requisitos para obtenção do título de Doutor em Psicologia

Área de concentração: Psicologia Social

Orientadora: Profa. Dra. Eda Terezinha de Oliveira Tassara 
Ficha Catalográfica preparada pelo Serviço de Biblioteca e Documentação do Instituto de Psicologia da USP

\section{Waisberg, Maria Thereza}

W143o O que eu me tornei para mim mesmo? O homem sem 2008 qualidades, e o caráter predatório da modernidade tardia/ Maria Thereza Waisberg. - 2008.

$419 \mathrm{f}$.

Orientador: Eda Terezinha de Oliveira Tassara.

Tese (doutorado) - Universidade de São Paulo, Instituto de Psicologia.

1. Psicologia - Teses 2. Identidade - Teses 3. Modernidade Teses. 4. Guerra - Teses 5. Estética-Teses 6. Ética-Teses I. Tassara, Eda Terezinha de Oliveira II. Universidade de São Paulo . Instituto de Psicologia III.Título 
MARIA THEREZA WAISBERG

\section{O QUE EU ME TORNEI PARA MIM MESMO? \\ O HOMEM SEM QUALIDADES, E O CARÁTER PREDATÓRIO \\ DA MODERNIDADE TARDIA}

BANCA EXAMINADORA

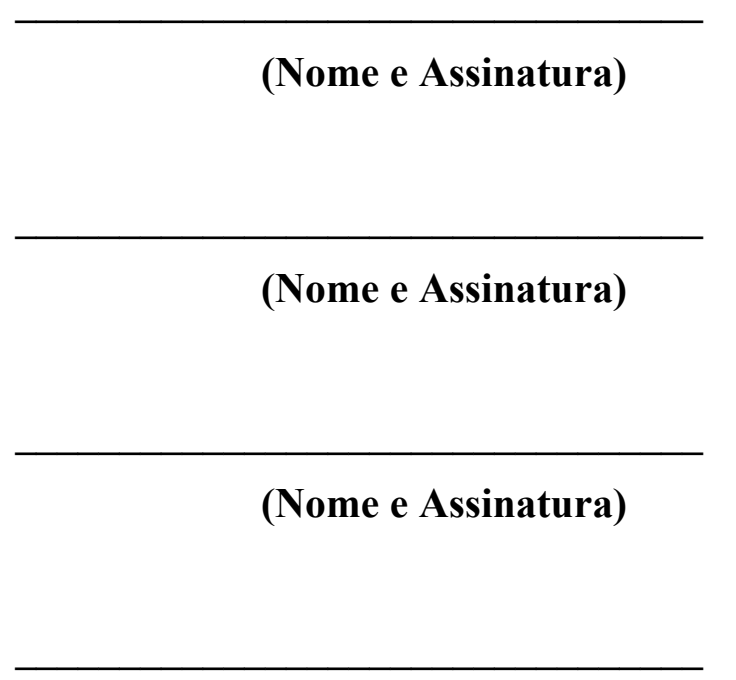

(Nome e Assinatura)

(Nome e Assinatura)

Tese defendida e aprovada em: 
A meus pais, Esther e Onaldo.

Mais do que agradecer,

esta tese lhes é dedicada.

Aos seis milhões de antepassados e a todas as incontáveis vítimas que pereceram no Holocausto nazista. 


\section{AGRADECIMENTOS}

Pela confiança, sabedoria, amizade, generosidade e infinita paciência, sou profundamente grata à Professora Dra. Eda Terezinha de Oliveira Tassara, minha orientadora.

Pela acolhida, incentivo, conselhos e palavras de confiança em momentos difíceis, sou grata aos professores doutores Rodrigo Antônio de Paiva Duarte, Jéferson Machado Pinto, Eunice Galery, Elaine Pedreira Rabinovich, Ecléa Bosi, Lúcio Kowarick, Lyslei do Nascimento, Luiz Nazário, Ruth Silviano Brandão e Maria Imaculada Kangussu.

Pelo generoso oferecimento do arquivo para seu livro Heranças e lembranças; pelo exemplo de força e perseverança inquebrantável diante de uma pesquisa, que muito inspirou esta tese, sou grata a Susane Worcman.

Pela presteza e dedicação, minuciosa leitura, comentários e revisão dos originais, agradeço a Rachel Kopit Cunha, querida amiga dos tempos de adolescência.

Por terem tornado este trabalho não apenas possível, mas também prazeroso, agradeço às amigas Luciana Barongeno, Solange Ribeiro de Oliveira, Laura Schreiber, Vera Zavarise, Liane Terezinha Shuh Pauli, Nagirley Kessin. A Ana Leonel Queiroz, Argentina Alves da Silva e Lílian Leles, pela colaboração com anotações, tradução e organização de arquivos. Agradeço a meus filhos Paulo, Michael e Marcelo. Aos momentos inesquecíveis de alegria, e como prova inequívoca de amor, agradeço aos meus queridos Eric, Miriam, Lara, David e Sophia.

Ao Benami, meu dedicado esposo, a minha gratidão pela paciência com as incontáveis horas de retiro nas madrugadas, voltadas à consecução desta tese; por sua inestimável generosidade e apoio financeiro imprescindível, sem os quais esta tese não seria possível.

Aos estimados amigos do LAPSI, agradeço os momentos fecundos de convivência.

Agradeço a Tarcísia Lobo e a Baruch Ashem o minucioso trabalho de tradução dos textos em alemão e italiano.

Agradeço a Nalva, Maria Cecília, Maria Clarice, Vanessa, Vilma Carvalho de Souza, bibliotecária-chefe da UFMG, e demais funcionários da USP e UFMG que colaboraram em diversos momentos.

Esta tese é o resultado do esforço de muitos que me ajudaram. Meu agradecimento a todos os que me acompanharam nesta jornada, ajudando direta e indiretamente, é infinito. A todos os amigos de quem porventura possa ter omitido os nomes, peço desculpas e deixo registrada a minha gratidão. 
vencer o gelo que parece ter pairado sobre o mundo e sobre ele.

Vencer a dureza do próprio coração, sair da caverna de aridez em que se enterrou,

purificar-se e recomeçar a viver.

Yehoshua, A mulher de Jerusalém

Quem sou? O que sou?

E dirigi-me a mim mesmo e disse-me tu, quem és tu? E respondi: um homem.

(...) Qual é a minha natureza?

Pois no grande mistério, há algo do homem que o próprio espírito do homem que nele está não sabe.

Agostinho, Confissões 


\section{RESUMO}

Esta tese tem como objetivo estudar a noção de identidade narrativa em Robert Musil, concentrada, sobretudo, em $O$ homem sem qualidades. Para alcançá-lo, parte-se do exame dos escritos musilianos, publicados como obras completas, a fim de reconhecer, na dissolução da identidade do personagem, a contribuição emblemática ao problema da identidade mutante do homem, desde o advento da modernidade. Compreendido o lugar reservado da identidade ética figurada pela manutenção de si, compreende-se como a falta de qualidades retira-lhe todo o ponto de apoio. O drama da dissolução da identidade do personagem de Musil deixa aberta a questão: pode o não-sujeito permanecer uma figura do sujeito, mesmo que fosse sobre o seu modo negativo? A ficção literária de Musil opera no duplo sentido de definir a condição de ipseidade e voltar à vida, quando se procura uma definição para identidade. Dessa análise se depreende que o si representado pela narrativa é confrontado com a hipótese de seu próprio nada. Certamente esse nada não é o nada do qual não se tem nada a dizer. Essa hipótese dá, ao contrário, muito o que dizer, como disso é testemunha a imensidade da obra analisada. Dessa análise reconhecem-se como não faltam à hipótese verificações existenciais sobre as transformações da identidade pessoal à prova desse nada de identidade que aparece nos momentos de desenraizamento como extremo despojamento dos valores da cultura, deixando a resposta negativa à pergunta quem sou eu? exposta não mais à nulidade da própria condição do homem verdadeiro, mas à nudez da própria questão. A análise do caso de um homem sem qualidades expõe que a identidade pessoal não é o que importa; levando ao apagamento não apenas a identidade do mesmo, mas a identidade de si. Ao revelar a negação do si, o homem sem qualidades expõe a passagem do "Quem" sou eu? ao "que" sou eu? como perda de pertencimento aos valores da cultura; tal perda é o caráter, isto é, o conjunto das disposições adquiridas e das identificações sedimentadas pela cultura. O personagem expõe a condição de impossibilidade atual de reconhecer a alguém sem uma maneira durável de pensar, de sentir, de agir, que, outrossim, seria impensável. Se há identidade no fluxo mutante da sociedade atual, esta só é praticável no fracasso de uma sucessão indefinida de tentativas de identificação as quais constituem a matéria de narrativas com valor interpretativo a respeito da contração do si. Manter-se no plano ético um si que, no 
plano narrativo, pode apagar-se é o desafio e um limite para encontrar, no indivíduo, a distância entre identidade narrativa e identidade moral em benefício da dialética viva entre uma e outra. Eis aqui como se vê tal oposição transformar-se em uma tensão frutuosa.

Palavras-chave: Identidade. Modernidade. Guerra. Estética. Ética. Qualidades. 


\begin{abstract}
This thesis is meant as a study of the notion of narrative identity in Robert Musil, especially as concentrated in The man without qualities ( $O$ homem sem qualidades). With this in mind, the starting point are Musil's writings, published as his collected works. The aim is to recognize in the dissolution of the character's identity the emblematic contribution to the question of man's changing identity, since the dawn of modernity. If we understand the place of represented ethical identity as the preservation of the self, we realize that the absence of qualities deprives it of all support. The drama of the dissolution of identity in Musil's character leaves open the question: can the nonsubject remain a figure of the subject, even though in a kind of negative way? As one searches for a definition of identity, Musil's negative fiction operates in a twofold way, both as a definition of the condition of "ipsidity" (ipsidité) and as a return to life. From this analysis one gathers that the self represented in the narrative is confronted with its own nothingness. Of course this nothingness is not the nothingness about which there is nothing to say. On the contrary, there is a great deal to be said about that hypothesis, as witnessed by the immensity of the work here analyzed. From this analysis one acknowledges that the hypothesis does not lack existential evidence about the transformations of a personal identity which is proof against the nothingness which, in moments of uprooting, shows up as an extreme emptying of cultural values, offering a negative answer to the question "What am I?" which is no longer exposed to the nullity of the real man's own condition but to the nakedness of the question itself. The case analysis of a man without qualities leads to the conclusion that personal identity is not what matters; it leads to the erasure not only of the identity of the same, but of the identity of the self. As he exposes the negation of himself, the man without qualities discloses the passage from "Who" am I? to "what" am I? as the loss of his belonging to the values of culture. Such a loss is what character consists in, that is, the blend of acquired dispositions and of identifications consolidated by culture. The character lays bare the present impossibility of recognizing any one without a durable way of thinking, feeling, behaving, which, otherwise, would prove unthinkable. If in the changing flux of present-day society there is such a thing as identity, it is only feasible in the failure of an indefinite succession of attempts at identification which make up the material of
\end{abstract}


narratives with an interpretive value about the contraction of the self. To keep on an ethical plane a self which, in the narrative plane, can erase itself, is the challenge and a limit to find, in an individual, the distance between narrative identity and moral narrative for the sake of a living dialectics between the two. Hence one can see how this opposition can be metamorphosed into a fruitful tension.

Key-words: Identity. Modernity. War. Aesthetics. Ethics. Qualities. 


\section{SUMÁRIO}

RESUMO

ABSTRACT

INTRODUÇÃO

NOTA PRÉVIA

PARTE I

Primeiro Capítulo - Identidades em crise ética e preparação do inimigo

Crise ética na modernidade tardia

A preparação do inimigo oculto

Segundo Capítulo - O que é a identidade sem qualidades

Distinções terminológicas

Este é o verdadeiro eu?

A identidade como construção

O idêntico não se define pela negação da diferença, assim como a diferença não se define pela negação do idêntico

A noção de identidade carece de rigor etimológico

A qualidade é condição necessária da identidade

Como o sujeito humano se constitui

A identidade do indivíduo se perde na massa

A identidade em colapso na sociedade unidimensional

A identidade - algo novo na sociedade pós-industrial

A identidade pessoal, se existe, é uma construção narrativa $\quad 66$

$\begin{array}{ll}\text { O caráter é o si sob a aparência da mesmidade } & 74\end{array}$

O homem sem qualidades é um laboratório para experiências de pensamento 84

Terceiro Capítulo - O homem, a obra, o tempo-lugar, Zeitgeist etc.: 89

Musil - matemático, engenheiro e psicólogo se transforma em escritor 89

$\begin{array}{ll}\text { O declínio da alta cultura } & 94\end{array}$

$\begin{array}{lr}\text { O jovem Musil e o círculo da vida } & 100\end{array}$

Como pode alguém inventar a pessoa interior? 102

$\begin{array}{lr}\text { Ficções musilianas: o indivíduo libertado do feitiço das imagens } & 108\end{array}$

$\begin{array}{ll}\text { A sociedade assombrada por suas próprias contradições } & 113\end{array}$ 
A ética que emerge do mais fundo dos abismos

O simulacro da totalidade e o desafio da linguagem em desconstrução

A realidade desestruturada da modernidade

A tendência disciplinar do século XX

A face dupla da experiência

Uma ponte extraordinária chamada realidade

O tempo congelado na linguagem

O falso casulo da subjetividade burguesa

O mundo do sentimento e do intelecto é incomensurável

A realidade escapa no indizível

A fé e a experiência da desrazão

\section{PARTE II}

Quarto Capítulo - Musil diante da "genialidade" de um cidadão kakaniano

O Homem Matemático e as vantagens da precisão científica

O empreendimento imaginativo da matemática não coincide com as especulações

sonhadoras do filósofo

O fascínio de Musil com estados místicos inefáveis

A cultura de nervos em decadência

O verdadeiro tecido da experiência ética

A profecia sobre o fim utópico das diferenças 165

A razão é meramente uma convenção histórica 166

O mal e o bem não são ficções simplistas 171

$\begin{array}{ll}\text { Criminosos no poder } & 173\end{array}$

“O objeto da psicologia é o caso geral. O objeto da literatura é o caso pessoal” 175

[EXCURSO] Um paralelo: "Nossa existência nada mais é do que um pálido fantasma"

i Das ilusões do progresso tecnológico a qualquer custo

ii O novo ethos

iii O indivíduo, na sua singularidade, se julga mônada independente e auto-suficiente

iv Uma ética para os bárbaros, outra para os não-bárbaros

$\mathrm{V}$ A cultura e a sociedade sob a vigência de duas ordens distintas

vi A impossibilidade da revelação mecânica das verdades

vii Quaestio mihi factus sum, O que me tornei para mim mesmo?

viii $\mathrm{O}$ homem não é simplesmente uma peça na Natureza

\section{PARTE III}

Quinto Capítulo - O pensamento unidimensional na base da modernidade 
A linguagem coisificada do homem sem qualidades

Psicologia e política: o caráter mágico e hipnótico da linguagem

O homem coisificado é o sujeito, enfim, sem qualidades

\section{PARTE IV}

Sétimo Capítulo - Uma obra inacabada para um homem sem qualidades

$\begin{array}{ll}\text { Paternidade da obra } & 273\end{array}$

Metamorfoses do sujeito no campo paralelo da guerra 276

A obra no espelho da guerra 285

Um homem sem qualidades tem uma genealogia remota 296

O legado da vida diante do caráter inexorável da morte $\quad 300$

Inacabamento e imortalidade da obra: a morte espreita o criador $\quad 310$

$\begin{array}{ll}\text { Dois caminhos para experimentar a realidade } & 319\end{array}$

Musil como persona no exílio do ideal iluminista 322

Honestidade, veracidade e recusa a fazer concessões: qualidades de um homem 325

$\begin{array}{ll}\text { Dilemas do engajamento intelectual } & 328\end{array}$

\section{CONSIDERAÇÕES FINAIS - CONCLUSÃO}

A ética indutiva do homem sem qualidades $\quad 360$

Ética e subjetivação em Musil 369

REFERÊNCIAS BIBLIOGRÁFICAS

$\begin{array}{ll}\text { BIBLIOGRAFIA } & 381\end{array}$ 


\section{INTRODUÇÃO}

A presente tese é um estudo teórico comparativo de certos aspectos do processo das transições da identidade contemporânea, principalmente aqueles voltados para as identidades híbridas. ${ }^{1}$ Procura-se acompanhar o desenvolvimento do pensamento de Musil sobre a ética, voltada para aqueles aspectos que se endereçam à compreensão psicológica das mutações identitárias na sociedade ocidental. Uma vez que tais mutações ocorrem no período nomeado "modernidade", os aspectos selecionados na obra desse autor, bem como na obra de Marcuse, servem como eixo ao desenvolvimento do raciocínio desta tese.

A obra do filósofo alemão Herbert Marcuse, com ênfase voltada para a sociedade industrial avançada, não deve ser o único, mas pode ser um bom e original caminho para o exercício de interpretação do romance de Robert Musil, traduzido no Brasil como $O$ homem sem qualidades.

$\mathrm{O}$ que se quer destacar, em um raciocínio paralelo entre os autores Musil e Marcuse, é a intensidade em que estes revelam que o social existe aqui e agora e não garante rendimentos pré-fixados na nova lógica das sociedades industrializadas. Nestas, o efêmero passa a ser a medida de todas as coisas, a fruição é a sua finalidade. Se o final da II Grande Guerra anunciava o novo tempo de liberdade, e Marcuse suspeita que ainda não, e se a identidade é um processo de construção ao longo de várias etapas, durante as quais se redefine a distinção entre o eu e o não-eu, seria possível pensar em menos Estado e mais sociedade, menos identidade e mais identificação, menos coletivo, mais individualidades responsáveis.

Porém, sob a influência da chamada Escola de Frankfurt, a teoria crítica dominante durante as quatro últimas décadas já não responderia à complexidade de todas as transições identitárias em fluxo nas sociedades abertas, pluralistas e democráticas. Se, por um lado, a unidimensionalidade entrou em colapso frente à idéia de adesão cega e à negação de fatos em nome de interesses ideológicos e difusão de notícias, como se fossem

\footnotetext{
${ }^{1}$ Os termos "identidades híbridas" têm a conotação extraída de Bruno Latour quando ele se indaga: "o que é um moderno?”. LATOUR, 2005, p.13.
} 
fatos para a sociedade, por outro lado, ela se revela perseverante, adotando novos nomes e criando novas faces para o fascismo. Se a sociedade requer uma carta de transparência, há, em contrapartida, aqueles que permanecem fiéis aos modelos do passado ou sedentos de autoridade e de referência segura, manifestando-se por toda a parte em nome da recuperação dos fundamentos. Se, por um lado, a idéia de autoridade se perde numa ética não-dogmática, mais o desejo de autoridade se renova em sectarismos e movimentos radicais.

Eminentemente voltada para a psicologia social, esta tese vai argumentar em favor da prioridade da interpretação ética do texto literário de Musil, com ênfase em seu romance, $O$ homem sem qualidades. Ela concebe a perspectiva ética inserida em seu contexto político não como método suplementar, não como auxiliar opcional de outros métodos interpretativos - a exemplo do psicanalítico e estilístico -, mas como horizonte da leitura e da interpretação cabível à dimensão e importância histórica concedida ao texto, reconhecido entre as três mais importantes obras de literatura do século XX, ao lado de James Joyce e Marcel Proust.

Tal postura metodológica pode parecer extremada frente à alegação de que o texto de Musil, além de se constituir em inequívoca contribuição à compreensão contemporânea da psicologia, tem ressonância social e histórica tanto quanto tem ressonância ética e política. A conhecida afirmativa de Croce de que "toda história é história contemporânea" não significa que toda a história seja a nossa história contemporânea. Os problemas começam a surgir no horizonte da pesquisa quando a nossa ruptura epistemológica desloca-se no tempo, segundo as interpretações atuais, de modo que Musil pode significar uma representação apagada diante da preocupação excessiva de se destacar tudo o que é textual e mesmo atual em sua obra.

Frente à preocupação de que nem todo o leitor possa dispor de paciência suficiente para dar conta da extensa leitura requerida à volumosa obra $O$ homem sem qualidades, a tentativa de descrever os capítulos de sua grande obra deve ser separada da ambição de reescrevê-la, e está longe de tratá-la como texto puro e écriture. Deve-se ressaltar que a descrição dos capítulos serve, antes, para empreender o trabalho hermenêutico do texto musiliano, cuidando de não substituir tal descrição nem pela biografia do autor nem pelas 
contradições externas a ele, como a política, a sociedade, a religião ou a cultura que o circundavam. O sentido de $O$ homem sem qualidades está no seu texto, e não na vida do autor ou no contexto histórico-cultural, ainda que tais aspectos não possam ser imediatamente dele desprendidos. Não há como recuperar a intenção original do autor supostamente escondida atrás da obra, tal como acreditava ser possível a hermenêutica romântica. É a obra que revela a intenção do autor e não o contrário. Da mesma forma, o historicismo se constitui em impeditivo para ver o universo que a obra revela, tratando-o como puro efeito de uma época.

Preocupando-se em não esgotar os incontáveis aspectos históricos, o empreendimento da tese revela que tal procedimento acaba por desviar a atenção da potencialidade expressiva do objeto investigado e dos elementos psicológicos que efetivamente o constituem. Durante a elaboração da pesquisa empreendida, não interessa substituir o texto pelo contexto e fazer de Musil, bem como de sua obra em foco, uma ilustração passiva do período de transformações em que se dá a modernidade até o momento em que esta passa a ser tratada em um momento "pós", e é inserida no contexto da modernidade nova ou tardia. Atentando-se para tais aspectos, pode-se assim encontrar as verdades ocultas por uma interpretação que parece desatenta às veredas do texto. Isso não quer dizer que o contexto em que a obra está sendo construída deva ser esquecido. Ao contrário, interessa ver o mundo das guerras que se descortina no século XXI por intermédio do legado escrito deixado por Musil, resgatando-o na concretude e na dimensão que o texto permite, e não por idéias apriorísticas, abstratas e gerais que, vistas de perto, mostram-se falazes e irrelevantes.

Por outro lado, é preciso evitar a tentação positivista de considerar o texto fato absoluto e insensível à interpretação do leitor. A "verdade" do texto só se desvela para quem o interpreta e o focaliza segundo uma intenção que não é nem a do público contemporâneo à obra nem a homologada pela tradição de seus críticos. É na fusão e na abertura do horizonte do texto com a interpretação que o leitor imprime à obra que esta adquire um sentido novo e permanece, refazendo-se ao longo do tempo. Como quis o próprio autor, $O$ homem sem qualidades nunca estará acabado. Sua história começa quando, terminada a tarefa do autor, a obra se põe diante dos olhos do fruidor. Sem essa interação, não há obra, tanto quanto não haveria sentido em circunscrever o seu campo de 
sentidos, de outra forma, inesgotável, em uma tese. Ela se mantém aberta ao presente e ao futuro, encarregados de se fundirem com ela, converterem-na de "coisa" em objeto fecundado por um sujeito que se quer com qualidades.

É nessa alquimia que a tese busca liberar significados nela abrigados; e que estes possam ser úteis a um mundo em contínuo fluxo de mudanças, distinto e semelhante àquele em que a obra foi produzida. Inversamente, cumpre evitar a tentação subjetivista que coloca o leitor no lugar do texto e faz deste mero "pré-texto" sobre o qual aquele impinge suas próprias idéias. O sentido do texto musiliano, especialmente $O$ homem sem qualidades, não se encontra nem dentro nem fora do texto, mas no círculo hermenêutico que, em torno dele e do intérprete, configura um "mundo". Este mundo é a contemporaneidade vista pelo texto constantemente aberto de Musil, sempre passível de ser reconstruído pelo leitor e adquirir novas formas.

A tese é assim é o efeito de uma falta que, a um só tempo, revelou-se útil e capaz de compreender e enfrentar o presente e conferir às frases musilianas frescor na atualidade. Para melhor compreender o presente, a leitura de Musil revela o que se desdobraria no horizonte futuro como impossibilidade humana de compreender as responsabilidades dos atores, que, sem incoporar as lições do passado, estão limitados, quando muito, à consciência dos efeitos de suas ações. A leitura de Musil, no presente, não se limita ao que se passou, no período em que o autor escreveu essa obra. As qualidades que dão vida à obra e a imortalizam esbarram na pretensão de uma leitura imanente.

O interesse pela pesquisa desta temática já se encontrava nas referências principais da dissertação de mestrado desta autora, que indagava se toda a construção simbólica - a de um sujeito com seus sonhos ou a de uma ciência em relação a seu objeto - é feita a partir do real, a partir da alteridade absoluta, cabendo tanto ao sujeito quanto ao pesquisador verificar de que modo esse estranho agente produz efeitos no discurso. Tal indagação foi respondida até os limites apontados na dissertação defendida na Universidade Federal de Minas Gerais, posteriormente, publicada em livro. ${ }^{2}$ Ela também

\footnotetext{
${ }^{2}$ WAISBERG, 2006.
} 
se revelou fecunda a partir do texto apresentado no Congresso Internacional Herbert Marcuse: Dimensão Estética, homenagem aos 50 anos de Eros e Civilização, e posteriormente publicado. ${ }^{3}$

Desta vez, o raciocínio a ser desenvolvido nesta tese segue a linha provocadora de Marcuse quando esse pensador se depara com duas proposições sobre a idéia de razão, que guiam a tradição lógica do pensamento ocidental. Para Marcuse é tão absurdo afirmar que “aquilo que é não pode ser verdadeiro", quanto dizer que "o real é racional” (MARCUSE, 1967, p. 125). Nesse momento de sua obra, a aposta é compreender, às últimas conseqüências, as componentes da equação razão + verdade + realidade de maneira a reunir o mundo subjetivo e o objetivo em uma unidade antagônica e encontrar as condições nas quais os homens e as coisas se tornam o que realmente são. Sua crítica ao racionalismo exacerbado revela a tentativa de demonstrar que a verdade da teoria e da prática não constituem uma condição subjetiva, mas objetiva. Esta era a preocupação original do pensamento ocidental e a origem de sua lógica. Lógica, não no sentido de uma disciplina especial da filosofia, mas como o modo de pensar apropriado para compreender o real como racional.

A tese demonstrada por Marcuse, e que interessa ao argumento que se pretende desenvolver, é que o universo totalitário da racionalidade tecnológica é a mais recente transmutação da idéia de razão. Desde então, se há lógica, ela se tornou objeto de dominação. Sua análise contribui, de forma substantiva, para a compreensão crítica do processo de desdobramento da razão teórica e prática em uma só. Tal lógica justifica o universo operacional fechado da civilização industrial tardia, nomeado unidimensional, com o seu ideal de harmonia entre liberdade e opressão, produtividade e destruição, crescimento e regressão, predeterminados na idéia de razão, como projeto histórico específico voltado para o progresso material. A ênfase na escolha desse autor revela que há um choque entre conceitos básicos sobre homem e natureza, como se houvesse um continuum entre diferentes modos de pensar. Contudo, tais conceitos pertencem a maneiras diferentes de apreender, organizar e modificar a sociedade e a natureza, e de tal

\footnotetext{
${ }^{3}$ DUARTE, R. (Org.) et al., 2006.
} 
maneira que as tendências estabilizadoras de tal conflito conduzam à vitória da realização unidimensional sobre toda a contradição.

É nesse ponto de tangência possível que esta tese encontra gancho para o contraste entre o homem unidimensional - tal como Marcuse o situa na lógica do operacionalismo científico tardio - e o homem sem qualidades, tal como Musil o descreve em sua ficção literária. Se há identidade entre o homem undimensional e o personagem de ficção que encarna a própria contradição inerente ao objeto do pensamento, quando esse passa ao estatuto de realidade, ultrapassando a imaginação literária, esta contradição se dá à mesma medida que Musil e Marcuse advogam que a razão é ainda anti-razão e o irracional é ainda racional.

Tanto no desenvolvimento do pensamento filosófico marcuseano quanto na estrutura do romance musiliano, a realidade estabelecida pela lógica do poder milita contra a lógica das contradições, favorecendo modos de pensamento que conservam as formas de vida estabelecidas e modos de comportamento que os reproduzem e aprimoram. A realidade em ambos, Marcuse e Musil, tem a sua lógica e verdade; o que os aproxima é o esforço para compreendê-la como tal. Ambos os autores se preocupam com as maneiras como o indivíduo escolhe transcender ou se submeter à realidade, da maneira como esta lhe é imposta e como ele a compreende ao se submeter ou se libertar dessa realidade. Ambos pressupõem que há uma lógica diferente, uma verdade contraditória que está tanto no indivíduo quanto na sociedade que, psicologicamente, determina suas ações em um plano não isento das forças históricas e políticas que atuam sobre ele.

A linha filosófica desenvolvida pelo raciocínio de Marcuse encontra sentido e eco na ficção literária de Musil - o engenheiro, matemático e psicólogo experimental. Enfatiza-se, nesta tese, a observação de Marcuse quando ele advoga que a psicologia do indivíduo é a psicologia social. O estatuto de realidade na sociedade tecnológica avançada situa o homem sem qualidades em modos de pensar voltados para mundos "possíveis". Estes são não operacionais em sua própria estrutura; sua condição de virtualidade soa tão estranha ao operacionalismo científico quanto ao senso comum. Por um lado, a concretude histórica de mundos virtuais advoga paradoxalmente contra a quantificação e a matematização, isto é: em sua operacionalização, voltada para o sujeito que se vê na 
realidade como usuário desta. Por outro lado, quando sobre tal realidade incidem a razão teórica e a crítica, a realidade é apenas um "realismo" contra o positivismo e o empirismo. Tais modos de pensar, ainda que pareçam uma relíquia do passado, como toda a filosofia não científica e não empírica (Marcuse, 1967, p. 141), justificam o exame, em tese, diante da teoria e da prática da psicologia social mais eficaz.

A tese é eminentemente teórica, com ênfase voltada para os escritos de Musil naqueles aspectos que se desenrolam em torno da questão das identidades no transcurso do século XX. O objetivo é, sobretudo, compreender a psicologia do homem sem qualidades em seu aspecto individual, como efeito da perda gradual do dogmatismo da sociedade moderna ocidental. Posto em contraste, ele é também secundariamente voltado para aquele homem unidimensional, quando se trata de examiná-lo como efeito da cultura de massa. Ainda que a leitura de Marcuse possa se constituir uma contribuição valiosa para um estudo comparativo, que estende e desloca o foco do indivíduo às suas manifestações na sociedade unidimensional industrializada tardia, o seu objeto é o homem sem qualidades. Há que se destacar a pesquisa bibliográfica sobre a obra de Musil e de seus diversos críticos, empreendida em 2001, na biblioteca da Case Western University, Cleveland, Ohio, durante os quatro meses de estudos literários nessa universidade.

A condição da modernidade, doravante denominada tardia, torna especialmente difícil para os indivíduos encontrar as coordenadas sociais, em cujo redor possam tecer seus mapas de identidade. A questão é mais bem formulada por Latour (2005) quando ele se refere ao termo modernidade como aquele que possui tantos sentidos quantos forem dados pelo que se pretende defini-lo. Todas as definições apontariam para a passagem do tempo. Há assimetria quando a modernidade é tratada como adjetivo:

o termo "moderno" assinala um novo regime, uma aceleração, uma ruptura, uma revolução do tempo. As palavras: "moderno", "modernização" e "modernidade" encontram-se sempre colocadas em meio a uma polêmica. Ao se referir a dois conjuntos de práticas diferentes para abrigar redes de ciências e técnicas cria-[se], por "tradução", misturas entre gêneros de seres completamente novos, híbridos de natureza e cultura. Criam-[se], por "purificação", duas zonas 
ontológicas inteiramente distintas, a dos humanos de um lado, e a dos não-humanos, de outro. ${ }^{4}$

Neste segundo conjunto, definido pela crítica, caberia a distinção entre humanos com qualidades e humanos sem qualidades. "Sem o primeiro conjunto, as práticas de purificação seriam vazias e supérfluas. Sem o segundo, o trabalho de tradução seria freado, limitado ou mesmo interditado". (LATOUR, 2005, p.16)

A constituição das identidades, na modernidade, será tomada enquanto se considera que esse termo inclui, por adesão, o projeto moderno de purificação crítica, e ainda que esse se desenvolva somente por meio da proliferação dos híbridos. Tal constituição identitária se resume essencialmente a uma operação narrativa, sendo o romance de Musil emblemático para a caracterização das ações humanas que se configuram sob o Zeitgeist da modernidade. Nele, o eu em si não possui qualidades: todas as qualidades residem nas permutações infinitas entre as ficções que caracterizam o sujeito da narrativa histórica como personagem.

A modernidade deixa de ter sentido e faz o futuro mudar, quando se desvia a atenção simultaneamente para o trabalho de purificação e o de hibridação. Deixa-se de ser moderno, no pretérito, quando se toma consciência, retrospectivamente, de que os dois conjuntos de práticas estiveram operando desde sempre no período histórico que se encerra. Tal posição implica admitir que o passado começa a mudar. Quanto mais se proíbe de pensar os híbridos, mais seu cruzamento se torna possível. E esse é um paradoxo dos modernos: o contínuo interesse por definir o que sejam as identidades expõe a separação entre "nós" e "eles". Se tal questão diz respeito a uma crise atual voltada para a modernidade como o tempo de busca do esclarecimento e do progresso, "como reduzir a sua marcha, curvar e regular a proliferação dos monstros da representação oficial de sua existência?" (LATOUR, 2005, p. 17).

No texto "A noção de progresso à luz da psicanálise" (2001, p.112-138), Marcuse apontava direções voltadas para a crítica diante da exploração gradual, dependência e diferenciação do homem em relação à natureza. Suas expectativas por uma alteração do

\footnotetext{
${ }^{4}$ LATOUR, 2005, p. 16.
} 
processo de degradação constante da natureza, causando o esgotamento de recursos necessários à sobrevivência da humanidade, são traduzidas em uma indagação: "produtividade para quê?", redirecioná-lo? Tal questão, atualizada por Latour, aponta para uma preocupação crucial com a necessidade de se reconceituar a democracia. Não se poderia deixar de distinguir os aspectos pré-modernos, modernos ou pós-modernos de uma noção que não pode ainda ser fechada em um conceito que lhe dá base e alcance.

A relevância de tais discussões inseridas no contexto desta tese se dirige à perpepção do indivíduo sobre a própria identidade, à medida que ela se torna um problema ético na modernidade em curso. A despeito de qualquer posição temporal que se dê às exigências de datação, criando nomenclatura adequada para situar eventos, os híbridos se forjam no jogo interminável e imprevisível entre identidades, consciente e inconsciente, além da aspiração a negar todas as limitações: temporais, familiares, grupais, nacionais, sexuais, étnicas etc., sobretudo aquelas limitações voltadas para o seu papel diante do esgotamento do provimento de recursos destinados à sobrevivência da própria espécie. Situado no campo da psicologia social, tal estudo prevê a interdisciplinaridade, principalmente na região de confluência entre a filosofia política, a literatura e a psicanálise.

Não são, portanto, de se desprezar os pontos de contato entre o homem unidimensional descrito por Marcuse sob o título inglês original One-Dimensional man (1964), traduzido no Brasil como A ideologia da sociedade industrial (1967), e o homem sem qualidades, tal como Musil o caracteriza em seu romance. A tese envolve a dificuldade de situar a modernidade em uma cronologia fixa, preferindo-a como conceito de contraste. Isto é: a modernidade pode aparecer em diferentes épocas com significados diversos, dependendo do que está sendo negado, e em contraste, do que está sendo afirmado.

A sociedade moderna carrega o marco da sociedade ocidental desde o século XVIII. Industrial e científica, sua forma política foi o Estado-nação, legitimado pela

\footnotetext{
${ }^{5}$ MARCUSE, 2001c, p. 115.
} 
soberania popular. A esta lhe é atribuído papel sem precedentes na economia e no crescimento econômico. Em todas as suas formas, a modernidade rejeitava não apenas o seu próprio passado, mas todas as outras culturas que não se mostravam à altura de sua compreensão. Seu impulso na direção do futuro é voltado para o progresso. Doravante, com o fracasso do socialismo de estado, a globalização da economia, o declínio do Estadonação, as grandes migrações populacionais, a modernidade, em sua fase tardia, se dá entre os princípios que fundam a sociedade ocidental, como tal, em contraste com a sociedade oriental. O compromisso com o crescimento e a inovação contínua exige que as formas identitárias existentes sejam encaradas como provisórias. Em contraste, há o recrudescimento de identidades cujos elementos se apresentam forjados sob o aparato de culturas que se sustentam sob a capa de ideologias fundamentalistas. Tanto em um aspecto quanto em outro, observa-se profunda cisão de princípios civilizatórios éticos, de maneira que as identidades sejam ainda encaradas como provisórias.

A difusão mundial do modo de vida industrial é um testemunho da continuidade de sua força. Ao mesmo tempo, tal modo de vida está ameaçando os sistemas de apoio à vida do planeta. É nesse ponto que o industrialismo pode esbarrar em seus limites. A trivialização de um estado permanente de crise, ao mesmo tempo em que testemunha o sentimento difuso de perigo - a percepção de que nada, sequer um simples detalhe doméstico, pode ser visto como garantido - também serve como estratégia de sobrevivência em si. Quando a retórica da sobrevivência invade a vida cotidiana, ela se intensifica e libera, simultaneamente, o terror do desastre iminente. A vítima das circunstâncias enfrenta a crise preparando-se para o pior e convencendo-se de que o pior deve ficar além das expectativas. Do ponto de vista estritamente lógico, nada se ganha insistindo nas más notícias. Cabe assim a indagação formulada por Marcuse (1968): “a ameaça de uma catástrofe atômica ou ecológica, que poderia exterminar a humanidade, serviria também para proteger as próprias forças que perpetuam tal perigo?"6

A hipótese é que uma sociedade de indivíduos, sem oposição, impõe nova forma de identidade. De outra maneira, a unidimensionalização, assim como o conformismo dos

\footnotetext{
${ }^{6}$ MARCUSE, 1968, p. 15. (Tradução nossa.)
} 
comportamentos, ocorre sobre a ruína de valores das culturas tradicionais. Tal ruína se conforma sobre o desenraizamento, legado pela sociedade de massa.

O termo "sociedade de massa" é usado para descrever a condição das sociedades modernas em que formas tradicionais de associação como comunidade, classe, etnicidade e religião declinaram, e em que a organização social é predominantemente de grande escala e burocratizada, pelo que as relações sociais são relativamente impessoais. A sociedade de massa é retratada de maneira que a população constitui uma multidão indiferenciada, sem raízes na comunidade, na tradição e na moralidade consuetudinária, incapaz de discriminação em matéria de gosto cultural e de política e, por conseguinte, sujeita a ondas de emoção e moda, fácil presa de manipulações por parte de líderes inescrupulosos e carismáticos.

A teoria da sociedade de massa foi particularmente influente no segundo quartel do século XX como diagnóstico dos males culturais e políticos que produziram o fascismo e o bolchevismo, e nas décadas de 1950 e 1960 como crítica de uma sociedade americana vista como conformista e politicamente desmoralizada. Em anos recentes, o termo tornouse impopular porque o seu pessimismo cultural elitista parece injustificado à luz das provas de um continuado e crescente pluralismo social e cultural, e também porque foi associado a uma política conservadora que não entendeu a mudança que, desde meados da década de 1960, vinha ocorrendo na natureza da participação política.

Nesta tese, enfatiza-se que a perspectiva crítica da sociedade de massa como algo perigoso à ordem não é novidade do século XX. A ameaça que as massas urbanas sem cultura, decadentes ou desesperadas, representam para as elites de talento ou virtude tem sido um tema recorrente em filosofia política desde a Antigüidade clássica, mas foram os acontecimentos do final do século XVIII e começo do século XIX que intensificaram essas preocupações e criaram as bases para o conceito moderno de sociedade de massa. A Revolução Francesa varreu, de forma precipitada, os regimes aristocráticos tradicionais. Assim, a democracia poderia significar um nivelamento por baixo, em que as paixões da massa se sobrepusessem à razão da elite educada e levassem à intolerância da dissidência e do inconformismo. 
O outro fator importante nesse processo foi a transformação de sociedades predominantemente agrárias pelos processos interligados de industrialização, burocratização e urbanização. A teoria da sociedade de massas apóia-se substancialmente nas obras dos teóricos do século XIX, sobretudo Tocqueville, Tönnies, Durkheim e Weber, que identificaram essas mudanças e, ao mesmo tempo, preocuparam-se com suas implicações para a coesão social e a ordem política. Assim como as relações características da sociedade pré-industrial foram transformadas pela industrialização, também a ordem política foi ameaçada pelo colapso da ordem moral antecedente e pelo relaxamento das coerções mecânicas que tinham, até então, ajudado a manter as sociedades coesas.

As várias versões da polaridade "comunidade-sociedade" pretendiam ser projetos heurísticos, consideradas mais como dimensões de processos sociais em curso do que como estados finais. Durkheim (1973), em particular, percebeu que, se o desenvolvimento social acarretava a destruição de formas tradicionais de comunidade e moralidade, também havia, não obstante, possibilidades de inovação. O equívoco dos teóricos da sociedade de massa estava no fato de a nostalgia os cegar a ponto de não enxergarem $o$ desenvolvimento de novas formas de comunidade e moralidade, mesmo em sociedades dominadas por modernas formas de associação.

Kornhauser (1959) sublinha o impacto desintegrador da rápida mudança social, econômica e política, mas atribui posição central às associações secundárias do pensamento de Tocqueville $(1987$; 1997), como decisivas à saúde e à estabilidade da democracia liberal. $\mathrm{Na}$ ausência de tais associações intermédias, a massa sofrivelmente integrada da população era suscetível de mobilização por elites políticas, enquanto as próprias elites eram perigosamente vulneráveis às pressões da opinião da massa. $\mathrm{O}$ resultado era a vulnerabilidade à volatilidade e ao extremismo político. As posições desse autor levam à generalização de argumentos voltados para compreender as sociedades totalitárias nas três primeiras décadas do século XX, no período compreendido, nesta tese, pelas análises psicossociais empreendidas por Musil em seu romance $O$ homem sem qualidades. 
As análises de Kornhauser se mostram igualmente fecundas quando ele se concentra na ascensão do nazi-fascismo atribuído ao caráter recente e à rapidez da transformação da Alemanha e Áustria em uma sociedade democrática de massa. Tão rápida foi essa mudança que as antigas associações de comunidade, classe e religião tinham desmoronado, deixando massas anômicas e desenraizadas à mercê das manipulações de políticos que dispunham de meios modernos de organização e comunicação. $^{7}$

Embora plausível como explicação da ascensão do nazismo, a teoria da sociedade de massa foi prejudicada pelas provas que contradizem sua proposição central. Com efeito, a Alemanha e Áustria eram constituídas por sociedades que sofreram rápidas e desarticuladoras mudanças, mudanças essas mais políticas do que primordialmente sociais. Antes da ascensão dos nazistas ao poder, estas não eram sociedades em que os segmentos intermédios fossem fracos. Se se pudesse fazer ampla generalização de tal argumentação, não se justificaria a atração pelos regimes totalitários como restrita, no período referido, à Alemanha e a rápida adesão da Áustria; não se estendendo, entretanto, com algumas exceções, a todos os países do bloco europeu.

A teoria da sociedade de massa atingiu o seu ponto mais baixo quando aplicada aos novos movimentos sociais das décadas de 1960 e 1970, pois, no caso dos movimentos que se dão nesse período, havia abundância de provas de que não se tratava de indivíduos anômicos, socialmente pulverizados, os que eram mais propensos a adotar uma ação política radical, mas, pelo contrário, eram pessoas que estavam relativamente bem integradas, no plano social, e mais do que usualmente motivadas por seu compromisso com sólidos princípios morais, bastante conscientes da defesa de seus interesses. O que é ponto de interesse à leitura de $O$ homem sem qualidades de Musil é a sua compreensão de que, apesar da rápida mudança ser perturbadora e, com freqüência, politicamente desestabilizadora, não são usualmente as pessoas mais afetadas pela rápida mudança as que se mostram mais propensas a assumir uma ação radical. Para aqueles que a assumem, o caráter do seu envolvimento político parece quase sempre ser um reflexo dos valores com que estavam previamente socializadas do que uma reação impulsiva às novas

\footnotetext{
${ }^{7}$ KORNHAUSER, 1959.
} 
circunstâncias. É frente a esse último quadro, que o homem sem qualidades se justifica ao exame nesta tese.

Sob uma perspectiva psicossocial, baseando-se em Freud, Marcuse (1968) identifica os sintomas da desagregação social e da destruição do ambiente de sobrevivência planetária, como efeitos gerados pelo conflito entre as pulsões de vida e de morte. E de tal maneira o conflito interno é intolerável, que dele se defendem os homens, projetando-o na constante ameaça exterior, em dupla mão, como se houvesse um eixo, que permitisse a divisão contornada por uma linha geográfica, para representar o próprio malestar.

A dificuldade de enfrentamento dos problemas mais cruciais gerados pelo contínuo estímulo ao progresso material humano e à destruição concomitante das fontes geradoras de energia e suprimentos na Terra se revelam, hoje, na iminência de guerra civil armada, entre o Oriente e o Ocidente. A tradicional divisão geográfica da Terra em dois hemisférios é hoje ressaltada como se houvesse uma fronteira real, por um lado servindo para destacar as intransponíveis barreiras culturais, por outro, para encobrir as verdadeiras motivações históricas, políticas, econômicas e psicossociais que, a cada, dia acirram facções políticas e religiosas investidas de retórica fundamentalista.

O termo "Ação Paralela", uma alegoria construída por Musil para descrever o cenário que dá base à compreensão da constituição do nazi-fascismo, reflete uma imagem que bem serviria para refletir o recrudescimento do espírito das guerras que ainda se revelam no horizonte dos dias atuais. A ação paralela, entretanto, é mais do que simples alegoria. Ela abre um campo de investigação dos bastidores da ação política, à medida que seus atores travam uma batalha discursiva em paralelo, mas, concretamente, o que se verifica é a congregação de interesses tanto pessoais quanto de grupos ou facções voltadas para a composição das forças que resultam em guerra armada.

A conformação de identidades coletivas e individuais na modernidade tardia vem afirmando a necessidade de um novo olhar sobre a história de culturas e etnias cujo entrelaçamento fez despontar, ao longo dos séculos, modos complexos de estar no mundo, numa rede de interações em que se confrontam, inevitavelmente, os modelos 
pretensamente hegemônicos da modernidade. A noção de univocidade do sujeito moderno, responsável, em última instância, pela nova ordem que se pôs em marcha ao final da Idade Média, deve ser acrescentada a tal processo identitário.

A nova ordem impõe desafio lançado à sociedade do novo século, diante da questão que ainda não pode ser inteiramente compreendida: "como foi que o século XX, que devia ser o Século das Luzes, do progresso científico e econômico, das maiores vitórias da inteligência, pôde se tornar o tempo das maiores opressões - aquele em que o homem se encontrou despojado no mais alto grau de si mesmo?" Essa questão, deixada em aberto por uma série de entrevistas no jornal Le Monde (ENTREVISTAS, 1989, p.7), endereçada aos mais importantes pensadores sobre problemas sociais da contemporaneidade, não deixa de assolar a consciência atual, a partir de seus efeitos, e está no centro das questões referentes ao curso evolucionário da imagem progressista que a humanidade traz em si, dispondo-se como eixo à demonstração desta tese.

A queda dos regimes que visaram ao socialismo, ao comunismo e ao nazifascismo, como formas acabadas de vida em sociedade, trouxe trágicas imagens do inferno social que nasce da necessidade que têm os homens de viver juntos. Ao mesmo tempo, expõe a forma psicológica totalitária como modo de criar uma cultura "superior" e hegemônica, nomeadamente fascista, a despeito das singularidades de cada cultura e de cada indivíduo em seu meio cultural.

Da queda resta uma extensa crise social que se revela, por um lado, como desilusão da vida coletiva compartilhada em igualdade de condições econômicas, e a experiência histórica sentida por muitos como "a maior traição ideológica de todos os tempos" (GAUSSEN, 1989, p.7). Em contrapartida, a crise revela as faces do desenvolvimento, da racionalização dos processos de industrialização, da promoção ao consumo, da midiatização, que só puderam se dar ao preço da alienação do indivíduo, gerido como elemento passivo na maquinaria produtivista, reduzido à simples função de agente econômico no sistema globalizante. Por outro lado, de forma aguda, a crise revela os efeitos da cultura psicológica que sustenta, ainda em dias atuais, o enquadramento e a normalização dos indivíduos de forma a suavizar o ordenamento social na diversidade cultural (CASTEL, 1989, p. 34-39). 
A cultura do progresso vista in extremis, sem aparato quantitativo, na forma qualitativa - entendida como estética predatória — suscita questões relevantes e atuais à sobrevivência do Planeta Terra, diante das catástrofes produzidas pelo desenvolvimentismo exacerbado dos modelos técnico-científicos que se apóiam unicamente nas ciências da matéria. A missão de organizar o sistema homem-máquina como se a natureza fosse passível de ser gerida com eficiência equivalente — revela que o progresso tecnológico foi raciocinado em termos de um homem-objeto, coisificado e dilacerado. Sua alienação não se limita à esfera econômica, mas aos campos de sua existência ontológica, de vidas sociais, públicas e privadas, de desejos, vontades e motivações inconscientes.

O personagem Ulrich, o homem sem qualidades, conforme o descreve Musil, é um eficiente operador de leitura para a compreensão dos tempos que, desde o Renascimento, moldam as constituições identitárias em curso histórico. Em outros termos, o homem sem qualidades é o homem ordinário, o herói comum. O homem sem qualidades se revela como desejo cujo objeto impossível ele representa. Musil dedica a ele a escrita que outrora se oferecia em homenagem aos deuses e às musas inspiradoras. Ele personifica o objeto das ciências que privilegiam o anônimo e o cotidiano, pontuando os detalhes metonímicos - as partes pelo todo na pesquisa. $\mathrm{O}$ homem sem qualidades se afasta dos representantes que simbolizavam famílias, grupos e ordens, quando o nome era uma insígnia. Ulrich é um personagem sem sobrenome. Ele é tanto uma persona, quanto é um número ordinário na administração das metrópoles da modernidade. Inserido na multidão móvel e contínua de pessoas sem nome e rosto, o homem sem qualidades personifica os processos da formação da identidade na modernidade. A falta de qualidades se apresenta como a marca de uma identidade cindida, da natureza esfacelada do sujeito contemporâneo, cada vez mais distante da ilusória segurança que dava forma às pressupostas identidades modernas, cujos pilares presumiam a certeza de coesão, de centralidade, de auto-suficiência.

Musil expõe a trajetória de Ulrich como um dramático embate entre uma falsa identidade assumida a contragosto, muitas vezes sob risco de morte, e as estratégias íntimas de manutenção do que seria uma identidade verdadeira, porém exercida nas sombras, sob o peso da ilegitimidade. O contínuo exercício do simulacro como condição 
de existência parece ter resvalado na configuração de uma identidade marginal híbrida que coloca em questão, a partir da negação de posições fixas, a própria localização do sujeito a partir de sua filiação e, por contaminação, de sua genealogia étnico-cultural.

Pode-se enxergar no homem sem qualidades a erosão e a derrisão do singular ou do extraordinário: ele é o novo herói, ou o anti-herói das massas, as primeiras a serem submetidas ao enquadramento das racionalidades niveladoras. Seu discurso se dá entre metáforas, e é como se fosse a citação indefinida de outro. Ulrich é cada um e ninguém, sábio e louco; irresponsável ele delega a responsabilidade de seus atos ao outro, ao acaso, à fortuna. Entretanto, seu autor cria para ele um teatro humanista que chega a revelar o aspecto risível da comédia humana. Lúcido e ridículo, seu destino se impõe a todos, reduzindo a nada a isenção da responsabilidade civil que cada um almeja na multidão.

O exame da estrutura imaginativa de $O$ homem sem qualidades permitiu ao autor avançar na discussão de questões ainda controversas no mundo contemporâneo. A experiência apóstata desse personagem, adotada a partir de sua condição extramoral, seria uma terceira margem, um interstício habitável em um momento de profundas rupturas com as tradições que configuravam os valores da civilização e da cultura européia, percebidas como conspurcadas pela duplicidade identitária e ameaçada pela existência de grupos étnicos não aderentes às transições em curso. Ocorre que ao homem sem qualidades era impossível reconhecer-se, embora sua vida pública, sua corporeidade, seu próprio testemunho assim o atestassem. Ao mesmo tempo, a tradição religiosa herdada, sua crença de origem, estava confinada à intimidade, violada pelo disfarce, pelo falseamento.

O estudo de Musil joga em cena a própria definição de literatura como mundo e de mundo como literatura. Doravante, o homem sem qualidades é, ao mesmo tempo, o pesadelo, o sonho filosófico da ironia humanista, e o referencial que dá credibilidade a uma escrita, contando a todo o mundo a sua ridícula desventura. Ele nos mostra o que se sucederia do plano psicológico ao plano político, revelando, paradoxalmente, como a falta de qualidades torna-se, a partir de então, no mundo globalizado, uma identidade possível 
no ponto mesmo em que identidades socialmente constituídas se desmantelam. Reaparece, assim, a necessidade permanente da figura persecutória do estrangeiro — este ainda é o inimigo externo - , para justificar a perda das referências que suportam os valores da civilização ocidental.

O homem sem qualidades - o frustrado, o deficiente, o inacabado - subtrai ao sujeito moderno uma essencialidade almejada, confiscando-lhe, de forma imaginária, a ilusão de pureza e integridade étnica como o vencedor, o auto-suficiente, o homem acabado da promessa iluminista. Contudo, na ficção que é obrigado a construir para si, o homem sem qualidades percebe-se também espoliado no embate entre o aparentar ser o que não é e o não poder ser o que acredita que é, trazendo à tona a dimensão de um "vazio da origem" que irá minar, paulatinamente, qualquer esperança de pertencimento.

A hipótese base da demonstração é a de que a obra $O$ homem sem qualidades possa ser o reflexo da humanidade, quando as situações do imediatismo e da urgência são a marca histórica da sociedade tecnológica unidimensional discutida por Marcuse (1968, p.8), no tempo pós-moderno, doravante nomeado capitalismo tardio. Essas situações impedem qualquer projeto de longo prazo, suscitando certo número de questões filosóficas dirigidas à responsabilidade da psicologia social, fazendo prever grande incerteza sobre o futuro.

A discussão que inspira tal hipótese se assenta sobre a emergência do novo paradigma da racionalidade diante das discussões que trazem a dúvida que conduz à incerteza sobre o monopólio da ciência como privilégio e prioridade no acesso à verdade. Dessa discussão, por sua vez, sucede a proliferação de interrogações sobre a idéia de que o discurso científico, mesmo o mais aberto, não atende à necessidade de engajamento do cientista, que não tem como responder a todas as questões concernentes ao mundo vivido.

O homem sem qualidades reflete o descentramento do eu freudiano e, constituindose como alteridade do sujeito moderno, enuncia que a duplicidade, a simulação, o estranhamento de si mesmo, o exercício de uma memória que vai exercendo também a 
lógica do olvido são um desdobramento involuntário e inexorável de sua própria origem, para sempre perdida e inapreensível. A psicopatologia cotidiana do homem ordinário reflete o mal-estar que se reflete na vida comum. É esta que apóia o real no curso da história. A doença de ser alguém comum fornece subsídio ao discurso esclarecido, prestando-se à verdade a respeito de todos; e, a partir de então, ele é a realidade da história. Sem trazer consolação nenhuma, o personagem de Musil revela verdades banais e amargas. O discurso de Ulrich é carregado de ironia: ele é locutor do homem sem qualidades, fazendo o retorno de todo o mundo e ninguém no lugar em que ele se distingue da trama que o autor lhe cria. Especialista na recondução do saber a seu pressuposto geral: ele não sabe nada de sério; ele é como todo o mundo. As trivialidades que enuncia não designam o objeto do discurso, mas o seu lugar. O trivial, aquilo que o distingue como "sem qualidades", não é mais o outro encarregado de reconhecer a isenção do seu autor das responsabilidades sobre o que pensa. As experiências do personagem são a própria razão de ser da produção do texto narrado pelo seu criador. $\mathrm{O}$ enfoque da cultura que o autor expõe à crítica do leitor começa quando o homem sem qualidades se torna ordinariamente o narrador, definindo o lugar comum do discurso e o espaço anômico de seu desenvolvimento.

Este lugar de personagem é dado tanto ao locutor do discurso quanto a qualquer outro, provocando vertigens no leitor, quando este se dá conta de que ele mesmo é o ponto de chegada de uma trajetória do personagem. Musil expõe que assim algo veio a ser o efeito de um processo de afastamento das práticas reguladas e falsificáveis em nome do discurso científico e do progresso da ciência. Como escritor de ficção, ele executa como um condenado a realização do luto pela elaboração ficcional do saber. Na nota introdutória de sua Obra póstuma publicada em vida (1996), ele se refere ironicamente a um tempo propício para o escritor que se dedica a escrever, em vida, como se estivesse escrevendo obras póstumas. O pensamento deve ser enunciado nas pequenas narrativas. Fingidor, ele deve demonstrar raiva por acontecimentos que não implicam qualquer perigo e falar de coisas secundárias, mesmo quando sabe que há tantas coisas fundamentais. 
A vida humana se dá nas entrelinhas, em seus menores traços. A história se revela quando a narrativa parece distraída e abandona o leitor aos sentimentos de espera, que aparentemente não têm nada a lhe dizer, até a hora em que ela se reanima e se expressa naquilo que ironicamente diz respeito a determinadas circunstâncias vividas nas sombras de uma vida que já não existe mais. A falta de unidade, de coerência no discurso traz uma espécie de aborrecimento tacanho ao leitor, sem, contudo, prejudicar o conjunto da obra. Como sátira, $O$ homem sem qualidades tem caráter duradouro. Como paráfrase ao seu pensamento, Musil diz que "numa única coisa malfeita vislumbramos a alegoria de todas as coisas malfeitas". Se sua obra expõe os pequenos erros de seu personagem, estes continuam sendo, ainda assim, erros, numa época em que se cometem impropriedades muito maiores.

A identidade, para Musil, deixa de ser apenas o estigma contingente de um contexto histórico brutal, para constituir-se também uma posição subjetiva, um "outro rosto" do sujeito moderno, gestado no momento mesmo em que o logos cartesiano lhe dava forma e autonomia. $\mathrm{O}$ rosto que se espelha como um outro execrado não pode, por isso mesmo, ser de todo alheio ao sujeito que a modernidade queria consolidar e, na sua existência críptica, será a imagem refratada de sua própria origem, guardando em si, em seus fragmentos, em sua ex-centricidade, aquilo que o sujeito moderno precisava superar para triunfar.

É na deriva entre o público e o privado, entre a luz e a sombra, entre a credulidade e a apostasia ou, no extremo, pela radical experiência de ruptura com o passado, que a trajetória do homem sem qualidades vai mimetizando o percurso da subjetividade moderna até os dias de hoje, em que se colocam em crise - muitas vezes pela ostentação de fundamentalismos — os pilares das culturas tradicionais, incapazes de reconhecer, até o momento, sua própria falta de acabamento como forma de permanência.

Assim, o elemento metodológico, de importância capital sobre a interrogação que inspira esta demonstração, refere-se aos excessos da fascinação exercida pelas ciências da natureza no desenvolvimento e na determinação da evolução humana da sociedade 
industrial e tecnológica contemporânea tal como Lipovetsky (2005) nomeia a sociedade pós-moralista: esta é insensível à dor nos novos tempos democráticos. Do ponto de vista da sua determinação histórica, há uma revolução em curso que foi mal-conhecida ou ocultada, fazendo com que a maior parte das críticas externas à ciência seja freqüentemente considerada não pertinente pelos próprios cientistas. Certos da verdade de seus discursos, em razão de sua eficácia técnica, os cientistas têm contemplado as tentativas das ciências humanas ou sociais em proferir uma verdade sobre suas próprias práticas de pesquisa. Por tais motivos, a obra $O$ homem sem qualidades foi escolhida para ser o objeto empírico desta demonstração. Ela está situada em campos de pesquisa que se estendem da ficção à filosofia; observa a interdisciplinaridade no âmago de um emaranhado reflexivo interno da universalidade de teorias e permite um caminhar progressivo na direção de um novo paradigma para a psicologia social.

Optou-se por se dividir a tese em quatro partes. A Parte I da tese é dividida em quatro capítulos. O primeiro capítulo - Identidades em crise ética e preparação do inimigo - segue o raciocínio de Marcuse (1967). Por um lado, visa à compreensão da crise ética na modernidade tardia. A idéia de crise constante suporta a ameaça de catástrofes que podem vir a exterminar a humanidade. Por outro lado, serve às próprias forças que perpetuam esse perigo. Os esforços para impedir as catástrofes ofuscam a procura de suas causas potenciais na sociedade contemporânea. Em vez de tratar objetivamente das causas, estas são consideradas uma ameaça que vêm do exterior, e de tal maneira que seja demasiado visível - do Oriente contra o Ocidente e do Ocidente contra o Oriente. O constante estado de alerta e guerra justifica a necessidade se estar preparado, de se viver armado e viver à beira de um abismo. $\mathrm{O}$ estado de crise interessa tanto à produção pacífica dos meios de destruição, quanto à defesa do consumo e desperdício voltados para a crença do crescimento econômico, ordem social e progresso humano. No segundo capítulo, é analisada a lógica de se manter o inimigo caracterizado, para justificar o estado de alerta e o investimento psicológico das massas voltados para a permanência do estado de crise. 
O terceiro capítulo - O homem, o tempo-lugar, Zeitgeist etc.: Musil matemático, engenheiro e psicólogo se transformam em escritor - volta-se para as reflexões que incidem sobre a escolha da obra $O$ homem sem qualidades, para caracterizar a identidade narrativa e a sua repercussão sobre o ethos da modernidade. As idéias desenvolvidas por Ricoeur (1991, p. 167-236), sobretudo quando esse autor discute o si e a identidade narrativa, em seus desdobramentos postos à perspectiva ética, são essenciais à estruturação do raciocínio, ora em tese.

O primeiro capítulo da Parte II - Musil diante da "genialidade" de um cidadão kakaniano - discute aspectos estéticos que habilitam o agente a compreender e superar as forças de coerção social na cultura em que ele se insere e para além de seu tempo. Nessa Parte II há um Excurso - Um paralelo: "Nossa existência nada mais é do que um pálido fantasma". Neste se discutem as idéias de diversos autores dedicados ao exame das principais temáticas que identificam o século XX quando culminam em choque as transformações que ocorriam desde o final da Idade Média. As guerras servem como campo de testagem dos grandes progressos em todas as áreas de conhecimento. Humanos, explicitamente tratados como não-humanos, especialmente os judeus, homossexuais, ciganos, bem como algumas minorias designadas pelo regime nazista como párias ao germanismo, são usados como cobaias de tais experimentos. As regras diplomáticas que envolviam os inimigos como partes em guerra são radicalmente alteradas, abrindo precedentes a uma série de questões, que ainda permanecem sem soluções adequadas nesta primeira década do século XXI.

Em tal Excurso, são escolhidos autores para uma discussão que se presta como instrumental teórico às análises das transformações sociais nos dois últimos séculos e no atual, de maneira a elucidar aspectos éticos voltados para o conceito de progresso, alienação e reificação como legados à cultura consumista atual. O esgotamento dos recursos que provêem a sobrevivência na Terra chega ao limite. Providências têm sido tomadas sobre experimentos de pensamento, mas estes não têm sido suficientes para acompanhar o ritmo requerido de todas as mudanças na prática. 
A Parte III é dividida em dois capítulos $\mathrm{O}$ quinto capítulo - O pensamento unidimensional na base da modernidade - aponta os elementos que possibilitam a construção de um paralelo entre o homem unidimensional e o homem sem qualidades. O sexto capítulo - O totalitarismo mistificado pela aldeia global -, revela os elementos que permitem o paralelo entre o homem unidimensional e o homem sem qualidades. Sua finalidade é encontrar, no totalitarismo, as configurações políticas e psicológicas cujas razões se prestam ao lugar do ideal de eu no sistema globalizado.

O sétimo capítulo da Parte IV - Uma obra inacabada para o homem sem qualidades - revela o processo de metamorfose do sujeito durante o processo das Guerras. O eu e o seu Ideal seguem caminhos inesperados diante da realidade que se expõe cruamente no conflito aberto. O saldo de guerra possibilita uma reflexão ética. Porém, o saldo resta como dilema intelectual ao sobrevivente. Por um lado, a obra de Musil deixa clara a impossibilidade de sobrevivência do seu autor no contexto referido. A obra revela a percepção concreta da perda de si, diante do exílio. O inacabamento da obra - a própria vida - expressa o drama ético do sujeito diante de suas escolhas em vida.

Os aspectos finais da tese ressaltam a distinção terminológica sobre a identidade à luz das discussões históricas que a situam nos campos da filosofia, ciências sociais (voltadas para a psicologia social) e psicanálise. Discute-se a relevância do problema da identidade diante da ameaça de perda de si quando esta se dá como perda da consciência social de nação. O nacionalismo e o racismo são sintomas que lastreiam as ideologias políticas criadas para justificar politicamente as Grandes Guerras do último século. O sentimento de alienação e a ameaça de perda da identidade são analisados sob o foco da construção narrativa que o indivíduo tem sobre si mesmo.

Nas Considerações finais postas à conclusão, o entendimento específico da modernidade serve como pano de fundo para moldar a investigação de Musil sobre a arte e a ética nos anos que antecedem a Primeira Guerra Mundial. Sua obra é analisada sob os diversos prismas que a compõem: do primeiro romance de Musil, $O$ 
jovem Törless, às recentes publicações de ensaios e cadernos de anotações. A conclusão revela o esforço de Musil em confrontar, de forma otimista, a contingência e a descentralização da experiência moderna, responsável pela sua posição peculiar dentro do modernismo. Tal posição peculiar não exclui a dependência contínua de Musil em relação a Kant em sua tentativa de harmonizar, com a sua obra, os reflexos da arte e da ética sobre os eventos históricos perturbadores do final das décadas de 1920 e 1930.

O homem sem qualidades é, assim, o experimento de pensamento concebido como um local de testes auto-referenciais para o projeto estético do que seriam as identidades na modernidade tardia, segundo o seu autor. Os esforços estéticos de Musil não se coadunam com uma ética. Tais esforços são delineados para fornecer o suporte à avaliação da utopia estética do protagonista no Livro Primeiro. A última seção interpreta a busca pela "outra condição" que se desenvolve no Livro Segundo. Este, por sua vez, se apresenta como parte fragmentada do romance, operando na narrativa uma imagem de espelho revertida da visão utópica apresentada no Livro Primeiro. $\mathrm{O}$ argumento desenvolvido mostra que a simetria entre os empreendimentos utópicos descritos nas duas partes do romance se estendeu ao fracasso. Tal fracasso deveria carregar uma mensagem positiva, a saber, o apelo para se aceitar, de modo otimista, a realidade moderna de um buraco negro ético, adiantando-se à mais modesta e sustentável utopia de uma atitude indutiva.

A parte final discute ainda a contribuição desta última visão utópica para a crise identitária nos dias atuais. A tese se encerra quando se demonstra que $O$ homem sem qualidades não é apenas um experimento notável para a compreensão psicológica e historiográfica do momento atual. Mais do que revelar os efeitos da morte do sujeito, o experimento de Musil expõe a face sem rosto do homem na multidão como se esta fosse o referencial para uma metamorfose perpétua. A identidade passa a se orientar pela criatividade aleatória, pela liberdade feita da indeterminação, ou apenas das certezas que se subordinam ao sujeito como se ele fosse um personagem de ficção. Com a velocidade das transformações requeridas pela modernidade, a identidade de um homem sem qualidades se apóia sobre sistemas autopoéticos, e assim será a reorganização coletiva na eventual situação de 
caos social. Na linha do horizonte, onde o presente é tão movediço que se torna rapidamente passado, Musil antevê com aguda precisão a indeterminação como a marca da identidade do homem moderno: esta se apóia sobre uma falta notadamente a falta de ética, paradigma das relações humanas. É para tal falta que se voltam as formas hodiernas da violência, do terror e das organizações criminosas no poder. Se é possível manter o fio que liga a positividade de uma utopia, que esta seja a possibilidade de combinações que se vislumbra como contribuição peculiar à teoria social do caos. 


\section{NOTA PRÉVIA}

A referência bibliográfica básica é o livro de Robert Musil, $O$ homem sem qualidades na tradução brasileira de Lya Luft e Carlos Abbenseth; Rio de Janeiro: Nova Fronteira, 2006. Quando necessário, foi consultada a versão original alemã Der Mann ohne Eigenschaften (v. 1-5, p. 9-2160), parte dos nove volumes da Gesammelte Werke, in neuen Bänden herausgegeben Von Adolph Frisé (1978).

A fim de se facilitar a leitura, optou-se por traduzir os termos, citados no corpo do texto, do alemão para o português. Os trabalhos de Robert Musil estão abreviados e serão citados como se segue:

$D$ Diaries 1899-1941. Trad. Philip Payne. New York: Basic Books, 1998.

GW Gesammelte Werke in neun Bänden. Reinbek bei Hamburg: Rowolht, 1978. 9 v.

MoE Der Mann ohne Eigenshaften. Gesammelte Werke. 9 v. Reinbek bei Hamburg: Rowolht, 1978. v. 1-5.

MwQ The man without qualities. Trad. Sophie Wilkins; Burton Pike. New York: Knopf, 1995. 2 v.

MSQ O homem sem qualidades. Trad. Lya Luft; Carlos Abbenseth. Rio de Janeiro: Nova Fronteira, 2006. (40 anos, 40 livros).

PS Precision and soul: essays and addresses. Trad. Burton Pike; David S. Luft. Chicago: University of Chicago Press, 1990.

T The confusions of young Törless. Trad. Shaun Whiteside. New York: Penguin, 2001.

JT O jovem Törless. Trad. Lya Luft. Rio de Janeiro: O Globo; S. Paulo: Folha de São Paulo, 2003.

TB Tagebücher. 2. ed. rev. Reinbek bei Hamburg: Rowohlt, 1983. 2 v.

Briefe Briefe 1901-1942. Adolf Frisé; Murray G. Hall (Ed.). Reinbeck bei Hamburg, 1980. 2 v.

Grande parte da obra de Robert Musil, interrompida em 1942, só foi publicada postumamente. A edição autorizada é a Gesammelte Werke, editada por Adolf Frisé (Reinbek bei Hamburg: Rowoholt, 1978), consultada inúmeras vezes durante a redação desta tese.

A edição de Frisé consiste de dois volumes - volume I, Der Mann ohne Eigenschaften, divididos em duas partes. A primeira contém as seções do romance publicado por Musil em 1930 e 1933; a 
segunda compreende uma ampla seleção de capítulos não publicados e dos primeiros rascunhos do romance, assim como pequenas peças e comentários extraídos das anotações de Musil, que hoje fazem parte da coleção manuscrita da Österreichische Nationalbibliothek em Viena. O volume 2, Prosa und Stücke; Klein Prosa, Aphorismen; Autobiographisches; Essays und Reden; Kritik, contém outras obras publicadas por Musil, além de inúmeras peças não publicadas e/ou inacabadas. A estas me refiro indiretamente, pois não foi possível consultá-las. As principais obras de Musil, originalmente escritas em alemão, foram consultadas em traduções inglesas ou portuguesas: $O$ jovem Törless (2003); a peça, Die Schwärmer (1924), traduzida em Portugal sob o título Os visionários, drama em três actos (1989); os contos Drei Frauen (1924) foram traduzidos em português e publicados em Três novelistas contemporâneos (1966). A maior parte dos cadernos de anotações de Musil foi publicada por Adolf Frisé numa edição de dois volumes, intitulada Tagenbücher (1976). A tradução inglesa correlata, Diaries 1899-1941, selecionada e apresentada por Mark Mirsky, publicada em 1999, embora incompleta, compreende anotações, experiências pessoais, aforismos filosóficos, opiniões políticas e rascunhos de trabalhos e ensaios literários. A tese de doutorado de Musil, por sua vez, foi publicada em inglês com o título On Mach's theories, em 1982.

Uma seleção dos ensaios de Musil pode ser encontrada em Precision and soul: Essays and addresses, editados e traduzidos por Burton Pike e David S. Luft, (1994), ainda não disponível em português. A tradução do texto Nachlass zu Lebzeinten (1936) recebeu, em inglês, o título Posthumous papers of a living author, traduzida por Peter Wortsman (2006). Esta obra corresponde à edição portuguesa $O$ melro e outros escritos de obra póstuma publicada em vida (1996).

Para o texto Vereinigungen (1911) e Vinzenz und die Freundin bedeutender Männer (1924) não foram localizadas traduções, seja em inglês ou em outros idiomas. Há, ainda, ensaios e artigos sobre política, ética, literatura e estética, igualmente sem tradução localizada.

Devido ao grande número de distorções entre as versões do texto de Marcuse em português, intitulado A ideologia da sociedade industrial. (Trad. Giasone Rebuá. Rio de Janeiro: Zahar, 1967), a partir da segunda impressão publicada por Beacon Press, Boston, 1966, e aquela em francês, cujo título é L'Homme unidimensionnel: essai sur l'idéologie de la société industrielle avancée (Trad. Monique Witting; Herbert Marcuse. Pref. Herbert Marcuse. Paris: Minuit, 1968 (Arguments, 34), optou-se, na maioria das vezes, por esta última. Para facilitar a leitura, sua abreviação será citada como $L H U$. 


\section{PARTE I}

\section{PRIMEIRO CAPÍTULO}

\section{Identidades em crise ética e a preparação do inimigo}

O personagem é um ser fictício. Mas tal expressão pode parecer um paradoxo. De fato, como pode uma ficção ser? Como pode existir o que não existe? No entanto, a criação literária repousa sobre este paradoxo, e o problema da verossimilhança entre personagem e leitor depende desta possibilidade de um ser fictício, isto é, algo que, sendo uma criação da fantasia, comunica a impressão da mais legítima verdade existencial. A literatura, e mais especialmente, o romance, se baseiam num certo tipo de relação entre o ser vivo e o ser fictício. Manifesto pelo personagem, o ser vivo é a concretização do ser fictício em uma espécie de projeção especular.

Em seu curto ensaio "O Édipo ameaçado", , pouco conhecido do grande público, Musil observa que o homem antigo tinha Cila e Caríbdis, monstros marinhos femininos que habitavam as grutas no estreito de Messina e devoravam todas as criaturas ao seu alcance, o homem moderno tem um aquário para conter tais monstros e assim deles se livrar. Porém, ele diz que nada é possível sem o Édipo, nem a vida familiar, nem a arquitetura; tudo se explica pelo protótipo do personagem, que imprime significado a tudo o que o homem é, faz ou deixa de fazer.

Musil afirma ter sido criado sem Édipo. Ao se recordar de um episódio tipicamente comum na infância, ele revela a força da palavra "idem" para replicar os insultos que só poderiam ser replicados nos breves momentos de uma contenda, em meio a uma pausa para respiração. A analogia se estende ao uso da represália a que a psicanálise submete todos que nela vão buscar uma pausa para reflexão sobre si mesmos. Musil se refere ao tempo de uma "suspensão" no tempo. Saindo da sua rotina habitual, um indivíduo pode voltar a se sentir o parâmetro para todas as coisas à sua volta. Carregada de sarcasmo, a

\footnotetext{
${ }^{8}$ MUSIL, “O Édipo ameaçado”. In: . O melro e outros escritos de obra póstuma publicada em vida, 1996, p.76-78.
} 
escrita de Musil aponta para a forma como os "reformadores de almas", profissionais voltados para o tratamento das doenças psíquicas, se reportam à conduta de Édipo, um personagem. Tal personagem é útil para falar da cultura como mais importante do que o próprio indivíduo, para explicar que a sua conduta se deve exclusivamente a ela. A tragédia do indivíduo, da qual o personagem é desde sempre sujeito, permitirá que, em seu último ato, na última fase humana quando finalmente se puder livrar de grande parte da cultura, ele se sinta mais uma vez um nada.

Ao descrever o caráter interminável da relação que se estabelece entre o sujeito e o seu "reformador", Musil observa os excessos cometidos para explicar quaisquer eventos cotidianos por meio do personagem. A abrangência de tais explicações suscita a possibilidade de esgotamento paradigmático, e de tal maneira que ele teme que depois de uma ou duas gerações já não haveria Édipo nenhum. ${ }^{9}$

Antevendo as profundas mudanças culturais que haveriam de modificar não apenas o papel feminino e o masculino na organização familiar, mas todos os padrões de organização social que embasam a civilização ocidental, Musil se indaga pela futura transmutação de Édipo em Orestes. Sua indagação se estende à própria psicanálise: ou ela renuncia a seus efeitos salutares, ou ela deveria fazer a si mesma o que prevê que os indivíduos façam consigo mesmos. ${ }^{10}$ Para acompanhar o raciocínio, convém lembrar o lugar ocupado por Orestes na genealogia da mitologia grega, desenvolvido na Orestéia de Ésquilo (2004)*.

Orestes era filho de Clitemnestra e Agamenon, rei de Micenas ou Argos, e irmão caçula de Ifigênia, Electra e Crisótemis. Clitemnestra e seu amante, Egisto, mataram Agamenon quando este voltava da expedição contra Tróia. Único que poderia vingar o

\footnotetext{
${ }^{9}$ STEIN. La mort d'Oedipe, 1959. Também STEIN. Prefácio de La mort d'Oedipe, in: MEZAN, Renato. (Org.). O psicanalista e seu oficio, 1988a. p. 191-197. Ver também: STEIN. As erínias de uma mãe: ensaios sobre o ódio, 1988b, p.33-65; SAFOUAN. Será o Édipo universal? In: introdução a uma teoria do sujeito, 1979, p.120-130. . Estudos sobre o Édipo:

${ }^{10}$ MUSIL, GW, v. 3, p. 671-1022; HSQ, "Rumo ao reino dos mil anos". [Os criminosos]. Livro Segundo, terceira parte, 2006. p. 705-1077.

* Ver Adendo imprescindível no final deste capítulo.
} 
crime, Orestes foi enviado, a mando de Electra, para a Fócida, pois suspeitava que o amante de sua mãe pretendia matá-lo também. Ali cresceu em segurança na corte de Estrófio e o filho deste, Pílades. Ao se tornar adulto, em obediência às ordens de Apolo e aos apelos de Electra, Orestes matou a mãe e Egisto. Perseguido pelas Erínias, refugiou-se no santuário de Apolo, em Delfos. Julgado por seu crime em Atenas, o voto da deusa Atena desempatou o resultado a seu favor. Novamente por ordem de Apolo, Orestes partiu para a Táurida a fim de roubar a estátua de Artemis e devolvê-la à cidade de Atenas. Preso com Pílades, foi condenado a ser sacrificado à deusa, mas sua irmã Ifigênia, sacerdotisa de Ártemis, reconheceu-o e fugiu com ele e com Pílades, levando a estátua da deusa. Salvo, herdou o reino de Agamenon, a que anexou Esparta e Épiro, depois do casamento com Hermíone, filha de Menelau e Helena. Morreu aos noventa anos picado por uma serpente. Assim como Ésquilo, Musil parece estar assim se referindo à uma sociedade construída sobre crimes hediondos, cuja justiça é corrupta e usa a prerrogativa de autoridade mística para a decisão da sentença.

O que se quer notar com a provocação posta por Musil aos psicanalistas, cujo ensaio reflete o que seria o Livro Segundo de $O$ homem sem qualidades é como, de forma precursora, Musil antevê que o Édipo já não é o protótipo a caracterizar o homem da sociedade contemporânea. Diferentemente de Édipo, ele reconhece no personagem Orestes aquele que melhor descreveria o anti-herói matricida, o homem que se encaminha, de foma irresponsável, sem qualquer sentimento de culpa, que possa levá-lo a se cegar, perante o tribunal da própria consciência, quanto aos crimes cometidos por ele e pelos seus ancestrais. Assim perdoado, por expiar as suas culpas, Édipo seria conduzido finalmente ao lugar sagrado, o Bosque das Eumênides. Entretanto, Musil destaca um outro personagem que haveria de ser o seu sucessor na Cultura. Orestes seria mais adequado para identificar o homem da modernidade tardia, como aquele que se estrutura sobre a própria falta de qualidades, como falta de caráter. Identificada com os seus algozes e ao mesmo tempo vítima do ódio que está na base da Cultura, a humanidade estaria condenada a ser conduzida por criminosos no novo milênio. ${ }^{\text {i }}$

Musil parece ressaltar as afinidades e diferenças essenciais entre o indivíduo, como ser vivo, e os entes de ficção nos quais o próprio indivíduo crê. Tais diferenças são tão importantes quanto as afinidades para criar o sentimento de verdade, que é a 
verossimilhança. A tentativa de investigação sumária das condições de existência essencial do personagem, como um tipo de ser, mesmo fictício, serve para descrever, do modo mais empírico possível, a percepção do indivíduo com seu semelhante.

Ao se abordar o conhecimento direto das pessoas, um dos dados fundamentais do problema é o do contraste entre a continuidade relativa da percepção física, em que se funda o conhecimento, e a descontinuidade da percepção que parece freqüentemente romper a unidade antes apreendida. No ser uno que a vista ou o contato nos apresenta, a convivência psicológica mostra uma variedade de modos de ser, de qualidades contraditórias.

A primeira idéia que ocorre, quando se reflete sobre isso, é a de que tal fato se sucede porque o indivíduo não é capaz de abranger a personalidade do outro com a mesma unidade com que ele é capaz de abranger a sua configuração externa. Disso é possível concluir que tal diferença é devida a uma diferença de natureza dos próprios objetos da nossa percepção. De fato, é possível se pensar que o primeiro tipo de conhecimento se dirige a um domínio infinito, pois a sua natureza é oculta à exploração de qualquer sentido e não pode, em conseqüência, ser apreendida numa integridade que essencialmente não possui. Daí ser possível se pensar que a noção a respeito de um ser, elaborada por outro ser, é sempre incompleta, em relação à percepção física inicial. E que o conhecimento dos seres é fragmentário.

Essa impressão se acentua quando se investigam os fragmentos do ser, dados por uma conversa, um ato, uma seqüência de atos, uma afirmação, uma informação. Como um desses fragmentos, mesmo considerado um todo, uma unidade total, não é una, nem contínua. Permite um conhecimento mais ou menos adequado ao estabelecimento das condutas, com base num juízo sobre o outro ser; permite, mesmo, uma noção conjunta e coerente deste ser; mas essa noção é oscilante, aproximativa e descontínua. Os seres são, por sua natureza, misteriosos, inesperados. Daí a psicologia ter sistematicamente ampliado e investigado no último século as noções referentes aos mecanismos inconscientes, que explicariam o que há de insólito nas pessoas que se reputa conhecer, mas que são constantemente surpreendentes, como se uma outra pessoa entrasse nelas, invadindo inesperadamente a sua área de essência e de existência. 
Tal constatação, mesmo que feita de maneira não-sistemática, é ressaltada de antemão pelo próprio Musil quando ele adverte o leitor de que "embora maliciosa e unilateral, [sua] crítica não reivindica a objetividade científica". ${ }^{11}$ Ela é fundamental em toda a literatura moderna e se desenvolveu antes das investigações técnicas dos psicólogos; depois se beneficiou dos resultados destas. A noção de mistério dos seres, produzindo as condutas mais inesperadas, sempre esteve presente na criação artística, e, antes, nos mitos, de forma mais ou menos consciente. Mas só foi conscientemente desenvolvida por certos escritores do século XIX em diante, como tentativa de sugerir e desvendar o mistério metafísico da própria existência.

A partir de investigações metódicas em psicologia, e mais extensivamente em psicanálise, essa investigação ganhou um aspecto mais sistemático e voluntário, sem com isso ultrapassar necessariamente as grandes intuições dos escritores que iniciaram e desenvolveram sua visão de literatura. Nas obras de escritores como Baudelaire, Nerval, Dostoievsky, Proust, Joyce, Kakfa, Machado de Assis, Guimarães Rosa, Pirandello e tantos outros do mesmo porte, concorrem de modo direto e indireto as concepções filosóficas e psicológicas voltadas para o desvendamento das aparências no homem e na sociedade, revolucionando o conceito de identidade, tomada em si e com relação ao seu meio. É o caso, entre outros, do marxismo e da psicanálise, que, como os autores mencionados, atuam na concepção de homem, e, portanto, de personagem, influindo na própria atividade criadora das artes, e aqui, de acordo com tais argumentos, no romance musiliano. O personagem passa a ter o estatuto de vivo, e mais vivo do que o seu criador, o seu tempo, as formas como a cultura o forja, promove ou esquece.

Tais considerações visam mostrar que o romance, ao abordar os personagens de modo fragmentário, nada mais faz do que retomar, no plano da técnica de caracterização, a maneira insatisfatória e incompleta, com que se elabora o conhecimento psicológico dos indivíduos. Na vida, é possível se estabelecer uma interpretação de cada pessoa, a fim de se conferir certa unidade à sua diversificação essencial, à sucessão dos seus modos de ser. No romance, o escritor estabelece algo mais coeso, mais variável, que é a lógica do

\footnotetext{
${ }^{11}$ MUSIL, GW, cap. 16, p. 56-60; HSQ, Uma misteriosa doença de época. Livro Primeiro. cap. 16, p. 76.
} 
personagem. Daí poder se afirmar que o personagem é mais lógico, embora não mais simples, do que o ser vivo.

Musil consegue justamente aumentar o sentimento de dificuldade do ser fictício, diminuindo a idéia de um esquema fixo com o seu romance $O$ homem sem qualidades. $\mathrm{O}$ personagem decorre de um extenso trabalho de escolha do autor, tal como o atestam os seus diários e anotações diversas. Essa combinação de escolhas permite que ele crie uma margem de experiência, de maneira a criar o máximo de complexidade, de variedade, com um mínimo de traços psíquicos, de atos e de idéias. O homem sem qualidades é complexo e múltiplo porque o romancista pode combinar com perícia os elementos de caracterização, de múltipla personalização, cujo número é sempre limitado se comparado com o número de traços humanos que se mesclam, a cada instante, no modo de ser das pessoas à sua volta.

Quando se teve noção mais clara do mistério dos seres, renunciou-se ao mesmo tempo, à psicologia literária, e tanto quanto nos modelos de pesquisa psicológica com indivíduos vivos, a uma geografia precisa de caracteres. Musil é justamente um autor que se permite conferir a seus personagens uma natureza aberta, sem limites para o leitor. Mesmo assim, tal natureza é uma estrutura limitada, obtida não pela admissão caótica de um sem-número de elementos, mas pela escolha de alguns elementos, organizados segundo certa lógica de composição, que cria a ilusão de infinitas possibilidades para a sua personalização. A idéia, ao escolher tal obra como objeto de investigação, é que ele cria uma tela, que pode ser mais ou menos extensível, comunicando o sentimento de um espaço sem barreiras aos diversos campos de conhecimento.

- Crise ética na modernidade tardia

Em seu estudo sobre a influência do niilismo que perpassa a literatura moderna, Magris (1994) destaca o final de um dos inúmeros confrontos verbais entre Ulrich, o protagonista de $O$ homem sem qualidades, com seu amigo de infância 
Walter e a esposa de Walter, Clarisse, quando ela tira sua aliança e comenta sobre sua forma redonda.

Eu acho isso importante - disse ela - que em todos nós haja uma impossibilidade. Isso explica tantas coisas. Enquanto ouvia vocês dois, tive a impressão de que, se nos pudessem abrir ao meio, talvez nossa vida toda parecesse um anel, apenas algo que circunda alguma coisa. - Ela havia tirado sua aliança de casamento um pouco antes, e espiou, pela abertura, a parede iluminada. - Quero dizer, no meio não há nada, mas o anel dá a impressão de que só isso é que lhe interessa. ${ }^{12}$

Esse, porém, se revela mais do que um artifício para mudar o assunto de uma conversa que não está indo a lugar algum. Contudo o que se segue não é uma daquelas declarações alusivas e vagamente perturbadoras tão típicas daquela personagem, uma fervorosa convertida a Nietzsche, cujas paráfrases recorrentes a esse pensador indicam nem tanto sua apreciação filosófica quanto o desequilíbrio mental e insanidade iminente de Clarisse. Entre outros aspectos ressaltados por Magris, o que parece apenas um incidente a expor a doença que espreita a jovem mulher, causada pelos perigos de uma recepção excessiva à leitura de Nietzsche, esse talvez seja o mais incisivo diagnóstico do apuro que confronta virtualmente todos os atores principais na crônica imaginativa de Musil da vida na monarquia austro-húngara de 1913. Irritada com a sensação de estupidez causada pelas "aspirações pequeno-burguesas" de seu marido, quando estas mais uma vez surgem na conversa com Ulrich, Clarisse se acha refletindo sobre o que ela chama de impossibilidade da existência humana, que, subitamente, vê simbolizada na aliança de casamento. Entretanto, o que ela tem em mente não é seu casamento instável com o frustrado e ressentido Walter: é o formato do anel que incendeia sua imaginação, o fato de ser apenas uma coisa que gira em volta de outra. Ao olhar pelo anel como que por um telescópio insatisfatório, Clarisse começa a enxergá-lo com perplexidade

\footnotetext{
${ }^{12}$ MUSIL, GW, cap. 84, p. 369; HSQ, cap. 84, p. 400. Sobre esse tema ver: MAGRIS. L' anello di Clarisse: Grande stile e nichilismo nella letteratura moderna, 1984; especialmente: Dietro quest'infinito, p.212-255.
} 
como o símbolo para uma vida inteira. Como ela explica: não há nada dentro, e ainda assim parece como se isso fosse precisamente o que mais importa.

A representação da vida como um anel - uma tira fina de metal precioso circulando o espaço vazio - não pareceria se sobrepor às imagens sentimentais comuns, tão caras ao marido de Clarisse, se não fosse por sua reviravolta peculiar. Contrário ao que seria de se esperar, não é o ouro ou a prata do anel que constitui seu valor, mas sim o que está dentro dele. Este interior, no entanto, não é nada além de espaço vazio, um vácuo. O que mais importa na vida, sugere Clarisse, é seu vácuo estrutural, o espaço vazio em torno do qual os eventos da vida se cristalizam.

Na narrativa de Musil, este vácuo representa a ética. A experiência ética, como a promessa inefável de felicidade incondicional e uma vida completa vislumbrada em momentos fugazes de iluminação, é apresentada no livro como uma "outra condição", que está destinada a permanecer um buraco negro para a linguagem e para o pensamento.

[Em 1923,] há uma série de rascunhos não publicados contendo o relato mais completo de Musil, da crise ideológica da cultura moderna. Apesar de sua qualidade fragmentária e inacabada, esta é também a tentativa mais segura de uma declaração abrangente sobre sua visão de tópicos como epistemologia, natureza humana, capitalismo e misticismo. Sua crítica à ideologia, (e seu entendimento dela como a experiência humana mais modeladora), é central [no ensaio "O alemão como sintoma"] quando ele conclui a sua mais completa avaliação da "outra condição". ${ }^{13}$

A "outra condição" é definida em, "O alemão como sintoma", como experiência ética. Porém essa se apresentaria como vácuo delimitado pelas circunstâncias não-essenciais, insignificantes da vida. Como o homem sem qualidades mais tarde aponta para sua irmã Ágata, tal questionamento reaparece com a metáfora de um anel: "há um círculo de perguntas que tem um diâmetro enorme, e

\footnotetext{
${ }^{13}$ MUSIL, "The German as symptom" [1923]; PS, 1990. p. 150-192; especialmente, p.150. (Nota dos tradutores ingleses, Pike e Luft.)
} 
não tem centro: e todas essas indagações dizem a mesma coisa: 'Como vou viver?", 14

Ao escolher a imagem de um círculo sem centro, Ulrich também procura esclarecer o paradoxo inerente à busca moderna por coordenadas morais. Em sua caracterização, a forma geométrica do círculo, apesar de muito estendida, está razoavelmente bem definida por uma miríade de perguntas individuais girando em volta da busca por uma boa vida. E ainda assim o espaço dentro do círculo - aquele espaço do meio de onde todos esses questionamentos serão endereçados - resulta em uma impossibilidade lógica.

O círculo como figura geométrica sugere uma classe de objetos estruturalmente providos de um centro. Nesse caso, o círculo cujo perímetro é formado pela busca por coordenadas morais, na verdade, padece de um centro, em um desafio patente às propriedades lógicas que se esperariam dele. Essas imagens de um círculo sem centro, ou de um anel cujo atributo mais precioso é o espaço vazio que encerra, são tão ostensivamente repletas de contradições que provocam todo um conjunto de questionamentos: o vácuo é normal ou é uma anomalia? Sempre foi dessa forma, ou alguma vez houve algo ocupando o lugar do nada do presente? E, se o círculo alguma vez esteve repleto com uma substância ética perdida, para onde foi essa substância e o que causou seu desaparecimento? Deverá o vácuo ser preenchido novamente? Essa é ainda uma proposição viável? Se não, o que vem depois? Esses questionamentos capturam a experiência da modernidade enquanto essa se revela em modernismo estético.

A idéia de disfunção e malformação sugerida pela metáfora de um círculo sem centro reverbera com a análise da crise cultural e ética que se tornou um artigo de fé da cultura germânica na passagem do século XIX para o século XX; manteve seu status ao longo das revoltas da Primeira Guerra Mundial - o período Weimar, e do triunfo do totalitarismo, tanto na Alemanha quanto na Áustria, chegando à sua

\footnotetext{
${ }^{14}$ MUSIL, GW, cap.24, p. 98-103; HSQ. Propriedade e cultura; a amizade de Diotima com o conde Leinsdorf, e o ofício de harmonizar convidados famosos com a alma, p. 119-124.
} 
culminância na primeira década do século XXI como verdadeira crise existencial humana exposta nas diversas faces do fundamentalismo atual.

A resposta de Musil a esses questionamentos é diferente da resposta modernista apresentada por seus contemporâneos. Para se ter certeza do que "devo fazer", as personagens de Musil em O homem sem qualidades são primariamente confrontadas com aquela "retirada da realidade", que Jean-François Lyotard colocou no coração da experiência da modernidade. ${ }^{15}$ Referindo-se à passagem do capítulo "O dissimulado sorriso da ciência, ou primeiro encontro detalhado com o mal"16, Lyotard refere-se ao pessimismo que alimentou a geração do início do século XX em Viena. Musil, tanto quanto Kraus, Hoffmannsthal, Loos, Schönberg, Bloch, e os filósofos Mach e Wittgenstein desenvolveram a consciência e a responsabilidade artística da deslegitimação. A força de tal posição é corroborada por Wittgenstein na sua investigação dos jogos de linguagem, diante da perspectiva de um outro tipo de legitimação do conhecimento, que não fosse apenas medida pelo desempenho. A nostalgia do grande relato está perdida para a maioria das pessoas. Porém Lyotard crê que "de forma alguma se segue a isto que elas estejam destinadas à barbárie" (2006, p.74). O que as impede disso é que elas sabem que a legitimação não pode vir de outro lugar senão de sua prática de linguagem e de sua interação comunicacional. Valendo-se da metáfora que Musil utiliza em um jogo de palavras irreproduzível, Lyotard verifica que, em face de qualquer escrúpulo moral, os homens de ciência, sem ironia, "sorriem dentro da barba" (alem. In den Bart Lächelns) ${ }^{17}$. Porém, tal como Musil teria notado, Lyotard adverte sobre a dura sobriedade do realismo.

Desprovida de suas muletas metafísicas tradicionais - as noções tradicionais de eu, sujeito, história, comunidade, Deus, dentro da tradição filosófica ocidental - a vida se recolhe do olhar humano que busca apreendê-la e interpretá-la e cai por terra em uma pilha de fragmentos. O âmago interior da existência humana, seu próprio centro e substância, torna-se um vácuo, uma idéia irrepresentável. Como em Diotima, outra das protagonistas de Musil, esse âmago envolve a sua busca por um

\footnotetext{
${ }^{15}$ LYOTARD, 2006, p. 69-76.

${ }^{16}$ MUSIL, $G W$, cap.72, p.301-307; HSQ, O dissimulado sorriso da ciência, cap.72, p.329-335.

17 MUSIL; HSQ, (Nota dos tradutores brasileiros, Luft e Abbenseth, p. 329.)
} 
símbolo que fará manifestar o sentido histórico-mundial da monarquia Habsburgo no século XX. Tudo que é apresentável são as partes estilhaçadas da vida, como os especialistas convocados ao salão de Diotima demonstram. Confiados à tarefa de articular e reavivar a idéia de nação austríaca, cada um é perdidamente preso na gaiola de seu conhecimento especializado, como asteróides que orbitam um buraco negro de sentido. Mas o romance de Musil oferece mais do que esse diagnóstico comum da condição moderna. Ele se propõe a interrogar a natureza do vácuo, seguindo um caminho que se aproxima do que Lyotard (2006) descreveu como sensibilidade pós-moderna, que, longe de representar um sucessor qualitativamente diferente do modernismo, alcança o próprio coração da era modernista, tornando seu ritmo acelerado.

As narrativas alemãs mais familiares do modernismo - exemplificadas em textos paradigmáticos como A montanha mágica de Mann (1980); e Os sonâmbulos de Hermann Broch (2003) - tendem a considerar este vácuo a resultante de um colapso de certezas antigas que supriam as bases para o conhecimento e para a autoridade, para a política e para a ciência, na civilização ocidental. Esse colapso, que havia sido preparado por processos épicos de racionalização, secularização e especialização, em funcionamento nas sociedades ocidentais desde pelo menos a Renascença, foi o derradeiro gatilho dos cataclismos históricos do século XX: duas guerras mundiais, o crescimento do totalitarismo, e a sua versão mais monstruosa, a indústria serial da morte, concretizada na sua forma mais perversa no Holocausto.

$\mathrm{Na}$ segunda metade do século XX, outros males vieram reforçar esta narrativa: a ameaça atômica, o estupro econômico dos chamados países emergentes, a destruição do meio ambiente, a manipulação da tecnologia genética. De maneira a reagir a essas evoluções sinistras, a narrativa musiliana revela aspectos críticos voltados para a análise social, isto é, como a sociedade deve restabelecer os velhos sistemas de coordenadas, opção que parece a cada dia mais implausível, dada a velocidade estonteante dos avanços e inovações que incessantemente alteram a fisionomia das sociedades pós-industriais, ou formular novos pontos de referência e visões que substituirão os antigos, tal como "reconceitualizar o projeto de 
modernidade" para se falar de Jürgen Habermas. ${ }^{18}$ Caso contrário, a civilização ocidental - um negócio mundial na era de globalização e integração compulsiva mergulhará no caos e anarquia produzidos pela busca ilimitada das pulsões humanas mais básicas: ganância, egoísmo, ódio, fome de poder, inveja, ressentimento.

Uma narrativa modernista competidora, apesar de bem menos popular, pinta um quadro bem diferente. Insiste em ver o vazio ético no coração da experiência moderna em outros termos que não os do fim de sistemas de valores e visões universais da boa vida, se os males contemporâneos forem confrontados efetivamente. Essa é a visão encabeçada por Musil, dentre outros, como aquela na qual Lyotard (2006) reconheceu a projeção tardia, nomeadamente pós-moderna, do modernismo.

Em um autêntico espírito nietzschiano, esse discurso contabiliza as alegadas bases perdidas da civilização ocidental. Em termos de construções históricas, foram estas que ajudaram as sociedades ocidentais a lidar com o vazio que caracteriza a condição humana, justamente por ocultá-lo. A condição moderna, então, se dá sobre a percepção desanuviada desse vazio. Mais especificamente, sobre a impossibilidade de se apresentar uma base duradoura ou unidade da existência humana, que somente é perceptível como artifício de uma harmonia inefável, enquanto se anuncia em momentos fugazes de felicidade.

Da Crítica da faculdade do juízo, de Kant, Lyotard contabilizou a impossibilidade de se articular tal experiência ao apontar para a discrepância estrutural entre as faculdades humanas, principalmente entre a faculdade de conceber e a habilidade de apresentar, ou, nos termos de Kant, a oposição entre o intelecto e a imaginação. É esta lacuna constitutiva existente entre as faculdades que faz do vácuo um vazio e não a perda de uma substância original ética. A arte moderna é, então, o

\footnotetext{
${ }^{18}$ HABERMAS, Modernity versus Postmodernity [1979]. New German Critique 22, 1981, p. 3-14. Ver também: HABERMAS, 1990, p.11-12. "Moderação justificada", in: O futuro da natureza humana. Existem respostas pós-modernas para a questão sobre a "vida correta"?, 2004, p.3-22. Ver, especialmente: BECK, La sociedad del riesgo: hacia uma nueva modernidad, 1998; GIDDENS, As conseqüencias da modernidade, 1991; LATOUR, Jamais fomos modernos, 2005.
} 
próprio esforço de se tornar visível algo que pode ser concebido e que não pode ser visto ou tornado visível; ela se dá sobre a tarefa impossível de se apresentar o inapresentável.

Como enfatiza Lyotard, há possíveis reações para esse enigma moderno. A resposta modernista própria permite ao inapresentável ser proposto apenas como conteúdos ausentes. Como sintoma, tal enigma se mantém preso a uma nostalgia pela presença de algo que melancolicamente faz o olhar se voltar para trás e cede, mesmo que involuntariamente, como reminiscência, ao desejo de certezas e bases passadas. A resposta mais madura, propriamente pós-modernista, por outro lado, perdeu a nostalgia pelo inatingível e pode então colocar sua ênfase no poder da faculdade de conceber, diante do júbilo que resulta da invenção de novas regras do jogo. ${ }^{19}$ A narrativa de Musil em $O$ homem sem qualidades está deliberadamente aninhada entre essas duas respostas, "a tentativa de limpar o quadro e o artifício de uma síntese," como o próprio autor resumiu o objetivo de seu projeto. ${ }^{20}$

Ao mencionar a distinção feita por Lyotard entre o modernismo estético e o pós-modernismo, pode-se focar a natureza peculiar do modernismo de Musil, nos modos em que ele difere de outros paradigmas modernistas contemporâneos, e nas razões pelas quais sua obra parece cada vez mais interessante nos dias de hoje, em um tempo no qual os ouvidos têm se tornado, cada vez mais, surdos à mensagem modernista familiar descrita acima. O que interessa em Musil, em particular, é a investigação do vácuo que reside no coração da experiência da modernidade, da forma como é recontada em seus ensaios, obras literárias, diários e anotações diversas. De maneira mais coerente, tal investigação é extensivamente desenvolvida em seu ambicioso experimento de pensamento, O homem sem qualidades.

O romance inacabado de Musil conta a história da busca de um indivíduo por uma "outra condição", o que pode ser uma reação contra a chegada do ora excitante, ora preocupante caleidoscópio da vida moderna na Áustria, um ano antes da Primeira Grande Guerra. Tal busca se origina na experiência pessoal de divisão

\footnotetext{
${ }^{19}$ LYOTARD, Os relatos da legitimação do saber. In: . A condição pós-moderna, 2006. p. 58-68.

${ }^{20}$ MUSIL, GW, v.7, p. 942. (Entrevista com Oskar Maurus Fontana). (Tradução nossa.)
} 
interior do homem sem qualidades, o protagonista emblemático do romance musiliano, diante da fragmentação de um mundo moderno descentralizado, destroçado por uma proliferação incontrolável de esferas de vida e culturas de especialistas. Nesta "outra condição", o homem sem qualidades acredita vislumbrar uma base ética ininteligível, que reside na crença pela unidade fundamental da vida humana. Suas tentativas de elevar tal crença ao nível de experiência ordinária e transformá-la em um princípio de conduta estão destinadas ao fracasso. Mesmo assim, esse fracasso carregaria uma valência positiva, de acordo com os planos de Musil para o romance. Ele retrata a "outra condição" como um vazio inerente à condição humana ao denunciar a violência espreitando em todos os esforços direcionados ao preenchimento sub-reptício desse vazio com uma visão absoluta da boa vida.

Em alguns rascunhos da conclusão do livro, a violência é disparada pelas manobras descuidadas da Ação Paralela e realizada no apocalipse da Primeira Guerra Mundial. Dessa forma, o experimento de Musil visava não apenas apontar o outro lado da nostalgia por preenchimento do vazio interno que ainda molestava sua época. Ele visava também suplantar a mal-ocultada intolerância pela diferença, expor a violência do desejo de impor forçosamente coerência e consenso, revelar o impulso de forçar as perspectivas incomensuráveis do mundo moderno na camisade-força da condição sociopolítica das ideologias aparentemente unificantes.

Tal atitude é posteriormente analisada por Marcuse em sua obra L'homme unidimensionnel (1968). É explicitada em Musil pela consciência que se expõe na obra O homem sem qualidades como apreensão do "retorno ao terror", servindo, nesta tese, às posições de Marcuse como plano paralelo à demonstração. Lyotard (2006) explicitamente menciona o trabalho de Musil em seu debate sobre a queda das grandes narrativas. Ele coloca este autor dentro do que nomeia de o horizonte do pessimismo vienense, no qual inclui, indiscriminadamente, Hofmannsthal e Kraus, 
Loos e Shoenberg, Mach e Wittgenstein. Significantemente, Lyotard não parece desviar-se para uma familiaridade direta com $O$ homem sem qualidades. ${ }^{21}$

É o advento do terror que Musil analisa em primeira mão durante a formidável ascendência do totalitarismo fascista nas décadas de 1920 e 1930. Em Marcuse, tal apreensão é exposta pela paralisia da crítica como efeito de uma sociedade unidimensional, sem oposição. De acordo com a visão marcuseana, na falta de agentes e veículos de transformação social, a crítica é levada a recuar para um alto nível de abstração psicológica, não havendo assim campo no qual teoria $\mathrm{e}$ prática, pensamento e ação se harmonizem. De tal maneira, mesmo a análise mais empírica das alternativas históricas parece especulação irreal, indicando o seu caráter utópico e transformando a adesão a ela em uma questão de preferência pessoal ou grupal. ${ }^{22}$

O apelo da marca peculiar de modernismo musiliano, então, reside em seu convite para reconhecer o vácuo como constitutivo da condição humana e apreciá-lo como uma oportunidade para repensar a ética na modernidade. Situando a solidão moderna como a condição que obriga cada homem, como se fosse um primitivo, a recriar seu próprio universo ex nihilo e inventar a própria idéia de sociedade, a única ordem que se poderia encontrar seria heurística, postulada pelo indivíduo diante do caos duradouro e inflexível de valores. O homem sem qualidades procura, doravante, descobrir a destrutividade que lhe é inerente e que se reflete como condição inexorável à sua volta, como uma "outra condição". Tal procura afirma o poder criativo - ainda que, em última instância, condenado - do homem.

\footnotetext{
${ }^{21}$ LYOTARD, 2006, cap. 11. Cf. nota 74, p.136, as citações do romance de Musil originam-se de um comentário de J. Bouveresse.

${ }^{22}$ MARCUSE, LHU, 1967a, p. 26-27.
} 
- A preparação do inimigo oculto

$\mathrm{O}$ conceito de moderno engloba em seu bojo um conjunto de lealdades específicas para se definirem em relação à história, à função e à estrutura cultural, em seqüência temporal. Não se poderia compreender que tal conceito tivesse utilidade, pois o termo moderno deve derivar seu sentido em relação negativa daquilo que, como história, o precede. Porém, no campo da arte, os expressionistas assumiram a tarefa de superação da história no ponto em que os exploradores do fim do século XIX a haviam deixado. Avançando em uma viagem interior até o reino da ansiedade ou da ira existencial crua, onde todas as estruturas anteriores pareciam falsificações fenomenológicas, o objeto de visão apocalíptica não era o passado nem a vida moderna, e sim a existência humana como tal. $\mathrm{O}$ movimento expressionista aponta para uma questão que ultrapassa o sentimento nacional para situar as identidades a partir de uma fronteira geográfica. Aqueles que o encabeçaram não se sentiam austríacos ou germânicos, mas humanos.

O historiador Karl Schorske (2000, p.175) ressalta que onde representantes do movimento expressionista pediam a retirada de fronteiras entre a Áustria e Alemanha, sua intenção não era reunir ou salvar as Alemanhas, mas remover um símbolo do Estado. Não se sentindo integrado na geração expressionista, Musil não parecia ignorar o conflito edipiano suscitado por seu contemporâneo Freud, desconsiderando sua importância como no centro de toda a existência social. Sua visão, ao contrário, incluía tal conflito numa realidade histórica proclamada morta. Schorske observa:

Onde o fin-de-siècle recuperava a pulsão sexual, Eros, os expressionistas recuperavam a pulsão de morte, tanatos. A ira metafísica dos expressionistas era talvez grande demais para encontrar foco na revolta edipiana ou no ressentimento geracional. $\mathrm{Na}$ verdade eles amavam e respeitavam (...) seus antepassados. (...) Talvez aceitassem os mais velhos como modelos porque eles é que haviam dissolvido a herança cultural anterior, enquanto os jovens 
começavam com a modernidade como a premissa para completar a trajetória de alienação dos mais velhos. Tendo em vista o conteúdo de suas idéias, o ressentimento geracional tinha pouco lugar. Robert Musil, numa inscrição para uma futura autobiografia, sugere a distância da cultura de seu grupo de uma autodefinição edipiana: 'meu pai era mais moço do que eu'. ${ }^{23}$

De maneira precursora, Musil consegue delinear a visão do preparo social e psicológico para a guerra, descrevendo-a em uma metáfora como Ação Paralela. A guerra é então travada por grupos sociais, os quais coabitam numa condição, por um lado mobilizada, mas imobilizada, por outro. Para a conduta dos assuntos cotidianos, os grupos sociais são integrados, unidos por processos desde a simples troca de mercadorias, serviços, ou interesses os mais diversos como favores, simpatias ou antipatias pessoais. Tais aspectos proporcionam continuidade e confiança entre os indivíduos, mantendo-se o aparato de coesão social. Mobilizados, esses grupos podem ser preparados para um esforço extra, para uma produção superior às necessidades da vida diária. Em tempos de guerra, as capacidades e sentimentos psicológicos, latentes para a ação, são postas em prática com a ajuda da capacidade que a sociedade tem para o amor e o ódio, fazendo ressurgir a incapacidade para a superação das disputas entre indivíduos, na sua expressão inter ou intragrupal.

Em O homem sem qualidades, Musil revela a preparação latente para encontrar o "inimigo", seja nos aspectos que envolvem a sua caracterização, seja no modo da dialética da organização da sociedade. Ele chega a comparar o mundo tribal - onde o inimigo geralmente está fora do sistema social - com o mundo relativamente independente da modernidade, quando o inimigo é, por definição e por necessidade dialética, parte, ao mesmo tempo que também não é parte da configuração social "amistosa" que age contra ele numa guerra.

O inimigo nos Estados modernos está ligado ao sistema social pelo comércio, por diversos laços culturais, por relações diplomáticas e, por que não, pelos laços afetivos que envolvem os grupos e indivíduos em certas disposições psicológicas

${ }^{23}$ SCHORSKE, Pensando com a história, 2000, p.175. 
conscientes ou inconscientes, mais ou menos arraigadas, dispostas em cadeias destrutivas de impulsos e atividades. O primeiro passo belicoso de rompimento de relações testemunha essa ambigüidade. O experimento da I Grande Guerra revela que, na modernidade, o inimigo fazia parte do sistema social dos países antagônicos e, ao mesmo tempo, não fazia parte dele. O inimigo se revelou como uma das invenções sociais mais virulentas da civilização moderna, pois se recuarmos até as histórias antigas perceber-se-á que as guerras anteriores à modernidade muitas vezes, embora nem sempre, eram travadas contra inimigos que não faziam parte do sistema social constituído pelas partes beligerantes.

Os inimigos da Grécia e Roma antigas freqüentemente eram meros objetivos da sua arrogância e rapina imperiais, sem nenhuma relação social prévia com a Grécia e Roma. Depreende-se que o homem sem qualidades seja o efeito de uma das realizações do mundo moderno: a direta incorporação da guerra ao sistema social, ao mesmo tempo em que define o inimigo como situado fora dele. Musil descreve o aspecto básico da guerra moderna que compreende certa psicologia: ela tem lugar dentro de uma economia política de mútua dependência e, portanto, todas as vitórias são derrotas para o povo - pois este tem suportado o fardo da morte pela tribulação, devendo suportar o fardo econômico da compaixão - e representam vitórias para os vencidos, pois eles muitas vezes vêem suas economias recuperadas como se não houvesse um preço inestimável a ser pago. 


\section{[* AdENDO IMPRESCINDÍvEL AO PRIMEIRO CAPíTULO]}

Em seus estudos à Orestéia de Ésquilo, Torrano (2006) a apresenta como um dos mais belos e ricos documentos literários da permanência e transformação do pensamento mítico arcaico dentro do horizonte político e do contexto cultural de Atenas no século V a.C. Essa obra expõe o pensamento político relativo às relações de poder e à questão da Justiça na pólis, mediante o uso sistemático de imagens e noções míticas legadas pela tradição. Em Agamêmnon, o coro de anciãos argivos, revela a perplexidade e angústia ante as contradições do presente, rememora a partida do grande exército coligado contra Tróia e interpreta os sinais divinos que acompanharam a partida. A terrivel clareza das reflexões sobre justiça e poder permitiria aos anciãos prever o curso dos acontecimentos, se a dor não os impedisse. Entre os extremos da sacralidade e da violência, move-se a doutrina do coro sobre a hibris e analisam-se os crimes e a guerra dentro dos horizontes e da perspectiva política democrática.

Em Coéforas, Ésquilo ressalta que o similar não é idêntico. Idêntico é o mesmo, em qualquer sentido: similar é, ao mesmo tempo, idêntico e diferente, o mesmo e outro. Mas o que há de idêntico, nessa similaridade entre o que se vê nessa tragédia e o que se lê nesse diálogo filosófico de Platão? Admitida a hipótese da correlação mítica de Theoi ("Deuses") e a noção filosófica de ideai/eide ("idéias"/"formas inteligiveis"), aos Deuses Olímpios pertencem os diversos domínios do ser, por partilha de Zeus e por participação em Zeus; aos deuses ctônios, filhos da Noite imortal, pertencem os diversos domínios da negação de ser e da privação de presença. Que unidade os une? Eis o que se põe em aporética questão e assim se mostra em cena terrivel e sublime, nessa tragédia. Interpelado por Apolo em diversas circunstâncias, e em Delfos pela voz do oráculo, a Orestes é o dever filial mesmo que impõe de modo irrecusável a execução da pena de morte contra a sua própria mãe. Os caminhos a serem percorridos por Orestes nessa aporia existencial mostram o nexo necessário, múltiplo e ininterrupto entre os diversos domínios de Phoîbos Apóllon, o deus profeta de Zeus em Delfos, e os não menos diversos domínios das sombrias e subterrâneas Erinies, Deusas filhas da Noite imortal.

Eumênides, a última parte da trilogia de Ésquilo, representa a veemente oposição, feita de repulsa e de exclusão recíprocas entre os deuses Apolo e Erínies. Esta implica uma unidade, feita de necessidade e de imanência recípocas entre esses Deuses. Em termos políticos, tal tragédia reflete a relação entre as contrapostas concepções de direito e justiça reivindicadas por essses deuses antinômicos. 


\section{SEGUNDO CAPÍTULO}

\section{O que é a identidade de um homem sem qualidades?}

- Distinções terminológicas

A palavra identidade é derivada da raiz latina idem, que significa igualdade e continuidade. A tradição de pensadores que, desde a Antiguidade, procuraram encontrar o seu significado, tem examinado a permanência em meio à mudança e a unidade em meio à diversidade. Mas, no período moderno, a identidade está ligada à ascensão do individualismo. No século XX, a palavra identidade foi divulgada, especialmente nos anos 1950, com a publicação de $A$ multidão solitária (RIESMAN, 1995). Esta obra e outras de teatro como Esperando Godot (BECKETT, 1976), e Ulisses (JOYCE, 2005), documentavam a crescente perda de significado do indivíduo na sociedade de massa e a posterior busca da identidade. Durante o último quartel do século XX, a palavra tornou-se amplamente utilizada em descrições de buscas como a de determinar quem a pessoa é, sobretudo quando examinada como temática relativa às áreas compreendidas pelas ciências sociais, psicologia, filosofia, e mais recentemente pela análise literária, quando ela compreende a compreensão da identidade narrativa.

Nas ciências sociais, o problema da identidade assume duas formas relevantes, a psicodinâmica e a sociológica. A tradição psicodinâmica surge com a teoria de Freud, conforme Psicologia de grupo e a análise do ego, (FREUD, 1921, p.133-147). O conceito freudiano de identificação enfatiza o núcleo de uma estrutura psíquica como tendo uma identidade contínua, embora conflitante. Segundo Lichtenstein (1977, p. 35), essa continuidade é a capacidade de permanência do mesmo em meio a uma mudança constante. Tal idéia é posteriormente desenvolvida pelo psicólogo Erikson (1968), que viu a identidade como um processo localizado no indivíduo e também no interior de sua cultura comunitária. Tal autor crê em um processo que estabelece a identidade a partir de outras identidades como se houvesse um continuum. Para justificar sua teoria, Erikson constrói um modelo baseado em oito estágios de desenvolvimento do homem, de maneira 
que haveria a necessidade psicológica universal de identidade, cabível a um sistema de idéias que proporciona uma imagem de mundo convincente. Seu pressuposto é que a crise de identidade e o momento histórico estão fortemente ligados. Esse autor toma como exemplo disso os efeitos psicológicos da Segunda Guerra Mundial, quando pessoas perderam o senso de igualdade pessoal, de sua raiz cultural, e de continuidade histórica.

- Este é o verdadeiro eu?

Conforme Outhwaite e Bottomore (1996), a tradição psicossociológica que investiga a teoria da identidade surge a partir da teoria pragmática do eu discutida por James, em 1892, e Mead, em 1934. Para James, a identidade se revela quando se pode dizer: "este é o verdadeiro eu". O eu é uma característica humana que permite ponderar de forma reflexiva sobre a sua própria natureza e sobre o mundo social através da comunicação e da linguagem. James e Mead encaram o eu como um processo com duas fases - o eu, que é interior, subjetivo, criativo, determinante e impenetrável; e o eu-mesmo, que é a fase mais conhecida exterior, determinada e social. O eu é reação do organismo à atitude de outros; o eu-mesmo é o conjunto de atitudes organizadas, advindas de outros, e que a pessoa assume, ela própria. É o eu-mesmo que está mais ligado à identidade, ao modo pelo qual chegamos a nos tornar nós mesmos, ele é como objeto que se dá mediante o ato de vermos nós mesmos e os outros.

- A identidade como construção

A identificação é um processo de permissão de nome, de nos colocarmos como nós mesmos em categorias socialmente construídas, e a linguagem nesse processo torna-se crucial. Em A construção social da realidade, Berger (1983, p. 228-247.) descreve a identidade como uma construção pessoal encarada como "socialmente transformada". As abordagens sociológica e psicodinâmica partem da premissa de que há o mundo interior e 
o exterior, porém suas ênfases diferem. O esforço para definir o ego está ligado ao modo como uma comunidade constrói concepções de pessoas e da vida.

O modo como as idéias sobre identidade se formaram, tendo por base um grande volume de práticas terapêuticas, fez surgir uma forma característica de política. A política da identidade tornou-se cada vez mais proeminente dos anos 1960 em diante, e está particularmente ligada às minorias étnicas e religiosas. Tal modo de descrever a identidade leva em conta o conceito marxista de consciência de classe, no qual um grupo social desenvolve uma percepção autoconsciente de sua posição e se volta para a ação política. Tal construção teórica revela o movimento político com base nas classes, que prevê, por sua vez, um conjunto mais amplo de alianças. Experiências como as da opressão às minorias ganham destaque como foco central para se criar uma identidade grupal distinta. Em torno de tal identidade, desenvolve-se uma forte cultura de apoio e uma análise política voltadas para o desenvolvimento e prática de temas correlatos.

Tais idéias prevêem a dialética cultural, política e identitária, promovendo mudança social. Próximo ao final do século XX, as políticas de identidade emergem como perspectiva voltada para o futuro. As tradicionais distinções entre "esquerda, centro, e direita" parecem um pouco mais dissolvidas, forjando novos alinhamentos (Hall, 2003; Yúdice, 2004).

Do ponto de vista etimológico, Lalande (1993, p. 504-509), distingue a origem latinizada da palavra idêntico: idem é o mesmo. O conceito do idêntico é um dos mais fundamentais do pensamento e é impossível de definir. O termo aplica-se àquilo que é único, ainda que percebido, concebido ou nomeado de maneiras variadas. Aplica-se também a um indivíduo, quando se diz que ele é o mesmo ou idêntico a si próprio nos diferentes momentos da sua existência, não obstante as mudanças, por vezes consideráveis, que podem nele acontecer. Por último, o termo aplica-se a dois indivíduos ou vários objetos que, sendo numericamente distintos, apresentam exatamente as mesmas propriedades ou qualidades. Esta definição opõe-se à de igualdade: características das coisas que podem ser substituídas umas pelas outras, salvas as exceções. 
Poder-se-ia definir diretamente a identidade; é idêntico aquilo que, parecendo múltiplo ou aparecendo sob diversos aspectos, é, na realidade, e no seu fundo, uno. Lalande (1993) aponta se não haverá nessa definição uma dupla dificuldade lógica. A cópula é, por um lado, ela própria a noção de identidade; e a palavra uno, por outro lado, parece ser, neste caso, apenas um sinônimo do termo a definir. Os lógicos modernos esforçaram-se, pelo contrário, para definir a unidade e a pluralidade numéricas por meio das noções mais fundamentais do mesmo e do outro.

- O idêntico não se define pela negação da diferença, assim como a diferença não se define pela negação do idêntico

Há dois conceitos que se implicam e que são a definição fundamental do pensamento. Deve-se notar que idêntico é privilegiado em relação à diferença: a diferença pura é impensável. Talvez se devesse dizer "o mesmo da identidade pura"; uma vez que a diferença é sempre imposta ao espírito como um problema a resolver, enquanto a identidade, pelo contrário, proporciona-lhe satisfação e resolve o problema.

Além das diversas acepções assinaladas, o termo idêntico comporta diversas distinções complementares. Do ponto de vista intelectual, o conhecimento é dito idêntico ao seu objeto pelos escolásticos e pelos metafísicos. É a possibilidade, é a própria inteligibilidade desta identidade na heterogeneidade que o pensamento crítico coloca em questão. Do ponto de vista afetivo e ético, os sentimentos e as vontades são idênticos quando se unem, permanecendo distintos e desfrutando da reduplicação na unidade. Do ponto de vista psicológico e metafísico, não existem seres idênticos uns aos outros, mas um ser permanece igual a si próprio quando, recolhendo continuamente o seu passado no seu presente e resumindo as suas próprias modificações, permanece solidário com o todo da sua tradição e constitui o seu fiere, múltiplo e heterogêneo num esse; unum et idem est. 
Por identidade, entende-se a característica daquilo que é idêntico desde que esta se refira a um indivíduo e ou a um ser assimilável. É sob este ponto de vista que um indivíduo se diz idêntico num segundo sentido, ou que é o mesmo nos diferentes momentos da sua existência.

Kant, em Crítica da razão pura (1989), utiliza a alegoria das "duas gotas d'água", retirando-a da locução popular. Estas só são idênticas se não se lhes exigir nada mais do que serem gotas d'água. Todos os objetos da experiência estão no mesmo caso, por vezes idênticos, porque podem receber a mesma denominação, mas apenas em aparência. A identidade qualitativa é, pois, uma concepção do espírito simplesmente sugerida pela experiência.

O conceito de identidade dos indiscerníveis é um princípio estabelecido por Leibniz em Novos ensaios sobre o entendimento humano (1999) segundo o qual dois objetos reais não podem ser indiscerníveis, ou seja, idênticos, sem se confundirem rigorosamente. Equivale à tese segundo a qual não existe na natureza nada indiscernível, ou idêntico, isso tomado no sentido de identidade qualitativa ou específica. Nesse mesmo sentido, há outro conceito que é a identidade parcial, assim a identidade de uma parte dos elementos que compõem um todo concreto, quer material, quer psicológico.

Por princípio de identidade enuncia-se geralmente sob a forma: aquilo que é, é; aquilo que não é, não é. É preciso efetivamente distingui-lo do princípio de contradição, segundo o qual o contrário do verdadeiro é falso; e do princípio do terceiro excluído, segundo o qual, de duas proposições contraditórias, uma é verdadeira e a outra é falsa.

Fora de seu uso puramente formal, o sentido de princípio de identidade não é sempre entendido da mesma forma. Pode significar que, por um lado, os conceitos lógicos devem ser determinados, fixos; ou seja, que um mesmo termo deve sempre representar um mesmo conceito no decurso de um raciocínio. Por outro lado, que o verdadeiro e o falso são intemporais, não variáveis. E, finalmente, alguns autores contemporâneos entendem por isso a asserção de que aquilo que existe verdadeiramente permanece sem alteração. Mas como este princípio seria então falso, é preciso, transformá-lo num ideal para o qual a razão tende, sem nunca poder realizá-lo integralmente. 
- A noção de identidade carece de rigor etimológico

Sobre a noção de identificação, diz-se a ação de identificar, quer dizer, de reconhecer como idêntico, quer numericamente, quer em natureza. Encontra-se ainda um outro sentido para este termo que é o ato pelo qual um ser se torna idêntico a um outro, ou pelo qual dois seres se tornam idênticos. Em particular, a identificação é um processo psicológico pelo qual um indivíduo determinado transporta para outro, de maneira contínua, e mais ou menos durável, os sentimentos que normalmente experimenta para consigo mesmo, a ponto de confundir aquilo que acontece consigo próprio, chegando algumas vezes a reagir de acordo com a confusão que se estabelece sobre a experiência que se tem de si. A ação de tornar idêntico e mesmo o verbo "identificar" carecem de rigor etimológico e só muito raramente apresentam a mesma acepção do que se define como identidade.

Sob os aspectos que correlacionam a identidade a partir de propriedades, Lalande (1993, p. 504-509) discute a noção de qualidade nos seus diferentes sentidos: por um lado, qualidade se refere a uma maneira de ser que pode ser afirmada ou negada relativamente a um sujeito. A qualidade, nesse sentido, opõe-se à quantidade, enquanto constitui o dado cuja continuidade ou repetição são objeto de determinação quantitativa; opõe-se também à relação, enquanto esta é exterior à natureza do sujeito ao passo que a qualidade mesmo momentânea lhe é inerente.

O termo qualidade tem conotação mais específica quando se refere aos aspectos sensíveis da percepção que não consistem em determinações geométricas ou mecânicas. Estas são geralmente consideradas o resultado de uma síntese efetuada pelo espírito entre as impressões elementares produzidas por movimentos demasiado rápidos ou estruturas demasiado finas para serem percebidas por tais. A qualidade entendida dessa forma opõese à quantidade. 
Pode-se falar de qualidade se se remeter a um sentido de propriedade formal do juízo que consiste em ser afirmativo ou negativo. Pode-se falar também de um sentido apreciativo: valor, perfeição. Lalande (1993, p. 896) destaca o uso que alguns filósofos fizeram do termo, como Descartes quando considerou o termo em dois sentidos. No sentido geral da propriedade; e também no sentido escolástico, para o qual Descartes diz qualidade real, em geral, ou mesmo, embora raramente, qualidade oculta. Em sua Crítica da razão pura, Kant (Kant, apud LALANDE, 1993, p. 896-897) utiliza o termo conforme Descartes, porém de uma maneira muito particular, representando duas aplicações diferentes de uma mesma função irredutível e fundamental do entendimento que opera: por um lado, a síntese dos termos no juízo; e por outro lado a síntese da representação, que é por natureza múltipla numa intuição.

O conceito de qualidade abrange a definição de qualidades primeiras ou primárias, termo que se opõe a qualidades secundárias. Estas expressões, aplicadas pelos escolásticos à distinção das quatro qualidades fundamentais a saber, o quente, o frio, o seco e o úmido e das que delas derivam, foram transpostas por Boyle para a distinção das propriedades geométricas ou mecânicas dos corpos e das propriedades sensíveis que, do ponto de vista cartesiano, se reduziam a estas. O termo, neste sentido, foi popularizado por Locke (Locke, apud LALANDE, 1993, p. 898). As qualidades primárias são aquelas inseparáveis da idéia de matéria e que os nossos sentidos percebem sempre em cada parte material suficientemente volumosa para ser percebida: são, segundo ele, a solidez, a extensão, a forma, o número e o movimento ou o repouso. Ele as designa também por qualidades originais porque admite que estas qualidades primeiras existem nos corpos tais como as percebemos, enquanto as qualidades segundas não existem tais como são percebidas e não são senão a tradução, pelo nosso pensamento, de certas determinações das qualidades primeiras, por exemplo, o movimento de partículas insensíveis pela sua pequenez. Leibniz adota esta distinção; acrescenta que "quando a potência que os corpos têm de produzir certas sensações em nós é inteligível e pode explicar-se distintamente, deve contar-se entre as qualidades primeiras; mas quando é apenas sensível e só dá uma idéia confusa, será necessário incluí-la entre as qualidades segundas”. (Leibniz, apud LALANDE,1993, p.899). 
O termo qualificação pode ser entendido como ação de qualificar, ou como termo que qualifica um sujeito, denominação. Já o verbo qualificar significa afirmar do sujeito uma característica que constitui uma qualidade, quer no sentido simplesmente descritivo, quer no sentido apreciativo desta palavra. Toma-se muitas vezes no mau sentido, por exemplo, a mentira qualificada.

Por qualitativo, diz-se que o termo corresponde, num sentido geral, à qualidade em qualquer dos sentidos desta palavra. Mais especialmente, aquilo que, pela sua própria natureza, não pode ser traduzido nem em termos quantitativos, nem em relações definidas e inteligíveis: por exemplo, a vida afetiva, enquanto experimentada por um sujeito que sente.

- A qualidade é condição necessária da identidade

Do ponto de vista da psicanálise, Laplanche; Pontalis (1994, p. 225-233) ressaltam que os termos identidade de percepção e identidade de pensamento são usados na Interpretação de sonhos por Freud (1900) para designar aquilo para o qual tendem respectivamente o processo primário e o processo secundário. O primeiro visa reencontrar uma percepção idêntica à imagem do objeto resultante da vivência de satisfação. No segundo processo, a identidade procurada é a dos pensamentos entre si.

Estes termos se referem à concepção freudiana da vivência de satisfação. $O$ processo primário e o secundário podem ser definidos em termos puramente econômicos: descarga imediata no primeiro caso, inibição, adiamento da satisfação e desvio no segundo. Com a noção de identidade de percepção, Freud abdica do registro econômico ao se referir às equivalências entre representações.

A vivência de satisfação constitui a procura de identidade de percepção. Ela liga a uma descarga eminentemente satisfatória a representação de um objeto eletivo. O sujeito vai daí em diante repetir a percepção que está ligada à satisfação da necessidade. A 
alucinação primitiva é o caminho mais curto para obter a identidade de percepção. De um modo mais geral, pode-se dizer que o processo primário funcionará segundo este modelo: a relação de identidade entre duas imagens é identificação entre as relações lógicas. É também a que melhor se harmoniza com o funcionamento mental próprio do sonho.

A identidade de pensamento tem uma relação dupla com a identidade de percepção. Por um lado, constitui uma modificação dela, uma vez que visa libertar os processos psíquicos da regulação exclusiva pelo princípio de prazer. Assim, essa modificação constituiria a emanação daquilo a que a lógica chama princípio de identidade. E, por outro lado, mantém-se a serviço da identidade de percepção.

Daniel Lagache (1962, apud LAPLANCHE; PONTALIS, 1994), mostrou muitas vezes todo o interesse da oposição estabelecida por Freud entre identidade de percepção e identidade de pensamento; ele vê nesta oposição um meio de distinguir as compulsões defensivas, em que o ego permanece sob o domínio da identidade de percepção, dos mecanismos de desimpedimento, que põem em jogo uma consciência atenta, discriminadora, capaz de resistir às interferências das idéias e dos afetos desagradáveis. A distinção entre esses dois modos de identidade não é redutível à oposição tradicional entre afetividade e razão, ou mesmo entre lógica afetiva e lógica da razão.

Por identificação pode-se afirmar que é o processo psicológico pelo qual um sujeito assimila um aspecto, uma propriedade, um atributo do outro e se transforma, total ou parcialmente, segundo o modelo desse outro. A personalidade constitui-se e diferenciase por uma série de identificações. O substantivo identificação pode ser tomado num sentido transitivo, correspondente ao verbo identificar, ou num sentido reflexo, correspondente ao verbo identificar-se.

Em Freud, encontramos estas duas acepções. Ele descreve como característico do trabalho do sonho o processo que traduz a relação de semelhança, o tudo como se, por uma substituição de uma imagem por outra ou identificação. Mas é, antes de qualquer coisa, para o sentido de identificar-se que o termo remete em psicanálise. A identificação abrange na linguagem corrente toda uma série de conceitos psicológicos, tais como imitação, empatia, simpatia, contágio mental, projeção etc. 
- Como o sujeito humano se constitui

Ao longo da obra de Freud, o conceito de identificação assumiu progressivamente valor central. A identificação é mais do que um mecanismo psicológico entre outros; ela é a operação pela qual o sujeito humano se constitui. A evolução de tal conceito tem relação direta com a colocação em primeiro plano do complexo de Édipo em seus efeitos estruturais, e também com a remodelação introduzida pela segunda teoria do aparelho psíquico, em que as instâncias que se diferenciam a partir do $i d$ são especificadas pelas identificações de que derivam.

No entanto, a identificação tinha sido desde muito cedo invocada por Freud, principalmente a propósito dos sintomas histéricos. É certo que os chamados fatos de imitação, de contágio mental, eram conhecidos de longa data, mas Freud vai mais longe, explicando-os pela existência de um elemento inconsciente comum em seus pacientes. Este elemento comum é uma fantasia; assim, o agoráfobo identifica-se inconscientemente com uma mulher na rua e o seu sintoma é uma defesa contra esta identificação e contra o desejo sexual que ela supõe. Freud observa desde cedo que podem coexistir várias identificações, autorizando-o ao emprego literal da expressão o eu como pluralidade das pessoas psíquicas (LAPLANCHE; PONTALIS, 1993, p. 227).

Posteriormente, o conceito de identificação é enriquecido por diversas contribuições: a noção de incorporação oral é descrita por Freud em Totem e tabu (Freud, 1913 [1912-1913]), e em Luto e melancolia (Freud, 1917[1915]). A noção de narcisismo, circunscrita aos efeitos do complexo de Édipo sobre a estruturação do sujeito, é descrita em termos de identificação. Isto é, sob uma perspectiva genética, Freud concebe a constituição do ego como unidade psíquica correlativa à constituição do esquema corporal. Tal unidade é precipitada por uma determinada imagem que o sujeito adquire de si mesmo, segundo o modelo do outro, num processo especular, que é precisamente o ego. $\mathrm{O}$ narcisismo seria a captação amorosa do sujeito por essa imagem. O conceito de identificação narcísica com o objeto é gradualmente desenvolvido por uma construção teórica denominada narcisismo primário e secundário. Os investimentos nos pais são 
abandonados e substituídos por identificações. Fato relevante é que a elaboração da segunda teoria do aparelho psíquico vem testemunhar o enriquecimento e a importância crescente da noção de identificação: as instâncias da pessoa já não são descritas em termos de sistemas em que se inscrevem imagens, recordações, conteúdos psíquicos, mas como resquícios, sob diversas modalidades, das relações de objeto.

Esse enriquecimento da noção em questão não resultou, nem em Freud, nem na teoria psicanalítica, numa sistematização que ordenasse as suas modalidades. Por isso, Freud declara-se pouco satisfeito com as suas formulações a este propósito. Em Psicologia de grupo e análise do ego (Freud, 1921) indica que, em certos casos, a identificação incide não no conjunto do objeto, mas num traço único dele. $\mathrm{O}$ estudo da hipnose, da paixão amorosa e da psicologia dos grupos leva-o a opor a identificação que constitui ou enriquece uma instância da personalidade ao processo inverso, em que o objeto é posto no lugar de uma instância.

Ainda segundo Laplanche e Pontalis (1994), o termo identificação deve ser diferenciado de termos próximos, como incorporação, introjeção e interiorização. $\mathrm{O}$ termo identificação com o agressor é designado por Anna Freud como mecanismo de defesa isolado. O sujeito, confrontando-se com um perigo exterior, representado tipicamente por uma crítica emanada de uma autoridade, identifica-se com o seu agressor, ou assumindo por sua própria conta a agressão enquanto tal, ou imitando física ou moralmente a pessoa do agressor, ou ainda adotando certos símbolos de poder que o caracterizam. Segundo Anna Freud, esse mecanismo ocorreria predominante na construção da fase preliminar do superego, pois a agressão mantém-se então dirigida para o exterior e não se voltou ainda contra o sujeito sob a forma de autocrítica.

O termo identificação primária descreve um modo primitivo de constituição do sujeito segundo o modelo do outro, que não é secundário a uma relação previamente estabelecida em que o objeto seria inicialmente colocado como independente. A identificação primária está em estreita correlação com a chamada relação de incorporação oral. 
A expressão identificação projetiva é utilizada por Melanie Klein (Klein, apud LAPLANCHE; PONTALIS, 1993, p. 232) para designar um mecanismo que se traduz por fantasias em que o sujeito introduz a sua própria pessoa totalmente no interior do objeto para o possuir, destruir ou controlar. Esta autora descreve as fantasias infantis de ataque contra o interior do corpo materno e de intrusão sádica nele. Porém, só mais tarde, essa autora designa uma forma especial de identificação como o protótipo de uma relação objetal agressiva. Essa acepção deixa intacta a questão de saber se se podem distinguir na identificação certas modalidades em que é o sujeito que se assimila ao outro e certas modalidades em que é o outro que é assimilado pelo sujeito. Agrupar tais acepções sob o título de identificação projetiva supõe uma atenuação do conceito psicanalítico de projeção. Pode-se preferir, portanto, uma oposição como a de identificação centrípeta e identificação centrífuga.

- A identidade do indivíduo se perde na massa

Sob foco diverso, a questão da identidade tem relevância no pensamento social do século XX, conforme Outhwaite; Bottomore (1996, p. 720-722), quando se vincula a aspectos relevantes à problematização da identidade do indivíduo na sociedade de massa. A massa é usada para descrever a condição das sociedades modernas em que formas tradicionais de associação como comunidade, classe, etnicidade e religião declinaram, e em que a organização social é predominante de grande escala e burocratizada, pelo que as relações sociais são relativamente impessoais. Em formulações mais extremas, a sociedade de massa é retratada como uma sociedade em que a população é uma massa indiferenciada, sem raízes na comunidade, na tradição e na moralidade consuetudinária, incapaz de discriminação em matéria de gosto cultural e de política, e, por conseguinte sujeita a ondas de emoção e moda, fácil presa de manipulações por parte de inescrupulosos líderes carismáticos.

A teoria da sociedade de massa foi influente no segundo quartel do século $\mathrm{XX}$ como diagnóstico dos males culturais e políticos que produziram o fascismo e o 
bolchevismo, e nas décadas de 1950 e 1960 como crítica de uma sociedade americana que era vista como conformista e em crise política moral. Em anos recentes, a discussão que cerca a sociedade de massa tornou-se impopular porque o seu pessimismo cultural elitista parece injustificado à luz das provas de um continuado e possivelmente crescente pluralismo social e cultural. O termo "massa" também foi associado a uma política conservadora que não entendeu a mudança que, desde meados da década de 1960, vinha ocorrendo na natureza da participação política.

A perspectiva da sociedade de massa não é uma novidade do século XX. A ameaça que as massas urbanas sem cultura, decadentes ou desesperadas representam para as elites de talento ou virtude tem sido um tema recorrente em filosofia política desde a Antiguidade clássica, mas foram acontecimentos do final do século XVIII e começo do XIX que intensificaram essas preocupações e criaram as bases para o moderno conceito de sociedade de massa. Depois da Revolução Francesa, a democracia poderia significar um nivelamento por baixo, em que as paixões da massa se sobrepusessem à razão da elite educada e levasse à intolerância da dissidência e do inconformismo.

Um outro fator relevante nesse processo foi a transformação de sociedades predominantemente agrárias pelos processos interligados de industrialização, burocratização e urbanização. Assim como as relações características da sociedade préindustrial foram transformadas pela industrialização, também a ordem política foi ameaçada pelo colapso da ordem moral antecedente e pelo relaxamento das coerções mecânicas que tinham, até então, ajudado a manter as sociedades coesas.

- A identidade em colapso na sociedade unidimensional

Os termos comunidade e sociedade pretendiam ser projetos heurísticos e eram considerados mais como dimensões de processos sociais em curso do que como estados finais. É como contribuição à sociologia política que a perspectiva da sociedade de massa atinge a sua mais clara especificação teórica. O colapso da Alemanha no nazismo foi 
atribuído ao caráter recente e à rapidez da transformação da Alemanha em uma sociedade democrática de massa.

Ainda que plausível como explicação da ascensão do nazismo, a teoria da sociedade de massa foi prejudicada pelas fortes provas que contradizem a sua proposição central. Com efeito, a Alemanha era uma sociedade que sofrera rápida e desarticuladora mudança, mas essa mudança fora mais política do que primordialmente social e, antes da ascensão dos nazistas ao poder, não era uma sociedade em que a organização social intermediária fosse fraca; pelo contrário, era mais forte do que em sociedades como a França, onde a sedução do fascismo foi relativamente fraca, mas não de todo ausente.

A teoria da sociedade de massa atingiu o seu ponto mais baixo quando aplicada aos novos movimentos sociais das décadas de 1960 e 1970, pois, no caso de tais movimentos, havia abundância de provas de que não se tratava de indivíduos anômicos, socialmente pulverizados, os que eram mais propensos a adotar uma ação política radical, mas, pelo contrário, eram pessoas relativamente bem integradas, no plano social, e mais do que usualmente motivadas por seu compromisso com sólidos princípios morais.

Por sociedade industrial, Outhwaite e Bottomore (1996, p. 722-727) compreendem primeiramente, uma mudança na natureza da economia de tal forma que um setor primário muito pequeno pode alimentar uma população envolvida nos setores secundário e terciário. Tais autores destacam a preponderância da produção mecânica nas fábricas, a urbanização da sociedade; o crescimento da alfabetização de massa, a aplicação do conhecimento científico à produção e, ainda, o recrudescimento da regulamentação burocrática de todos os aspectos da vida social.

- A identidade - algo novo na sociedade pós-industrial

Por sua vez, o problema da identidade também se associa temporalmente ao período relativo à sociedade pós-industrial. A idéia de que o processo de industrialização 
sofre alterações substanciais na pós-modernidade, ocorre no começo do século XX. Esta idéia preconizava a criação de um estado pós-industrial, antes baseado na pequena oficina artesanal e em unidades descentralizadas de governo. O conceito viria a ser adotado na década de 1960, quando the foram atribuídas características inteiramente novas. Em seu sentido atual, é usado para descrever as novas estruturas e movimentos sociais que marcam a evolução das sociedades industriais na parte final do século XX. Recentemente, muitos dos usos mais comuns do termo também incluíram ou foram definidos lado a lado com um conceito de sociedade contemporânea como sociedade pós-moderna. Economicamente, a sociedade pós-industrial é marcada pela mudança de uma economia produtora de bens para uma economia de serviços; no plano ocupacional, pela proeminência da classe de profissionais liberais e de técnicos; e na tomada de decisões, pela difusão muito ampla da tecnologia intelectual.

Esta sociedade está principalmente interessada na produção mais de serviços do que de bens, a maioria de sua força de trabalho está em profissões de colarinho branco em vez de em atividades manuais, e muitos de seus trabalhadores são profissionais de nível superior, empregados em funções executivas, gerenciais ou técnicas. A sociedade pósindustrial depende de conhecimentos imateriais e teóricos, bem como aqueles desenvolvidos por universidades, centros de pesquisas e novos tipos de local de trabalho. Essa mudança de ênfase deve-se ao aumento da importância de uma classe caracterizada pelo saber, composta por cientistas, profissionais de nível superior e instituições eruditas.

Embora as sociedades industrial e pós-industrial não estejam simplesmente ligadas pelas mudanças fundamentais na natureza do trabalho, da tecnologia e das classes sociais, várias áreas problemáticas podem ser indicadas, as quais constituem o desafio central para todos os atores sociais envolvidos - cientistas e produtores, especialistas ergonômicos e usuários -, todos se defrontam com a arquitetura da complexidade de mudanças identitárias fundamentais e novidades sem precedentes que vão além dos métodos e ferramentas teóricas convencionais da sociedade pós-industrial.

Com esse extenso percurso sobre a especificação dos termos acima mencionados, quer-se compreender a explosão teórica sobre o conceito de identidade, como já observava Stuart Hall na introdução de um volume de seus estudos publicados em 2003 (Hall, 2003, 
p.7-22). Pode-se dizer com esse autor que a identidade se converteu agora em um prisma por meio do qual se descobrem, compreendem e examinam todos os demais aspectos de interesse da vida contemporânea. As questões estabelecidas da análise social estão se referindo e se renovando para se ajustarem ao discurso que agora gira em torno da identidade. A espetacular ascensão do discurso da identidade pode nos revelar mais acerca da situação atual da humanidade do que os resultados analíticos e conceituais que se tem até agora. Dessa forma, o autor pretende centrar-se nas bases experimentais e, por meio destas, em suas raízes estruturais, dessa notável mudança nas preocupações intelectuais da qual é um sintoma muito destacado a nova posição central do discurso da identidade.

Hall (2003) verifica que as coisas não conservam sua forma de uma vez para sempre e podem ser diferentes de como são. Disso se instaura a imprevisibilidade que gera ansiedade e temor diante de acidentes e surpresas geradas constantemente pelos meios de comunicação. A instabilidade e a flexibilidade constantemente alardeadas podem tanto desencadear a capacidade de adaptabilidade e a ambição de que cada um é responsável e capaz de fazer com que a sua própria vida seja melhor, como podem favorecer o sentimento de apatia, medo e intolerância radical às mudanças, de forma a levar à total insensibilidade e aquiescência cega a todas as informações, como se estas se constituíssem em ordenamentos do que se deve fazer no cotidiano, por mais diferentes que sejam as condições individuais.

Apoiando-se em Kant, sobretudo na Crítica da razão prática (2003), Hall destaca o argumento de que todos nós, cada um de nós, somos dotados da faculdade da razão, esse instrumento que nos permite comparar as opções possíveis e fazer nossas eleições individuais. Porém, se utilizássemos esse instrumento adequadamente chegaríamos todos às mesmas conclusões se aceitássemos o tipo de convivência que a razão nos diz que é a melhor. Porém nem todos os pensadores são otimistas como Kant. Hall destaca que, de acordo com Rousseau, é preciso obrigar as pessoas a ser livres.

Tais comentários aparentemente não mantêm relação com o tema aqui proposto, mas a intenção é esclarecer e desfazer equívocos conceituais e não apenas terminológicos. O caráter incompleto da identidade está, de fato, intimamente relacionado com todos os demais aspectos da condição moderna. É como se a questão identitária estivesse plantada 
em nossa época e, tal como se apresenta nestas reflexões aqui apresentadas, a identidade não é um assunto privado nem uma preocupação privada. É uma verdade trivial que a individualização é produzida socialmente, faltando examinar o inverso desta verdade: a formação do caráter social e de como este se faz representar nas formas como uma sociedade se apresenta. O caráter depende, por sua vez, da maneira em que se demarca a tarefa da individualização e em que se responde a ela.

A individualização consiste em um indivíduo se tornar diferente dos demais. Tal processo pressupõe que o outro, um observador, distinga este indivíduo de outros. Já a individuação é um processo que pressupõe não apenas a diferenciação quanto à separação, a independência do todo em partes cada vez mais independentes. (Cf. Houaiss, 2001, p.1607-08) É também uma ação de se tornar consciente de si mesmo. A individualização consiste em converter a identidade humana de algo dado em uma tarefa; é ela que encarrega os atores com a responsabilidade de realizar esta tarefa com os efeitos de sua realização; em outras palavras, consiste em estabelecer uma autonomia de jure, ainda que necessariamente de fato. A modernidade recoloca a determinação da posição social por uma autodeterminação compulsiva e obrigatória.

Não são somente os indivíduos que estão de um lado para outro, mas também as linhas de meta e de pistas a correr. Hoje em dia não são os meios que constituem a fonte primordial de insegurança e ansiedade. Por outro lado, no entanto, os fins se tornaram mais difusos, dispersos e incertos: é a maior fonte de ansiedade, nos grandes desconhecidos das vidas dos homens e mulheres. A tarefa já não é mais reunir a suficiente força e determinação para avançar, por meio de provas e erros, triunfos e derrotas, pelo caminho trilhado que se estende ante nós. A tarefa é escolher o menos arriscado na encruzilhada seguinte, mudar de direção antes que o caminho se torne impraticável. Em outras palavras, o dilema que atormenta homens e mulheres na mudança do século XX para o atual não é tanto como conseguir as identidades de sua eleição e como fazer que as reconheçam os que estão ao redor, quanto à questão sobre qual identidade eleger e como se manter alerta para que seja possível fazer outra eleição se a identidade anteriormente eleita é retirada de mercado ou despojada de sua capacidade de sedução. A preocupação principal do indivíduo é como encontrar um lugar sólido dentro de uma classe, seja tal 
lugar nomeado como estamento, estrato, ou categoria social, e, uma vez encontrado, como conservá-lo.

Bauman (2001) relaciona o ritmo acelerado de modificações dos papéis identitários desde o advento da modernidade, como algo permeável e líquido. O que causa preocupação aos indivíduos é a suspeita de que se há um marco onde o indivíduo possa se enxergar estável, ele logo se romperá ou se fundirá. De outra forma, Berger (1983, p. 230) enxerga "tipos" de identidade relativamente estáveis da realidade social, ainda que ele se indague, como sociólogo, "o que é a realidade?" Esse autor vê como problemática a questão das teorias psicológicas empiricamente adequadas ou inadequadas para entender os fenômenos identitários da vida cotidiana.

Sob outra vertente, à questão de como se percebe a identidade quando alguém chega a ser consciente do feito de que indubitavelmente tem uma identidade, Erikson (1968) responde: até que se perceba como um sentido subjetivo de uma mesmidade e continuidade estimulantes. As novas dependências são agora verdadeiramente mundiais, porém nossas ações são locais, como antes. Os poderes que determinam as condições frente aos problemas individuais estão fora do alcance de todos os agentes inventados pela democracia moderna em seus dois séculos de história.

A rápida globalização da rede de poder parece conspirar e colaborar com uma política de vida privatizada; estimulam-se, sustentam-se e reforçam uma a outra. Tudo parece estar no lugar e fazer que tanto a globalização das condições de vida como o esfacelamento, a atomização e a privatização das lutas da vida se impulsionem e se perpetuem a si mesmos. É neste plano de fundo que se pode examinar e entender a lógica e a endêmica ilógica das preocupações contemporâneas com a identidade e as ações que desencadeiam.

Não pode haver nenhuma resposta racional à crescente precariedade das condições humanas enquanto tal resposta tenha que se limitar à ação do indivíduo; a irracionalidade das possíveis respostas é inevitável, dado que o âmbito da política da vida e da rede de forças que determinam suas condições são incomparáveis e desproporcionais. 
A atividade, que consome tempo e esforço, de reunir, desmantelar e reordenar a própria identidade é outro desses passatempos suplentes. Tal atividade se leva a cabo em condições de profunda insegurança: os objetivos da ação são tão precários como incertos são seus efeitos. Todavia mais forte é a tentação de fazer como se fosse a similitude de medos individuais o principal motivo para se construir uma comunidade, e acreditar que só assim cada individuo pode sair de seu isolamento.

A identidade pode oferecer um sentido de segurança e, desse modo, cumprir com certa "função curativa" o sentimento de fragmentação do indivíduo na massa. A identidade permite que o indivíduo desconsidere a sua origem, ao mesmo tempo em que ele pode negar que sua identidade adquirida é mais que um substituto de suas raízes culturais, ou de valores familiares ou grupais de referência. A identidade brota no cemitério das comunidades, mas floresce graças a sua promessa de ressuscitar os mortos.

O efeito globalizador mais ameaçador é que as fronteiras entre as diversas culturas estejam desaparecendo. Mas, pelo contrário, pode-se dizer que cada vez mais há a necessidade de se levantar muros cercados de arames farpados, cercas elétricas, e um verdadeiro aparato de proteção, com fronteiras definidas nos novos rincões de ruas em todos os bairros onde a violência é descontrolada, em todas as partes do planeta.

As fronteiras não são traçadas para afastar e proteger identidades já existentes. Ao contrário, as identidades comunitárias, aparentemente compartidas, são subprodutos de um traçado febril de fronteiras. Ao em vez de se falar de identidades, herdadas ou adquiridas, seria mais adequado falar de identificação, uma atividade interminável, sempre incompleta, inacabada e aberta na qual participam todos, por necessidade ou por eleição. A frenética busca de identidade não é um resíduo dos tempos da pré-globalização ainda não totalmente extirpado e destinado a extinguir-se conforme o progresso da globalização; ela é, bem ao contrário, o efeito secundário e o subproduto da combinação das pressões globalizadoras e individualizadoras. O que se observa é que as guerras da identificação não são contrárias à tendência globalizadora nem se interpõem em seu caminho. 
- A identidade pessoal, se existe, é uma construção narrativa.

Em sua obra $O$ si mesmo como um outro, Ricouer (1991) destaca aspectos relevantes ao estudo da identidade pessoal comparando-a à identidade narrativa. Segundo esse autor, na análise da linguagem, a teoria da ação constituía uma disciplina autônoma, em razão dos próprios traços do agir humano e da originalidade do vínculo entre o agir e seu agente. A teoria da ação assumia o papel de propedêutica na questão da ipseidade. A questão do si, retomando o passo sobre a questão da ação, suscita remanejamentos consideráveis no próprio plano de agir humano.

Nesse estudo, Ricouer afirma que a lacuna mais considerável de seus estudos anteriores concerne à dimensão temporal tanto do si quanto da própria ação. Nem a definição da pessoa na perspectiva da referência identificante, nem a do agente no quadro da semântica da ação levaram em conta o fato de que a pessoa da qual se fala, o agente do qual depende a ação têm uma história, ou melhor, eles são sua própria história. A abordagem do si, na filosofia da linguagem, também não suscitou nenhuma reflexão particular concernente às mudanças que afetam um sujeito capaz de se designar a si próprio, expressando o mundo. Porém, uma problemática inteira foi omitida - a problemática da identidade pessoal, que só pode precisamente se articular na dimensão temporal da existência humana.

O autor se propõe a recomeçar o trabalho da teoria narrativa, não mais na perspectiva de suas relações com a constituição do tempo humano, como o trabalho feito em Tempo $e$ narrativa (Ricoeur, 1994, v. 3), mas na sua contribuição do si. Com um olhar nos debates contemporâneos no campo da filosofia anglo-americana, Ricouer vê uma ocasião para abordar a distinção entre mesmidade e ipseidade, sempre pressuposta nos estudos precedentes, mas nunca tratada tematicamente. Ele mostra, então, tardiamente, que é no quadro da teoria narrativa que a dialética concreta da ipseidade e da mesmidade atinge sua plena expansão. 
A noção de identidade narrativa é confrontada com as perplexidades e os paradoxos da identidade pessoal para poder se desenvolver de forma menos polêmica e mais construtiva. Entretanto, a tese segundo a qual a teoria narrativa encontra uma de suas justificativas no papel que ela exerce entre o ponto de vista prescritivo prevalece em Ricoeur. Este autor enxerga uma nova imposição sobre a tríade: descrever, narrar, prescrever, e, a cada momento, tal imposição implica uma relação específica entre constituição da ação e constituição do si.

A teoria narrativa não poderia exercer essa mediação. Isto é, ela não poderia ser mais que um segmento intercalado na sucessão discreta dos estudos de Ricoeur se não pudesse mostrar que o campo prático coberto pela teoria narrativa é mais vasto que aquele coberto pela semântica e pela pragmática das frases de ação. As ações organizadas em narrativa apresentam traços que só podem ser elaborados tematicamente no quadro de uma ética. Com tal afirmação, pode-se dizer que a teoria narrativa só faz verdadeiramente mediação entre a descrição e a prescrição se a ampliação do campo prático e a antecipação de considerações éticas estão implicadas na própria estrutura do ato de narrar. Durante todo o percurso elaboração em Tempo e narrativa (1997), sobretudo no tomo III, Ricoeur verifica que, em muitas narrativas, é pela escala de uma vida inteira que o si procura sua identidade, que se dispõe em graus de complexidade que levam a teoria da ação ao nível requerido pela teoria narrativa. Mais adiante em sua obra, o autor afirma que não existe narrativa eticamente neutra, de maneira que "a literatura é um vasto laboratório onde são testadas estimativas, avaliações, julgamentos de aprovação e de condenação pelos quais a narrativa serve de propedêutica à ética" (Ricoeur, 1991, p.140), de maneira que haveria uma dupla visão em direção ao campo prático e prospectivo tanto quanto em direção ao campo ético.

O problema da identidade pessoal constitui, conforme Ricoeur, o lugar privilegiado da confrontação entre os dois usos maiores do conceito de identidade. De um lado, tem-se a identidade como mesmidade (lat. idem; ingl: sameness; alem: Gleichheit), do outro lado, tem-se a identidade como ipseidade (latim: ipse, inglês: selfhood; alemão: Selbstheit). A ipseidade não é a mesmidade, essa distinção é desconhecida e, por isso, as soluções trazidas ao problema da identidade pessoal, ao ignorar a dimensão narrativa, malogram. 
A justificativa plausível de que a questão não foi tratada anteriormente é porque ela só se dispõe na condição problemática quando suas implicações temporais passam para o primeiro plano. Um problema relevante surge com a questão da permanência no tempo, quando se dá a confrontação entre as duas vertentes da identidade. Inicialmente, a questão da permanência no tempo liga-se exclusivamente à identidade - idem. É sob essa rubrica que as teorias analíticas abordam a questão da identidade pessoal e os paradoxos que aí se ligam. A fim de apontar o lugar eminente que mantém a permanência do si no tempo, Ricoeur (1991) evoca a articulação conceitual da mesmidade.

A mesmidade é um conceito de relação e uma relação de relações. Se há uma prioridade posta ao exame, o primeiro problema se refere à identidade numérica. Este se expõe entre as duas ocorrências de uma coisa designada por um nome invariável na linguagem comum. Diz-se que elas não formam duas coisas diferentes, mas uma única e mesma coisa. Desta maneira, a identidade é sinônimo de unicidade, e é o contrário da pluralidade. A essa primeira componente da noção de identidade corresponde a operação de identificação entendida no sentido de reidentificação do mesmo, que afirma que conhecer é reconhecer: a mesma coisa duas vezes, $n$ vezes.

Posteriormente, tem-se a identidade qualitativa, a semelhança extrema: diz-se de $\mathrm{x}$ e de $\mathrm{y}$, que eles vestem a mesma roupa, isto é, vestuários semelhantes, que é indiferente à troca de um pelo outro; a essa segunda componente corresponde à operação de substituição sem perda semântica, salva veritate.

As duas componentes da identificação são irredutíveis uma à outra; a exemplo das categorias de quantidade e as de qualidades em Kant (1997), elas já não são por isso estranhas uma à outra. É precisamente porque o tempo está implicado na sucessão das ocorrências da mesma coisa que a reidentificação do mesmo pode suscitar a hesitação, a dúvida, a contestação. A semelhança extrema entre duas ou várias ocorrências pode então ser invocada como critério indireto para reforçar a presunção de identidade numérica.

Há uma fraqueza do critério de similitude, no caso de uma grande distância no tempo que faz com que se evoque outro critério, o qual depende da terceira componente da noção de identidade, ou seja, a continuidade ininterrupta entre o primeiro e o último estágio do 
desenvolvimento do que se considera o mesmo indivíduo. Tal critério prevalece em todos os casos em que o crescimento e o envelhecimento operam como fatores de dessemelhança, e, por implicação, de diversidade numérica.

A demonstração dessa continuidade funciona como critério anexo ou substitutivo da similitude; a demonstração repousa na colocação em série ordenada de mudanças fracas que, tomadas uma a uma, ameaçam a semelhança sem destruí-la. O tempo é o fator da dessemelhança, de afastamento de diferença, a não ser que coloquemos na base da similitude e da continuidade ininterrupta da mudança um princípio de permanência no tempo. Isso será a estrutura invariável de um instrumento no qual teremos progressivamente mudado todas as peças. A idéia de estrutura, oposta à de conhecimento, responde a esse critério de identidade, por mais difícil que se possa admiti-la; tal admissão confirma o caráter relacional da identidade que não aparecia na antiga formulação da substância, mas que Kant restabelece, classificando-a entre as categorias da relação, como condição de possibilidade de pensar a mudança, como chegando a alguma coisa que não muda, pelo menos no momento da atribuição do acidente à substância. A permanência no tempo torna-se, assim, o transcendental da identidade numérica. A problemática da identidade pessoal girará, a partir de então, em torno da busca de uma invariante relacional, dando-lhe a significação forte de permanência no tempo.

Feita a análise conceitual da identidade-mesmidade, volta-se para a questão: a ipseidade do si implica uma forma de permanência no tempo que não seja redutível à determinação de um substrato, mesmo no sentido relacional que Kant destinou à categoria de substância; em suma, uma forma de permanência no tempo que não seja simplesmente o esquema da categoria de substância. Isto é, uma forma de permanência no tempo ligada à questão quem?, como irredutível a toda pergunta $o$ quê?. Por sua vez, tais questões sugerem uma forma de permanência no tempo que seja uma resposta à pergunta: "quem sou eu?". Isto é: ao falar de nós mesmos, dispomos de dois modelos de permanência no tempo, descritivos e emblemáticos: o caráter e a palavra considerada, respectivamente. Nos dois modelos, reconhece-se uma permanência que afirmamos ser de nós mesmos.

Mas em que sentido o termo caráter tem, ao mesmo tempo, valor descritivo e valor emblemático? Por que dizer que ele acumula a identidade do si mesmo? O que é que trai 
sob a identidade do mesmo a identidade do si e impede de destinar pura e simplesmente a identidade do caráter à do mesmo? O caráter é o conjunto das marcas distintivas que permitem reidentificar um indivíduo humano como o mesmo. É o caráter que acumula a identidade numérica e qualitativa, a continuidade ininterrupta e a permanência no tempo. É por esse meio que ele designa de modo emblemático a mesmidade da pessoa.

$\mathrm{O}$ que se quer destacar é que, em vez de conceber o caráter dentro de uma problemática da perspectiva e da abertura como o pólo acabado da existência, Ricouer o interpreta em função de seu lugar no processo da identidade. Esse autor retoma a questão do estatuto da imutabilidade do caráter tido como adquirido em suas análises anteriores. Tal imutabilidade revela-se como gênero particular, como atesta a reinterpretação do caráter em termos de disposição adquirida. Com essa noção, é possível tematizar, por ela própria, a dimensão temporal do caráter. Este designa o conjunto das disposições duráveis com que reconhecemos uma pessoa. É por essa razão que o caráter pode constituir o ponto-limite em que a problemática da ipse torna-se indiscernível da do idem e leva a não distinguir entre uma e outra. É ressaltado que é conveniente a interrogação sobre a dimensão temporal da disposição, pois é ela que enviará para mais adiante, no tempo, o caráter no caminho do narrável da identidade narrativa.

Nota-se, por um lado, que a noção de disposição liga-se à de hábito, com sua dupla valência de hábito em via de ser e de hábito já adquirido. Esses dois traços têm uma significação temporal evidente: o hábito dá uma história ao caráter, mas é uma história na qual a sedimentação tende a recobrir e, em última análise, a abolir a inovação que a precedeu. É essa sedimentação que confere ao caráter a espécie de permanência no tempo que o autor interpreta aqui como o recobrimento do ipse pelo idem. Mas esse recobrimento não elimina a diferença das problemáticas: mesmo como segunda natureza, meu caráter sou eu, eu mesmo, ipse; mas esse ipse anuncia-se como idem. Cada hábito assim contraído, adquirido e tornado disposição durável, constitui um traço - um traço de caráter, precisamente, isto é, um signo distintivo com o que se reconhece uma outra pessoa, como é identificada novamente como a mesma, não sendo o caráter outra coisa que o conjunto desses signos distintivos. 
Por outro lado, deixa-se ligar à noção de disposição o conjunto das identificações adquiridas pelas quais o outro entra na composição do mesmo. A identidade de uma pessoa ou de uma comunidade é feita dessas identificações - com valores, normas, ideais, modelos, heróis, nos quais a pessoa e a comunidade se reconhecem. Os pólos de identidade se compõem, provando que não se pode pensar até o fim o idem da pessoa sem o ipse, mesmo quando um recobre o outro. Estabilizam-se as preferências, apreciações, estimações, de tal modo que a pessoa se reconhece em suas disposições avaliativas.

Por essa estabilidade emprestada dos hábitos e das disposições, o caráter assegura, ao mesmo tempo, a identidade qualitativa, a continuidade ininterrupta na mudança e, finalmente, a permanência no tempo, definindo a mesmidade. Existe, assim, um modelo de permanência no tempo diferente daquele do caráter: o modelo da palavra mantida na fidelidade à palavra dada. É a palavra mantida que se afirma numa manutenção de si que não se deixa inscrever, como o caráter na dimensão de alguma coisa em geral, mas unicamente naquela do quem?. O uso das palavras é um bom guia. Uma coisa é perseverar o caráter, outra, perseverar a fidelidade à palavra dada. Uma coisa é a continuação do caráter, outra coisa é a constância na afinidade.

Essa nova maneira de opor a mesmidade do caráter à manutenção de si mesmo na promessa abre um intervalo de sentido que é preciso preencher. Este é aberto pela polaridade, em termos temporais, entre dois modelos de permanência no tempo: perseverar o caráter e manter a promessa. É na ordem da temporalidade que a mediação está à procura, e é esse meio que vem a ocupar a noção de identidade narrativa. Portanto, não é surpresa ver a identidade narrativa oscilar entre dois limites, um inferior, em que a permanência no tempo exprime a confusão do idem e do ipse, e um limite superior, em que o ipse coloca a questão de sua identidade sem a ajuda nem o apoio do idem. Antes, é preciso examinar as teorias da identidade pessoal que ignoram ao mesmo tempo a distinção do idem e do ipse e os recursos que a narrativa oferece para resolver os paradoxos da identidade pessoal.

Os filósofos de cultura analítica aprenderam em primeiro lugar, em Locke e em Hume, que sem o fio condutor da distinção entre dois modelos de identidade e sem o 
auxílio da mediação narrativa, a questão da identidade pessoal se perde nos arcanos de dificuldades e de paradoxos paralisantes.

De Locke, a tradição posterior reteve a equação entre identidade pessoal e memória. Mas é preciso analisar as conseqüências disso. Em primeiro lugar, inconseqüência na argumentação: no começo do capítulo XXVII do Ensaio filosófico acerca do entendimento humano (2005), intitulado "Identidade e diversidade", Locke introduz um conceito de identidade que, segundo Ricouer, parece escapar à alternativa da mesmidade e ipseidade apresentada. Após ter dito que a identidade resulta de uma comparação, Locke introduz a idéia singular da identidade de uma coisa consigo mesma; isto é: comparando uma coisa consigo mesma em tempos diferentes, formamos as idéias de identidade e de diversidade.

Mas a série da análise decompõe as duas variantes da identidade. O elemento comum é a permanência da organização que, segundo Locke, não pressupõe nenhum substancialismo. Porém, no que tange à identidade pessoal, Locke não confunde a identidade de um homem. Ela é reflexão instantânea que ele destina à mesmidade consigo mesmo alegada pela definição geral. Resta então desenvolver o privilégio da reflexão do instante à duração; para isso, considera-se a memória como a expansão retrospectiva da reflexão tão longe quanto ela pode se estender ao passado; em favor dessa mutação da reflexão na memória, a mesmidade consigo mesmo pode estender-se ao longo do tempo.

Locke acreditou poder introduzir uma cesura no curso de sua análise sem ter de abandonar seu conceito geral de mesmidade de uma coisa consigo mesma. Porém é a curva da reflexão e da memória que marcava uma desordem conceitual onde a ipseidade substituía silenciosamente a mesmidade. E a tradição creditou a Locke a invenção de um critério de identidade, a saber, psíquica. É esse aspecto que, para Ricouer, torna-se motivo de maior perplexidade. Ele pretende opor a Locke e seus partidários as aporias de uma identidade suspensa apenas pelo testemunho da memória. Tais aporias psicológicas são concernentes aos limites, às intermitências como acontecem durante o sono, às perdas da memória, mas também as aporias mais propriamente ontológicas. Ricouer diz que, sem têlo previsto, Locke realçava o caráter aporético da própria questão da identidade. Dessa 
forma, a era dos puzzling cases - casos intrigantes, como aqueles utilizados na fíç̧ão literária -, estava aberta, a despeito da certeza de Locke.

Com Hume foi aberta a era da dúvida e da suspeita. No início da análise do Tratado da natureza humana (2000, Livro I, $4^{\mathrm{a}}$ parte, sexta seção), pode-se perceber um ponto de ambigüidade, só existindo um modelo de identidade, a mesmidade. Assim como Locke, Hume cita vários exemplos-tipos, mas, de maneira diferente, ele introduz, desde seus primeiros exemplos, graus da destinação da identidade. A questão da identidade encontra-se assim subtraída desde o início às respostas em oposição, como preto e branco, quente e frio, como conceitos opostos. Também diferentemente de Locke, Hume não confunde seus critérios de destinação da identidade, quando ele passa das coisas e dos seres animados ao si. Como bom empirista, ele exige para cada idéia uma impressão correspondente e que no exame de seu interior só encontre uma diversidade de experiências e nenhuma impressão invariável relativa à idéia de um si, ele conclui que esta última é ilusão.

Porém essa conclusão não encerra o debate, pelo contrário, ela o abre. É na explicação da ilusão de identidade que Hume emprega os recursos de sutileza que, após ter causado grande impressão em Kant, deixaram uma marca durável na discussão ulterior. Dois novos conceitos entram em cena: a imaginação e a crença. A primeira é atribuída à faculdade de passar com facilidade de uma experiência à outra se sua diferença é fraca e gradual, e assim transformar a diversidade em identidade. A segunda preenche o déficit da impressão. Dizer que a crença gera ficções significa anunciar um tempo em que a crença tornar-se-á incrível. Ricouer diz que Hume não supera ainda esse passo e sugere que a unidade da personalidade pode ser assimilada à de uma república ou de uma Commonwealth, cujos membros não cessam de mudar enquanto os laços de associação permanecem. Caberá a Nietzsche concluir o passo da suspeita. 
- O caráter é o si sob a aparência da mesmidade

Ricouer objeta se Hume não procurava o que ele não podia encontrar: um si que é apenas um mesmo? E se não pressupunha o si que ele não procurava? $\mathrm{O}$ autor diz que não se deterá na questão de saber se o melhor critério da identidade é de ordem corporal ou psicológica, e isso por muitas razões. Uma delas é que ele não quer fazer crer que o critério psicológico teria uma afinidade privilegiada para a ipseidade, e o critério corporal para a mesmidade. O critério psicológico não se reduz à memória; tudo o que foi dito mais acima sobre o caráter é suficientemente confirmado, pois o caráter é o que mais leva a identidade em termos de mesmidade. O caráter é o si sob a aparência da mesmidade.

O uso do termo critério é questionado na presente discussão. É entendido por critério aquilo que permite distinguir o verdadeiro e o falso numa competição entre pretensões à verdade. Porém a questão é saber se a ipseidade e a mesmidade se prestam do mesmo modo a esse tipo de julgamento de verdade. Para a mesmidade, o termo critério designa as provas de verificação e de falsificação dos enunciados sobre a identidade como relação: mesmo que... Pode-se então legitimar o uso do termo critério para as asserções acerca da mesmidade. Porém não se afirma o mesmo no caso da ipseidade, pois a atestação se presta a uma prova de verdade, de uma ordem diferente da prova de verificação ou de falsificação, dado que a memória é o pretendido critério privilegiado, e afirma-se que ela também acontece no campo da atestação. A discussão só pode ser bem conduzida quando a problemática em torno da ipseidade e da mesmidade tiver sido solidamente estabelecida e depois que o leque inteiro de casos tiver sido percorrido. O que só acontecerá ao fim das reflexões acerca da identidade narrativa, e esta tese não se propõe a esgotá-la.

Antes de entrar na discussão sobre os critérios de identidade pessoal, Ricoeur diz ter escolhido por base uma obra que transcende o debate sobre os méritos respectivos do critério psicológico e do critério corporal e dirige-se diretamente às crenças que é ligada ordinariamente à reivindicação da identidade pessoal. Essa obra é a de Derek Parfit, em Reasons and people, 1986 (Parfit, 1986, apud RICOUER, 1991). Nela, esse autor diz ter 
reconhecido o adversário, não o inimigo mais temível para sua tese da identidade narrativa, uma vez que suas análises desenvolveram-se sobre um plano onde a identidade só pode significar mesmidade, com exclusão expressa de toda a distinção entre mesmidade e ipseidade, e, portanto, de toda a dialética, narrativa ou outra, entre mesmidade e ipseidade. A obra lembra a de Locke e a de Hume no que tange aos puzzling cases que servem de prova de verdade ao longo do livro de Parfit. Isso faz com que se pense que a própria questão da identidade possa revelar-se vazia de sentido, uma vez que, nos casos paradoxais, pelo menos, a resposta é indeterminada. A questão é saber se, assim como Hume, Parfit não procurou o que não podia encontrar, a saber, um estatuto firme da identidade pessoal definida como mesmidade, e se ele não pressupõe o si, que não procurava, quando ele desenvolve a sua tese, com um pensamento vigoroso, pouco comum às implicações morais, chegando a escrever: a identidade pessoal não é o que importa.

É às crenças de base, subjacentes ao manejamento dos critérios de identidade, que Parfit se opõe. A primeira tese de Parfit é que a crença comum deve ser reformulada em termos que não lhe são próprios, a saber, nos da tese adversa que ele considera a única verdadeira e a que ele chama reducionista. A tese adversa será, portanto, chamada tese não-reducionista, a identidade através do tempo restabelece-se sem vestígios por um certo encadeamento entre acontecimentos, quer sejam de natureza física ou psíquica. É com a condição de uma descrição impessoal que toda a pesquisa de conexão pode ser conduzida, seja no plano físico ou corporal ou no plano mental ou psíquico. Tomada no sentido amplo da noção de acontecimento, a tese reducionista pode ser formulada assim: a existência de uma pessoa consiste exatamente na existência de um cérebro e de um corpo e na ocorrência de uma série de acontecimentos físicos e mentais ligados entre si.

Essa tese exclui o fato de que somos entidades existindo separadamente. Para Parfit, a noção de substância espiritual com o que ele identifica o puro ego cartesiano, só é provavelmente uma das versões da tese não reducionista, mas é a mais conhecida mesmo que uma versão materialista seja igualmente concebível; o essencial disso é a idéia de que a identidade consiste num fato suplementar com respeito à continuidade física e/ou psíquica. Ricoeur, por sua vez, julga que Parfit ignora a dicotomia do ipse e do idem e que 
ele não tem outro recurso senão conservar como supérfluo o fenômeno de minha totalidade com relação à factualidade do acontecimento (Ricoeur, 1991, p. 159).

Além disso, a crença que Parfit não aceita é aquela em que a questão da identidade é sempre indeterminável, portanto em que todos os casos aparentes de indeterminação podem ser respondidos por sim ou não. Essa crença é subjacente à precedente: é porque consideramos determináveis os casos aberrantes que procuramos a fórmula mais estável da identidade. A invenção de puzzling cases com o auxílio da ficção científica, em que se confirma a indeterminação da questão da identidade, exerce uma função decisiva, a que Parfit dedica parte de sua obra. É insinuada a vacuidade de uma questão que suscita tal indeterminação da resposta desde o começo. A questão da identidade tem sempre suscitado o interesse para os casos paradoxais, por isso o autor dedicará um lugar considerável ao equivalente dos puzzling cases de Parfit - casos intrigantes, como aqueles utilizados na ficção literária -, no quadro de uma concepção narrativa da identidade pessoal. A confrontação entre as duas espécies de puzzling cases será um dos pontos fortes a favor da tese apresentada por Ricouer, limitando-se à observação seguinte:

essa continuidade surpreendente no recurso à imaginação de casos suscetíveis de paralisar a reflexão dá a entender que a questão da identidade constitui um lugar privilegiado de aporias. Talvez seja necessário concluir não que a questão seja vazia, mas que ela pode permanecer como uma questão sem resposta; aí está precisamente o começo dessa estratégia singular. (RICOEUR, 1991, p.161)

Para resolver os paradoxos gerados pelos puzzling cases é necessário dissolver a questão, em suma, considerar a problemática da identidade vazia. Isso é o que faz Parfit. Porém, seria necessário variar e dizer: a questão é indeterminada. Outra crença que Parfit submete à crítica concerne ao julgamento de importância que nós associamos à questão da identidade. $\mathrm{O}$ elo entre a crença aqui combatida e a crença precedente é o seguinte: se a indeterminação nos parece inaceitável, é porque ela nos perturba; isso está claro em todos os casos nos quais está em jogo a sobrevida - "o que vai me acontecer?, pergunto-me". O autor aponta também para o fato de que, se estamos inquietos, é porque o julgamento da identidade nos parece importante. Se se renuncia a esse julgamento de importância, deixa- 
se a preocupação. Essa crítica contra o julgamento de importância ocupa, na obra inteira de Parfit, uma posição estratégica central, tanto quanto no $O$ homem sem qualidades, de Musil.

Ricoeur destaca ainda a terceira parte da obra de Parfit quando este coloca em questão o si em sua dimensão ética. A tese de Parfit é que a disputa entre egoísmo e altruísmo não pode ser decidida no plano em que ela se desenvolve se se toma posição sobre a questão de saber que espécie de entidades são as pessoas, de onde é advindo o título da obra, Reasons and persons. As razões válidas da escolha ética passam pela dissolução das crenças falsas sobre o estatuto ontológico das pessoas. É todo o peso das questões éticas que recai sobre a questão da identidade, esta se torna um começo axiológico: o julgamento de importância que proporciona a ordem na hierarquia das estimações. Porém qual identidade? Tudo leva a pensar que Parfit, em favor da indistinção entre ipseidade e mesmidade, visa à mesmidade por meio da minha totalidade (mienneté). Para Ricouer, isso está longe de ser desinteressante porque a espécie de budismo que a tese moral de Parfit insinua consiste em não fazer diferença entre mesmidade e minha totalidade. Como se pode interrogar o que importa, se não se pode perguntar a quem a coisa importa ou não? A interrogação sobre o que importa ou não dependeria da preocupação de si, que parece realmente constitutiva da ipseidade? E se deslocar do terceiro nível ao segundo, depois ao primeiro nível das crenças passadas pelo crivo da crítica, não continuamos a nos mover no elemento da crença concernente ao que somos?

\footnotetext{
A questão de importância colocar-se-ia se não ficasse alguém a quem a questão de sua identidade deixasse de convir? Acrescentemos agora: se minha identidade perdesse toda a importância em todos os aspectos, a dos outros não se tornaria, ela também, sem importância? (RICOUER, 1991, p.166)
}

Com tal raciocínio, a reflexão moral de Parfit provoca finalmente uma crise interna à ipseidade. Esta consiste em que a própria noção de dependência das experiências para consigo mesmo tem um sentido ambíguo; há posse e posse. Parfit visa ao egotismo que alimenta a tese do interesse próprio contra a qual sua obra é dirigida. 
Ao comentar $O$ homem sem qualidades, o escritor Juan José Saer, em artigo publicado em 20/05/2001, "Genealogia do homem sem qualidades", disponível em http://biblioteca.folha.com.br/1/27/2001052001.html (acesso em15/09/2008), relata que o sinólogo francês Paul Demiéville (1977) tradutor de "Lições" de Lin-Tsi, mestre de uma das seitas budistas, faz uma comparação, que se revela mais surpreendente, quando é utilizada para designar Buda: “Toda definição do homem verdadeiro só pode ser imprópria (...) posto que, por definição, é o que escapa a toda definição".

A expressão homem verdadeiro procede dos filósofos taoístas da Antiguidade, embora também tenha sido usada para designar Buda, nas primeiras traduções chinesas. A palavra "situação" aplica-se, no vernáculo chinês, à situação de um funcionário na hierarquia oficial. Como essa hierarquia incluía toda a elite social, que era o único grupo que contava na antiga China, um homem sem situação era um ente marginal, carente de status, uma entidade indefinida.

Segundo Saer, o homem sem qualidades é aquele que, desembaraçado de todas as convenções, das posturas sociais, dos conteúdos intelectuais e morais, das máscaras de identidade, dos sentimentos e emoções calcados pelo entorno, da sexualidade canalizada nos diques do socialmente aceito, volta para o grau zero da disponibilidade e constrói sua vida opondo-se a todo o automatismo e a todo o lugar-comum da inteligência, da vida afetiva e do comportamento.

Saer (2001) ressalta que

no Império Austro-Húngaro decadente, acossado pelas pomposas pretensões da corte e pelas constantes reivindicações do arquipélago de pequenas e grandes nações e culturas que o compunham, ser um homem sem qualidades, reivindicar apenas a própria disponibilidade sem prévias adesões compulsórias a supostas causas, sagradas ou não, a determinadas normas de conduta, ditadas como eternas e pensadas para reger a sucessão de gerações fugitivas, supostamente idênticas umas às outras, representava não uma forma de egoísmo ou um modo de virar as costas para a realidade, mas uma saudável desconfiança quanto ao consabido, ao irrefletido, ao imposto pela esmagadora inércia do entorno.

Ao se referir aos homens sem qualidades, Saer os denomina fiapos de homens. Para ele, "Ulrich, o protagonista de $O$ homem sem qualidades, não tem nada de 
aventureiro ou sensualista que quisesse desfrutar indefinidamente de novas experiências, à maneira dos decadentistas do final do século XIX”. Ele representa:

\begin{abstract}
um espírito racional, sistemático, amável e jovial. Sua vida transcorre no marco de uma existência burguesa banal. Seu único ato verdadeiramente transgressivo é a relação amorosa que mantém com sua meio-irmã, que, ao longo do romance, vai se transformando no elemento simbólico de uma vida sistematicamente voltada a transcender as convenções exorbitantes que o mundo impõe aos indivíduos. (SAER, 2001)
\end{abstract}

Portanto, o homem verdadeiro, sem situação, aquele a que se refere o mestre budista, reaparece inesperadamente em nosso tempo no romance de Robert Musil, conforme deduz Saer. Mas, em outro registro, ele também poderia ser representado por esses fiapos de homens que são os personagens de outros autores, como Samuel Beckett e James Joyce. Finalizando seu raciocínio, Saer afirma que o homem sem qualidades "está presente nas reflexões atuais sobre a crise e o estatuto do sujeito, bem como na desconfiança de alguns sobre todas as ideologias que exaltam, sem maior precisão, os discutíveis méritos do conceito de identidade".

De acordo com as questões examinadas, o tratamento da identidade narrativa passa a ser diferente do encontrado nos estudos anteriores de Ricoeur, nos quais a abordagem foi feita de modo mais polêmico e defensivo do que construtivo. Restam, assim, duas tarefas a cumprir. A primeira é levar ao mais alto grau a dialética da ipseidade e da mesmidade, implícita na noção de identidade narrativa. A segunda é completar a investigação do si relatado, pela exploração das mediações que a teoria narrativa pode operar entre teoria da ação e teoria moral. Esta tarefa terá, ela própria, duas vertentes. Tendo como base o descrever, relatar, prescrever, questiona-se sobre a extensão do campo prático que a função narrativa suscita, se a ação descrita deve poder igualar-se à ação relatada. Em seguida, o exame se deterá sobre a maneira da narração, de que modo esta, que nunca é eticamente neutra, mostra-se como o primeiro laboratório do julgamento moral. Sobre essa dupla vertente, prática e ética, da teoria narrativa, prosseguirá a constituição recíproca da ação e do si.

A verdadeira identidade narrativa só se revela na dialética da ipseidade e da mesmidade. Esta última representa a maior contribuição da teoria narrativa à constituição 
do si. Ricoeur segue uma ordem de argumentação quando mostra que primeiramente, no prolongamento das análises de Tempo e narrativa, há um modelo específico de conexão entre acontecimentos que constitui a intriga. É esta que permite integrar à permanência da identidade no tempo ao que parece ser o contrário sob o regime da identidade-mesmidade, a saber, a diversidade, a variabilidade, a descontinuidade e a instabilidade. Em seguida, é mostrado que a noção de intriga, transposta da ação para os personagens da narração, gera a dialética dos personagens - uma dialética da mesmidade e da ipseidade.

O retorno aos puzzling cases da filosofia analítica no espaço de variações imaginativas, aberto pela dialética da ipseidade e da mesmidade, abre-se aos casos-limites de dissociação entre duas modalidades de identidade, dignas de entrar em competição com os casos indetermináveis de Parfit. Tal estratégia se torna uma ocasião oferecida para confrontar os recursos respectivos da ficção literária e da ciência-ficção diante do caráter eminentemente problemático da identidade pessoal.

Quando Ricoeur recorre a Dilthey, na Introducción a las ciencias del espíritu Ensayo de uma fundamentación del estudio de la sociedad y de la historia (Dilthey,1966) (Introdução às ciências do espírito - Ensaio de uma fundamentação do estudo da sociedade e da história) (Tradução do título nossa.), este formava o conceito de conexão de vida e o considerava como conceito equivalente ao de história de uma vida. É essa précompreensão da significação histórica da conexão que a teoria narrativa da identidade pessoal tenta articular, no nível superior de conceitualidade. A identidade narrativa pode ser chamada, por convenção de linguagem, de identidade do personagem. Essa identidade é situada no campo da dialética do mesmo e do si.

Ricoeur revela como a identidade do personagem se constrói em ligação com a intriga. Essa derivação de uma identidade à outra, somente indicada em Tempo e narrativa (1997, p. 173-327), é então explicitada em O si mesmo como outro (1991, p. 167-198). Em Tempo e narrativa, a identidade no plano da intriga é caracterizada pela concorrência entre uma exigência de concordância e a admissão de discordâncias que, até a conclusão da narração, põem em perigo essa identidade. Por concordância, entende-se o princípio da ordem que preside ao que Aristóteles chama de agenciamento dos fatos. Por discordância, entendem-se as reviravoltas da fortuna que fazem da intriga uma transformação regulada 
desde uma situação inicial até uma situação terminal. O termo configuração é aplicado a essa arte da composição que faz mediação entre concordância e discordância. A fim de estender a validade desse conceito de configuração narrativa para além do exemplo privilegiado de Aristóteles - a tragédia grega e, em menor grau, a epopéia - na qual se inseriria o romance $O$ homem sem qualidades -, Ricoeur propõe definir a concordância discordante, característica de toda a composição narrativa, pela noção de síntese do heterogêneo. Por esse meio, Ricouer tenta explicar as diversas mediações que a intriga opera - entre a diversidade dos acontecimentos e a unidade temporal da história relatada; entre os componentes díspares da ação, intenções, causas e acasos e o encadeamento da história; enfim, entre a pura sucessão e a unidade da forma temporal - mediações que, em última análise, podem subverter a cronologia a ponto de aboli-la. Essas múltiplas dialéticas só fazem explicitar a oposição, presente no momento trágico, segundo Aristóteles, entre a dispersão episódica da narrativa e o poder de unificação desenvolvido pelo ato configurante que é a própria poiésis.

É preciso comparar a configuração narrativa com a conexão reivindicada por uma descrição impessoal. A diferença que distingue o modelo narrativo de qualquer outro modelo de conexão reside no estatuto do acontecimento. Não pode, assim, ser fortuito que Musil intitule as duas partes que compõem o Livro Primeiro de O homem sem qualidades, situando-as entre dois acontecimentos que, a rigor, não são diferentes e tampouco opostos. Os títulos que ele escolhe para conectá-las na narrativa revelam tal indiferenciação no estatuto de acontecimento. A primeira parte é então iniciada pelo primeiro capítulo:"Do qual singularmente nada se depreende" (Musil, HSQ, p.27-30), enquanto a segunda parte se intitula: “A mesma coisa acontece"(Musil, HSQ, p.101-704). Enquanto, num modelo de tipo causal, acontecimento e ocorrência são indiscerníveis, o acontecimento narrativo, tal como ocorre em Um homem sem qualidades, é definido pela sua relação com a própria operação de configuração; ele participa da estrutura instável de concordância discordante característica da própria intriga; ele é fonte de discordância, quando surge, e é, ao mesmo tempo, fonte de concordância, no que tange ao avanço da história.

O paradoxo da intriga é que ela inverte o efeito da contingência, no sentido daquilo que poderia acontecer de outro modo ou mesmo não acontecer, incorporando-o de algum modo ao efeito de necessidade ou de probabilidade, exercido pelo ato configurante. A 
inversão do efeito de contingência em efeito de necessidade produz-se no próprio centro do acontecimento, como simples ocorrência, limitando-se a frustrar as expectativas criadas pelo curso anterior dos acontecimentos; ele é simplesmente o inesperado, o surpreendente, não se tornando parte integrante da história.

A noção de intriga, antes de toda a consideração da dialética do personagem que é seu corolário, resulta que a operação narrativa desenvolve um conceito completamente original de identidade dinâmica, que concilia as próprias categorias que Locke considerava contrárias uma à outra: a identidade e a diversidade.

Quando se passa da ação ao personagem, pode-se dizer que tal procedimento é um passo decisivo no âmbito da concepção narrativa da identidade pessoal, pois é o personagem que faz a ação na narrativa, sendo assim uma categoria. A questão é saber o que a categoria traz para a discussão da identidade pessoal. A tese até aqui sustentada é que a identidade do personagem compreende-se por transferência para ele da operação de intriga primeiramente aplicada à ação relatada - o personagem é ele próprio a intriga.

O problema moral enxerta-se no reconhecimento da dissimetria essencial entre aquele que faz e aquele que sofre, culminando na violência do agente poderoso - o escritor ou o demiurgo?. Ser afetado por uma série de acontecimentos relatados, eis o princípio organizador de toda uma série de papéis de pacientes segundo a qual a ação exercida é uma influência, um melhoramento ou uma deterioração, uma proteção ou uma frustração. Um enriquecimento extraordinário da noção de papel diz respeito à introdução dessa última no campo das valorizações, depois no das retribuições, onde o paciente aparece como beneficiário de méritos ou vítima de deméritos, segundo o qual o agente revela-se alternativamente distribuidor de recompensas e de punições. É nesses estágios que agentes e pacientes encontram-se alçados à classe de pessoas e de iniciadores de ação. Desse modo, vem se confirmar no plano narrativo, por meio dos papéis dependentes do campo das valorizações e do das retribuições, a conexão estreita entre teoria da ação e teoria ética.

Apesar de tudo, de um ponto de vista paradigmático, as perguntas quem?, o quê?, como? podem designar os termos discretos da rede conceitual da ação. Mas, de um ponto 
de vista sintagmático, as respostas a essas questões formam uma cadeia que não é outra que não o encadeamento da narrativa. Relatar é dizer quem fez o que, por que e como, mostrando, no tempo, a conexão entre esses pontos de vista. Igualmente, pode-se descrever separadamente os predicados psíquicos tomados fora da atribuição a uma pessoa, o que é a própria condição da descrição do psíquico. Mas é na narrativa que se recompõe a atribuição do ponto de vista de um eu que é um nós em uma trama.

Do mesmo modo, a articulação entre intriga e personagem permite encarar uma investigação virtualmente finita no plano da atribuição a alguém. As duas investigações confundem-se no duplo processo de identificação da intriga e do personagem. A narrativa resolve, a seu modo, a antinomia, de um lado, conferindo ao personagem uma iniciativa, isto é, o poder de começar uma série de acontecimentos, sem que esse começo constitua um começo absoluto, um começo do tempo, por outro lado, dando ao narrador, como tal, o poder de determinar o começo, o meio e fim de uma ação. Desse modo, fazendo coincidir a iniciativa do personagem e o começo da ação, a narrativa satisfaz à tese sem violar a antítese. Ela constitui, em seus múltiplos aspectos, a réplica poética que a noção de identidade narrativa traz às aporias do que foi registrado ou sujeitado no texto.

Até certo ponto de suas reflexões, mais precisamente em $O$ si-mesmo como um outro (1991), a função narrativa não dava a Ricoeur uma resposta especulativa a essas aporias, mas tornava-as produtivas num outro registro de linguagem. Por um lado, da correlação entre ação e personagem da narrativa, resulta uma dialética interna ao personagem que é o corolário da dialética de concordância e de discordância desenvolvida pela intriga da ação. Na linha da concordância, o personagem tira sua singularidade da unidade de sua vida, tida como a própria totalidade temporal singular, que o distingue de qualquer outro. Por outro lado, pela linha da discordância, essa totalidade temporal é ameaçada pelo efeito de ruptura dos acontecimentos imprevisíveis, tais como encontros, acidentes etc., que a pontuam. A síntese concordância-discordância faz com que a contingência do acontecimento contribua para a necessidade de algum modo retroativa da história de uma vida, ao que se iguala à identidade do personagem.

Dessa forma, o acaso é transmutado em destino, e a identidade do personagem será o signo dessa dialética. O personagem da narrativa não é uma entidade distinta de suas 
experiências, pelo contrário, ela divide o regime da própria identidade do personagem que pode ser chamada sua identidade narrativa, construída pela identidade da história relatada. É a identidade da história que faz a identidade do personagem. E vice-versa.

Ricoeur nota a necessidade de inscrever nessa dialética da concordância discordante a dialética da mesmidade e da ipseidade. Trata-se agora de mostrar como a dialética do personagem vem inscrever-se no intervalo entre esses dois pólos da permanência no tempo para fazer mediação entre eles. A função mediadora que a identidade narrativa do personagem exerce entre os pólos da mesmidade e da ipseidade é, essencialmente, confirmada pelas variações imaginativas às quais a narrativa submete esta identidade. Sobre essas variações pode-se dizer que a narrativa só faz tolerá-las; ela as produz, procura-as, e, nesse sentido, os recursos de variação da identidade narrativa são postos à prova da própria narrativa.

- O homem sem qualidades é um laboratório para experiências do pensamento

O teatro e o romance contemporâneo - do qual $O$ homem sem qualidades é experimento emblemático para esta tese - mostram que a narrativa também tem seus casos desconcertantes, deixando-se neles descrever as ficções da perda de identidade. Com a argumentação desenvolvida até o presente momento, Musil cria um personagem, Ulrich, de maneira a expor como o homem, em seu sentido genérico - se é que há homem genérico, senão enquanto uma ficção - torna-se não-identificável, num mundo dito de qualidades ou de propriedades sem homens. A ancoragem do próprio adjetivo que o autor lhe confere -sem qualidades - torna-se derrisória a ponto de se tornar redundante. O nãoidentificável torna-se o inominável, e, daí em diante, com a experiência das Guerras, ele será o inumano.

Para precisar o começo filosófico de semelhante eclipse da identidade do personagem, convém observar que, à medida que a narrativa se aproxima do ponto de anulação do personagem, o romance perde também suas qualidades propriamente 
narrativas, mesmo interpretadas de modo mais flexível e mais dialético. A perda da identidade do personagem corresponde à perda da configuração da narrativa e a uma crise da conclusão da narrativa.

Mas o que se pode compreender como perda de identidade? A tese até aqui levantada é, recolocando no quadro da dialética do idem e do ipse, esses casos desconcertantes da narração se deixam reinterpretar como desguarnecidos da ipseidade pela perda de suporte da mesmidade. O que se perdeu agora, sob o título de propriedade, tal como Musil toma o termo qualidades para o título de seu romance, é o que permitia igualar o personagem a seu caráter. A mimesis é o pressuposto pela narrativa literária submetida ao constrangimento, pois a ação imitada na e pela ficção fica também submetida ao constrangimento da condição corporal e terrestre.

O que os puzziling cases marcam diretamente, com uma contingência radical, é que sob tais condições, a hermenêutica da existência, subjacente à noção do agir e do sofrer, considera instransponível. A operação dessa inversão de sentido pelo que a invariante existencial se torna a variável de uma nova montagem imaginária é dada pela técnica, ou melhor, para além da técnica disponível, a técnica concebível, enfim, aqui nesta tese, o sonho tecnológico cujo desejo é representado pelo homem-unidimensional, tal como Marcuse o descreve. Esse sonho, contextualizado na sociedade tecnológica, está correlacionado ao tratamento impessoal da identidade no plano conceitual. Assim, pode-se dizer que as variações imaginativas da ciência-ficção são variações relativas à mesmidade, enquanto as da ficção literária são relativas à ipseidade ou mais exatamente à ipseidade em sua relação dialética com a mesmidade. A verdadeira perplexidade não reside no interior de um ou outro campo de variações imaginativas, mas, pode-se dizer que ela ocorre entre um que é outro.

Pretende-se assim compreender o processo de identidade que se dá entre descrever e narrar. Tratar-se-ia de justificar por que a teoria narrativa ocupa no percurso da investigação proposta uma posição de articulação entre a teoria da ação e a teoria ética. A questão tem duas vertentes: uma que diz respeito aos estudos lógico-práticos que são objeto de um experimento concreto, isto é, quando este utiliza fatos e dados obtidos em um plano de realidade nomeada concreta. De outra maneira, o experimento com o campo 
da ficção mostra-se igualmente conveniente para a medida da conexão revelada pela teoria narrativa, entre intriga e personagem. Além de permitir uma outra ordem de esclarecimento, tal experimento lança sobre as dificuldades ligadas à relação da ação com o seu agente uma extensão considerável do campo prático; isto é: se a ação descrita podese igualar à ação narrada. De outra vertente - aquela que diz respeito aos estudos morais -, a questão é a dos apoios e das antecipações que a teoria narrativa propõe à interrogação ética. A relação da intriga com o personagem não traz novas luzes para a relação entre a ação e seu agente. Isto é, a não ser quando se pensa no preço de uma extensão do campo prático, além dos segmentos da ação que a gramática lógica inscreve mais facilmente nas frases de ação. E mesmo além das cadeias de ação, cujo interesse reside no modo de conexão lógica, este é dependente de uma teoria epistemológica, que estuda as ações humanas, o comportamento e suas leis, induzindo a conclusões operacionais.

As primeiras unidades compostas são as que merecem o nome de práticas. Os exemplos mais familiares a respeito delas no campo da psicologia social são as profissões, as artes, os jogos. Pode-se formular uma primeira idéia do que são as práticas, partindo da descrição das ações de base na teoria analítica da ação. As ações de base, tais como os gestos, as posturas, as ações corporais elementares, são aquelas que aprendemos a coordenar e a dominar, mas das quais não aprendemos verdadeiramente os rudimentos.

Por contraste, todo o resto do campo prático é construído sobre a relação em vista de: para fazer Y é preciso primeiramente fazer X. Poder-se-ia então objetar à introdução do conceito de prática que ele é supérfluo: faz-se chegar $\mathrm{Y}$ em nós procurando X. Essa mistura entre finalidade e causalidade, intencionalidade e conexões sistemáticas, é certamente constitutiva dessas ações longas que são as práticas. Todavia, falta a unidade de configuração que divide uma profissão, um jogo, uma arte nessas longas cadeias de ações. Outra espécie de conexão contribui para a delimitação das práticas como unidades de segunda ordem e trata não mais das relações lineares, mas de relações de encaixe. Essa ligação de encaixe, portanto de subordinação das ações parciais a uma ação total, não se articula com a ligação de coordenação entre segmentos sistêmicos e segmentos teleológicos, a não ser na medida em que as conexões de uma e outra espécie são unificadas sob as leis de sentido que fazem de qualquer profissão uma prática. 
A unidade de configuração constitutiva de uma prática repousa em uma relação particular do sentido, que exprime a noção de regra, a qual foi obtida por empréstimo precisamente da teoria dos jogos antes de ser estendida à teoria dos atos de discurso, logo reintegrada à teoria da práxis. A regra constitutiva se dá no sentido de que ela não é, acrescentada ao modo de um regulamento exterior aplicado aos movimentos que teriam, em sua própria organização, um conjunto de regras. Somente este conjunto reveste o gesto de significação e é constitutivo precisamente da significação do valer como.

Convém notar que as regras constitutivas não são morais, elas constituem somente a significação de gestos particulares. Porém, pode-se dizer que tais regras ajudam a encontrar as regras morais, uma vez que regem as condutas suscetíveis de assumir uma significação. A introdução da noção de regra constitutiva, nesse estágio da análise, tem outra virtude, introduzir, na estrutura das práticas, relações específicas de significação. Tal regra contribui para sublinhar o caráter de interação que se liga à maioria das práticas.

Há uma relação estreita com a esfera narrativa, reforçada pelos aspectos de interação próprios às práticas: é a esses que a narrativa confere a forma polêmica de uma competição entre programas narrativos. A mesma relação entre práxis e narrativa repete-se num grau mais elevado de organização, mas, ao seguir tal raciocínio, o objetivo é evidenciar que o campo prático não se constitui de baixo para cima. Este não se dá por composição do mais simples ao mais elaborado, mas segundo um duplo movimento de dificuldade ascendente. Ele se dá a partir das ações de base e das práticas, e de especificação descendente, do horizonte vago e móvel dos ideais e dos projetos à luz dos quais uma vida humana apreende-se em sua unicidade. As narrativas literárias e histórias de vida, longe de se excluírem, completam-se, a despeito ou por causa de seu contraste. Essa dialética nos lembra que a narrativa faz parte da vida antes de se exilar da vida na escrita; ela volta à vida segundo as múltiplas vias da apropriação e ao preço de tensões inexpugnáveis.

A noção de identidade narrativa acarreta dificuldades ligadas à confrontação entre a versão narrativa e a versão ética da ipseidade. O enraizamento da narrativa literária no solo da narrativa oral, no plano da prefiguração da narrativa, permite entender que a função narrativa não existe sem implicações éticas, como atesta a tese desenvolvida por 
Ecléa Bosi (1994). Na troca de experiências que a narrativa opera, as ações e os agentes não deixam de ser aprovados ou desaprovados.

O prazer que se tem em seguir o destino dos personagens implica que os leitores suspendem todo o julgamento moral real, ao mesmo tempo em que é esse prazer que coloca em suspenso a ação efetiva do leitor. Mas, no recinto irreal da ficção, não se deixa de explorar novas maneiras de avaliar ações e personagens. As experiências de pensamento conduzidas no imaginário são também explorações levadas ao reino do bem e do mal. Supervalorizar, ou ainda desvalorizar, é ainda avaliar. O julgamento moral não é abolido, ele é, antes, submetido às variações imaginativas próprias da ficção. É a favor de tais exercícios de avaliação, na dimensão da ficção, que a narrativa pode finalmente exercer sua função de descoberta e também de transformação em relação ao sentir e ao agir do leitor, e justamente na fase de refiguração da ação pela narrativa. Mesmo a narrativa historiográfica não é neutra, pois é pelo menos sobre o modo da imaginação e da empatia que esta faz reviver maneiras de avaliar que continuam a pertencer ao sentido de humanidade, que seria, de outra forma, inerente à condição humana.

A identidade narrativa mantém-se entre a ipseidade e a mesmidade; tornando narrável o caráter, a narrativa restitui-lhe o movimento, abolido nas disposições adquiridas, nas identificações. Tornando narrável a perspectiva da verdadeira vida, este lhe dá os traços reconhecíveis de personagens amados ou respeitados. A identidade narrativa mantém juntas as duas pontas da cadeia: a permanência no tempo do caráter e a da manutenção de si.

Podemos dizer que a dificuldade vem dos casos limites que parecem propor uma problematização de identidade narrativa, que não confirmam identidade ética figurada pela manutenção do si, mas retiram todo o ponto de apoio. Por que, efetivamente, nós nos interessaríamos pelo drama da dissolução da identidade do personagem de Musil e seríamos mergulhados por ele na perplexidade, se o não-sujeito não permanecesse uma figura do sujeito, mesmo que fosse sobre o modo negativo? Um não-sujeito não é nada, como lembra a semiótica do sujeito de discurso ou de ação. Esse defensor para a ipseidade, que documentam os casos perturbadores da ficção literária, começa a mudar para seu contrário quando, a ficção voltando à vida, o leitor à procura da identidade encontra-se diante da hipótese de sua própria perda de identidade, (...) que foi ao mesmo tempo o tormento de Musil e o efeito de sentido interminavelmente cultivado pela sua obra. $\mathrm{O}$ si aqui representado pela 
narrativa é na realidade confrontado com a hipótese de seu próprio nada. Certamente esse nada não é o nada do qual não se tem nada que dizer. Essa hipótese dá, ao contrário, muito o que dizer, como disso é testemunha a imensidade de uma obra como $O$ homem sem qualidades. A frase "Eu não sou nada" deve conservar sua forma paradoxal: "nada" já não significaria nada, se "nada" não fosse, como efeito, atribuído ao "eu". Mas quem é ainda eu quando o sujeito diz que não é nada? Um si privado do auxílio da mesmidade, dissemos e repetimos. (RICOUER, 1991, p.196)

Como então manter no plano ético um si que, no plano narrativo, parece apagar-se? Como dizer ao mesmo tempo Quem sou eu? e Eis-me aqui? A distância entre a questão na qual se absorve a imaginação narrativa e a resposta do sujeito tornado responsável pela expectativa do outro torna-se uma falha secreta no próprio centro do engajamento. Essa falha secreta faz a diferença entre a modéstia da manutenção do si e o orgulho estóico da inflexível constância a si. É exatamente nesse ponto que o caminho aqui seguido torna a cortar o de Parfit. Num sentido, a caracterização da ipseidade pela relação de posse ou de dependência entre a pessoa e seus pensamentos, suas ações, suas paixões, em suma, suas experiências, não existe sem ambigüidade no plano ético. Numa filosofia da ipseidade, a posse não é o que importa; o que sugerem os casos-limites gerados pela imaginação narrativa é uma dialética da posse e da espoliação, da preocupação e da despreocupação, da afirmação de si e do desaparecimento de si. Assim, o nada imaginado do si torna-se crise existencial do si. 


\section{TERCEIRO CAPÍTULO}

\section{O homem, a obra, o tempo-lugar, Zeitgeist etc.:}

- Musil - matemático, engenheiro e psicólogo se transforma em escritor

Este capítulo visa traçar, em seu objetivo principal, a imensa empreitada intelectual de Musil, voltada para a reflexão da ética moderna. $O$ homem sem qualidades pode ser o desdobramento do retrato kantiano que levou Musil a interpretá-lo como o vazio resultante de uma discrepância estrutural no psiquismo humano. Contudo, não está em questão a incongruência da conceituação voltada para o sublime de Kant (1995), ressaltada pelo poder de conceber e a habilidade de apresentar, na questão revista na discussão empreendida por Lyotard (2006).

O que se quer enfatizar é a discrepância estrutural entre dois estados psicológicos incompatíveis, alojados de modo fugaz na glória momentânea da experiência estética, enquanto essa se eleva pela conjunção de intelecto e imaginação no julgamento que particulariza o belo, e muitas vezes sem que se perceba que, sob tal forma de crítica, abriga-se grande parte das decisões políticas. A reapropriação original de Musil da estética kantiana conduz o modelo modernista para a concepção da relação entre literatura, ética, e ação humana, que diz muito sobre os pioneiros da cultura no transcurso dos séculos XIX-XX, permitindo que se compreenda os seus efeitos até o início do século atual.

Musil goza de uma reputação ambivalente até os dias de hoje como autor altamente respeitado, mas igualmente negligenciado. Sua canonização no início da década de 1960 não foi capaz de se traduzir na larga recepção pela qual ele ansiava e a qual ele perseguia em vida. Tal negligência tem sido atribuída à complexidade e ao grande escopo de questões que ele escolheu reunir, tanto em seus trabalhos quanto em sua ficção. A complexidade e sofisticação teórica de sua reflexão são responsáveis por sua reputação como um autor difícil, não prontamente acessível a 
uma audiência maior. Deve-se acrescentar ainda que os trabalhos de Musil não são facilmente incorporados dentro dos paradigmas que controlaram a recepção do modernismo até os debates sobre pós-modernismo, que, a despeito de importantes diferenças ideológicas, muitas vezes pareciam excessivamente preocupados em apresentar avaliações nítidas de autores e textos baseados em polaridades como início/fim, direita/esquerda, engajado/despolitizado, modernismo/avant-garde.

Os estudiosos do início do modernismo ${ }^{25}$, portanto, tendem a classificar textos modernistas sob uma categoria geral de interpretação que contempla, também, as primeiras fases da obra de Musil. Os debates considerados pós-modernos favoreceram a introdução de categorias menos dicotômicas para a apreciação de textos modernistas, em especial o interesse renovado no trabalho de Musil. Esta substituição no entendimento do modernismo cultural e literário está simbolicamente refletida no interesse de expandir e distinguir categorias desenvolvidas na leitura de textos modernistas. É típico das primeiras fases de escritos de Musil que os valores humanistas da harmonia e reconciliação, como observados na busca existencial de muitos personagens no Homem sem qualidades, sejam considerados como estando no centro da suposta mensagem modernista desse autor. Quando forçado a paradigmas interpretativos dominados por escolhas ou/ou, Musil parece um pensador indeciso, o explorador irresoluto de antinomias: o apoiador da razão e de um enfoque empírico antimetafísico à experiência, e ao mesmo tempo proponente de estados místicos; o campeão da multiplicidade e da ambivalência, e ainda assim advogado de soluções parciais; um escritor declaradamente despolitizado, mas ainda assim um pensador profundamente engajado. Mesmo quando comparado com contemporâneos cuja reflexão também demonstra um alto grau de ambivalência, tais como Benjamin, Adorno ou Bloch e outros frankfurtianos, Musil aparenta ser um pensador nadando contra a maré, agarrando-se a bóias fora de moda como razão, precisão científica, soluções parciais, ou as aparentemente ineficazes utopias de trabalhismo e atitude indutiva em um tempo que viu o levante inexorável do totalitarismo na Europa.

\footnotetext{
25 BATHRICK; HUYSSEN, Modernity and the text: revisions of German modernism, 1989, p. 1-16. Ver também por BERNSTEIN, Five portraits: modernity and the imagination in twentieth-century German writing, 2000, p. 35-55.
} 
A biografia de Musil reflete a vida de um intelectual cujo senso claro de seus méritos e compromisso resoluto para com a sua missão como escritor o impediram de fazer concessões e formar alianças que teriam assegurado a ele a influência e o reconhecimento que merecia. ${ }^{26}$ Nascido em Klagenfurt, em 1880, foi treinado como engenheiro, matemático e um psicólogo experimental.

Depois que seu primeiro romance, O jovem Törless, foi saudado como êxito literário em 1906, Musil abriu mão de uma carreira na academia para se dedicar completamente à escrita. Em casa, na cultura de Viena, bem como na dinâmica Berlim, Musil logo conquistou o respeito e o apoio de escritores proeminentes e intelectuais, incluindo Franz Blei, Alfred Döblin, e o influente crítico literário Alfred Kerr. Apesar do prestígio de que gozava nos círculos literários contemporâneos, conforme documentado pelos importantes prêmios literários que ganhou na década de 1920, nunca obteve sucesso em angariar uma audiência mais abrangente, em parte devido à sua produção literária relativamente sofisticada, descontínua e instável. Suas tentativas, sem sucesso, de assegurar um meio de vida para si e sua família por meio de sua atividade como cronista e crítico de teatro levaram-no a dificuldades financeiras que o atormentaram por toda a vida. Ao final da década de 1920, apuros financeiros crônicos e a frustração de ter que competir pela atenção de um público menos culto, aparentemente faminto por literatura, criaram nele uma amargura crescente, aumentando o seu ressentimento por escritores de sucesso como Thomas Mann e Hermann Broch. ${ }^{27}$

Não obstante, no final dos anos 20 Musil tinha conseguido consolidar sua posição nos círculos literários de Berlim. Sua reputação foi ainda mais enaltecida pelo sucesso de crítica do primeiro volume de $\mathrm{O}$ homem sem qualidades, publicado em 1930. Contudo ele deixou de capitalizar sua visibilidade aumentada, em parte devido à sua falta de habilidade em dar continuidade ao segundo e último volume do romance. A eclosão do socialismo nacional na Alemanha, em 1933, levou-o ao seu

\footnotetext{
${ }^{26}$ ROGOWSKI, Distinguished outsider: Robert Musil and his critics, 1994, p. 8-17; PIKE, Robert Musil: an introduction to his work, 1961; HICKMAN, Robert Musil and the culture of Vienna, 1991. Veja também: LUFT, Robert Musil and the crisis of European culture, 1880-1942, 1980. Para a mais compreensível documentação da vida e do trabalho de Musil veja CORINO, Robert Musil, 1989.

${ }^{27}$ CANETTI, O jogo dos olhos, 1990, Parte III, p. 159-166.
} 
eclipse gradual como intelectual de destaque na cena alemã. Crescentemente atormentado por um bloqueio psicológico que o impedia de escrever, assim como outras enfermidades físicas que o acometiam, Musil se encontrou trabalhando a um passo ainda mais lento na seqüência do primeiro volume do romance, que se tornou o objeto de sua preocupação quase obsessiva. No relato mais completo sobre a vida de Musil, Karl Corino descreve minuciosamente tal episódio:

No início do ano de 1928, Musil foi acometido por uma crise no seu trabalho de escritor: andava em círculos ao redor da sua escrivaninha, não conseguiu escrever nem uma linha. 'Descontentamento com o que já tinha feito, dúvidas quanto à continuação, indecisão quanto ao melhor caminho a ser seguido na continuação do romance e também a imprevisibilidade da concepção como um todo, a saber, nos contextos e entrelaçamentos do desenrolar dos acontecimentos e desenvolvimento intelectual', foram as causas apontadas pelo seu colega O.M. Fontana, fazendo o papel de confidente a pedido de Musil. (p.393). Mediante a intervenção de Bela Balász, Musil teve sessões individuais de tratamento psicológico com o aluno de Adler, Dr. Hugo Lukács, que restabeleceu sua capacidade de trabalhar através de uma série de entrevistas. Obedecendo a um pedido do médico, Musil tentou pesquisar ele mesmo os mecanismos das suas inibições, o que ele fez sob o título: 'Técnica sub specie Lukács': sintoma principal: 2 metas que concorrem entre si; paralisia. Livrar-se de uma das metas parece impossivel; fusão \{das duas metas\} dificil. Normalmente: I. a meta original; II. Das anotações feitas para esta meta surgem submetas que concorrem entre si; III. Amplitude. Monotonia. Ficando cada vez mais longo. Solução costumeira: esperar um ou alguns dias; a força da determinação se enfraquece. Um novo pensamento consegue criar um reagrupamento. $O$ inversamente, um reagrupamento leva a um novo pensamento. Algo importante torna-se sem importância e é descartado. Sempre surge teoria demais e ensaio. (p. 338) Se você sabe o que você quer, então você consegue. Você sempre consegue saber o que você quer. [...] Requisito mais importante: uma idéia condutora (necessária tanto para escrever como para compreender). Tanto no conjunto quanto nos detalhes. [ele usa a palavra Vorstellung = imaginação, representação e cria Leitvorstellung, semelhante a Leitmotiv na música; mas podia ser também 'idéia dominante']. "Qual é propriamente o conteúdo?" - Esta pergunta expressa exatamente a necessidade disso [do requisito].Uma idéia condutora tem que ser simples e drástica, ou não ajuda em nada. (p. 393) Como conseqüência de tais análises, Musil fez toda uma séria de folhas condutoras, que deveriam ordenar o material em idéias para a redação: como comprova a figura fragmentada do romance, mesmo não se tornando uma receita de patente até ao fim da vida, ele conseguiu concluir o primeiro volume da obra nos dois anos subseqüentes. $\mathrm{O}$ agradecimento público ao Dr. Lukács foi ambíguo/obscuro/pressagiador. Em sua resenha da brochura de Lukács, Psicologia do aprendiz, Musil escreveu aos 30 de maio de 1928: [...] O total do arsenal de sofrimentos $e$ desvios da vida revela-se, em muitos casos, como sendo só algumas pequenas falhas/erros da técnica da vida, que 'cresceram' e podem ser debelados e resolvidos do modo mais suave do mundo, através de uma série de entrevistas, que mal exigem intimidade, são como uma conversa amiga, e depois também através do exercício contínuo. Esta técnica nada mais é do que um tipo de escola da vida dirigida por um médico, mas 
creio poder dizer que com sua ajuda se consegue literalmente atacar o destino de modo surpreendente (p. 394). ${ }^{28}$

Esta passagem ilustra o quadro em que Musil se encontrava. Porém, mesmo com o agravamento do seu estado de saúde, a anexação da Áustria pela Alemanha em 1938 o forçou a deixar Viena com sua família e buscar refúgio na Suíça. Quando da sua morte repentina em Genebra em 1942, ele ainda estava trabalhando no que parecem ser capítulos relativamente iniciais do segundo volume do romance. A primeira edição pós-guerra de $O$ homem sem qualidades, publicada por Adolf Frisé em 1952, tirou o nome de Musil do esquecimento no qual havia mergulhado no final da década de 1930 e rapidamente o colocou entre os novelistas mais exímios e incisivos do século XX. Sua inclusão no panteão do modernismo europeu, ao lado de Joyce e Proust, finalmente deu a Musil o sucesso que lhe havia escapado durante a vida. $^{29}$

A sensibilidade modernista de Musil fica plenamente compreensível quando considerada à luz de seu posicionamento singular em relação à modernidade, assim como suas visões sobre arte e ética o deixaram à parte de outros modernistas proeminentes. Musil se viu como representante de uma geração de 1900, uma geração de intelectuais e artistas que amadureceram no meio de narrativas de crise e histórias de redenção, com as quais se viram confrontados.

- O declínio da alta cultura

No caso de Viena, a alta cultura sofre declínio no começo da década de 1860. Junto com seu contexto formador, há o fracasso do liberalismo político, concomitante ao processo de unificação entre as diversas partes do império austrohúngaro seguido ao período de depressão econômica na Alemanha na década de

\footnotetext{
${ }^{28}$ Cf. CORINO. Musil, Leben und Werk in Bilden und Texten, 1989. Foram mantidos os grifos, quando Corino se refere à escrita original de Musil. (Tradução nossa.)

${ }^{29}$ PEYRET, Musil ou les contradictions de la modernité, Critique, agosto-setembro 1975, Paris, t. XXXI, n. 339-340, p.846-863.
} 
1870. A universidade se tornou o centro da frustração política para os jovens herdeiros das famílias liberais. São estes jovens que desenvolveram a contracultura populista como suporte para suas críticas e aspirações políticas. Por um lado, essa contracultura entregou-se ao anti-semitismo, da mesma forma que o racionalismo jacobino gerou o reino do terror, com suas graves conseqüências intelectuais para a cultura iluminista. Por outro lado, aqueles que recuaram, chocados diante das conseqüências racistas do nacionalismo, tornaram possível a pesquisa sobre o psiquismo, estendendo a sua compreensão à dimensão não racional do homem. Entretanto a consciência do rompimento com a história e a busca por uma natureza especial da modernidade pertenciam à experiência da despolitização. A subordinação do social ao psicológico como arena onde se deveria encontrar o sentido para o sentimento de decadência econômica e política foi a contribuição expressionista à cultura liberal tardia. À luz da trajetória de mudança cultural não é surpreendente que os jovens expressionistas mais violentos rejeitassem a sociedade $\mathrm{e}$ a cultura, mostrando menos senso de identidade com aqueles que criaram tais valores no final do século XIX. Sob esse prisma, o racismo se deve ao sentimento irracional exacerbado pela experiência da desestruturação social. Do ponto de vista de uma reação psicológica, o racismo revela, em negativo, o abandono dos ideais predecessores como cruzada regeneradora dos antigos valores. Para Musil, o caráter irracional insano do racismo se revela na tentativa de encontrar o fundamento do ser em um mundo liberal em desintegração. ${ }^{30}$ Tal indisposição é concomitante às dificuldades com as profundas transformações em curso nas sociedades ocidentais.

Estão em curso, na segunda metade do século XIX, fenômenos como industrialização, urbanização e a mecanização da vida diária, possíveis pelos avanços extraordinários da ciência e tecnologia. Esses fenômenos produziram a subversão de estruturas sociais existentes, particularmente como resultado do declínio de velhas elites econômicas, e a emergência de uma classe trabalhadora urbana, esta, em si, tornada mais ameaçadora pelo aumento da política e cultura de massa sob a égide de ideologias altamente polarizadas.

\footnotetext{
${ }^{30}$ SCHORSKE, 2000, p.177-178.
} 
Na década de 1890, a crítica de Nietzsche da racionalidade explodiu como uma bomba na arena cultural, suplantando a fé em uma noção ontologicamente fundamentada e racional da verdade que havia sustentado questionamentos tanto científicos quanto filosóficos ao longo do século XIX, abrindo caminho para o ceticismo, relativismo e niilismo. Mas se as ciências naturais tinham emergido comparativamente sem danos, e de fato prosperaram com o confinamento dentro de uma moldura cética e relativista, o golpe para as ciências humanas foi demasiadamente grande. Promoveu uma reorientação radical, em parte ao longo das linhas de uma filosofia de vida que radicalizava a crítica da razão de Nietzsche que, muitas vezes, eram baseadas na noção não específica de experiência, bem como em categorias conceitualmente obscuras como vida, alma, espírito, sentimento e intuição.

Tal perspectiva foi com freqüência reforçada pelo irracionalismo autoindulgente e pelo ressentimento incondicional em relação aos fenômenos pouco compreendidos da industrialização, urbanização, especialização e racionalização que dirigiam o desenvolvimento das sociedades modernas. Estas se alimentavam em um clima cultural regressivo disposto a buscar refúgio na noção enfática de cultura (alem. Kultur), como último depositário da mais íntima substância da existência humana. A moldura de desespero cultural com a qual freqüentemente foi associada encontrou expressão nas narrativas populares de corrupção e declínio tecidas por pensadores conservadores como Oswald Spengler, Walther Rathenau e Ludwig Klages, bem como no chauvinismo cultural agressivo que culminou nas "idéias de $1914 " 31$

Em seu ensaio A teoria do romance: um ensaio histórico-filosófico sobre as formas da grande épica ${ }^{32}$, Georg Lukács proferiu talvez a mais rigorosa análise da condição moderna de uma perspectiva colorida pelo desespero cultural do início do

\footnotetext{
${ }^{31}$ EVERDELL, The first Moderns: profiles in the origin of twentieth-century thought, 1997. Ver também: BERMAN, Preface to modernism, 1994, p. 21-97. BAMBACH, Heidegger, Dilthey, and the crisis of Historicism, 1995, p.21-55. Para a discussão do assim chamado espírito de 1914, i.e., o aparecimento nacionalista que resultou na mobilização de eminentes artistas e intelectuais alemães a favor da I Guerra Mundial, veja MOMMSEN, Imperial Germany 1867-1918: politics, culture, and society, 1995 , p. 205-16.

${ }^{32}$ LUKÁCS, 2000.
} 
século XX. É significante que Lukács também empregasse a imagem de um círculo da vida para tecer temas familiares de modernidade, alienação e desorientação ética. Dessa forma, uma década depois, ele aparentemente prenuncia o diagnóstico de Clarisse - a personagem atormentada de Musil - sobre a condição humana como um anel oco. Lukács retrata a unidade perdida da experiência humana - cujos ecos podiam ainda ser percebidos na arte harmoniosa da Grécia Antiga - como consignada ao tranqüilizante horizonte confinado de um mundo autocontido que ainda não provou do fruto da racionalidade desenfreada.

A vida para os gregos era um círculo bem acabado, adornado com um centro estável de significado a partir do qual todos os aspectos da experiência poderiam ser interpretados e organizados. Mas a afirmação progressiva e unilateral de um modo racional para se confrontar a existência explodiu os confinamentos seguros do mundo grego. Tal afirmação acompanha a fratura do círculo harmonioso da vida, deixando a matéria cinza da civilização ocidental se espalhar pelas estrelas em um redemoinho de dispersão cósmica. Segundo Lukács:

O círculo em que vivem metafisicamente os gregos é menor do que o nosso: eis por que jamais seríamos capazes de nos imaginar nele com vida; ou melhor, o círculo cuja completude constitui a essência transcendental de suas vidas rompe-se para nós; não podemos mais respirar em um mundo fechado. ${ }^{33}$

Dessa forma os modernos foram obrigados a suportar o pecado original da razão, perpetrado por seus ancestrais quando cederam à tentação de soltar o poder. A despeito de similaridades superficiais, a imagem musiliana de um círculo da vida convocado pelo anel de Clarisse evoca uma visão bem diferente da modernidade e da condição humana - a visão dependente de uma narrativa não de perda e declínio, mas sim de não reconhecimento de si e auto-ilusão decorrente. Essa diferença é instrutiva, pois marca a distância que separa Musil do pessimismo cultural que permeia o modernismo alemão. Por meio de uma deformação e ruptura sucessiva do círculo da vida, o relato de Lukács pretende capturar o dinamismo da história, visto como um processo de dispersão e declínio, alimentado por uma difusão desordenada

\footnotetext{
${ }^{33}$ LUKÁCS, 2000, p. 30.
} 
de substância humana preciosa, cujo círculo a conteve em determinado tempo. Em contraste, a imagem de Musil é estática e insinua uma condição atemporal em vez de um desenvolvimento histórico. O círculo da vida simbolizado no anel de Clarisse está intacto, mas ainda assim seu centro é oco. Nada sugere que alguma vez tenha havido algo no lugar do vácuo. É precisamente a natureza do vácuo que constitui o principal ponto de contenção entre Musil e Lukács.

Musil não acreditava que o vazio ético fosse o resultado de um desenvolvimento não próspero conduzido por um processo histórico de racionalização que culminou em uma crise cultural de proporções sem precedentes. Ao contrário, suas investigações o levaram a enxergar esse vazio em termos de um traço estrutural embutido na condição humana. Ele se traduz no vácuo que, por séculos, havia sido disfarçado, e sub-repticiamente preenchido com narrativas que postulavam a existência de uma substância ética primordial, seja enraizada em um deus cristão, seja em uma outra construção metafísica.

Para Musil, a razão não era culpada, mas sim a faculdade humana cujo desenvolvimento ajudou a desfazer o impacto das narrativas, ao mesmo tempo que buscava providenciar um meio para discernimento e reflexão sobre o vácuo. Relutando contra as narrativas disparatadas de declínio e profecias de perdição que dominaram a arena cultural alemã no início do século XX, ele insistiu em transformar a percepção prevalente de crise em uma oportunidade para confrontar o vazio no coração da ética.

A percepção de ausência, de um fundamento ético perdido, como resultado de uma perda ou de um vazio estrutural, está bem no centro do discurso modernista: encontra modulações ricas no modernismo vienense da investigação de Freud sobre o inconsciente, no desejo de Kraus de restaurar a desprezada língua da velha Áustria, na admiração de Rilke pelos anjos sempre ausentes, assim como na evocação negativa de Kafka à desfaçatez da autoridade. A dívida de Musil para com essa tradição não pode ser relevada, contudo sua distância dos vienenses talvez seja ainda mais instrutiva para se compreender a especificidade de sua visão modernista. $O$ homem sem qualidades mapeia a colcha de retalhos da crise de identidade na Viena 
da passagem do século XIX para o século XX, chamando a atenção para o elo entre a distintiva "perda da realidade" que marca a decadência vienense e o legado de baluartes antigos de identidade individual. ${ }^{34}$ A proclamação de Hermann Bahr $^{35}$ de um eu irretratável permanece como a mais incisiva expressão do colapso de noções tradicionais de subjetividade e individualidade, tanto na ciência quanto na filosofia, sob o ataque da crítica de Nietzsche à metafísica e o empiriocriticismo de Mach. ${ }^{36}$

O sentimento moderno de alienação se afunilou na percepção de uma divisão interior, em linhas de especulação que reformulam temas primeiramente articulados no romantismo alemão na véspera do século XIX. Conseqüentemente, a vida humana é retratada como dividida entre, por um lado, uma experiência feia e ordinária, dominada pela racionalização, modernização, especialização, falta de alma e mecanização, e, por outro lado, o artifício de uma esfera alternativa que escapa à linguagem e ao pensamento, e vem à tona em momentos fugazes de iluminação. Enquanto o interesse por este último domínio abriu novos campos de investigação nas ciências humanas, da psicologia da religião à investigação do inconsciente, muito do modernismo vienense tendeu a focar sua atenção na inadequação de estruturas lingüísticas e conceituais para a compreensão e a descrição dessa esfera alternativa de experiência.

Seguindo os passos de Nietzsche, Fritz Mauthner forneceu um modelo para uma investigação de linguagem que era simultaneamente uma crítica poderosa de conhecimento, procedente de uma identidade fundamental entre linguagem e pensamento. Ao mesmo tempo, o "misticismo sem Deus" de Mauthner salientou a mistura peculiar de ceticismo lingüístico, suspeição da razão e neomisticismo que

\footnotetext{
${ }^{34} \mathrm{O}$ estudo de Le Rider enfoca particularmente a subversão do gênero da identidade e da ameaça percebida que emana da identidade judaica, articulada nas narrativas do fim do século XIX. Le RIDER, A modernidade vienense e as crises de identidade, 1993. Para análises do final do século da cultura vienense, JANICK; TOULMIN, Wittgenstein Vienna, 1973.

${ }^{35}$ Bahr apropriou-se desta frase de Ernst Mach: "análise das sensações". BAHR, Dialog von Tragischen (Diálogo da tragédia;) especialmente a parte "Das unrettbare Ich" ("O Eu Irrecuperável"), 1904, p. 79-101. (A tradução dos títulos é nossa.)

${ }^{36}$ FEYERABEND, P. A teoria da investigação de Mach e a sua relação com Stein. In: 1991. . Adeus à razão,
} 
formavam a marca registrada da cultura vienense na passagem para o século $\mathrm{XX}{ }^{37}$ Mauthner encontrou um documento emblemático em "Chandos Letter" de Hofmannsthal, que não somente traçou a desintegração simultânea de linguagem, pensamento e coordenadas morais compartilhadas, como também identificou a arte como o novo idioma que garantiria expressão àqueles momentos de iluminação para os quais parece que a experiência ética fugiu no período moderno. Em uma tentativa similar de delimitar a esfera da lógica psicológica, Wittgenstein reafirmou com o Tratado lógico-filosófico (1987) a afinidade entre a estética e a ética como duas esferas experimentais diversas, que estão localizadas fora do alcance de estruturas lingüísticas e conceituais ordinárias.

- O jovem Musil e o círculo da vida

Em seu romance $O$ jovem Törless, Musil se situou diretamente dentro dessa tradição filosófica. Ele explora a desorientação de um adolescente confrontado pela primeira vez com a percepção de uma divisão interna fundada na emergência intermitente e inquietante de um modo pré-lingüístico e pré-conceitual de experiência. Tal estado de emergência é vislumbrado tanto nos paradoxos de conceitos matemáticos quanto no abuso sádico de um colega de sala nas mãos de dois intimidadores do colégio interno. Mas a resolução das provações internas de Törless é também sintomática da distância que separa Musil da "cultura de nervos" da décadance, pois as tribulações do rapaz chegam a um fim quando ele aprende a aceitar esta dualidade como um fato da vida. Törless era um personagem bem diferente dos jovens macilentos e supersensitivos que apareciam nos contos rarefeitos da literatura romântica decadente. Isso é devido, em parte, ao fato de que a exploração pelo romance de uma ruptura na existência humana não está enquadrada dentro do ceticismo lingüístico e do niilismo epistemológico tão característicos da

37 MAUTHNER, Beiträge zu einer Kritik der Sprache (Dissertações sobre uma Crítica de Linguagens), 1967; ___. Gottlose Mystik (Misticismo sem Deus), 1924. (A tradução dos títulos é nossa.) Para uma análise de correntes neomísticas da cultura alemã da passagem do século XIX para o século XX, ver SPÖRL, Gottlose Mystik in der deutschen Literatur um die Jahrhundertwende, 1997. 
cultura vienense. O que molda a investigação de Musil é a sua formação nas ciências naturais e seu treinamento subseqüente nas ciências humanas experimentais durante seus estudos em Berlim (1903-8) sob a supervisão de Carl Stumpf, que culminaram em sua dissertação sobre Analysis of sensations, sob a orientação de Mach. Foi durante este período e nos anos que se seguiram à eclosão da Primeira Guerra Mundial, que Musil esboçou os contornos principais de sua empreitada estética, que antevia a literatura como meio que arrola rigor, flexibilidade e otimismo do pensamento científico à investigação de questões morais.

A ênfase científica sobre a observação factual e a primazia da experiência permitiram a Musil colocar em primeiro plano a natureza singular e contingente das escolhas éticas e expor o anacronismo da visão tradicional de moralidade, que é "em seu método estática, com o fixo como seu princípio básico", prevendo a formulação de normas de conduta atemporais e universalmente transparentes ( $P S$, p. 63). Leitor cuidadoso de Nietzsche, Musil entendeu que a desconstrução sem misericórdia da moralidade ocidental, para esse filósofo, não abria caminho para o niilismo, mas sim oferecia terreno fértil para serem repensadas categorias filosóficas morais obsoletas. Musil também reconheceu na noção antiessencialista e descentralizada de subjetividade que emergiu da psicologia de Ernst Mach o suporte para uma apreciação mais realista da identidade individual. Isso levou Musil a crer na maleabilidade histórica da consciência individual: “O bem e o mal, dever e violação do dever, são formas nas quais o indivíduo estabelece um equilíbrio emocional entre si mesmo e o mundo" ( $P S$, p. 39). Aos seus olhos, a literatura oferecia um meio flexível para se destacar o emaranhado intrincado de circunstâncias materiais, condicionamento social, história pessoal, sentimentos, emoções e pensamentos que sustentam as escolhas morais; um meio que coloca o observador em posição de apreciar corretamente a singularidade e a contingência do ético, em vez de tratar tais escolhas como aberração. 
- Como pode alguém inventar a pessoa interior?

A perspectiva que afirma que a singularidade ética não confere rejeição total às normas de conduta codificadas fornece uma diretiva que destaca suas contingências e limitações. O propósito final é propor novos "modelos atraentes de como alguém pode ser humano, inventando a pessoa interior" e encontrando soluções parciais, contingentes para as questões urgentes do dia (PS, p. 64). Dentro deste quadro, a literatura é reconfigurada como uma esfera para a experimentação imaginativa com alternativas criativas para a realidade. Ela é sustentada por uma atitude indutiva que trata o certo, a realidade dos fatos, como meramente uma das opções atualizadas de inúmeras outras possibilidades não realizadas.

Musil associou o modo de operar de escritores ao movimento de ensaísmo, que ele definiu como a atitude intelectual determinada a estender o rigor metodológico das ciências naturais ao domínio de eventos radicalmente singulares pertinentes à arte e à ética. Sua insistência precoce em um escrutínio rigoroso da experiência levou-o a se distanciar da irracionalidade e do antiintelectualismo que permeavam o discurso contemporâneo da arte que, em seu julgamento, comprometiam irreparavelmente os experimentos estéticos do impressionismo, do simbolismo e do expressionismo. Esta fidelidade aos dados da experiência o impeliu a rejeitar as mistificações que viu como as duas premissas ideológicas primárias compartilhadas por estas correntes, ou seja, a polarização de uma dimensão pura de sentimento por um lado e uma racionalidade corrupta e opressiva por outro, bem como seu corolário: fé nas artes como um porto seguro não contaminado no domínio puro da irracionalidade. Aos olhos de Musil, o culto à imediaticidade relacionado à postulação de um conhecimento fantástico intuitivo, do expressionismo presumivelmente consignado à arte, não somente terminou por impedir a possibilidade de uma investigação do tecido da imaginação e dos mecanismos da experiência estética, como também alimentou a suspeição determinada a culpar a racionalidade por todos os males da civilização. 
No veemente antiintelectualismo do seu tempo, Musil reconheceu o sinal de um desejo perdido de escape da problemática realidade de um tempo de transição amaldiçoado por uma falta endêmica de "conceitos ordenadores". (PS, p. 126). Ele acreditava que o levantamento equilibrado do papel exercido pela razão na erosão épica dos hábitos metafísicos ocidentais de pensamento era necessário para desvendar o nó das enfermidades culturais contemporâneas. Para ele, a aceleração de processos de secularização e a racionalização que estavam em movimento, desde pelo menos a Renascença, podem ter precipitado o reconhecimento da insustentabilidade dos sistemas morais no início do século $\mathrm{XX}$, mas certamente não causaram a sua deposição.

A contragosto de Musil, as tendências escapistas dos anos por volta de 1910 somente foram ampliadas nos anos seguintes à Primeira Guerra Mundial. O desejo disseminado de voltar o olhar para o passado, para visões confortantes, que caracterizou os anos pós-guerra, motivou Musil a retornar a muitas das questões que havia endereçado antes da guerra. Após servir como oficial no exército austríaco durante a guerra, Musil voltou a Viena, onde retomou sua atividade de ensaísta e crítico de teatro. Ele se pôs a dar continuidade à sua investigação da ética em ensaios maiores a partir da década de 1920 e em O homem sem qualidades, que ele considerou como uma contribuição decisiva à crise que estava empurrando seus contemporâneos a abraçar os "fetiches familiares de época: nação, raça, catolicismo, o homem intuitivo" (PS, p. 127).

Particularmente, insistiu em distinguir as raízes históricas que assombravam as recém-constituídas repúblicas alemã e austríaca: por um lado, seu atoleiro econômico, seu senso de orgulho nacional violado pela derrota sofrida na guerra, seu clima político tumultuado, rapidamente atribuído às falhas da democracia, e, por outro lado, a percepção de um buraco negro ético que definia a condição moderna. Musil acreditava que o vácuo moral e ideológico alardeado na década de 1920 não era o resultado da liquidação de tradicionais certezas morais. Ao contrário, representava a manifestação desobstruída de um vazio que é constitutivo da condição humana, cuja percepção desembaraçada se tornou possível pelas condições da modernidade. 
A visão de Musil ressoa com a advertência de Dominick LaCapra (1999, p.701-2) contra a fusão dos conceitos de ausência e de perda no esforço para lidar com eventos traumáticos e apocalípticos. LaCapra argumenta que muitas culturas abrigam uma ansiedade sobre a ausência de fundações básicas e também metafísicas. Para lidar com esse ponto de vista, é imperativo que essa ausência não seja misturada com a perda produzida pelo evento traumático de uma magnitude insondável como o Holocausto. Sua crítica sobre algumas tentativas em lidar com o trauma do Holocausto ecoa na crítica de Musil dirigida a seus contemporâneos, a quem ele repreendeu por misturar o trauma histórico psicológico da Primeira Guerra Mundial com o ponto de vista político dentro da impossibilidade de certezas metafísicas. ${ }^{38}$ Musil era inflexível quanto a salientar o potencial otimista e emancipatório da existência moderna marcado pela insustentabilidade ética, pois "se ao final se descobrir que nosso ser mais íntimo não está dependurado nas cordas de marionete de algum duende do destino, mas que pelo contrário nós somos cobertos com uma multiplicidade de pequenos pesos aleatórios unificados, então nós mesmos podemos alterar a balança" (PS, p. 122).

Tais argumentos desenvolvidos servem para revelar o quadro do engajamento intelectual de Musil do qual poucos discordariam hoje. Esse consenso se acaba, contudo, quando diz respeito à afirmação da significância e validade das teorias desenvolvidas por Musil nas décadas de 1920 e 1930, baseadas em seu diagnóstico da condição moderna. Bebendo em fontes tão diversas quanto os estudos seculares sobre o misticismo de Martin Buber, a investigação fenomenológica de estados emocionais exaltados por Max Scheler e Ludwig Klages, as observações da psicologia da Gestalt, bem como o inventário psicopatológico de Ernst Kretschmer, Musil rearranjou a ruptura fundamental da existência humana como a coalescência de dois estados mentais incomensuráveis no indivíduo: uma condição ordinária presidindo as experiências diárias e "outra condição" extática de sentimentos que emerge em momentos fugazes de iluminação. Ao manter sua convicção de que a

\footnotetext{
${ }^{38}$ LaCAPRA, Trauma, Absence, Loss, Critical Inquiry 25, 1999, p. 696-727, especialmente p. 70102 .
} 
estética, e a literatura em particular, fornecem o local mais apropriado para uma investigação sobre esta última condição, Musil partiu para explorá-la em $O$ homem sem qualidades. A narrativa de várias camadas do romance oferece um retrato excepcional do tempo antes da Primeira Grande Guerra, e da incapacidade humana de com a Guerra aprender as lições.

O Livro Primeiro de O homem sem qualidades, publicado em 1930, acompanha as vicissitudes do protagonista Ulrich enquanto ele busca na modernidade um centro de gravidade ético impossível. Sua missão se desenrola contra o pano de fundo da Ação Paralela, uma iniciativa política ficcional montada em Viena em 1913. Sob o pretexto de planejar as celebrações dos setenta anos de reinado de Franz Joseph em 1918, a Ação Paralela incorpora a última tentativa de fornecer muletas ideológicas necessárias para sustentar a monarquia austro-húngara que desmoronava, em seu estado terminal.

O Livro Segundo, do qual somente trinta e oito capítulos foram publicados durante a vida de Musil, de 1932 a 1933 - e que se dissipa em uma miríade de rascunhos e variantes - reconta a investigação de Ulrich acerca da "outra condição" de ser, na qual o protagonista do romance acredita vislumbrar a fonte da experiência ética. Rascunhos iniciais documentam a intenção de Musil em dramatizar o fracasso das tentativas de Ulrich de fundamentar sua vida nessa condição totalmente moral, que ele persegue em um relacionamento místico-erótico com sua irmã Ágata.

É precisamente a visão mística que se desdobra no fragmento do Livro Segundo que tem apresentado os maiores desafios de interpretação. Sua avaliação parece crucial para determinar a investigação estética de Musil no romance e nos ensaios. Críticos das décadas de 1960 e 1970 muitas vezes leram o desenvolvimento do romance na direção da aventura fraterna, inaceitável do ponto de vista social, como um símbolo do desejo de Musil de se distanciar da terrível realidade política da década de 1930, um distanciamento que pode ser visto como uma retirada. Para muitos, o eclipse da realidade sócio-histórica no Livro Segundo representou uma forma de Musil reconhecer que o aumento do totalitarismo nos anos de 1930 havia 
transformado suas visões utópicas iniciais - as utopias relacionadas ao ensaísmo e a uma precisão científica - em ineficazes e datadas.

Quando a ditadura nazista concretamente pôs fim ao experimento democrático da Alemanha em 1933, as expressões de desencorajamento e insegurança de Musil se tornaram mais fortes e freqüentes, uma vez que ele e sua esposa judia, Martha Marcovaldi, foram obrigados a deixar Berlim, onde haviam residido em intervalos desde 1910, e fixar sua residência permanente em Viena até 1938. Tal circunstância levou alguns críticos a falarem até mesmo em fracasso do projeto de Musil como um todo. O que não estava disponível para os primeiros comentaristas, no entanto, eram edições confiáveis e compreensíveis do romance tanto quanto dos Ensaios e Diários, que apareceram em 1976 e 1978. Os materiais não publicados anteriormente, incluídos nas novas edições, demonstram que o desenvolvimento em favor de uma utopia da "outra condição" narcisista tinha sido planejado pelo menos desde meados da década de 1920, uma circunstância que torna a leitura da "outra condição" uma espécie de saída, um escape resignado de Musil ao nazismo. Porém, tendo em vista a sistemática e concreta perseguição aos intelectuais, sobretudo os judeus, ou aqueles que tinham qualquer ligação com estes, tal atitude de resignação torna-se difícil de ser sustentada, de acordo com farta documentação que expõe a violência dos eventos que explodiriam nessa época.

Desde os anos 1980, leituras versadas em paradigmas pós-estruturalistas têm se agarrado às qualidades místicas e inefáveis dessa visão e relacionado seu fracasso à incompletude do romance e à incapacidade presumida de completá-lo. Dentro desse quadro, o romance tem sido lido como antecipando um entendimento desconstrutivo de linguagem e de literatura. Se, até o presente, o romance de Musil é largamente reconhecido como um documento de valor literário incontestável, o caráter místico das visões éticas não cessou de intrigar leitores, especialmente quando colocado à prova pelos desenvolvimentos políticos na Europa, nas décadas de 1930 e 1940.

A "outra condição" é, nesta tese, entendida como a dramatização de Musil para o vazio ético entranhado na existência humana. Para este fim, focos mais 
afiados são lançados sobre o desenvolvimento do pensamento desse autor. Majoritariamente negligenciado, sua contribuição é aqui ressaltada nos aspectos referentes à arte em suas implicações éticas e estéticas no campo literário. Enfatizam-se, sobretudo, suas análises sobre o comportamento psicológico social que iluminam o Zeitgeist de seu tempo, justamente na medida em que estas se dão no desenvolvimento das circunstâncias históricas mutantes dos anos entre as duas Grandes Guerras. Tal desenvolvimento toma a forma de uma dependência crescente em conceitos cruciais da Crítica da faculdade do juízo (1995), de Kant, que Musil adaptou para encaixá-los em paradigmas psicológicos contemporâneos.

O foco na emergência gradual de um suporte kantiano torna possível apreender a continuidade fundamental na reflexão de Musil sobre literatura e ética. Não somente dissipa a impressão de uma dispersão ou mesmo regressão desse autor, sob a pressão de problemas relacionados ao advento do nazismo, como também fornece uma chave essencial para a interpretação da mudança aparentemente despolitizada do romance no Livro Segundo, cujo foco na aventura mística dos irmãos deve ser visto como um comentário crítico do desejo por visões absolutas e verdades definitivas que levaram o nazi-fascismo ao poder.

A dívida de Musil com Kant se torna especialmente evidente em seus ensaios maiores, sobretudo aqueles da década de 1930. Reinscrevendo o relato de Kant do julgamento estético em paradigmas psicológicos contemporâneos e gestalt teóricos, Musil identificou um estado mental extático momentâneo, que é acionado por uma coalescência peculiar de faculdades intelectuais e emocionais e se anuncia em um sentimento de prazer desinteressado. Este uníssono especial de faculdades concede um vislumbre da unidade, de outra forma incompreensível, que fundamenta a vida humana; é então percebida como uma condição de ser alternativa moral. Apropriando argumentos importantes da Terceira Crítica de Kant, Musil conceitua a arte como meio que permite a união inefável de faculdades emergirem momentaneamente na vida comum, prestando-se assim a servir como ponte temporária entre a experiência ordinária e a "outra condição". Para Musil, essa é a quintessência da condição literária. 
- Ficções musilianas: o indivíduo libertado do feitiço das imagens

No relato de Musil, a experiência extática acionada pelo sentimento estético favorece um rearranjo na percepção do indivíduo da realidade e atrapalha modos formalistas de experiência, liberando o indivíduo do feitiço de imagens estabelecidas do mundo e abrindo espaço para o jogo imaginativo agregado aos elementos de experiência. É importante apontar que esse rearranjo não foi acionado pela libertação de uma outra racionalidade, que serviria como fiador da autenticidade e da verdade, como no surrealismo. Diferentemente, tal rearranjo está consignado a uma união especial das faculdades humanas comuns, tais sejam: emocional e intelectual. O prazer estético é assim dependente do despertar da inteligibilidade, ou seja, é predicado na revelação de uma compreensão nova da realidade, e é então acompanhado por um sentimento de propósito.

Quando mais pressionado a especificar a importância ética da experiência estética confrontada vis-à-vis aos desenvolvimentos políticos do fim da década de 1930, que levaram a década à ruína de valores humanos, Musil foi tão longe quanto a avançar a hipótese de que o equilíbrio estético de intelecto e sentimento é também o depósito de um princípio imanente, não generalizável de conduta humana proposital, que é estética por natureza, uma vez que é guiada por sentimentos e não por conceitos. Musil alegou reconhecer a deterioração desse princípio na estupidez que levou os alemães a ceder à tentação do nazi-fascismo.

$O$ homem sem qualidades, então, dramatiza o entendimento de uma discrepância estrutural entre dois estados mentais incomensuráveis, cuja lacuna produz o que os humanos percebem como um buraco negro ético. Especificamente, o romance apresenta as tentativas fracassadas do protagonista de suturar a lacuna entre uma condição mental ordinária e uma "outra", que, no Livro Primeiro, toma forma de uma utopia ensaísta com fins de elevar a "outra condição" ao nível cognitivo de experiência ordinária. A segunda parte, não acabada, do romance deveria remontar à tentativa reversa de mergulhar a vida ordinária dentro da "outra 
condição". O fracasso da última tentativa dos irmãos, tornada mais sinistra pela explosão da guerra, pretendia ser um alerta contra os perigos da sobredeterminação do ético pelo preenchimento de seu vazio cognitivo com mais uma visão absoluta da boa vida.

Nos termos de Lyotard (2006), o romance assume a tarefa de compreender o desejo humano de apresentar o inapresentável, isto é, a "outra condição", que fundamenta a experiência ética. $O$ fato de que a ética se revela como um vazio para a linguagem e para o pensamento não implica um estado disfuncional, mas é talvez o mais profundo discernimento da condição humana que a modernidade ganhou. A partir dessa perspectiva, a imagem de Clarisse sobre um anel oco simbolizando a impossibilidade da vida humana contém um desafio produtivo para se encarar o paradoxo da ética, o impulso - entranhado na condição humana - de se pensar no mais importante princípio que estruturalmente se refere às categorias experimentais da vida ordinária.

À falta de fundamento ontológico para a investigação do romance na ética, o texto é impelido a estabelecer auto-referencialmente essa fundamentação; isto é: levantar a questão fundamental de como é possível se investigar a ética por meio da arte. Na perspectiva sob um plano auto-referencial, o texto explora condições de possibilidade de sua própria investigação. Ele tematiza a relação com seu objeto de investigação especificando-o ao apresentar o literário como situado na interseção entre a experiência ordinária e a "outra condição".

O romance de Musil levanta a questão da função da arte na modernidade da perspectiva do reconhecimento das coordenadas contingentes da experiência humana de maneira a separá-la de muitos empreendimentos modernistas contemporâneos. Identifica a arte como meio privilegiado para o reconhecimento da singularidade da experiência ética, mas também extrai os limites de reflexão sobre a ética na modernidade, enquanto formula sua própria função e puxa seus próprios limites. $\mathrm{O}$ que emerge é um ethos paradoxalmente baseado na observação da impossibilidade de articulação de um fundamento ético permanente para o mundo moderno. Como ethos que se configura sob a experiência da modernidade, ele é a instância que aceita 
a coexistência e a confrontação de várias ideologias e jogos de linguagem, não com base em um fundamento comum presumido, mas sim porque reconhece a ausência de tais fundamentos.

O horizonte kantiano que cobre a reflexão de Musil sobre literatura e ética significa que estas não se constituem em rede sistemática de princípios. Ao contrário, tal horizonte aponta para um reservatório de categorias heurísticas e imagens produtivas que molduram as observações de Musil derivadas em parte de seus estudos científicos. Ao reconstruir este horizonte de estudo, não se visa somente enfatizar a originalidade da resposta de Musil dentro do modernismo alemão. Mais do que isso, enfatiza-se a posição original desse autor, revelando o desejo de mostrar que a noção de escritor e intelectual público contrasta com os modelos contemporâneos e reflete uma visão de modernidade que é especialmente tempestuosa na modernidade tardia, pois ajuda a escrutinar consagradas assunções sobre o mandato crítico dos intelectuais e artistas. ${ }^{39}$

As reflexões de Musil se desdobram contra o pano de fundo da crescente consciência moderna intelectual na passagem do século XIX-XX. Como mudanças profundas no funcionamento de elites culturais, disparadas pelas extensas transformações sociais, econômicas e políticas no cerne das sociedades ocidentais, elas abriam o caminho para o surgimento de um novo estrato intelectual, relativamente desprivilegiado. As experiências de alienação, marginalização e desenraizamento social, semeadas pelo confronto com um cenário econômico e social rapidamente mutante, moldou uma consciência autocrítica de intelectuais e escritores. Freqüentemente deu motivo para relatos amargos como intentos em interpretar a crise da identidade dos intelectuais como símbolo de uma crise mais geral nas sociedades modernas. Peculiar ao contexto alemão é o recurso a uma noção idealizada de cultura, vista como a última esfera social ameaçada que ainda poderia funcionar como reduto contra o desenvolvimento ameaçador da economia capitalista e da política de massa.

\footnotetext{
${ }^{39}$ SARTRE, Que é a literatura?, 2004. Sobretudo "Situação do escritor em 1947”, p. 124-218. Veja também as críticas dirigidas aos intelectuais franceses durante o período das Guerras. TODOROV, Política dos intelectuais. In: O homem desenraizado, 1999, p. 141-151.
} 
A percepção de uma crise na cultura Weimar estava inextricavelmente vinculada a um senso de identidade intelectual ameaçada, tanto que a articulação do mandato crítico dos intelectuais veio a depender bastante de uma leitura específica do presente como um tempo de crise. Em outras palavras, a percepção de um estado de emergência, que distinguia a cultura Weimar, funcionava como uma fonte de legitimação e ancoragem para o discurso crítico dos intelectuais. O discurso intelectual, por si só, estava destinado a reforçar as narrativas de crise que o autorizavam, mesmo quando não as gerava diretamente. Seria uma desfaçatez duvidar dos motivos ou questionar a integridade dos intelectuais e escritores alemães e austríacos que se encontravam presos neste círculo de crítica e autolegitimação. Ainda assim, o baixo grau de consciência demonstrado por muitos intelectuais, no que dizia respeito a refletir sobre seu interesse pessoal e auto-implicação nas narrativas que estavam tecendo, muitas vezes parece incompreensível.

Ao examinar a relação entre a percepção de crise e a articulação da missão dos intelectuais e escritores na cultura Weimar, verifica-se um padrão desconcertante de apatia e auto-ilusão, relacionado com "uma tentação de distância". ${ }^{40}$ A distância assume um significado duplo em seu relato cuidadoso. De um lado, denota o hiato que separa as narrativas produzidas pelos intelectuais e escritores de Weimar e, de outro, a realidade histórica da Alemanha na década de 1920. Ao revisar a parábola esotérica de Thomas Mann em A montanha mágica (1980), é possível salientar como a grande maioria de pensadores contemporâneos a Musil se mostrou perigosamente propensa a tomar ao pé da letra seus próprios relatos ficcionais da realidade social, deixando de colocá-los à prova da experiência vivida.

A distância da ação política como desapego dos poderes mandantes, particularmente da influência contagiante de ideologias e de instituições políticas existentes, funcionava como uma estratégia para legitimar o relato da realidade como desinteressado, não contaminado, verdadeiro e, portanto, inerentemente superior. Ao estilizar sua função social - como fundamentada em um ponto de 
vantagem privilegiado fora ou acima do sistema social, e imaculado pelo jogo sujo da política de Weimar, incorporada pela visão do intelectual livre de engajamento político de Mannheim -, vários pensadores, como destaca Peter Uwe Hohendahl (1997, p. 228-29) deixaram de perceber e articular sua própria implicação e autointeresse na sua auto-atribuição de uma missão crítica. Entre eles, sob uma perspectiva que também leva em consideração a mudança de papel do intelectual durante o período pós-Segunda Guerra Mundial, Hohendahl chamou a atenção para o duplo laço vinculado à auto-autorização intelectual. Ao mesmo tempo que os intelectuais definem a si mesmos como o próprio discurso crítico que os coloca fora dos interesses materiais e políticos imediatos, eles também insistiram em manter controle sobre a produção e disseminação deste discurso que, então, passa a ser sua propriedade, base de força e arquivo de legitimação. ${ }^{41}$

Gay (1997, p. 217-32) chama a atenção para o entrelace da nostalgia da totalidade e o incompreensível repúdio das políticas que definiram muito do clima intelectual Weimar. A avaliação estabelecida do clima intelectual na cultura Weimar $^{42}$, que se estende a alguns escritores da língua alemã na primeira República Austríaca, reverbera com a hipótese bastante plausível de um impulso de fuga abrigado pelo sentimento de repúdio mundial e de intolerância para com a realidade contemporânea. É significante que Musil seja escolhido como o exemplar de uma instância intelectual que não cede a esta tentação de distância, devido a seu comprometimento com o confronto da complexidade do presente com um otimismo guiado por uma atitude indutiva liberal. Especialmente após a Primeira Guerra Mundial, Musil indagou abertamente sobre a tendência de seus contemporâneos de "darem as costas ao presente" ( $P S$, p. 176), ou seja, de fugir dos desafios da realidade contemporânea e buscar refúgio em ficções estéreis.

$\mathrm{Na}$ esfera estética, Musil infligiu o que denominou "fome sem sentido, enganosa, universal por redenção artística, por uma simplicidade homérica na qual

\footnotetext{
${ }^{41}$ HOHENDAHL, The Scholar, the Intellectual, and the Essay: Weber, Lukács, Adorno, and Postwar Germany, The German Quartely, 70, 3 Verão de 1997, p. 217-32.

${ }^{42}$ GAY, Weimar culture: The outsider as insider, 1968; particularmente o capítulo IV, The hunger for wholeness: trials of Modernity, p. 70-101.
} 
poderíamos, com todas as nossas diferenças, um dia subsistir novamente em unidade" ( $P S$, p. 34). Ele criticou veementemente o que viu como uma propensão relacionada a fundamentar o mandato crítico dos intelectuais e escritores em um dom presumido de intuição ou algum poder cognitivo distintivo análogo, que, por sua vez, daria a ele uma posição fora da realidade social degenerada. Em seu discurso sobre modernismo e pós-modernismo, Jochen Schulte-Sasse (1980) delineou as implicações desse posicionamento, identificando no sonho de uma esfera estética imaculada pelos males do corpo social o impulso dirigente do alto modernismo e do movimento avant-garde. Além de suas importantes diferenças, Schulte-Sasse argumenta que ambos os discursos partem de uma visão de arte como uma esfera que ainda não foi permeada completamente pelas transformações implacáveis do progresso tecnológico e dos mecanismos da economia monetária razão instrumental em funcionamento nas sociedades capitalistas maduras. Devido à sua posição fora do corpo social corrupto, a arte é então tida como fornecedora de um terreno autoritário do qual se pode lançar a crítica.

Com base em conceituações da esfera estética por Herbert Marcuse, SchulteSasse argumenta que qualquer crítica que dependa da assunção de um exterior estético deixa de refletir sobre suas implicações nos mecanismos sociais que busca criticar. Esta então corre o risco de se tornar um instrumento de consolo e compensação que involuntariamente fornece uma saída para os conflitos não resolvidos, derrotando o corpo social, e reforçando o sistema no próprio ato de sujeitá-lo ao escrutínio. ${ }^{43}$

- A sociedade assombrada por suas próprias contradições

Conforme a descrição de Canetti sobre Musil em O jogo dos olhos - história de uma vida/1931-1937 (1990, p. 159-200), Musil encontrou em Thomas Mann o exemplo egrégio de uma atitude intelectual que, sob o pretexto de crítica inflexível,

\footnotetext{
${ }^{43}$ SCHULTE-SASSE, Foreword: theory of Modernism Versus theory of the Avant-Garde. In: BURGER. Theory of the Avant-Garde, 1984, vii-xlvii.
} 
forneceu um local para se articular e difundir de vez as contradições que assombravam a sociedade. É certo que o desgosto de Musil pela estilização em causa própria de Mann como a consciência poética moral da nação alemã na década de 1930 não estava livre de ressentimento pessoal pelo romancista incomparavelmente mais bem-sucedido. Ainda assim, Musil não se excedeu quando salientou que Mann, em seu papel crítico auto-adjudicado de intelectual público da Alemanha e, por fim, porta-voz heróico da sabedoria humanista ameaçada, fez pouco mais que refinar os preconceitos e convicções de sua audiência burguesa, reforçando esses preconceitos no próprio gesto de sujeitá-los ao escrutínio. Sob a ótica de Musil, com o pretexto de liderar sua audiência burguesa, Mann estava na verdade sendo liderado por ela.

Elias Canetti descreve o episódio ocorrido em 1935, em que ele sente duramente o afastamento de Musil. Ao relatar ao amigo que recebeu uma carta de Thomas Mann elogiando a publicação de seu livro Komödie der Eitelkeit (Comédia da vaidade) (Tradução nossa.), Musil se mostra imediatamente frio e se distancia de Canetti para sempre. Canetti declara que para Musil "era sempre importante que as pessoas se definissem claramente entre ele e Thomas Mann". "Musil tinha plena consciência de quem era Thomas Mann, e era principalmente a medida do prestígio [deste] comparado ao seu próprio que o irritava". ${ }^{44}$

Em 1922, o industrial e político, Walther Rathenau personificou um caso exemplar de miopia intelectual suspeita, de acordo com Musil. Rathenau gozava de enorme popularidade nas primeiras duas décadas do século graças à sua ensaística prolífica, que o situou na interseção de debates vanguardistas sobre filosofia, psicologia e sociologia. Musil admitiu a acuidade de Rathenau e sua amplitude intelectual, mas também reconheceu em seu diletantismo de moda a ocasional debilidade intelectual estratégica nos vícios representativos de uma época. Sua crítica não se refere somente à visão de Rathenau sobre uma sociedade préindustrial, pré-capitalista, congelada em uma utopia austera estremecida tanto pela realidade presente do capitalismo maduro quanto pela própria implicação de Rathenau como um magnata da próspera indústria elétrica. Rathenau exemplificava

\footnotetext{
${ }^{44}$ CANETTI, Uma carta de Thomas Mann. In: ___. O jogo dos olhos, 1990, p. 255-256.
} 
aos olhos de Musil o desejo de perspectivas absolutas completamente abrangentes, que se alimentavam de uma tendência perniciosa de absolutizar observações advindas de uma disciplina ou subsistema da sociedade, ampliando-as em um corpo de verdades coerentes, favorecido com a força de uma nova visão redentora.

Musil entendia que, nas sociedades modernas, caracterizadas pelo que Max Weber descreveu como "diferenciação funcional de esferas de vida e perda de coordenadas de orientação unificadoras", era forte a tentação para que estas se tornassem "o centro de um panorama modesto" (PS, p. 53), como efeito que "todo galho se estende ao microcosmo" ( $P S$, p. 52). As visões distorcidas então produzidas estavam mal-equipadas para lidar com a pluralidade moderna de discursos cognitivos competitivos e domínios especializados de experiência. A inevitável discrepância entre a visão reduzida da realidade de Weber e a verdadeira complexidade da vida moderna abrigava o sentimento de denúncia e condenação do presente. Tais visões revelavam a incapacidade de perseguir ideais imponentes e perdidamente arruinados pelo ceticismo, niilismo, e a proliferação implacável de ideologias discordantes.

Sob certo foco, a perspectiva musiliana era cética quanto à estrutura pluralista do mundo moderno: esta era inerentemente má e deveria ser superada. Ao contrário, ele via em tal pluralismo uma chance ainda não reconhecida para o progresso e a emancipação. Convencido de que a arte e a literatura, em particular, ofereciam um veículo muito bem ajustado para crítica e mudança positiva, a crítica estética não deveria, contudo, ser ancorada na reivindicação de um ponto de vantagem superior, presumivelmente fundamentado em uma posição fora da sociedade, permitindo ao artista retirar uma verdade ofuscada ou restaurar um horizonte compreensivo de significado perdido.

Insistia Musil que a arte permanece o tempo todo implicada na sociedade; que ela é um de seus subsistemas funcionais, e acreditava que a crítica estética é sustentada pela habilidade da arte de disparar o estranhamento e o rearranjo de narrativas compartilhadas da realidade, operando em um nível de produção, por intermédio do poder combinado de imaginação estética e, pelo lado da recepção, por 
meios de reorganização de percepções em experiências estéticas. Tal crítica se estendia à habilidade combinatória e o poder de desafiar o status quo pela produção de visões alternativas, que entram em competição com a percepção entrincheirada da realidade. Dessa maneira, a arte pode oferecer um contraste imaginário ao real que desafia visões estabelecidas de mundo enquanto permanece firmemente fundamentada nele. Conseqüentemente, a crítica a qual a literatura sujeita a realidade é imanente e contingente, pois permanece entrelaçada como o sistema social que busca escrutinar. Tudo que tal prática pode produzir são soluções parciais que imploram estruturalmente por reexame e revisão futuros.

- Mudanças irreversíveis que a modernidade trouxe em seu despertar

Em sua discussão das atitudes intelectuais que definem o modernismo e pósmodernismo, Zygmunt Bauman (2003, p. 5-96) lista características que capturam a qualidade distintamente modernista de teóricos-chave da modernidade na passagem para o século XX. Bauman salienta primeiro a insistência modernista em reconhecer o "caráter irreversível das mudanças que a modernidade representou ou trouxe em seu despertar", independentemente de quão positivas ou negativas essas mudanças possam ter parecido. A modernidade é apresentada como essencialmente não terminada; ela também é um interminável projeto, sendo a sua falta de limites vista como o atributo supremo, talvez definidor. Um importante critério para se discriminar entre visões modernistas mais ou menos valiosas reside, para Bauman, em sua perspectiva temporal relativa e em seu autoposicionamento. As visões que parecem mais confiáveis e informativas hoje são aquelas que reconhecem a modernidade como um "fenômeno com uma rica pré-história, mas com nada visível além dele, nada que pudesse relativizar ou tornar objetivo o fenômeno em si”. Como não há nenhum ponto de vantagem exterior que possa fornecer uma moldura de referência para a percepção da modernidade em si, as visões mais valiosas são aquelas que a aproximam e a representam em seu interior, como era, de uma 
perspectiva que constantemente reflete sua própria contingência, parcialidade e autoimplicação. ${ }^{45}$

Esses traços, que para Bauman moldam a reflexão grandiosa de Nietzsche, Freud e Simmel, entre outros, fornecem uma descrição poderosa da perspectiva modernista de Musil. O que distingue ainda mais a visão modernista de Musil é seu otimismo fundamental, do qual os modernistas supramencionados não compartilhavam necessariamente. Tal otimismo fundamenta-se, no entendimento de Musil da razão, como uma faculdade humana complacente apropriada para iluminar o aspecto intrincado da experiência moderna. O empirismo não dogmático de Musil o levou a reconhecer na faculdade intelectual não um adversário da imaginação estética, mas sim um dos seus componentes indispensáveis. Eis que sua fé no poder da imaginação estética permaneceu todo o tempo dependente de sua confiança na razão. A razão de Musil parece, contudo, bem diferente do conceito domesticado e confuso de humanismo. Também tem pouco em comum com narrativas propensas a ver na racionalidade o telos ou planta inevitável da modernidade.

A razão não representava para Musil nem o suporte normativo da modernidade, como no modelo iluminista reivindicado por Jürgen Habermas ${ }^{46}$, nem seu destino inescapável, como na triste visão de um mundo dominado pela racionalidade instrumental tornada famosa por Theodor W. Adorno e Max Horkheimer. Ao contrário, Musil viu na racionalidade a mais significante força modeladora do período moderno. Segundo o autor, na realidade, as faculdades humanas são deixadas como um meio de orientação para certezas religiosas e metafísicas antigas que ruíram, mas de modo algum elas podem traçar o destino a ser abraçado ou resistido sem crítica. A crença na visão não normativa, não fatalista

45 BAUMAN, Legistators and legislators and interpreters: on modernity, postmodernity and intellectuals, 1987, p. 115-16. Para Bauman, modernos/modernistas intelectuais são definidos pela sua noção de cultura monolítica como um reino que capacitará o intelectual/legislador a impor uma ordem uniformizada sobre a incompleta multiplicidade da vida no mundo. $\mathrm{O}$ debate de Bauman sobre o modernismo e pós-modernismo deve ser visto no contexto dos debates sobre pós-modernidade em meados da década de 1980. BAUMAN, Ética pós-moderna, 1997; __. Modernidade e ambivalência, 1999.

${ }^{46}$ HABERMAS. Textos e contextos, 2001. Especialmente os capítulos: Max Horkheimer: para a história da evolução da sua obra, p. 85-102; Para uma frase de Max Horkheimer: "querer salvar um sentido absoluto sem Deus é pretensioso", p. 103-117; Psicologia social de Alexander Mitscherlich, p.159-171; Sociologia na República Weimar, p. 173-192. 
da razão concede ao relato de Musil o contorno para a modernidade como falta de limite e otimismo que retiveram sua força, mesmo em vista do crescente totalitarismo. Porém, sua qualidade antiutópica e antiapocalíptica contém uma lição que ainda hoje é convincente.

- A ética que emerge do mais fundo dos abismos

Originalmente publicado em 1906, O jovem Törless é o primeiro romance de Musil. Em sua epígrafe, Musil cita uma passagem de Maeterlinck, bastante elucidativa para descrever o clima de desilusão que se abate sobre a juventude de sua época:

Tão logo expressamos uma coisa com palavras, [sic] e estranhamente ela como que se desvaloriza. Pensamos ter mergulhado no mais fundo dos abismos, e, quando retornamos à superfície, a gota d' água que trazemos nas pálidas pontas dos nossos dedos já não se parece com o mar de onde veio. Imaginamos haver descoberto uma mina de tesouros inestimáveis, e a luz do dia só nos mostra pedras falsas e cacos de vidro. Mas o tesouro continua a brilhar, inalterado, no fundo escuro. ${ }^{47}$

Usando a metáfora de um tesouro que brilha no fundo do oceano, que se revela falso quando trazido à superfície, Maeterlinck articula um topos central da poética impressionista e simbolista. Tal metáfora é uma ilusão à apresentação obscura de um domínio antes da linguagem e do pensamento; ela presume que esse domínio forneça o fundamento final para a experiência ordinária enquanto alude à conceituação. Como sugere a imagem de Maeterlinck, os objetos retirados do mar parecem sem valor uma vez examinados à luz do dia. Essa metáfora não questiona a autenticidade e preciosidade do tesouro, que continua a brilhar em toda plenitude em seu santuário no fundo do mar. $\mathrm{Na}$ verdade, é o ato de retirar essas pedras preciosas de seu ambiente submarino e expô-las à luz do dia que mina sua autenticidade e as transforma em fragmentos de vidro sem valor. A visão de um tesouro submerso oferece uma dramatização apta para a crença de Maeterlinck na existência de um

\footnotetext{
${ }^{47}$ MAETERLINK, Le trésor des humbles, [publicado originalmente em 1896], citado por MUSIL como epígrafe de $O$ jovem Törless, 2003.
} 
domínio inconsciente intacto, uma "alma pura" que repudia a verbalização pela linguagem prosaica da vida rotineira e, em vez disso, busca expressão em um "silêncio ativo" ou nos discursos concisos de um idioma místico-poético. ${ }^{48}$ Como o tesouro que perde seu charme ao ser trazido à superfície, Maeterlinck declara o domínio inconsciente que brilha unicamente na arte, mas é de modo irretratável alterado quando traduzido para categorias da vida cotidiana.

O liricista e dramaturgo belga tinha se tornado uma sensação no mundo da língua alemã após a publicação, em 1898, da tradução alemã de sua coleção de ensaios de 1896, Le trésor des humbles, do qual foi extraída a passagem acima. Ao escolher introduzir o texto de $O$ jovem Törless por meio da imagem evocativa de Maeterlinck, Musil buscou relacionar sua narrativa da desorientação existencial de um adolescente a um sentimento crucial no começo do século. Sua narrativa contém a premonição de que a experiência ordinária não exaure completamente as possibilidades de existência. Mas ela se desdobra ao lado de uma realidade alternativa, ou estado de ser, que se revela dentro da experiência normal em momentos fugazes de iluminação. É precisamente este tipo de iluminação mística que forma o pano de fundo para as experimentações e tribulações de Törless.

Retirado do ambiente seguro e acalentador de sua família e colocado em um colégio interno, Törless é deixado à própria sorte durante a transição crucial da infância para a adolescência. Os adultos à sua volta, professores e educadores, mostram-se incapazes de lhe oferecer qualquer orientação, pois se agarram a noções claramente anacrônicas da experiência humana. Törless deverá enfrentar sozinho as experiências, ora cativantes, ora inquietantes, que perturbam a rotina plácida da consciência da infância. O romance gira em torno do envolvimento de Törless com a chantagem e a perseguição sádica de um colega de sala, o fraco Basini. A submissão masoquista de Basini a seus torturadores bem como o atrativo de suas fantasias sexuais transgressivas capturam a imaginação de Törless, sugerindo a existência de um domínio além do bem e do mal, no qual a glória da dissolução de barreiras do ser e a fusão com os objetos do mundo exterior, a falta de limites do eu (alem. Ich-

\footnotetext{
${ }^{48}$ Estes são os termos-chave do programa poético de Maeterlinck encontrados em Le trésor des humbles. Veja o resumo da coleção de artigos de Maeterlinck em MUSIL (TB, v. I, 134-35).
} 
Entgrenzung) encontra uma correlação na liberação do ato sexual. No entanto, como Törless logo descobre, o relacionamento erótico com Basini pode fornecer um relance dos momentos de glória que ele está buscando, mas não pode se tornar permanente. Não é um meio de fechar a lacuna entre a consciência ordinária e os estados mentais exaltados, que ele experimenta de maneira fugaz.

Significativamente, Törless aprende a fazer as pazes com sua consciência dividida quando ele finalmente é capaz de verbalizar suas experiências perturbadoras. É na memorável conclusão do romance, um julgamento no qual Törless é chamado pelas autoridades do colégio interno a explicar seu envolvimento com Basini, que ele consegue encontrar uma maneira de lidar com a divisão entre a experiência ordinária e suas iluminações místicas. A eloqüência incomum de Törless e sua loquacidade nesta última cena parecem contradizer Maeterlinck, ao menos em parte. Se é verdade que linguagem e pensamentos ordinários podem não fazer justiça à vida pré-consciente da alma, ainda fornecem um meio válido para se fazer as pazes com sua incapacidade de alusão.

Ao longo de toda a vida de Musil, a investigação de uma esfera inefável de experiência associada obscuramente com a ética, que forma o cerne da narração em Törless, também constitui um horizonte para a constante investigação que busca entender a relação entre ética e literatura. Dentro da cultura alemã, o paradigma modernista que segue o caminho indicado por Maeterlinck interpreta a intuição de um "outro" modo de ser como símbolo da existência de uma esfera alternativa além das restrições da razão e do pensamento conceitual, uma esfera a ser penetrada pelo meio irracional da arte. ${ }^{49} \mathrm{O}$ primeiro romance de Musil parece, àa primeira vista, encaixar-se perfeitamente neste paradigma, no entanto as semelhanças são apenas superficiais. Um olhar mais próximo mostra que o romance marca a distância de Musil da decadência literária, precisamente porque modula temas-chave desta tradição. Determina o curso da investigação distintiva de Musil da intuição

49 HABERMAS, O discurso filosófico da modernidade, 1990. Veja: Excurso acerca das cartas de Schiller sobre a educação estética do homem, p. 51-55. O problema central de Habermas é que, pelo menos desde Nietzsche, a reflexão ética desistiu de esperar a arte como um meio de expandir o campo da razão além de suas aplicações instrumentais, dentro de uma modalidade verdadeiramente comunicativa e emancipadora - um esforço de Habermas para ver mais consistentemente o intento de Schiller na reapropriação da ética kantiana. 
modernista de uma esfera ética inefável, abrindo caminho para a pesquisa sobre o vazio ético em seu trabalho mais maduro.

- O simulacro da totalidade e o desafio da linguagem em desconstrução

Musil começou a escrever O jovem Törless em 1903, enquanto era assistente na Universidade Técnica de Stuttgart. Ele tinha vinte e seis anos quando o romance foi publicado. Após interromper seu treinamento como oficial do exército e, subseqüentemente, como matemático e engenheiro, mudou-se para Berlim para dar início a estudos universitários em psicologia e filosofia, em 1903. Ele havia escrito o romance em seu tempo livre para lutar contra sentimentos de falta de propósito e desorientação que o estavam consumindo enquanto estava ocupado em recuperar o treinamento humanista que havia perdido na escola secundária. $\mathrm{O}$ manuscrito do romance foi rejeitado primeiramente por diversas editoras, até chegar às mãos do crítico de Berlim Alfred Kerr, que imediatamente fez a mediação entre o jovem autor e várias editoras, ajudando a tornar o romance um dos sucessos literários do ano. Kerr rapidamente reconheceu que a virtude primária da narrativa de Musil não estava em seu tratamento direto de questões controversas como a homossexualidade ou a educação sexual de adolescentes, que não obstante se refletem na imaginação de muitos leitores contemporâneos. Ao contrário, era o relato inovador e fresco de um tema fundamental da poética simbolista que Kerr elogiou, a saber, sua habilidade para invocar a realidade de um jovem lutando para encontrar sentido em suas condutas místicas inconcebíveis em um estilo desapaixonado, factual, quase lacônico. Foi a ausência completa de preciosidade lírica do romance, do erotismo opressivo e verborrágico de alguns escritores da décadance, e, em contraste, sua narração firme e factual, que Kerr achou inovadoras. ${ }^{50}$

\footnotetext{
${ }^{50} \mathrm{O}$ romance foi publicado por Wiener Verlag em 1906. A revista que lançou Musil em sua carreira como escritor aparece em um jornal de Berlim, Der Tag, em 21 de Dezembro, 1906. Este foi reimpresso: CORINO, Robert Musil und Alfred Kerr. Der Dichterund sein Kritiker. (Robert Musil e Alfred Kerr. O poeta e seu crítico), 1970, p.240-45, 246-47. (Tradução nossa.)
} 
O personagem Törless representou para Musil uma tentativa de lidar com um tema central de literatura decadente enquanto evitava as ciladas da décadance literária. A apresentação de uma esfera de experiência inexprimível deu causa a um modo literário comprometido com a evocação de um vazio, ora concebido positivamente como o cerne não conceituável da existência, ora experimentado negativamente como a charada ameaçadora do vácuo mais íntimo da vida. O jovem Musil se sentiu profundamente atraído por esta literatura, como testemunham seus primeiros registros em diário sobre Mallarmé e Baudelaire. Mas no início de 1900 sua fascinação já tinha quase se esgotado. Ele havia encontrado na denúncia de Nietzsche da décadance categorias severas de crítica, que o habilitaram a pôr o dedo na preciosidade ostensiva da literatura decadente, seu flerte inconclusivo com sensações elusivas, sua linguagem evocativa e imprecisa. ${ }^{51}$

Em um registro do diário por volta de 1900, Musil descreveu uma passagem na qual Nietzsche fornece uma incisiva caracterização da décadance (TB, v. I, 2829). O estilo da décadance, argumenta Nietzsche na referida passagem, é testemunho da circunstância moderna de que a vida não mais mora no todo. A palavra se torna soberana e pula para fora da frase, a frase se estica e obscurece o sentido da página, a página toma vida ao custo do todo - o todo não é mais um todo. Mas este é o sorriso de todo o estilo de décadance: a todo momento, a anarquia de átomos, desagregação da vontade, "liberdade do indivíduo", para se usar termos morais expandidos para uma teoria política, "direitos iguais para todos". A vida, vitalidade igual, a vibração e a exuberância da vida reduzidas às menores formas; o resto, pobre em vida. Em todo o lugar paralisia, aridez e torpeza ou hostilidade e caos: ambos mais e mais óbvios quanto mais alto se ascende nas formas de organização. O todo não mais reside: é composto, calculado, artificial, e [sic] artefato. $^{52}$

\footnotetext{
${ }^{51}$ Para a discussão do tema da décadence em Musil e Nietzsche, veja BALTZ-BALZBERG "Antidekadenzmoral bei Musil und Nietzsche", in: STRUTZ, Josef; STRUTZ Johann. Robert Musil: Theater, Bildung, Kritik, 1985, p.204-26.

${ }^{52}$ NIETZSCHE, The Case of Wagner. In: KAUFMANN (Ed.). Basic writings of Nietzsche, 2000, p 626. A caracterização da decadência feita cautelosamente por Nietzsche relembra a analogia formulada pelo crítico francês Paul Bourget, cujos artigos sobre a decadência Nietzsche conhecia bem.
} 
Talvez nenhuma outra passagem ofereça uma descrição comparavelmente concisa e afiada da decadência literária como sintoma de uma condição moderna maior. Não causa estranheza o fato de Musil ter sido afetado por tais idéias de forma a registrá-las textualmente em seus diários. A famosa denúncia de Nietzsche sobre a decadência oferece ao leitor seu diagnóstico das civilizações doentes e em declínio do Ocidente, que ele viu mais bem exemplificado no sucesso da música de Richard Wagner. Dentro deste cenário, o estilo decadente denota um crescimento canceroso da linguagem e do corpo social, um processo pelo qual os constituintes distintos de um organismo se emancipam de seu ambiente natural e começam a prosperar sem controle. Enquanto esse processo pode, de início, traduzir-se em um aumento de ser revigorante para o elemento discreto, tal acréscimo do particular sempre ocorre à custa da estrutura como um todo, pois as partes individuais podem se explodir somente por roerem o todo sem misericórdia. O resultado é uma desagregação interior arrasadora e o esvaziamento do organismo, que deverá resultar em seu colapso final. Mas o colapso do todo, por sua vez, priva as células individuais da vida e do sangue que as nutriam e lhes davam sentido; elas morrem como resultado de terem canibalizado a totalidade que as continha. E onde ainda há tentativas de invocar o simulacro de uma totalidade, isso aparece dissimulado, inventado, inautêntico, artificial, como nos simulacros monstruosos que são as óperas de Wagner.

O desafio que a descrição de Nietzsche sobre a linguagem desintegrante representava para o filósofo e escritor não passou incólume pela geração que amadureceu após 1890. Alimentou tanto o ceticismo quanto a experimentação lingüística que moldaram os trabalhos de Rilke, Hofmannsthal e Kafka. Diferentemente de seus colegas escritores, contudo, Musil parecia despreocupado com o todo com a subversão do empreendimento poético que a erosão da linguagem conferia. Pelo contrário, é a ausência sanguinária completa e o tédio absoluto do erotismo sufocante de D'Annunzio ou do estilismo requintado de Huysmann que Musil rejeitava. A absolutização e fetichização de um aspecto da experiência ao custo de todos os outros, como encontrado na "sobrevalorização estética do detalhe, o momento distinto da beleza" de D'Annunzio ( $D$, p. 13$)$, havia de parecer não convincente no final das contas, seu desengajamento esteticista de uma experiência 
vivida inútil. ${ }^{53}$ Pode parecer irônico que a explicação disparatada de Nietzsche sobre a decadência supria Musil com argumentos afiados para se negar a ser um entusiasta precoce tanto de Nietzsche quanto de D'Annunzio. Ainda assim, é inegável que precisamente os traços esteticistas incorporados por escritores como o poeta e profeta italiano ensimesmado foram de uma só vez sintoma e meio para expressar a experiência penetrante da modernidade.

Como claramente denunciado no diagnóstico de Nietzsche da decadência, a exuberância estilística do particular e a emancipação do detalhe da totalidade que a continha espelhavam uma desagregação maior de estruturas sociais e culturais existentes. Os entusiastas de Nietzsche da virada do século viram na proposição de que "a vida não mais mora no todo" o reflexo da aceleração formidável da vida moderna e a proliferação de contextos de experiência que haviam radicalmente transformado a existência humana, desde os meados do século XIX. Tal proposição destilou suas respostas às cicatrizes profundas causadas por fenômenos aparentemente incontroláveis como a industrialização, urbanização, intelectualização e mecanização, pelos excessos de um capitalismo rompante e a ameaça de movimentos políticos de massa. ${ }^{54}$

Max Weber buscou esclarecer a condição moderna como perturbadora, apontando processos centenários de especialização e diferenciação, que em sociedades ocidentais haviam trazido à tona a afirmação de um modo racionalista. Tal modo havia se apropriado do método científico moderno em sua busca pelo domínio da natureza humana e do mundo natural. Weber descreveu como a forma instrumental de racionalidade gradualmente conseguiu infiltrar e regular todos os domínios da experiência, incluindo a esfera religiosa, cuja secularização progressiva ele detalhou em seu relato revolucionário do protestantismo. Essa intelectualização desenfreada teve o efeito de enfraquecer a tradição cristã de ser a depositária do sentido elementar e abrangente da vida. Ao mesmo tempo, Weber salientou que a

\footnotetext{
${ }^{53}$ MUSIL, D, p. 93. Sobre Gabriele D'Annunzio, veja $D$, p. 13-14 e 86-87.

${ }^{54}$ Para uma descrição aprofundada do crescimento alemão entre 1870 e 1914 e seu impacto cultural e social, veja Cap. II, Berlin. In: EKSTEIN. Rites of spring: the Great War and the birth of the modern age, 1989, p. 55-94. Para a recepção de Nietzsche na Alemanha entre 1890 e 1918, veja: ASHHEIM, The Nietzsche legacy in Germany, 1890-1900, 1992.
} 
verdade objetiva da ciência não era capaz de substituir o valor e o sentido invocados pela religião e pela especulação metafísica. Como resultado, o mesmo desenvolvimento que havia tornado a realidade absolutamente explicável e calculável também a havia despido de qualquer sentido e finalidade coerente. Weber, então, viu a intelectualização e a secularização como as raízes da percepção moderna de um mundo "desencantado". Este é, de uma vez por todas, despido de um sentido inerente e consignado a uma indiferença fundamental. ${ }^{55}$

- A realidade desestruturada da modernidade

A realidade moderna se torna sinônimo de uma proliferação desordenada de esferas parcialmente interligadas, parcialmente incoerentes da experiência - econômica, jurídica, religiosa, política, científica - e é percebida como fragmentada, desconjuntada, desprovida de significado. Apesar de o relato de Weber não estar sobrepujado dentro dos termos de corrupção e declínio que de Nietzsche migraram para o pessimismo cultural do início do século XX, mesmo assim ele evoca fortemente o diagnóstico nietzschiano da modernidade. Quando a esfera de vida individual assumiu uma dinâmica própria, minando a unidade do corpo social, o resultado passa a ser hostilidade e rixa advindas do confronto de alegações diferentes de verdade ou a letargia e a paralisia produzida pela impossibilidade de se orientar dentre elas. A vida moderna - pode-se concluir com Nietzsche - aparenta-se tão opaca, desconjuntada, sobrecarregada e não autêntica quanto se revela no estilo das composições musicais de Wagner.

O senso de crise predominante na passagem do século XIX-XX foi ainda mais exacerbado pela ameaça percebida aos fundamentos do conhecimento, advinda da fragmentação e da especialização dos discursos cognitivos em curso. Esse

\footnotetext{
55 Sobre a momentânea articulação da modernidade desencantada ver: WEBER, Science as a Vocation. In: GERTH; MILLS. From Max Weber: Essays in Sociology, 1991, p. 129-56; especialmente p. 139. Sobre a diferença moderna das esferas em Weber. Religious rejections of the world and their directions, ibidem, p. 323-59.
} 
desenvolvimento havia levado à emancipação definitiva das ciências naturais do discurso filosófico, minando, então, de uma vez por todas, a reivindicação tradicional da filosofia de servir como scientia universalis, ou seja, o fundamento deontológico para todos os outros empreendimentos cognitivos e árbitro universal em suas disputas. ${ }^{56} \mathrm{O}$ próprio Nietzsche havia denunciado o engessamento da filosofia acadêmica, desaprovando sua tendência ao sonho metafísico e seu agarramento obstinado a um modo sistemático de especulação, que pouco tinha a ver com as exigências da experiência vivida. Se, por um lado, ele elogiava as ciências naturais por estabelecerem padrões de convicção e verdade fundados na observação factual e no senso de aventura experimental, por outro, ele condenou a ingenuidade e a presunção da fé positivista na ciência e zombou da extensão descuidada do positivismo às ciências humanas. Como argumentou Nietzsche (2003), em sua meditação Na segunda consideração intempestiva: da utilidade e desvantagem da história para a vida, o historicismo, análise aparentemente livre de valor e ideologia da história moldada nas ciências naturais, trazia uma visão perturbadora da experiência humana como uma exibição de épocas e eventos desprovidos de um telos intrínseco, que podem, somente em retrospecto, ser investidos de significado.

- A tendência disciplinar do século XX

A observação decorrente da historicidade, isto é, a contingência e a ausência de necessidade - de categorias epistemológicas e cognitivas supostamente atemporais - minaram o esforço tanto da ciência quanto da filosofia em sua fundação, sem aparentemente oferecer qualquer alternativa concreta. Enquanto a ciência moderna realmente lucrou com seu confinamento em um suporte cético e relativista, a visão histórica da existência proferiu um golpe substancial às ciências humanas, abrindo a porta para o ceticismo epistemológico e para o niilismo. O discurso reflete a crise epistemológica e disciplinar, no início do século XX, voltadas para as preocupações culturais que continuam ostentando pensamentos pós-

\footnotetext{
${ }^{56}$ Para um esboço da crise do discurso filosófico no início do século 20, SCHNEIDER. Deutsche Philosophie im 20. Jahrhundert, 1998, p. 9-47.
} 
estruturalistas. Tais preocupações podem ser aparentemente traçadas pelos dilemas insolúveis enfrentados pelas ciências humanas, que viu suas bases metafísicas arruinadas pelo irresistível crescimento do critério cético da verdade e dos conhecimentos desenvolvidos dentro das ciências naturais. ${ }^{57}$

A reflexão de Fritz Mauthner sobre a linguagem e a trajetória intelectual geral (1849-1923) pode servir de exemplo para ilustrar o resultado cético da perda da fé na linguagem e no conhecimento das ciências humanas no fim do século XIX e início do século XX. Mauthner se estabeleceu como jornalista de sucesso e escritor satírico depois de se mudar para Berlim em 1876, influenciado tanto pela crítica da razão de Nietzsche quanto pela noção funcional do ser de Ernst Mach. Tomando como seus pontos de referência as tradições filosóficas do nominalismo medieval e empirismo inglês, partiu para explorar a estrutura de linguagem e pensamento em seu volumoso Beiträge zu einter Kritik der Sprache (Ensaios sobre uma Crítica da Linguagem, 1901-2) (Tradução nossa.), que combinou filosofia da linguagem, epistemologia e lingüística. O trabalho de Mauthner é devotado primariamente à demonstração de como a linguagem humana é uma construção metafórica que carece de qualquer fundamento e correspondência direta com objetos de realidade. Embora seja adequada como um meio de comunicação, a linguagem e o pensamento em geral - uma vez que Mauthner equalizou ambos - não produzem conhecimento, pois o conhecimento não mantém nenhuma relação necessária com o real. Segue-se que o que temos por conhecimento nada mais é que uma ilusão tornada possível pela nossa desconsideração da capacidade essencial de metaforização da linguagem. Depois da virada do século, Mauthner começou a apontar um caminho para fora do niilismo decorrente de sua crítica radical do conhecimento ao colocar crescentemente em primeiro plano a subcorrente mística implícita em sua teoria da linguagem. Seu último trabalho, Gottlose Mystik (Misticismo sem Deus) (Tradução nossa.), publicado em 1924, um ano após sua morte, propõe novamente um tema que passa por sua reflexão, a saber, o diagnóstico de uma condição moderna, definido pela não-confiabilidade da linguagem e do conhecimento:

\footnotetext{
${ }^{57}$ NIETZSCHE. Unfashionable observations, 1995, p. 157-510. Ver o segundo discurso proferido em 1874.
} 
Enquanto isso, os pálidos humanos doentios haviam aprendido pensamento e linguagem da serpente negra, o todo de sua razão pequena, e haviam cultivado todo tipo de desejo - já que eram, por demais, desprezíveis para o único, o grande desejo produtivo -, sem fé verdadeira, sem desejos infrutíferos. Também seu fraco desejo pelo inatingível, o invisível, o desconhecido. E eles rezavam com palavras para as criações de palavras trêmulas de seus desejos impotentes, pois sabiam que o grande, forte desejo onipotente, era o único criador, o criador do céu e da terra, de deuses e humanos. ${ }^{58}$

O conto místico no qual esta passagem está inserida reformula a narrativa judaico-cristã da queda da humanidade do Éden para recontar a dissipação de um desejo primordial, que precedeu pensamento e reflexão e era sustentado pela fé verdadeira. Este desejo - não definido mais de perto - foi deslocado quando os humanos se renderam à tentação de uma serpente negra que lhes prometeu pensamento, razão e conhecimento. Desde que receberam esses dons dúbios, os humanos buscaram reacender o fogo do desejo primordial, mas suas tentativas produziram somente uma dispersão daquele desejo original em uma miríade de desejos infrutíferos: criações sem valor, feitas da linguagem que os humanos adoram com orações, mas que não são nada mais do que linguagem. A despeito de ocasionais inconsistências conceituais, o relato de Mauthner transfere, de forma poderosa, o senso de impotência da humanidade ao tentar se livrar da gaiola de ferro que ela mesma havia erguido pela linguagem e da racionalidade, cuja única esperança residia na fraca memória inefável daquele desejo primordial que é a fonte de toda vida.

Tal linha de raciocínio interessa por ser o caminho exemplar que leva a dúvida da adequação da linguagem a desfiar por completo a possibilidade de conhecimento, e a invocar o retorno a um intuitivo domínio místico da experiência. Ela expõe a razão, junto com seus desdobramentos de pensamento conceitual e linguagem ordinária, como o principal obstáculo no caminho para a modalidade intuitiva, ou, como no relato crítico religioso de Mauthner, o pecado original da raça humana. É uma narrativa que radicaliza a crítica de Nietzsche à ciência positivista e à razão instrumental. Em suas variações mais rudimentares, Nietzsche atribui todos

${ }^{58}$ Para uma discussão da filosofia da linguagem de Mauthner contra a queda do fim do século epistemológico, veja ARENS, Functionalism et fin-de-siècle: Fritz Mauthner's critique of language, 1984. 
os males da modernidade à influência corrupta da racionalidade e prega a erupção de forças inconscientes primordiais como remédio. Esse tema atravessa diversas subcorrentes culturais da época, do pessimismo cultural de nazistas ao desejo do rejuvenescimento no coração do movimento jovem, ao antiintelectualismo e ao vitalismo que alimentaram a propagação de doutrinas filosóficas de vida no começo do século XX. ${ }^{59}$

- A face dupla da experiência

A investigação de uma esfera alternativa de experiência feita por Musil na edição inglesa de $O$ jovem Törless pode também ser lida como refletida neste tema. ${ }^{60}$ O romance explora a desorientação do indivíduo que deve confrontar a ruptura entre uma experiência ordinária desconjuntada e sem sentido - o crescimento anômalo de Nietzsche do detalhe que se fez autônomo do todo - e o artifício de momentos de iluminação místicos, cuja glória, contudo, não é traduzível em categorias da vida ordinária. A questão é se e em qual medida as tribulações de Törless no fim também engendram uma suspeição da razão que subscreve o diagnóstico da condição moderna descrito acima. A narração se abre como um vislumbre na rotina maçante da vida de um colégio interno, que parece dominada pelo tédio e vazio. Törless, filho único de uma bem-sucedida família burguesa, é mostrado enquanto gasta seu tempo na esperança de que alguma ocorrência extraordinária o sacuda da letargia intelectual e emocional que caiu sobre si desde sua passagem para a puberdade. Essa esperança se alimenta na experiência ocasional do menino de humores ou estados mentais peculiares, para o qual eventos, coisas e pessoas ordinários aparecem transfigurados.

\footnotetext{
${ }^{59}$ Para uma análise deste fenômeno no contexto da recepção de Nietzsche na passagem do século XX, ver ASHHEIM, The Nietzsche legacy in Germany, 1890-1900, 1992.

${ }^{60}$ Assim como foi lido, por exemplo, por BRAUN. "Confusions of young the Törless", The Germanic Review 40 (1965): 116-31.
} 
Tais experiências são para Törless como um horizonte elástico, que parece ininteligível e cheio de sentido como intuição primária, mas se recolhe à incompreensão a qualquer hora que ele tenta contê-las em pensamentos e palavras ( $T$, p. 25). O adolescente inicialmente encontra uma maneira de perseguir estes momentos singulares em encontros sexuais com a prostituta Bozena. O que o impele a superar sua repugnância pela prostituta envelhecida e se engajar em um singular "culto de auto-sacrifício" ( $T$, p. 31) feito de descarga sexual e degradação moral é a chance de se livrar do mundo do condenado: "O excitava ter que deixar para trás tudo que normalmente o confinava, sua posição privilegiada, os pensamentos e sentimentos inculcados nele, tudo que não dava em nada e o oprimia" ( $T$, p. 31). Mas Törless está realmente buscando o artifício de um outro mundo sob a superfície reconfortante da burguesia. Quando dois de seus colegas descobrem em seu par Basini o culpado por pequenos furtos que haviam importunado o colégio interno por algum tempo, o plano deles para coagi-lo a entrar em um programa sádico de expiação e purificação torna-se para Törless uma ocasião para observar de perto o mecanismo psicológico que permite a um indivíduo violar princípios fundamentais de conduta e invade um mundo absorvente "de aventura, cheio de escuridão, mistério, sangue e surpresas inimagináveis", um mundo que existe próximo ao familiar "em que tudo acontecia de modo regular e racional" ( $T$, p. 44).

Todo o experimento se torna ainda mais impressionante quando Törless toma conhecimento de que parte da punição pensada por seus colegas para o indefeso Basini envolve atos sexuais degradantes. Enquanto vai se permitindo tornar um espectador e cúmplice passivo nas torturas de Reiting e Beineberg, ele começa a perceber que os dois mundos, entre os quais se sente dividido, são duas facetas, ou faces da mesma realidade; na verdade, são a verdadeira marca da duplicidade e da ambivalência fundamentais da realidade ( $T$, p. 57). Dessa forma, Basini, pode, em alguns momentos, parecer-se com um ladrão comum, enquanto, em outros, parece deter o segredo obscuro de um modo de ser totalmente diferente. E isso, por sua vez, leva à descoberta surpreendente de que o que Törless vê como um mundo incomensurável detrás da experiência ordinária é, na verdade, uma força obscura dentro de si, que parece de uma só vez cativante e potencialmente destrutiva: "É uma lei universal que há algo dentro de nós que é mais forte, maior, mais bonito, 
mais apaixonado, mais escuro do que nós somos? Algo sobre o qual somos tão impotentes que podemos somente espalhar sem rumo milhares de sementes até que de repente uma delas brote como uma chama negra que finalmente eleva-se sobre nós" ( $T$, p. 103). É a experiência de uma ruptura entre seu "eu" consciente e seu lado mais escuro que assombra o adolescente e o impele a buscar uma passagem que conecte os dois mundos; uma conexão que lhe permitiria ao menos aumentar a representação obscura da outra realidade para categorias da vida ordinária: "Ele sentia a necessidade de persistir em sua busca por uma ponte, um contexto, uma comparação - entre ele e aquilo que estava silencioso diante de sua mente." ( $T, \mathrm{p}$. 72). Linguagem e pensamento conceitual parecem não oferecer assistência alguma neste sentido. Como Törless deve descobrir mais de uma vez, tais esferas simplesmente englobam o lado ordinário das coisas e as tentativas de utilizá-las para incursões no outro mundo somente fariam esse mundo retroceder para o silêncio.

Inesperadamente é um paradoxo da matemática que fornece a Törless uma imagem que joga luz às suas experiências. Em uma das cenas mais celebradas do romance, o adolescente se acha maravilhado com o uso de números imaginários em algumas das suas aulas. Como ele percebe com espanto, o começo e o fim das computações contêm números reais, mas o caminho que leva de um a outro deriva de uma construção numérica que carece da realidade positiva de números ordinários. "Isto não é como uma ponte", indaga Törless, "que consiste somente da primeira e última pilastra, e ainda assim você caminha sobre ela seguramente como se estivesse tudo lá?” ( $T$, p. 82). O que torna a ponte matemática marcante é sua habilidade inquestionável de conectar dois bancos de terra numérica firme, e ainda assim esses dois bancos estão "conectados um ao outro por algo que não existe" (T, p. 82). Em outras palavras, o cálculo com números imaginários produz resultados concretos, praticáveis, expressáveis em números reais. Longe de ser o fruto de uma especulação caprichosa que a mente entretém em momentos de ócio, a ponte imaginária forma um requisito indispensável para se chegar ao outro banco; representa uma feição necessária do cálculo. 
- Uma ponte extraordinária chamada realidade

Mas do que é feita esta ponte extraordinária entre as duas pontas que os matemáticos chamam de real? O que significa ser a mente capaz de cruzar uma ponte inexistente como se estivesse andando em algo real? Em que tipo de "outra" realidade estará a mente engajada sem que consiga percebê-la como real? Estes são os questionamentos que Törless tem que atacar enquanto confronta a natureza dupla da experiência que ele encontra ampliada ao caso de Basini. Se os matemáticos inventaram um procedimento formalizado para atravessar a ponte - a saber, os números imaginários - talvez, nele pudesse também se encontrar o elo faltante entre as duas realidades cuja divisão está profundamente inscrita dentro de Törless. Contudo os questionamentos do menino com o professor de matemática produzem poucos frutos, pois o jovem professor fica constrangido quando solicitado a olhar além do confinamento estreito de sua rotina matemática e discutir as assunções transcendentes em que repousa sua edificação matemática. Mesmo quando ele menciona por alto a investigação imanente de Kant aos limites da razão e do conhecimento, seu melhor conselho para Törless é simplesmente aceitar os mistérios da matemática como um artigo de fé.

Em contraste, o envolvimento físico de Reiting e Beineberg com Basini parece oferecer justamente esta ponte. Como Törless mesmo experimentou com Bozena, o despertar físico da sexualidade parece conter a promessa obscura do mundo efervescente, apaixonado de experiências vívidas, finalmente livre das amarras da sociedade burguesa. A sensualidade vem a incorporar para o adolescente como uma fonte autêntica, original de força; ela é a proteção contra as intrusões alienantes do mundo exterior, talvez a verdadeira fundação de seu ser mais íntimo: “ele sentiu pela primeira vez que havia algo em sua sensualidade... que ninguém poderia tirar dele, que ninguém poderia sequer copiar, algo que o protegia contra qualquer forma de inteligência estranha como um muro muito alto, muito escondido.” ( $T$, p. 97). Apaixonado por Törless, uma noite Basini entra em seu quarto. A recém-adquirida confiança de Törless na força libertadora do sexo o ajuda 
a superar suas últimas inibições quanto ao ato homossexual. Mas é a consumação de seu desejo sexual que também começa a minar a atração homoerótica de Törless por seu colega. Tal ato o ensinará a distinguir entre a turbulência de sua sexualidade desperta e o artifício de um mundo além das amarras éticas da realidade ordinária, que ele tanto havia associado às façanhas criminais de Basini quanto à sua tortura nas mãos dos colegas famintos por poder. Enquanto Basini cada vez mais parece a Törless nada mais que um ladrão comum e uma vítima indigna de uma perseguição perversa, a fascinação de Törless por ele se torna desilusão, nojo e, finalmente, indiferença. Ao fim de suas peregrinações emocionais, Törless se encontra tentando compreender o sentimento de vergonha e culpa que cai sobre si ao pensar em seu envolvimento no caso de Basini. Isso, por sua vez, o ajuda a tirar uma lição importante:

[Ele] sabia apenas que perseguia algo indefinido, num caminho que conduzia ao seu mais remoto interior; e isso o deixava exausto. Habituara-se a esperar por descobertas extraordinárias, coisas ainda secretas, e fora assim que chegara aos estreitos e tortuosos aposentos da sexualidade. Não por perversão ele era perverso, mas devido à sua momentânea desorientação psicológica. E ser infiel a uma coisa séria, desejada, dava-lhe um vago sentimento de culpa; uma repulsa indefinida e secreta jamais o abandonava; um medo obscuro perseguia-o como a alguém que, em meio às trevas, não sabe mais se anda no caminho certo ou se já o perdeu. (JT, p. 127)

Ao perseguir a agitação de algo inominado em seu âmago, ao tentar identificar seu sexto sentido, que revela uma visão completamente diferente da realidade, Törless havia descoberto e se emaranhado nas manobras da sexualidade. Ele havia confundido a libertação advinda dos sentidos com a emergência de uma outra face da realidade que ele intui, mas não consegue nomear. Bastante notável 
não é a lembrança da sua participação na humilhação de Basini, que alimenta sua consciência culposa, mas sim a ciência de que seu instinto sexual na verdade o enganou, e de fato o distraiu e o levou a trair o ser mais profundo que ele perseguia. $^{61}$

O caminho de aprendizagem no romance o leva a reconhecer o que é e o que não é a sexualidade, e isso se revela uma lição duradoura, como confirmado pela única inserção que interrompe o fluxo narrativo para fornecer um vislumbre da vida posterior de Törless como um jovem refinado. Se o objetivo de Törless havia sido encontrar uma porta ou uma passagem entre os dois lados de seu ser e então curar a divisão que o assombrava, sua experiência fracassada com a sensualidade o habilitou a aprender a viver com o que tem sido chamado de "visão dupla". ${ }^{62}$ É na cena final do romance, quando Törless é chamado para explicar seu envolvimento no caso Basini aos insuspeitos e bem dispostos superiores do colégio interno, que ele encontra palavras que encaixam para descrever o que ele passou e o que aprendeu:

Sei que me enganei. Não tenho mais medo de nada. Sei que as coisas são coisas e sempre o serão, e que sempre as verei ora de um jeito, ora de outro. Ora com os olhos do raciocínio, ora com aqueles outros... E nunca mais tentarei comparar as duas coisas... $(J T$, p. 154)

Não interessa que os adultos reunidos no escritório do diretor se tornem crescentemente irritados enquanto tentam sem sucesso entender o sentido das explicações de Törless, porque o leitor não tem problema algum em apreender o significado das palavras do garoto. A cura para Törless não exige fechar o espaço entre dois modos de ver a realidade, mas sim reconhecer este mesmo espaço como um fato da vida. Em sua discussão do romance, Alfred Kerr (Kerr, apud Corino, 1989, p. 243-45) rearranjou esta fenda como uma discrepância entre a experiência e

\footnotetext{
${ }^{61}$ Para uma análise da estrutura narrativa do romance, focada nos aspectos voltados para questionar a moralidade da conduta do protagonista do romance, ver CORNGOLD, Complex pleasure: forms of feeling in German literature, 1998, p.103-20. Para uma discussão da problemática sexual em Törless, da perspectiva de uma compreensão psicanalítica do desejo e da linguagem, ver WEBBER, Sense and Sensuality in Musil's Törless, German life and letters 41.2 (1988): 106-30, e DAWIDOWSKI, Die geschwächte Moderne: Robert Musil episches Frühwerk im Spiegel der Epochendebatte, 2000, p. 3376.

${ }^{62}$ HICKMAN, 1991, p. 28-54.
} 
a verbalização, de fato, como uma qualidade fundamental do que é comensurável relativa a algumas experiências com linguagem e pensamento. Um certo sentimento ou estado mental, explica Kerr, faz as confiáveis imagens da realidade ordinária vibrarem com a representação obscura de um modo diferente de experiência; um modo que desafia implicitamente a legitimidade de uma realidade ordinária e parece tanto mais ameaçador enquanto evita a linguagem e o pensamento. Ao manter o uso virtuoso que Musil faz de metáforas visuais no romance, Kerr descreve o experimento de Törless como uma tentativa de inundar com luz essas experiências inexpressíveis que normalmente ocupam uma zona de penumbra da consciência. Ao ir além com a imagem de Kerr, poder-se-ia retratar a fascinação de Törless por Basini como uma imagem de holograma que oferece um retrato do abuso esquálido praticado contra um adolescente vulnerável, se visto de um ângulo, mas se transforma em um desafio cativante às categorias morais da vida cotidiana quando observado de outro. O olho não pode bem ao certo visualizar os contornos da imagem para decidir entre os dois; a impossibilidade da visão de focar corretamente confunde a percepção e enche o indivíduo de uma tontura nauseante.

As experiências desta zona de penumbra não são invenções da imaginação, não são menos reais que aquelas que podem ser ininterruptamente colocadas em palavras. Se Törless havia buscado apagá-las, elevando-as à plena luz da consciência e da linguagem, ele finalmente reconhece que isso não é possível. Como ele aprende, a ambivalência e a face dupla fundamental da experiência estão aninhadas no âmago da vida emocional do indivíduo e não pode ser desfeita.

Kerr deve ter reconhecido, no primeiro romance de Musil, todos os ingredientes para o sucesso literário, uma vez que tocava em temas que ecoavam profundamente as preocupações fundamentais de seu tempo. Ele enfrentou a questão da sexualidade humana e sua relação com a moralidade, sem fugir de questões-tabu, como a sexualidade de crianças e adolescentes, a homossexualidade e a aberração sexual, que formavam o foco de diversos questionamentos, da psicopatologia da sexualidade de Krafft-Ebing, da psicanálise de Freud, passando pela filosofia do gênero influente de Weininger, até a impiedosa crítica da dupla face da moral sexual da sociedade burguesa nos trabalhos do romancista Alfred Schnitzler. 
A relação precária de Törless com a linguagem deve ter trazido de volta de imediato os apuros de um antecessor ilustre, Chandos de Hofmannsthal, para quem o colapso de padrões conceituais e de lingüística confiáveis se torna um sintoma de uma desintegração mais fundamental da subjetividade. De fato, a narração de Musil parecia fornecer uma modulação para a reflexão cética sobre a linguagem de muitos contemporâneos vienenses ao reformulá-la como a relação duvidosa entre pensamento e razão, de um lado, e a esfera de emoções e sentimentos, de outro.

- O tempo congelado na linguagem

A descoberta de Törless de que a verbalização nada mais é que um congelamento no tempo de um nó inextricável de percepções e sentimentos aponta para a recepção de Musil das teorias que revolucionaram a investigação psicológica nas últimas décadas do século XIX, mais notadamente o empiriocriticismo de Ernst Mach. Mas enquanto é inquestionável que Törless reflete muito dos temas cruciais da época, ainda mais revelador é o quanto o romance, ao final, deixa de reforçar sentimentos-chave expressados pelos contemporâneos de Musil, enquanto, por outro lado, leva a algumas questões em novas, inesperadas direções.

Um caso em vista é o engajamento de Musil com as visões revolucionárias de Ernst Mach sobre percepção e subjetividade, que fornecem uma moldura, pelo menos em parte, para o retrato do ser sitiado de Törless e os riscos de sua "visão dupla”. O impacto das teorias psicológicas de Mach na cultura vienense não pode ser exagerado. Conforme Paul Feyerabend, em seu estudo Adeus à razão (1991, p. 227257), o empiriocriticismo de Mach havia se tornado um pára-raios para as inquietudes e desejos de muitos intelectuais, cientistas e artistas associados à Jovem Viena, seguindo uma republicação de sua Analysis of sensations, plenamente acessível dez anos após ter aparecido em $1886 .{ }^{63}$ Nos anos de 1870, Ernst Mach

\footnotetext{
${ }^{63}$ Para uma discussão da psicologia de Mach dentro do contexto das teorias que revolucionaram o campo da psicologia na virada do século, ver: RYAN, The vanishing subject: early Psychology and Literary Modernism, 1991, p. 6-22.
} 
embarcou em uma crítica radical da epistemologia tradicional que o levou a desafiar o status de categorias centrais do discurso científico - conceitos como tempo, espaço, matéria, consciência, ser.

Abraçando um atomismo radical epistemológico, Mach havia passado a ver a realidade como constituída somente dentro da percepção, em um procedimento automático que envolveu a organização arbitrária dos "elementos" livres das sensações. Dessa premissa se seguiu que nem o ser percebível nem o mundo exterior eram entidades estáveis autocontidas, independentes do evento da percepção. O ser, declarou Mach, não é nada além de um monte de sensações relativamente estáveis. Enquanto negava qualquer fundamento ontológico ou psicológico, Mach insistia que o ser retivesse um lugar importante dentro da epistemologia e da ciência como uma construção pragmática, econômica. Os contemporâneos de Mach não deixaram de apreender as enormes ramificações de sua rejeição não só do ser cartesiano, mas de qualquer centro essencial de subjetividade. O endosso otimista de Hermann Bahr de uma noção funcional do ser sem substância refletia o júbilo e o desejo nietzschiano para a renovação que alguns contemporâneos buscaram para chegar ao desafio de Mach. ${ }^{64}$ Outros mais aptos, ao contrário, viram suas ansiedades refletidas nas polêmicas de Otto Weininger contra a redução machiana da psique humana a uma mera "sala de espera para sensações". ${ }^{65}$

Musil havia se deparado primeiramente com uma edição de Popular Scientific Lectures de Mach, publicado originalmente em 1898, mas não foi até seus estudos em Berlim, no Instituto Psicológico liderado por Carl Stumpf, entre 1903 e 1908, que teve a oportunidade de examinar as teorias de Mach dentro de uma moldura científica rigorosa. A dissertação de Musil, Sobre as teorias de Mach (alem. Breitrag zur Beurteilung der Lehren Machs) (Tradução nossa.), de 1908, dois anos após a publicação de $O$ jovem Törless, é testemunha de seu engajamento crítico com o empreendimento de Mach. Sua análise simpática ofereceu uma avaliação favorável da visão pragmática que Mach tinha do desenvolvimento do discurso científico.

\footnotetext{
${ }^{64}$ BAHR, Dialog von Tragischen (1904) (Diálogo sobre a tragédia) (Tradução nossa.) Sobre Hermann Bahr, ver: BITHELL, J. Modern German literature 1880-1950. London: Methuen, 1959.

${ }^{65}$ WEININGER, Geschlecht und Character: Eine prinzipielle Untersuchung, (Gênero e caráter. Um estudo de dois princípios) (Tradução nossa.) 1980.
} 
Musil enfatizou as vantagens da noção de Mach sobre modelos científicos baseados em relações funcionais que ofereciam uma alternativa muito precisa à reivindicação tradicional da ciência em fornecer explicações sobre o mundo, baseadas em princípios, como o da casualidade, que tornavam essenciais os fenômenos em observação.

Ao mesmo tempo Musil não hesitou em expor as inconsistências perturbadoras na argumentação de Mach. Alguns dos pronunciamentos de Mach, ressaltou Musil, foram muito além da moldura empírica cética que Mach havia examinado em seu empreendimento e invadido a simples especulação. ${ }^{66} \mathrm{O}$ criticismo de Musil demonstra o quanto ele era simpatizante do empreendimento de Mach. Sua crítica não estava focada na desconstrução radical dos postulados psicológicos e epistemológicos sobreviventes, operada por Musil; postulados, aliás, endossados fortemente, mas sim na falta de consistência e rigor metodológico nessa busca. Como resultado de seu esforço de crítica ao monismo e atomismo intransigentes de suas assunções, Musil acreditava que Mach havia adentrado as mesmas armadilhas metafísicas sobre as quais buscou alertar os outros.

Judith Ryan descreveu vividamente o relacionamento próximo conectando a subversão das noções tradicionais de subjetividade ao despertar das novas teorias psicológicas entre 1870 e 1900, por um lado, e a inovação extraordinária e a experimentação estilística que moldaram a literatura do modernismo, por outro. Em questão está a busca de novos modos de se conceber a relação entre o corpo e a mente, o emocional e o intelectual, a razão e a alma, dada a erosão de sua confiável substância metafísica. Ao escolher o caso exemplar de Hermann Bahr, Ryan mostra como o foco empírico das novas psicologias foi compreendido amplamente como tendo estabelecido uma primazia da experiência imediata, sensual, sobre os dados da consciência. ${ }^{67}$ O ensaio de Bahr de 1891 sobre "A Nova Psicologia" contém a apologia a um novo estilo literário que aperfeiçoa a lição de naturalismo ao retratar o emaranhado de sensações, sentimentos e estímulos nervosos no indivíduo antes da

\footnotetext{
${ }^{66}$ Neste ponto, veja a discussão da crítica de Musil sobre Mach em HICKMAN, 1991, p. 26.

${ }^{67}$ RYAN, 1991, p.20.
} 
invenção da consciência. ${ }^{68} \mathrm{O}$ engajamento contínuo de Bahr com as novas teorias psicológicas, mais notadamente sua recepção de Mach, culminou em sua famosa proclamação de um "Unsalvageable Self" na seção homônima de seu Dialog von Tragischen, (1904) (Diálogo sobre o trágico), (Tradução nossa.). Aqui o olhar machiniano para a fluidez da subjetividade é celebrado como uma validação científica do apelo de Nietzsche para se descartarem todas as noções limitadoras de um sujeito estável, idêntico a si próprio. A polêmica de Bahr, no Dialog, contra a influência asfixiante da razão e do intelecto, que ele joga contra o poder regenerador do instinto e dos sentidos, é nietszchiana. Como sustenta Bahr, a linguagem e o pensamento se mostram incapazes de expressar a intoxicação do indivíduo que, após se despir das falsas amarras do ser e se tornar um com o mundo à sua volta, atinge o estado elevado de ser típico da experiência extática.

- O falso casulo da subjetividade burguesa

Inicialmente, o experimento erótico ardente de Törless com Basini parece se desdobrar de acordo com o script no Dialog de Bahr. A descoberta pelo adolescente da sensualidade como uma fonte de força que o define de modo único reverbera com a desconstrução do ser machiniano celebrado por Bahr, que serve ao propósito de estraçalhar o falso casulo da subjetividade burguesa e de retornar à imediaticidade da experiência que é baseada primariamente nos sentidos. Contudo a lição que Törless tira de suas tribulações é bem diferente daquela apregoada no Dialog, pois o adolescente vem a perceber que a liberação do desejo sexual em seu envolvimento com Basini tem somente uma leve semelhança para com o mundo obscuro que ele intui em momentos de epifania inexpressáveis. Enquanto é verdade que este mundo está consignado a um estado emocional particular, uma condição que se esquiva a pensamentos e palavras, não é possível concluir que qualquer estado que ainda não

68 BAHR, WUNBERG, (Ed.)."Die neue Psychologie", ZurÜberwindung des Naturalismus. Theoretische Schriften 1887-1904, 1968, p. 53-64. 
tenha se formado pela consciência possa garantir acesso a este, tal como o despertar dos sentidos típicos da sexualidade. ${ }^{69}$

A apropriação de Mach por Bahr serve às polêmicas nietzschianas contra a mediação intelectual da consciência. Esta é acusada de frustrar e tornar concretos os dados da experiência. Por causa da existência imediata e autêntica, a consciência pode se tornar visível na confusão de sensações, emoções e estímulos nervosos da vida mental. Sua noção da consciência, como uma força derivativa e secundária, destinada a impor uma forma inautêntica na vida sensual e espontânea do indivíduo, mantém-se junto ao monismo descompromissado de Mach, que desautorizou qualquer distinção fundamental entre o físico e psíquico, os sentidos e a mente. Em contraste, no romance de Musil a sensualidade possui uma qualidade primordial, instintiva, sem mediações, que está destinada a ser confundida pelo "outro" estado emocional inexpressável. Contudo esse outro estado não é idêntico àquele, como descobre Törless ao perceber que a liberação sexual não é o caminho para se chegar ao "outro" mundo. Sua percepção de que pensamento, linguagem e, por implicação, conhecimento são incomensuráveis com a esfera alternativa que ele intui desautoriza implicitamente a convicção de Mach de que todas as facetas da experiência são, ao final, reduzíveis à estrutura elementar observável e reconhecível das sensações. De fato, o dualismo está praticamente descartado na aceitação final de Törless da consciência dividida. ${ }^{70}$

Ao revisar a recepção de Nietzsche, que moldou os movimentos avant-garde na passagem do século XIX para o século XX, Steven Ashheim destacou o papel privilegiado atribuído ao erotismo e aos sentidos como últimos guardiões de uma experiência imediata ainda não corrompida pela influência corrosiva da doentia civilização moderna. $\mathrm{O}$ corolário dessa fé na experiência não mediada é muitas vezes uma polêmica generalizada contra a influência repressora da razão, do

\footnotetext{
${ }^{69}$ Alfred Kerr apontou para a decepcionante similaridade entre os dois reinos. Segundo ele, Törless perde seu caminho dentro da sexualidade. Ele se refere às experiências homoeróticas de Törless como "abominações peculiares da vida que vislumbra em plena luz do dia tal qual o outro reino escondido". CORINO, Robert Musil und Alfred Kerr, Studien 1970, p. 236-83.

${ }^{70}$ Para uma análise comparativa da recepção de Mach feita por Bahr e Musil, bem como o avanço no desenvolvimento de Musil em direção à teoria gestalt, veja: MONTI, Musil, la metafora della scienza, 1983, p. 29-51.
} 
pensamento conceitual e do conhecimento científico, culpados pela falta do sentimento de autenticidade e pelas distorções da vida moderna. A demanda nietzschiana para se restaurar a autenticidade à vida humana, retomando a guia inenarrável dos instintos e sentidos, ecoa na suspeição contra linguagem e pensamento, peculiar à cultura vienense, uma suspeição que o romance de Musil, à primeira vista, também parece endossar.

Os vislumbres pré-verbais de Törless de um modo alternativo de ser insinua a possibilidade de uma existência intuitiva que, ao se esquivar à mediação pela linguagem e pelo pensamento, é capaz de revelar uma imagem diferente do real uma experiência mística que lembra de perto as epifanias mudas experimentadas pelo personagem Lorde Chandos, de Hofmannsthal. Estas epifanias lançam dúvidas sobre a habilidade da linguagem e do pensamento para confinar o que é mais precioso na existência humana. Para Chandos, esta dúvida se estende até um ceticismo radical em relação à adequação da linguagem como um meio para representar e negociar a experiência.

Ao se olhar mais de perto, contudo, O jovem Törless frustra as expectativas daqueles leitores que buscam nele um testemunho da crise de linguagem da Viena de 1900. É certo que a dolorosa percepção do adolescente de que a linguagem está destinada a deixá-lo na mão no momento em que ele mais precisa representa um tema recorrente na narrativa. Com a recém-descoberta inabilidade da linguagem para transmitir a experiência de "outra condição", de um "outro mundo", descortina-se a falta de conjuntura mais geral entre linguagem e realidade. Ao tomar conhecimento do espaço que separa a linguagem da experiência, Törless é compelido a considerar até a experiência verbal de maior sucesso como pouco mais que uma mentira:

Era a falha das palavras que o torturava, a vaga consciência de que palavras eram apenas subterfúgios transitórios para as coisas realmente experimentadas. E hoje lembrava-se dessa cena, lembrava-se das palavras, e nitidamente lembrou-se da sensação de que mentira sem saber o porquê. Na memória seu olhar reviu tudo mais uma vez. E sempre tudo retornava sem alívio. Um sorriso de encantamento ante a riqueza de idéias, que ele ainda mantinha no rosto distraidamente, aos poucos assumia um quase imperceptível traço de dor. Sentiu necessidade de procurar uma 
ponte, uma ligação, uma comparação entre si próprio e aquilo que se instalava mudamente diante de seu espírito. Contudo, sempre que se acalmava com um pensamento, retornava aquela falta incompreensível: mentira. (JT, p. 72)

Porque a linguagem e pensamento não revelam o que mais importa, pode-se concluir que geralmente merecem ser tomados com desconfiança. Se falharem em tarefa tão importante, o que atestaria, de fato, a confiabilidade e a autenticidade da experiência ordinária em geral, a qual a linguagem e o pensamento ajudam a moldar e mediar? Contudo, Törless nunca chega a essas conclusões porque ele não vai tão longe a ponto de culpar sua inabilidade em articular suas outras experiências em falhas da linguagem e do pensamento. Seu senso da qualidade acidental e a desconfiança na linguagem crescem de sua observação de que a linguagem ordinária se mostra incapaz de funcionar como uma "ponte" entre ele e as experiências inefáveis que o confrontam. A lição importante que Törless aprende no fim de suas tribulações não é de que se deve sempre desconfiar da linguagem. A linguagem se mostra uma ótima ferramenta para a experiência ordinária, mas é inadequada para capturar a experiência do "outro" mundo. Em vez de desautorizar a linguagem pelo que não pode atingir, no fim Törless jura que nunca mais tentará comparar os dois mundos novamente, isto é, ele nunca mais fitará a "outra" esfera com os olhos do intelecto e do pensamento conceitual.

Hickman (1991) ofereceu um relato convincente da relação de Törless com a linguagem ao comparar de perto os problemas lingüísticos do adolescente com aqueles do Lorde Chandos. Para Chandos, palavras e conceitos são braços indispensáveis da subjetividade. Uma vez que o escrutínio mais próximo simbolizado na imagem de uma lente de aumento - revela a fenda fundamental que separa a linguagem da experiência, a própria estrutura do ser se revela inautêntica e começa a se desenrolar, tal como uma mentira se dissolve sob a pressão da verdade. Dessa forma, o que está em jogo na visão ampliada de Chandos é a desintegração final do ser. Hickman aponta para uma imagem similar no romance de Musil, mostrando como, contudo, a lente de aumento é usada por ele não para indicar a desintegração da subjetividade, mas sim para apontar para a distorção da visão: "Para Musil, por outro lado, a ampliação produz distorção: a insistência em se usar 
palavras em situações em que seu uso é inapropriado leva, é verdade, à maior definição, como em uma imagem ampliada; mas ipso facto a precisão excessiva decorrente resulta em uma falsificação da experiência emocional original."71

- O mundo do sentimento e do intelecto é incomensurável

Tal linha argumentativa se sustenta com o aviso contido na passagem de Maeterlinck no início da narrativa: ele lembra ao leitor a inutilidade de tentar levar à superfície o tesouro do fundo do mar, de se esforçar para expressar o que é inexpressável. Não obstante, a narração não fecha um círculo simplesmente. O experimento perturbador de Törless não confirma o que foi citado no princípio, e a lição que ele aprende não contém simplesmente um endosso da poética do silêncio de Maeterlinck. A consciência de Törless sobre os limites da linguagem não é um ponto de chegada, mas sim um ponto de partida na narração. Mesmo quando o adolescente acaba por reconhecer que a linguagem ordinária é inadequada para englobar as agitações do outro mundo, sua própria verbalização do problema na cena final do julgamento representa um enorme passo para frente. Ser capaz de expressar que há esferas emocionais, e estas se recolhem ao olhar da linguagem e do pensamento, ser capaz de reconhecer e explicar a outros que o ser dividido está fundamentado nesta incomensurabilidade constitui uma enorme realização, uma realização que cura Törless de suas aflições e o ajuda a encontrar seu caminho para a maioridade, como esteta sensível e cético retratado no único avanço de tempo do romance. $^{72}$

O que está em jogo nas tribulações de Törless é como articular corretamente a relação entre o intelecto e o sentimento, o mental e o emocional, a mente e os sentidos. Se fosse enquadrado dentro dos termos de um desequilíbrio entre as faculdades intelectuais e emocionais, o tratamento de Musil a essa questão poderia

\footnotetext{
${ }^{71}$ HICKMAN, 1991, p. 40.

72 VARSAVA, Törless at the Limits of Language: a Revised Reading, Seminar: a Journal of Germanic Studies 20.3, Setembro 1984, p. 203.
} 
ser visto como o relato pessimista da modernidade oferecido por Mauthner e endossado por muitos contemporâneos. Parece duvidoso, contudo, que a articulação desse tema crucial tenha sido feita de forma a reforçar o diagnóstico amplamente divulgado da condição moderna que advogava a renovação da humanidade mediante liberação da garra opressiva da razão e das forças primordiais, irracionais. Em outras palavras, a questão é se Musil acredita que os apuros do adolescente deveriam ser traçados de volta ao desequilíbrio entre as faculdades intelectual e emocional. ${ }^{73}$

Em uma carta de março de 1905, Musil relata a uma amiga suas inseguranças sobre os méritos do romance, que afirma ter terminado. A carta aparenta uma tentativa de desculpas, antecipando a crítica de alguns aspectos ambiciosos de seu projeto como a estilização da personagem e a falta da análise psicológica tradicional. A despeito de todas as suas falhas, sugere Musil, a narrativa transmite firmeza: "o mundo do sentimento e aquele do intelecto são incomensuráveis". Ele cita o exemplo do poder emocional da música, particularmente sua habilidade de convocar um mundo emocional inconcebível: "que mau julgamento o de tentar clarear música por palavras e pensamentos." 74 Mas todas as formas de arte compartilham dessa qualidade, ele continua, pois a arte é a esfera que engloba sentimentos e emoções que não podem ser satisfatoriamente articulados nem conceituados.

Enquanto essa discussão parece armar uma oposição familiar em volta de polaridades como a mente e o sentimento, o intelectual e o emocional, a vida comum e a arte, a última parte da carta torna claro que essa incomensurabilidade dos mundos emocional e intelectual não resulta em uma relação antagônica entre os dois. Ao contrário, a incomensurabilidade implica o desafio de expressar aquilo que, a princípio, está fora do escopo de expressão:

\footnotetext{
${ }^{73}$ As críticas de Musil têm rotineiramente considerado o assunto de um desequilíbrio entre intelecto e as emoções como a raiz dos problemas de Törless. Veja, por exemplo, as sugestões de Hickman de que o problema em Törless é o "dualismo do intelecto e sentimento" (p. 36) ou o "equilíbrio entre intelecto e emoção" (p. 45).

${ }^{74}$ MUSIL, Briefe 1900-1942, v. 1, 1981, p. 13.
} 
Eu sei que agora apreendo a pintura como a única pessoa nesta sala, e não sei bem com e com o quê. Posso transmitir minha impressão somente por meio de palavras bastante impróprias. E ainda a certeza com a qual a apreendo é indescritivelmente forte. Em outras palavras, é como se houvesse uma pessoa em mim a quem a pintura se refere, como se tal apreensão pudesse estar contida em sua sombra. E acredito que nos possuímos somente até onde podemos nos apreender compreensivelmente. ${ }^{75}$

Essa passagem traz de volta a consciência inquietante de Törless de um “outro" estranho com o qual o seu ser consciente é incapaz de se relacionar por meios da linguagem e do pensamento. Mas essa caracterização acrescenta um elemento importante ao familiar tema da divisão interior na psicanálise, pois liga a emergência do lado sombrio do indivíduo ao momento da experiência estética. $\mathrm{O}$ trabalho de arte dá margem a uma resposta do ser sombrio cuja clareza e persuasão podem ser sentidas, mas tal tarefa não é propriamente articulada pelo ser consciente. Não há menção a uma hostilidade entre os dois, quanto mais um antagonismo entre o sentimento e o intelecto, o emocional e o conceitual. Mais exatamente, a questão é como encontrar meios de expressar aquilo que escapa à verbalização, para ir além dos limites do dizível de forma a se tornar conhecido da pessoa invisível que está debaixo do seu ser consciente. E isso não é só uma descrição do caminho de aprendizado de Törless, mas também uma caracterização do próprio experimento literário de Musil no romance.

- A realidade escapa no indizível

A atualidade da experiência recontada no primeiro romance de Musil - isto é, o vislumbre de uma realidade invisível que astuciosamente escapa aos automatismos estabelecidos da percepção, conceitualização e verbalização - pode ser atestada ao se reverem as tentativas ecléticas de se expandir a experiência do mundo natural além dos confinamentos tradicionais da percepção na passagem do século. Esses

\footnotetext{
${ }^{75}$ O que segue é uma descrição apta do compromisso de Törless: "O eu literalmente torna-se dividido, ganha um terreno duplo e através de um vidro escuro do primeiro \{eu\}, que era até agora apenas um, alguém busca misteriosamente movimentos sem estar apto a interpretá-los". MUSIL, Briefe 1900-1942, v. 1, 1981, p. 14. (Tradução nossa.)
} 
esforços englobam fenômenos tão diversos quanto a popularidade de práticas espiritualistas e ocultas, o ressurgimento da fé em uma sabedoria mística intuitiva do mundo na passagem do século, teosofia e antroposofia, ou a busca pela captura do conteúdo espiritual da experiência pelo meio sensual da arte, que dirigiu experimentos de pintores avant-garde como Wassily Kandinsky e Franz Marc.

Enquanto os avanços sensacionais das ciências naturais, a descoberta dos raios-X por Röntgen, a investigação de Marie Curie da radioatividade, aumentaram o escopo da experiência material, também chamaram a atenção, simultaneamente, para as limitações inerentes ao método científico e para a necessidade de se perseguir modos alternativos para a revelação da realidade intangível presumidamente escondida atrás do mundo material. Esses experimentos foram alimentados pela esperança de que uma apreensão holística intuitiva da realidade providenciaria meios de se superar o sentimento difundido de crise ligado aos processos de modernização, especialização e mecanização, de forma a revelar novas coordenadas de orientação e horizontes éticos. A constelação de experimentos intelectuais deixados na esteira de Nietzsche redescobre, na arte e na experiência estética, não somente um terreno alternativo para experimentação, mas também um meio para reinvestir a experiência humana do significado perdido no despertar da modernização. $^{76}$

O renascimento do interesse no romantismo nas últimas décadas do século XIX se encaixa nesta moldura. O romantismo foi o primeiro esforço deliberado de explorar, dentro da arte ,aquelas camadas de realidade que residem fora do alcance da cognição conceitual e são presumivelmente consignados às profundezas éticas de um inconsciente submerso ou à magia inconcebível do mundo natural. ${ }^{77}$ Logo após completar $O$ jovem Törless, Musil registrou em seus diários sua intenção de se “tornar aprendiz" dos românticos e místicos ( $D$, p.87). O programa poético que Musil delineou é tanto mais formidável por exibir as profundas diferenças que o

\footnotetext{
${ }^{76}$ Ver tal "constelação cultural” em: HENDERSON, "Die moderne Kunst und der Wissenschaften", em Okkultismus und Avantgarde. Von Munch bis Mondrian 1900-1915, 1995, p. 13-31, especialmente 14-15.

77 Sobre ressurreição do neo-romantismo na virada do século, veja LINDNER, Leben in der Krise, Zeitromane der neuen Sachlichkeit und die intellektuelle Mentalität der klassischen Moderne, 1994, p.131-37.
} 
separam não só da decadência literária, como do renascimento neo-romântico contemporâneo. A principal preocupação de Musil é como articular a relação correta entre as faculdades intelectuais e emocionais na busca da realidade ética inconcebível que é dada aos humanos quando vislumbradas em momentos místicos de iluminação.

Na longa entrada em seu diário, que contém comentário sobre Törless, Musil se engaja em uma discussão sobre os primórdios do romantismo. Em questão está a crença dos românticos de que as camadas submersas da consciência são cruciais para entender "relacionamentos éticos mais finos" (TB, p. 138) e, portanto, representam a fonte do comportamento humano autêntico. A oposição romântica entre "pessoa visível" e uma "alma" submersa ${ }^{78}$ certamente reverbera com as experiências do jovem protagonista de Musil, que se sente dividido entre um ser diurno e sua sombra pré-consciente. A questão se torna como seguir na investigação desse lado sombrio, uma investigação que, presume Musil, é mais bem conduzida no meio literário. Os detalhes que ele esboça para seu plano de aprendizado do romantismo são bastante reveladores: "A única atividade crítica a se fazer aqui”, ele escreve, "é reduzir suas [dos românticos] idéias do puro cerne 'senti-mental', i.e., de se cortar fora qualquer coisa que seja possível somente de um ponto de vista metafísico específico, por exemplo, a filosofia da natureza de Schelling” ( $D$, p.87). O objetivo é despir a especulação romântica de sua bagagem metafísica até que seu cerne "senti-mental" seja revelado. O sentido de "senti-mental" é especificado mediante um contraste com a prática do esteticismo: "Qual seria a atitude de Jena [o círculo romântico de Jena] para com D'Annunzio, por exemplo? Sentiria que o mental estava faltando em seu trabalho. Poderiam até achar que sua sensualidade era plebéia”. ( $D$, p.87).

A justaposição do romantismo primordial e D'Annunzio, como representante nietzschiano do esteticismo e da decadência, é significante porque sugere que Musil vê a polaridade romântica de consciência e inconsciência, a pessoa visível e a alma reinscrita na moderna dicotomia de mente e de sentimento, de intelecto e de

\footnotetext{
${ }^{78}$ Lindner (1994) destaca que tal passagem se refere à antologia de HUCK, Die Blütezeit der Romantik, 1905. O contraste entre o sentido de sentimental e a prática do esteticismo é mencionado na referência a um trecho, que Musil erroneamente atribui a Novalis.
} 
sentidos, de razão e de emoção. Dentro desse quadro, a celebração moderna do sensual aparece como outro modo de liberação do ser inconsciente. Mas isso é fruto de uma confusão, alerta Musil, pois a prática moderna de exaltar a sensualidade só se assemelha superficialmente à investigação romântica do inconsciente. Como sustenta Musil em seu comentário sobre ao sensualismo reles de D’Annunzio, a moderna exaltação dos sentidos representa "uma cultura do físico de forma a trazer alívio ao espiritual". ( $D$, p.87).

Dentro do "movimento moderno", a falsa justaposição do intelecto e dos sentidos relega a sensualidade a uma válvula de escape sem sequer começar a entender sua importância verdadeira. É uma prática dualista que arma uma oposição artificial entre o mental e o físico, uma oposição que se presta a polarizações distorcidas, à demonização de um lado de forma a melhor romantizar o outro. Dessa maneira, tende a considerar o mental como inferior, sem valor ou até mesmo danoso. No todo, isso representa uma profunda incompreensão do empreendimento romântico, e é por isso, conclui Musil, que os primeiros românticos perderiam um conteúdo "mental” ou intelectual crucial.

Em seus diários ( $D$, p. 92), Musil observa que a arte representa uma fonte indispensável de nutrição para a alma, que engloba a fonte pré-consciente e inconsciente de energia vital em qualquer indivíduo, a formar a corrente subterrânea essencial que sustenta a vida em comunidade. Ao entrar em contato com a obra de Ellen Key (Century of the child, publicada em inglês em 1909), Musil encontra exemplos de "artistas da vida" (alem. Lebenkunstlers), que vão da antiguidade à modernidade. Segundo Musil, Key repropõe a metáfora central romântica de forma que a vida em si deveria ser moldada conforme um processo que estimula a criação artística. Central para esse programa é o cultivo de todos os aspectos da natureza humana, de forma a assegurar o desdobramento harmonioso do ser. Segundo essa autora, vários fatores vieram a prejudicar o crescimento harmônico do indivíduo na modernidade. Além da propagação da ambição de lucro capitalista e de um sistema educacional opressivo, Key aponta os excessos de intelectualização e uma forma agressiva de racionalidade como responsáveis por expulsar a vida instintiva da alma. 
Sensibilizado e ao mesmo tempo perturbado pelas observações de Key, Musil se volta para "uma linha de pensamento" que ele havia, em algum ponto, abraçado e da qual se sentia alienado ( $D$, p. 92). Ao longo de vários dias, ele desenvolve suas idéias, anotando aspectos pontuais do pensamento de Key, como se estivesse na busca de razões para a sua sensação de irritação com o raciocínio da autora.

Mas, em certo ponto, Musil observa que uma das maiores falhas do trabalho de Key é a sua crença ingênua na inocência da criança e do primitivo, nutrida por um panteísmo banal "daquelas pessoas simples cujos corações são mais pesados que suas cabeças". "Key polemiza contra a razão" ( $D$, p. 96), conclui Musil de forma desaprovadora. Enquanto seu propósito de chamar a atenção para as camadas submersas da consciência é salutar, sua crítica subseqüente da razão permanece espúria e tendenciosa e pouco faz para jogar luz sobre o problema do empreendimento romântico, cuja ruína ora estava em questão.

- A fé e a experiência da desrazão

A investigação de Musil de modo pré-lingüístico ou pré-conceitual de experiência em seu primeiro romance reflete apenas superficialmente o tema neoromântico de uma consciência individual dividida. A preocupação de Musil em traçar uma linha entre o neo-romantismo contemporâneo e sua própria investigação advém de sua suspeição em relação às categorias dicotomizantes empregadas habitualmente no enquadramento do problema. Como o pensamento conceitual e a linguagem se mostram incapazes de alcançar o outro ser, a fé é colocada diante das possibilidades de experiências que não são mediadas por eles: a intuição, a emoção, os sentidos, o erotismo. A divisão fundadora do indivíduo é então construída como uma oposição entre a razão e a desrazão, o intelecto e os sentidos, a vida e a arte, a civilização racional e a cultura intuitiva. A narrativa retrata a razão como um obstáculo que previne o acesso à fonte não racional de experiência, que pode ser 
acessada somente pela arte irracional. A polêmica contra a razão e a favor da intuição permeia quase todos os experimentos estéticos que floresceram nas primeiras décadas do século, do esteticismo e simbolismo ao expressionismo e surrealismo.

Com Törless, Musil caminha em uma outra direção. Enquanto o romance reafirma a qualidade não comensurável percebida do mundo do intelecto e do mundo das emoções, também torna claro que esse espaço não é necessariamente o caso de uma relação distorcida entre os dois ou de um desequilíbrio que deva ser retificado. A divisão interna de Törless se anuncia como pré-requisito de uma consciência adulta. Ao levantar a questão se todos os adultos seriam amaldiçoados por uma divisão interior, Törless a torna uma pré-condição da transição para a maturidade. Em outras palavras, em Törless o espaço entre uma esfera ordinária e outra inefável é retratado não como uma condição anômala que deve ser revertida, mas sim como um estado mental da maioridade, um estado mental com o qual se lida ao aceitar a incomensurabilidade das duas esferas. Ou, para falar como Törless, ao perceber que não se pode aplicar o olhar da razão à outra esfera. Razão, pensamento conceitual e linguagem não se tornam obstáculos ou inimigos contra quem lutar, porque a consciência dividida é retratada não como uma queda de um estado passado de graça, mas sim como uma pré-condição da passagem para a maioridade.

A conclusão do primeiro romance de Musil não deve ser lida, no entanto, como um convite para se renunciar à investigação da "outra" esfera inconcebível. A questão se torna assim até onde e com quais meios se é possível ultrapassar os limites da expressão de forma a capturar a substância inefável da ética. Ecoando a resposta de poéticos simbolistas e decadentes, Musil encontra na literatura um meio apropriado de investigação. Contudo, sua noção evolutiva de literatura se separa do discurso estético da decadência, que permanece preso a um irracionalismo muitas vezes impensado. Musil extrai de seu treinamento nas ciências naturais para redefinir a literatura como um empreendimento intelectual ambicioso informado por um empiricismo liberal e precisão científica. Tal investigação não compõe uma oposição programática entre o intelecto e o sentimento, mas, ao contrário, busca 
descobrir sua reciprocidade sem idéias pré-concebidas, esforçando-se para explorar produtivamente a qualidade distintiva "sentimental" do literário. 


\section{PARTE II}

Quarto Capítulo

Musil diante da "genialidade" de um cidadão kakaniano

- O Homem Matemático e as vantagens da precisão científica

Em um pequeno ensaio de 1913, Robert Musil embarcou em uma discussão singular e apaixonada com o objetivo de elucidar um aspecto neglicenciado da especulação matemática. ${ }^{79}$ Apesar de o texto refletir parcialmente o engajamento de Musil com essa disciplina como parte de seus estudos doutorais em Berlim, seria um engodo buscar uma discussão técnica do horizonte em expansão da pesquisa matemática no despertar do século XX. Ao contrário, Musil reenquadrou a matemática como um modelo para a investigação intelectual arrojada, que prometia revolucionar as ciências humanas. Enquanto os aspectos utilitários da disciplina, isto é, sua aplicação no desenvolvimento da ciência e tecnologia, são geralmente reconhecidos, um lado importante do pensamento matemático moderno ainda está para ser reconhecido, alega Musil. Ele descreve este aspecto como a vontade dos teóricos matemáticos em confrontar aberta e construtivamente as fundações contingentes de sua disciplina. Musil esboça o despertar da "consciência matemática" moderna como se segue:

Toda a vida que gira em torno de nós, corre e pára, não é dependente da matemática somente para sua compreensão, mas efetivamente veio a ser por ela, e depende dela para sua existência, definida de tal e tal forma, pois os pioneiros da matemática formularam noções utilizáveis de certos princípios que levaram a conclusões, métodos de cálculo e resultados e estes foram aplicados por físicos para se obter novos resultados; e por fim vieram os técnicos, que muitas vezes pegavam somente os resultados e acrescentavam novos cálculos a eles, e então faziam nascer as máquinas. E de repente, depois que tudo havia sido

\footnotetext{
${ }^{79}$ O artigo The Mathematical Men (PS, p. 39-43) aparece em Der Lose Vogel, um jornal mensal publicado por Franz Blei e Kurt Wolff, em Leipzig. Nota dos tradutores ingleses, PIKE; LUFT.
} 
trazido à mais linda existência, os matemáticos - aqueles que se mantêm entre si mesmos - apareceram com algo errado nos fundamentos de toda a coisa que não podia de forma alguma ser consertada. Eles realmente olharam até o final e descobriram que todo o prédio estava de pé em pleno ar. Mas as máquinas funcionavam! Devemos tirar disto que nossa existência é um pálido fantasma; nós a vivenciamos, mas somente com base em um erro sem o qual ela não teria despertado. Hoje não há outra possibilidade de se ter um sentimento tão fantástico e visionário quanto o têm os matemáticos. ( $P S, \mathrm{p} .41-42)$

Assim como em $O$ jovem Törless, aqui também a audácia das construções matemáticas se torna um meio para descobertas surpreendentes. Estas são possíveis por causa de um "sentimento visionário" que Musil atribui aos matemáticos. Esse sentimento imaginativo os levou a presumir, por exemplo, que os princípios matemáticos podem ser infundados, em um movimento cujas ramificações epistemológicas vão muito além da questão de confiabilidade e sustentabilidade de uma única disciplina. ${ }^{80} \mathrm{Na}$ realidade, a presunção dos matemáticos resulta em que toda nossa civilização foi fundada em um "erro". Mais precisamente, a civilização deve sua própria existência a esse erro, pois os cálculos matemáticos estão no coração do desenvolvimento da ciência moderna e da tecnologia. Essa observação leva à conclusão de que nossa existência nada mais é que um "pálido fantasma". A circunstância que sustenta o edifício matemático que paira no ar, sabendo-se que não está fundado em bases epistemológicas firmes, não é uma concepção tão alarmante, pois as máquinas, talvez o resultado mais importante da revolução científica, ainda assim funcionam. Não se pode exagerar o significado do sentimento imaginativo dos matemáticos. Tal significado não somente carrega a visão de um sistema sem fundações, isto é, ele é totalmente contingente, e ainda assim pode ser completamente operacional. Ele também ajuda ao matemático ver o contingenciamento da civilização moderna, isto é, sua falta de fundamentação real, não como uma condição ameaçadora, um estado anormal a ser superado, mas sim como a própria condição que tornou a civilização possível.

\footnotetext{
${ }^{80}$ A razão de Musil reflete o desenvolvimento na matemática e nas ciências naturais. As brilhantes averiguações dentro do suporte teórico da matemática no século XIX e no início do século XX impulsionaram as bases das averiguações científicas. No artigo está especialmente a visão da impossibilidade de fundamentar as suposições matemáticas básicas e as regras por meio de princípios racionais.
} 
Qual é então o erro ao qual Musil atribui o despertar da civilização? No contexto de seu argumento, o termo erro não se refere à falsidade presumida das fundações matemáticas que implicariam a existência de fundações não contingentes, na busca relacionada à sua origem. A imagem de um edifício que paira no ar, na verdade, sugere que o engano está em presumir a possibilidade de uma base não contingente - certamente um engano produtivo que alavancou a epistemologia e a ciências ocidentais até o fim do século XIV.

Musil, o matemático, parece não estar aterrorizado pelos escândalos intelectuais que se tornam possíveis por causa de sua imaginação subversiva; muito pelo contrário, ele os exibe com orgulho. Sua vantagem reside em sua vontade de se acertar com os dados da experiência, embora sem abrir mão de observar a natureza mediada e construída de tais dados. Essa ancoragem em experiência é responsável pela franqueza e pela abertura do matemático em confrontar esta observação com as fundações contingentes de sua disciplina.

- O empreendimento imaginativo da matemática não coincide com as especulações sonhadoras do filósofo

Com os argumentos ora desenvolvidos, Musil distingue o empreendimento imaginativo da matemática das especulações sonhadoras do filósofo. (PS, p.42). Esta atitude, que desautoriza os sonhos escapistas e as nostalgias regressivas, representa para Musil o modelo ótimo para o intelectual e escritor do futuro:

É tolice sustentar que tudo isso é uma questão de mero conhecimento, pois pensar há muito é o fim. Com suas reivindicações de profundidade, arrojamento e originalidade, o pensamento ainda se limita provisoriamente aos aspectos racional e científico. Mas este intelecto devora tudo à sua volta, e assim que se depara com o sentimento, se torna espírito. Tomar este passo é tarefa para os escritores. ( $P S$, p. 43$)$ 
Somente convenções históricas podem explicar o confinamento presente do arrojado espírito científico aos domínios das ciências naturais e uma racionalidade primordialmente instrumental. Estas recaem sobre o escritor, sugere Musil, ao adotálas como modelo para uma investigação inovadora dos domínios que não pertencem à ciência. Se o escrutínio das coordenadas básicas do pensamento científico tornou possíveis realizações revolucionárias tal como a mecânica quântica e a teoria da relatividade no começo do século $\mathrm{XX}$, os mesmos resultados revolucionários poderiam ser obtidos nas ciências humanas. Em virtude de seu caráter arrojado e de sua franqueza, a reflexão matemática moderna descobriu um território intelectual inexplorado, mostrando que a ciência - e a civilização em geral -, não são necessariamente prejudicadas pela observação do contingenciamento de suas fundações. O escritor Musil está pronto para estender essa investigação aos domínios da arte e da ética, responsabilizando-se por uma investigação da ética que se inicia não na ficção de leis morais atemporais, mas na qualidade emocional esquivada da experiência ética.

O sonho de Musil de infundir à literatura o espírito da ciência deve ser visto contra o pano de fundo do fermento cultural disparado pela crise das ciências humanas na Europa do final do século XIX, uma crise que moldou o discurso intelectual alemão até um período considerável da Primeira Guerra. Wolf Lepenies (1988) reconta as principais fases dessa crise, traçando um realinhamento dos discursos disciplinários que acompanharam o crescimento da Sociologia na segunda metade do século XIX. Seu relato se volta para a tentativa da Sociologia de ocupar o espaço discursivo e cognitivo que separava a literatura da ciência. Esse era um espaço que tradicionalmente delimitava uma determinada prática literária voltada para a apresentação empática da experiência humana singular, tratando, ao mesmo tempo, de uma categorização neutra e sistemática do mundo natural no discurso científico.

Ao narrar a história do humor intelectual conhecido como pessimismo cultural, Lepenies reconstrói os modos em que a divisão epistemológica separa as ciências naturais das ciências humanas e como tal separação se tornou ideologicamente reinscrita, por volta da mudança do século XIX para o século XX. 
Sua perspectiva ressalta a rivalidade entre a tradição Iluminista de fé na ciência, na razão e no progresso e a exaltação neo-romântica da vida intuitiva do "homem", retratada como ameaçada pelos excessos do espírito frio de ciência e da razão instrumental. A polarização subseqüente da arte, da cultura, do sentimento e da intuição, por um lado, e da racionalidade, do pensamento sistemático e das ciências naturais, por outro, produziu um entendimento de razão e de sentimento, de ciência e de literatura como funcionalmente incompatíveis. ${ }^{81}$

- O fascínio de Musil com estados místicos inefáveis

O projeto de Musil está inscrito na mesma disposição disciplinária e ideológica como desafio à mudança social. Contudo, de maneira efetiva, explode a dicotomia redutiva da arte e da ciência, do sentimento e da razão como parte de muitos discursos sobre a Grande Arte nas primeiras décadas do século XX. Efetivamente explode tal dicotomia, rejeitando como redutivista a visão da ciência como prática estreitamente utilitária com fins ao domínio da natureza, presa a um antagonismo irredutível com o domínio intuitivo da arte. Ao contrário, Musil acreditava que o ilimitado e a atenção para com a experiência da reflexão científica poderiam fornecer um modelo para uma jornada intelectual até o terreno novo estético e ético - aqueles momentos singulares de epifania explorados em $O$ jovem Törless. Ao mesmo tempo, a produtiva fertilização cruzada entre a literatura e o espírito científico a que ele visava não tem nada em comum com a reivindicação ingênua de objetividade científica do naturalismo. Infundir a literatura com o espírito exato da ciência produziria critérios diferentes de convicção e precisão do que aqueles das ciências naturais. Esses deveriam ser critérios para apreensão da qualidade distintiva do literário.

\footnotetext{
${ }^{81}$ Lepenies reconhece a bem-sucedida oferta para a preeminência epistemológica feita pela ciência experimental no decorrer do século XX, com resultado na afirmação de uma moralidade estreita, indiferente à noção de verdade. Sobre isso ver: LEPENIES, 1988.
} 
Em jogo está o equilíbrio específico de sentimento e intelecto que permite ao escritor explorar o domínio da experiência ética situada com acurado rigor científico. O fascínio de Musil com estados místicos inefáveis o situa em boa companhia junto a modernistas proeminentes como Walter Benjamin, Ernst Bloch, Hermann Broch, Hugo von Hofmannsthal, Marcel Proust e James Joyce. O que o distingue entre outros é a sua confiança declarada na razão, que nasceu de sua crença no papel central que o intelecto desempenha na experiência estética.

Os anos logo antes da Primeira Guerra foram uma época de atividade ensaística intensa para Musil, enquanto ele lutava para firmar um nome para si ao contribuir para os principais periódicos literários na Alemanha e na Áustria. ${ }^{82} \mathrm{Em}$ 1909, desistiu do prospecto de uma carreira acadêmica segura quando recusou uma posição como assistente acadêmico ao lado de Alexius Meinong, que detinha uma cadeira de filosofia na Universidade de Graz. ${ }^{83}$ Ao deixar Berlim, em 1910, para Viena, onde aceitou um posto como bibliotecário na Universidade Tecnológica, esperava que essa ocupação lhe permitisse dedicar o melhor de suas energias para escrever, mas essa acabou por provar a sua incapacidade de agüentar as pressões do emprego. Logo foi dada a ele uma licença do cargo por tempo indeterminado, após chegar próximo a um colapso nervoso. Em Viena, Musil cultivou ativamente os relacionamentos pessoais e contatos literários estabelecidos em Berlim, entre esses o seu melhor amigo e rival intelectual Johannes Allesch, um psicólogo experimental treinado, que se tornaria figura proeminente na psicologia da arte. ${ }^{84}$

A despeito da recepção decepcionante de seu segundo trabalho de ficção, as duas novelas publicadas sob o título Vereinigungen (Uniões) (Tradução nossa.) em 1911, Musil logrou êxito em assegurar, em 1914, um posto editorial de prestígio na Neue Rundschau de Samuel Fischer. Contudo, não lhe foi possível colher os frutos de seu prestígio, pois sua carreira foi interrompida pela eclosão da Primeira Guerra

\footnotetext{
${ }^{82}$ HICKMAN, 1991, p. 68.

${ }^{83}$ CORINO, 1988, 150.

${ }^{84}$ Musil estava ativamente envolvido nos debates culturais e literários dos seus dias. Seu primeiro artigo publicado, The Obscene and the Pathological in Art, de 1911, é um apelo passional contra a censura na arte. Um outro pequeno artigo, Analysis and Synthesis, foi publicado em $1913 \mathrm{em}$ Revolution como parte de uma campanha que denunciou o confisco de um dos artigos do jornal pela polícia, $G W$, v. 8, 1008-9.
} 
Mundial. Musil foi designado inicialmente para o Tirol do Sul como oficial do exército austríaco e subseqüentemente designado para um posto como editor do jornal do exército, no qual permaneceu até o final da Primeira Guerra. ${ }^{85}$

A indicação de seu nome parece ainda mais incrível à luz do fato de que o periódico, considerado geralmente como o principal jornal avant-garde publicado em alemão, havia imprimido uma crítica feroz tanto de $O$ jovem Törless quanto de Vereinigung. Zwei Erzählungen (1911) (Uniões, duas narrativas) ${ }^{86}$ (Tradução nossa.), em 1911. O autor da crítica, Jacob Schaffner, não fez tentativa alguma de minimizar seu sarcasmo enquanto discutia os defeitos das novelas recém-publicadas. Tal posição crítica visava à parcimônia narrativa das duas histórias, que se focam primordialmente nos estados mentais das personagens principais. A primeira novela The perfecting of a love reconta a história de uma mulher de classe média bem casada que, guiada pela compulsão inexplicável de provar a profundidade de seu amor por seu marido, comete adultério com um conhecido, um homem que ela acha repulsivo. A segunda narrativa, Die Versuchung der stillen Veronika ${ }^{87}$ (As tentações da calma Verônica) (Tradução nossa.), gira em torno da perplexidade de uma jovem com a mente repleta de fantasias eróticas, que se sente dividida entre dois homens, um padre e um bruto.

A resposta pouco simpática de Schaffner ao segundo trabalho de ficção de Musil não foi de forma alguma uma exceção. As novelas deixaram a maioria dos críticos desconcertada com os excessos de erotismo e foram recebidas friamente, até mesmo por Alfred Kerr, o editor proponente mais influente de Musil. Os críticos se viram justificados ao igualarem a perspectiva radical das novelas, com fins de registrar estados mentais não convencionais, antes censurados à exposição literária e experiências fronteiriças, a uma prática moderna introspectiva, determinada a evocar representações vagas e humores indefinidos em um estilo nebuloso.

\footnotetext{
${ }^{85}$ CORINO, ibidem, p. 222.

${ }^{86}$ MUSIL, GW, v. 6, p. 156.

${ }^{87}$ MUSIL, ibidem, p. 194-223.
} 
Dado o foco em experiências sexuais transgressivas em Vereinigung. Zwei Erzählungen (Uniões, duas narrativas), Corino (1989) salientou a conexão com a revelação pouco saudável da depravação humana em $O$ jovem Törless, atribuindo fama a Musil como um autor que se regozija com o doentio e o perverso. ${ }^{88}$ Do mesmo modo, tal crítico apontou o apelo das duas histórias à evocação ambivalente de situações chulas, direcionadas para fazer instilar os instintos mais básicos do leitor.

- A cultura de nervos em decadência

Mas o que deve ter sido mais desalentador do que as acusações de torpeza moral é que vários críticos, explícita ou implicitamente, colocaram as novelas dentro da mesma tradição de prosa psicológica decadente da qual Musil buscava se distanciar, às vezes ecoando de perto a própria crítica de Musil da decadente "cultura de nervos". Mas uma análise nas entradas nos diários de Musil, que dizem respeito aos rascunhos dessas obras, mostra o quanto ele estava distante do espírito de decadência “fim-de-século".

Em uma anotação de agosto de 1908, Musil tenta esclarecer para si mesmo as questões no cerne das provações às quais se submete a jovem protagonista em Die Versuchung der stillen Veronika ${ }^{87}$ (As tentações da calma Verônica) (Tradução nossa.). Ele se indaga sobre a questão feminina: qual é seu problema de verdade? O que ela quer? Um desejo se origina nesta personagem por uma classe de experiências difíceis de se conceber, mas ainda de algum modo definidas. Musil as define como experiências fortes, mas, no entanto, impessoais. ${ }^{89} \mathrm{O}$ comportamento enigmático, sonhador de Veronica, sugere Musil, é guiado por um desejo por

\footnotetext{
${ }^{88} \mathrm{O}$ ultraje moral levantado pela novela é exemplificado pela importância de uma revisão no Berliner Börsen-Courier: "É uma atmosfera doente, corrupta e nebulosa que entrei... Mas tenho a obrigação, através de Musil, de avisar aqueles leitores que não se alegram com o excessivamente estranho, o altamente anormal, o caótico, o intelectualmente perverso, o absolutamente doente e histérico dentro da literatura". CORINO, 1989, p.179. (Tradução nossa.).

${ }^{87}$ MUSIL, ibidem, p. 194-223.

${ }^{89}$ MUSIL, $G W$, v. 3, p. 671-1022; $G W$, v. 1, p. 141-155.
} 
experiências dificilmente representáveis que se aproximam das experiências místicas. Como em Törless, estes momentos extáticos estão situados na interseção do erótico e do ético. Musil vislumbra em alguns trabalhos do naturalismo uma tentativa de se capturar esse tipo de experiência. Em autores como Knut Hamsun e Zola se encontra o artifício da "emoção" peculiar de uma modalidade de sentimento que é direcionada a um "objeto inominado que é representado pela primeira vez" ( $D$, p. 120). A deficiência dos pontos de vista de tais autores reside, segundo Musil, em uma "falta de consciência de seu objetivo verdadeiro" ( $D$, p. 120), isto é, a falta de habilidade de refletir sobre a tentativa de se aventurar por este território afetivo inexplorado. Esta falta de habilidade faz do naturalismo "uma promessa que nunca foi cumprida" $(D$, p. 120).

O naturalismo fornece ainda uma ocasião para se levantar a questão dos meios apropriados para a apresentação dessas experiências na literatura. Após reler, em dezembro de 1910, um ensaio de Alfred Kerr que havia aparecido alguns meses antes na Neue Rundschau, Musil se lembra da importância da narrativa fundamentada na descrição de eventos, em vez de nos humores: "Não se deve pintar o humor, mas permitir a quantia desejada de lirismo aflorar do enquadramento dos fatos" ( $D$, p. 128). Afinal, a virtuosa narrativa que Kerr havia elogiado em Törless estava no lirismo sutil que emanava do tom desapaixonado, factual da narração. Musil parece se perguntar aqui como a injunção de Kerr de se narrar fatos (e não humores) se aplicaria à narração que se configura na atmosfera de suas novelas, nas quais os eventos são refratados ao prisma da consciência das protagonistas. Essa perspectiva audaz de narrativa representa uma radicalização do objetivo perseguido em seu primeiro romance, a saber, de apreender e apresentar "coisas que até então eram inexpressáveis" ( $D$, p. 128).

O objetivo de se aprofundar nos aspectos psicológicos das protagonistas para dar voz ao inexpressável é novamente contrastado com a prática prosaica de alguns naturalistas. O problema com os trabalhos de Ibsen, por exemplo, é que lidam com "coisas que se pode discutir com qualquer pessoa sensata" ( $D$, p. 128). Por que se apegar à literatura, parece perguntar Musil, se os problemas em jogo podem ser 
endereçados dentro de um meio comunicativo que é, para se dizer, mais comum do que a literatura?

- O verdadeiro tecido da experiência ética

Após completar o rascunho da história de Veronica, Musil busca, mais uma vez, definir a substância de sua prática literária ao distanciá-la do naturalismo. Ao refletir sobre o comportamento desconcertante das personagens principais em suas novelas, ele percebe que o que realmente está nos bastidores são "os verdadeiros fatores (éticos, não psicológicos) determinantes da atividade, pois as pessoas de Hauptmann e Ibsen não são determinadas; o que as impele não me impele.” ( $D, \mathrm{p}$. 129). O problema com Hauptmann e Ibsen, portanto, é que deixam de transmitir os motivos mais profundos que justificariam o comportamento de suas personagens. A despeito de uma verossimilhança psicológica superficial que supostamente fundamenta suas ações, o leitor deixa de se identificar empaticamente com estas, isto é, de apreender o ético e não somente os "gatilhos" psicológicos de seus comportamentos. Em jogo está o esforço de decompor a estrutura atômica de estados emocionais e alcançar o verdadeiro tecido da experiência ética.

O confronto de Musil com o naturalismo tem por objetivo definir o desafio principal no cerne do empreendimento literário, a saber, a dificuldade de apresentar a emergência de momentos místicos na experiência ordinária sem se envolver diretamente na evocação de humores preciosos ou estados mentais fantasiosos típicos da décadance. Ao mesmo tempo, a tarefa da literatura, em si, fica mais claramente definida. A literatura aparece como o meio apropriado para apresentar estados mentais quase incomunicáveis localizados na periferia da experiência ordinária. Essas experiências fronteiriças garantem o acesso a alguns gatilhos éticos escondidos do comportamento psicossocial, aqueles gatilhos que a investigação tradicional psicológica deixa de descobrir. 
A promessa não redimida do naturalismo estava, de acordo com Musil, em sua compreensão insuficiente daquelas experiências sombrias que convocava sem intenção deliberada. No início do século XX, novos experimentos literários haviam florescido na interseção da ficção, dos ensaios e da investigação filosófica, dando continuidade ao legado da decadência literária ao investigar, muitas vezes de ecléticas perspectivas disciplinárias àqueles momentos místicos de iluminação que o naturalismo desconsiderava. Uma busca análoga para se alcançar um modo místico de experiência não conceitual levou a alguns dos experimentos avant-garde mais inovadores dentro da cultura alemã em Munique, que, sob a liderança de Wassily Kandinsky, conceituou a arte como o meio moderno que dá acesso único ao mundo sobrenatural, espiritual, presumivelmente obstruído por um mundo material. ${ }^{90}$

Algumas críticas de livros de 1913 documentam o engajamento de Musil com esse horizonte estético, colorido por vagos humores neo-românticos, culturalmente pessimistas. Ao responder aos trabalhos de Margarete Susmann, Hetta Mayr, Hermann Bahr e Walther Rathenau, Musil se acha compelido a deplorar a auréola equivocada de metafísica engolfada pelas investigações desses autores quanto às experiências místicas fronteiriças. Um exemplo paradigmático é o Inventur (Inventário) de Hermann Bahr, uma coleção de ensaios que apareceu em 1912, que Musil criticou no ano seguinte. ${ }^{91}$

O que chama a atenção de Musil é o esforço de Bahr para definir o conhecimento estético em termos de um tipo de verdade; uma observação que Bahr toma emprestada de Goethe, uma lenda viva, um ícone cultural daquele período. Sem colocar a questão sobre a diferença entre o conhecimento estético e outras práticas de conhecimento, aponta Musil, Bahr procede a generalizar essa observação e a lançar dúvida sobre a possibilidade de todo conhecimento, o que resulta em uma grande rearticulação previsível do ceticismo epistemológico. A saída para o niilismo é então encontrada em uma noção de religião, nas próprias palavras de Bahr, possuída por aqueles "que através dos sentimentos tomam consciência de uma

\footnotetext{
${ }^{90}$ KANDINSKY, 1989, p. 65-71; 147-87.

${ }^{91} G W$, v. 9. Essaybücher (Setembro, 1913), p. 1450-57.
} 
certeza maior da vida do que pode transmitir o intelecto, e que estão imediatamente seguros do caminho certo mesmo sem provas". (GW, v. 9, p.1452).

A certeza interior desse sentimento religioso secularizado se empresta para dar suporte ao ideal de uma "bondade combativa" intuitiva que, como salienta Musil, forma o cerne de um programa vitalista enovelado, despido de qualquer convicção intelectual. Contudo, a consistência dos escritos de Bahr não será encontrada no nível da argumentação lógica; reside, na verdade, no teor geral de seus argumentos: "Este livro coloca uma leve ênfase em todas as coisas ilógicas e calmamente deprecia tudo que tem a ver com o intelecto" ( $G W$, v. 9, p. 1453). A fascinação discreta com o irracional e a hostilidade de baixo nível para com a razão, acredita Musil, são indicações de uma atitude geral entre os intelectuais e artistas contemporâneos, que surge de sua inabilidade para chegar a termos como a "paixão intelectual" que guia as ciências exatas no presente. O problema de trabalhos como o de Bahr é que deixam de desenvolver uma abordagem liberal, inovadora para com a investigação de experiências fronteiriças e, ao contrário, eles as descartam, recorrendo à metafísica pobremente disfarçada. Por essa razão, pouco têm a oferecer, além das lastimáveis narrativas religiosas lançadas dentro de um anteparo conceitual frouxo. Mas ainda mais prejudicial é a polêmica contra a razão que implícita ou explicitamente guia a argumentação de tais autores. O desentendimento básico, que equaliza a emergência de experiências místicas com os trabalhos de um domínio puro, irracional, é presumivelmente subjugado pela razão.

Uma das discussões mais extensivas dessa posição intelectual é encontrada nos panfletos de cultura pessimista de Walther Rathenau, o proeminente ensaísta e magnata da indústria elétrica que alçou à posição de ministro do exterior nos primeiros anos de Républica Weimar e foi assassinado no ataque terrorista de direita em 1922. O fato de Rathenau constar entre um dos mais populares autores da editora de Samuel Fischer não impediu a publicação, em 1914, da crítica polêmica de Musil dirgida ao trabalho sob influência de Rathenau, Zur Mechanik des Geiste oder Von 
Reich der Seele (Sobre a Mecânica do Espírito ou Referente ao Domínio da Alma) (Tradução nossa.), que apareceu um ano antes. ${ }^{92}$

O panfleto de Rathenau desdobra uma investigação pseudofilosófica da vida espiritual teoricamente ameaçada do indivíduo moderno. Em um estilo messiânico e evocativo, Rathenau tece temas familiares do pessimismo cultural, particularmente a crítica a aspectos do caráter desalmado produzido pela intelectualização e mecanização da modernidade e um apelo para a preservação dos domínios teoricamente ameaçados da intuição, da alma e da transcendência. Musil reconhece a importância da investigação de Rathenau do "espírito" e da "alma" modernos, conceitos fundados na experiência de uma condição mística intermitente próxima do ético e sobre a qual muito pouco é sabido. Um defeito fundamental vicia o empreendimento de Rathenau, a saber, seu objetivo aparente de tornar a condição mística uma base para o sistema filosófico ( $P S$, p. 56). Como observa Musil, enquanto Rathenau reivindica para sua investigação um ponto de vista relativamente não contaminado pelo mecanismo que disseca a razão, ele deixa de ver que essa reivindicação é proferida dentro da mesma racionalidade discursiva a qual supostamente desautoriza. O resultado inevitável de uma abordagem tão irrefletida é uma falsa sistemática baseada em conceitos destilados por experiências narrativas racionalizantes camufladas. $\mathrm{O}$ gesto não reconhecido generalizante dessas narrativas inevitavelmente deixa de fazer justiça às experiências singulares que propõe apreender.

Musil acha pouco surpreendente que a investigação de Rathenau termine por fornecer pouco mais que um previsível "programa do tipo humano" ( $P S$, p. 54) baseado em um script moral idealizado - riqueza da alma, do amor, da intuição, da generosidade, da fé - ao arrepio da complexidade e da ambivalência da experiência vivida. Termina por reforçar uma crítica da civilização moderna que afasta a observação factual e, no lugar, recicla vários clichês da época:

\footnotetext{
${ }^{92} \mathrm{O}$ artigo de Musil é intitulado Commentary on a Metaphychics (PS, p. 54-58). Musil tornou Rathenau conhecido poucos meses antes, aparentemente em um sarau organizado por Franz Blei. Ver: $T B$, v. 1, p. 295; veja também a nota de rodapé 125 com uma nota de Martha Musil em TB, v. 2, p. 173.
} 
a despeito de toda a modernidade, o mundo está aqui novamente sendo dilacerado entre o céu e o inferno, quando está entre ambos, formado por um tipo de mistura; e é precisamente de tal mistura (que ainda precisa de um pouco mais de estudo) do bem e do mal, do doente e do sadio, do egoísta e do generoso, que as questões da terra florescem. (PS, p.55)

Os argumentos de Rathenau vêm simbolizar para Musil a incapacidade intelectual abrangente para confrontar a realidade, reduzindo sua complexidade a uma horda de dicotomias cuidadosamente delineadas, tais como mente/sentimento, racional/não racional, socialismo/capitalismo, comunidade/sociedade, cultura/civilização.

- A profecia sobre o fim utópico das diferenças

Musil leva em consideração não tanto as dicotomias em si quanto a prática de se brandir algo como incondicional e inequivocamente mal, ou, alternativamente, de avançar a profecia sobre o fim utópico das diferenças, uma superação paradisíaca de oposições. Aos olhos de Musil, ambas as estratégias simplificam indevidamente as relações complexas de esferas diferentes da experiência, resultando em uma visão maniqueísta do mundo, mais adequada a escolher bodes expiatórios para se livrar de quaisquer culpas do que se defrontar produtivamente a consciência com a realidade social, econômica e política intricada.

Além de ser um dos literatos alemães mais visíveis dos anos por volta de 1910, Rathenau era um industrial poderoso com acesso a círculos políticos influentes. A crítica polêmica de Musil foi sem dúvida um passo ousado para um autor comparativamente pouco conhecido. ${ }^{93}$ No entanto, sua crítica não constitui um ataque ad hominem em benefício próprio com fins à publicidade fácil. Os ensaios de Musil dos primeiros anos por volta de 1910 desenvolvem uma crítica abrangente do clima intelectual que ele encontrou exemplificado em Rathenau. Dentro de tal

\footnotetext{
${ }^{93}$ Corino declara que Rathenau reagiu amargamente às críticas de Musil. CORINO, 1989, p. 212. (Tradução nossa.).
} 
aparato, o industrial aparece como um representante emblemático dos infindáveis "literatos que se tornaram hostis à análise e se lisonjeiam com sínteses" ( $G W$, p. 8, 1008); isto é, de uma tendência ampla de evitar análises intelectuais laboriosas em troca de sínteses glamourosas.

Musil traçou a atitude de retorno ao "desejo por simplificação da literatura e da vida, por um clima homérico ou religioso, por unidade e integridade" ( $G W$, p.8, 1009) - em outras palavras, retorno a uma vontade ingênua de soluções simples, retrógradas, para os problemas intratáveis do presente. Para ele, esse preconceito antiintelectual, anticientífico, antimoderno do pessimismo cultural incorporado por Rathenau surgiu de uma crítica à razão que tomou seu partido, ao menos em parte, devido aos dilemas do capitalismo tardio. Em questão estava a posição intelectual determinada a culpar os problemas das sociedades modernas na "racionalidade da sociedade de classe média" ( $P S$, p. 22$)$, um tipo instrumental de razão que toma o sucesso econômico como critério não declarado da verdade.

O trabalho de Rathenau então exemplifica os perigos dessa atitude intelectual para utilizar o artifício de suas experiências místicas insuficientemente compreendidas como fundação para uma falsa transcendência baseada na esfera não racional idealizada. Ao mesmo tempo em que tal discurso urge pela liberação de uma alegada racionalidade opressiva, ele toma partido do conhecimento obtido pela intuição nebulosa apresentada como panacéia para todos os problemas de uma sociedade fraca e doentia.

- A razão é meramente uma convenção histórica

Para Musil, uma análise mais próxima a tal campo de experiências demonstraria como o sentimento e a intuição, longe de constituir a base de um conhecimento distinto, representam componente indispensável de toda a cognição, 
incluindo o chamado conhecimento científico, racional - sendo a ênfase exclusiva no intelecto em processos cognitivos uma mera convenção histórica:

Mas não há conhecimento emocional ou outro segundo tipo de conhecimento que possa existir em oposição à ciência... Há somente um conhecimento, mas se estimar na reunião de conhecimentos somente as realizações da razão é meramente uma convenção histórica. (PS, p. 23)

Musil acreditava que a precisão científica poderia fornecer um antídoto para esse tipo de transfiguração metafísica do poeta e do processo artístico em virtude de sua ênfase na observação fática e no compromisso de atestar continuamente seus limites epistemológicos auto-impostos. Tal posição inclui a restrição do pensamento científico ao domínio da ciência predominante como o resultado de um processo histórico que não respondia a nenhuma necessidade fática. Da mesma maneira, um desenvolvimento centenário havia confinado o pensamento exato a um domínio circunscrito de fenômenos que, em virtude de sua interação, mensurabilidade e previsibilidade, permitiam a generalização e a sistematização, e então se emprestaram a aplicações tecnológicas e retornos econômicos.

Tal desenvolvimento histórico alimentou o mito de que o pensamento rigoroso não podia ser estendido à outra esfera principal da existência humana, a saber, o domínio de fenômenos singulares. O objetivo de Musil era virar essa situação de ponta cabeça: "A razão científica, com sua consciência dura, sua falta de preconceito e sua determinação de questionar todo resultado que possa levar à mínima vantagem intelectual, faz na área do interesse secundário o que deveríamos fazer com as questões básicas da vida." (PS, p. 34).

Em sua tentativa de se posicionar fora do lugar comum, endereçando a questão da relação entre a mente e os sentimentos, o racional e o não-racional, Musil se viu compelido a tirar seu foco das vantagens ou ameaças presumidas apresentadas por faculdades humanas específicas como razão ou intuição, para, de fato, afastar-se totalmente de um anteparo conceitual centrado em um sujeito. 
Ele presumiu que a existência humana se desdobra dentro de dois domínios distintos de experiência definidos pela natureza de seus respectivos fenômenos, que ele desastradamente chamou de "racióide" e "não-racióide" (ratioïdes e nichtratioïdes Gebiet) em uma tentativa de evitar binários mais familiares e equivocados. O "racióide", o domínio próprio à ciência e ao conhecimento, engloba aqueles fenômenos iterativos, passíveis de mensuração e verificação. Esses fenômenos permitem a sistematização para a elaboração de leis e princípios que se emprestam à articulação de "uma ordem espiritual de longo alcance" (PS, p. 48) que torna possível o domínio sobre a natureza. Se o foco sobre fenômenos regulares e verificáveis no "racióide" torna possível criar a ilusão de coordenadas estáveis e pontos firmes de referência no domínio das "regras com exceções" ( $P S$, p.63), essa ilusão se torna impossível na esfera do "não-racióide" que compreende a "outra metade" da existência humana, a saber, julgamentos e valores, idéias e ideais, experiências éticas e estéticas:

\footnotetext{
Nesta região os fatos não se submetem, as leis são peneiras, eventos não se repetem, mas são infinitamente variáveis e individuais. Não há melhor maneira de caracterizar esta região do que apontar que ela é uma área da reatividade do indivíduo ao mundo e a outros indivíduos, a esfera de valores e avaliações, de relacionamentos estéticos e éticos, a esfera da idéia. ( $P S$, p. 63)
}

Os fatos singulares do "não-racióide" - aqueles fatos relacionados aos julgamentos éticos e estéticos, por exemplo - não permitem a abstração e a sistematização, mas extraem seu significado exclusivamente da situação em que estão incrustados. Conseqüentemente, o "não-racióide" é definido por uma fundamental "dominância de exceções sobre a regra" (PS, p. 63). Musil se recusa a definir qualquer dos domínios em termos de alguma faculdade específica, tais como: o intelecto domina o "racióide", o sentimento governa o "não-racióide". Em vez disso, ele enfatiza a natureza dos fenômenos que compõem os dois domínios e que demandam modos específicos de observação. Alguns fenômenos são facilmente apreendidos por meio dos critérios da cognição racional, a saber, estabelecer regularidades, extrair conclusões gerais, ordenar e antecipar a experiência por meio da abstração e da sistematização. Para outros, esses critérios de observação não rendem tanto. Os últimos fenômenos formam a esfera "não-racióide". 
A caracterização de Musil da ética como englobando uma esfera de experiência singular constituiu sua declaração de guerra à taxonomia de leis e diretrizes que moldavam o pensamento contemporâneo sobre moralidade. Era bastante irônico, pensava Musil, que uma época determinada a professar sua aversão descomprometedora à razão e à ciência endossaria um sistema moral controlado pelas mesmas estratégias generalizantes e categorizantes próprias da esfera do "racióide".

O primeiro ensaio publicado de Musil focava as mesmas questões ao endereçar a relação da arte com a moralidade. O texto, publicado no periódico cultural de Berlim Pan, em março de 1911, representava sua resposta a um caso notório de censura envolvendo o próprio periódico. ${ }^{94} \mathrm{O}$ cerne desse caso era a admissibilidade da "arte obscena e doentia" como está no título do ensaio certamente uma questão vital para um autor cujo primeiro romance havia sido criticado por chafurdar na retratação da depravação humana. Musil fez ouvir seu protesto contra o objetivo que ele situava no centro da decisão do censor, a saber, domar e controlar a prática estética, reduzindo-a a um exercício didático centrado na descrição de casos morais edificantes. Neste primeiro ensaio, Musil se prende a argumentos que reavivaram a velha polêmica sobre a moralidade da arte na estética neoclássica no século XVIII. Ele dirige um alerta contra a fusão da imoralidade de um evento, com um objeto estético que o representa, explicitando a viabilidade da demanda de se apresentar situações morais sadias sem que nunca se toque em seus aspectos insalubres.

Dois fragmentos de ensaios não publicados do mesmo período levam esta reflexão ainda mais longe ao focarem nas inconsistências do pensamento corrente sobre a moralidade. ${ }^{95}$ Ambos exploram a incongruência do pensamento moral que se

\footnotetext{
${ }^{94} \mathrm{O}$ chefe de polícia de Berlim, Traugott von Jagow, confiscou um controverso artigo de Pan, o jornal bimestral publicado por Wilhelm Herzog e Paul Cassirer em 1910, que continha trechos de novos diários publicados, escritos por Gustave Flaubert durante suas viagens à Itália e ao Egito. A censura continua por causa de conteúdos sexuais explícitos nos trechos de Flaubert. Traugott ainda proibiu o artigo de Pan devido à recusa dos editores de se absterem de publicar novos trechos do diário confiscado. Veja os comentários de FRISÉ em $G W$, v. 9, p.1803-4.

${ }_{95}$ MUSIL, GW, v. 8, p. 1305-1311. Die gesuchte Moral (1910/11?) (Moralidade pretendida); Quantificierbarkeit der Moral. Die Moral des Dichters. [1910/11?] (Quantificação da moralidade. A moral dos escritores. (A tradução dos títulos é nossa.)
} 
considera uma "ciência da experiência" (alem. Erfahrungswissenschaft), mas opera com critérios e princípios que são, no máximo, ficções idealizadas. Estes são subproduto da compulsão de se reduzir o comportamento humano a variáveis quantificáveis e categorizáveis de forma a fazê-las encaixar em uma taxonomia de leis e diretrizes controláveis. As leis comportamentais e morais resultantes, autorizadas em parte por um entendimento mal-concebido de rigor psicológico científico, são então formuladas para suportar o entendimento antigo da moralidade como predicado da correlação entre dever e felicidade ( $G W$, v.8, p.1306).

A ironia dessa abordagem, insinua Musil, é seu empiricismo perpetrado porque se as ciências morais fossem realmente praticar a precisão empírica que pregam, veriam seu palanque de preceitos e regras ruir:

Uma vez colocada no terreno dos fatos... a ciência moral deveria reconhecer que leis não são tão fáceis de se apreender - o que é lei em um domínio se torna ausência de lei em outro... e o que é lei em um dado domínio é atingido por contradições mesmo neste. Pode-se pensar na simples proibição de se matar com suas exceções de jurisdição legal, para o duelista, o guerreiro - com suas restrições para os inferiores, os intoxicados, os doentes, que não obstante poderiam enovelar a esfera da norma. ${ }^{96}$

Como regra, tem-se esperado que a experiência ética se conforme ao sistema de diretrizes abstratas e leis universais, nivelada por uma lógica rígida de oposições: bom/mau, justo/injusto, desejável/indesejável. Contudo, a reivindicação absoluta que as leis morais colocam em cima do comportamento humano irá inevitavelmente de encontro à complexidade e à ambivalência da experiência concreta. Mesmo o menos controverso dos preceitos morais - tal como a injunção "Não matarás" - requer um leque confuso de isenções ou exceções para funcionar na vida cotidiana, por exemplo, para permitir aquelas práticas autorizadas no interesse do estado, como matanças de guerra ou a pena de morte.

De acordo com Musil, o problema reside nos anteparos legais dos costumes ocidentais, que permanece fundamentado em uma noção pseudo-objetiva de lei que

\footnotetext{
${ }^{96}$ MUSIL, $G W$, v. 8, p. 1305.
} 
pode somente endereçar o feito, mas não se responsabilizar pelo executor. Esse anteparo se mostra inadequado para confrontar a questão incontornável da responsabilidade individual. No caso da proibição de assassinato, torna-se difícil atribuir responsabilidade pessoal pelas mortes cometidas devido à insanidade, ou em um ato de fúria, ou sob intoxicação.

- O mal e o bem não são ficções simplistas

A primeira formulação de Musil sobre um pensamento mais frutífero a respeito da moralidade é encontrada em um breve ensaio que apareceu no Der Lose Vogel em 1913 e trata do caráter infrutífero da moral. ${ }^{97} \mathrm{O}$ texto começa com uma discussão que parece divertida sobre duas pedras fundamentais conceituais das ciências morais empíricas, a saber, as noções opostas de altruísmo e egoísmo. Estas acabam por se revelarem pouco mais que ficções simplistas implementadas pelo filósofo moral no interesse de uma ordenação pragmática da existência porque, como argumenta Musil, nossa experiência concreta de altruísmo e egoísmo, ou, quanto a esse assunto, do bem e do mal, parece ser mais intricada do que qualquer dessas abstrações:

\begin{abstract}
o mal não é o oposto do bem, ou sua ausência; o mal e o bem são fenômenos paralelos. Não são antíteses morais fundamentais ou definitivas (...), mas sim resultados de processos práticos e impuros. A oposição diametral entre o bem e o mal corresponde a um estágio prévio de pensamento que esperava tudo desta dicotomia; de qualquer forma, esta oposição não é muito científica. (PS, p. 38)
\end{abstract}

Como sugere essa passagem, o bem e o mal não são opostos bem definidos, mas sim ocorrências emaranhadas. As categorias abstratas usadas normalmente para os denotarem são pouco mais que sumários imperfeitos, uma vez que deixam de transmitir as complexas conexões que as tornam complementares no lugar de opostos irreconciliáveis. No entanto, Musil não está aqui falando em nome do

${ }^{97}$ MUSIL, $P S$, 1994, p. 37-39. Moral Fruitfulness. 
vitalismo amoral de derivação nietzschiana. O objetivo não é negar a possibilidade de se distinguir entre o bem e o mal, mas sim enfatizar a necessidade de se superar um hábito dicotomizante de pensamento, determinado a implementar abstrações, que podem parecer sedutoras em sua retidão, mas que não têm utilidade alguma para a contabilização da complexidade da experiência vivida. A dificuldade reside no fato de que a experiência central da moralidade tem, em seu cerne, um estado mental quase incomunicável; de acordo com Musil:

a moralidade começa, na verdade, somente na solidão que separa cada pessoa de outra. Aquilo que é incomunicável, o encapsulamento no ser, é o que torna as pessoas boas e más. Bem e mal, dever e violação do dever são formas pelas quais um indivíduo estabelece seu equilíbrio emocional entre si e o mundo. O que é mais importante é não somente estabelecer uma tipologia dessas formas, mas sim compreender a pressão que as cria ou a agonia em que estão, e estas são infinitamente variáveis. $\mathrm{O}$ ato é somente uma linguagem vacilante para expressar se estamos lidando com um herói, um santo, ou um criminoso. Mesmo um assassino sexual é, em algum recanto de sua alma, cheio de dor interior e apelos escondidos... (PS, p. 39) (Grifo e tradução nossos.)

Os gatilhos éticos da conduta humana têm pouco a ver com os princípios morais abstraídos do comportamento, pois se originam em um estado mental quase solipsistas. O bem e o mal, a observância ou a violação de normas éticas são meios pelos quais os humanos respondem a esta condição, ao estabelecer um equilíbrio afetivo entre eles e o mundo. Mesmo os atos hediondos de um assassino sexual compulsivo podem ser traçados de volta a um emaranhado intricado de motivos, respostas afetivas e influências ambientais que devem ser considerados com cuidado em sua configuração absolutamente singular. A evocação aparentemente simpática de Musil, no final do ensaio, dos problemas do assassino sexual que encontra em atos repugnantes o único meio disponível de estabelecer uma relação com o mundo, deixará muitos dos leitores de hoje tão desconcertados quanto deve ter deixado os próprios contemporâneos de Musil. É de se imaginar por que, para firmar seu ponto sobre a ética, Musil escolheu um dos perfis criminosos mais repulsivos. 
- Criminosos no poder

O exemplo que Musil escolhe para ilustrar o que antevia para os próximos milênios - uma era de criminosos no $\operatorname{poder}^{98}$ — traz de volta a hipótese, explorada em Törless, de acordo com a qual a sensualidade ocupa um território emocional de algum modo próximo ao território da ética. Eis então que o comportamento desviado do assassino sexual pode revelar discernimentos a respeito daquelas alavancas do comportamento ético que passam despercebidas na experiência ordinária. Casos extremos de comportamento criminoso - Musil se esforça para evitar o termo "imoral" - podem fornecer um campo de testes ideal para sua presunção de que a ética pouco tem a ver com construções metafísicas confiáveis como o livre arbítrio e é, pelo contrário, consignada a momentos cegos de iluminação. Em outras palavras, o foco reside na tentativa de desagrupar noções convencionais de moralidade de forma a perseguir uma intuição do que a experiência ética pode realmente ser. ${ }^{99}$

A discussão iconoclasta de Musil sobre a moralidade no ensaio "The Mathematical Man"100 deve ser vista como uma tentativa de implementar o programa "matemático" delineado com fins a estender o pensamento rigoroso da ciência àqueles domínios que residem fora deste, mais notadamente a ética. $\mathrm{O}$ pensamento exato permite ao observador reconhecer que a ciência e o conhecimento estão incrustados no domínio da certeza relativa, em que questões de valor, sentido, interpretação da experiência caem no domínio da exclusividade e incomensurabilidade e, portanto, não permitem resultados certos e inequívocos. $\mathrm{O}$ debate de Musil expõe à crítica que aplicar o rigor e a precisão do pensamento científico à esfera da ética implica buscar estabelecer regularidades e regras para a conduta moral. Tal busca envolve reconhecer o caráter singular e contingente dos eventos éticos, bem como tentar se responsabilizar por estes sem apagar quaisquer

\footnotetext{
${ }^{98}$ MUSIL, GW, v. 3, p. 671-1022; HSQ. Rumo ao reino dos mil anos [Os criminosos]. HSQ. Livro Segundo, Terceira Parte, p. 705-1097.

${ }^{99}$ Ver o retrato do personagem de Moosbrugger em MUSIL, HSQ. cap.18, p.87-96. Moosbrugger é um assassino sexual compulsivo. Misógino, sua personalidade demente é, na psicopatia, o produto de uma explosiva mistura de abuso às leis e dissolução do eu.

${ }^{100}$ MUSIL, PS, p. 39-43.
} 
singularidades. Musil posicionou, de forma frutífera, a noção de função desenvolvida dentro da matemática e física moderna como pedra fundamental do pensamento ético inovador, que supera a rigidez de categorias morais absolutas:

O bem aparece não como uma constante, mas como uma função variável. Somente o embotamento intelectual tem nos mantido longe de encontrar a expressão lógica para esta função, que satisfaz nossa necessidade pelo inequívoco sem suprimir as multifacetas dos dados. É improvável o colapso da moralidade por causa disso como também é improvável que a matemática pereça por se ter um mesmo número como o quadrado de dois números diferentes. $(P S, \text { p.114 })^{101}$

Em sua dissertação, Musil havia analisado a apropriação por Ernst Mach do conceito de função para o domínio da psicologia, que tornou possível descrever os processos mentais como uma rede de correlações potencialmente infinitas entre elementos e forças díspares. Musil utiliza tal conceito para identificar regularidades e correspondências em tais relações como dados puros de observação, isto é, sem extrair da ficção explanações casuais e leis que são regidas pela noção de necessidade. Quando aplicada à esfera da moralidade, o conceito de função apropriadamente se adianta à dependência do contexto, da complexidade e da ambigüidade potencial da experiência ética. É certo que esta perspectiva joga por terra o sonho da moralidade como um sistema de princípios gerais. Não previne ou absolve do julgamento ético, mas, ao contrário, clama por um reexame da ética que trata a ambivalência, a multiplicidade e a contingência como condições inevitáveis das escolhas morais. ${ }^{102}$

\footnotetext{
${ }^{101}$ Tal passagem refere-se ao comentário de Musil quando se reporta ao texto de Kassner (1905), Die Moral der Musik (TB, v. 1, p. 481). Kassner parece ter provido um golpe para a reflexão de Musil sobre a moralidade neste artigo. A referência de Musil para a articulação de Kassner entre a arte e a moralidade encontra-se em uma passagem escrita em torno de 1921-23 (TB, v.1, p. 660).

${ }^{102}$ Para a discussão de Musil sobre a noção de função de Mach, veja as últimas duas partes (quatro e cinco) na sua dissertação sobre Mach, On Mach's Theorie, 1985, p. 44-80.
} 
- "O objeto da psicologia é o caso geral. O objeto da literatura, o caso pessoal".

Foi precisamente o desejo de reconhecer a singularidade da experiência ética que levou Musil, um psicólogo treinado, a se distanciar da psicologia, certamente uma das disciplinas régias listada pelas ciências empíricas morais: "O objeto da psicol[ogia] é o caso geral. O objeto da literatura, o caso pessoal." (PS, p. 46). O problema com a psicologia, mesmo com seus novos ramos experimentais, é que mesmo quando persegue um empiricismo descritivo rigoroso, ela permanece governada pela compulsão à generalização e à sistematização de discursos científicos estabelecidos. ${ }^{103}$ Por essa razão, "A psicologia pertence à área "racióide", e a multiplicidade de seus fatos não é de forma alguma infinita... $O$ que é incalculavelmente múltiplo é somente o funcionamento da alma, e com isso a psicologia não tem nada a ver" ( $P S$, p. 64).

Se a psicologia visa à apresentação de casos gerais sob os quais se incluem instâncias individuais dentro da moldura de relações casuais, o objetivo da literatura é delinear constelações singulares de significado, apresentar motivos individuais que possam ser empaticamente transmitidos ao se estabelecer uma ligação emocional com o leitor. A literatura então aparece como o domínio adequado para a investigação dessas ocorrências singulares que compõem a experiência ética. Mas se o literário aparece como um domínio fronteiriço de premonições, ambigüidades e singularidades que não podem ser apreendidas pelo procedimento sistemático e racional próprio da psicologia, o papel que o intelecto desempenha nesta investigação permanece, mesmo assim, crucial.

Uma das declarações mais incisivas de Musil sobre o papel desempenhado pelo intelecto dentro do literário é encontrada em um ensaio de 1913, "On Robert

\footnotetext{
${ }^{103}$ Sobre a relação entre a literatura e psicologia, veja os dois rascunhos do Profile of a Program, um artigo de 1912, (PS, p. 10-17). (Tradução nossa.)
} 
Musil's Books" ${ }^{104}$, que contém uma resposta afiada aos ataques efetuados contra $O$ jovem Törless e Vereinigung. Zwei Erzählungen (Uniões, duas narrativas). O ensaio tem a forma de diálogo sobre os méritos da ficção moderna que envolve um "geólogo literário" (um amálgama pomposo de crítico e acadêmico), um escritor de costumes, presumivelmente com emoções sadias, e o próprio Musil. O lugar dessa conversa é o espaço cavernoso do próprio cérebro de Musil, retratado como uma paisagem lunar surreal. Enquanto o escritor se joga em uma crítica aos trabalhos de Musil, que revisita satiricamente algumas das acusações lançadas por críticos como Schaffner, a personagem de Musil tenta pôr as coisas em pratos limpos, oferecendo um conceito mais inovador de narrativa do que o conceito puído, endossado por seus interlocutores. Como ele nota, em tempos remotos, o propósito da ficção pode ter sido o de recontar as experiências poderosas para neutralizar sua mágica. Desde o surgimento do romance, contudo, um novo desenvolvimento se instalou e requer:

a descrição da realidade finalmente se torna uma ferramenta subserviente da pessoa que é conceitualmente forte, que a usa para esgueirar-se sobre o reconhecimento de sentimentos e sublevações do pensamento. Estes não devem ser apreendidos no abstrato e em conceitos, mas somente - talvez - no pestanejar do caso individual. Não podem ser englobados na pessoa de classe média orientada para negócios, mas por unidades menos consolidadas que a transcendem. (PS, p. 27)

Na contemporaneidade, é a pessoa "conceitual" que se beneficia do potencial abrigado pela ficção para explorar discernimentos emocionais e comoções intelectuais que não podem ser apreendidos por meio da estrutura generalizante do pensamento conceitual. A arte consegue fazer isso, contrapõe a personagem de Musil, em virtude de seu status "como algo entre o conceitual e o concreto" (PS, p. 27), isto é, um híbrido entre o conceitual/geral/abstrato e o concreto/singular. Esta posição intermediária da arte é, por sua vez, refletida na habilidade do poeta de articular sentimento com o intelecto: "O que o escritor cria por meio de grandes sentimentos é uma interpenetração de sentimento e compreensão.” (PS, p. 29). Determinado a suplantar o lugar-comum do entendimento de arte como uma esfera de sentimento puro, o personagem de Musil mantém firmemente que o sentimento

${ }^{104}$ MUSIL, PS, p. 25-31. 
por si só é impessoal e não diferenciado. Isso o leva a ressaltar o componente intelectual essencial da arte: "Os elementos decisivos [de um trabalho de arte...] são - a despeito de um preconceito confortável por parte do escritor - idéias" ( $P S$, p. 29). O local caprichoso dessa conversa, o próprio cérebro pulsante e barulhento de Musil, corrobora ainda mais essa observação, ao apresentar alegoricamente a conversa imaginada como uma ficção que somente poderia ser tecida dentro do espaço "intelectual” do cérebro de Musil.

Ao enfatizar o estético como a esfera do singular, Musil se coloca dentro da tradição que na cultura alemã se estende do Sturm und Drang ao ora decadente, ora ascético modernismo do início do século XX mediante o experimento romântico. Essa tradição segue a caracterização de Kant do estético como uma experiência incapaz de se submeter a conceitos, isto é, não concebível inteiramente em termos de cognição racional. Contudo, Musil não compartilha de um dos corolários mais significantes dessa tradição, a saber, a crença de que a arte é também a esfera de um conhecimento alternativo baseado na premência de sentimento e intuição.

Em questão está o entendimento neo-romântico do dom distintivo do poeta como consignado a um "conhecimento intuitivo" presumido que fundamenta uma personalidade "excepcional". Como nota Musil em um ensaio de 1918, que assume a tarefa de descrever a modalidade cognitiva do escritor, "na verdade, o escritor é um forasteiro. Ele é a pessoa que presta atenção a exceções: [Ele] não é nem 'louco' nem 'visionário' nem 'a criança' ou qualquer outra deformação da razão, nem aplica qualquer tipo diferente de capacidade de percepção que a pessoa racional” ( $P S, \mathrm{p}$. 64). Longe de confiar em faculdades diferentes daquelas do indivíduo "racional", o escritor opera em um domínio que é governado parcialmente por uma lógica diferente daquela que caracteriza fenômenos repetitivos e verificáveis. Conseqüentemente, sua missão é ditada por uma natureza singular de experiências sob investigação e não por dom poético ou por inclinação. Em vez de reivindicar para si algum conhecimento fantástico, intuitivo, o escritor é chamado a cultivar um tipo de pensamento cuja qualidade "sentimental" aponta para uma inter-relação peculiar entre intelecto e sentimento. 
Esse modo de pensar é especificado pela articulação distintiva de Musil de ensaísmo, que constitui para ele um meio de atingir "a forma mais severa atingível em uma área onde não se pode trabalhar com precisão" (PS, p. 48). Em um fragmento de ensaio muito citado de 1914, Musil o apresenta tanto como um modo de escrita quanto como uma atitude intelectual que habita o espaço entre a ciência e a arte, esferas "racióides" e "não-racióides". Como na ciência, tais aspectos permitem estabelecer conexões entre fatos e objetos; contudo, os fatos com que opera não são geralmente observáveis, e as conexões que estabelecem são absolutamente singulares. A marca de um ensaio, como posto sucintamente por Musil em uma crítica de uma coleção de ensaios de 1913, é:

\begin{abstract}
que esta substância interior é dificilmente traduzível para pensamento conceitual como um poema para linguagem de prosa... Seus pensamentos estão ligados intrinsecamente a um terreno feito de sentimento, vontade, experiências pessoais e conexões que recebem e refletem luz somente na atmosfera mental de uma situação interior única. Não fazem reivindicações à universalidade... São instantâneos de situações que somente podem ser apreendidas por instantâneos. Respondem a uma lógica mais flexível, mas não menos severa. ( $G W$, v. 9 , p. 1450)
\end{abstract}

O ensaio aparece aqui como o meio que estende a precisão da ciência à esfera da experiência humana singular, permitindo ao leitor apreender o emaranhado de respostas pessoais, idéias e sentimentos que pertencem a situações não repetíveis. Apesar da imagem do mundo que apresenta não poder reivindicar validade geral, é, não obstante, formada por uma lógica severa. Contudo, essa lógica atende a uma categoria de experiências que podem ser capturadas somente por instantâneos singulares. Musil encontrou no crítico literário dissidente e amigo Franz Blei o modelo de um ensaísta que podia executar com maior sucesso "a articulação do sentimento pelo intelecto" que para ele estava no verdadeiro cerne do ensaísmo e dos empreendimentos literários em geral ( $G W$, v.8, p. 1024).

É significante que o dom mais notável que Musil elogiava em seu amigo é justamente o que outros contemporâneos julgavam como o maior de seus defeitos, a saber, sua "alternância de pontos de vista" multiforme e sua impaciência intelectual. Longe de apontar para a superficialidade e o capricho intelectual, como acusavam os 
críticos de Blei, essas qualidades incorporavam para Musil o movimento perspectivo e a abertura fundamental do pensamento ensaísta, preenchendo o critério de exame da experiência perseguida do ponto de vista de sua singularidade irreduzível e inexaustão exuberante. Como uma modalidade de pensamento singular, fluída, mas rigorosa, o ensaísmo extrai do relativismo saudável da ciência o livre significado de objetificação, desse modo liberando as imagens estabelecidas do mundo de sua fixação semântica e engessamento moral. Fornece, então, o terreno intelectual onde se tocam a arte e a ética: "Para mim, ética e estética estão associadas com a palavra ensaio" (PS, p. 48). Dentro deste horizonte ensaístico, a tarefa da literatura se configura como uma investigação da experiência que não se rende à compulsão do inequívoco, mas oferece uma interpretação que respeita as constelações infinitas, particulares dos fatos e motivos díspares que sustentam as ações humanas. Contudo, em jogo está mais que uma hermenêutica retrospectiva da vida, mais do que a demanda de se fazer sentido do que aconteceu.

O programa estético engendrado pelo ensaísmo consiste em uma permuta experimental dos elementos da experiência que compõem uma lógica combinatória preconcebida: "dissolver almas em seus elementos e a permuta ilimitada desses elementos; aqui tudo está relacionado com tudo o mais e pode ser construído a partir desses elementos" (PS, p. 13). A tarefa do escritor implica descobrir "sempre novas soluções, conexões, constelações, variáveis, para montar protótipos de uma ordem de eventos, modelos atraentes de como se pode ser humano, de inventar o ser interior." (PS, p. 64). O objetivo final é desenvolver alternativas viáveis e desejáveis para a forma como são as coisas enquanto procedentes de um exame franco do concedido, por meio de um procedimento experimental que libera um "pensamento ético mais livre" (PS, p. 13).

Como qualquer cientista, o escritor se dedica à investigação rigorosa dos fatos, em uma busca cognitiva que envolve tanto intelecto quanto sentimento, mente e intuição. Onde o cientista é capaz de atingir o que parece ser conhecimento firme, devido ao caráter peculiar dos fatos em seu domínio de investigação, tudo o que o escritor consegue atingir são soluções contingentes e parciais, que pertencem somente à situação para a qual foram previstas. Apropriar-se do pensamento exato 
da ciência permitiu a Musil embarcar em uma investigação imanente da ética como a esfera da experiência absolutamente singular e das iluminações inefáveis que pouco têm a ver com leis e preceitos de conduta. A literatura se configura como o meio para apreensão da experiência humana em sua singularidade irreduzível, acreditava Musil, em virtude de sua qualidade psicológica peculiar ou, para se usar uma outra formulação musiliana, de estar aninhada entre intelecto e sentimento.

Nesta parte da tese, enfatizou-se a convicção de Musil sobre o papel que o intelecto desempenha no processo estético para marcar a distância que o separa daqueles contemporâneos que viam na arte uma esfera pura de emoção intocada pela racionalidade. Na década de 1920, Musil se achou compelido a acrescentar especificidade à sua visão, em um esforço de responder à crise cultural dos anos seguintes à Primeira Guerra Mundial. Sua articulação estética do sentimento pelo intelecto constitui talvez o aspecto do pensamento de Musil menos investigado no período pós-guerra. Seu resultado permite uma conceituação da experiência estética que modula imagens-chave da Crítica da faculdade do juizo de Kant. 


\section{[EXCURSO]}

\section{Um Paralelo: "Nossa existência nada mais é do que um pálido fantasma"}

i Das ilusões do progresso tecnológico a qualquer custo

O debate político, traçado como paralelo aos aspectos psicológicos em foco, começa por desvendar as ilusões do progresso tecnológico a qualquer custo. Partindo da pergunta dirigida por Marcuse à intelectualidade de sua época: "produtividade para quê?" (2001c, p.115), inaugura-se com ela um campo de discussão que busca compreender a nova natureza humana, o novo psiquismo e, se há propriamente novidade, se ela se constitui nas bases para uma nova cultura. As diversas visões que compuseram o termo "natureza" na tradição filosófica, o compreendem como princípio do movimento ou substância, como ordem necessária, conexão causal, exterioridade, enquanto contraposto à interioridade da consciência. Porém o termo também compreende a visão criada pelo campo de encontro ou de unificação de certas técnicas de investigação. ${ }^{105}$

Entendida como verdadeiro apelo à racionalidade tecnológica, a pergunta se volta ao futuro da humanidade, é central nas discussões empreendidas por Marcuse e está atrelada ao contexto histórico das manifestações públicas que cercaram os anos próximos a 1968, que, desde então, abalaram o mundo político nas últimas décadas. A escalada dos movimentos que se originaram na França, naquele período, e se estenderam por quase todos os continentes, é entendida como caixa de ressonância das questões filosóficoexistenciais do pós-guerra que ficaram em aberto, relacionadas à proposta de sua decisiva contribuição à vertente de uma utopia pessimista para o novo humanismo.

Tal como Freud, Marcuse acreditava que tanto o indivíduo quanto a sociedade estão profundamente doentes, não havendo, na contemporaneidade, uma solução evidente para o mal-estar que se apresenta à Cultura. O pessimismo de Marcuse não nasceu como

${ }^{105}$ ABBAGNANO, 1982, p.669-672. 
resposta direta ao fascismo, nem tampouco ele identificou a etiologia da doença como decorrente da banalização do mal causada pelas atrocidades criminosas dos líderes autoritários, posição defendida por outros frankfurtianos.

O discurso sobre a perversão completa no Estado totalitarista era desmentido pela referência à consideração da essência do homem, que se mantinha por meio de toda a perversão efetiva e cuja representação era legitimada pelo Estado. A ontologia marxista, endossada pelos frankfurtianos, não cessava de apontar, insistentemente, o fim do Estado totalitarista como último elo da cadeia de eventos históricos.

Segundo Wiggershaus ${ }^{106}$ (2002), influenciado pela leitura de Heidegger quando foi trabalhar com ele, em Freiburg, em 1928, Marcuse pensava de acordo com a antropologia existencialista, isto é: a teoria do homem encarado como um ser finito, não estabelecido, lançado no mundo. Porém, tal posição era atenuada e assumia a idéia de um homem que, por meio de desvios, chegava a coincidir com sua essência. Em lugar da filosofia marxista que reclamava a auto-reflexão mantida incessantemente alerta e aprofundada, do homem sobre sua situação histórica atual no mundo - compreendendo-se tal argumento como reflexão sobre as possibilidades e necessidades fundadoras do ser, do agir e do devir —, Marcuse chegou a uma filosofia que via, no presente, em bloco, um modo de existência capitalista desumano. E tal caráter desumano era a quintessência da humanidade.

Qualquer proposta de transformação seria alcançada por meio da revolução de valores estética, e não de ideologia. ${ }^{107}$ Porém, em estudo crítico sobre Karl Jaspers in Philosophie des Scheiterns, 1933, Marcuse acreditava que "a caracterização da existência humana como essencialmente histórica deve devolver à filosofia a acuidade do concreto que ela perdeu há muito tempo, a seriedade suprema de um acontecimento humano no qual "se trata de tudo". Sua crítica por uma filosofia concreta dirige-se àquilo que "a filosofia faz à miséria aqui e agora”. O que Marcuse criticava em Heidegger, na revista Philosophische Hefte, em 1928, era o fato de ele não tratar das questões realmente decisivas, "integrando o momento atual e sua situação". Marcuse indagava: "Que é uma existência concretamente autêntica? Como uma existência concretamente autêntica existe

\footnotetext{
${ }^{106}$ WIGGERSHAUS, 2002, p.134-135.

${ }^{107}$ WIGGERSHAUS, 2002, p.133-135.
} 
e é simplesmente possível?"Como não estudar minuciosamente as "condições históricas concretas sob as quais existe um Dasein concreto", e entender que conduzir tudo ao Dasein solitário deva ser substituído pela orientação para a decisão da ação? Após esse período, Marcuse optaria por se aproximar das posições marxistas afastando-se, gradualmente do pensamento heiddegeriano, até a sua ruptura, bem como optou por se afastar da forte influência que Hegel exerceu no seu pensamento (criticando o hegelianismo como movimento fascista em Razão e revolução (1978). Para Marcuse, o texto de Marx era "realmente concreto" e superava o marxismo estático teórico e prático dos partidos políticos que se alinhavam a essa posição. Entretanto, suas críticas a Heidegger custariam caro a Marcuse na época do estabelecimento do nazismo na Alemanha. Em carta documentada de Husserl a Riezler, Heiddeger bloqueou o concurso de Marcuse ao exercício do magistério. Esse documento permitiu, nas provas de reexame pela República Federal da Alemanha, que ele fosse reconhecido como alguém que, normalmente, deveria ter sido aprovado e se tornado professor.

ii O novo ethos

Para Marcuse, o capitalismo empreendeu guerra contra a natureza interna e externa ao homem. As exigências de uma exploração sempre mais intensa contrariam a natureza mesma, visto que ela é a fonte e o lugar da pulsão de vida que luta contra a pulsão de agressão e destruição. As exigências de exploração reduzem e desperdiçam progressivamente os recursos materiais: quanto maior a produtividade capitalista, maior é a sua destrutividade. Esta é uma das manifestações das contradições internas do capitalismo. A Natureza é sempre vista como uma dimensão do trabalho, mas, além do trabalho, ela é uma imagem de beleza, de tranqüilidade, de uma ordem não repressiva. A luta ecológica vai de encontro às leis que governam o sistema capitalista, ela é uma luta política: é a negação pura e simples da lógica do sistema. Marcuse acredita que a verdadeira ecologia culmina em um combate social militante que deve alcançar as raízes do capitalismo. Esse combate é uma atitude engajada, na qual não há preocupação de purificar a sociedade, mas de transformá-la. 
O debate que se segue ao Ecología y revolución (1975) ${ }^{108}$ gradativamente se preocupa com as inter-relações dos seres vivos e suas funções em ambientes diversos. $\mathrm{O}$ estudo de rede tão intricada permitiu uma base filosófica de pensamento, a construção de um corpo teórico junto com outros pensadores, para a análise e compreensão das teias da vida, e, em conseqüência, iniciou-se um movimento, na pesquisa, para a compreensão de como os seres vivos se agrupam e quais as implicações que existem na organização da população, comunidade e ecossistema.

Os princípios que nortearam a construção do arcabouço teórico marcuseano mostraram-se válidos até o ponto onde elucidavam os mecanismos responsáveis pela organização, adaptação, distribuição e substituição das espécies vegetais e animais na biosfera. Entretanto, ainda hoje, o que se vê mostra-se insuficiente quanto aos estudos comparativos de comunidades humanas, em relação qualitativa, em um mesmo ambiente, às outras comunidades não-humanas. As inter-relações processadas nas comunidades são comandadas por processos que estão além dos puramente biológicos e merecem minuciosos e amplos debates. ${ }^{109}$

O ecologista humano defronta-se com um conjunto complexo de problemas, ao ser forçado pela natureza de seus estudos a conceber o homem como animal ligado, por um lado, à teia da vida em condições idênticas à dos demais seres vivos e, por outro, ao sistema social como autor e ator. A humanidade compartilha da Natureza como um animal, mas é a condição do trabalho que estabelece um processo singular de controle e modificação das condições naturais com fins determinados à garantia de sua sobrevivência. Mas não apenas isso: a ecologia humana, no grau de complexidade em que atingiu a sociedade globalizada, não está mais restrita ao exame do caráter exploratório das comunidades ao seu ambiente. Mais do que isso, ele necessita ampliar seu quadro teórico para dimensionar a ênfase holística que está implícita nesta atual condição humana.

Em meados da década de 1960, diversos pesquisadores se dispuseram à interdisciplinaridade de estudos antes restritos à área da biologia. Voltados para a

\footnotetext{
${ }^{108}$ MARCUSE et al. La lucha por la extensión del mundo de la belezza, de la no-violencia, de la calma, es una lucha política. In: _. Ecología y revolución, 1975, p. 79-85.

${ }^{109}$ HABERMAS, O futuro da natureza humana, 2004.
} 
compreensão das peculiaridades da ecologia humana como o agente principal que provoca a destruição do meio ambiente da Terra, tais pesquisadores impuseram uma ruptura com a ecologia, em lato sentido, dispondo-se à interdisciplinaridade com estudos sociológicos, antropológicos e econômicos. Porém, tais estudos, quando se voltam para uma ação prática, encontram-se ainda em fase embrionária. A ação engajada dos pesquisadores situados em tais áreas é atingida em cheio pelas políticas ambientais que a restringem de diferentes maneiras.

No momento atual, esses estudos contam com um número razoável de trabalhos descritivos compartimentalizados, nos quais a interação homem-Natureza está reduzida a distribuições espaciais e funcionais. Esses trabalhos adotam abordagem cultural-biológica ou sociobiológica das comunidades humanas, sem que se avalie o real impacto do papel humano de consumidor no ecossistema natural global.

Marcuse acompanha a idéia da historicidade do homem incluída em sua determinação essencial, contida nos escritos de juventude de Marx. Entretanto, o motor da revolução radical é, precisamente, a consideração do caráter essencialmente humano. Esse aspecto de uma ação radical não se refere apenas a uma crise econômica ou política na situação factual do capitalismo, e sim a uma verdadeira reversão da essência humana. Compreender isso significa condenar ao fracasso antecipado, e sem apelação, toda reforma puramente econômica ou política e exigir, incondicionalmente, a supressão do estado factual do destino catastrófico da humanidade, pela revolução total de sua "natureza". O aspecto mais contundente da proposta filosófica marcuseana é, de fato, segundo Wiggershaus, uma utopia (2002) ${ }^{110}$.

A humanidade, com seu consumismo desenfreado, impõe uma doença ainda sem cura no horizonte da pesquisa quando posta em prática. Marcuse teria ficado profundamente marcado pela total aquiescência das massas nos países industrializados da década de 1950 e pela aparente incapacidade da classe dominante de subornar a militância dos trabalhadores mediante a oferta de padrões materiais de vida mais elevados. Sua descrença parte da crescente invisibilidade das relações de poder nas estruturas

\footnotetext{
${ }^{110}$ WIGGERSHAUS, 2002, p. 134-135.
} 
organizacionais e também da paralisia concomitante da crítica social em benefício de um monopólio de raciocínio tecnocrático. A crítica se estende à facilidade com que meios de comunicação de massa geram necessidades artificiais, induzem à apatia política e conduzem à cínica desumanidade com que o capitalismo explora o Terceiro Mundo, dentro e fora das fronteiras deste.

O mundo privatizado e manipulado pelas periferias urbanas é a tônica de uma nova ordem. Por um lado, esta é construída pelos moradores dos novos bairros de classe média abastada, onde seus habitantes se refugiam dos problemas urbanos mais graves (como a violência disseminada) em condomínios fechados ou em novos bairros urbanos com tipologia demarcada pelo novo classismo. Por outro lado, a nova ordem continua a manter o exílio, dentro das próprias cidades, daqueles que se vêem fora da linha de consumo. Esta linha costura os padrões que definem o progresso, de acordo com as novas fronteiras valorativas medidas pelas estatísticas que avaliam a saúde da sociedade. Há os consumidores que estão dentro do padrão de desenvolvimento humano e há o operariado com baixo poder de consumo, que, sem garantias trabalhistas, é considerado uma "nãopessoa", outsider, underclass, ou "pária", quando desempregado, formando a massa daqueles que se situam abaixo da linha traçada e fora da ordem do progresso.

Mais do que fronteiras a demarcar espaços geográficos, sempre existiram fronteiras políticas operando como impossibilidade de uma transformação visível nas instituições democráticas. Como barreiras, tais fronteiras fazem parte da prática do convívio social democrático. Nas estruturas urbanas, elas compõem as margens da sociedade constituída pelos conglomerados periféricos pobres, como uma nova versão dos antigos guetos medievais.

Mais do que uma nova era de alienação há um paradoxo na plácida coexistência dos indivíduos na nova urbanidade. Tal placidez se vê continuamente ameaçada por grandes máquinas burocráticas e militares que decidem o destino da humanidade na nova ordem social instalada no pós-guerra. A relação entre governo e governados, entre a administração e os que lhe são submetidos se modificou de maneira significativa, porém, os sinais de perigo são uma constante. Nada parece, assim, ser diferente das condições que 
propiciaram a crítica histórica de Marx ao esboçar o conceito de alienação, contido no seu Primeiro Manuscrito.

De forma atualizada e sistemática, a crítica histórica deve refletir sobre a dicotomia do processo homem e Natureza, isto é, deve examinar, em uma perspectiva histórica, a separação entre o que diferencia o homem do ecossistema natural. A política contemporânea, em todo o planeta, desarticula e esvazia tradições e crenças, ideologias e religiões, identidades e comunidades, rearticulando-se com a ontologia. A vida política qualificada é a vida natural, e é como o homem, sujeito político ou animal vivo, bios e zoé, perfeitamente distintos para os gregos, foram progressivamente entrando numa zona de indiferenciação na qual a vida nua se foi tornando súdita do Poder Soberano e a política foi assumindo contornos de uma biopolítica. De Aristóteles a Auschwitz, do Habeas Corpus às Declarações de Direitos, ainda subsistem enigmas que o século XXI mantém vigentes à razão histórica. ${ }^{111}$

Após as teorias evolucionistas e em face dos novos resultados da política contemporânea - no seu aspecto de tecnociência e esvaziamento gradual das tradições culturais - a presente rearticulação com a ontologia pode levar ao dogmatismo de posições anti-históricas e fundamentalistas, em oposição ao pensamento dialético. Diante de perguntas ainda sem respostas ou de respostas que precisam ser formuladas sobre o estatuto ontológico dos primeiros estágios da vida humana, não existiria mais uma interpretação capaz de se impor universalmente.

O termo ontologia não mais consegue dar suporte político ao problema do sujeito e do objeto, do pensamento e do ser no território das éticas particulares, que desafiam o "bem comum" como teoria das decisões coletivas. O conceito de "bem comum" retorna à cena atual com novo referencial, isto é, ele se refere à análise econômica dos bens coletivos e às concepções do neocontratualismo ${ }^{112}$. É bem público o que gera vantagens

\footnotetext{
${ }_{111}$ AGAMBEN, O poder soberano e a vida nua, 1998.

${ }^{112}$ O termo "neo-contratualismo", na fase contemporânea, refere-se ao campo da filosofia política. De modo genérico, o termo parte do pacto social, ou seja, das regras de jogo que hão de ser estabelecidas antes de seu início. Seu objetivo é encontrar um fundamento para a obrigação política e para o cumprimento da lei. Seus principais expoentes (RAWLS, 1971; BUCHANAN, 1977; NOZICK, 1975) não chegam a conclusões políticas idênticas. J. Rawls visa a uma maximização de igualdade de direitos; J. Buchanan visa a readequar os princípios liberal-democráticos ao Welfare State; R. Nozick visa reapresentar a liberdade individual e
} 
indivisíveis em benefício de todos, não subtraindo o gozo de um indivíduo ao gozo dos demais.

Por um lado, o bem público não transcende, na verdade, o bem privado, porque é igualmente um bem do indivíduo e é alcançado por intermédio do mercado ou, mais freqüentemente, por meio das finanças públicas. Por outro lado, o neocontratualismo mostra como se deve deduzir do contrato social um conceito universal de justiça, um "bem comum", que consiste na maximização das condições mínimas do atendimento das necessidades dos indivíduos. Porém, esse tem sido o verdadeiro desafio posto às ciências, entre elas, a psicologia social, para a reformulação das regras do jogo social, de forma a refletir sobre os limites de uma ação competitiva excessiva entre os indivíduos.

Tal reflexão pretende que, no seio da psicologia social, na sua forma de ação política engajada se encontrem as forças cooperativas, que maximizem, além do interesse individual, o bem coletivo, que é bem diferente da simples soma dos interesses individuais. É bem sabido pela ciência política que, sem um mínimo de cultura homogênea, sem um mínimo de consenso acerca dos valores últimos da comunidade e das regras de coexistência, a sociedade corre o risco de se desintegrar ou de encontrar sua integração unicamente mediante o uso da força.

Diante da complexidade da resultante como consenso globalizado entre partes com desiguais interesses, que, em verdade, pode ser o negativo da formulação tradicional do conceito de sociedade, a integração social baseada no consenso, tal como foi elaborado por sociedades agrícolas e sacralizadas, não consegue, hoje, se adaptar satisfatoriamente às sociedades industrializadas e dessacralizadas.

Nesta linha de pensamento não se pode descartar a influência decisiva do pessimismo de Freud sobre o futuro da humanidade a partir de uma cisão irreparável entre Natureza e Cultura, sobretudo quanto às visões sombrias que se estendem à compreensão

anarquia, de modo radical. Entretanto, não se trata de mera discussão acadêmica de filosofia política, porque as diferentes soluções propostas por estes autores são traduzidas numa maior ou menor interferência do Estado na vida social e econômica, sugerindo, assim, novos limites constitucionais na época da crise do Estado assistencial ou do bem-estar (BOBBIO et al., 2004, p. 282-283). 
da verdadeira "natureza humana", dominada pelas pulsões que coabitam, de forma conflituosa e lado a lado, o psiquismo. ${ }^{113}$

Freud (1930[1929]) observa que, por meio do trabalho e da diferenciação de tarefas requerida na organização societária humana, o caráter civilizador é representado pela capacidade de observar os fenômenos da Natureza, reproduzi-los e acumular conhecimento. Ao elaborar e aplicar o conhecimento, a humanidade desenvolveu sua criatividade na busca para eliminar as barreiras encontradas na Natureza.

Agindo de tal modo, a civilização distanciou, gradualmente, o homem da sua condição natural, aumentou seu poder na transformação da Natureza, desenvolveu sua capacidade de ajustamento e imprimiu à intervenção um caráter ativo, de luta e dominação. Em conseqüência, quando o homem foi capaz de aplicar o conhecimento na solução de problemas cotidianos, iniciou uma nova forma de intervir na Natureza. O processo de interação que, até certo ponto, caracterizou-se por respeitar os limites suportáveis do equilíbrio ecológico, passou a ter efeitos negativos na modificação do conhecimento e possibilitou a utilização de técnicas cada vez mais sofisticadas.

Paralelamente, os homens deixaram de ser seres gregários e mergulharam no processo de interação que os conduziu a uma intervenção organizada em seu meio natural e dirigida para o processo da produção material. Enquanto ocorre a ascensão no processo da produção material, a organização social define o modo de interagir com a Natureza e com os indivíduos, visando aumentar o poder de dominação sobre ela. De forma muito sucinta para descrever tão longo processo, pode-se dizer que a maneira de interação homem-natureza reflete o grau de evolução na aplicação do conhecimento, ou seja, o grau de desenvolvimento tecnológico, e, em decorrência, deduz-se que o poder de uma sociedade, para explorar os recursos naturais, passa a depender de seu desenvolvimento tecnológico. ${ }^{114}$

\footnotetext{
${ }^{113}$ A perspectiva psicanalítica sobre o que é o homem aparece de forma marcante sobre a leitura de mundo de Marcuse e se faz em sua obra Sobre o caráter afirmativo da cultura, originalmente publicada em Psychoanalyse und Politik, 1968. Tradução brasileira de Isabel Loureiro em MARCUSE (2001b, p.112-139). ${ }^{114}$ Dada a importância e extensão do problema, o conceito tradicional de cultura (alem. Kultur) relacionado ao seu caráter afirmativo e à proposta de sua redefinição, cabe examinar os textos Sobre $o$ caráter afirmativo da cultura (MARCUSE, 2001a [1937]) e Comentários para uma redefinição da cultura (MARCUSE, 2001b [1965]), contidos em Cultura e psicanálise, 2001, p. 7-111.
} 
iii O indivíduo, na sua singularidade, se julga mônada independente e auto-suficiente

No texto "A noção de progresso à luz da psicanálise", Marcuse (2001c) aponta direções para a crítica sobre os resultados da exploração gradual, dependência e diferenciação do homem em relação à Natureza. Suas expectativas de uma alteração sobre o processo de degradação constante da Natureza, causando o esgotamento de recursos necessários à sobrevivência da humanidade, caberiam em uma indagação: "parar o progresso ou redirecioná-lo?”, que poderia ser compreendida como uma visão utópica de um mundo recriado sobre novas bases. Tal utopia apresenta-se diante da impossibilidade de se alcançar a libertação do indivíduo, uma vez que ela só se efetiva em uma sociedade erigida sobre a oposição de interesses dos indivíduos e não sobre a solidariedade. $\mathrm{O}$ indivíduo, em sua singularidade, se julga mônada independente e auto-suficiente; sua relação com o mundo humano e extra-humano constitui o mundo em si mesmo. De maneira abstrata e mediata, o indivíduo, como um eu dotado de conhecimento, sentidos e vontade, é determinado pelas leis cegas da produção de mercadorias e do mercado. O ato de crença na disposição humana para uma outra direção vai no sentido contrário à sua autodestruição e à destruição da Terra.

Diante dos impasses para mudanças dos hábitos culturais como um todo, ainda não superados pela globalização, e frente às diferentes realidades nas diversas regiões da Terra, em contrapartida ao que sugere Marcuse, a psicanálise abre a possibilidade de transformações do caráter social da humanidade, que se constitui em uma utopia - um novo mundo para a verdadeira natureza humana - , por meio da sublimação das pulsões. Entretanto, a possibilidade apresentada requer o desvio do objetivo primeiro da pulsão que é a busca da satisfação. O desvio de alvo passa a ser dirigido para objetos socialmente valorizados, sem qualquer relação aparente com a sexualidade. Na perspectiva freudiana, a noção de sublimação envolve a meta e a mudança de objeto no processo pulsional, mas não ocorre de forma a alcançar uma descarga total do elemento propulsor, como ocorre na força da pulsão sexual. A impossibilidade de catarse não ocorre, portanto, sem que reste um mal-estar. A saída é o indivíduo buscar o ato que o liberte do status quo como atitude de não-conformismo à ordem vigente. Porém, tal atitude tem como efeito o estado de crise permanente nos processos, percebido como mal-estar na cultura. 
Ressalta-se que, apesar de o termo crise ter vários registros, interessa destacar a imagem de um destino que se conjuga, nos escritos de Marcuse, como crítica a uma aposta política, moral e espiritual humanista. $\mathrm{O}$ mesmo registro se encontra, com diferentes matizes, nos escritos do socialismo utópico de Saint-Simon e seus seguidores (Fourier e Proudhon), que, ao descobrirem a sucessão de períodos orgânicos e períodos críticos no passado, percebem um giro novo e definitivo para o futuro da humanidade e proclamam o advento do mundo industrial regido por um poder espiritual ${ }^{115}$.

Porém, anteriormente, Tocqueville, em A democracia na América (1977), originalmente publicada no período de $1835-1840$ e em $O$ antigo regime e a revolução (1982) originalmente publicado em 1856, não distingue um pathos para a crise de valores que se estende sobre o progresso material. Este autor entende a necessidade de se decifrar, no Estado Social, o modo de governo nas leis promulgadas, as opiniões, costumes e o progresso de um novo tipo de servidão.

Sua previsão sobre a ruptura que a democracia moderna introduziria na história da humanidade haveria de ser corroborada por Marcuse como denúncia à destruição dos fundamentos da autoridade, da excisão entre os indivíduos voltados para a luta pela autoindependência e o advento das novas potências anônimas que são o Estado, a Sociedade, a Opinião. Surge, assim, a hipótese de que os indivíduos, desligados uns dos outros, ficariam voltados para o seu próprio bem-estar e, portanto, poderiam ser devorados por um novo despotismo.

Não se pode desconsiderar que os signos de decomposição interna da civilização já estavam contidos nos profetas da crise atual (FREUD, 1930 [1929]); ARENDT (2000a, 2000b, 2001), mais proximamente, e dois séculos antes, Tocqueville, em sua obra $A$ democracia na América, teria examinado os dilemas com que a democracia atual haveria de se defrontar como tarefa hercúlea à toda sociedade que tem, por ideal, a preservação da liberdade de seus indivíduos.

$\overline{115}$ REALE, v. 3, 1991, p. 174-183. 
De acordo com Tocqueville, o mundo da igualdade moderna é também o do indivíduo interessado, antes de tudo, em si mesmo, o que esvazia a política dos sentidos tradicionais do bem comum e transforma a coisa pública em arena de pilhagem dos desejos particulares. Ora, se a igualdade entre os seres humanos é o critério justo para a constituição política do presente, o que se pode fazer para que a liberdade individual seja preservada das ameaças coletivas e a política se oriente para o bem comum?

Para Habermas (2004, p.4), a filosofia acreditava que era possível assegurar a totalidade da natureza e da história, de maneira consolidada: a vida individual e comunitária estava nelas inserida. A "vida correta" se calcava na estrutura do cosmos, na história universal e na história sagrada, que ofereciam regras para a sua elucidação. A transformação social cada vez mais acelerada, entretanto, deixou de ser orientada por modelos orientados pautados numa ética rígida tal como seria na pólis grega, na sociedade civil medieval, no período do Renascimento urbano, voltados, conforme Hegel, para o convívio familiar, a sociedade civil e o Estado.

\section{Entretanto,}

o liberalismo político reage ao pluralismo ideológico e à individualização crescente dos estilos de vida, a partir das tentativas filosóficas de designar determinados modos de vida como exemplares ou universalmente decisivos. A 'sociedade justa' deixa ao critério de todas as pessoas aquilo que elas querem 'iniciar com o tempo de suas vidas'. Ela garante a todos a mesma liberdade para desenvolver uma autocompreensão ética, a fim de formar uma concepção pessoal de 'boa vida' segundo capacidades e critérios próprios. (HABERMAS, 2004, p. 5)

A importância capital da crítica desses autores aos desafios que a sociedade democrática tem enfrentado faz importante coro, para situar, nesta tese, a atualidade da obra de Marcuse quando ele revela, de forma pontual, a dúvida sobre o êxito da revolução do proletariado como fim da pré-história da humanidade, proposto pelo marxismo. Tal êxito dependeria da práxis da classe engendrada pelo capitalismo, vítima de uma alienação que precisaria ser desfeita. 
É cada dia mais questionável a capacidade do proletariado para assumir o seu papel verdadeiramente revolucionário. Ao substituir o esforço humano por máquinas mais eficientes, a capacidade de enfrentamento ao capitalismo torna-se, a cada dia, mais difícil. Diante das mudanças impostas às esferas do trabalho, terminam os problemas com trabalhadores e a necessidade de contrato entre as partes, e, assim, submetem-se todos os modos de propriedade que subsistem nas sociedades ocidentais avançadas, de forma a alcançar o triunfo sobre quaisquer adversários estrangeiros ao sistema.

Dessa forma, a sociedade atual enfrenta o dilema entre os contextos intersubjetivos partilhados entre os indivíduos que formam as normas de convivência na sociedade e os projetos individuais de cada um.

não pode nem deve haver proteção cultural das espécies. De modo semelhante, num Estado constitucional democrático [avançado], a maioria não pode prescrever às minorias a própria forma de vida cultural - na medida em que estas se distanciam da cultura política comum do país - como uma suposta cultura de referência. (HABERMAS, 2004, p.5)

Advogar uma tal posição implica que o novo ethos satisfaz às condições do pluralismo ideológico; ele esbarra nas questões relativas a uma ética da espécie. De acordo com o mesmo autor:

\begin{abstract}
É nessa situação que nos encontramos hoje. O progresso das ciências biológicas e o desenvolvimento das biotecnologias ampliam não apenas as possibilidades das ações humanas [de controle e exploração sobre o meio natural], mas possibilitam um novo tipo de intervenção. O que antes era "dado" como natureza orgânica e podia quando muito ser "cultivado", move-se atualmente no campo da intervenção orientada para um objetivo. $\mathrm{Na}$ medida em que o organismo humano também é compreendido nesse campo de intervenção, a distinção entre "ser um corpo vivo" (alem. Leib sein) e "ter um corpo" (alem. Körper haben) adquire uma atualidade impressionante: a fronteira entre a natureza que "somos" e a disposição orgânica que "damos" a nós mesmos acaba se desvanecendo. (HABERMAS, 2004, p.17)
\end{abstract}

Por conseguinte, a questão que envolve a condição humana de trabalho do homem sobre a Natureza dirige-se a novos horizontes. A concepção tradicional de trabalho que se traduz em sujeito produtor e sujeito consumidor sugere, hoje, novo tipo de referência, que 
alcança o nível mais profundo do substrato orgânico entre o homem e a Natureza. A nova concepção dependerá da autocompreensão dos sujeitos que produzem bens, não apenas para a garantia de sua sobrevivência, mas também dependerá da autocompreensão daqueles que consomem de forma aparentemente ilimitada, de acordo com o seu poder de consumo, a partir dos recursos limitados que a Natureza provê. Tal autonomia equivale à garantia alcançada no capitalismo tardio pela nova margem de decisão individual da liberdade de consumir, como conquista arbitrária, em função das preferências subjetivas de cada indivíduo.

iv Uma ética para os bárbaros, outra para os não-bárbaros

Entretanto, a autocompreensão ética do quanto consumir e de como consumir implica um esforço comum que está na base de qualquer organização social. Esta não se refere apenas à atitude crítica cultural, aos avanços louváveis do conhecimento científíco, mas à compreensão dos sujeitos, e leva a pensar se a implementação de tal conquista acompanha a ação responsável sobre o ambiente que provê sobrevivência e, em caso afirmativo, de que modo isso se dá. (HABERMAS, 2004, p. 16, 18)

A alternativa que Marx formulou em seus escritos de 1961 [1853-1851], entre a barbárie capitalista e o socialismo, se vincula, estreitamente, na atualidade, como campo de luta ideológica e armada como se a única alternativa fosse um confronto inevitável entre a civilização ocidental capitalista e a barbárie oriental (MUNFORD, 1952) ${ }^{116}$.

Preocupado com as questões internacionais, Marx multiplicou os artigos destinados a denunciar a ameaça que pesava sobre o Ocidente devido à ignorância política ou a traição entre os dirigentes das grandes potências mundiais, que acabaram por criar verdadeira cisão entre dois lados — bárbaros e não bárbaros — no mundo.

\footnotetext{
${ }^{116}$ MUNFORD, A condição do homem, 1952, p.337-441.
} 
O formidável progresso material que passou a existir com a expansão da sociedade industrial trouxe a erosão dos costumes e a decomposição dos modos de coexistência, sob a crença no progresso material como portador da revolução que daria o passo em direção a uma sociedade plenamente humana. Crença que permeia, agudamente, a sensação de vazio psicológico e mal-estar que o consumo pelo consumo induz como valor maior na cultura ocidental atual (LIPOVETSKY, 1983; TODOROV, 1989; BAUMAN, 2001).

Para Marcuse, se há alguma revolução que dê "saída" ao mal-estar na cultura, ela é de natureza estética. Não ocorrerá sem contradição, mas por meio de um salto que é uma tarefa qualitativa de transformação individual. Necessariamente, esta implica uma ação de recusa à ordem estabelecida pelo coletivo. Se há possibilidade de saída coletiva para mudar a trajetória aparentemente irrefreável rumo à autodestruição da humanidade, ela deve ser uma ação de liberdade somente alcançada por via de uma revolução estética, que, em si, é contraditória com a ação política.

\begin{abstract}
O estético é mais do que o mero 'estético'. Ele é a razão (alem.Vernunft) da sensibilidade [...]. A idéia utópica de uma realidade estética tem de ser sustentada até o ridículo que hoje está necessariamente ligado a ela. Pois talvez a diferença qualitativa entre a liberdade e a ordem existente esteja nela indicada. (MARCUSE, 2001, p. 51) ${ }^{117}$
\end{abstract}

Esta passagem revela a tensão subjacente ao dilema político do engajamento intelectual diante da realidade estética. Palavra e ação, teoria e prática são o espelho da impossibilidade de se manter o sonho de imparcialidade diante da condição humana.

Mas o bem comum, como orientação do ethos, regrediu à ciência triste, conforme pensa Adorno na Mínima moralia. O gesto de escrever - isto é, de olharmos nossa própria imagem refletida nas palavras - não deve admitir qualquer concessão à facilidade, mesmo correndo o risco de nos tornarmos incompreendidos. Adorno não contemporiza: se, por um lado, "a expressão vaga permite àquele que a ouve representar-se aproximadamente o que lhe convém e que ele de todo modo já tem em mente", por outro, a expressão "rigorosa impõe uma compreensão inequívoca, um esforço conceitual, do qual as pessoas

\footnotetext{
117 Grifos no original. Trad. R. C. Barbosa do texto de Marcuse originalmente publicado como "Die Gesellschaft als Kunstwerk", em Neues Forum, ano XIV, n. 167-168, nov.-dez., 1967. Novos Estudos CEBRAP, n. 60, julho de 2001, p. 45-52.
} 
perderam deliberadamente o hábito, exigindo delas diante de todo conteúdo a suspensão dos juízos habituais e, deste modo, um certo afastamento, a que elas resistem violentamente". ${ }^{118}$

O pensamento não resignado de Adorno, para quem "o talento talvez nada mais seja do que a fúria sublimada de um modo feliz" ${ }^{119}$, deixa claro que se a barbárie se instalou definitivamente em nosso meio; se o irracional e o econômico, de mãos dadas, preponderam; se o consumo e a indústria cultural se encarregam de submergir os homens em um pântano de cega euforia, cabe àquele que escreve, em exercício diário de autoreflexão, um pessimismo que, paradoxalmente, resgate seus leitores à esperança e uma lucidez destituída de qualquer ambigüidade, capaz, ao mesmo tempo, de enternecer e afligir o leitor.

Tal postura se conjuga, assim como faz Sartre (1993), com a defesa da posição engajada do intelectual que escreve,

\begin{abstract}
[...] ao falar, eu desvendo a situação por meu próprio projeto de mudá-la; desvendo-a a mim mesmo e aos outros, para mudá-la; atinjo-a em pleno coração, traspasso-a e fixo-a sob todos os olhares; passo a dispor dela; a cada palavra que digo, engajo-me um pouco mais no mundo e, ao mesmo tempo, passo a emergir dele um pouco mais, já que o ultrapasso na direção do porvir. Assim, o prosador é um homem que escolheu determinado modo de ação secundária, que se poderia chamar de ação por desvendamento. É legítimo, pois, propor-lhe esta segunda questão: que aspecto do mundo você quer desvendar, que mudanças quer trazer ao mundo por esse desvendamento? O escritor "engajado" sabe que a palavra é ação: sabe que desvendar é mudar e que não se pode desvendar senão tencionando mudar. ${ }^{120}$
\end{abstract}

A superação deste dilema implica a ação de desvendar o discurso e impedir que o monopólio da força torne-se também o monopólio da verdade.

\footnotetext{
${ }^{118}$ ADORNO, Mínima moralia, 1993, p.88. (Fragmento 64)

${ }^{119}$ Ibidem, p. 95. (Fragmento 72)

${ }^{120}$ SARTRE, 2004, p. 21.
} 
[...] podemos concluir que o escritor decidiu desvendar o mundo e especialmente o homem para os outros homens, a fim de que estes assumam em face do objeto, assim posto a nu, a sua inteira responsabilidade... a função do escritor é fazer com que ninguém possa ignorar o mundo e considerar-se inocente diante dele. (SARTRE, 2004, p. 21)

Entretanto, conforme Habermas (2004), a língua não é uma propriedade privada. Além disso, ninguém dispõe exclusivamente do meio comum de compreensão, o qual devemos compartilhar intersubjetivamente. Nenhum participante individual pode controlar a estrutura ou mesmo o desenrolar dos processos de compreensão e autocompreensão. O modo como os falantes e ouvintes fazem uso de sua liberdade de comunicação para tomar posição favorável ou contrária não é uma questão de arbítrio subjetivo. Com efeito, são livres apenas graças à força vinculante das pretensões, que necessitam de justificativas e são reivindicadas reciprocamente por tais falantes e ouvintes. No logos da língua, personifica-se um poder intersubjetivo, que é anterior à subjetividade dos falantes e a sustenta". 121

v A cultura e a sociedade sob a vigência de duas ordens distintas

Marcuse (1998) dirigiu suas críticas aos seguidores de Freud que não haviam ainda compreendido que a força da obsolescência da psicanálise não implicava que esta fosse um entendimento falso dos destinos da humanidade. Assim,

os conceitos freudianos invocam não apenas um passado que está atrás de nós, mas também um novo futuro a ser conquistado. Ao denunciar sem concessões o que o homem sofre numa sociedade repressiva, ao predizer que com o progresso da civilização aumenta a culpa, que a morte e a destruição ameaçarão sempre mais eficazmente as pulsões de vida, Freud lançou uma acusação que foi corroborada desde então pelas câmaras de gás e campos de trabalho [forçado], pelos métodos de tortura praticados nas guerras coloniais e nas operações policiais, pela habilidade e solicitude com que os homens se preparam para uma 'vida' subterrânea. ${ }^{122}$

${ }^{121}$ HABERMAS, 2004, p. 16.

${ }^{122}$ MARCUSE, 1998, p. 110. 
Às discussões que marcam o campo de oposição entre as noções de sociedade e cultura, Marcuse acrescenta a noção atual do progresso a qualquer custo. As noções que cercam as discussões entre Natureza e progresso estão imbricadas na condição de sobrevivência da humanidade, recolocaram o homem fora do centro da Natureza, desde que Darwin e Freud não mais permitiram que a condição humana estivesse extrínseca às suas regras. Assim, a Natureza não existe por causa do homem, ela não existe porque o homem a percebe, ainda que dela se sirva, de forma irresponsável, sem pensar em garantir a sobrevivência das futuras gerações. ${ }^{123}$

Doravante, o termo "Natureza", assinalado com letra maiúscula, será referido a todas as características e processos exterioes à espécie humana, bem como a toda a ação desta. A Natureza é o que precede a atividade humana, "um meio ambiente natural" é aquele que não foi alterado pela ação humana. Assim, pode também se referir a processos não vivos e, logo, as "leis da natureza" incluem a "gravidade". Em oposição, o termo "Cultura", grafado com "C" maiúsculo, será referido como: todas as idéias, crenças, valores, conhecimentos e capacidades técnicas que são a base da ação partilhada por um indivíduo ou comunidade. A Cultura se transmite de geração em geração e está, normalmente, sujeita a alterações contínuas.

Se a psicanálise tem uma parcela de verdade, esta se dá inserindo a humanidade no campo da razão que é dominada pela disposição natural do indivíduo, a qual é modelada pela cultura e pela sociedade que obedecem, ainda, à vigência de ordens naturais em relação de oposição: prazer e desordem, caos e realidade, ordem e progresso. ${ }^{124}$

As "ordens" supra-referidas não são propriamente antagônicas na obra de Freud. Formuladas como princípios que regem o funcionamento psíquico, não se constituem em um problema simples para Freud. Ele teria que lidar com o problema da tradução das informações externas que chegam à borda do aparelho psíquico como "quantidades" e a sua subseqüente percepção interna como "qualidades", na extensão de sua obra. A divisão do funcionamento psíquico em duas ordens, que é operada a partir do Princípio de prazer funciona, portanto, e até certo ponto, como uma ilustração do par prazer-desprazer. A

\footnotetext{
${ }^{123}$ SIMMONS, 2001, p. 15.

${ }^{124}$ LAPLANCHE; PONTALIS, 1994, p. 364-371.
} 
atividade psíquica, no seu conjunto, tem por objetivo evitar o desprazer e proporcionar o prazer. Do ponto de vista estritamente quantitativo, dinâmico, as "ordens" estão ligadas ao aumento das quantidades de excitação e, o prazer, à sua redução. Porém, Freud só defende a existência de princípios ou de forças pulsionais que transcendem o princípio do prazer quando opta por uma interpretação que tende a confundi-lo com o princípio de constância. Quando, pelo contrário, o princípio do prazer tende a ser assimilado a um princípio de redução a zero (princípio de Nirvana), o seu caráter fundamental e último, associado às pulsões de morte, deixa de ser contestado. A noção de princípio do prazer intervém na teoria psicanalítica de par com a noção do princípio da realidade.

O termo "natureza" na tradição filosófica diz respeito ao Estado de Natureza (alem. Naturzustand) e se enquadra no eixo de teorias que designam a condição do homem, anterior à constituição da sociedade civil. A doutrina do contratualismo está tradicionalmente situada no curso destas idéias que se conformam ao platonismo, vindo a constituir as bases teóricas do Estado moderno.

A noção de progresso à luz da psicanálise não é arbitrária em Marcuse (2001c [1968]). Ele retoma o fio das tradições no seio da filosofia, de acordo com a conotação que se refere ao homem comum, utilizada pelas doutrinas políticas utopistas, as quais projetam o estado de natureza como uma "perfeição do porvir". Tal noção deveria ser revista e não está livre dos equívocos que ainda prevalecem, como é demonstrado por autores (HEELAS, 1966; GROSS; LEWITT, 1998) que inserem o ideário marcuseano, talvez de forma indissolúvel, no imaginário dos adeptos de uma nova era.

Isso seria um equívoco, visto que, como leitor atento e adepto do caráter revolucionário das concepções freudianas mais pessimistas sobre a humanidade, Marcuse não poderia oferecer nenhuma alternativa política à direção do progresso que serve às massas e muito menos à fuga das responsabilidades do indivíduo perante a sociedade, pela da religião. Ele restabelece, com Freud ${ }^{125}$, a chance de liberdade na sociedade, como o progresso dos indivíduos, desde que sua autonomia e racionalidade impliquem recusa e oposição à ordem estabelecida pela massa.

\footnotetext{
${ }^{125}$ Esse tema foi desenvolvido em FREUD, Psicologia de grupo e a análise do ego (1921); FREUD, O futuro de uma ilusão (1927); FREUD, O mal- estar da civilização (1930 [1929]).
} 
Sobre esse importante aspecto, Marcuse mostra que não é culpa da psicanálise ser impotente para combater o desenvolvimento. Tampouco ela pode aumentar sua força, assimilando modas como o zen-budismo, o existencialismo etc. A verdade da psicanálise consiste em manter a fidelidade às suas hipóteses mais provocadoras.

No prefácio de Eros e civilização (s.d., p.15 [1966]), Marcuse afirma ser impossível extinguir senhores e escravos e ser improdutiva a repressão:

\begin{abstract}
Hoje em dia, essa união de liberdade e servidão tornou-se 'natural' e um veículo de progresso. A prosperidade apresenta-se, cada vez mais, como pré-requisito e um produto marginal de uma produtividade autoimpulsionada, em constante busca de novas saídas para o consumo e a destruição, no espaço exterior e interior, embora impedida de 'extravasar' nas áreas de miséria - tanto as internas como as externas. Em contraste com esse amálgama de liberdade e agressão, produção e destruição, a imagem da liberdade humana está deslocada: converte-se em projeto e subversão dessa espécie de progresso. A libertação das necessidades instintivas de paz e tranqüilidade, do Eros 'associal' autônomo, pressupõe a emancipação da afluência repressiva: uma inversão no rumo do progresso.
\end{abstract}

Pode-se entender, com essa passagem, que Marcuse esteja se referindo ao divórcio que ocorre entre a consciência e a razão com o advento da psicanálise. Diferentemente de quando estavam inseridos na linha de disposição natural do espírito, como na Fenomenologia do Espírito de Hegel (1807 [1992)]) ${ }^{126}$, esses termos não são sinônimos. Eles se referem ao conceito de natureza humana tal como teria sido proposto por Darwin e desenvolvido por Freud $(1915 ; 1923)$ com o modelo de funcionamento tópico, dinâmico e estrutural do sistema inconsciente.

A fórmula darwiniana para a compreensão das origens da humanidade está contida em A origem do homem e a seleção natural [1871 (1974)], e promove uma verdadeira revolução no conceito de progresso, uma vez que a evolução envolve a extinção ou a involução das espécies, entre elas, a espécie do Homo Sapiens que não está fora do curso da Natureza da qual faz parte como um animal dotado de razão, se a cultura assim lhe dotar para o exercício desta faculdade. Entretanto, para Marcuse (2001b) ${ }^{127}$, o progresso passa a não ser, necessariamente, sinônimo de "marcha do progresso espiritual e material"

\footnotetext{
${ }^{126}$ HEGEL, 1992, p. 221-227.

${ }^{127}$ MARCUSE, 2001b, p. 112-139.
} 
do homem, de acordo com a cartilha positivista. A intenção de Darwin, em seu estudo sobre a origem do homem, pode ser dividida em duas finalidades fundamentais. A primeira objetiva verificar se o homem, como os demais seres vivos, descendeu de uma outra espécie, ou seja, de onde surgiu a espécie humana. A outra, procurará investigar sobre o seu desenvolvimento, sua transformação de uma espécie anterior até o momento atual.

Para Marcuse, mais do que qualquer uma das espécies, que habitam o mesmo planeta, a humanidade está inserida, definitivamente, no curso evolucionário das espécies e delas se distingue por sua incomensurável capacidade de autodestruição e de destruição do meio ambiente que a cerca. A idéia de evolução foi imaginada antes de Darwin; no entanto, este pensador teve a capacidade de externá-la precisamente. Teve também o mérito de superar Lamarck e Malthus por conseguir traduzir tais pensadores em uma unidade coerente. Porém, Marcuse estende sua crítica à influência que a teoria da evolução causou aos ideais da escola positivista. Conhecida por sua filosofia científica, no pensamento europeu do século XIX, nesta predominava a atitude de somente valorar como legítima a filosofia quando aplicada aos fenômenos naturais, os quais se encontram presos às leis imutáveis. Seu fundamento é a negação total de qualquer pesquisa de causas primeiras ou finais. A teoria de Darwin, dessa forma, não repercutiu apenas no âmbito da biologia, mas também nos estudos da sociedade. Nestes estudos, os primeiros cientistas positivos fundaram o "darwinismo social". Cumpre lembrar que Darwin não era um darwinista social. Ele não abordou problemas da filosofia social e, possivelmente, inclinava-se a afirmar o contraste existente entre os processos da evolução biológica e social.

Deslocada a crença da humanidade que se acreditava originada e com um destino fora da ordem da Natureza, a experiência das duas Guerras trouxe a mudança que se produziu no domínio da filosofia. Tais posições foram, gradualmente, fragmentando as tendências que traduziam "natureza" e "progresso" como pontos de origem e alcance do espírito humano. Não mais como pedra angular da filosofia, o ideário que entrelaçava e distinguia esses dois conceitos passou, desde então, a ser considerado válido como uma complexa esperança ao empenho moral de preservação da vida para as gerações no futuro. 
Um dos primeiros pensadores a aplicar à sociedade, do ponto de vista político, os princípios da seleção natural e da variabilidade natural foi W. Bagehot (1956) que destacou a luta essencial entre os grupos. As lutas não seriam somente entre indivíduos, mas seriam conduzidas por grupos de homens. As tribos mais coesas e possuidoras de variabilidade prevaleceriam sobre as demais, representando a sobrevivência das mais aptas. A coesão seria a principal característica dos vitoriosos na lutas entre os grupos. A variabilidade seria o principal fator que daria sentido à luta pela existência, pois dela resulta um melhoramento da organização biológica ou social. Os melhores grupos seriam, de acordo com esse autor, aqueles que pudessem equilibrar a coesão, baseada nos costumes, com variação e a sua conseqüente tendência à transformação. De forma diferente dos outros evolucionistas, Gumplowicks (1898) não acreditava na evolução da humanidade como um todo. Para este autor, cada grupo teria sua evolução de maneira esporádica e interrompida, apresentando progressos e retrocessos próprios. Outros darwinistas (RATSENHOFER, 1975) acreditam em uma "teoria do conflito social", identificam conflitos intergrupais e solidariedade intragrupal.

De outra forma, o conceito de progresso no pós-guerra passou por uma transformação nos parâmetros quantitativos e qualitativos para medi-lo. A idéia de progresso infinito é abalada ainda pelas discussões que cercam o determinismo em Durkheim (1973) quando afirma que, no universo social mediano, nada se produz por acaso e que a sociedade é regida por leis. ${ }^{128}$

A leitura atualizada de Marcuse não pode prescindir de seus diversos comentadores: Habermas et al. (1980) ${ }^{129}$; J.-M. Domenach et al. (1970); Macinthyre $(1973)^{130}$. Este último destaca importantes aspectos do texto L'homme unidimensionnel (MARCUSE, 1968), abrangendo aspectos da crítica à sociedade contemporânea e à filosofia moderna. MacIntyre discute a decepção de Marcuse com a filosofia hegeliana como aquela que termina em "dúvida e resignação", tal como ele demonstrara em Razão e revolução (1978). Segundo este autor, Marcuse não se mostra "resignado", chegando a dizer que o hegelianismo induz a "uma faculdade mental que corre risco de ser

\footnotetext{
${ }^{128}$ DURKHEIM, 1973, p. 348-351.

${ }^{129}$ MARCUSE et al., 1980, p. 11-81.

${ }^{130}$ MACINTYRE, 1973, p.73-107.
} 
obliterada". Entretanto, se, para Marcuse, o pensamento negativo é a única fonte de crítica social criativa, o que há de transparecer como uma dúvida que ele teme e que o leva a escrever $L H D$ é a obliteração da criatividade na vida social.

Além dos citados, Kellner (1999) ${ }^{131}$ destaca, em suas análises do ideário marcuseano, um pensamento distinto, porém inserido entre os frankfurtianos, em geral ${ }^{132}$. Para contrabalançar os excessos da crítica da "teoria da manipulação" pela cultura de massa, com ênfase acentuadamente determinista dos frankfurtianos e da utopia pessimista marcuseana, estes autores enfatizam o poder que os indivíduos têm para resistir à cultura dominante e lutar contra ela.

Hall (2003, p. 57-76) pondera que os indivíduos podem produzir seus próprios significados com os textos veiculados pela mídia. Para ele, mesmo o pensamento hegemônico é negociado entre as instâncias vinculadoras e receptadoras de informação. Essa negociação é vulnerável a ataques e à subversão de grupos que se dispõem à sua margem, rejeitando ou se opondo aos modelos dominantes, na formação de suas identidades e opiniões. Tais posições permitem pensar que desde o final do pós-guerra já estavam dados os pré-requisitos tecnológicos básicos para o novo estágio do capitalismo, assim como as pré-condições lançadas pela reorganização das novas potências mundiais. São estas as condições que possibilitaram o surgimento de um novo sistema global, a nova onda longa do capitalismo, chamado tardio. Não obstante, as pré-condições culturais surgem com as transformações sociais e psicológicas da década de 1960, que, por sua vez, fazem surgir o habitus psíquico de uma nova era.

Com o surgimento de um mercado ampliado, tanto no sentido espacial quanto no que diz respeito às mercadorias propriamente ditas, a produção estética também passa a fazer parte do âmbito da produção de mercadorias em geral, com a urgência desvairada da produção ininterrupta de novas mercadorias para alimentar um mercado em expansão permanente. A estética se transformou em mais uma mercadoria de sedução ao consumo, que necessita sempre de inovações constantes.

\footnotetext{
${ }^{131}$ KELLNER, 1999, p. 15-18.

${ }^{132}$ WOOLF; MOORE, Jr. (Ed.), The critical spirit, 1967.
} 
vi A impossibilidade da revelação mecânica das verdades

Vista dessa forma, a estética do capitalismo tardio é tão predatória quanto o ideário que o sustenta. Sua função, como representante qualitativo na linguagem que representa a Natureza, faz desta um simulacro, o pastiche de uma visão telúrica, matéria morta ou manipulável pelo desejo humano. A estética, nesse estágio, representa os interesses do capitalismo tardio e expressa a concepção mecânica do mundo sensível. Ela revela o tumulto das sensações, a multiplicação de estímulos na intensidade da vida cotidiana, nutre a esperança de que, só assim, é possível uma vida mais completa. O "homem estético", como útil instrumento da ordem no capitalismo tardio, não consegue se enxergar por meio de uma atitude crítica - que seria a condição própria da sensibilidade estética. Em outras palavras, a estética, como medium das qualidades do sentir, traduz, como uma aporia, o anseio humano de uma revelação mecânica da verdade.

Esse último aspecto está na base da apatia social, que indica ser, por um lado, indiferença, estranhamento, passividade e falta de interesse pelos fenômenos políticos. Por outro lado, ela é o sintoma de pessimismo com as instituições políticas e demais manifestações da vida política, que ocupam uma posição bastante periférica no horizonte psicológico do apático. Este não é o protagonista de acontecimentos políticos, mas acompanha-os como espectador passivo e, mais freqüentemente, ignora-os inteiramente. A apatia política é acompanhada de baixa receptividade em relação aos estímulos políticos de todo tipo, e, freqüentemente, embora nem sempre, de um baixíssimo nível de informação sobre os fenômenos políticos.

Se a apatia é um comportamento ditado pelo sentimento de alienação, ela não tem no capitalismo tardio o aspecto virtuoso do cinismo como radicalização e comprometimento filosófico do ceticismo e abolição do interesse pela vida materialista, voltada para a forma consumista. A apatia está bastante difundida nas modernas sociedades industriais de tipo avançado, também caracterizadas por altos níveis de instrução e de difusão capilar das comunicações de massa. O fenômeno se dá em regime de tipo democrático e nos regimes autoritários e totalitários e, não obstante, a existência de mecanismos competitivos que, direta ou indiretamente, solicitam a participação do público 
nos primeiros e a existência de mecanismo de mobilização e de enquadramento das massas, a partir de cima, nos segundos.

Ao refletir sobre os múltiplos fatores que levam as sociedades à apatia, Bobbio (2004, p.56) revela que as margens de manobra política são maiores para os segmentos economicamente privilegiados, e mais ainda para aqueles que se investem de poder político privilegiado pela indiferença pública sobre as decisões. Porém, a indiferença representa um relevante obstáculo quando o alcance de metas econômicas requer o envolvimento e a participação de largos estratos populacionais. Do ponto de vista da dinâmica interna do sistema e do equilíbrio das forças políticas, a existência de tais estratos de apáticos constitui reservatório e massa de manobra, que pode ser útil para reforçar ou subverter as relações de poder.

Para entender o resultado das pesquisas que indicam o crescimento da apatia como comportamento típico, em ascensão, nas sociedades do pós-guerra, há necessidade de se analisarem as alterações históricas que se processaram não apenas na esfera do trabalho, mas também na ciência e na técnica formadas no interior das relações de produção. Há também a aposta no retorno do pensamento utópico, que, se por um lado, permite o desvencilhar da abordagem hipnótica que leva à crença no caráter irredutível da destruição da humanidade e, ao fim, "ganhou" a luta contra a Natureza, por outro, permite alcançar as diversas conotações da alienação como sintoma mais evidente da impossibilidade de historicizar, a partir das histórias pessoais, a expectativa que se tem para o futuro, a partir do presente que se constrói.

Termina-se aqui o quadro, ainda descritivo, para um contorno epistêmico corroborado pela discussão entre os diversos autores, permitindo constituir a perspectiva analítica desta tese que justifica a escolha dos termos estética predatória no capitalismo tardio em seu título.

Posto isso, estudar o século XX é fundamental para entender as transformações que se impõem como nova ordem social no novo século. A Europa do século XX, na maioria dos campos de atividade intelectual, proclamou sua independência em relação ao passado. Conforme o historiador Carl E. Schorske (1988, p. 13), no século XVIII, a palavra 
moderno adquirira certa ressonância de grito de guerra, mas apenas como antítese de antigo - incluída aí a antiguidade clássica. Nos últimos cem anos, porém, o termo moderno tem servido para diferenciar tanto o tempo de uma vida quanto os tempos de tudo o que a precedeu, bem como de toda a história enquanto tal. A arquitetura, a música, a filosofia e a ciência moderna se definem não a partir do passado, nem contra o passado, mas em independência do passado. O pensamento moderno tornou-se cada vez mais indiferente à história porque esta, concebida como matriz contínua, revelou-se inútil a ela.

Compreender a morte da história interessa tanto ao próprio pesquisador de história quanto àqueles que se situam nos campos da psicanálise e da psicologia social e trabalho. Tal posição funesta evidencia a profunda ruptura de um laço com o passado. Seu sintoma mais evidente se revela na revolta das novas gerações contra seus progenitores, na não aceitação de valores consagrados pela cultura e na busca por novas identidades. Os movimentos que podem ser inseridos no movimento modernista contêm, em seu cerne, a idéia de perda do sentido do eu, ou o que Schorske, pautado em Kohut, nomeia reembaralhamento do eu (p.13).

A transformação histórica obriga o indivíduo a buscar uma nova identidade da mesma maneira que impõe a tarefa de rever ou substituir sistemas de crenças já mortas às mais diversas etnias. Tal transformação evidencia, entretanto, um paradoxo. No esforço de lançar fora os grilhões da história, a modernidade acelerou os processos históricos. A indiferença a qualquer relação com o passado liberaria a imaginação, permitindo que proliferassem novas formas de expressão e de construção identitária. Em sentido inverso, a consciência da rápida transformação na história presente enfraquece a autoridade da história como passado relevante.

Para revelar a cultura a-histórica da modernidade, não é fortuita a escolha nesta tese, de identificar Viena como a cidade que, em seus interstícios históricos, situa o epicentro onde se sente mais fortemente os abalos da desintegração social e política que se estende ao longo do século XX até a contemporaneidade. Nela se situaram os grandes inovadores intelectuais que romperam os laços com a perspectiva histórica essencial que dava base à construção do novo século. 
Como representantes de uma cultura nômade, Freud e Musil enfrentaram, cada um a seu modo, as culturas que modelaram suas obras. Ambos os autores revelam, em suas obras, o desmoronamento da ordem liberal que garantia ao indivíduo modalidades racionais e previsíveis de socialização e de integração, ainda que sob a capa das aparências, no período que antecede a queda do Império Habsburgo. Como é corrente entre pesquisadores, o contato com Musil se deu inicialmente pelo interesse voltado à sua obra $O$ homem sem qualidades, e assim a um conjunto de problemas que se evidenciavam com eminentemente éticos, postos à singularidade da atividade clínica psicanalítica.

O problema crucial que ora se expõe em tese se dá na mesma medida em que Musil se vê sozinho, como que sem par, para compor a sua obra entre experiências profissionais, intelectuais e políticas. A desordem social e cultural que o cerca atinge sua própria identidade, de maneira que sua obra realça o desespero da perda ou da falta da consciência do eu judaico (alem. jüdescher Selbsthass) para salvar o equilíbrio de sua personalidade.

O homem sem qualidades, um personagem da ficção musiliana, talvez seja a descrição do sintoma mais evidente legado pelo extenso período de transição da modernidade. Com seu personagem, Musil consegue traduzir a tentativa que cada um faz ao elaborar, consciente, mas também inconscientemente, uma estratégia identitária pessoal, psicológica e intelectual. Para chegar a alcançar a reconstrução de uma identidade que se transforma numa busca, numa interrogação, numa invenção perpétua, o eu se torna flutuante e indeterminado.

O homem sem qualidades expõe as combinações, mesmo as mais paradoxais, os encaminhamentos, os mais tortuosos, que doravante, na modernidade, tornam-se parte de sua mais secreta intimidade. A dessubstancialização da identidade do judeu assimilado pode ser o protótipo do eu pós-moderno. Ao entregar-se às identificações, por vezes apressadas, que lhe são oferecidas, o autor e seu personagem se encontram na obra como presos em um gueto. Le Rider (1993, p. 344) define o status de condenação de judeu imaginário ao homem das grandes cidades, como aquele que é instável e solitário, liberado, se for do seu agrado, das ideologias coercitivas, autônomo e, contudo, constantemente perturbado pelo olhar alheio, envolvido pela constante tentação em abdicar do desconfortável privilégio de ser um homem sem qualidades. 
A leitura de A noção de progresso à luz da psicanálise (MARCUSE, 2001) ${ }^{133}$ é central para conduzir o debate. No texto, Marcuse define dois tipos fundamentais do conceito de progresso. Um deles evita qualquer valoração positiva e é definido de forma quantitativa, pois envolve o curso do desenvolvimento da civilização e a ampliação dos conhecimentos e capacidades humanas em seu conjunto. Estes foram utilizados com fins à dominação universal do meio humano e natural. O desenvolvimento da civilização teve, como resultado do progresso, a riqueza social crescente, aumentando as necessidades humanas e os meios de satisfazê-las. Entretanto, ainda que muitas conquistas tenham sido empreendidas, permanece aberta a questão - o progresso técnico contribui para o aperfeiçoamento humano, do ponto de vista de uma existência mais livre e mais feliz?

Em oposição ao aspecto quantitativo do conceito, Marcuse distingue o aspecto qualitativo, conforme a elaboração desenvolvida pelo idealismo hegeliano. De acordo com essa vertente filosófica, o conceito de progresso está atrelado à démarche histórica do processo de libertação humana da escravidão, do arbítrio, da opressão e do sofrimento. A noção de progresso está atrelada à consciência da liberdade entre os indivíduos e é subjacente a ampliação de uma atitude moral humana, de maneira que tal consciência se estenda à toda a sociedade em seu processo histórico de transformações.

Contudo, há conexão íntima entre os aspectos quantitativos e qualitativos do conceito de progresso. O caráter técnico parece ser a pré-condição de todo o progresso humanitário. Na sua vertente histórica, a ascensão humana, a partir da escravidão e da miséria, a uma liberdade cada vez maior, pressupõe o progresso técnico com um alto domínio da Natureza. Essa conexão é a única via que leva à riqueza social de forma a satisfazer as necessidades humanas; mas o progresso técnico não implica necessariamente progresso humanitário. A riqueza social, aquela que tem como prerrogativa o progresso técnico, é administrada, tanto na existência privada quanto na existência social, do berço ao túmulo e não é repartida de forma equânime entre os indivíduos, de acordo com as suas diferentes necessidades, como prevê um Estado de bem-estar totalitário.

${ }^{133}$ MARCUSE, Cultura e psicanálise, p. 112-139. 
O conceito qualitativo de progresso se encontra nos sistemas pré-científicos e, em seguida, nos socialista-científicos, mas este não é neutro, não é livre de valores, pois se mostrou, em sua realização, um projeto utópico. Os ideais que orientam a sua pretensão revelam, nos fundamentos filosóficos do conceito, uma tendência que neutraliza o próprio progresso. A base liberal, que se expressa por meio da ambição de liberdade, igualdade e fraternidade do século XVIII até a Revolução francesa, não encontra apoio no século XIX. Sem critério de valor que defina o progresso a partir do aperfeiçoamento técnico, requerido como ideal na Revolução Industrial, daí em diante, este se torna inseparável das pretensões do humanitarismo idealista. Seu valor mais elevado consiste no crescimento da produtividade, no sentido de dominação universal da natureza para a fabricação e aquisição de bens materiais e intelectuais. Tal aspecto qualitativo prevê, como norma, o poder igualitário dos indivíduos ao consumo.

A produtividade cada vez maior e mais acelerada de bens serve a satisfazer as necessidades de uma sociedade voltada para produção e consumo de mercado, cujo valor de uso busca, em escala crescente, um fim em si mesmo, e para além das necessidades de sobrevivência digna de todos os indivíduos. Do ponto de vista qualitativo, o progresso envolve o desenho de uma sociedade medianamente sustentada pelos valores voltados para o consumo.

Uma vez que a produtividade é inseparável do conceito moderno de progresso, a vida atual é sentida como trabalho: o próprio trabalho passa a ser a condição da vida, é concebido como socialmente necessário, sem ser satisfatório no plano individual.

Os conceitos de Labor, Trabalho e Ação, conforme Hannah Arendt os descreve, servem como contraste para que se compreenda a crise de valores que se instala na sociedade de consumidores. Arendt antecipa apropriadamente os problemas ecológicos para descrever a nova ordem no mundo do pós Grandes Guerras, como um projeto que supera a própria condição humana. 
A Terra é a própria quintessência da condição humana e, ao que sabemos, sua natureza pode ser singular no universo, a única capaz de oferecer aos seres humanos um habitat no qual eles podem mover-se e respirar sem esforço nem artifício. O mundo - artifício humano - separa a existência do homem de todo o ambiente meramente animal; mas a vida, em si, permanece fora desse mundo artificial, e através da vida o homem permanece ligado a todos os outros organismos vivos. Recentemente, a ciência vem-se esforçando para tornar "artificial" a própria vida, por cortar o último laço que faz do homem um filho da natureza. O mesmo desejo de fugir da prisão terrena manifesta-se na tentativa de criar a vida numa proveta, no desejo de misturar, "sob o microscópio o plasma seminal congelado [...] a fim de produzir seres humanos superiores" e "alterar-lhes o tamanho, a forma e a função", e talvez [essa esperança seja] o desejo de fugir à condição humana. (ARENDT, 2000a, p. 10-11)

Preocupada, como Marcuse, com o futuro da humanidade, Arendt observa que a humanidade parece motivada contra a sua existência, tal como nos foi dada. Tendo vivido a experiência do extermínio em massa com a lógica fria e a escala de uma linha de produção industrial, Arendt não duvida da atual capacidade humana de destruir toda a vida orgânica na Terra. ${ }^{134}$

Ela observa a crise que se instala como novos dilemas da liberdade, a partir dos primeiros efeitos do progresso técnico como grandes aquisições da ciência. Esta crise revela o possível divórcio definitivo entre o conhecimento e o pensamento. Dessa forma, Arendt observa que o progresso quantitativo não nos livrará da condição de escravos indefesos, não tanto de nossas máquinas quanto do nosso conhecimento. Ainda seremos as mesmas "criaturas desprovidas de raciocínio, à mercê de qualquer engenhoca tecnicamente possível, por mais mortífera que seja" (ARENDT, 2000a, p. 11).

Essa fala apresentada faz coro à discussão empreendida por Marcuse quando ele diz que o trabalho que se torna a própria vida é trabalho alienado, e tal posição, ainda que verdadeira, deve ser revista à luz da atualidade do discurso de Arendt na cena presente. Posto que o mundo do trabalho, em sua forma tradicional, está em franco retrocesso com a informatização e a robotização das linhas de produção, elevando as taxas de desemprego mesmo nos países desenvolvidos ou em desenvolvimento, o sentido do progresso conquistado pela opulência de mercadorias produzidas traduz, de fato, uma contradição.

\footnotetext{
${ }^{134}$ ARENDT, A condição humana, 2000a, p. 10-11.
} 
Entretanto, mais do que nunca, o conceito de alienação, associado à reificação, precisa ser revisto. A alienação como condição de subserviência às forças de dominação da massa ao consumo deve ser posta em causa. Se a sociedade está livre para consumir, a liberdade como fim em si, e rigorosamente dissociada da satisfação, torna-se liberdade infeliz diante da impossibilidade de aquisição de bens para o consumo.

Alijado das condições que inserem o indivíduo como incluído ou excluído, em uma sociedade cujo valor maior é medido pelo poder de consumo, sua liberdade aparece como um fardo, e quanto a isso, Marcuse tem razão. Nesse aspecto, a revolução proposta por Marx, como quebra de todo o sistema de exploração e mais valia na esfera do trabalho, é apenas uma dobra na história. Destituída do valor de Homo laborans, porque sem trabalho a condição humana afasta-se, cada vez mais, da natureza humana, e ao invés de o progresso ter proporcionado alegria, satisfação e paz, ele se mostra no seu reverso. Frustrada, sem poder consumir, ou consumindo com o sentimento de vazio dentro de si, a humanidade parece ter chegado a um profundo paradoxo.

vii Quaestio mihi factus sum, O que me tornei para mim mesmo?

A questão trazida por Arendt (2000, p. 18) se dá na indagação agostiniana: quaestio mihi factus sum? (a questão que me tornei para mim mesmo), dilema que a psicanálise expõe à exaustão, diante do mal-estar que o princípio de realidade impõe às conquistas obtidas pelo progresso tecnológico na busca obsessiva da ordem do prazer. A sociedade da opulência, no capitalismo tardio, comprova a incompatibilidade de se alcançar felicidade e liberdade com igualdade de condições a toda a humanidade. $\mathrm{O}$ ideal de progresso enfrenta, agora, a perspectiva de a natureza se voltar contra o homem. O princípio do prazer deve ser substituído pelo princípio da realidade, se quisermos que a sociedade humana não mais, simplesmente, avance do estágio animal ao humano. Para compreender a sobrevivência da humanidade, o esforço racionalista, como um todo, foi feito para mostrar que o melhoramento das condições humanas necessita que as forças irracionais, que o orientam pela pulsão de morte à sua destruição e à destruição da Terra, 
subordinem-se à razão. A afirmação freudiana Wo Es war, soll Ich werden ${ }^{135}$ (onde isso estava, como sujeito, devo advir) (Tradução nossa.) é a mais racional de todas as formulações que se possa imaginar em psicologia. A subjugação do princípio do prazer ao princípio da realidade é mais do que indispensável ao desenvolvimento da civilização: ele é condição da própria sobrevivência da humanidade e da Terra.

O que está em jogo é a cisão criada entre a necessidade de afirmação do homem pela sua própria estrangeiridade como ser de cultura, mas inserido na Natureza, e a aposta no desvelamento dessa condição. A sensação de vazio que pode advir não deixa de ser uma via dolorosa diante do mal-estar e do gradual esvaziamento narcísico de forças, que, de outra forma, não permitiria que o indivíduo se dirigisse ao outro, que o identifica e o singulariza como ser humano.

Tal via dolorosa compreende, da mesma forma, a identificação humana com as leis que regem a Natureza, que está em si, mas que só se faz compreendida e respeitada de acordo com as leis que estão para além do interesse de cada indivíduo. A questão mais crucial pode ser assim enunciada: a sociedade de apáticos é equivalente à descrição do quadro psicopatológico do autismo?

A utopia pessimista na passagem do século XX-XXI é ainda uma tentativa de resposta às condições que possibilitam uma reflexão para o enfrentamento dos efeitos causados pela desilusão diante dos ideais utópicos que lastreavam as tendências políticas em direção ao progresso da humanidade. $\mathrm{O}$ abandono desses ideais, que serviam de esteio à dissidência, aos movimentos da transformação social, e de estímulo para o caráter visionário dos intelectuais, deve enfrentar o esgotamento e a obsolescência das alternativas políticas diante do mal-estar e da falta de uma visão do futuro. ${ }^{136}$

\footnotetext{
${ }^{135}$ FREUD, Novas conferências introdutórias, (1933 [1932]), 1976 (Conferência XXXI: A dissecção da personalidade psíquica), p.102. (ESB, v. XXII).

${ }^{136}$ A necessidade de se retomar o fio do pensamento utópico encontra o desafio diante do impasse criado, por um lado, pelo conformismo da cultura de massa, e a sua aposta no multiculturalismo, festejada como rebeldia nas "tribos urbanas", por outro lado, devido ao impacto causado pelo pensamento de Francis Fukuyama (1989), Daniel Bell (1960), Christopher Lash (1969), que apostam no fim das alternativas políticas diante do colapso da idéia de identidade. A posição desses autores deve vir acompanhada, em paralelo, do texto $O$ fim da utopia (JACOBY, 2001).
} 
O desafio está em realizar a utopia no capitalismo tardio, tal como ela se apresenta no século XX, a partir do processo de ruptura com o saber fechado do historicismo, dotado de um sentido único - o da nação, que equivale dizer o do progresso. Em grande parte tributário da tradição historicista, seja porque esta permanecia ainda viva, ou adormecida onde menos se esperava, o século XX realiza as profecias do progresso, não sem pagar o tributo de tal objetivo com guerras de proporções inauditas.

O rompimento com a tradição historicista se reflete na mudança do paradigma que se estrutura na crença de que uma teoria de história é um pré-requisito para uma perfeita compreensão dos fenômenos sociais. Tal teoria deveria fornecer os padrões para uma crítica objetiva das instituições sociais que bitolaram suas funções e seus fins pelas potencialidades históricas da liberdade humana. Assim, não se desconhece mais que a psicologia está imbricada no poder político. Mais do que a soma total de opiniões e avaliações, a teoria política alia-se à psicologia para encontrar respostas à indagação sobre por que a liberdade e felicidade humana declinam no estágio de uma civilização amadurecida quando as condições objetivas para serem atingidas se apresentam maiores do que nunca.

A tendência das massas a apoiar e legitimar os regimes totalitários é visível na fragmentação do sindicalismo, indicando a dissolução da tradição marxista e as formas como o capitalismo é capaz de se moldar para acompanhar o ritmo das transformações. $\mathrm{O}$ declínio do pensamento e da ação política engajada não se explica apenas pela desilusão, pela apatia ou pela corrupção. A sociedade atual carece de novos paradigmas que estão para ser elaborados, fornecendo novas condições da liberdade.

O propósito de investigar as relações entre o poder político e a psicologia social parte das definições de poder que coexistem de forma conflituosa como controle da Natureza e controle do homem. O poder sobre a natureza não é senão um poder intelectual, e o conhecimento acumulado sobre as leis que regem a Natureza é o que representa a base da produtividade de qualquer sociedade. E, se assim é, a compreensão da legalidade sobre o uso da Natureza se dá com fins exclusivos para alcançar o objetivo final de submetê-la às necessidades da humanidade. 
viii $\mathrm{O}$ homem não é simplesmente uma peça na Natureza

O poder político é o poder social que se focaliza no Estado. Este trata do controle dos indivíduos submetidos às suas atividades legislativas, administrativas e jurídicas. Uma vez que o poder político é o controle de alguns homens sobre a sociedade, ele representa uma relação de ambigüidade em contraste com o poder que a humanidade exerce sobre a Natureza. O homem não é simplesmente uma peça na Natureza; ele se diferencia desta por se julgar um ser dotado de razão. Entretanto, aqueles que detêm o poder político são compelidos a criar reações emocionais e racionais sobre os governados, induzindo-os a aceitar, implícita ou explicitamente, as ordens de comando que emanam da liderança política. Quando essa liderança não consegue criar reações de obediência nos governados, de forma a manter o acordo social tácito que lhe garante o poder, a força das leis faz uso das instituições que o representam, instituindo a violência sob seu controle, podendo chegar à liquidação dos insubordinados.

O caráter bivalente do poder político revela que, essencialmente, o caráter político que organiza uma sociedade em torno de um líder está fora das ciências que estudam as leis da Natureza. O poder político não pode ser comparado ou enquadrado na categoria da energia na Física e não é a única categoria da ciência política. O caráter eminentemente político do homem, seja aquele que comanda ou aquele que se subordina, não é apenas a arte de conseguir algo sem levar em conta os meios e os fins para tanto. Os valores que regulam as relações políticas entre líderes e subordinados têm, por hipótese, as meras preferências pessoais, válidas se funcionam, ou inválidas se fracassam. A história ilustra a falta de sentido de uma repetição, indiferente à massa, entre os grupos que estão dentro e fora do poder. A fortuna, com seu caráter de transitoriedade, de aleatoriedade, e irracionalidade parece ser, assim, a base teórica para serem entendidos os aspectos psicológicos que subjazem às estruturas de poder. Ainda que tenha havido progresso material, ele apenas reflete as conquistas psicológicas, do ponto de vista qualitativo, que podem ser retratadas como o desenvolvimento típico de um indivíduo. A mesma irracionalidade que transparece como violência na luta entre a vida e a morte pelas 
conquistas alcançadas encontra respaldo nas teorias que descrevem o que é o poder e como ele reflete o caráter desumano da humanidade. ${ }^{137}$

A psicologia do poder está, inequivocamente, atrelada ao caráter bivalente da natureza humana. Formulada como uma hipótese, essa proposição não expõe uma visão otimista do que é a condição humana. Embora o indivíduo seja dotado de razão, esta não é guiada apenas pelos interesses de garantia da sobrevivência dele e de sua espécie. As contribuições da psicanálise são elucidativas, mas não chegam a fornecer uma teoria do poder político. A ação de cada indivíduo é o resultado da forma como ele se situa no ambiente que o rodeia e de como se apresenta, em sua singularidade, como personalidade no processo de identificação com seus pares. A própria personalidade é condicionada à história do indivíduo e dos processos de transformações do seu ambiente. O conceito de meio ambiente compreende as afinidades que existem entre o poder e a cultura do ambiente. Tal conceito se estende ao simples exercício contemplativo se for da conveniência da cultura do ambiente. A manipulação de tais valores revela a forma como o poder, invisível em sua força, pode alterar o equilíbrio entre a Natureza e a sociedade que nele habita como meio de subsistência ou para usos diversos e afins ao seu interesse.

Por um lado, os aspectos de apatia, cinismo e anomia se refletem como tipologia do indivíduo alienado nas estruturas de poder que o inserem, de forma indiferenciada, tanto na massa quanto sujeito em uma comunidade fechada. Tal indivíduo enxerga os problemas ambientais que ele provoca e que terminam por atingi-lo como se fossem circunscritos a um território delimitado, esquecendo-se que ele faz parte de um todo. A luta de grupos que aparentemente não têm causa política se localiza à margem das estruturas do poder oficial, moldando a sociedade de acordo com a imagem parcial ou local que os veículos da mídia criam artificialmente. Por outro lado, estes tendem a definir o meio ambiente como uma categoria virtual como se "o mundo" fosse unificado na sua diversidade, por meio da sociedade totalizada ou globalizada.

A luta armada no palco urbano não é apenas uma luta de grupos de poder pelo poder, mas, talvez, uma tentativa de obtenção de autonomia, da intenção oculta de moldar

${ }^{137}$ CASSIRER, 2003, cap. 10-12. 
o mundo de acordo com a imagem que os veículos da mídia o constroem, de fazer prevalecer os pontos de vista dissonantes com o status quo que é revelado como "a" realidade, porém, aquela realidade midiatizada.

Temporariamente, pode-se aceitar a implicação entre a formulação tradicional de que o campo da política contém tanto a luta de idéias como a luta pela conquista da força de dominação e de subjugação do poder e a psicologia - como parte substantiva na composição das forças que sustentam o poder -, sabendo-se que ela não está fora deste campo.

A estrutura de um romance convencional levaria em conta datas precisas a tempos de acontecimentos transcorridos. Entretanto, a disposição dos capítulos de $O$ homem sem qualidades é que estes são muito curtos, por vezes têm a estrutura de um conto, ou de um ensaio, suscitando a hipótese de um "tempo lógico" que não é passível de ser medido analogicamente. Os títulos lembram as anotações que um psicanalista faria no seu trabalho de escuta, enquanto a narrativa segue o curso livre do pensamento e a atenção, flutuante. Seu estilo irônico revela a apreciação do autor como a forma mais adequada para descrever aspectos que singularizam a modernidade. A falta de sentido nas ações do personagem demonstra, além do inacabado essencial, que as coisas acontecem ao não acontecerem. O clima desse absurdo é amenizado na velocidade dos fatos, na rapidez da circulação dos boatos, o dito e o não-dito, e acabam por criar a trama do mundo onde tudo acontece, mas as pessoas não têm tempo, não se dão conta de sua relevância para definir o seu próprio destino, e acabam por não percebê-lo de forma responsável.

O romance se desenrola sob o signo da indefinição: o homem sem qualidades é, antes de tudo, o homem sem definições. Ele está sempre pronto para o novo acontecimento. A falta de previsão sobre o que pode vir a seguir, como conseqüência de seus atos, é mais do que uma falta de reflexão. Ele reflete, mas, ao pensar, a tensão emoção-razão, antigo-novo aparece sem contradição. Se ele se pré-ocupa, suas reflexões não se estendem além da linha estreita do seu cotidiano. Estas revelam uma preocupação com a sua própria condição humana em uma modernidade mutante. Se tudo é vago, fluido, indefinido, Ulrich se prende aos signos, simples simulacros de um tempo pretérito, que o mantém em terra firme. Se há um eixo que dá coerência à sua vida, este é revelado pela 
antítese dos valores de seu pai. Suas reflexões servem como ponto de partida para o entendimento do homem que está entre a linha de forças que compõem a linha mediana dos acontecimentos que estão na base do capitalismo global. Sua falta de qualidades é emblemática para revelar a força dos regimes ditatoriais mais tiranos descritos, desde então, pela história política. A falta de qualidades é também um disfarce; ela é uma espécie de contraposição à ditadura da curva mediana para expressar o que está contido no comportamento da sociedade ocidental.

Marcuse é convocado para questionar se no universo do homem unidimensional haveria critério para distinguir o que é normal do que é patológico. Em uma sociedade na qual o crime é a norma medida em expressivas cifras estatísticas, haveria uma regularidade do crime, tal como este se torna a norma no Estado nazi-fascista. O critério para o comportamento desviante ou anormal na sociedade seria dado pelo arbítrio estabelecido de acordo com os interesses do Estado e não quando houvesse número excessivo de crimes cometidos por indivíduos. Tais posições equivaleriam a usar a mediana como um ideal secretado pela própria estatística quantitativa. Dessa forma, não se teria nenhuma prescrição de nenhum comando que não o próprio Estado. Seriam as próprias cifras manipuladas pelos órgãos de informação estatal que dariam o ideal da norma, distinto da lei.

Isolar a referência à norma permitiria ver que, embora ela seja extraída da estatística, decidir conformar-se à norma, fazer da norma a lei é uma escolha política. Em LHD de Marcuse, é possível encontrar analogias ao romance inacabado, O homem sem qualidades, de Robert Musil (1989 [1930-1933]). Em seu texto, entende-se que Marcuse queria construir, com argumentos filosóficos, o clima que dá base à trama do imaginário subjacente à cultura nazi-fascista ficcionada por Musil.

A leitura em paralelo desses dois importantes textos muito serve à compreensão da intolerância e do individualismo que se seguem na segunda metade do século XX e na entrada do novo século e permite compreender o abismo que se abre da norma à lei. A crítica filosófica de progresso na obra de Marcuse acompanha, assim, a ficção psicológica de Musil quando revela que a perseguição sistemática de todos os que se desviam em relação à norma pode ser um fator de estagnação na dinâmica da sociedade humana. 
O mérito maior de Musil que o leva a descrever o homem sem qualidades, de forma a, futuramente, corroborar o estudo da sociedade unidimensional de Marcuse, foi antever, com aguda precisão, como os cálculos estatísticos serviriam para determinar, na psicologia da saúde mental de um indivíduo, um novo tipo de destino que era até então desconhecido. O destino estatístico que pesa na escrita de Musil reaparece na crítica de Marcuse como o efeito mais visível para fazer evaporar o único e substituí-lo pelo típico.

As analogias entre o homem unidimensional de Marcuse e o homem sem qualidades de Musil se estendem à crítica filosófica do progresso a qualquer custo, sobretudo nos desdobramentos imputados à perda do caráter, típica do indivíduo que não encontra identidade com seus pares em uma sociedade em que a anomia é a regra institucionalizada. $^{138}$

Diante de tal perspectiva, é possível enxergar o mal-estar gradual que se instala como uma versão da morte do espírito absoluto como ponto de culminância da travessia do espírito humano, como aquele que vai da consciência de si em movimento de superação em direção ao ponto máximo do progresso da humanidade. A substituição do absoluto pela mediana, ou seja, pelo cálculo estatístico, é, para Marcuse, assim como para Musil, falar do verdadeiro como sendo suplantado pelo provável.

A entrada do indivíduo na quantificação traduz-se pelo que Musil nomeia como “desencantamento", o que acontece no decorrer de um episódio de seu grande romance, no qual seu herói, Ulrich, se vê levado a acreditar. Esse personagem acredita na ciência, que o levou a meditar sobre os efeitos da estatística quando estava, por força das circunstâncias criadas, no posto de polícia. Como diz Musil, de maneira requintada, Ulrich continuou capaz de apreciar, mesmo naquele momento, o desencantamento que a estatística infligia à sua pessoa. E o método de descrever os sinais de identificação e de mensuração que o policial lhe aplicava entusiasmou-o como um poema de amor satânico.

\footnotetext{
${ }^{138}$ Pode-se encontrar a ressonância dessa argumentação entre outros autores, tais como Bourdieu (2003, p. 255-279), Ortega y Gasset (2002) e Canetti (1995), quando identificam o espanto, a devastação, a deploração de filiação romântica dos intelectuais, dos escritores, dos artistas, diante daquilo que emerge como o homem das massas. Em consonância com estes últimos autores, as posições de Marcuse em Eros e civilização (1966 [s.d.]) descrevem a influência crescente das massas, tornando a compreensão do caráter humano algo cada vez mais mediano. Sua crítica à civilização estende-se ao crescimento específico daquilo que nela é o triunfo do mediano.
} 
De fato, Ulrich se encanta ao constatar que o operador disseca sua pessoa em elementos insignificantes, irrisórios e que, depois, a partir de tais elementos, pode recompô-lo, torná-lo novamente distinto dos outros e reconhecê-lo por seus traços. A operação policial, em questão, é a operação científica decomposta em elementos insignificantes.

Referindo-se aos aspectos que a sociedade tecnológica haveria de tomar como signo de controle e valor de medida - para englobar o particular na massa - , é possível reconhecer na passagem citada uma espécie de estoicismo, que, gradualmente, se instala como modo de vida apático do homem sem qualidades, no cosmopolitismo atual. Esse ideal condena todas as emoções e exalta a apatia diante do particular, como neutralidade ou imparcialidade do cientista, tendo-o como meta de sua prática na ciência. A referida posição é congruente com a visão de homem globalizado, assim como o é o cientista, que é cidadão não de um país, mas do mundo.

$\mathrm{Na}$ sociedade tecnológica do capitalismo avançado, a falta de qualidades revela, em negativo; o não deixa de ser uma nova moralidade, se considerada a forma irônica como o autor faz o personagem representar o absurdo "encantamento" com a normalização típica das instituições burocráticas. A orientação filosófica que guia o pensamento do personagem é, em seu modus operandi, como se ele se situasse no seio do estoicismo (MILLER, 2004, p.73-97).

A equiparação entre a apatia — significando um estado de indiferença, estranhamento, passividade e falta de interesse pelos fenômenos políticos é um comportamento ditado muitas vezes pelo sentimento de alienação. As instituições políticas e as demais manifestações da vida política ocupam, no horizonte psicológico do apático, uma posição bastante periférica. Ele não é nunca protagonista ativo de acontecimentos políticos, ao contrário, ele os acompanha como espectador passivo e, mais freqüentemente, ignora-os inteiramente. A apatia política é acompanhada do que se poderia chamar de uma baixa receptividade em relação aos estímulos políticos de todo o tipo e, freqüentemente, embora nem sempre, de um baixíssimo nível de informação sobre os fenômenos políticos. 
Norberto Bobbio (2004, p. 56) afirma que tal fenômeno está bastante difundido até nas modernas sociedades industriais de tipo avançado, que também são caracterizadas por altos níveis de instrução e de difusão capilar das comunicações de massa. O fenômeno se dá em regimes democráticos tanto quanto nos regimes autoritários e totalitários e, não obstante, a existência de mecanismos competitivos que, direta ou indiretamente, solicitam a participação do público nos primeiros, e a existência de mecanismo de mobilização e de enquadramento das massas, a partir de cima, nos segundos. Bobbio se pauta em pesquisas que fazem pensar que as taxas de apatia são mais freqüentes nas sociedades tradicionais em vias de modernização, tal como nos sistemas autocráticos do passado, antes da integração de grandes estratos de público na vida política. Esse autor verifica que os fatores ligados à apatia são múltiplos, e estão relacionados com certas propriedades estruturais dos sistemas políticos tais como visibilidade, acesso às informações e outras. Tais propriedades são consideradas características da cultura política de acordo com a presença ou a ausência de traços culturais ou subculturais, que premiam ou desencorajam o interesse pelos fenômenos políticos. Outros fatores de ordem sociológica, todavia, parecem variar bastante de sistema para sistema e ser também relevantes.

Num sistema político caracterizado por uma ampla apatia, as margens de manobra das elites que ambicionam o poder são maiores. Todavia, deve-se ressaltar que esta significativa diferença representa um obstáculo bastante sério quando o alcance de metas socioeconômicas pressupõe o envolvimento e a motivação de largos estratos da população. Do ponto de vista da dinâmica interna do sistema do equilíbrio de forças políticas, deve-se notar que a existência de grandes estratos apáticos constitui um reservatório não indiferente de potenciais participantes, que as elites governamentais e de oposição podem atrair e mobilizar, na tentativa, respectivamente, de reforçar suas posições ou de subverter as relações de forças existentes. (BOBBIO, 2004, p. 56)

Entretanto, quer-se ressaltar, com tal definição, que há um paralelo possível entre a apatia e a falta de qualidades (alem. Eigenschaften). O termo "sem qualidades" não equivale, na língua nativa de Musil, a proprietas - termo latinizado equivalente, na língua alemã - que significa "a predicação individual de uma característica atribuída, tanto a uma coisa, quanto de sua constituição como um todo". A falta de qualidades, tal como Musil a descreve, é diferente das conotações dadas pela psicologia como 
“disposições", tais como: atributos essenciais ou substanciais (permanentes); modos nãoessenciais ou acidentais (casuais); qualidades constitutivas (determinantes); propriedades consecutivas (derivadas); particulares (de apenas uma coisa); ou universais (compartilhadas com outras coisas).

Segundo Hanke (2004, p.129), a intenção da obra de Musil, cuja categoria central é a falta de qualidades, tem como base filosófica um distanciamento da terminologia ontológica estabelecida e seus modos de pensar. A posição que define a falta de qualidades é diferente da ontologia substancialista clássica, cuja visão de mundo consistiria em coisas (objetos, substâncias) determinadas por diversas qualidades (cores, formas, faculdades etc.), e interligadas por relações múltiplas. A tradição que define "qualidades" como tudo "que é ou pode ser" se reporta ao termo ente (coisas, qualidades e relações). Tal tradição diferencia a essência (alem. Wesen), como aquilo que o ente é, e sua existência (alem. Dasein), ou o fato que o ente é. Ao definir o que é o homem sem qualidades, Musil rompe com a tradição que reconhece as substâncias como núcleos da realidade do mundo, defendida na antiguidade clássica por Platão e Aristóteles, e tardiamente, por Descartes e Hegel. Tal tradição reconhece atributos de "qualidades" às substâncias, que servem como substratos ontológicos para a sua essência. De tal tradição, deriva a descrição do mundo nos moldes do esquematismo essencialista da metafísica ocidental, e seu desdobramento como cosmos ou ordo, começando pelas substâncias sensíveis e acabando em um ente supremo que lhes é inerente e externo ao mesmo tempo. Hanke discute os diversos autores comentadores da obra de Musil, de forma a demonstrar que ele não obedece à lógica aristotélica clássica, e rompe com o esquematismo que constrói pirâmides de gêneros abstratos a partir de substâncias e qualidades.

Segundo o mesmo autor (p.130), Musil não pretendia construir um relato ou uma descrição da sociedade de sua época. Sua intenção era examinar como a consciência moderna do indivíduo poderia situar-se diante do problema da realidade social. Musil assim como o fará Marcuse (1964), e em seguida, em sua crítica dirigida ao conceito de cultura (2001 a; 2001b [1965]) — descreve e critica os elementos centrais da sociedade na transição de valores herdados da modernidade, em um subseqüente quadro inacabado de desdobramentos. Sua temática abrange a dissolução, a erosão e colapso de um mundo envelhecido com suas formas de organização. A falta de qualidades seria o efeito de uma 
crise e mudança da consciência identitária que, desde a Idade Média, não tinha alcançado dimensões tão expressivas quanto se pode notar nesta obra literária de Musil. A transição é marcada pelo sentimento de decadência, perda da identidade com o sistema de organização social, e vácuo de tais valores diante do que seria a ambição de inovação moderna de alguns, cujo objetivo é politicamente situado como "progressista". A crise, que se estende da transição da modernidade aos tempos atuais, influencia os fenômenos da experiência do tempo e do espaço, da constituição da realidade e da auto-imagem dos indivíduos que se identificam com os valores da cultura ocidental moderna.

Assim, a obra $O$ homem sem qualidades revela, por meio de seu personagem Ulrich, certa aspiração por uma nova ordem. Ele leva em conta as tentativas sociais e privadas de recuperar o sentido de segurança no mundo antigo no seu aspecto mais conservador. Musil critica o conhecimento e a metafísica, mas, sobretudo, dirige sua crítica social ao plano místico, isto é, sexual-mítico que intervém na forma como os indivíduos se situam em época de transições. Tal mistificação se deve à impossibilidade de o personagem Ulrich conciliar as leis e convenções culturais com as exigências de uma vida segundo a ordem da Natureza. Seu comportamento revela traços de impudência, desfaçatez, descaramento. Sua filosofia de vida (alem. Lebenswelt) poderia ser chamada de cínica porque ela se opõe ativamente aos valores culturais vigentes, porém, o cinismo não tem o caráter virtuoso que é o traço original de uma forma de vida afastada de interesses materiais. Essa forma cínica está associada ao fenômeno da alienação do personagem em relação às mudanças referentes a uma nova ordem que se impõe, mas não está perfeitamente definida. Ela intervém na obra de Musil para mostrar setores autônomos e fragmentários da sociedade dirigidos pela racionalização baseada no cálculo e por uma eficiência que tinha a si mesma como fim, podendo-se encontrar em Marcuse extensão análoga à maneira de descrever tal fenômeno.

A alienação é, originalmente, entendida por Marx como um conceito inconcluso ${ }^{139}$, mas dirige-se, na sociedade tecnológica descrita em Marcuse, não apenas à esfera do trabalho. Especialmente, ela é uma condição repressiva individual, e grupal nos aparelhos

${ }^{139}$ MARX, apud. FROMM, 1962. 
anônimos e reificados da civilização como um todo; bem como a alienação é, conforme o mesmo autor, princípio que se presta à racionalidade instrumental.

O mundo da serialidade e da prática inerte, requerido como condição do indivíduo na sociedade tecnológica, é o reflexo da condição de tal homem sem qualidades. Sua crise existencial só seria revelada pela psicanálise freudiana, como alienação e mal-estar na cultura, quando, no capitalismo tardio, as finalidades que guiam os fins do progressismo iluminista mudam em anônima contrafinalidade, e os homens se tornam objeto de processos que não controlam mais.

Marcuse se pauta em sua leitura de Freud para dizer que, para haver inovação em uma sociedade, é essencial que a norma não seja a lei, e, nesse aspecto, o termo progresso, como inovação, está correlacionado à não-subjugação dos valores da massa; mais do que isso, essa inovação é revolução.

O raciocínio lógico de Marcuse (1998) vem acompanhado de sua leitura crítica da psicanálise freudiana, que, por sua vez, sustentaria a morte do Saber Absoluto do idealismo hegeliano. O Iluminismo (alem. Aufklärung) social — o "triunfo das Luzes na sociedade" - faria com que aquilo que não pudesse ser dito, exibido, massificado, como a repressão do erotismo humano, ressurgisse na possibilidade de libertação da humanidade com a psicanálise. Porém, Marcuse adverte que a psicanálise apareceu na época do homem sem qualidades, e, se ele está certo, a humanidade, como um todo, não saiu dessa época.

Para Adorno (1985), o Iluminismo não protegeria a humanidade da ameaça que haveria de pairar sobre o caráter mediano da massa, visto que o reino do cálculo, isto é, o avanço dos números em uma sociedade voltada para o progresso tecnológico, guiada por uma política tecnocrática, não deixaria de absorver as medidas quantitativas no domínio do psiquismo e não livraria a psicologia das pressões do nivelamento da norma para a compreensão do indivíduo e da sociedade.

Para se alcançar tal raciocínio, torna-se necessário compreender as diferenças conceituais entre alienação e objetificação. Este último conceito, nas correntes dialéticas contemporâneas, refere-se ao momento em que o homem dissocia o produzir, que lhe é 
próprio, do produto, de tal modo que o pode conhecer, tornando-o objeto da consciência. Para não se incorrer na posição idealista que o jovem Marx critica em Hegel, é oportuno destacar a força contra-revolucionária que há no seio do próprio capitalismo tardio que, sistematicamente, administra a gênese das transformações histórico-sociais.

A emergência do homem sem qualidades - aquele que Marcuse distingue como "unidimensional" na sociedade capitalista avançada - tem como contraponto a tarefa que a psicanálise tomaria a seu cargo na crítica da cultura. O modelo de escuta da psicanálise trata dos efeitos do sujeito na sua singularidade incomparável, na sua forma de constituir parte da sociedade ou no caráter típico de sua ação na cultura.

Marcuse não deixaria de antever as dificuldades que adviriam como infelicidade na cultura, ainda que houvesse progresso e opulência na ponta extrema do desenvolvimento da sociedade capitalista, se não se resguardassem as diferenças do que é próprio à natureza humana - o um por um, a difícil convivência do único com o outro. O autor ressalta aquilo que há em cada indivíduo, assim como está presente no seu outrem, e diz respeito ao que é, essencialmente, constitutivo da natureza humana e que nela habita, em seus avessos, como espécie de duplo. Se a identidade pressupõe uma equivalência entre pares, há que se pensar no campo do que não é idêntico, do que está contíguo, do que é oposto e, ainda assim, forma a identidade e não está excluído dela. A preocupação com o processo identitário humano, atualizada pela crítica marcuseana, torna a crítica filosófica atual mais do que necessária diante da expectativa de insurgência do homem unidimensional.

Para Habermas (HABERMAS et al., 1980), esses lados humanos têm avessos; eles são sentidos com absoluta estranheza diante do outro que está normatizado como unidade discreta em uma mediana que o engloba nos padrões de inclusão e exclusão em segmentos diferenciados da sociedade - como se houvesse critério único para decretar a democracia no mundo materialista do consumo. É o critério único que, de forma implacável, abre ou fecha as portas para o convívio em sociedade e faz do ideal de conformidade do indivíduo ao padrão uma realidade de convívio insuportável. 
Os eventos históricos que se desenrolaram no período entre e pós-guerras não se mostraram suficientes para resultar em qualquer síntese, indicando uma tendência da história em operar sem coerência frente ao princípio lógico dialético. Tese e antítese, em vez de se superarem, fundem-se, provendo um círculo vicioso incapaz de ser superado pela razão.

Pode-se, assim, pensar que o caráter aberto da obra $O$ homem sem qualidades revele paridade com as críticas empiristas voltadas para a impossibilidade de encontrar acesso ao eu mediante análises físicas, e de uma impossibilidade decorre outra, que é a sua representação integral. A dissolução do sujeito em complexos sensoriais isolados em qualidades sensoriais e perceptivas levou ao desvelamento da ilusão de identidade do eu unitário. Ao revelar o caráter de dissolução do conceito tradicional do eu como unidade, e ao romper com a doutrina que distinguia o indivíduo como elemento, Musil critica o conhecimento cientificista que se dá por meio da garantia de sua substancialidade. Influenciado pela compreensão monista psicofísica de Ernst Mach, Musil usa seus próprios argumentos para contraditá-lo. Se não se pode encontrar o "eu" a partir do fracionamento de seus elementos, também não é possível inferi-lo a partir das suas qualidades.

Musil traduz o monismo psicofísico de Mach na representação de um sistema anônimo de domínio social, que registra as relações fixas entre sujeito e objeto como marcas funcionais. Em outras palavras, o sistema de Mach desconecta as qualidades tanto dos sujeitos quanto de seus objetos e as insere como simples elementos funcionais na sociedade. 140 Conforme Hanke (2004, p. 132), "um homem sem qualidades consiste em qualidades sem homem", de modo que o pressuposto sistemático da falta de qualidades é a perda de substância na forma da perda do eu, o que implica uma "virtualização da personalidade".

Hanke ressalta que Musil era especializado em psicologia strictu sensu. Após ter-se formado em Engenharia em 1901, ele se matriculou em 1903, em Psicologia e Filosofia na Universidade de Berlim. Em 1908, ele se doutorou em Filosofia, nas subáreas Física e Matemática, ao defender tese sobre o monismo positivista de Ernst Mach, e teve como

\footnotetext{
${ }^{140}$ HANKE, 2004, p. 132.
} 
orientador o psicólogo experimental Carl Stumpf, discípulo de Brentano. Apesar de seu conhecimento da psicanálise, o próprio Musil negou ser psicólogo ou um escritor de textos de psicologia e, aos 30 anos, resolveu abandonar a carreira acadêmica, pouco antes de terminar a Livre-Docência, preferindo tornar-se escritor.

A falta de qualidades, nos termos da crítica marcusena dirigida à sociedade atual, expressa analogia com os efeitos da alienação social no cotidiano do homem sem qualidades. Ela pode ser inferida, como alusão, Ação Paralela ou "coisa similar acontecendo", marcando, entre dois "eus" virtuais, a dialética que se apresenta, mas que não denota a conexão mútua entre a pessoa do autor e a sua narrativa, dissolvendo a autonomia do sujeito em falta de qualidades ou em fenômenos pulsionais elementares.

A influência da psicanálise é decisiva para a compreensão de Musil quando ele expõe o "eu" que se revela sob a superfície das "qualidades" como um "efeito" apenas. O "eu" cindido se revela como efeito da luta pulsional entre a vida e a morte, Eros e Tanatos, que reside no fundo da natureza humana. De outra maneira, e sem que a negação aceite o seu oposto como antítese, Marcuse observa que há entre a humanidade uma insistência pela guerra e pela destruição. Seu operador é a pulsão de morte, tal como Freud a teria descrito ao propor uma revisão do primeiro modelo tópico de $O$ inconsciente (1915) para O Ego e o Id (1923). O resultado de tal revisão é a transposição do primeiro modelo do sistema inconsciente estruturado como linguagem, na sua forma substantiva, como uma noção indissoluvelmente tópica e dinâmica, para uma forma adjetiva; isto é: ele deixa de ser o que é próprio de uma instância especial, visto que qualifica não apenas intersistemicamente o id e, em parte, o ego e o superego. A formulação de novo sistema inconsciente intra-sistêmico (alem. unbewust, adjetivo de Unbewusste), onde o ego e o superego são em parte pré-conscientes e em parte inconscientes, gera uma espécie de circularidade que inunda o processo dialético, conforme teria sido proposto por Hegel, dando impressão a Marcuse de que a história encontrara um obstáculo ininteligível, tornando a razão, como a depositária da verdade, sem sentido.

Quando Freud descreve o $e u$, ele tem por objetivo diversas significações que nem sempre se preocupou em conciliar. Existe uma definição do eu como "aparelho percepçãoconsciência”, padrão de realidade. Mas há uma concepção genética e estrutural que torna 
impossível a manutenção da primeira. A introdução do conceito de narcisismo leva Freud à formulação do eu como uma "ação psíquica particular" e a defini-lo como unidade, totalidade imaginária, onde se aliena o sujeito. Isso é admitir que o eu não poderia ser tomado como referência privilegiada: pela própria natureza, ele faz parte de uma dialética em que aparece como uma Gestalt e como um termo. Não poderia a psicanálise centralizar-se, exclusivamente, no eu, termo indevidamente valorizado, se não se acompanhar todo o seu desenvolvimento dentro da obra freudiana, uma vez que, gradualmente, para Freud, ele é objeto e mesmo objeto de miragem para o ser humano.

Em sua obra $O$ mal-estar na civilização (1930[1929]), Freud recorre ao princípio de realidade para situá-lo como "doença da civilização". O desejo humano só teria chance de se realizar para além da oposição cúmplice do princípio de prazer e do princípio de realidade. A realidade, enquanto dado, cria um obstáculo à emergência da verdade; o eu, enquanto objeto, cria um biombo que impede a produtividade, ou o "progresso" do sujeito numa linha de disposição natural: uma e outro bloqueiam o movimento, são os próprios pontos de "resistência". Nesse raciocínio, sobressai a intenção totalizante frente à contingência histórica, tal como ela sustenta o pensamento hegeliano, sem que, por isso, haja evolução e progresso infinitos (MARCUSE, 1978, p. 363-370).

No plano político e social, a unidimensionalização da sociedade se manifestaria no capitalismo tardio, de forma mais decisiva, como introjeção dos valores do sistema em todos os segmentos da sociedade. Tal introjeção é ideologicamente sustentada pelos ideais de prosperidade global. Por sua posição central no processo produtivo, as classes que o representam não perdem sua significação objetiva como agente histórico de transformação. De forma diferente como seria vista na perspectiva hegeliana, Marcuse observa que, potencialmente, a classe operária é uma classe revolucionária "em si", mas não o é mais "para si". A perda de sua subjetividade, como alienação, esvazia a sua capacidade de ser a negação viva do sistema. O espaço de contestação radical é atenuado pelo sentimento de integração que caracteriza, em diferentes níveis, a sociedade unidimensional globalizada.

Atento à absorção da cultura pela civilização, Marcuse se vê obrigado a reformular suas teses da juventude, uma vez que encontra, na liberdade individual, um objetivo 
irrealizável nas condições totalizantes da cultura de massa. Ele observa que a fruição estética e intelectual das minorias, representadas pelos artistas e intelectuais, era assegurada pelas privações impostas à maioria, cujo trabalho gerava o excedente sem o qual a esfera da cultura careceria de base material.

O processo de globalização opera como espelho da massificação civilizatória e contribui para dissimular a violência silenciosa que há no processo de aculturação. Exatamente por funcionar como esfera relativamente autônoma, para além da civilização, tal processo de unidimensionalização global representa a nova ordem social como ideal de normatividade. Ele encobre a heteronomia, a "consciência infeliz" da humanidade, que lateja na cultura como memória da injustiça, integrando-a de forma não problemática na consciência feliz da ordem unidimensional.

O impacto estético deixado pelas imagens dos horrores das guerras e das trilhas imprevisíveis ocorridas dentro do movimento em busca do esclarecimento teria abalado os valores mais caros da civilização ocidental, se tais imagens tivessem, de fato, criado um hiato essencial. Porém, esse impacto é atenuado pela sua repetição na própria história: ele não é novidade, e já se encontrava em Platão a ilustração da forma como os homens se defrontam após as catástrofes que destroem as suas cidades, quando não são eles seus próprios destruidores: "solidão medrosa e sem limites, a terra imensa e abandonada, perecidos quase todos os animais e os bovinos e somente alguns grupos de cabras sobraram aos pastores, como resto mísero, para recomeçar a vida". ${ }^{141}$

Não só as vítimas ludibriadas, mas também os chefes de Estado haveriam de pagar o preço do progresso humano, fora das leis que regem a Natureza. Ao glorificar o herói, o sacrifício pela cidade, o Estado ou a nação, é ainda bastante atual a indagação marcuseana: as organizações humanas merecem o sacrifício de seus indivíduos pelo todo?

Ao enfrentar a sociedade e a cultura como um tabu, Marcuse (1968) lembra-nos de que o todo sempre foi mantido e imposto, tanto mais brutalmente quanto se supõe que ele é composto de indivíduos livres. Se assim é, o caráter inerente da agressividade como

${ }^{141}$ ABBAGNANO, 1982, p. 672. 
"aparato material e intelectual da sociedade tecnológica" haveria de ser confirmado nas descrições da condição humana. A contínua busca pela liberdade encontra-se em permanente contradição com o caráter idílico que se tem dela. A condição "real" de liberdade da sociedade, tal como é idealizada pela democracia, segue, no capitalismo tardio, a condição que Hobbes julgou própria do estado de natureza humana: a guerra de todos contra todos.

Preocupado com as incertezas sobre o destino da classe operária como sujeito da emancipação política, cujo espírito revolucionário seria capaz de resolver os dilemas das lutas de classes, absorvendo as diferenças entre interesses presentes entre os indivíduos de uma coletividade, Kellner (2001, p. 73-104) sugere queMarcuse não acreditava que as contradições entre razão e revolução seriam superadas dialeticamente, uma vez que o sujeito empírico estava ameaçado pelo sujeito revolucionário, e este não era ainda um capítulo virado da história, tal como pregava a cartilha socialista mais ortodoxa de sua época.

À guisa de ilustrar um canal paralelo de comunicação, seria interessante criar um diálogo para descrever um encontro fictício entre Musil e Marcuse em uma "sala de chat", como se estivessem congelados, por um instante, no plano virtual de uma intimidade ocasional e descompromissada, como é própria ao "ambiente" na atualidade, onde o que conta como valor, afinal, é o anonimato e as qualidades aparentes. Entretanto, o diálogo entre os gigantes do pensamento do século XX, ainda que numa realidade virtual, pretenderia alcançar uma reflexão aprofundada, e poderia ser a versão mais radical do que implica a sentença de Giambattista Vico: verum et fieri convertuntur (MARCUSE, 1978, p. 366) - "a verdade e o que se faz se confundem" - , que deveria se tornar norma entre os relacionamentos virtuais interpessoais daí em diante. A tarefa da crítica teria, assim, de se desvencilhar das reminiscências que ainda pairam na cultura representada por aqueles que crêem na organização fascista da sociedade e na adesão das massas por meio do terror.

Como salvaguarda para o progresso a qualquer custo, a crença no caráter indissolúvel e amoral da superioridade natural de um homem sobre outro requer mudança total no cenário da cultura atual. Sem que tal tarefa se realize, as angustiadas apreensões de Marcuse haverão de se cumprir como uma profecia "distópica", isto é, de acordo com a 
sua compreensão do que seria o advento do neofascismo como imposição a uma nova ordem no futuro.

O encontro virtual entre Musil e Marcuse se torna um campo para revelar como a cultura não foi abolida, mas incorporada à esfera da civilização. A grande arte e a grande filosofia revelam-se absorvidas pelo universo instrumental. Sem valor de "aura" no sentido benjaminiano $^{142}$, arte e filosofia se mostram dessacralizadas e incorporadas ao mundo profano da internet. Valores, outrora críticos, constituem simples mercadorias no capitalismo tardio. O diálogo que se prevê revelaria o resultado da reprodução em série nas comunicações de massa.

Entre os autores da Escola frankfurtiana, Marcuse é o pensador emblemático para mostrar que a fillosofia pode ser agente de ampla transformação paradigmática à psicologia social. Assim, também, a obra literária de Musil, O homem sem qualidades, foi escolhido por representar processos e efeitos das forças pulsionais inconscientes, que se exteriorizam como caóticas, diante dos dilemas que a sociedade deve enfrentar.

Pensar e vivenciar não são conceitos opostos, de forma que pensamentos e experiências de ficção podem reproduzir fenômenos de realidade social, que, de outra maneira, passariam desapercebidos por métodos de investigação tradicional. A psicologia está imbricada com a região de significados humanos peculiares, potencialmente traduzíveis pela literatura, podendo transmitir clareza e exatidão a assuntos correlatos em campos de pesquisa. A vantagem de analisar o conteúdo expresso na obra literária, como recurso de pesquisa, e que o distingue de qualquer procedimento científico, é que ele não exclui a subjetividade do cientista, podendo ser, metodologicamente, superior à compreensão do que acontece no psiquismo.

Ao captar e transmitir as transições e nuances mais sutis, que seriam imperceptíveis se fossem enquadradas em esquemas que ameaçam e excluem as multiplicidades desordenadas da vida psíquica, a função narrativa do autor destrói o nexo causal no qual se baseia a pesquisa psicológica. A narrativa ficcional dispensa os excessos

${ }^{142}$ BENJAMIN, A obra de arte na era da reprodutibilidade técnica, 1975. 
de envolvimento racional na busca da causalidade entre "fatos" ou representações. Ao estender o conceito de psiquismo para além da mera explicação de acontecimentos psicológicos reais, a obra $O$ homem sem qualidades pode levar à compreensão da perda de identidade e do senso de individualidade, ao revelar, em seu âmago, os fenômenos de anomia e alienação social. Fadado a ser lido como um fragmento, tal obra expõe a dificuldade de captar e separar o que é próprio do indivíduo. Seu roteiro indica ações paralelas que se juntam para compor o perfil do homem atual, e revela o que há de mais típico na era das relações midiatizadas: o sistema mundo, onde sujeitos são personas e, ao mesmo tempo, objetos na sociedade unidimensional sem qualidades. A obra é, assim, o espelho dos paradoxos da época atual, que, consciente da inexorável condição de transitoriedade, conjuga a condição da perenidade humana com anonimato e alienação.

Até este momento, a tese demonstra a importância da atitude política engajada que se quer efetivada pelo trabalho cotidiano da consciência, voltada não apenas para o controle e preservação da vida humana, mas para o controle e a preservação de todas as diferentes formas como a vida se revela em seus diferentes atributos. Tal posição reafirma a responsabilidade da psicologia social, como agente de transformação das mentalidades que hoje tendem, novamente, ao recrudescimento do fundamentalismo como resposta da desconstrução das identidades no processo de globalização até a autoficção gerada pelo individualismo exacerbado.

À guisa de conclusão parcial, que não deve se esgotar como conclusão da tese, a apreensão sobre o destino que homens sem qualidades impõem como imperativo catastrófico ao futuro se conjuga com uma advertência não moralizante, mas que deve se constituir em um novo ethos. Conforme Adorno (1993), uma minima moralia encontra sentido na dedicatória ao leitor:

\footnotetext{
A triste ciência, da qual ofereço algo a meu amigo, refere-se a um domínio que em tempos imemoriais era tido como próprio da Filosofia, mas que desde a transformação desta em método ficou à mercê da desatenção intelectual, da arbitrariedade sentenciosa, e, por fim, caiu em esquecimento: a doutrina da vida reta. Aquilo que "vida" significava outrora para os filósofos passou a fazer parte da esfera privada e, mais tarde ainda, da esfera do mero consumo, que o processo de produção
} 
arrasta consigo como um apêndice sem autonomia e sem substância própria. Quem quiser saber a verdade acerca da vida imediata tem que investigar os poderes objetivos que determinam a existência individual até o mais recôndito nela. Se falarmos de modo imediato sobre o que é imediato, vamos nos comportar quase como aqueles romancistas que cobrem suas marionetes de ornamentos baratos, revestindo-as de imitações dos sentimentos de antigamente, e fazem agir as pessoas, que nada mais são do que engrenagens da maquinaria, como se algo dependesse de sua ação. O olhar lançado à vida transformou-se em ideologia, que tenta nos iludir escondendo o fato de que não há mais vida.

A relação, porém, entre a vida e a produção, que rebaixa realmente aquela a uma efêmera manifestação desta, é em tudo absurda. Meio e fim vêem-se confundidos. O pressentimento desse quid pro quo insensato ainda não foi inteiramente extirpado da vida. $\mathrm{O}$ ser reduzido e degradado opõe-se tenazmente ao encantamento que o transforma em fachada. A própria mudança das relações de produção depende largamente do que se passa na "esfera do consumo", mera forma de reflexão da produção e caricatura da verdeira vida: na consciência e no inconsciente dos indivíduos. É graças apenas à sua oposição à produção, como uma esfera que apesar de tudo não foi inteiramente alcançada pela ordem, que os homens podem criar uma ordem mais digna. Uma vez extinta inteiramente a aparência de vida, que é defendida por razões tão más pela esfera do consumo, a essência desnaturada [alem.Unwesen] da produção absoluta triunfará. ${ }^{143}$

${ }^{143}$ ADORNO, Minima moralia, 1993, p. 7-8. 


\title{
PARTE III
}

\author{
QUINTO CAPÍTULO
}

\section{$O$ pensamento unidimensional na base da modernidade}

- O homem unidimensional é também o homem sem qualidades

O pensamento bidimensional nasceu com a filosofia grega. O seu contrário, o pensamento não negativo unidimensional, dali decorre igualmente. À primeira fase da abstração conceitual, que deu origem ao discurso socrático, e à sua dimensão subversiva, ao distinguir a essência da existência, o dever-ser do ser, as virtualidades das formas imóveis, sucedeu uma segunda abstração, que dividiu o universo num domínio do pensamento, distinto do domínio da realidade existencial. A filosofia construiu assim um reino da razão, livre das contingências históricas e empíricas. Aristóteles lastreou esta fuga da realidade com um regresso a uma realidade transcendente - Deus, que atrai o mundo inferior como causa final. Em Deus se reconciliam o logos e o Eros, razão e liberdade. É em definitivo o que, no termo de um empreendimento de destruição sem igual até ele, Hegel escolheu, seguindo Aristóteles, o caminho da unidimensionalidade transcendente.

Mas, paralelamente à sua metafísica, Aristóteles pretendeu criar uma espécie de álgebra do pensamento, ou lógica formal, cuja finalidade era definir as formas gerais do pensamento. O conceito tornado sujeito formal perdeu, de uma só vez, as suas virtualidades e as suas significações antagônicas, dado que Aristóteles o substituiu por uma letra. Do mesmo modo para o predicado. Desde então, as diferenças apagam-se entre os objetos: "quer sejam mentais ou físicos, quer pertençam à sociedade ou à Natureza, estão sujeitos às mesmas leis gerais de organização, de avaliação e de conclusão - , mas são-no como signos ou símbolos intercambiáveis, abstraindo da sua substância particular." 144

${ }^{144}$ MARCUSE, LHD, p. 160. 
Eis instituída a primeira condição da ordem e do controle universal. "O conceito geral que a lógica discursiva desenvolveu tira a sua realidade do princípio da dominação" ${ }^{145}$, naquele sentido em que o universal autoriza uma manipulação cômoda dos casos particulares. Embora ainda ligada ao conteúdo formalizado, a lógica de Aristóteles é o primeiro passo que conduzirá ao pensamento científico, pois passa uma esponja sobre os conflitos entre a essência e a existência, o ser e o parecer, excluindo as causas finais e separando a identidade da contradição. Além disso, "anuncia como mais tarde se reduzirão as qualidades segundas em qualidades primeiras, graças ao que as qualidades secundárias se tornarão propriedades que a física poderá quantificar e controlar. Na medida em que a sua lógica se extenuou numa analítica, Aristóteles instaura um liame entre a racionalidade pré-tecnológica e a racionalidade tecnológica. ${ }^{146}$

$\mathrm{Na}$ esteira do Organum ${ }^{147}$, desenvolveu-se a lógica matemática e simbólica da época contemporânea, por intermédio da algebrização da geometria, que substituiu, por sua vez, as figuras por operações puramente mentais. ${ }^{148}$

Daí em diante, a idéia de uma substância objetiva, distinta e independente do sujeito cai por terra. Privada da sua interpretação em termos de metafísica platônica e pitagórica, a natureza é uma natureza matematizada, a realidade científica parece uma realidade de idéias ${ }^{149}$, a menos que não esteja ligada às virtualidades qualitativas. Ora, a quantidade é uma forma vazia para Hegel, um caráter exterior do ser que o depura de todo o conteúdo e autoriza a utilização de símbolos indiferentes.

Essa esclerose do pensamento formalizado não se deu sem arrastar consigo a perda de força da filosofia e, mais particularmente, da metafísica. É o que Marcuse verifica ao examinar o problema dos universais: "a filosofia analítica contemporânea encarniça-se em exorcizar os mitos, fantasmas metafísicos tais como a consciência, o espírito, a vontade, o

\footnotetext{
${ }^{145}$ HORKHEIMER; ADORNO. Dialética do esclarecimento. Apud, MARCUSE, LHD, p. 25.

${ }^{146}$ MARCUSE, ibidem, p.162.

${ }^{147}$ Chama-se Organum ou Organon ao conjunto organizado pelos comentadores gregos de tratados das obras lógicas de Aristóteles. Nele estão contidos: o livro das Categorias; o livro da Interpretação; os dois livros dos Analíticos primeiros; os dois livros dos Analíticos posteriores; os oito livros dos Tópicos e o livro dos Elencos sofisticos. Todavia, o título Organon não tem relação exata com a tarefa atribuída à lógica. ABBAGNANO, 1982, p. 704.

${ }_{148}$ MARCUSE, ibidem, p.171.

${ }^{149}$ MARCUSE, LHD, p.172.
} 
ego, ao dissolver o conteúdo desses conceitos em fórmulas que enunciam operações particulares, realizações, forças, tendências, especializações particulares e precisas. ${ }^{150}$ Marcuse detecta essa ameaça no ego cartesiano: na medida em que o ego se aparenta com a res extensa, ele seria o protótipo do sujeito científico, para quem a Natureza não é mais que uma refração do sujeito, nunca do sujeito hegeliano, saturado de virtualidades, mas do sujeito que observa e mede ${ }^{151}$. Em tal contexto, os universais se degradam e se reduzem a formas de comportamentos mentais e físicos. Traduzidos em comportamentos, os conceitos de espírito ou de ego apresentam um aspecto mistificador, quando é precisamente esta tradução que é mistificadora pelo fato de abrir para uma realidade mutilada e reprimida. ${ }^{152}$

Isso se torna mais evidente ao se examinarem universais tais como nação, estado, constituição, pátria, partido, universidade ou o próprio sujeito. Os indivíduos que falam em seu nome não são mais que os representantes dos interesses que essas organizações detêm. A sua decisão não lhes pertence: "julga-se morrer pela pátria, morre-se pelos empresários." ${ }^{153}$ Assiste-se à coisificação dos universais, sob as aparências de universalidade, apenas exprimindo-se instituições egoístas e desumanas. Tal pensamento voltado para uma coexistência humana pacífica está longe de tangenciar os conceitos hegelianos ou os universais marcuseanos.

É o positivismo que encarna o processo da coisificação. Para essa concepção filosófica, todo o caráter transcendente e metafísico deve ser repudiado. Segue-se que os conceitos filosóficos vão ao encontro do concreto na medida em que a realidade se deixa docilmente encerrar na ciência e na sociedade na esfera tecnológica. Nessa ótica, o mundo-objeto reduz-se a instrumentalidades. Com Saint-Simon, a metafísica, cujo valor era devido à impotência da ciência, perde o seu caráter racional ao mesmo tempo em que a ciência progride. Ela já não é mais que o aspecto residual do esforço de conhecimento científico. Sobre tal posição, por um lado, Wittgenstein afirma que "a filosofia deixa toda a coisa como ela é". ${ }^{154}$ Por outro lado, Hume considera que esse desdobramento evita as

\footnotetext{
${ }^{150}$ MARCUSE, LHD, p. 227.

${ }^{151}$ Ibidem, p. 176.

${ }^{152}$ Ibidem, p. 228.

${ }^{153}$ Ibidem, p. 231.

${ }^{154}$ WITTGENSTEIN, apud. MARCUSE, LHD, p. 196.
} 
aventuras inúteis do pensamento e garante boa adaptação ao meio, tal como ele nos é dado. Para Marcuse, trata-se de "auto-humilhação, de autodenúncia dos intelectuais, cujo trabalho não produz realizações científicas, eles são a prova do sadomasoquismo acadêmico. $^{155}$

Sob o prisma de discussões postas por Marcuse, os filósofos que desempenharam o papel mais danoso ao pensamento negativo foram Comte e Stahl. O primeiro porque se dirigiu contra a herança de Descartes e das Luzes. O segundo porque foi contra a filosofia negativa de Hegel. A dupla finalidade que os positivistas perseguiram consistiu, por um lado, em vencer toda a subordinação da realidade à razão dialética e transcendente ao dado e, por outro, em tornar os fenômenos dóceis às leis que neutralizam os seus antagonismos. Ao esclerosarem todo o real dos fatos aparentes, ao tornarem sagrado o estado de fato, estes filósofos assentaram as bases do positivismo moderno. Eles censuraram em Hegel a atitude de negar as coisas tais como elas são com motivo na sua orientação conceitual, bem como a recusa ao dado, em dar-lhe a sua dignidade ao considerá-lo como limitado, transitório e negativo. ${ }^{156}$

Ao encorajar a abdicação do pensamento perante o dado e o estado de coisas existente, Marcuse observa esta conseqüência mais grave: o positivismo impediu a interpretação dos fatos nas categorias de uma crítica geral do próprio dado, e esta falta de recurso e de humor, em relação ao dado, constitui um vício.

Foi o positivismo radical e sem falhas de Comte, que proporcionou uma ciência independente: a sociologia. Daí em diante, a sociedade é encarada como um complexo mais ou menos circunscrito de fatos regidos por leis mais ou menos gerais ${ }^{157}$, o que permite que os conceitos utilizados sejam extraídos dos fatos e, conseqüentemente, a serviço da ordem estabelecida. Ao contrário de Hegel e Marx, o imediato é o real, e o natural constitui o racional. Comte exorciza a pretensão do homem em modificar as

\footnotetext{
${ }^{155}$ MARCUSE, ibidem, p. 196.

${ }^{156}$ MARCUSE, LHD, p. 374.

${ }^{157}$ MARCUSE, ibidem, p. 388.
} 
instituições sociais segundo a sua vontade racional ${ }^{158}$, de maneira que a negação se faz suprema virtude.

E o que fazer senão resignar-se, quando as leis naturais, logo, sociais, são invariáveis? Se elas constituem a expressão da razão, se o progresso faz parte dos mecanismos estabelecidos, as classes sociais são necessárias, e também a propriedade, assim como o governo que as protege. Em contrapartida, a imaginação deve ceder o lugar à observação e ao trabalho, a espontaneidade do pensamento às suas funções passivas. Nenhuma evasão é já possível para uma ordem superior: em tudo à sua volta o homem encontra as leis de coexistência e as leis de sucessão e o tempo, tal como o espaço, estão escalonados pela segurança racional. As virtualidades devem estar submetidas a ela. A submissão é tanto mais razoável quanto o positivismo mergulha na relatividade, pois a verdade é relativa aos fatos e à tolerância universal ${ }^{159}$.

Dessa maneira, o positivismo seria a solução de todos os antagonismos. Acrescida às posições defendidas por Comte, a idéia de autoridade, tal como é concebida por Sthal, vai culminar na submissão absoluta dos indivíduos ao Estado, e daí passa-se a deduzir que o indivíduo desapossado do pensamento negativo, da sua imaginação, está literalmente emparedado, logo que absorvido pela sociedade. Tal conclusão vai ser reforçada pelo exame das diferentes atividades dos homens, quando fundadas na lógica matemática e no pensamento positivo.

- Quantidade e qualidade como critérios de predicação do sujeito

Se o positivismo se constituiu ao privilegiar os fatos e o método científico, Marcuse observa que a racionalidade tecnológica é o efeito da integração da ciência e da técnica. A lógica formal do organum e a lógica simbólica moderna castraram o

\footnotetext{
${ }^{158}$ MARCUSE, $L H D$, p. 391, 392.

159 Marcuse esclarece que não se trata da tolerância do século XVIII, mas do conceito formalizado da tolerância às forças de repressão. MARCUSE, Raison et révolution. Hegel et la naissance de la théorie sociale, 1968, p. 407. Há tradução do original inglês para o português: Razão e revolução: Hegel e o advento da teoria social, 1978.
} 
pensamento ao que elas são capazes de suprimir a sua força de negação, a única capaz de detectar o irracional da realidade estabelecida, a qual funda a racionalidade positivista. ${ }^{160}$ A ciência degrada a filosofia, quando esta se torna positiva, incitando-a a abandonar os juízos de valor transcendente em favor da análise. Os valores filosóficos tradicionais eram impotentes para transformar a Natureza, e a ciência, para se tornar eficiente, devia se desligar da filosofia. Traduzida em ação, a realidade perde a espessura, o dever-ser perde a sua importância capital à ciência. A pergunta "Que é" passa a ser funcional. O ser como ser passa a ter caráter operacional em sua nova versão de ser como instrumento. E se a filosofia científica começou com a noção de duas substâncias, a res cogitans e a res extensa, a segunda perdeu o seu caráter de substância independente pelo fato de que a matéria vasta foi expressa por equações matemáticas, que, traduzidas numa forma tecnológica, recriam essa matéria ${ }^{161}$.

Um passo mais, e a ciência se faz tecnologia. Eliminar as substâncias independentes e as causas finais equivale a voltar à formalização da idéia de objetividade, na seqüência da qual o objeto se constitui a si mesmo numa relação quase prática com o sujeito. A esse passo, a matéria é definida como objeto suscetível de ser manipulado pelo homem. ${ }^{162}$

Quando esse operacionalismo está no centro da empresa científica, a racionalidade toma a forma de uma construção metódica, organiza e trata a matéria como simples substância de controle, como uma instrumentalidade que tende para todos os objetos e todos os fins - uma instrumentalidade per se, em si mesma. Isso acontece de maneira que o logos conforme é uma tecnologia. Por si mesma, a ciência e a sua instrumentalização, como pura objetividade, são depuradas de todo o fim, ou telos: são neutras. A conseqüência mais próxima e visível é que o sábio, como tal, não podendo explicar a Natureza com a ajuda das causas finais, encontra-se à margem das suas funções humanas tradicionais - ética, política e estética —, em exclusivo benefício de seu observador. De maneira que o verdadeiro e o bem, a ciência e a ética não têm qualquer relação intrínseca, e, como conseqüência, a neutralidade parece ser a característica fundamental da

\footnotetext{
${ }^{160}$ MARCUSE, LHD, p. 163.

${ }^{161}$ Ibidem, p. 175, 169.

${ }^{162}$ Ibidem, p. 179.
} 
racionalidade tecnológica. Na conjuntura social atual, numa sociedade em que a metafísica foi repudiada pela lógica matemática, e, uma vez que a lógica matemática passa a ser, pelo positivismo, a projeção filosófica, qualquer referência à sensibilidade deve ser banida, e a qualidade, como valor, deve ser relegada. O caráter imponderável da sensibilidade passa a pertencer ao campo insustentável à medida da subjetividade.

Enquanto a ciência liberta a Natureza de todos os fins inerentes e somente concede à matéria qualidades quantificáveis, a sociedade liberta os homens da hierarquia natural. Fundada na dependência de pessoa para pessoa, para uns aos outros, segundo os critérios de quantidade, ou seja, como unidades de força de trabalho, estas podem ser avaliadas em unidades de tempo ${ }^{163}$. A Natureza e o homem estão assim frustrados das qualidades e dos fins, que são, para Marcuse, universais. Em outras palavras, a partir da quantificação das qualidades secundárias, a ciência procederia à quantificação de valores ${ }^{164}$.

Se os valores, as finalidades, as qualidades, a essência do homem e a liberdade são quantificáveis, os antagonismos entre ser e dever ser, existência e essência, são literalmente absorvidos, mas em detrimento do dever-ser e da essência. O pensamento esgota-se no unidimensional, a consciência coisifica-se no nível da quantificação geral das coisas e dos seres ${ }^{165}$. A conseqüência moral é o desaparecimento da culpabilidade: a consciência é feliz. A esse processo, Marcuse nomeia dessublimação.

Se isso é verdade, então se pode afirmar não só que a racionalidade tecnológica é neutra, mas ainda que ela neutraliza a Natureza e o homem em sua totalidade, e de tal modo que à instrumentalização da Natureza se juntaria uma instrumentalização do homem. Tais considerações se revestem de uma singular importância, e torna-se relevante perguntar, com Marcuse, se a quantificação social é paralela, ou se ela está numa relação de causalidade com a quantificação científica ${ }^{166}$. Em outros termos, existe uma associação fortuita ou premeditada entre razão prática e razão teórica?

\footnotetext{
${ }^{163}$ MARCUSE, LHD, p. 180.

${ }^{164}$ Ibidem, p. 256.

${ }^{165}$ Convém notar que, se os antagonismos fossem resolvidos em proveito do dever-ser ou da essência, se, portanto, a metafísica se tornasse imanente à ciência, essa quantificação teria uma significação inteiramente diversa. MARCUSE, ibidem, 256.

${ }^{166}$ MARCUSE, ibidem, p. 180.
} 
Para Marcuse, a resposta não poderia estar em dúvida: a neutralidade da ciência e da técnica é ilusória, pois envolve, a priori, uma dupla direção. O contexto tecnológico define em primeira instância a forma na qual os objetos devem aparecer ${ }^{167}$, o que significa que o projeto de conhecimento pelo qual o cientista desenvolve operações sobre os objetos está contido em e depende do seu universo de discurso e de ação; os fatos científicos são fatos de certa maneira, tal como os dados são dados: "As estrelas que Galileu observava eram as mesmas estrelas que se viam na Antiguidade. Mas o universo do discurso e da ação tinha mudado. A realidade social abrira um novo ponto de vista para a observação, descobrira os meios de ordenar os dados". 165

No projeto de conhecimento articula-se um projeto histórico fundado em um $a$ priori político, uma vez que o mundo-objeto é o meio em que se elabora a prática histórica que compreende uma escolha determinada para apreender e organizar a realidade: "A escolha inicial determina a série de desenvolvimentos que se oferecem nesta direção, elimina as escolhas que não são compatíveis com ele." ${ }^{166}$ Em outras palavras, o projeto, ou terminus a quo, depende do projeto histórico, ou terminus ad quem, e isso é possível uma vez que a formalização da ciência se presta indiferentemente a todos os fins.

Mas essa formalização é pretendida, ela não é, per se, uma relação de causalidade ligada a uma determinada sociedade. A ambigüidade que justifica a questão de saber se os dois sistemas de quantificação, científico e social, eram, ou não, dependentes, provém do fato de a sociedade querer provar o seu liberalismo, e a sua neutralidade, ao se declarar dependente da neutralidade científica, tecnológica e da sua racionalidade. Mais precisamente, o sujeito oculto da racionalidade científica, que justifica e verifica a ciência como forma pura e o mundo como objeto, é o processo político: “É unicamente por intermédio da tecnologia que o homem e a Natureza se tornam objetos de organização mutáveis entre si, em benefício dos interesses particulares que se dissimulam por detrás de uma produtividade e de uma eficácia novas." $" 167$

\footnotetext{
${ }^{167}$ MARCUSE, LHD, p.243.

165 Ibidem, p. 181.

166 Ibidem, p. 243.

${ }^{167}$ Ibidem, p. 191.
} 
Conseqüentemente, os princípios da ciência moderna foram estruturados a priori, de uma maneira tal que puderam servir de instrumentos conceituais a um universo de controle produtivo que se renova por si mesmo, pelo que o operacionalismo teórico chegou a coincidir com o operacionalismo prático. Assim, o método científico permitiu o domínio da Natureza cada vez mais eficaz, forneceu também os conceitos puros, embora tivesse fornecido, da mesma forma, o conjunto dos instrumentos que favoreceram o domínio do homem pelo homem cada vez mais eficaz, mediante o domínio da Natureza.

Tal esquema de dominação é tão radical que põe o homem em situação de aceitar, como razoável, a supressão da liberdade e, paralelamente, como irracional, uma liberdade que apenas poderia advir fora do domínio definido pela ciência e organizado pela técnica. Não só a racionalidade tecnológica, isto é, a ciência e a técnica como integradas numa ideologia social de domínio, o capitalismo, não contesta a legitimidade do domínio, mas defende-o de tal modo que a sociedade das democracias atuais é uma sociedade racionalmente totalitária. ${ }^{168}$

Os homens têm cada vez menos consciência de que essa razão lógica decorre da lógica matemática e do positivismo, cuja razão é a antítese da verdadeira razão que Hegel e Marx definiram. Cada vez menos, os homens são levados a contestar esse domínio, isto é: ao melhorar o seu conforto, eles multiplicam as suas liberdades imediatas e o grau de tolerância se estende às piores excentricidades nos mais diversos domínios.

Mas como se deixaram os homens se integrarem na racionalidade tecnológica? Como pôde o homem esquecer a sua essência, a sua dignidade, os seus valores, as suas virtualidades indefinidas? Como pôde ele apagar de sua consciência a recordação das atrocidades cometidas nos campos de concentração ou impedir-se de pensar nas ameaças da guerra atômica? Como chegou ele a aceitar uma sociedade onde reina o domínio do homem pelo homem, o esbanjamento mais desenfreado dos bens de consumo e por decorrência, a degradar o seu próprio ambiente? Como se fez possível a submissão à opressão alucinante que ele escalona a cada momento de sua existência, na fúria consumista dos dias atuais?

${ }^{168}$ MARCUSE, LHD, p.191. 
O que teria acontecido para que o homem perdesse a consciência infeliz que habitava pobres e ricos das cidades antigas até a Renascença? Pelo menos, sob a perspectiva dos historiadores que narram a história humana, a injustiça era flagrante e sem desculpa. O bem e o mal, o verdadeiro e o falso, o belo e o feio não tinham possibilidade de ser confundidos na linha das tradições culturais que os separavam de acordo com atributos. Nenhuma racionalidade manipulava as consciências, e os caminhos da transcendência - moral, econômica, política ou artística - estavam abertos e traçados, assim como os da esperança ${ }^{169}$.

Sem pretender encontrar todas as respostas às indagações cruciais à compreensão dos tempos atuais, será preciso analisar mais do que a técnica que desloca, em todos os níveis, a sociedade contemporânea. Mas há que se pautar pelos limites impostos pelas formalidades requeridas às exigências de formato e prazos da pesquisa acadêmica. Hipóteses e modelos de investigação já deveriam ser suficientes para compreender por que homens se submetem a ficar imersos, por sua própria vontade, na racionalidade tecnológica. Depois de todo o conhecimento técnico e científico acumulado, como e por que os homens agem como se desconhecessem ou estivessem apáticos diante das conseqüências de tal submissão voluntária?

${ }^{169}$ MARCUSE, ibidem, p.84. 


\section{SEXTO CAPÍTULO}

\section{O totalitarismo aperfeiçoado pela aldeia global}

- A linguagem coisificada do homem sem qualidades

As palavras são os símbolos dos conceitos. Se os conceitos exprimem a verdadeira realidade, então a linguagem autêntica deveria ser aquela dada pelas perspectivas do pensamento hegeliano. Entretanto, pela relação com o pensamento positivo, esses conceitos revestem um excesso de significação que os torna pouco manejáveis e tão pouco eficazes que a ciência teve que se libertar deles e abandoná-los à metafísica. Desde então, a ciência fez as suas provas e o fez tão bem que a filosofia positiva tomou o caminho ao reduzir os seus conceitos à sua função social depois de ter reduzido a ciência a uma estrutura operacional. A partir de então, a linguagem deverá ser o objeto de um esgotamento semântico. "Se é preciso empregar as palavras linguagem, experiência, mundo", diz Wittgenstein, "que seja tão simplesmente como as palavras mesa, lâmpada, porta." 170 A linguagem, nessas condições, deve deixar de designar os verdadeiros conceitos ou os universais, para só designar objetos. "Devemos acabar com tudo aquilo que é explicação para dar lugar apenas à descrição."171 Sob forte abordagem psicológica do homem, reduzindo a palavra a clichês e, como clichê, "reina na linguagem falada ou escrita; a comunicação impede, desde então, um autêntico desenvolvimento do sentido". ${ }^{172}$ A redução da linguagem ao comportamento apresenta a vantagem, aos olhos dos lingüistas sob a influência do behaviorismo, de aderir ao concreto. Assim, a linguagem verdadeira é a do homem da rua. Desse ponto de vista, a análise lingüística da pesquisa deveria desalojar da linguagem o vocabulário e os signos que exprimem um conteúdo que excede aquele que a sociedade fornece. A filosofia lingüística apaga assim "aquilo que é essencialmente suprimido nesse universo de discurso e de comportamento" $" 173$. Entretanto, se a análise lingüística se lança em busca das estruturas fundamentais, então não resta

\footnotetext{
${ }^{170}$ WITTGENSTEIN, Philosophical investigations, 1960, p.44, apud., MARCUSE, LHD, p.201.

${ }^{171}$ Ibidem, p.49, 61, 62, apud. MARCUSE, ibidem, p.197-223.

${ }^{172}$ MARCUSE, LHD, p. 112.

${ }^{173}$ MARCUSE, ibidem, p.198, 122.
} 
mais do que o esqueleto do discurso, que é ainda mais fantástico que a referência ao concreto que ela analisa ${ }^{174}$.

Sob o impulso do behaviorismo e da análise lingüística, o conceito acabou por se degradar em imagens, pelo imediatismo e univocidade nas quais se esgota. Nada melhor para apagar o pensamento do que identificar uma coisa à sua função, ela própria reduzida a uma imagem.

Partindo da linguagem literária crítica de George Orwell sobre o uso abusivo de siglas para encobrir as contradições que identificariam as verdadeiras intenções usadas em um nome, Marcuse observa que tal crítica se refere ao discurso público, sobretudo naquilo em que ele deixa de designar funções ou objetos, porque esse é o papel do conceito tecnológico. Com a finalidade de designar o comportamento conforme as regras politicamente aceitáveis ou corretas, estas o revelam como essencialmente artificial, o que acentua a degradação, ou, ao limite, a própria depravação da linguagem. Tais clichês, repetidos ad nauseum pela mídia, efetivamente são as palavras-chave, os predicados analíticos dos discursos "à Ocidente e à Oriente". Eles também se prestam ao Leste da Europa e à grande extensão da China comunista. Operários, camponeses, sem-terras, semteto, párias, excluídos, outsiders, terroristas em nome da abolição do mal, ou terroristas do eixo do mal, em nome da extinção dos inimigos do sistema, são termos constantemente usados, que ultrapassam a denotação de sentido que eles conotam no plano político de interesses em jogo. No universo do discurso público, a palavra é um deslocamento de sinônimos e tautologias. A palavra não procura a diferença qualitativa, de maneira que se ela representa um conceito, ele está ritualizado e previamente imune à contradição.

De acordo com a contração espacial da linguagem e do pensamento - redução da palavra ao gesto e à imagem, redução das contradições -, existe uma contração temporal. "A linguagem funcional é uma linguagem radicalmente anti-histórica." 175 A importância de tal afirmação marcuseana deve-se à tradição filosófica que vincula Marcuse, sob alguns aspectos, a Hegel e a Marx. São estes últimos que associavam o conceito à história e ao devir. O distanciamento em relação ao dado é a intrusão do universal no particular. Tal

\footnotetext{
${ }^{174}$ MARCUSE, ibidem, p. 218.

${ }^{175}$ Ibidem, p. 123.
} 
distanciamento é também o local do terror e da esperança, dos receios e aspirações, tanto quanto ele promove a subversão do presente, encontrando a abertura que o faz explodir. Dessa maneira, o pensamento é bidimensional, tornando-se irredutível perante a linguagem unidimensional totalizante do universo descrito na escrita literária de Orwell.

Ao examinar os patamares históricos, da linguagem funcional da sociedade e da sua psicologia até à dos predicados analíticos dos discursos públicos e o parcelamento semântico da linguagem, torna-se então possível defrontar o campo de suas conseqüências práticas. No primeiro plano, encontra-se a eficácia do controle e da repressão. Em tal plano, a linguagem exerce o controle ao operar uma redução nas formas e nos signos lingüísticos da reflexão, da abstração, do desenvolvimento, da contradição, reduzindo-os pela substituição, a imagens dos conceitos que eles abrangem. Os critérios para o que é verdadeiro e falso são estabelecidos ou impostos. Tal imposição não aparenta ser terrorista; se ela surge como repressiva, é assim que impede, por si mesma, de se ir mais longe. Um conceito estritamente operacional não tem grandes chances de ser ultrapassado; ele não tem nada de transitivo. Ligado à ação de vender e comprar, ou consumir, nada transborda do imediato. Sem refletir sobre o que tal gesto implica, além da ação em si, a crítica está bloqueada ao pensamento encerrado no próprio gesto.

Tal controle exercido entre os indivíduos penetra os próprios indivíduos. Sem perceber nitidamente, quando descrevemos nossos amores e ódios, nossos sentimentos e ressentimentos, costumamos utilizar os termos dos anúncios publicitários, dos filmes, dos discursos políticos, dos best-sellers ${ }^{176}$. Nada fica no ser-para-si que seja privado e pessoal. Ao contrário, qualquer descrição está habitada pelo material lingüístico, adaptado ao grupo social.

Sobre a eficácia de tal controle da linguagem funcional, acresce-se uma segunda conseqüência prática: o caráter terapêutico, que visa à melhor maneira de adequação do perfil dos indivíduos à sua função social. Sob tal perspectiva de acomodação dos indivíduos às comodidades do sistema, a psicologia se presta a criar boas relações entre operários e gerentes, e entre gerentes e seus superiores. Tal eficácia se estende a manter o

${ }^{176}$ MARCUSE, LHD, p. 217. 
equilíbrio entre os desejos e as necessidades dos compradores, de acordo com os interesses dos empresários e dos políticos que determinam o ritmo e o clima da economia de mercado. A função da psicologia se vê diante da tarefa de abrandar as queixas dos trabalhadores quando estes reivindicam melhoria salarial ou outras condições de trabalho. A contestação é logo desviada das condições de injustiça da sociedade para determinar as causas imediatas da reclamação. O sistema se volta para a realização imediata da satisfação, de maneira que ela encubra, com a mesma eficiência, os aspectos não verdadeiros ou artificiais da pacificação encontrada ${ }^{177}$.

À pobreza da linguagem, de maneira a inibir o diálogo, a sociedade dispõe de meios cujo poderio de penetração é irresistível: a publicidade, os meios de comunicação de massa, a comunicação funcional, as motivações psicossociais de acordo com os parâmetros referenciais da pesquisa estatística em psicossociologia.

O caráter autoritário e repressivo da linguagem de propaganda é acrescido da sintaxe que visa criar imagens fixas. Estas podem ser bastante evidentes ou ainda subliminares, derivem do cansaço do significado ou da utilização dos pontos que excitam ou desviam a atenção, de acordo com os interesses publicitários. Ao mesmo tempo em que consegue estrangular a reflexão, a publicidade consegue fascinar, transformar o homem em autômato, gerando um sistema de comportamento passivo, fixo e previsto. A operação publicitária favorece um clima de aparente intimidade e auto-identificação dos indivíduos com o que eles próprios e com o que outros realizam na sociedade estabelecida. A autoidentificação é obtida por técnicas psicológicas desenvolvidas, imunizando o indivíduo e a massa contra as angústias e sofrimentos do cotidiano. $\mathrm{O}$ recurso lingüístico a expressões como cientistas-militares, bomba-limpa, tecnologias limpas, contribui para criar uma estreita relação de fascínio entre o aniquilamento, por um lado, e o sentimento de integridade moral e física, por outro ${ }^{178}$.

Os mesmos processos de autoridade e repressão se estendem da publicidade à informação. Desde a primeira infância, tais processos fixam o modelo de conformismo e também da rebelião, sob o controle de modismos nas TVs, Internet, revistas em

${ }^{177}$ MARCUSE, LHD, p.131.

${ }^{178}$ Ibidem, p.118. 
quadrinhos, rádios, jogos eletrônicos, shows ao vivo. Quaisquer afrontas cometidas em relação aos modelos lançados são punidas não tanto no interior da família, mas externamente e contra os papéis dos membros conservadores, envolvidos na preservação dos valores tradicionais. Os veículos de informação de massa têm os seus especialistas, peritos em oferecer a perfeita educação da eficácia, tenacidade, personalidade, sentimentalismo, controle da privacidade e realização de sonhos. A técnica consiste em suprimir os termos mediatos, que fariam correr o risco de instaurar espaço para tensões entre a aparência e a realidade. Apaga-se assim a distância entre a substância e o atributo, a verdade tal como ela é pensada criticamente e a verdade tal qual é estabelecida, a essência e a existência, a coisa e a sua função ${ }^{179}$. Por decorrência, a informação é operacional quando tal operacionalidade incita a considerar os nomes das coisas como o nome das propriedades ou qualidades, e dos processos como representações da aparelhagem utilizada para detectá-los e produzi-los. A informação, filtrada pelos interesses que subjazem a ela, estabelece a promoção sistemática do pensamento e da ação positiva, tanto quanto promove hábitos e pensamentos sociais. A informação operacionalizada pelos meios que a distribuem afeta todas as camadas da vida de um indivíduo, alterando-lhe sensivelmente a capacidade de apreender a realidade de múltiplas maneiras. Conceitos tirados da tradição cultural são depurados pela sua contração em termos operacionais. Estes já não visam à ausência daquilo que aparecem, como acontece no pensamento negativo, mas ressaltam a aparência daquilo que está presente e que não é presença de coisa alguma.

- Psicologia e política: o caráter mágico e hipnótico da linguagem

A comunicação funcional é, assim, a camada externa do mundo unidimensional. Nele, o homem é levado a esquecer, a traduzir o negativo em positivo de tal modo que possa continuar a funcionar. Diminuído em seu potencial, é levado a se sentir mais adaptado às condições que lhe concedem o direito à inclusão no sistema de forças onde ele está contido. A comunicação é antidialética, hipnotiza o indivíduo sobre um ponto no

${ }^{179}$ MARCUSE, LHD, p.110-111. 
espaço e sobre um ponto no tempo. Sob tais condições de unidimensionalidade, o indivíduo acaba por se tornar puntiforme, sem qualidades.

A publicidade, o discurso público ou o noticiário de informação, comportamentos sociais que facilitam ou induzem comportamentos individuais, todos servem ao mesmo objetivo de integração ao sistema. Desejos e necessidades são nivelados ou obliterados pelo caráter mágico e hipnótico da linguagem. Esta decorre da maneira como é manipulada pelas técnicas da publicidade e da informação no interior de uma sociedade fundada sobre a produtividade e o lucro.

É no tocante à linguagem que a contribuição da perspectiva do homem unidimensional de Marcuse constitui um complemento singular ao pensamento marxista. Tal contribuição explica as razões por que, e não obstante as suas crescentes condições, o capitalismo é adaptável às diversas culturas nas quais se instala. Explica também o que o torna mais resistente à extinção, frente a outros sistemas políticos. Por um lado, a linguagem esclerosa o pensamento segundo as direções que ele possa seguir; por outro, ele encerra a sociedade e os indivíduos em um molde de comportamentos que, igualmente, compreenderiam gestos e reações imediatas. Tal sistema trata e cura as distorções mentais que possam ameaçar a sua estrutura totalitária e repressiva. Nenhuma fuga, mesmo que apenas imaginária, é possível. Nenhuma contradição poderia aparecer sob condições em que as categorias da liberdade se tornam permutáveis e se tornaram idênticas às categorias que lhes são opostas. A burocracia e o regime de anonimato do direcionamento técnico de tal aparato determinam tanto a sociedade comunista, em suas novas versões, quanto os regimes ditatoriais neo-fascistas, recrudescentes no cenário político atual. Ambos fazem a função de parceiros dos países do mundo livre. A contradição que adviria à reflexão é anulada pela própria democracia, quanto mais os antigos conceitos históricos são postos em xeque por redefinições operacionais ao calor das principais bolsas de valores dos países que exercem a sua influência sobre os demais. Tais redefinições são falsificações dos conceitos impostos pelos poderes econômicos e políticos que as determinam. Pela força de fatos estabelecidos, e graças a ela, o falso torna-se verdadeiro. 
A atrofia da linguagem não tem mais que uma origem, e essa origem é política, mas é também essencialmente psicológica. Quaisquer regimes que pretendam ser diferentes do status quo, já não se singularizam por modos de vida diferentes. Se eles se distinguem é porque empregam técnicas diferentes de controle e manipulação. Sob tais condições, a linguagem não é unicamente o reflexo dos controles. Ela se faz instrumento de controle, e isso precisamente no momento em que não transmite ordens, mas simplesmente informação. E mais precisamente no momento em que faz apelo à escolha, $\mathrm{e}$ não à obediência, tanto quanto clama pela liberdade, e não à submissão. Dessa maneira, é cabível indagar: existe escolha para um homem hipnotizado ou condicionado? Existe liberdade para um autômato ou para uma máquina de servidão?

Tais indagações sugerem que a escolha é predeterminada: ao se exprimir ela revela que o seu instrumento é o controle. Em tal conjuntura, todo o ato livre do pensamento não será mais do que gesto a reforçar a servidão e a repressão. Sem se enxergar dilacerada, a consciência é cega e, portanto, paradoxalmente, feliz. Se o indivíduo já não pensa, mas é pensado; se já não fala, mas é falado; se já não escolhe, mas é escolhido; a definição que mais lhe cabe é a de um homem sem qualidades.

- O homem coisificado é o sujeito, enfim, sem qualidades

A essência do homem é genérica. Para que se pense em sua condição específica, é necessário inferir as faculdades intelectuais, psicológicas e físicas, assim como suas virtualidades. Contudo, tal condição só se pode realizar quando todos os homens existam como seres específicos. E, se a Natureza envolve as condições sem as quais o homem não poderia engendrar-se, ela deve tornar-se a sua obra, o seu corpo não-orgânico. Tais são as condições do conhecimento e do autodesenvolvimento da humanidade.

Tais observações levam ao exame do trabalho naquilo em que ele não conduz às condições de liberdade do homem. Para Marx, "o processo de trabalho determina a 
totalidade da existência humana", contrariamente a Feuerbach ${ }^{180}$. Na conjuntura capitalista, o trabalho está alienado, pois implica a negação do homem. E não poderia ser de outra maneira. A essência do capitalismo reside no lucro e na produtividade que condiciona o lucro. É o reino do fetichismo da mercadoria. Nessas condições, o trabalho se define como produtor de mercadorias, e como mercadorias têm sentido em função de uma troca, o trabalho não tem mais que um valor de troca - é uma mercadoria. Chega-se assim à homogeneidade universal. Do ponto de vista dos trabalhadores e produtos, essa homogeneização é quantificável ${ }^{181}$.

As conseqüências que advêm apontam para duas direções. A primeira determina que os valores de uso, concretos e qualitativos, diluem-se nos valores de troca. A outra determina que o trabalho separado das suas características humanas torna-se quantidade de uma força de trabalho medida pelo tempo. Em função de um nível técnico de rendimento médio, obtém-se o tempo de trabalho socialmente necessário. Tal é a origem da teoria marxista do valor-trabalho. Por um lado, o trabalho criador de troca é trabalho geral abstrato, mas, por outro, ele contém trabalho específico concreto, tanto quanto o valor de troca compreende um valor de uso. Essa distinção, original em relação a Hegel, é capital no pensamento marxista. Marx considera que o trabalho concreto transfere para o produto o valor dos meios de produção, enquanto o valor novo do produto, admitido no mercado, é atribuído ao trabalho abstrato e quantificado. A força de trabalho é assim uma mercadoria diferente das outras. O seu valor de uso tem mais valor que o seu preço de compra pago pelo empregador, a título de troca da mercadoria. O valor de troca é determinado pelo tempo de trabalho necessário à produção. Até então, e antes que as linhas de produção de mercadorias fossem quase totalmente robotizadas, o tempo de trabalho necessário à produção da força de trabalho era aquele que requerido para produzir mercadorias em número suficiente. A existência do trabalhador o vinculava como parte do preço da mercadoria pago pelo comprador ${ }^{182}$. Mas se ao valor de uso do trabalhador, ou ao trabalho concreto se junta um valor adicional, ou mais-valia, a título de ser abstrato, ele é frustrado, pois o seu trabalho não é pago proporcionalmente à sua produção. Se o trabalho nada custa ao trabalhador, ele traz muito ao capitalista, e tanto quanto os meios de produção

\footnotetext{
${ }^{180}$ MARCUSE, 1968, p. 304.

${ }^{181}$ Ibidem, p. 304.

${ }^{182}$ Ibidem.
} 
aumentam a produtividade. Nessa seqüência, segue-se que o capitalista é um explorador, porque possui os meios de produção.

Tal sistema pretende que seja o próprio trabalhador, pelo seu livre contrato de trabalho, quem perpetue a sua própria exploração ${ }^{183}$. É a força de trabalho humano, e, hoje em dia, cada vez menos, que confere ao produto do trabalho uma mais-valia, isto é, um acréscimo do capital. Para que se verificasse o contrário, seria necessário que o capitalista não reinvestisse, mas consumisse a mais-valia. E de fato isso acontece quando o capitalista reaplica a mais-valia no jogo do mercado de capitais. Marx acreditava que assim acabaria o incitamento para produzir mercadorias. Mas como não acontece assim, o capitalismo não cessa de crescer, o aporte de mercadorias que chega ao mercado é variado e abundante. Ao mesmo tempo em que cresce o volume de mercadoria e o trabalhador é estimulado ao consumo, o sistema gera a pauperização dos trabalhadores.

Tal processo de coisificação não se detém com essa dinâmica descritiva. O acréscimo da mais-valia é paralelo ao aumento da produtividade. Tal acréscimo é devido à maior tecnicidade dos meios, que aumentam as cadências nas linhas de produção. À medida que o progresso técnico leva à substituição progressiva do trabalho concreto pela máquina, há a substituição do fator subjetivo humano - que é objeto de exploração — pelo fator objetivo, que, por sua vez, mantém os meios de produção mais eficientes.

Uma nova composição de valores resulta para aumentar a composição orgânica do capital, de tal modo que a concorrência se torna monopolista. Uma das razões principais é a diminuição da taxa de lucro que decorre da diminuição da força de trabalho, única fonte de mais-valia, em proporção inversa ao crescimento dos meios técnicos de produção.

Tal é a descrição do trabalho alienado e das suas conseqüências mais discerníveis que desembocam na obsessão desenfreada pelos lucros do mercado de capitais. Contudo, esses processos têm implicações negativas em relação à essência do homem. Isto é, a noção capitalista de trabalho trai, em dois níveis, as bases do conceito de trabalho. O primeiro nível aponta para a eliminação do seu aspecto essencial, ou seja, o ato de criação

${ }^{183}$ MARCUSE, 1968, p. 334. 
ou de objetivação do homem em si mesmo. O segundo nível revela a traição à sua função biológica, que consiste em satisfazer as necessidades vitais do homem, destinando-o aos valores de troca mais do que aos valores de uso. Sobre esse último aspecto, os valores de uso constituem uma condição primária da existência, sendo a produção de mercadorias uma condição secundária. O conjunto de valores de uso define a necessidade social de que o mercado é a expressão. Segue-se que os valores de uso de um indivíduo se encontrarão no mercado se a sociedade dedicou um determinado tempo de trabalho, socialmente necessário, a produzi-los ${ }^{184}$. Em outros termos, a necessidade social é um fator determinante do trabalho social, e a sociedade tem uma missão primordial: repartir o tempo de trabalho necessário à produção de cada um desses valores.

Porém a sociedade capitalista não é o sujeito consciente do devir histórico, não pode, portanto, assegurar a planificação da produção em função das necessidades reais da sociedade $^{185}$. Em tal sistema, o indivíduo é livre para escolher o trabalho que lhe agrade, como é livre para satisfazer as suas necessidades, livre para trocar as mercadorias que produz por outras mercadorias de que necessita. Mas isso pressupõe a existência de uma planificação no termo da qual existe correspondência entre mercadorias. Como é improvável que esta planificação exista, se não for como paliativo, e uma vez que o lucro dependendo dela dependa, o esbanjamento é inevitável, em proporção à não-cobertura dos valores de uso pelos valores de troca. Assim, é apenas no nível do mercado, demasiado tarde, que a lei do valor se verifica ou não.

Assim, o indivíduo perde até mesmo a sua liberdade de gesto ou de comportamento. Aliás, a liberdade é ilusória em relação à essência genérica do homem, pois depende do mercado no qual rigorosamente não tem nenhum poder. A esta nãoliberdade se junta a injustiça, uma vez que o valor de troca de que o indivíduo dispõe é insuficiente para a aquisição dos valores de uso de que experimenta a necessidade, a não ser que pertença à "fração solvente da necessidade social" 186 . Mas para a massa de trabalhadores a necessidade social não é idêntica à necessidade real de cada indivíduo.

\footnotetext{
${ }^{184}$ A partir de $O$ Capital, Marx só utilizará as categorias econômicas para desenvolver o seu raciocínio. Ver MARCUSE, 1968, p. 321.

${ }^{185}$ Ibidem, p. 334, 318, 319.

${ }^{186}$ MARCUSE, 1968, p. 76, 77.
} 
E, mesmo que isso acontecesse, somente poderia ser o resultado de um mecanismo cego desempenhando o papel de uma lei natural, em que necessidade e acaso confluiriam para aumentar o domínio sobre os indivíduos. Em suma, graças ao tempo de trabalho necessário à produção dos valores de troca, tal situação poria indivíduos independentes em relação de acaso e, guiados pela necessidade cega, a sociedade chegaria à anarquia à frustração no nível de mercado. Mas a destruição desses valores faria surgir o desejo das necessidades reais ou vitais e desorganizaria o sistema de produção e a civilização, tal qual hoje ela se constitui.

O acaso, a frustração e o esbanjamento seriam, como o são em certa medida, daí em diante, conseqüências relativamente suportáveis se fossem as únicas negativas. Poderse-ia imaginar, com Marcuse, uma sociedade civil que absorveria tais conseqüências. De fato, ele imagina uma sociedade em que os salários corresponderiam ao valor do trabalho e da mais-valia. Nela, o capital não seria mais que uma acumulação das riquezas necessárias à produção. A propriedade do capital não originaria mais do que o benefício, servindo para remunerar os empresários. Em tal utopia, não haveria injustiça nem opressão, mas ela seria regulada por um sistema inteiramente racionalizado onde se harmonizariam os valores e as necessidades, a oferta e a procura ${ }^{187}$. Mesmo sob tais circunstâncias, a situação do homem seria fundamentalmente desumana, pois daí resultaria uma substituição da matemática pelo lucro, e não a instauração de melhores relações existenciais entre os homens. E tal pressuposição é de tal maneira verdadeira que se poderia chegar à conclusão que a economia é inseparável da existência histórica dos homens.

Existe, portanto, algo mais grave que o acaso, o esbanjamento, o reforço do capital pela mais-valia, e o desenvolvimento da técnica a serviço do capital. A alienação do trabalho é um atentado às relações do trabalhador com o produto do seu trabalho. É um atentado às relações do trabalhador com o produto do seu trabalho, tanto quanto atenta às relações do trabalhador com a sua própria atividade e às relações dos homens entre si. A sociedade capitalista concentra todos os seus esforços em torno da produção e da troca de mercadorias com vista ao lucro.

${ }^{187}$ MARCUSE, 1969, p.107. 
Em tal estrutura, o trabalhador cede o produto de suas capacidades na base de um contrato e, ao fazer isso, ele aumenta o capital. Assim, o trabalho não produz apenas mercadorias, mas produz o trabalhador como mercadoria. Ao se tornar uma mercadoria, o trabalhador perde o produto de seu trabalho, que se transforma em uma entidade estranha, é também o seu corpo não orgânico, em vez de ser a sua própria objetivação. O resultado do modo de apropriação capitalista é a expropriação do trabalhador de si mesmo. Sentindo-se alienado em relação ao produto de seu trabalho, o trabalhador tem o sentimento de estar ele mesmo fora do trabalho, mas no trabalho ele se sente fora de si. Por sua vez, a alienação conduz à divisão do trabalho como característica de uma sociedade de classes. A distinção de classes dá a aparência de que o desenvolvimento da técnica torna o parcelamento racional e necessário. Tais divisões acabam por se tornar verdadeiros cativeiros em esferas de atividade exclusivas e determinadas de que não se pode facilmente evadir. Uma sociedade que se orienta sobre o lucro não respeita as capacidades nem as necessidades dos indivíduos. Isolados uns dos outros, são as mercadorias que estabelecerão o liame entre os indivíduos e não as suas relações pessoais.

A coisificação atinge o seu ponto culminante como totalidade negativa: o capitalista não vale mais que suas posses materiais e só atua para possuir mais. Entretanto há que se ressaltar o paradoxo que iguala uns e outros: pela possibilidade maior ou menor de se fazer moeda, isto é, de se utilizar a sua essência como meio de existência. O que se observa como aporia maior no sistema capitalista é que o prazer e a felicidade se degradam. Em vez de permitir aos homens que desenvolvam a sua natureza universal, eles se tornam egoístas, voltados para os seus interesses, para a posse e a aquisição de bens materiais. De tal modo que tudo aquilo que no capitalismo é universal - comércio, livre concorrência, interdependência e ideais - torna-se negativo ao se revelar como o efeito de uma força estranha, não controlada.

Em resumo, na sociedade capitalista, o lucro transforma o homem e Natureza em mercadorias, sob a capa dos conceitos universais. Cada indivíduo, expropriado ou possuidor, perde-se ao perder os seus objetos ou faz-se objeto ao possuí-los, e cada indivíduo torna-se estranho a si e estranho aos outros. As relações possíveis são as relações de mercado em que tudo se vende e em que se manifestam o acaso e o 
esbanjamento. Essa é a conseqüência extrema do capitalismo tardio. Como uma totalidade negativa, tanto em relação à essência humana, como nas relações com a Natureza, o capitalismo, em suas formas hodiernas, é um tecido de contradições, cada vez mais amplas e dramáticas. Diante da possibilidade de esgotamento das fontes naturais de recursos que sustenta tal sistema, Marcuse observa uma crise inelutável: a sociedade capitalista se encaminha para a sua própria negação ${ }^{188}$.

${ }^{188}$ MARCUSE, 1969, p. 341. 


\title{
PARTE IV
}

\author{
SÉTIMO CAPÍTULO
}

\section{Uma obra inacabada para um homem sem qualidades}

A ação de $O$ homem sem qualidades desenrola-se nos doze meses que antecedem à deflagração da Primeira Guerra Mundial. Embora Musil, com freqüência, rejeite detalhes reais em literatura, como sem importância, não pode haver dúvida de que o romance publicado resulta da mesma profunda preocupação com a crise na Europa e com o futuro das nações civilizadas. Toda a obra, mas especialmente o Primeiro Livro, deve ser visto como um retrato de uma sociedade caminhando inexoravelmente para a guerra, como os passageiros profundamente adormecidos num trem em movimento para colisão. Essa conseqüência inevitável lança uma sombra de ironia em toda a narrativa, uma vez que os vários personagens, cada um deles uma figura representativa da época, perseguem seus próprios interesses e buscam sua própria salvação. Apenas Ulrich, o homem sem qualidades, é clarividente o suficiente para perceber o mal no coração da civilização, mas seus esforços para alertar aqueles em posição de poder sobre os perigos à frente foram recebidos com quase total falta de compreensão. Eventualmente, ele empreende um esforço pessoal, junto com sua irmã, para encontrar um modo de vida dedicado apenas à 'outra' dimensão dos seres humanos, visando a uma vida de imaginação, sentimento e misticismo. Os planos do autor, até o ano de 1936, mostram que a aventura pessoal de Ulrich e Ágata estava também destinada ao fracasso, que a obra terminaria com a deflagração da I Guerra Mundial, com Ulrich alistando-se voluntariamente no serviço militar. Durante os últimos anos de Musil, ele escreveu diversas versões para os capítulos finais do romance, em sua procura pela conclusão mais adequada. Embora a obra não estivesse completa, por ocasião de sua morte, em abril de 1942, uma nota escrita em janeiro daquele ano relaciona idéias para a parte final, incluindo comentários sobre desenvolvimentos políticos e sociais durante a Segunda Guerra Mundial; esses mostram que, naquela ocasião, ele ainda estava preocupado com questões mais amplas. ${ }^{189}$

${ }^{189}$ MUSIL, GW, v. 5, p. 1943. U's Nachwort, Schlusswort. (NR. 36) 
O primeiro esboço de $O$ homem sem qualidades apareceu em 1926. O amigo de Musil, Oskar Maurus Fontana, conta que o autor fora convidado pelo editor da revista semanal de Berlim, Die Literarische Welt a falar sobre sua obra, mas declinara do convite. Contudo, no início de 1926, a revista publicou uma entrevista de Fontana com Thomas Mann. Em conseqüência disso, compreendendo que uma declaração pública de obra em andamento poderia, afinal, ter sua utilidade, Musil perguntou a Fontana se ele faria uma entrevista literária similar com ele, que foi publicada em abril daquele ano. ${ }^{190}$ No início da conversa, o título do romance é dado como "A irmã gêmea" (alem. Die Zwillingsschwester), mas, por ocasião da publicação, em 1930, foi mudado para o presente nome. Tendo declarado que o livro conclui com a deflagração da guerra, Musil imediatamente contradiz qualquer suposição de que poderia estar escrevendo um romance histórico. Seu interesse, declara com firmeza, não está dirigido a fatos como esse, mas a aspectos de eventos fundamentais, típicos, mesmo misteriosos.

Antes de entrar em detalhes, Musil inicia a cena. A estrutura irônica para a ação do romance é fornecida pela rivalidade existente, há muito tempo, entre Áustria-Hungria e Alemanha. O ano de 1918 deveria ser marcado pelas celebrações do jubileu de dois imperadores: naquele ano, Francisco José I da Áustria estaria reinando por setenta anos e Guilherme II, da Alemanha, por trinta. Acontece, como os leitores de Musil sabem, que, em fins de 1918, Francisco José morreu. Carlos, seu sucessor, e Guilherme tinham ambos abdicado, e os dois impérios tinham entrado em ruína e derrota. No primeiro livro do romance, Musil registra os esforços imaginários de patriotas austríacos, das classes mais altas da sociedade, de promover a idéia de uma Áustria Gloriosa. Pretendem, com suas atividades, competir com as preparações similares de Berlim, visando à celebração da imagem da Alemanha e, por essa razão, os esforços austríacos são aludidos como a Ação Paralela. Enfatiza a missão mundial da Áustria-Hungria como um exemplo de coexistência pacífica de muitos povos diferentes, numa época em que agrupamentos nacionalistas ameaçam sua coesão, de todos os lados, no ano que antecede o assassinato do Príncipe herdeiro da Coroa Austríaca, em Saravejo. Os patriotas austríacos, retratados por Musil, pretendem organizar as festividades do jubileu, de significação histórica, ultrapassando em

${ }^{190}$ MUSIL, GW, v. 7, p. 939. Was arbeiten Sie? Gespräch mit Robert Musil [30. April 1926]. 
brilho qualquer coisa que a Alemanha possa fazer, apesar de sua superioridade tecnológica e manufatureira.

No decorrer de sua conversa com Fontana, Musil resume vários aspectos do romance. Ulrich, o protagonista, um jovem formado em matemática, física e tecnologia descobre, para seu espanto, que a vida real, como vivida hoje, atrasa em pelo menos cem anos os avanços do pensamento científico. Musil enfatiza que quando diz "hoje" quer dizer 1926, a data da entrevista, exatamente como o período pré-guerra da narrativa. Essa diferença de fase entre pensamento e vida, repetidamente observada nos ensaios de Musil, forma a base para um dos temas centrais da obra: como deve uma pessoa arraigada na vida da mente e do espírito relacionar-se com o mundo real? Tal indagação é explicitada como se a realidade se situasse em "castelos de nuvens: quando pairam sobre uma rua cheia de vida, em vez de sobre uma paisagem solitária, não acreditamos realmente neles. A causa era talvez não saber que grau de solidez deveria atribuir às experiências que (...) [nos] comoviam". 191

Ulrich encontra um homem descrito como seu pólo oposto, um industrial rico e influente, que combina, em uma pessoa, perspicácia nos negócios e habilidade para escrever. No ínterim, a Ação Paralela começou seu trabalho, sob a presidência da esposa de um diplomata austríaco; essa senhora, a quem Ulrich chama de "Diotima segunda" [em alusão a Diotima, personagem de Platão no diálogo $O$ banquete], por causa de sua conhecida sensatez, é aparentada com sua família, e em conseqüência ele é atraído para a Ação Paralela. Prosseguindo a ação, Diotima e Arnheim, industrial, se apaixonam, mas seu relacionamento, grandemente baseado em pretensão, não dá em nada.

O segundo tema principal tem origem no encontro de Ulrich com sua irmã, Ágata, que ele não via há anos. Na entrevista, Musil descreve o ideal utópico de uma irmã gêmea como 'a idéia de fazer-se manifesto', e para Ulrich a idéia se torna um ser vivo. Ele e Ágata retiram-se da atividade frenética da campanha, para viverem suas vidas num estado de bondade mística, ou pelo menos assim tentarem; acontece que tal vida é impossível. O autor comenta que o mundo não pode existir sem o mal, pois o mal produz

${ }^{191}$ MUSIL, GW, v. 3, cap.28, p. 940-945; HSQ, Alegria demais. Livro Segundo, cap. 28, p. 996. 
movimento; a bondade sozinha leva à rigidez. Um fio adicional da ação está associado à figura de Clarisse, uma jovem senhora casada com Walter, amigo de Ulrich. No decorrer do romance, ela se torna cada vez mais desequilibrada e é, finalmente, declarada insana. Essa figura, com suas obsessões, desempenha um papel significativo na obra; ao mesmo tempo, tanto Clarisse como Moosbrugger, não mencionado na entrevista, são discutidos de maneira tal que levanta a questão de definições não usuais de realidade.

O autor então descreve como o dinheiro destinado à Ação Paralela é disputado por representantes de vários interesses, mas eventualmente apropriado pelo delegado do Ministério da Guerra e gasto em armamento. Após outras aventuras, o desejo de Ulrich de participar dos eventos, nunca muito firme, é abandonado. Todas as rivalidades e contradições da sociedade finalmente conduzem ao horror da guerra, quando, para Ulrich, assim como para outros personagens do romance, escolhas pessoais não são mais possíveis.

Quando o entrevistador observa que esse esquema certamente corre o risco de se tornar teórico em demasia, Musil concorda, explicando como espera enfrentar o perigo: primeiramente por meio de uma abordagem irônica, não como um gesto de superioridade, mas empregando a ironia como uma arma, um meio para atingir um fim; em segundo lugar, escrevendo cenas vívidas, convincentes. Fontana pergunta se a atitude fundamental de Musil é de pessimismo. Ao contrário, Musil responde, a humanidade precisa de uma nova moralidade para competir de maneira equilibrada com suas inauditas realizações em nosso tempo. Seu objetivo é fornecer material para essa nova moralidade, por meio de seu romance, que descreve como uma tentativa simultânea de dissolver o mundo existente e mapear uma nova síntese possível de seus elementos.

Ao iniciar o primeiro capítulo de $O$ homem sem qualidades ${ }^{192}$, o leitor pode ser desculpado por acreditar que, por algum engano, ele tivesse aberto um relatório meteorológico. Altos e baixos, temperaturas e umidade, tudo combina para produzir, afinal, a informação de que se tratava de um belo dia de agosto de 1913. Segue-se um relato gráfico do tráfego de uma cidade moderna, descrito em termos de luz e sombra,

${ }^{192}$ MUSIL, $G W$, v. 1, cap. 1, p. 9-11; HSQ, Do qual singularmente nada se depreende. Livro Primeiro, cap. 1, p. 27-30. 
pulsação, vibrações e metáforas de barulho retiradas da ciência da metereologia. Somos informados de que a cidade é Viena, mas imediatamente advertidos de que esse fato é de somenos importância. $\mathrm{O}$ autor deliberadamente introduz-nos em uma cena anônima, como se tivéssemos chegado lá, naquele momento, puramente por acaso. Como o movimento de nuvens no céu, os assuntos dos homens, na visão de Musil, dependem, em larga medida, de coincidência de fatos casuais, e a abertura do capítulo pretende ser uma declaração simbólica dessa verdade.

Segundo Musil, as pessoas de sua época transformaram a raça na "causa" do indivíduo. Ele se refere à sua tentativa para reduzir o verdadeiro relacionamento entre o indivíduo e sua expressão social à seguinte fórmula:

uma pequena amplitude do íntimo ser corresponde a uma grande amplitude de expressão. Sem negar que a humanidade assumiu formas muito diferentes, de tal maneira que ela teria que estar cega para desconsiderar e, na verdade, partindo precisamente dessa suposição, podemos argumentar que mesmo isso é quase tudo tão fácil, e que as pessoas o fazem com mudanças tão triviais nelas mesmas, da mesma forma como uma brisa pode mover a água em qualquer direção. As roupas fazem as pessoas, e então as pessoas fazem as roupas, repetidamente, e a ordem é revertida com freqüência: o que as fisionomias características dos vários períodos produziram é uma ação recíproca completamente inextricável de dar e receber, entre o indivíduo e seu mundo, essência e acidente, impulso e força, o "eu" e a expressão. Precisamente a deformidade de sua disposição requer que o indivíduo se acomode a formas, para assumir o caráter, costumes, moralidade, estilo de vida e todo o aparelhamento de uma organização. É um dito bem conhecido de que em nossa idade da máquina as máquinas governam as pessoas, e essa explicação tem sido apresentada para justificar os horrores de guerra e da política. Isto é bem verdadeiro: força e impotência são uma coisa só. A terrível crueldade de nossas formas de política e de organização econômica, que faz violência aos sentimentos do indivíduo, é tão inescapável por ser essa organização tudo o que há, que oferece ao indivíduo uma face e a possibilidade de expressar-se. Podemos dizer que o ser humano se torna humano, em primeiro lugar, através da maneira como se expressa e a sociedade molda as formas dessa expressão. (É, na realidade, uma simbiose.) Essa é uma visão diferente daquela que explica o indivíduo como um produto simples, determinista do cruzamento de raças, ou como um caso individual de épocas e culturas. Parece faltar a dignidade da necessidade, que torna a outra visão tão pomposa, e sua lei da história do mundo não é realmente nada mais do que o princípio do velho Estado Austríaco de "alcançar o objetivo." O caminho da história não é, de fato, o da bola de bilhar, que, uma vez golpeada, segue um curso que pode ser prognosticado, mas assemelha-se antes ao caminho de uma nuvem, que também segue as leis da física, mas é igualmente influenciado por algo que pode apenas ser chamado de uma coincidência de fatos. Em todos os lugares o vento sopra de 1 [este] para o[este], porque no 1 [este] há um má[ximo] e no o[este] um mí[nimo] de pressão de ar; mas um lugar está entre ambos, 


\begin{abstract}
onde nenhuma massa de montanha próxima desvia o curso do ar, ou onde, de outra maneira, influências concorrentes fazem-se sentidas, todas essas circunstâncias constituindo a temperatura: todos esses elementos, quando vêm juntos, mesmo se calculáveis, são na verdade fatos e não leis. Acontece o mesmo, quando uma pessoa anda pelas ruas, atraída aqui pelas sombras, ali por um grupo, mais além por um estranho perfil de rostos; quando uma outra pessoa "acidentalmente" cruza seu caminho e lhe diz algo que a faz decidir-se por um itinerário específico - e ela se encontra, finalmente, a ponto nem de saber ou não querer ir: cada passo desse itinerário ocorreu também pela necessidade, mas a seqüência dessas necessidades individuais não tem coerência alguma. Que eu repentinamente permaneça onde estou é um fato, um resultado, e se alguém qualifica isso de necessário, porque em última análise tudo tem sua causa, então tem o caráter de preservar algo em nome da causalidade; mas é completamente inútil, uma vez que então nunca seremos bem sucedidos. ${ }^{193}$ (Tradução nossa.)
\end{abstract}

Sob tal perspectiva, o indivíduo possui a qualidade do real, do individual, do que aconteceu, do que conduziu seu curso (em ambos os sentidos), como uma mistura tipológica, à semelhança do que ocorre com eventos históricos, nações e culturas. Parece que a questão européia: o que sou? significa, na realidade: onde estou? Não é uma questão de uma fase num processo regido por leis, e nem uma questão de destino, mas simplesmente de uma situação. As pessoas não podem mudar as leis; mas certamente podem mudar situações nesse sentido, não importa quantas leis iminentes possam ter contribuído para essas mudanças.

Os dois personagens que aparecem na cena de entrada do romance são igualmente tratados de maneira impessoal. Descritos como um homem e uma mulher, pertencentes às classes altas; suas identidades são apenas sugeridas, não reconhecidas, e eles são vistos caminhando, como quem troca confidências, ao longo de uma das principais ruas da cidade. Subitamente, a paz da cena da rua, aparentemente normal, é interrompida; uma multidão se junta, e em seu centro aparece algo como um buraco fundo. Um pedestre descuidado tinha sido atingido e ferido por um caminhão pesado. Os transeuntes estão chocados e preocupados com a segurança do homem; logo que chega uma ambulância, contudo, e seus tripulantes iniciam seus eficientes serviços, os espectadores prosseguem em seus caminhos, aliviados por não mais se sentirem obrigados a agir. Da mesma maneira, de acordo com Musil, a civilização, em sua superfície, pode subitamente cair em profundezas insuspeitadas; mas, em seguida, a maioria das pessoas pode também apenas

${ }^{193}$ MUSIL, GW, v. 8, p. 1364-5, Der deutsche Mensch als Symptom Aufbau; PS, The German as symptom. 1923 , p. 150. 
estar pronta para ir-se embora, sem considerar se seria capaz de evitar que catástrofe semelhante ocorresse no futuro.

Em Ulrich, o homem sem qualidades, Musil mostra um homem preocupado com uma séria busca, tentando descobrir quem ele é, qual sua função na vida e qual deve ser seu lugar na sociedade; no processo, o autor discute e esclarece alguns dos dilemas centrais do século XX. Em sua mocidade, Ulrich inflamava-se de admiração por Napoleão e mentalmente decidiu tornar-se um Grande Homem. Seguindo os passos de seu herói, alistou-se no exército, mas logo descobriu que se tornar um general famoso era, provavelmente, algo além do que tinha imaginado. Sua segunda tentativa de conquistar grandeza levou-o a se tornar um engenheiro, profissão muito bem considerada na passagem do século XIX, como possuidora da chave do futuro. No decorrer de todo este século, ciência e tecnologia haviam progredido de uma descoberta a outra, e aqueles que trabalhavam nessa área de potencial aparentemente ilimitado olhavam com mal-disfarçada impaciência para artistas, filósofos e outras pessoas tolas o suficiente para desperdiçar seu tempo com assuntos indeterminados como beleza ou moralidade. Todos os problemas do mundo, assim parecia, podiam ser resolvidos com a ajuda de uma régua de cálculo: "quem possui uma régua de cálculo, e encontra alguém que faz afirmações grandiosas ou sem sentimentos grandiosos, diz: um momento, primeiro vamos calcular as margens de erro e o valor mais provável de tudo isso!"194

As obras de Emerson, assim Ulrich pensava, estavam cheias de senhas para engenheiros e máximas como "Os homens caminham de acordo com as profecias da próxima era deviam estar penduradas na parede de todas as oficinas". ${ }^{195}$ Infelizmente, Ulrich foi logo forçado a reconhecer que a maioria dos engenheiros, embora bravos e inovadores em suas atividades profissionais, deixavam de prolongar esse modo destemido de pensamento em suas vidas privadas, em que se revelavam tão obtusos e ultrapassados como ninguém mais. A essa altura, a desilusão manifestou-se, e ele, rapidamente, deixou a profissão.

\footnotetext{
${ }^{194}$ MUSIL, GW, v. 1, p.38; HSQ, Segunda tentativa. Inícios de uma moral do homem sem qualidades. Livro Primeiro, cap.10, p. 56.

${ }^{195}$ Ibidem, p. 56.
} 
$\mathrm{Na}$ terceira e última tentativa de encontrar uma carreira compensadora, Ulrich, voltou-se para a matemática. As ciências matemáticas, na visão de Musil, representam o espírito da era moderna e a base das vastas e fundamentais mudanças que a distinguem dos séculos precedentes. O avião, o automóvel, o submarino, o telefone, o gramofone e incontáveis outras invenções, todas elas tornadas possíveis pelos matemáticos; a realização de antigos sonhos, não tanto ciência como mágica; a revelação dos segredos de Deus. Reconhecidamente, um preço tem de ser pago: "ganhou-se em realidade, perdeu-se em sonho". ${ }^{196}$ Muitas pessoas, diz Musil, estão sempre prontas para acusar os matemáticos, por seu vazio interior, pela perda de senso de direção e pela crise de cultura em nosso tempo. Ulrich, por sua parte, amava os matemáticos, em oposição àqueles que os odiavam. Estava apaixonadamente convencido de que o pensamento científico anunciaria, de fato, uma nova era: se pelo menos os seres humanos pudessem aprender a pensar de novas maneiras, descobririam um novo modo de vida.

Alguns anos mais tarde, contudo, apesar de indubitável sucesso no seu campo de atividades, Ulrich ainda não estava satisfeito, e sua inquietação, aparentemente inata, ligava-se intimamente a uma característica descrita como um "senso de possibilidades", que se opunha a um senso de realidade. Ainda quando criança tinha chocado seus professores, ao sugerir, em um ensaio, que Deus faz o mundo, mas pensa, quando o faz, que bem poderia ser completamente diferente: "Deus gostava de falar do seu mundo no conjuctivus potencialis (...), pois era Deus quem fazia o mundo, pensando que bem podia ser de outra maneira”. ${ }^{197}$ À medida que Ulrich avançava em anos, esse ponto de vista de livre-pensamento, em vez de dar lugar a sólido realismo, tornou-se cada vez mais forte. $\mathrm{O}$ que algumas pessoas chamariam de sonho inútil, o autor descreve como "consciência utópica”, e nesse espírito Ulrich considerava o mundo existente como não finito, mas como um desafio. As possibilidades inerentes no mundo tinham, para ele, igual validade com os chamados fatos reais; ele os considerava divinamente inspirados e potencialmente ilimitados. Um homem com esse ponto de vista naturalmente levaria o mundo "real" menos seriamente do que o mundo se considera; ele pode bem ser imprevisível no seu trato com os outros, e inclinado, por exemplo, a atribuir culpa por um crime não à perversidade do criminoso, mas às faltas da sociedade. Segundo Musil: "É bem possível

${ }^{196}$ MUSIL, $G W$, v. 1 , p. $39 ; H S Q$, A tentativa importante. Livro Primeiro, cap. 11, p. 58.
${ }^{197}$ MUSIL, $G W$, v.1, cap.5, p. $17-18 ; H S Q$, Ulrich. Livro Primeiro, cap. 5 , p. 37. 
que um crime que prejudique a outros the pareça apenas um erro social, cuja culpa não cabe ao criminoso, mas à ordem social". ${ }^{198}$ Além disso, ele provavelmente estenderá sua atitude não-ortodoxa a si mesmo, recusando-se a dar, ainda que à sua própria pessoa, o benefício de obediência incontestada. A educação científica de Ulrich o tinha levado a trabalhar arduamente em sua profissão, mas além das demandas de sua pesquisa ele olhava para si mesmo, nos termos de Nietzsche, como um explorador do espírito, trabalhando para o futuro. Chegou um dia, contudo, em que reconheceu que estava tão distante de qualquer objetivo como nunca, e entrementes a estupidez do mundo exterior tinha, aparentemente, atingido o estágio onde mesmo um cavalo de corrida podia ser descrito como um gênio. Avaliando, Ulrich viu que possuía todas as habilidades e qualidades apreciadas em sua época, mas tinha perdido a vontade de fazer uso delas, pelo menos da maneira que o mundo exterior provavelmente aceitaria. Parecia ter nascido com um talento para o qual, no presente, não existia um uso. Tendo chegado a essa conclusão, Ulrich abandonou sua pesquisa e decidiu tirar licença de um ano em sua vida, para se tornar, temporariamente, um homem sem quaisquer qualidades, a fim de buscar uma aplicação adequada para seus talentos. Preocupado com a carreira do filho e diante da visível descrença de que ele encontrasse independência financeira e ascensão social com a carreira acadêmica, o pai de Ulrich lhe escreve uma carta, ressaltando a decisão do filho por um doutorado:

o fato de que, desde seu doutorado, você fale muito vagamente de seus
planos, que se relacionam com os mais vários terrenos e que você, como
de hábito, talvez supervalorize, mas nunca escreva que lhe daria
satisfação, obter um cargo de professor, nem sobre contatos com tal
propósito feitos com alguma universidade, nem mesmo sobre contatos
com círculos importantes, é o que por vezes me enche de
preocupações.

A ação do romance de Musil se passa em um país que ele chama de Kakânia, nome composto da letra dupla K associada à Monarquia Dual de Áustria-Hungria: kaiserlich (imperial) e königlich (real). Em um primeiro apontamento no caderno de anotações, ele descreve o fundo de cena do seu projetado romance como a capital de um país em declínio, cheio de disputas de partidos, uma cidade como Madri ou Viena, onde as

\footnotetext{
${ }^{198}$ MUSIL, GW, v.1, cap.4, p.19; HSQ, Se existe senso de realidade, tem de haver senso de possibilidade. Livro Primeiro, cap.4, p. 36.

${ }^{199}$ MUSIL, $G W$, v. 1, cap. 19, p. 77; HSQ, Carta de exortação, e oportunidade de obter qualidades. Concorrência de duas ascensões ao trono. Livro Primeiro, cap.19, p. 97.
} 
necessidades da sociedade, em geral, não podem ser mais encontradas, enquanto o desenvolvimento do indivíduo e da alta sociedade chegou ao auge. ${ }^{200}$ Isso proporciona uma descrição resumida da sociedade vienense encontrada por Ulrich. Embora fique evidente que o autor dá grande importância ao "senso de possibilidades", tão vital para o seu protagonista, não se deve pensar que o cenário do romance, todavia, seja, de modo algum, abstrato ou imaginário. Ao contrário, porque o império em declínio e a sociedade constituem uma realidade muito sólida que também reivindica ser única, Musil fica tão preocupado em mostrar que isso não é necessariamente assim.

A descrição de Kakânia no Capítulo 8 do romance é precedida de um resumo do seu oposto, um retrato exagerado de uma cidade ultramoderna, com arranha-céus, elevadores e trens subterrâneos, onde todo mundo se precipita, numa correria sem propósito: um retrato em que o autor pretende, claramente, fazer uma caricatura do futuro, mas que atinge este século em que ora vivemos de maneira desconfortavelmente familiar. Nas palavras de Musil, alguns habitantes desse universo em rápida mutação são eventualmente acometidos por um irreprimível desejo de escapar, de gritar:

\begin{abstract}
desembarcar! Saltar! Ânsia de parar, de não avançar mais, de ficar atolado, de voltar a um ponto antes daquela encruzilhada falsa! Nos bons velhos tempos do Império Austríaco, podia-se saltar do trem do tempo, entrar num trem comum e voltar à terra natal. Em tempos passados, quando o império austríaco ainda existia, poderíamos, de fato, fazer assim e voltar para Kakânia. ${ }^{201}$
\end{abstract}

O centro da Europa era considerado o lugar onde os eixos do velho mundo se cruzavam, um imenso país estendendo-se das geleiras ao mar, sumamente consciente de seu papel histórico como a herdeira do Santo Império Romano medieval, abrangendo, dentro de suas fronteiras, um vasto número de diferentes povos. Bastante auto-suficiente, o império tinha pouca ambição quanto ao poder do mundo, seja econômico ou político. Era regido pelo imperador, pela melhor burocracia na Europa: embora nominalmente democrático, seus postos de mando ainda eram, como nos tempos feudais, ocupados, com

\footnotetext{
${ }^{200}$ MUSIL, GW, v. 4, p. 1436-1437, Zu Kakanian. Não há passagem correlata na tradução brasileira. Porém, ela está na tradução inglesa, $M w Q$ (1996, p.1474-1475), com o título: The day after this dismal conversation Clarisse arrived. Worked-Out Sketches from the 1920s. New Sketches, 1930/31-1933/34.

${ }^{201}$ MUSIL, GW, v.1, cap. 8, p. 32; HSQ, Kakânia. Livro Primeiro, cap. 8, p. 50.
} 
poucas exceções, por membros da aristocracia. "Todos os cidadãos eram iguais diante da lei, mas então, nem todos eram cidadãos". ${ }^{202}$

De acordo com o ponto de vista de Musil, o colapso do império foi, em ampla medida, devido à combinação de atitudes feudais com uma compreensão insuficiente da natureza de um estado que abrigava tantas nacionalidades diferentes. Desde 1867, a Hungria possuía novo parlamento separado e estava, por conseguinte, em posição de se considerar politicamente igual à Áustria. Contudo, a Áustria, ou o restante da Monarquia Dual, que consistia de tchecos, alemães, poloneses, italianos, eslovenos, sérvios e muitos outros, tornou-se uma estrutura impossível de ser administrada, cujos cidadãos, incapazes de considerá-la uma entidade, naturalmente preferiram pensar em si mesmos como tchecos, alemães etc. Todos os aspectos da vida da nação sofriam de falta de coesão, enquanto os vários grupos dentro da monarquia, cada um olhava o outro com permanente suspeita e comportavam-se como os membros de uma criatura que distendesse todos os diferentes músculos de modo a evitar que assumissem qualquer forma reconhecível que fosse. $^{203}$

Acontece que esse cenário provavelmente deveria produzir um efeito adverso no desenvolvimento de um jovem como Ulrich, inclinado, por sua própria natureza, a observar e analisar, mais do que se lançar seriamente a uma carreira exigente. Crítica recente tem apontado, com alguma aceitação, que a posição de Ulrich como um observador descomprometido só foi possível porque, por alguma razão não especificada, ele não tinha nenhuma obrigação de ganhar a vida. Seja como for, o autor não nos deixa em dúvida sobre a conexão entre estagnação política e uma falta de pensamento positivo no estado, e a insatisfação e desorientação do protagonista. Num país que sofria em virtude da divisão decisiva entre as idéias nas quais o povo acreditava e as coisas de fato existentes, uma profunda falta de autoconfiança deveria ser sentida, pelo menos por alguns membros da população. A Kakânia de Musil é descrita com afetuosa ironia, mas também com tristeza, como o estado mais avançado a esse respeito, o estado cuja vida foi prolongada por absoluta inércia, sem íntima convicção, até finalmente o sentimento geral

\footnotetext{
${ }^{202}$ MUSIL, GW, v.1, cap. 8, p. 34; HSQ, Kakânia. Livro Primeiro, cap. 8, p. .52.

${ }^{203}$ MUSIL, GW, v. 1, cap. 42, p.170-171; HSQ, A grande sessão. Livro Primeiro, cap. 42, p. 193-194.
} 
de que não houve razão suficiente para que sua existência ulterior fosse traduzida em fato histórico.

Para Musil, o sentimento político austríaco, como de resto qualquer sentimento nacionalista, na verdade era apátrida.

\begin{abstract}
Muitos chamavam-se simplesmente tchecos, poloneses, eslovenos ou alemães, dando assim início àquela decadência e àqueles conhecidos 'desagradáveis fenômenos de política interna' (...), eram 'obra de elementos irresponsáveis, imaturos, sensacionalistas', que a massa dos habitantes politicamente pouco esclarecidos não sabia repelir suficientemente. Depois dessas alusões, sobre as quais muitos livros bem-informados e inteligentes escreveram desde então, há de se receber com prazer a afirmação de que, nem aqui nem mais adiante, faremos a duvidosa tentativa de pintar um [quadro] histórico e competir com a realidade. (...) Mais ou menos por toda a parte o processo histórico se assemelha a um processo jurídico, com cem cláusulas, adendos, acordos e recursos. (...) O homem comum vive e morre no meio deles sem nada notar, mas é para o seu bem; pois se quisesse saber em que processo, com que advogados, despesas e motivos está enrolado, provavelmente em qualquer país poderia ser tomado de mania de perseguição. Compreender a realidade é exclusivamente assunto para o pensador histórico e político. ${ }^{204}$
\end{abstract}

No capítulo 15 - Revolução espiritual -, Musil faz um vívido relato do clima cultural e intelectual na Áustria, na mudança do século XIX-XX; o título do capítulo resume o espírito subjacente daqueles anos. Durante as duas últimas décadas do século XIX, o considerável progresso em tecnologia, pesquisa e comércio fora acompanhado por uma marcante falta de originalidade na arquitetura e em outras artes. Subitamente, ou assim parecia, a mudança espalhou-se por toda a Europa e, em toda parte as pessoas se levantaram para lutar contra a tradição:

\begin{abstract}
Amava-se o super-homem e também o sub-homem; adoravam-se a saúde e o sol, adorava-se a fragilidade de mocinhas tuberculosas; havia entusiasmo pelo herói e pelo homem comum; havia a um só tempo crentes e céticos, naturalistas e sofisticados, robustos e mórbidos; sonhava-se com alamedas de castelos, jardins outonais, lagos de vidro, pedras preciosas, haxixe, doença, demônios, mas também com prados imensos, forjas e laminadoras, lutadores nus, rebeliões de operários escravizados, casais primitivos e destruição da sociedade. Eram realmente contradições e gritos de guerra muito diversos, mas tinham, todos juntos, um ritmo comum; se alguém dissecasse aquele tempo, a insensatez apareceria (...). ${ }^{205}$
\end{abstract}

\footnotetext{
${ }^{204}$ MUSIL, GW, v. 1, cap.42, p.170; HSQ, A grande sessão. Livro Primeiro, cap. 42, p.194.

${ }^{205}$ MUSIL, $G W$, v. 1, cap. 15, p. 55; $H S Q$, Revolução espiritual, cap. 15, p. 74.
} 
Ninguém sabia ao certo o que estava nascendo, se uma nova arte, um novo homem, uma nova moralidade ou a reestruturação da sociedade. A pletora de ferventes paixões e idéias contraditórias tinha apenas uma coisa em comum: a expectativa de que a "data mágica" do novo século anunciaria, de fato, uma nova era.

Contudo, dentro de um curto espaço de tempo, talvez dez ou doze anos, o fervor tinha diminuído. No capítulo 16, - Uma misteriosa doença de época -, Ulrich observa que apesar de tanta atividade externa havia começado um senso de desilusão. O que, então, tinha sido perdido? "Algo difícil de definir. Algo imponderável. Um presságio. Uma ilusão. Como quando um ímã larga a limalha e esta se mistura toda outra vez. Como quando um cortejo se dispersa. Quando uma orquestra começa a desafinar. (...) todas as proporções tinham se deslocado um pouco. ${ }^{206}$

Todas as fronteiras e distinções tinham-se tornado embaçadas; idéias dúbias eram levadas em consideração seriamente; pessoas que anteriormente não teriam sido consideradas eram elevadas à proeminência. E subitamente todas as posições de poder, em assuntos da mente e espírito, eram ocupadas por essas pessoas, e todas as decisões eram tomadas por elas. Uma enfermidade misteriosa invadiu todos os aspectos da vida cultural. Para se livrar do desalento causado por essas reflexões, Ulrich concluiu que a enfermidade não era nada mais do que estupidez comum que, como ele a via, é perita em assumir múltiplos disfarces, a fim de deslocar a verdade, sempre que possível. Foi nesse ponto que Ulrich se tornou tão consciente da sua própria falta de simpatia com a era na qual vivia. E, por fim, desesperou-se por não encontrar qualquer lugar útil dentro dela.

Depois de sua volta para Viena, Ulrich tinha escolhido uma casa simbólica das camadas históricas que constituíam a Áustria no ano de 1913. O proprietário original, , a tinha construído, no século XVII, como uma casa de campo, talvez uma cabana de caça, e cada era que se sucedia tinha deixado sua marca no exterior. Deparando-se com o problema de mobiliar o interior, Ulrich tinha tentado escolher um estilo consistente, mas, achando-se confuso pelos conflitantes apelos da Art Nouveau, do funcionalismo e vários outros, eventualmente confiou a tarefa a uma firma de decoradores de interior. O resultado

\footnotetext{
${ }^{206}$ MUSIL, GW, v. 1, cap. 15, p. 57-58; HSQ, Uma misteriosa doença de época. Livro Primeiro, cap. 16, p. 77.
} 
foi encantador, mas de certa maneira tão alheio a si mesmo como o resto de sua vida naquele tempo. ${ }^{207}$

Algumas semanas depois de ter-se mudado para a nova casa, Ulrich arranjou uma nova amante. Essa senhora, que podia ter saído diretamente das páginas de Arthur Schnitzler, é conhecida no romance como Bonadea, a Boa Deusa, a deusa romana da castidade, cujo templo se tornou famoso por causa dos excessos que lá aconteciam. Como a deusa, Bonadea levava uma vida dupla. Era a esposa de um advogado bem conhecido e a mãe devotada de dois meninos pequenos; mas, ao mesmo tempo, era dominada por seus sentidos, em proporção que podia ser descrita apenas como ninfomania. Seu caso amoroso com Ulrich começou quando, numa noite, dirigindo-se para casa, viu o jovem caído na sarjeta. Ele tinha sido atacado e roubado; o cocheiro de Bonadea colocou o jovem na carruagem e o levou para sua casa. Na manhã seguinte, Bonadea fez-lhe uma breve visita para perguntar por sua saúde, depois do que a visita rapidamente evoluiu para um relacionamento mais íntimo. ${ }^{208}$

Nessa parte do romance, todas as descrições parecem confluir para situações de contradição, de maneira a refletir em paradoxos, incoerência e imperfeições. As cenas são, ao mesmo tempo risíveis, grotescas e aterrorizantes. $\mathrm{O}$ que parece se situar apenas na descrição de um episódio de violência urbana dá entrada para a descrição do clima de conflito e tensão que se desenhava como uma tempestade iminente no ar. Sem saber por que, ao ser subitamente agredido na rua onde transitava, Ulrich pensa que a raiva e o desprezo de seus agressores não revelavam apenas a ambição ao lhe roubar o dinheiro, mas sim ódio contra o que ele personificava. Podiam ser malandros os que o insultavam com palavras grosseiras, mas podiam ser igualmente cidadãos comuns. Os insultos eram uma forma de expressar "o ódio que está em todo o mundo à espera de uma pessoa estranha, como uma tempestade iminente no ar”. Ele próprio, Ulrich, verifica que já sentira algo parecido. É nesse momento que Musil descreve mais exatamente a violência gratuita, como traço fundamental de pessoas fora de seu meio. $\mathrm{O}$ ódio, na forma de preconceito, não é apenas "a atitude de um ariano que considera um judeu um ser

\footnotetext{
${ }^{207}$ MUSIL, $G W$, v. 1, cap. 2, p. 11-13 e cap. 5, p.18-21; HSQ, Casa e moradia do homem sem qualidades. Livro Primeiro, cap. 2, p.30-31 e Ulrich, cap. 5, p.36-39.

${ }^{208}$ MUSIL, $G W$, v. 1 , cap. 7, p. 25-30; HSQ, Num momento de fraqueza, Ulrich arranja outra amante. Livro Primeiro, cap.7, p.43-49.
} 
incompreensível e inferior". O autor afirma que "não se pode negar que a mais intensa inclinação do homem por seus irmãos se baseia na repulsa por eles”. (HSQ, p.44) É bastante curioso que Musil interfira nesse momento, como personagem-autor que expõe as suas próprias reflexões, como, aliás, ele o faz em outras partes do romance. Ele diz que o seu personagem "Ulrich não pensou em tudo isso tão minuciosamente, é claro". Ele apenas era capaz de reconhecer "aquela vaga hostilidade que inunda nossa civilização". A violência que se cristaliza em gestos anônimos, entre desconhecidos que atacam, sumindo depois para sempre, é motivo para um sentimento de quase alívio. Mesmo tendo sido atacado e não tendo reagido, Ulrich se questiona se se teria portado "adequadamente". Após esse episódio, ele se dá conta de que:

\begin{abstract}
Junto das ruas onde a cada trezentos passos um policial pune a menor infração da ordem, há outras que exigem força e atenção, como uma floresta virgem. A humanidade produz bíblias e armas, tuberculose e tuberculina. É uma democracia com reis e aristocratas; constrói igrejas, mas constrói universidades que as combatem; transforma mosteiros em casernas, mas nas casernas coloca capelães militares; naturalmente também coloca nas mãos de bandidos mangueiras de borracha recheadas de chumbo, para atormentarem outras pessoas, e depois prepara cobertores macios para as vítimas desses maus-tratos (...). ${ }^{209}$
\end{abstract}

Entretanto, Ulrich não se enxerga assim. Ele odiava a mescla de apego e desapego como forma de se lidar com as contradições e meias-verdades inerentes à vida. Esse é um momento crucial para revelar as posições do homem sem qualidades em relação à ética. Sua posição se esclarece: "fazer pessoalmente o mal e fazer o bem, mas não se importar com a ordem geral, é, em muitos sentidos, um compromisso precipitado com a consciência à custa da causa, um curto-circuito, uma fuga para o mundo particular". (HSQ, p. 46) O que ele ganha com a experiência involuntária da agressão sofrida é a constatação de que

\begin{abstract}
valia muito pouco se eliminarem armas, ou reis, e reduzir a ignorância e maldade humanas com o progresso; pois as objeções e maldades são sempre substituídas por outras, como se uma perna do mundo escorregasse para trás cada vez que a outra avança. Seria preciso entender a causa e o mecanismo secreto desse processo! Isso seria mais importante do que ser um bom homem segundo princípios brevemente superados; assim, em assuntos de moral Ulrich preferia o serviço no estado-maior ao heroísmo cotidiano da prática do bem. ${ }^{210}$
\end{abstract}

\footnotetext{
${ }^{209} G W$, v. 1, cap.7, p. 27; $H S Q$, Num momento de fraqueza, Ulrich arranja outra amante. Livro Primeiro, cap. 7, p. 45 .

${ }^{210}$ MUSIL, $G W$, v. 1, cap.7, p.29; $H S Q$, Num momento de fraqueza, Ulrich arranja outra amante. Livro Primeiro, cap.7, p. 46.
} 
Desde seu retorno à capital, Ulrich tinha reatado sua amizade com Walter e Clarisse. Walter, seu amigo desde seus dias de escola, era um artista, algumas vezes um musicista, professor, crítico, e ora uma espécie de funcionário em um instituto de arte. Embora bem dotado, não parecia realizar grande coisa; pior ainda, agora que estava numa posição que lhe permitia pintar, as grandes obras esperadas por todos seus amigos deixavam de se materializar. Em vez de pintar, passava a maior parte de seu tempo ao piano, tocando Wagner, cuja música ele tinha anteriormente rotulado de decadente, mas à qual agora se dedicava.

Antes de seu casamento, Clarisse acreditava que Walter fosse um gênio em potencial. Seu pensamento estava dominado pelas idéias de Nietzsche; em conseqüência ela considerava ser vocação de Walter tornar-se um gênio, objetivo que, em sua visão, poderia ser alcançado simplesmente pela força de vontade. Quando Clarisse começou a compreender que seu marido jamais atingiria qualquer espécie de grandeza, viu nisso; cada vez mais; uma traição pessoal e; embora ainda tocassem juntos duetos, ao piano, o resto de suas vidas de casados era cheio de crescente tensão.

As figuras de Walter e Clarisse, bem como de alguns outros personagens principais no romance, são baseadas em pessoas reais conhecidas de Musil, e seus modelos, para fins literários, foram delineados nos Cadernos de Anotações. Contudo, não se pode esquecer que, em todos esses casos, o autor não está esboçando o retrato da pessoa original como tal, mas usando-a como um modelo, freqüentemente com uma boa dose de licença poética, para estabelecer o personagem, a fim de atender a seus propósitos particulares. ${ }^{211}$

Os modelos para Walter e Clarisse, Gustav e Alice Donath, são discutidos em detalhes nos primeiros Cadernos de Anotações existentes de Musil, iniciados por volta de 1904-5. Em setembro de 1910, ele registra que Alice foi levada para um hospital de doenças mentais. Essa familiaridade pessoal, com uma mulher que gradualmente perde seu equilíbrio mental, sem dúvida reforçou seu interesse nas questões de personalidade, estabilidade ou desintegração, evidentes em toda a ficção e drama de Musil. Os principais protagonistas, seja Törless ou Ulrich são, naturalmente, modelados em aspectos do autor e,

${ }^{211}$ MUSIL, GW, v. 1, cap. 14, p. 47-54; HSQ, Amigos de juventude. Livro Primeiro, cap. 14, p. 66-74. 
no romance mais importante, Musil expõe a alienação da figura central, da sociedade e a conseqüente desorientação em si mesmo.

A amizade de Musil com alguns psicólogos da Gestalt intensificou seu interesse por esses assuntos, enquanto seu próprio esgotamento, em 1929, e subseqüente tratamento pelo psicanalista adleriano Dr. Hugo Lukács, proporcionou-lhe experiência de uma outra abordagem para o estudo da personalidade. Os Cadernos de Anotações contêm inumeráveis comentários breves sobre pessoas que ele encontrou na vida diária, de humildes a eminentes; um aspecto ou outro de uma personalidade é selecionado. No romance, ele mostra a atuação recíproca de muitas personalidades diferentes, uma com a outra e com Ulrich. Nas reflexões de Ulrich sobre outras figuras, sobre si mesmo e sobre o estado de sociedade, sua principal preocupação é sempre com o equilíbrio entre os fatores que compõem a personalidade e o caráter humanos, particularmente o equilíbrio entre intelecto e emoção.

O Livro Segundo de $O$ homem sem qualidades centra-se no debate que considera o papel da emoção na vida humana e, no Livro Primeiro, Ulrich retorna a essas questões ocasionalmente, não apenas durante as reuniões do comitê da Ação Paralela, mas mesmo durante seus encontros mais íntimos com Bonadea.

No extremo mais distante da razão situa-se o espectro da loucura, e, não contente em relatar a gradual descida de Clarisse para a insanidade, Musil introduz, no início do romance, a figura de Moosbrugger, o psicopata. Moosbrugger, um homem grande, com força descomunal, mas mentalmente anormal, que matara uma prostituta de maneira horrível.

No capítulo mais longo de sua introdução, Musil descreve em detalhes a vida anterior desse homem, à primeira vista um trabalhador aparentemente decente, de boa índole como qualquer outro, que já havia cometido um sem-número de crimes. Se ele era ou não responsável por suas ações era uma questão que mesmo os psiquiatras pareciam incapazes de decidir. $\mathrm{O}$ autor escreve como se de dentro da mente de Moosbrugger. $\mathrm{O}$ assassino levara uma vida errante como um aprendiz de carpinteiro, nunca tivera um 
pouso, estava sempre sem dinheiro e assim era incapaz de abordar qualquer mulher, a não ser pela força. Na noite do crime, a prostituta assassinada o havia, de fato, abordado, mendigado, adulado e seguido, até que finalmente ele a esfaqueou, apenas para que ficasse quieta. No tribunal, Ulrich ficou impressionado com as diferentes atitudes dos participantes. Moosbrugger, decidido em sua dignidade, recusou que seu advogado de defesa sugerisse diminuição de responsabilidade; por outro lado, quando o juiz, citando numerosas condenações anteriores, procurou provar assassinato premeditado com intenção criminosa, Moosbruger contestou também essa interpretação. Em sua mente simples, não havia conexão alguma entre os sucessivos incidentes de sua vida solitária. Estava totalmente incapaz de compreender os argumentos apresentados pelo juiz. Mas o juiz, de sua parte, na visão de Ulrich, apresentou para o caso princípios legais e morais inadequados e ultrapassados. Quando a pena de morte foi pronunciada, Moosbrugger bradou em voz alta que estava contente, mas gostaria de confessar que era insano. Ulrich ficou fascinado com esse comportamento incoerente; evidência clara, ele pensou, de insanidade, mas ao mesmo tempo não mais do que uma distorção dos elementos da vida normal. Naquele momento, ele estava certo de que a conexão entre si próprio e Moosbrugger era muito mais íntima do que qualquer pessoa podia suspeitar. Ao final do julgamento, quando o advogado de defesa anunciou que iria apelar, assegurou assim que Moosbrugger apareceria mais tarde no romance. ${ }^{212}$

- Paternidade da obra

O pai de Ulrich, diferente de seu filho, era um homem com qualidades. De modesto começo como advogado, tinha chegado a uma cadeira universitária de jurisprudência; além disso, cultivava assiduamente os relacionamentos com a aristocracia, desde sua juventude, quando era um jovem professor particular em grandes famílias, tornando-se não só confidente íntimo de dignitários de tribunais de justiça, mas também sendo nobilitado e nomeado membro da Câmara Alta do Parlamento. Certo dia, Ulrich recebeu uma carta de seu pai, descrevendo em linhas gerais os planos para o jubileu do

${ }^{212}$ MUSIL, GW, v.1, cap.18, p.67-76; HSQ, Moosbrugger. Livro Primeiro, cap.18, p.87-96. 
imperador no ano de 1918. Solicitava com insistência que seu filho, cuja falta de vontade de se estabelecer lhe tinha causado amargo desapontamento, entrasse em contato com um seu amigo, funcionário graduado do tribunal, que lhe tinha prometido conseguir um lugar para Ulrich no comitê do jubileu. Ulrich foi também solicitado a não perder tempo e visitar logo uma parenta distante, esposa do Sr. Tuzzi do Ministério das Relações Exteriores, que estava, ela mesma, intimamente envolvida nos preparativos do jubileu. ${ }^{213}$ Essa carta forma o prelúdio da participação de Ulrich na Ação Paralela e, por conseguinte, a principal parte do Livro Primeiro de $O$ homem sem qualidades. Todo o título, no cabeçalho dessa seção é uma frase curta ligada para dar dor de cabeça a qualquer tradutor. Trata-se de "Do qual singularmente nada se depreende" (alem. Woraus bemerkenswerter Weise nichts hervorgeht), porém poderia ser: -A história se repete - ou "Não há nada novo debaixo do sol". O autor usa o mesmo título para o capítulo 83, acrescentando por boa medida: "Acontece a mesma coisa, ou: por que não se inventa a história?" (alem. Seinesgleichen geschieht oder warum erfindet man nicht Geschichte?). A essa altura ficará aparente que a Ação Paralela atrai toda a força de sátira de Musil. As reuniões do comitê, petições, deliberações, adiamentos e uma variedade de eventos sociais, como último recurso, não chegando a resultado algum, são descritos de maneira perspicaz, demonstrando um espírito observador, transformados, de vez em quando, em alta comédia.

As figuras líderes da campanha eram Diotima Tuzzi e o conde Leinsdorf. Apesar de sua idade avançada, o conde, dono de vastas propriedades, estava muito interessado em desempenhar uma parte ativa na vida da nação. Como o próprio imperador, com oitenta e três anos, em 1913, Leinsdorf pertencia a uma outra era e controlava seus camponeses com benevolente despotismo. Patriota fervoroso tomou a si a suprema responsabilidade dos preparativos do jubileu, contentando-se em deixar a organização nas mãos de Diotima. Quando Ulrich conheceu sua prima, achou-a bonita, encantadora e, para sua surpresa, relativamente jovem. Seu marido, embora não sendo nobre de nascimento, ocupava um alto posto no Departamento de Assuntos Exteriores da Kakânia e era considerado o braço direito do ministro, um dos poucos homens com real poder e influência nos assuntos

\footnotetext{
${ }^{213}$ MUSIL, GW, cap. 3, p. 13-15 e cap. 19, p. 77-79; HSQ, Também um homem sem qualidades tem um pai com qualidades, cap. 3, p. 32-34. $H \mathrm{~S} Q$, Carta de exortação, e oportunidade de obter qualidades. Concorrência de duas ascensões ao trono, cap.19, p. 97-99.
} 
europeus. Graças a sua influente posição e à aptidão de Diotima para organizar e dizer frases de efeito, sua casa se tornara conhecida como um salão, um lugar de encontro dos ricos e grandes, e assim, o centro óbvio para os eventos da Ação Paralela. ${ }^{214}$

Apesar do patrocínio do conde Leinsdorf e da responsabilidade de sua posição, Diotima não era feliz, e a razão estava em seu casamento. Era usual nesse período que o casamento fosse baseado mais em conveniência do que em amor. Seu marido era consideravelmente mais velho do que ela e, conquanto encorajasse suas atividades culturais, ele era bem consciente das vantagens potenciais para si próprio, mas não estava preparado para levá-las, de modo algum, seriamente. Como não tinham filhos, ela ficava livre para ler bastante; seus autores favoritos eram Maeterlinck, Novalis e outros escritores interessados, acima de tudo, nos aspectos da alma. Certo dia, Diotima recebeu uma visita do Dr. Paul Arnheim, um rico e poderoso industrial prussiano que chegara a Viena, assim ele disse, para se recuperar das pressões dos negócios, confiante em que o encanto barroco da cultura austríaca restauraria sua mente e alma. Ela já soubera que, além de suas responsabilidades na firma da família, ele havia escrito livros defendendo um uso muito maior de idéias em negócios, diplomacia e em todas as esferas de poder. Quando esse homem importante demonstrou estar receptivo não somente a sua pessoa, mas igualmente impressionado por sua mente, ela ficou encantada e imediatamente teve uma idéia brilhante. $^{215}$

A idéia de Diotima foi a de que o grande homem deveria assumir a liderança da campanha. $\mathrm{O}$ fato de ser ele prussiano e de que a campanha originara da rivalidade contra a Prússia, não apresentavam, em sua animada disposição, um obstáculo insuperável. O conde Leinsdorf, por outro lado, foi inflexível, declarando que a liderança estava fora de questão, embora permitisse, eventualmente, que Arnheim se juntasse ao comitê. Ele declarou que o único homem que ele consideraria para o posto de secretário honorário da

\footnotetext{
${ }^{214}$ MUSIL, GW, v.1. cap. 21-23, p. 87-98; HSQ. A verdadeira invenção da Ação Paralela pelo conde Leinsdorf. Livro Primeiro, cap. 21, p. 107-112; HSQ, A Ação Paralela, na forma de uma dama influente de indescritível graça espiritual, dispõe-se a devorar Ulrich. Livro Primeiro, cap. 22, p. 112-116; HSQ. Primeira aparição de um grande homem. Livro Primeiro, cap.23, p. 116-119.

${ }^{215}$ MUSIL, GW, cap. 23, p. 95-98; cap. 25, p. 103-107; cap. 27, p. 110-111; HSQ, Primeira aparição de um grande homem. Livro Primeiro, cap. 23, p. 116-119; HSQ, Sofrimentos de uma alma casada. Livro Primeiro. cap. 25, p.124-129. HSQ, Natureza e substância de uma grande idéia, cap. 27, p. 132-133.
} 
campanha era Ulrich, e logo o homem sem qualidades viu-se nomeado, quisesse ou não. ${ }^{216}$ Arnheim permaneceu em Viena por algum tempo, e o caso amoroso entre ele e Diotima desenvolveu-se ao longo de linhas não usuais. Sem dúvida, houve atração de ambos os lados, mas depois de prolongada hesitação, a precaução finalmente prevaleceu, de modo que, ao final do relacionamento, sobrou pouco mais do que a troca de frases exageradas citadas de Maeterlinck.

Um caso paralelo entre a bela criada judia de Diotima, Raquel, e o jovem criado negro de Arnheim, Solimão, seguiu um curso mais prognosticado. Talvez a principal justificativa de introduzir Arnheim no enredo tenha sido a de mostrar um pólo oposto a Ulrich. O personagem é baseado em Walther Rathenau, a quem Musil encontrou em 1914, em Berlim; era um industrial e escritor e mais tarde foi Ministro do Exterior da República Weimar. ${ }^{217}$ No romance, a presença de Arnheim em Viena não é tão inocente como pretende, desde que envolve motivos comerciais. Ele é primeiramente um realista e, por conseguinte, a antítese de Ulrich, envolvido no mundo de negócios, interessado em dinheiro, pelo próprio dinheiro e pelo poder que este confere; contudo, reivindicando o direito de se pronunciar em detalhes sobre assuntos nos quais, de acordo com Ulrich, pode ser considerado apenas um amador. A tensão entre esses dois homens chega ao clímax no capítulo 121 - A conversa.

- Metamorfoses do sujeito no campo paralelo da guerra

Para completar o panorama da sociedade vienense, o autor introduz um número de figuras, por exemplo, General Stumm von Bordwehr, do Ministério da Guerra. A intenção é que ele presumivelmente fosse um representante das forças do mal, mas surge como um velho amigo de Ulrich, dos seus dias de exército, franco e com os pés no chão, dono de um estilo de frase despretensioso que causa uma mudança agradável, depois da linguagem quase-filosófica de alguns outros personagens. Uma outra secundária, mas significativa

${ }^{216}$ MUSIL, GW, cap. 40, p. 151-162; HSQ, Um homem com todas as qualidades, mas elas the são indiferentes. Um príncipe do espírito é preso, e a Ação Paralela recebe seu secretário honorífico. Livro Primeiro, cap. 40, p. 174-186.

${ }^{217}$ MUSIL, Diaries, p. 295. 
personagem, é a do banqueiro judeu Leo Fischel, com sua gentil esposa Klementine, cuja filha Gerda é colhida não apenas no fogo cruzado de discordâncias dos pais, mas também na fricção entre velhas e novas visões do papel da mulher na vida. Em sua determinação para mostrar sua independência, para se libertar do estereótipo da jovem elegante esperando em casa que apareça um marido, Gerda se envolve no movimento Nacionalista Alemão, precursor do Socialismo Nacional, que estava ganhando terreno nas áreas de língua alemã do Império nesse tempo. O movimento é representado, no romance, por um jovem pouco atraente chamado Hans Sepp, com quem Gerda se envolve, num frustrante relacionamento platônico, que se torna cada vez mais difícil, por causa da tendência dele de expor com freqüência suas teorias irracionais e anti-semitas na casa dos pais dela. ${ }^{218}$ Para equilibrar os pontos de vista nacionalistas de Hans Sepp, Musil também planejou incluir um jovem revolucionário socialista chamado Schmeisser, cujo nome contém uma sugestão de "derrocada", mas essa figura não aparece no texto final.

É nas sessões plenárias da Ação Paralela que o dom de Musil para comédia encontra a maior oportunidade de ação. O salão de Diotima era há muito tempo conhecido como o lugar onde era possível encontrar os ricos, os poderosos e a nata da sociedade, juntos com aqueles tidos como autoridades mundiais em alguma especialidade ou outra da qual nunca se ouvira falar. Graças à ação do Conde Leinsdorf, de designar a residência Tuzzi como o centro oficial da Ação Paralela, as noites culturais de Diotima adquiriram ainda maior brilho. Ela decidiu instalar um comitê especial, a fim de formular um roteiro das resoluções para as celebrações do jubileu do imperador; os membros desse grupo deveriam ser retirados dos campos da arte, literatura e de estudiosos, aos quais se juntariam outros convidados como meros observadores. Por ocasião da primeira reunião, cada hóspede foi graciosamente saudado pela anfitriã com algumas palavras bem escolhidas, com referência à sua última obra, realização admirável que apenas se tornou possível graças à assistência do secretário particular de Arnheim, que preparou uma coleção de extratos apropriados. Os móveis foram retirados dos cômodos contíguos ao salão do apartamento, à exceção de uma grande estante contra a parede final, e quando os distintos hóspedes abriam caminho no meio dos grupos, cada um podia ser observado

${ }^{218}$ MUSIL, $G W$, v. 1, cap. 51, p. 202-208; cap 73, p. 307-315; cap. 113, p. 549-563; HSQ, A família Fischel. Livro Primeiro, cap. 51, p. 228-234; HSQ, Gerda, filha de Leo Fischel. Livro Primeiro, cap. 73, p. 335-344. Ulrich conversa com Hans Sepp e Gerda na linguagem mista da fronteira entre supra e sub-racionalidade. Livro Primeiro, cap. 113, p. 585-600. 
examinando os livros à mostra, com altruísta curiosidade até que, finalmente, tendo localizado suas próprias obras, assumiam um ar de tranqüila satisfação. ${ }^{219}$

Surpreendentemente foi o General Stumm que, em sua admiração por Diotima e por seu desejo de ajudá-la em suas investigações, atribuiu a si a tarefa de pôr os pensamentos da idade moderna numa espécie de ordem. A confusão de atuação recíproca de idéias e ideologias, novas direções em arte, ciência e política, expressionismo, socialismo, marxismo, psicanálise e outras, todas elas representadas nas reuniões na casa de Diotima, tinham, por qualquer razão, deixado de produzir a idéia salvadora que ela esperara encontrar. $\mathrm{O}$ general decidiu, por conseguinte, entrar em ação.

Como não era um homem de fazer jamais coisas pelas metades, dirigiu-se diretamente à Biblioteca do Tribunal Imperial onde, ele pensava, com certeza seria capaz de descobrir a maior idéia dos tempos modernos. Seu plano original era ler o material acumulado, à razão de um livro por dia, mas, ao verificar que a leitura assim planejada exigiria dez mil anos para ser levada a cabo, foi obrigado a mudar sua tática. $O$ bibliotecário que o estava orientando ficou perplexo com a falta de precisão do general, a respeito do objeto de sua procura.

Quando o bibliotecário encaminhou o general Stumm à sala do catálogo central e lhe entregou "a bibliografia das bibliografias", na esperança de que isso resolvesse o problema, o general, talvez de maneira compreensível, ficou apavorado e quando the explicou que ele apenas poderia colocar esses milhões de livros em ordem, mas nunca ler um único, o general ficou pasmo. Dada a atualidade das questões apresentadas, o diálogo entre o bibliotecário e o general deve ser ressaltado:

\footnotetext{
${ }^{219}$ MUSIL, GW, v. 1, cap. 24, p. 98-103; cap. 42, p. 167-173; cap. 44, p.177-182; cap. 71, p. 296-301; HSQ, Propriedade e cultura; a amizade de Diotima com o conde Leinsdorf, e o ofício de harmonizar convidados famosos com a alma. Livro Primeiro, cap. 24, p. 119-124; HSQ, A grande sessão. Livro Primeiro, cap. 42, p. 191-197. Prosseguimento e final da grande reunião. Ulrich agrada-se de Raquel. Raquel de Solimão. A Ação Paralela recebe uma organização firme. Livro Primeiro, cap. 44, p. 202-207; HSQ, Começa a reunir-se a comissão para a jornada de uma resolução diretiva quanto ao jubileu dos setenta anos de reinado de Sua Majestade. Livro Primeiro, cap. 71, p. 324-329.
} 


\begin{abstract}
'Senhor general, aqui tenho uma bibliografia das bibliografias.' Você sabe o que é isso? É o registro alfabético dos registros alfabéticos dos títulos daqueles livros e trabalhos que, nos últimos cinco anos, trataram dos progressos das questões éticas, exceto teologia moral e belas letras'. (...) [E o general exclamou:] 'Senhor bibliotecário! (...) Não me abandone sem me ter revelado como consegue se orientar nesse (por descuido eu disse hospício) 'hospício de livros'. Ele deve ter me entendido mal; depois me ocorreu que se diz que os loucos gostam de chamar os outros doidos. [O bibliotecário respondeu:] 'Senhor general (...), o senhor quer saber como conheço cada livro? Posso the dizer: é porque não leio nenhum! (...) O segredo de todos os bibliotecários é que nunca lêem senão os títulos e índices de conteúdo dos livros que lhes são confiados. [O bibliotecário continuou:] 'Muitas vezes senhores da Escola de Guerra vêm aqui. Basta que o general me diga qual tema o interessa no momento. (...) Leis de defesa? Discussões de orçamento? (...) os alunos da Escola de Guerra, quando têm uma tarefa escrita, às vezes o procuram pedindo livros (...) ou então o senhor deputado, que precisa escrever o relatório sobre o orçamento de educação, vem e me pergunta que obras consultou o deputado que fez a mesma coisa no ano passado, (...) ou um dos professores da universidade, se queixa de que há três anos está pedindo um livro sem o receber, e aí preciso procurar em todas as prateleiras vizinhas para ver se não o colocaram fora do lugar, até descobrir que o professor está com o livro há dois anos e não o devolveu. ${ }^{22}$
\end{abstract}

Sem saber explicar ao bibliotecário o que desejava ler, este sugeriu que o general lesse Kant, ou algo assim, sobre os limites de conhecimento. Após explanar sobre o que entendia por uma "ordem civil perfeita", o general se dá conta de que não quer ler mais coisa alguma. Ele tem a "sensação engraçada":

\begin{abstract}
imagine apenas uma ordem humana total universal, em suma uma ordem civil perfeita: eu afirmo, essa é a morte, a rigidez cadavérica, uma paisagem lunar, uma epidemia geométrica! (...) Compreendo porque no exército, onde temos a maior ordem, ao mesmo tempo devemos estar juntos para dar nossa vida a qualquer momento. Não posso explicar por quê. De alguma forma a ordem passa a ser desejo de matar. ${ }^{221}$
\end{abstract}

\footnotetext{
${ }^{220}$ MUSIL, GW, v. 2, cap. 100, p. 461-462; HSQ, O general Stumm se infiltra na biblioteca pública e colhe experiências sobre bibliotecários, serventes de bibliotecas, e ordem intelectual. Livro Primeiro, cap. 100, p. 495.

${ }^{221}$ MUSIL, $G W$, v. 2, cap. 100, p. 465; HSQ, O general Stumm se infiltra na biblioteca pública e colhe experiências sobre bibliotecários, serventes de bibliotecas, e ordem intelectual. Livro Primeiro, cap.100, p. 497.
} 
Ao final, foi deixada a um velho carregador a tarefa de ajudar Stumm. O que o bibliotecário fez para ajudá-lo foi encontrar todos os livros que a própria Diotima lia, em suas visitas regulares à biblioteca, causando grande satisfação ao general. ${ }^{222}$

A visão irônica de Musil, a respeito do bibliotecário profissional, certamente remonte ao seu próprio emprego na biblioteca da Universidade Tecnológica de Viena, de 1911 a 1914. No final do capítulo 100 - O general Stumm se infiltra na biblioteca pública e colhe experiências sobre bibliotecários, serventes de bibliotecas, e ordem intelectual -, o relato divertido de sua expedição à biblioteca subitamente assume uma nota mais séria, quando reflete sobre o conceito de ordem como tal. A ordem é necessária, a ordem é boa; mas, se na esfera de idéias, política ou moralidade, um sistema de ordem universal, sem exceções, onde cada simples coisa funcione de acordo com as regras, pode terminar matando a coisa que objetiva preservar. Quando o sistema em si se torna predominante, rígido e destituído de vida, tudo dentro dele deve eventualmente enrijecer. Esse conceito de ordem como morte potencial forma um lado da dicotomia à qual Ulrich constantemente retorna, e a fantasia a ela associada usualmente focaliza o contraste entre rigidez, rigor mortis, e a abundância da vida como metáfora para a imaginação e sentimentos.

Uma das primeiras ocasiões em que Musil faz esse contraste numa obra publicada é no importante ensaio sobre a natureza e o funcionamento da mente criativa do escritor, e lá, como depois, a oposição entre rigidez e movimento ganha significação vital. Ele expõe assim o seu raciocínio com sarcasmo:

\footnotetext{
Há séculos (...) o mundo conhece a verdade dos pensamentos e, por isso, até certo grau, conhece a liberdade de pensamentos. Durante esse tempo, o sentimento não teve nem a severa escola da verdade, nem a liberdade de movimento. Pois cada moral em sua respectiva época regulou os sentimentos apenas (e ainda rigidamente) na medida em que certos princípios e sentimentos básicos fossem necessários ao comportamento por ela desejado; o resto, porém, ela deixou ao arbítrio, ao jogo pessoal de sentimentos, aos esforços incertos da arte e da discussão acadêmica. A moral adaptou, portanto, os sentimentos às necessidades da moral, e com isso deixou de desenvolvê-los, embora dependa deles. Essa é a ordem e unidade do sentimento. ${ }^{223}$
}

\footnotetext{
${ }^{222}$ MUSIL, GW, v. 2, cap. 85, p. 370-380 e cap. 100, p. 459-465; HSQ, Esforço do general Stumm para colocar ordem no espírito civil. Livro Primeiro, cap. 85, p. 401-411; HSQ, O general Stumm se infiltra na biblioteca pública e colhe experiências sobre bibliotecários, serventes de bibliotecas, e ordem intelectual. Livro Primeiro, cap. 100, p. 491-497.

${ }^{223}$ MUSIL, GW, cap. 38, p. 1027-8; HSQ, Prepara-se um grande acontecimento. Mas ninguém notou, Livro
} 
$\mathrm{Na}$ opinião de Ulrich, um exemplo impressionante de engessamento entre pensamento e prática deveria ser encontrado na atitude da lei para com o psicopata Moosbrugger. Embora no julgamento os psiquiatras estivessem plenamente de acordo quanto à sua insanidade, a relutância deles, como cientistas, em fazer reivindicações exageradas, com base nas evidências disponíveis, impediu que se opusessem ao veredicto dos advogados. De acordo com critérios legais há muito estabelecidos, Moosbrugger foi, por conseguinte, declarado responsável por suas ações e assim culpado de assassinato. $\mathrm{O}$ julgamento levou Ulrich a refletir que a divisão entre psiquiatras e advogados poderia ser vista como um mero exemplo da divisão difundida na vida diária entre, de um lado, cientistas e outros trabalhadores cujas atividades estivessem baseadas em fatos e evidência empírica, do outro, filósofos, advogados e escritores cuja esfera profissional fosse a de valores. Ele observava que os racionalistas estavam muito preparados para deixar as decisões vitais no campo da beleza, justiça, amor e crença para as suas companheiras e esposas, como se tais decisões pertencessem exclusivamente à esfera feminina. Quando muito, tal campo deveria ser tratado por outro grupo de homens que consideravam tais valores pertinentes exclusivamente ao domínio profissional deles. Muito estranho era o fato de que aqueles que, em seus trabalhos, eram campeões dedicados à causa por uma verdade efetiva se permitissem, em campo oposto, fazer afirmações em assuntos que, afinal, afetavam a todos, sem acreditar numa só palavra dita pelas mulheres - tanto quanto aqueles em que Musil parece se referir aos homossexuais, porém de maneira camuflada, sob os termos "outro grupo de homens" - sem considerar que se pudesse administrar tal campo de modo diferente dessa preconceituosa dicotomia. Ora um lado estava em ascensão, ora o outro. Muito recentemente a opinião tinha se voltado contra a visão científica, e agora era a mentalidade oposta que dominava a vida pública, depreciando o conhecimento exato e clamando com fervor por uma nova crença no homem, na alma e nos valores eternos. ${ }^{224}$

Ulrich, de sua parte, declinou considerar essas atitudes seriamente. Sua perspectiva, desde seus primeiros anos, tinha sido formada por uma visão da vida como uma hipótese: nada é definitivo, todas as coisas no mundo, incluindo os próprios seres

\footnotetext{
Segundo, cap. 38, p. 1083.

${ }^{224}$ MUSIL, GW, v.1, cap. 60-62, p. 242-257; HSQ, Passeio ao reino lógico-moral. Livro Primeiro, cap. 60, p. 269-271; O ideal dos três tratados ou a utopia da vida exata. Livro Primeiro, cap. 61, p. 271-274. Também a Terra, e particularmente Ulrich cultuam a utopia do ensaísmo. Livro Primeiro, cap. 62, p. 274-285.
} 
humanos, estão empenhados num invisível, mas constante processo de mudança; as possibilidades são ilimitadas e periodicamente pode-se vislumbrar de maneira breve a intensa flama da verdade. É um ponto de vista semelhante ao de Emerson, para quem são poucos os humanos a quem se poderia considerar homens acabados. Musil tirou excertos do ensaio de Ralph Waldo Emerson, "Circles", publicado originalmente em $1841^{225}$, para as primeiras partes do romance; nessas notas, ele usa a frase "moralidade dinâmica" para denotar uma visão aberta de vida e uma crença na possibilidade de aperfeiçoamento. A dívida de gratidão de Musil para com pensadores como Emerson é claramente mostrada no capítulo 62 - Também a Terra e, particularmente, Ulrich cultuam a utopia do ensaísmo -, uma das declarações mais explícitas no romance das crenças pessoais de Ulrich. Com crescente maturidade, Ulrich tinha abandonado a idéia de uma hipótese como uma abordagem básica à vida e ora preferia considerar o mundo e sua própria existência de uma maneira não distinta daquela de um ensaio, considerando ora esse aspecto, ora aquele, a fim de obter uma imagem tão plena e completa quanto possível. Essa perspectiva, contudo, retinha a flexibilidade essencial da abordagem anterior, estando ligada a uma visão de moralidade na qual o valor de uma ação ou qualidade, ou mesmo sua própria natureza dependia das circunstâncias resultantes ou do todo do qual formavam uma parte. Pode-se enxergar isso como uma extensão da teoria Gestalt na esfera da moralidade: nessa visão, a significação moral de uma ação condicionava-se ao "campo de força" ou à "constelação" das circunstâncias, de maneira que um assassinato, por exemplo, poderia ser considerado um crime ou, em circunstâncias diferentes, a ação de um herói. ${ }^{226}$

O capítulo 62 se inicia com a idéia de ação e ser exato. A exatidão como comportamento humano pediria tal convergência. Porém, o autor faz uma distinção. Como atributo potencial, não existe apenas a exatidão da fantasia. Existiria também a exatidão circunspeta, e as duas se diferenciam porque a fantasia se atém aos fatos, e aquela que é a circunspeta se atém às imagens da fantasia. Musil orienta o seu raciocínio para definir o que possa ser exatidão justamente a partir de como o espírito do assassino Moosbrugger está inserido num sistema de conceitos jurídicos de dois mil anos. Ele se assemelha aos

\footnotetext{
${ }^{225}$ A primeira série de Nature Centers into Balls, Ensaios de Emerson, "Circles", originalmente publicada em 1841, encontra-se disponível, em sua versão digitalizada em inglês, em: $<\mathrm{http} / / /$ www.rwe.org/works/Essays-1st_Series_10_Circles.htm>. Acesso em: 27/04/2007.

${ }^{226}$ MUSIL, $G W$, v. 1 , cap. 62 , p. $250 ; H S Q$. Também a Terra, e particularmente Ulrich, cultuam a utopia do ensaísmo. Livro Primeiro, cap. 62, p. 276
} 
circunspectos esforços de um louco que não se interessa pelos fatos, e sim pelo conceito fantasioso da lei. Musil estende a sua crítica aos psiquiatras diante da indagação quanto ao dever de sentenciar ou não esse assassino à morte. A indagação para tais especialistas era uma questão exata, pois eles não se atreviam a dizer que o perfil clínico de Moosbrugger não correspondia a nenhum perfil até então observado. Para Musil, a sala do tribunal desse assassino era um retrato da vida, pois todas as pessoas vivas da vida que julgam aspectos corriqueiros do cotidiano, fazem isso com a mesma pretensão de racionalizar tudo o que está a seu alcance.

\footnotetext{
Todas elas deixam a questão da beleza, da justiça, do amor e da fé, em suma: todas as questões da humanidade - enquanto não tenham nelas interesses comerciais - entregues às suas mulheres; e quando essas não são suficientes, entregam-nas a uma subespécie de homens que lhes falam do cálice e da espada da vida em frases milenares, e a quem escutam sem muita atenção, céticas e aborrecidas, sem acreditar em nada, e sem pensar na possibilidade de agir de outra maneira. ${ }^{227}$
}

Nesse capítulo, Musil mostra ilustra com clareza o que haveria de examinar como a “outra condição" estendendo-a à visão do que é propriamente o homem sem qualidades. Ele se revela como a corporificação de suas possibilidades, o homem potencial, em contraste com a visão tradicional de homem como uma realidade sólida ou um caráter estável. O inquietante corolário desse entendimento da natureza humana resultou que Ulrich se sentiu capaz de todas as virtudes e de todos os vícios. Ele considerava a moralidade, no seu sentido usual, um sistema exaurido pelo passado. O homem sem qualidades pensava que, no mundo moderno, os seres humanos deveriam criar, constantemente, sua própria moralidade vital, mediante a reforma deliberada de assunções subjacentes, considerando fatos e circunstâncias particulares. Esse entendimento existencialista de moralidade seria interpretado não mais como um conjunto de regras rígidas, mas como uma balança minuciosamente equilibrada, que exige esforço incessante para sua constante renovação. Parecia a Ulrich que muitos desenvolvimentos isolados nos últimos anos apontavam para o possível reconhecimento dessa nova abordagem. Ele pensava que isso exigiria, acima de tudo, uma combinação de exatidão e paixão, dos elementos matemáticos e emocionais nos seres humanos - contudo, não na forma de filosofia sistemática que ele, como muitos de seus contemporâneos, consideravam com

\footnotetext{
${ }^{227}$ MUSIL, GW, cap. 62; HSQ, Também a Terra, e particularmente Ulrich, cultuam a utopia do ensaísmo, cap. 62 , p. 275.
} 
desconfiança. A experiência the tinha ensinado que os filósofos tendiam a aprisionar as idéias dentro de um sistema, enquanto sua própria busca de iluminismo fora abrasada pela esperança de que a verdade poderia ser conhecida sem recurso a sistemas e à inevitável rigidez. Novamente, Musil utiliza o conceito do ensaio literário que veio em auxílio de Ulrich, uma forma entendida como a expressão única da vida interior de um pensador, num momento particular. Os escritores desses ensaios, "mestres de uma vida interior em equilíbrio", eram, para ele, homens de verdadeira sabedoria, santos com e sem religião. Para discutir a perda da força intelectual na ação política, requerida à Ação Paralela, Musil teria anteriormente criado um diálogo entre os protagonistas, envolvido em sarcasmo. No capítulo 49 - Contrastes iniciais entre antiga e nova diplomacia -, ele havia revelado como chegar a tal raciocínio, usando as palavras do empresário Arnheim. Este pondera sobre o sentimento de desintegração e falta de segurança interior como algo insalubre nos tempos modernos. Quando se pensa em convocar um representante religioso para ser o representante da Ação Paralela o empresário afirma que a religião, tanto quanto a nação, o Estado, a ciência e a cultura, não é algo que reflete a modernidade. Restaria a arte como possibilidade de espelhar "a unidade da existência e sua ordem interna" (p. 222). Porém, a desintegração também a atinge, levando a extremos sem ligação entre si. Stendhal, Balzac e Flaubert souberam criar a epopéia dessa nova vida social e sentimental mecanizada, enquanto Dostoievski, Strindberg e Freud descobriram demônios das camadas subjacentes. Nada teria sobrado por fazer.

O autor coloca o protagonista central de tal discurso como um "cavaleiro cavalgando, montado em sua cela". Suas palavras assumem o tom da retórica, nivelando no mesmo horizonte a Bíblia, Homero, Cristo, Napoleão, os Faraós do Egito, a obra de Kant, Buda e Goethe. A argumentação do empresário se encaminha para concluir que "o problema da civilização só se resolve com o coração, com o surgimento de uma nova personalidade. Com o rosto interior, e a vontade pura. A razão só conseguiu reduzir a grandeza do passado até o liberalismo. (...) Cada minuto pode ser uma virada no mundo" (p. 223), ele exclama. ${ }^{228}$

\footnotetext{
${ }^{228}$ MUSIL. $G W$, cap. 49, p. 197-198; HSQ, Contrastes iniciais entre antiga e nova diplomacia. Livro Primeiro, cap. 49, p. 222-223.
} 
Não obstante, Ulrich estava convencido de que qualquer esforço para extrair e codificar os ensinamentos desses mestres estava destinado ao fracasso: uma vez separados de suas formas vivas, apropriadas, não podiam esperar sobreviver, não mais do que o delicado iridescente corpo de uma água-viva, lançada da água para a areia seca. A atmosfera emocional de seus escritos era tão essencial como o conhecimento nela encarnado, e ao considerar esse aparente paradoxo, Ulrich se achou preso na oposição entre as metades emocional e lógica de seu próprio ser.

Lógica versus emoção - foi essa a real razão de ter abandonado sua pesquisa matemática? Qual tinha sido a força impulsionadora original por trás de seu trabalho? A busca para a vida legítima; mas o que era, e quando esperava atingi-la? Ulrich subitamente compreendeu que, em suas tentativas de conhecer, antes que se permitisse sentir, em sua determinação de excluir a emoção completamente de sua vida tinha, por anos, vivido contra si mesmo. Desejou ardentemente que alguma coisa inesperada ocorresse, para resolver o conflito entre seu próprio coração e mente. Seis meses tinham agora se passado, desde sua decisão de tirar uma licença de um ano da vida, e o que tinha alcançado? Nada, a não ser sua participação insignificante na Ação Paralela. Ele estava esperando; esperando por trás de sua própria pessoa, e seu surdo desespero, refreado como a água contida numa represa, aumentava cada vez mais a cada dia que passava. Foi a crise mais profunda de sua vida, e ele se desprezou pelas coisas que tinha deixado de fazer. Tudo o que restou foi uma espécie de obstinada persistência, uma implacável determinação de se manter firme, na esperança de que o futuro trouxesse uma solução para seus problemas.

- A obra no espelho da guerra

Contudo, as atividades da Ação Paralela continuavam, como sempre. Além de atuar como secretário do conde Leinsdorf, Ulrich era solicitado por várias outras pessoas que esperavam tirar proveito de sua influente posição. Leo e Klementine Fischel achavam que seria uma excelente idéia reavivar o antigo interesse de Ulrich em sua filha Gerda e assim livrá-la de sua infeliz relação com Hans Sepp. O pai de Ulrich, o eminente jurista, 
escrevera-lhe uma longa carta sobre a questão debatida de definir um estado de diminuição de responsabilidade; ele estava muito ansioso e esperava que, na versão revisada da lei criminal, então sendo minutada, sua própria interpretação pudesse prevalecer sobre a de seu rival, Professor Schwung. ${ }^{229}$ Moosbrugger permanecia na prisão, esperando ser reexaminado pelos psiquiatras. Entre Walter e Clarisse, como entre Diotima e Arnheim, a tensão estava aumentando, e, em ambos os casos Ulrich estava de algum modo envolvido.

Quando o comitê de organização da Ação Paralela se reuniu uma vez mais, seus membros revelavam uma falta de progresso desanimadora na escolha de um tema condutor para o ano do jubileu do imperador. Nada até agora apresentado tinha merecido aprovação incondicional, e novas idéias eram escassas. "Talvez a defesa do Reino, em outras palavras, novos armamentos?" Sugeriu o general. Isso conduziu a um intenso debate, no curso do qual evidenciou-se que uma demonstração contra a campanha estava sendo planejada nos círculos de nacional-socialistas alemães, que a consideravam hostil aos próprios interesses dos alemães. Finalmente, o conde Leinsdorf, exasperado pelo curso infindável de palavras em torno de um vácuo, anunciou lenta e firmemente: "Alguma coisa deve ser feita!" Inquirido sobre o que tinha em mente, foi incapaz de ser mais específico, mas insistiu de novo que alguma coisa deveria ser, de fato, feita, com toda força de sua autoridade. ${ }^{230}$

Ulrich, presente, tinha a mente em outro lugar; uma vez mais, estava preocupado com seus próprios problemas. Na manhã após sua súbita compreensão de que a liberdade de meio ano não lhe tinha trazido nada mais próximo a uma solução das suas dificuldades, recebeu uma visita de Bonadea. Determinado a não se tornar emocionalmente enredado dessa vez, Ulrich prendeu-a em conversação, durante a qual ela se esforçou, por razões próprias, a interessá-lo na possibilidade de salvar Moosbrugger da pena de morte. Ulrich desviou tanto dessa questão como de outras intenções óbvias de Bonadea, mas eventualmente sua mente começou, uma vez mais, a meditar, com ansiedade, sobre uma imagem mental de si próprio altamente negativa. O que lhe restava agora? Um homem que

\footnotetext{
${ }^{229}$ MUSIL, GW, cap. 34, p. 128-133 e cap. 111, p. 534-539; HSQ, Um raio ardente e paredes frias, cap. 34 , p.150-155. Para juristas não há semiloucos, cap. 111, p. 569-574.

${ }^{230}$ MUSIL, $G W$, cap. 116, p. 583-600; $H S Q$, As duas árvores da vida e a exigência de um secretariado-geral da exatidão e da alma, cap. 116, p. 620-639.
} 
imaginava que, por amor, sua liberdade interior pudesse desconsiderar a maioria das leis da sociedade. Contudo, a liberdade interior consistia em saber, em cada situação humana, por qual razão não necessitamos estar sujeito a ela, e ao mesmo tempo jamais acharmos qualquer coisa pela qual desejássemos estar sujeitos. A capacidade de enxergarmos ambos os lados de cada questão era nada mais do que ambivalência moral, uma predisposição compartilhada pela maioria de seus contemporâneos. Suas relações com o mundo tinhamse tornado pálidas, sombrias e negativas, baseadas em um ressonante vazio interior. ${ }^{231} \mathrm{~A}$ angústia de Ulrich, a esse ponto, pode estar ligada à de Törless. Tal estado de angústia é brevemente delineado no fim do primeiro romance de Musil, quando Törless, então, estaria mais velho. A liberdade proveniente de restrições morais - ironicamente predita em $O$ jovem Törless - tinha se transformado, na vida de Ulrich, em cinzas e amarga desilusão.

No dia da última reunião do comitê, a mente de Ulrich estava se voltando para uma direção mais positiva, pois ele começava a ver que, para encontrar a salvação, teria, de alguma forma, de restaurar o equilíbrio em si, entre intelecto e emoção. Esperava-se apenas que um homem como Ulrich devesse pensar em emoção em termos de amor, mas o fato extraordinário era que, com uma exceção significativa, em todos seus encontros amorosos tinha faltado real envolvimento de sua parte. Seu caso com Bonadea significou paixão de uma espécie, mais resistida do que buscada por ele e, em suas condutas com Diotima, Clarisse e Gerda, ele certamente estava consciente das qualidades femininas delas. Contudo, apenas uma vez, quando era um oficial muito jovem, fora verdadeiramente arrebatado pelo amor de uma mulher mais velha, a esposa de um major do seu regimento, e mesmo então logo se sentira compelido a fugir de uma situação impossível para uma ilha distante. Estando sozinho entre oceano, rochas e céu, teria pensado em sua amada; mas um sentimento maior o acabrunhava, uma sensação de unicidade com o mundo, um enfraquecimento de causa e propósito, uma claridade e intensidade tais como nunca antes conhecera, uma "outra condição" de vida. ${ }^{232}$

\footnotetext{
${ }^{231}$ MUSIL, $G W$, cap. 63, p. 258-266; HSQ, Bonadea tem uma visão, cap. 63, p. 285-294.

${ }^{232}$ MUSIL, $G W$, cap. 32, p. 120-126; $H S Q$, A esquecida e importantíssima história da esposa de um major. Livro Primeiro, cap. 32, p. 143-148.
} 
Agora, estava se tornando claro para ele que era essa "outra condição" que deveria, de alguma forma, recuperar se quisesse recobrar a verdadeira saúde. Deveria, por conseguinte, abandonar o intelecto? Essa não era solução alguma, mesmo que ele tivesse sido capaz de assim proceder. Quando se assentou, na sala de reuniões, meio consciente do que estava sendo dito, contudo tencionado a clarear seus próprios pensamentos, reluziu na mente de Ulrich que toda a criação bem como a sua própria natureza poderiam ser resumidas nos conceitos de poder e amor. Imaginou seu próprio ser dividido em duas árvores, crescidas e floridas, mas separadas uma da outra. A árvore do poder continha o intelecto, a lógica, certa tendência à violência, um desejo de atacar a vida mostrada mesmo em seus planos napoleônicos da juventude; mas também seu isolamento de pessoas e eventos, seu senso de possibilidades, seu clamor por uma moralidade nova, dinâmica, e todas suas outras demandas, cujo propósito era nada menos do que a transformação do mundo real. A outra árvore, a outra metade de sua própria vida, era mais difícil de perceber, uma vez que grande parte dela situava-se em sonhos e sombras. Conservava memórias de um relacionamento anterior, infantil com o mundo, relacionamento de confiança e abertura, e desde então, um anseio por um estado de "amor" não restrito ao seu sentido usual, mas como uma "outra condição" na qual todas as coisas são mudadas e brilham com intensidade. Sua única tentativa de desenvolver esse lado de seu ser tinha sido o caso da esposa do major, porém, desde aquele tempo, a árvore da emoção tinha permanecido escondida da vista e sua continuada existência tinha de ser inferida das folhas e ramos amontoados na superfície do chão. Talvez a mais clara indicação de sua sobrevivência estivesse no fato de Ulrich estar ciente de que, não importava o que fosse empreendido pela sua metade ativa, ele não poderia escapar à sensação de que todos os seus esforços eram temporários e possivelmente inúteis. Sua vida tinha sido dividida em dois caminhos, um situando-se na luz do dia, o outro na escuridão; portanto, o sentimento de impasse que o oprimira por tanto tempo possivelmente era devido ao fato de nunca ter conseguido unir esses caminhos um ao outro. ${ }^{233}$

Nesse ponto, Ulrich reconheceu que o que havia descoberto continha um significado bem maior do que a mera aplicação em seus próprios problemas. Desde o começo da história, duas atitudes fundamentais podiam ser delineadas nos assuntos da

\footnotetext{
${ }^{233}$ MUSIL, $G W$, cap. 116, p. 583-600; HSQ, As duas árvores da vida e a exigência de um secretariado-geral da exatidão. Livro Primeiro, cap. 116, p. 620-639.
} 
humanidade. O pensamento claro, sem ambigüidade, é, por um lado, comum a argumento lógico e ação efetiva e em qualquer esfera e resulta da mera necessidade de sobreviver. As associações irreais da imaginação, por outro lado, a "lógica desacorrentada da alma", pertencem à arte e à religião, mas também aos relacionamentos afetivos de toda a espécie. Musil apresenta suas idéias com uma pletora de exemplos e alusões, muitos dos quais ainda se aplicavam à vida no fim do século XX, assim como ao ano de 1913. Ulrich, completando suas idéias, a fim de aplicá-las à humanidade, chegou à conclusão de que se sua vida tivesse qualquer significado que fosse, devia ser o de demonstrar como as duas esferas fundamentais da humanidade eram divididas e opostas uma a outra, dentro dele mesmo. E como poderiam ser reunidas? Ele não poderia dizer; sabia apenas que empreender essa tarefa por iniciativa própria estava além de suas forças.

Gradualmente, a mente de Ulrich retornou para as outras pessoas na sala, ainda envolvidas, como estavam, em discussão inútil. Ele se sentia muito solitário, com um pressentimento de que logo seria solicitado, pela primeira vez em sua vida, a tomar uma real decisão; ao mesmo tempo, queria contribuir com o que pudesse para o debate. Voltando-se para o conde Leinsdorf, Ulrich sugeriu que se dedicassem ao "único" empreendimento "que valia a pena": redigir um inventário da mente e do espírito. "O que aconteceria se o Dia do Julgamento caísse no ano de 1918, quando o velho espírito estivesse no fim e um outro, superior, prestes a começar?” Ele propôs que estabelecesse, em nome do imperador, uma Secretaria Mundial para Exatidão e para a Alma, uma vez que, sem esse órgão, todas as outras tarefas seriam insolúveis. Pode-se imaginar a reação do comitê da Ação Paralela. Muito estranhamente, foi o próprio conde Leinsdorf, o velho aristocrata, que melhor compreendeu a intenção de Ulrich. Mas, depois de algum tempo, a reunião foi dissolvida sem se chegar a um acordo, como era o usual.

Os próximos quatro capítulos vão das palavras à ação, ocupando-se de paixão e ameaça de violência. Após um capítulo recontando o clímax do caso entre Raquel e Solimão, o autor descreve uma cena tensa entre Walter e Clarisse, na qual a obsessão dela por Nietzsche e o ciúme dele de Ulrich, e a recusa dela em dar um filho a Walter tudo desempenhava uma parte. No capítulo 119 - A bolsa e a sedução-, contudo, num outro encontro amoroso, o próprio Ulrich estava envolvido: Gerda foi visitar, sozinha, a sua 
casa. Em conseqüência do que ele, relutantemente, presumiu que ela queria ser seduzida; contudo, no exato último momento ela começou a gritar num acesso de histeria. Assim, Ulrich tentou desesperadamente confortá-la e tranqüilizá-la, mas, ao mesmo tempo, viu-se tentado a interromper seus gritos sufocando-a com travesseiros, reação não muito diferente daquela de Moosbrugger para com a prostituta que assassinara. Finalmente, a esperada demonstração contra a Ação Paralela aconteceu: o capítulo 120 - A Ação Paralela causa tumultos - descreve uma revolta de histeria em massa que Musil, como outros escritores europeus de seu tempo, tinha tido oportunidade de observar. A multidão marchava para o palácio do conde Leinsdorf, mas, para alívio de todos, a violência foi evitada.

No capítulo 122 - A caminho de casa, Ulrich foi abordado por uma prostituta, quando retornava para casa, deu-lhe dinheiro e evitou maior envolvimento e então, continuando sozinho, lembrou-se de Moosbrugger na noite do assassinato. Por uma estranha inversão, sentiu por um momento que até a compulsão doentia de Moosbrugger ao agir seria preferível à sua própria e infindável inação. "Tudo isso tem de ser decidido!", disse com força não costumeira. Em casa, encontrou um telegrama anunciando a morte de seu pai, mas encontrou-se também com Clarisse, em conseqüência do que se seguiu outra cena extraordinária. Ulrich passou a noite escrevendo cartas e fazendo malas, uma vez que tinha de partir para o funeral num trem da manhã. ${ }^{234}$ Sentiu que estava em um momento decisivo. Nas horas que precederam a aurora, muito cansado, contudo estranhamente acordado, a mente cheia de fragmentos de sua vida passada: lugares, melodias, cheiros, os detalhes insignificantes e desconsiderados de muitos anos, agora a única realidade a ele deixada. E, muito mais estranhamente, a luz fluindo das lâmpadas ainda acesas, provocavam uma sutil mudança entre ele próprio e o ambiente. A tensão em seu corpo e mente cedeu; ocorreu um efeito de alívio, como se um fio bem apertado tivesse sido desfeito. O espaço em volta de Ulrich e seu relacionamento com ele pareciam estar alterados. Contudo ele não sabia como ou por quê. Havia um modo diferente de ser nele e, portanto, nas coisas ao seu redor. Todas suas proporções estavam, de alguma forma, mudadas, e a emoção sobre a qual os sentidos e intelecto estavam normalmente baseados parecia estar num estado de fluxo.

${ }^{234}$ MUSIL. GW, cap. 123, p. 654-665; HSQ, Reviravolta. Livro Primeiro, cap. 123, p. 693-704. 
Após algum tempo, Ulrich compreendeu que essa era a "outra condição" que experimentara há muito tempo, quando tinha fugido de seu envolvimento com a esposa do major para uma ilha isolada. Seria isso um sinal? Ele não sabia. Passou, e logo ele se vestiu e partiu para a estação.

A publicação, em 1930, do Livro Primeiro de O homem sem qualidades foi saudada com críticas entusiásticas na Alemanha, Áustria e República Tcheca. Os críticos louvavam a abordagem analítica corajosa e a observação aguda de Musil, combinadas com seu conhecimento dos níveis mais profundos do psiquismo humano. Contudo, a situação pessoal de Musil permanecia tão precária como sempre, e ele foi obrigado, uma vez mais, a escrever ensaios e artigos diversos para ganhar dinheiro. Além disso, sua saúde deteriorava e, em fevereiro de 1931, teve de se submeter a uma operação de vesícula biliar. Em resultado da depressão econômica da Áustria, o próprio editor de Musil, Rowohlt, se viu em dificuldades financeiras, mas foi eventualmente persuadido, em setembro de 1931, a estender a ajuda financeira a Musil, por mais seis meses. Musil e sua esposa, então, se mudaram para Berlim, em parte porque lhe foi assegurada ajuda por um grupo de admiradores, liderado por Kurt Glaser, Diretor da Biblioteca Nacional de Arte. Uma outra razão para se mudar era seu desejo de conseguir uma maior objetividade. Ele decidiu se mudar para Berlim, para estar mais próximo dos eventos contemporâneos, acreditando que, ao se distanciar de Viena, com seus ecos do império austro-húngaro, poderia ter uma projeção do mundo no centro de seu romance. ${ }^{235}$

Por volta de 1933, contudo, Rowohlt começou a insistir na publicação de pelo menos parte do segundo livro do romance. A experiência do método de trabalho de Musil levou-o a temer que, por ocasião em que todo o livro estivesse pronto, o interesse do público tivesse evaporado; conseqüentemente, com relutância, o autor concordou em publicar os primeiros trinta e oito capítulos, em março de 1933. Esse foi também o mês em que o novo regime nazista pôs fogo no Reichstag e anunciou decretos de emergência para abolir o partido comunista e o socialista na Alemanha. Como testemunha ocular desses eventos, Musil os registrou em seu Caderno de Anotações com comentários sobre os líderes nazistas, as atividades do partido e as reações do público. A Sociedade Musil, que

${ }^{235}$ HICKMAN, 1991, p. 156-159. 
consistia, na maior parte, de judeus ou opositores do regime nazista, foi dissolvida e conseqüentemente, acabou o apoio financeiro a Musil, em Berlim. Portanto, ele retornou para Viena, onde ainda tinha um apartamento. ${ }^{236}$

Uma vez que os primeiros trinta e oito capítulos do segundo livro completam aquela parte de $O$ homem sem qualidades publicada em vida do autor, e desde que ela é também a extensão da presente tradução inglesa, essa seção da obra será aqui considerada; os capítulos restantes do livro e os problemas de conclusão do romance serão também discutidos brevemente.

O título completo do Livro Segundo - Rumo ao reino dos dois mil anos -, tem um subtítulo entre colchetes, [Os criminosos]. Esses dois títulos, aparentemente contraditórios, fazem sentido quando entendidos à luz das reflexões de Ulrich no Livro Primeiro. Ele chegara à conclusão de que, enquanto dedicava muito esforço para desenvolver seu intelecto, faculdade lógica e força de vontade, tinha também negligenciado a outra área fundamental da vida humana, a das emoções, imaginação e religião. A função, no romance, da irmã de Ulrich, Ágata, baseada parcialmente, como alguns personagens femininos em obras anteriores, na esposa de Musil, Martha, é a de representar esse "outro" aspecto da natureza humana. Ela complementa Ulrich como seu alter ego, ou, em termos jungianos, sua anima. Há muito tempo, Musil se preocupava com a natureza das emoções e das áreas da vida quase ilimitadas nas quais elas desempenham uma parte.

No Livro Primeiro, o irracional é representado pelas figuras de Clarisse, com sua gradual descida para a insanidade, e por Moosbrugger, o psicopata. Contudo, mesmo aqui, há um elemento de comportamento anti-social, culminando em, pelo menos, um ato criminoso, como se para enfatizar que aqueles que vivem pela emoção, mesmo se aparentemente normais, não estão provavelmente de acordo com as normas da sociedade. Assim, Ulrich e Ágata, empenhados em buscar o milênio, o reino de Deus aqui na terra, também se tornam criminosos por transgredir a lei que funda o tabu do incesto.

\footnotetext{
${ }^{236}$ HICKMAN, 1991, p. 157.
} 
Quando Ulrich chegou à cidadezinha provinciana onde tinha crescido, foi recebido pelo velho criado de seu pai, que lhe informou que sua irmã já estava em casa. Ulrich tinha quase se esquecido de Ágata, desde o tempo em que, seguindo-se à morte prematura da mãe, tinham sido enviados para diferentes internatos. Ele se lembrava que ela se casara por amor, muito jovem, que seu marido, igualmente jovem, morrera tragicamente no primeiro ano de seu casamento, e que eventualmente ela se casara outra vez. Por ocasião do casamento, Ulrich tinha tido uma impressão bem pouco favorável do segundo marido, Hagauer, embora o primeiro fosse, em todos os aspectos, um cidadão merecedor de respeito, e mesmo um educador respeitado. Ulrich acreditava que sua irmã deveria ter agora uns vinte e sete anos.

Durante as duas semanas necessárias para arranjar a casa da família, após o funeral, Ulrich e Ágata chegaram a se conhecer bastante um ao outro. Ágata tinha decidido, impulsivamente, a não retornar para Hagauer, a quem ela nunca amara e com quem tinha se casado apenas para agradar ao pai. Ela estava descontente, não apenas com seu casamento, mas também com toda sua vida anterior: faltando-lhe inteira autoconfiança, ela se descrevia como estúpida e indolente, embora sua prosa fosse animada e inteligente e possuísse uma extraordinária memória. Seu senso de inutilidade provinha da incapacidade de ser bem-sucedida, mesmo em seu casamento, em grande parte resultante de sua secreta devoção a seu primeiro marido, ou em qualquer atividade pessoal, como uma carreira. Ela não podia encontrar satisfação nem mesmo nos filhos; na verdade, é curioso que, em um romance passado num tempo em que se esperava que todas as mulheres se casassem e tivessem filhos, nenhuma criança apareça. Quer deva esse aspecto da obra de Musil ser atribuído à sua visão particular, ou quer tenha qualquer conexão com um sentimento geral de esterilidade subjacente à época em que ele viveu, é, contudo, uma questão a ser esclarecida.

A partir do exato momento do primeiro encontro, Ulrich sentiu que existia uma afinidade entre ele e Ágata, tão íntima como a existente entre um par de gêmeos. Durante todo o período do funeral, passaram muito tempo simplesmente conversando um com o outro e descobrindo que, em muitas coisas, pensavam do mesmo modo, muito embora a abordagem dele fosse mais intelectual e a dela, mais emocional. Ele se lembrava da crença 
antiga de um princípio masculino e feminino trabalhando em toda experiência humana. $\mathrm{O}$ autor sublinha a crescente consciência de Ulrich da importância de Ágata, ao descrever como a irmã transformara a sala de visitas da casa, rigidamente formal, para ajustá-la a seu gosto, colocando uma luxuriante planta de interior e um tapete oriental em volta do divã onde se assentava, para ler à luz de uma única lâmpada. Assim, criava um domínio pessoal pleno de linhas livres e padrões da floresta, de natureza, símbolos da imaginação em contraste propositado à pureza racional da sala de visitas neoclássica. ${ }^{237}$

Ágata, de sua parte, estava fascinada ao descobrir que, como ela mesma, Ulrich era essencialmente um rebelde contra o autoritarismo tradicional da sociedade, representado pelo pai e por Hagauer. Muitos dos ditos de Ulrich tinham nela um efeito como que familiar, como se ela tivesse pensado o mesmo sem ser capaz de traduzir em palavras. "As virtudes da sociedade são vícios do santo", ele citava Emerson para ilustrar seu próprio ponto de vista; mas a impressão que essas observações causavam em Ágata era bem mais profunda do que ele supunha. ${ }^{238}$ Uma diferença fundamental entre os irmãos ficou logo aparente. A mente de Ulrich estava cheia de conhecimentos, contudo ele hesitava sobre a mais simples ação e, por vezes, desejava desesperadamente, como Törless no primeiro romance de Musil, envolver-se em eventos - inconscientemente -, mesmo eventos criminosos, exatamente como se fossem reais. Ágata, por outro lado, faltando-lhe qualquer instrução intelectual era, contudo dotada de capacidade intuitiva para compreender os seres humanos, inclinava-se a se aventurar impulsivamente num curso de ação que ela então defendia com todas as forças a seu alcance. Assim ela não só resolveu romper com Hagauer, mas foi também inflexível quanto ao fato de que ele não deveria herdar um vintém do dinheiro de seu pai, muito embora para atingir esse propósito fosse necessário alterar o testamento por meio de um documento forjado. Quando Ulrich tentou demovê-la de imitar a letra do pai deles, ela retrucou que ele próprio tinha descrito o bem e o mal como conceitos relativos, dizendo que regras eram contrárias ao espírito mais íntimo de moralidade. Ulrich foi obrigado a admitir que ele não só havia dito todas essas coisas e

\footnotetext{
${ }^{237}$ MUSIL, GW, cap. .8, p.715-725; HSQ, Família a dois. Livro Segundo, cap. 8, p.756-766.

${ }^{238}$ MUSIL, $G W$, cap. 4, p.696; cap. 13, p.46; HSQ, Ah, eu tive um companheiro. Livro Segundo, cap.4, p. 733. Se existe um senso de realidade, tem de haver senso de possibilidade, Livro Primeiro, cap.4, p. 34-36.
} 
mais: ajudou e acumpliciou-se com os planos de sua irmã, mentindo para Hagauer no dia do funeral. ${ }^{239}$

Ulrich retornou para Viena, onde Ágata logo se juntou a ele. Após algum tempo, Hagauer compreendeu que, em vez de retornar para casa, ela estava tratando do divórcio. O curso posterior dessa parte do romance envolve ação legal, fuga, e possível incesto, porém ele foi deixado indefinido após a morte do autor. Nesta parte do romance, os negócios da Ação Paralela continuavam como antes, mas Ulrich informou que desejava, logo que possível, retirar-se de qualquer parte adicional nos assuntos. Ficou claro para ele que sua experiência de vida, como um observador isolado, fracassara, e pretendia, de agora em diante, dedicar todas suas energias a uma nova experiência, junto com a irmã, um modo de vida sustentado pelo amor, imaginação e misticismo. Ágata e Ulrich viviam em sossego, evitando contatos sociais sempre que podiam, conversando juntos e lendo as obras dos grandes ensaístas e místicos. Musil conhecia a coleção de Martin Buber de relatos pessoais de experiências místicas, e alguns desses são citados no romance por Ulrich ou por Ágata. ${ }^{240}$ Também passavam uma grande parte do tempo discutindo a natureza do bem e do mal, na medida em que sua interpretação de moralidade coincidia com o entendimento do mundo a esse respeito, ou o relacionamento entre razão e imaginação.

Musil já tinha expressado essas idéias, a exemplo daquele ensaio sobre o escritor. Mas no romance põe suas próprias teorias a teste, ao colocá-las na boca de dois personagens fictícios que, então, envidam um sério esforço para viverem por elas. Ulrich e Ágata são explicitamente descritos como não religiosos, como habitantes deste mundo, não do outro, o além; contudo, o autor acentua que eles também são capazes de ter visões, de conhecer a vida da imaginação e de sonhos. A vida deles juntos é uma busca, uma viagem “à beira do possível” que não pode, totalmente, evitar os perigos que isso implica. É um caso limítrofe de duas pessoas - ambas tendo até aqui deixado de encontrar a realização, preparadas para apostar tudo em uma intensa e desesperada procura de sua própria visão da verdade. ${ }^{241}$

\footnotetext{
${ }^{239}$ MUSIL, $G W$, cap 15, p.792-802; HSQ, O testamento. cap.15, p. 836-846.

${ }^{240}$ HICKMAN, 1991, p. 160.

${ }^{241}$ MUSIL, GW, cap. 12, p. 761; HSQ, Diálogos Sagrados. Livro Segundo, cap.12, p. 794-814.
} 
Os últimos capítulos dessa seção do Livro Segundo sublinham o aspecto irracional dos assuntos humanos, vistos de dois outros ângulos. O capítulo $32-$ Nesse meio tempo, o general leva Ulrich e Clarisse ao hospício - (HSQ, p. 1025-1030) e o capítulo 33, -Os loucos saúdam Clarisse - (HSQ, p. 1030-1047) descrevem a visita a um hospital de doenças mentais, onde Moosbrugger aguardava uma decisão sobre seu caso. Clarisse, estando decidida a livrá-lo da pena de morte, tinha, de algum modo, obtido permissão para visitar o hospital, junto com diversas outras pessoas, inclusive Ulrich. O relato detalhado do autor, de várias categorias de pacientes mentais e de seus comportamentos, é baseado em sua própria visita, em 1913, ao Hospital Municipal de Doenças Mentais de Roma, registrado no Caderno de Anotações ${ }^{242}$. Finalmente, os capítulos de 34 a 38 descrevem a última reunião da Ação Paralela à qual Ulrich compareceu, ocasião que poderia ser resumida como uma cacofonia de opiniões opostas, um barulho ensurdecedor atrás do qual, despercebido, o espectro da guerra caminha gradativamente.

- Um homem sem qualidades tem uma genealogia remota

O homem sem qualidades é uma obra grande e complexa, mas suas idéias centrais já haviam sido desenvolvidas em escritos anteriores de Musil: a base teórica do Livro Primeiro fundamenta-se nos ensaios publicados após a Primeira Guerra Mundial, enquanto os principais personagens ficcionais têm também uma genealogia remota. É instigante que seu autor, em hora nenhuma, mesmo em seus rascunhos, não faça nenhuma alusão à mãe do personagem Ulrich. De fato, o lugar ou o nome da mãe deste personagem é sequer aventado. É de se perguntar por quê...

O próprio autor declarou que o romance bem poderia ser abordado via $O$ jovem Törless e The enthusiasts (1983), e é possível traçar uma linha reta de O jovem Törless e Thomas/Anselm a Ulrich, de Regine a Ágata, e de Josef a Hagauer. Os elos entre Ulrich e o jovem Törless mostram como Musil tratou de maneira consistente os mesmos temas no decorrer de sua vida, como escritor. Tanto o jovem estudante quanto o adulto têm

${ }^{242}$ HICKMAN, 1991, p.160. 
problemas de aceitar as definições atuais da realidade; ambos estão certos de que outras espécies de realidade são também válidas, mas têm a maior dificuldade em convencer alguém mais de que assim sejam. Esse ponto de vista pode ter conseqüências particulares. Uma é a preocupação com a identidade: sem saber o que é real, como pode alguém saber quem é? Além disso, uma pessoa que não sabe quem é achará quase impossível tomar decisões e agir. Essa é uma fraqueza fundamental no jovem Törless, e em $O$ homem sem qualidades, Ulrich progressivamente retira-se de todas as situações que exigem ação por parte dele, até que é deixado a Ágata tomar qualquer ação positiva; no caso, uma ação criminosa. Contudo, enquanto parece que a preocupação de Ulrich com palavras e idéias o impede de realizar uma ação exterior, de modo inverso, as palavras podem impor ordem no caos, e isso em si pode ser contado como uma ação de espécie diferente. Finalmente, tanto no primeiro romance como no último, o tema do equilíbrio entre razão e emoção, intelecto e imaginação atinge cada parte do todo. Talvez uma das principais diferenças entre a primeira e a última obra esteja no espectro mais amplo, a maneira pela qual os temas centrais são explorados em um número muito maior de figuras e situações, e com uma série consideravelmente ampliada de referências. Um tema desenvolvido com alguma profundidade em $O$ homem sem qualidades, que mostra a maior percepção social de Musil, depois de trabalhar como jornalista no período entre Guerras, é o da responsabilidade ou ação no contexto social. À primeira vista, parece estar ligado apenas ao caso de Moosbrugger, mas uma reflexão mostra que muitas figuras no romance, particularmente Ulrich e Ágata, são examinadas à luz de responsabilidade de suas ações ou falta de ação, enquanto a disputa legal minuciosa e aparentemente irrelevante sobre esse assunto é levada ao ridículo.

Algumas das influências que ajudaram a formar a mente de Musil na juventude estão ainda presentes em $O$ homem sem qualidades, muito embora o escritor maduro as aborde com maior objetividade. Pode haver pouca dúvida de que foi Nietzsche quem o influenciou - e na verdade toda a sua geração - mais profundamente. De acordo com Karl Löwith, a importância de Nietzsche, como um crítico de sua época, foi tão decisiva como a de Rousseau no século XVIII, opinião partilhada por Thomas Mann e outros contemporâneos. ${ }^{243}$ No romance mais importante de Musil, a conexão mais imediata com

${ }^{243}$ HICKMAN, 1991, p. 162. 
Nietzsche é vista na figura de Clarisse, obcecada pelo conceito de gênio. Ulrich the havia dado as obras de Nietzsche como presente de casamento, e ela ingenuamente tenta, daí em diante, seguir os ensinamentos do mestre como um guia literal para a vida, recitando-os mesmo para seu marido, para provar que ele não merece um filho. Com o passar do tempo, a discrepância entre o que ela considera sua missão e o que é capaz de realizar completamente perturba sua personalidade instável. O próprio Ulrich tinha aprendido, por experiência, que no século XX não se pode seguir com fidelidade os brilhantes vôos de retórica de Nietzsche; contudo, as próprias características que fazem dele um homem sem qualidades, nomeadamente, ceticismo, lógica, bravura e a busca apaixonada de uma nova moralidade, lembram as atitudes heróicas de Nietzsche e seu elogio de "espíritos livres". Nietzsche louva os "imorais" que compreende, mais do que condena, e Ulrich procura entender o assassino Moosbrugger, com quem sente ter uma afinidade inexplicável. Em seus diários, Musil utiliza a expressão monsieur le vivisecteur para descrever "um tolo, um poeta, assim como o assassino de uma jovem mulher, que foi enforcado ontem", mostrando que, originalmente, ele via nas figuras do pesquisador científico, do escritor e do psicopata um e o mesmo homem."244

A influência de Maeterlinck no jovem Musil tinha sido considerável, mas, em $O$ homem sem qualidades, ele se distancia desse escritor, sem dúvida porque sente que aqueles que constantemente citam Maeterlinck para se referir à "alma" são os mesmos que depreciam o valor do pensamento exato e propositado em qualquer esfera. $\mathrm{O}$ ensaio de Musil sobre Spengler (1921) demonstra seu alarme em relação a essa tendência, que ameaçou, especialmente na Alemanha, minar avanços no pensamento moderno por uma ênfase inadequada e perigosa na emoção, no domínio público e político. O romance de Diotima e Arnheim, um relacionamento amplamente sustentado por suas referências inconscientes tomadas com freqüência de Maeterlinck, evoca a sátira de Musil. Contudo, ao discutir o que quer dizer com a "outra condição", Musil refere-se ao escritor belga num

\footnotetext{
${ }^{244}$ MUSIL, Diaries, 1899-1941, p. 2-4. "A noção de 'vivisecção intelectual' foi tomada de empréstimo de Nietzsche, cuja influência em Musil é inegável". Cf. comentário de Philip Payne, in: MUSIL, ibidem, nota 1, p. 508. Nesta época (1899? Até 1984 ou mais tarde), Musil refere-se a si mesmo como: "monsieur le vivisecteur": "Recently I invented a very fine name for myself: 'monsieur le vivisecteur'. Of course, inventing such a fine-sounding name for oneself has to be a pose but, occasionally, in moments of profound exhaustion, in depression of limp lassitude, it is necessary to recover one's poise by making a word do service for those major stimulants: strength, pleasure, striving. No shame attaches to such a ploy." "Monsieur le vivisecteur" - that's who I am!" Optou-se por manter a tradução feita do alemão para o inglês.
} 
tom diferente, e é significativo que a reunião inesperada e dramática de Ulrich com sua irmã, por ocasião do funeral do pai, seja prefigurada, quase palavra por palavra, num ensaio de Maeterlinck: "Devemos aprender a ver, a fim de aprendermos a amar. Eu tinha vivido por mais de vinte anos ao lado de minha irmã, um amigo (...) disse-me, e eu a vi pela primeira vez por ocasião da morte de nossa mãe”. A associação, na mente de Musil, entre Ágata como representante da "outra condição" e o escritor belga, é sustentada por uma observação no Caderno de Anotações 8, onde ele se lembra do ponto de vista deste último, de estarem as mulheres mais próximas do estado primitivo e, por conseguinte, mais perceptivas e mais perto da natureza. Ao descrever Ágata lendo Maeterlinck, ele diz: "Ela o lê não (...) como um poeta, mas como um mensageiro de sua terra natal."245

A posição quase única de Musil como um escritor do século XX provém do fato de que, por natureza e escolaridade, era capaz de transpor o abismo entre as duas culturas, que ele define como ciência e humanidades. Um pensador cuja influência certamente permaneceu durante toda a sua vida foi Ernst Mach. Embora Musil se recusasse a aceitar todas as teorias de Mach, ele era todo louvor com os métodos desenvolvidos por esse físico e filósofo: observação de fatos, formulação de hipóteses apropriadas, comparação e analogia, em outras palavras, métodos experimentais; mas Musil então sugeria estender seu uso além do campo científico. Uma crítica tem visto aqui a base de "senso de possibilidades" de Musil, embora provavelmente fosse mais verdadeiro dizer que o conhecimento de Mach reforçasse a tendência natural de sua mente. ${ }^{246}$ Um outro elemento do pensamento de Musil, que pode estar ligado a essa fonte, é sua visão de espaço e tempo como relativa, mais do que absoluta. São os valores que o capacitam a concentrar atenção no aspecto subjacente, típico, mesmo excepcional de eventos que ele reivindicou como um interesse central em $O$ homem sem qualidades. Os conceitos matemáticos de teoria funcional - também enfatizados por Mach - são similarmente usados por Musil para argumentar que os fenômenos naturais e mesmo o comportamento humano são, com freqüência, demasiadamente complexos para serem explicados simplesmente em termos de causalidade. Assim, ele defende a abolição das divisões rígidas e caracterizações absolutas de moralidade convencional e de lei criminal, em favor de esforços para

\footnotetext{
${ }^{245}$ HICKMAN, 1991, p.162.

${ }^{246}$ Ibidem, 163.
} 
compreender as causas sociais e psicológicas, quer sejam normais ou criminosas; no romance, esses esforços estão associados ao caso de Moosbrugger.

Outras conexões entre $O$ homem sem qualidades e as idéias da época têm sido atualmente exploradas em um bom número de estudos, porém o espaço de uma tese exige foco. Assim, não seria cabível esgotar a temática estendendo a discussão ainda além do que se prevê nesta tese como limite concreto ao extenso conteúdo da obra musiliana. Nas novas publicações dos escritos de Musil, em $1980^{247}$ e $1986^{248}$, alguns aspectos antes desconhecidos têm vindo à luz, e certamente ainda serão devidamente analisados.

- O legado da vida diante do caráter inexorável da morte

Qualquer um que se dispuser a ler o vasto material do Livro Segundo de $O$ homem sem qualidade, no qual Musil vinha trabalhando de 1930 até sua morte, em 1942, ficará impressionado com o tamanho da tarefa a qual ele se impôs. Musil tentou manter o fluxo livre de seus pensamentos preso ao que escrevia. De maneira coerente com a sua forma de ser, essa parece ter sido a máxima salutar para manter o próprio equilíbrio mental. Embora regularmente se propusesse ao desafio de se impor uma ordem, contudo, ele parecia incapaz de cumpri-lo. As tensões de sua vida são reveladas em cartas a amigos, algumas reeditadas, agora à disposição na nova edição dos Cadernos de Notas (1983), e na nova edição da separata das Cartas (1981). Para Franz Blei, por exemplo, ele escreve em maio de 1930 que observa ter Rowohlt enviado a Blei as provas do Livro Primeiro do romance. Ele espera que seu amigo tenha tido impressão favorável da obra, cujas partes foram escritas sob forte pressão. Musil menciona também seu imenso alívio ao receber algum dinheiro, finalmente, da fundação responsável pelo prêmio Hauptmann, a ele concedido no ano anterior: "Quando ouvi dizer que o dinheiro seria pago, dormi três noites seguidas, pela primeira vez depois de longo tempo." 249

\footnotetext{
${ }^{247}$ MUSIL, Beitrag zur Beurteilung der Lehren Machs, 1908, 1980. (Colaboração para avaliação a quem ensina Mach) (Tradução deste título nossa).

${ }^{248}$ MUSIL, Selected writings, 1986; MUSIL, Briefe 1901-1942, 1981, 2 v.

${ }^{249}$ HICKMAN, 1991, p. 166.
} 
Contudo, ele estava obcecado pelo receio de que enquanto estivesse corrigindo as provas, deparasse com "algumas coisas terríveis". Musil reconhece que grande parte da sua ansiedade é devida a exaustão nervosa, depois de um ano em que esteve muito sobrecarregado; não é de admirar que, por mais que quisesse ler o último livro de Blei, não pôde encontrar a energia para fazê-lo. Finalmente ele pede sugestões com relação a um outro projeto: Rowohlt the havia pedido para produzir, depois do aparecimento de $O$ homem sem qualidades, uma versão grandemente reduzida da obra, apropriada para publicação em série em um jornal; Musil confessa que não tem a menor idéia de como poderia ser feita tal adaptação. ${ }^{250}$ Esse projeto, de fato, nunca foi realizado, embora partes isoladas do Livro Segundo fossem publicadas em 1931-32. ${ }^{251}$

Tais cartas lidas em conjunto com a imensa quantidade de escritos para conclusão do romance, criam a impressão de um homem solitário, empenhado numa sincera luta para terminar sua magnum opus, apesar da grande insegurança financeira, saúde variável, as exigências comerciais a serem cumpridas diante da insistência de seu editor, a situação política deteriorada e, em última instância, o seu próprio perfeccionismo. Essa impressão é verdadeira apenas em parte.

Os sete últimos cadernos de notas, compreendendo o período de 1928-41, revelam, como os anteriores, um homem da mais extensa ordem de interesses possíveis. Em 1936, Musil foi membro fundador de uma sociedade austríaca para promover a compreensão do cinema. Seu interesse por filmes como forma de arte é documentada no ensaio inspirado no livro de Béla Balázs sobre o assunto. ${ }^{252}$ Ele gostava de filmes, particularmente os de Fred Astaire e Ginger Rogers, e o cinema proporcionava uma das poucas distrações que ele se permitia. A leitura de Musil, durante esses anos abrangia também um amplo campo. O Caderno de Anotações 30 relaciona entre os livros lidos: Gide, Georges Bernanos, Goethe, Thomas Carlyle, Clare Sheridan, Gerhart Hauptmann, Bauderaire, Joyce, os discursos de Clemenceau, uma vida de Abraham Lincoln, e muitos outros.

\footnotetext{
${ }^{250}$ MUSIL, TB, v. II, p. 1184-5.

${ }^{251}$ Ibidem, p.1188, nota c.

${ }^{252}$ MUSIL, GW, v. 8, p. 1137-1154; PS, Toward a New Aesthetic: Observations on a Dramaturgy of film, 1925, p. 193-208.
} 
O Caderno de Anotações 30 vai de 1929 a 1941, e assim sobrepõe a todos os outros cadernos de anotações posteriores. Ao passo que não é sempre fácil obter uma clara imagem da seqüência de eventos, as notas detalhadas do editor e as cartas citadas fornecem muitas informações úteis. Com relação à vida diária, Musil e sua esposa davam grande valor a caminhadas regulares à tarde, e alguns de seus passeios são brevemente descritos. As noites sociais nas casas de seus amigos ou em cafés, visitas a exibições de arte ou ao cinema, evocam descrições detalhadas das pessoas ou obras encontradas. Mesmo uma cirurgia penosa de um abscesso dentário é analisada tão objetivamente quanto possível. Musil observava não somente suas próprias reações psicológicas como um paciente, mas também a personalidade do cirurgião-dentista, e as particularidades externas. ${ }^{253}$ Nos anos em que morou na Suíça, especialmente enquanto ele e sua esposa viviam em um apartamento ajardinado em Genebra, Musil dedicou muito tempo a descrições de árvores, cores, luz em diferentes horas do dia, aspectos das montanhas que circundavam a cidade, demonstrando seu prazer por poder observar todas essas coisas bem de perto, enquanto em outros aspectos a vida com freqüência parecia sem esperança.

O Caderno de Anotações 33 (1937-41) consiste de uma série de anotações para o projeto de autobiografia. Nesses apontamentos Musil fornece muito material a respeito de seus pais e de sua própria juventude; outros apontamentos também esclarecem as mudanças sociais e políticas pelas quais passou durante sua vida. No Caderno de Anotações 32, iniciado em 1939, ele empreende um exame detalhado do relacionamento entre política e mente e espírito. Nesses termos, ele se refere principalmente à literatura e a escritores criativos, mas Maquiavel e os filósofos são também discutidos, além de exemplos contemporâneos. Seu objetivo é analisar a situação política na Alemanha e na Áustria, a ausência de democracia e a queda do Nacional Socialismo, comparando esses países com a Itália, Inglaterra e França como exemplos de democracia, e com a União Soviética como um estado comunista. Musil já havia tentado analisar e entender os desenvolvimentos políticos na Áustria e na Alemanha antes e depois da Primeira Guerra Mundial. O Caderno 32 representa um esforço adicional mais intenso de encontrar uma conexão entre os desenvolvimentos políticos contemporâneos e as características pessoais, tanto dos políticos como do povo, interpretados aos olhos do romancista. Ao realizar essa

${ }^{253}$ MUSIL, TB, v. I, p. 717-20. 
análise, Musil está também procurando justificar para si mesmo sua visão para a função do escritor nessa era, como sendo não de mero entretenimento, mas, no mais profundo nível, de um intérprete da vida, o que confirma a sua atitude política engajada. ${ }^{254}$ Os Cadernos de Anotações 30, 31 e 34 contêm outras referências aos líderes do partido Nacional Socialista, embora seus nomes estejam sempre disfarçados, por medo de os livros serem confiscados pela Gestapo. O ditador nazista é muitas vezes mencionado simplesmente como H.; algumas vezes, Musil usa a letra C., ou o nome Carlyle para indicar tanto o ditador como o nazismo em geral. ${ }^{255}$ Em diversas ocasiões, Musil alude a $O$ jovem Törless, e também ao internato militar onde ele próprio tinha sido um aluno, e aos dois fanfarrões cujos nomes verdadeiros eram Reising e Boineburg. Numa referência a si mesmo como uma pulga, "uma pulga alemã", comenta: "ele conheceu os ditadores de hoje desde os seus tempos de escola". ${ }^{256}$

Depois de saírem de Berlim em 1933, Robert e Martha Musil voltaram para Viena. Por quase um ano não possuíram fonte de renda regular alguma, mas em 1934 Bruno Fürst e outros amigos estabeleceram um fundo austríaco para sustentar Musil e a obra de seu grande romance. ${ }^{257}$ A vida na Áustria era ainda obscurecida pela derrota de 1918 e pelo colapso do império, junto com a depressão econômica mundial. Na política austríaca, o partido Democrático Social e o partido do governo Socialista Cristão, acrescidos de alguns elementos do partido Nacional Socialista, estavam todos empenhados numa luta pelo poder que preparava o terreno para a anexação (alem. Anschluss). Engelbert Dollfuss, Chanceler Federal desde 1932, foi assassinado em 1934. Seu sucessor, Kurt Schuschnigg, foi eventualmente convocado pelo ditador nazista, em princípio de 1938, para uma reunião em Berchtesgaden que terminou com as concessões forçadas do chanceler austríaco. Quatro semanas mais tarde, em 12 de março de 1938, as tropas nazistas marcharam Áustria adentro.

Durante todo esse tempo, Musil continuou a trabalhar na Áustria, e seus cadernos de anotações e cartas fornecem uma visão sem igual do período nacional-socialista. Aspecto não menos pungente de seu registro pessoal da época é a lista de nomes de

\footnotetext{
${ }^{254}$ MUSIL, $T B$, v. 1, p. $967,969$.

${ }^{255}$ MUSIL, $T B$, v. 1, p.740, 907; TB, v. 2, p. 537.

${ }^{256}$ Ibidem, p. 893, 834, 914, 955.

${ }^{257}$ Ibidem, TB, v. 2, p. 576.
} 
amigos ou conhecidos emigrando para a França, Suíça ou além-mar, a erradicação, a perseguição e o assassinato de quase uma geração inteira de escritores, músicos e intelectuais. Enquanto os campos de concentração estavam sendo construídos, Thomas Mann, Hermann Broch, Arnold Schönberg, Albert Einstein, Sigmund Freud, Elias Canetti, Kurt Lewin, entre outros, alcançaram o exílio. E, mais cedo ou mais tarde, foram capazes de continuar suas obras nos Estados Unidos, Inglaterra, Irlanda, e demais países que aceitaram receber imigrantes de origem judaica. Durante todo o período de perseguições, em princípio mais ou menos veladas, e, gradualmente explícitas, Musil vivia na Áustria, e depois na Suíça, conseguindo acompanhar os acontecimentos de perto.

Nada poderia estar bem mais distante da verdade do que enxergar em Musil um escritor em sua torre de marfim, sem contato com o mundo exterior. Os cadernos de anotações provam que ele estava muito consciente de tudo que estava acontecendo, e isso pode muito bem ser uma das principais razões por que seu progresso no Livro Segundo do romance era tão penosamente lento. Sua preocupação constante era tornar o romance relevante para os eventos que cercavam a deflagração da Segunda Guerra, assim como as circunstâncias que haviam precipitado a Primeira Guerra. Suas anotações nesse período revelam que quanto mais a vida ao seu redor divergia do normal, mais seus planos originais precisavam ser adaptados às novas circunstâncias.

Em 16 de dezembro de 1934, Musil foi convidado a fazer uma palestra, para a qual escolheu o título O Escritor Sério em Nosso Tempo, na Sociedade para a Proteção de Escritores Alemães na Áustria, por ocasião do vigésimo aniversário dessa fundação, da qual tinha sido vice-presidente por cinco anos. ${ }^{258}$ As idéias fundamentais expressadas em sua palestra podem ser relacionadas a seus ensaios escritos durante a década de 1920. Em 1934, contudo, o desamparo da Europa, que fora por ele diagnosticado em 1922, tinha dado lugar, pelo menos na Alemanha, a uma ditadura, apoiada pela Áustria, de maneira que Musil precisou de muita coragem para falar. Ele resume seu ponto de vista sobre a situação política da época, do coletivismo como filosofia política e suas conseqüências para o indivíduo. Nesses escritos, ele expõe suas posições sobre humanitarismo, liberdade

${ }^{258}$ MUSIL, GW, v. 8, p. 1243-1258. The Serious Writer in Our Time, 1934; PS, p. 250-264. 
e objetividade, todas elas essenciais à literatura, mas consideradas como obsoletas nessa época.

Apesar da visão predominante, Musil enfatiza o caráter internacional e o poder infinito da verdadeira arte, embora não hesite em apontar que, no campo das letras, muitas obras que reivindicam ser literatura não merecem o nome. Ainda mais grave, na sua visão, é o fato de que na Alemanha e na Áustria considerações políticas tenham se infiltrado em todas as áreas da vida e da cultura, de maneira que muitos achavam impossível encarar qualquer atividade livre de política; contudo, segundo ele, para que a literatura fosse criada, a liberdade era essencial. Ao final, numa referência que nenhum de seus ouvintes deixará de ter entendido, Musil lembra a queima da grande biblioteca do mundo antigo, em Alexandria, comparando tal ato ao bibliocausto: a decisão de Goebbels, em 1945, de queimar publicamente os livros considerados censurados ou malditos. Para Musil, tais atitudes hostis traduzidas em poder político acabariam por destruir o espírito alemão. Não obstante seu pessimismo, ele esperava um novo tempo quando a verdadeira cultura européia ressurgisse.

Esse discurso foi entusiasticamente recebido, não apenas pela audiência, mas também pela crítica. Musil foi convidado a repetir, publicar e traduzir o texto. Porém, diante dos eventos que se sucedem, ele não pôde fazê-lo. Menos bem sucedida foi sua aparição em Paris, no Congresso Internacional de Escritores para a Defesa da Cultura, em julho de 1935. ${ }^{259}$ Participando do congresso estavam André Malraux, André Gide, Heinrich Mann, Aldous Huxley e muitos outros; a reunião pretendia ser uma demonstração contra o fascismo, e diversos participantes eram comunistas ativos. Embora uma testemunha ocular comentasse mais tarde que a própria presença de Musil, que viera da Áustria, demonstrasse grande coragem, seu discurso despertou irritação: seguiu as linhas de seu discurso em Viena, mas soou para a audiência, em Paris, demasiado abstrato e imparcial. Entre os ouvintes, estava um grande número de escritores refugiados da Alemanha nazista, e quando Musil falou de bolchevismo e fascismo, no mesmo fôlego, a platéia o vaiou. Musil ficou desconcertado pelo que considerou uma série de malentendidos, especialmente após o aparecimento de uma crítica da sua palestra. Ele

${ }^{259}$ MUSIL, GW, v. 8, p. 1259-1265; PS, [Lecture. Paris], 1935, p. 264-267. 
preparou uma réplica, mas antes que fosse impressa, a revista interessada interrompeu a publicação. ${ }^{260}$

Uma vez ao ano Musil costumava ministrar uma aula, a partir de suas obras, numa Escola de Educação de Adultos em Viena. Em novembro de 1935, foi convidado a visitar a Suíça, onde deu uma aula em Zurique, seguida de duas outras, em Basel. Harry Goldschmidt, que tomara a iniciativa de organizar a viagem, relata que solicitara a Thomas Mann, então exilado perto de Zurique, para apresentar Musil. Mann declinou o convite, mas esteve presente, e depois os dois escritores sentaram-se perto um do outro, em conversa amigável. ${ }^{261}$ Essa foi a única ocasião, tanto quanto se saiba, em que esses dois homens, dois dos maiores escritores alemães do século XX, realmente se encontraram face a face. Os Cadernos de Anotações de Musil mostram que ele lia as obras de Mann, mas tinha ciúmes de seu maior sucesso, comparado ao seu próprio. Em janeiro de 1933, Thomas Mann, de sua parte, tomou a iniciativa, junto com seu irmão Heinrich e com o poeta Gottfried Benn, de conseguir algum apoio financeiro para Musil, na Academia Alemã de Escritores. Mais tarde, em 1939, Mann também aderiu a um apelo organizado por Rudolf Olden, sob os auspícios do Clube Britânico PEN, que pretendia ajudar Musil, possivelmente possibilitando-lhe o exílio na Inglaterra. Infelizmente, nada aconteceu. ${ }^{262}$

Em 1935, os amigos de Musil, em Viena, estavam cada vez mais preocupados com a situação aparentemente sem esperança, na qual ele se encontrava. Quanto mais as circunstâncias externas de sua vida deterioravam, mais lento era o seu progresso quanto ao Livro Segundo do romance. Acima de tudo, além dos problemas financeiros, estava o sentimento de que tinha perdido contato com o público leitor; isso o oprimia e o tornava amargo. Para aliviar esse estado de coisas, seu amigo Otto Pächt conseguiu publicar uma seleção das muitas histórias que havia escrito em prosa, no período 1920-29. Musil intitulou o pequeno volume, que apareceu no Natal de 1935, O melro e outros escritos de obra póstuma publicada em vida, título explicado com sua auto-ironia típica. A primeira parte de histórias, - Imagens (1996, p.11-40), consiste de peças curtas, poemas em prosa, com freqüência com um toque de ironia, todos eles revelando aspectos desconhecidos,

\footnotetext{
${ }^{260}$ MUSIL, TB, v. 2, p. 742, 1255-61.

${ }^{261}$ MUSIL, $T B$, v. 2, p. 580-3.

${ }^{262}$ Ibidem, p. 1275-80; 1690-1786-7; ibidem, v. 1, p. 1003.
} 
estranhos do mundo. A essas histórias seguem-se Considerações Inamistosas (1996, p. 4178), um número de peças dedicadas à discussão de questões culturais, aparentemente despreocupadas em tom, mas perversamente aguçadas em ataque político e social. A terceira parte, - Histórias que não são (1996, p.78-100), contém quatro fábulas que esclarecem, de diferentes pontos de vista, a vasta área de caráter e moralidade. Finalmente, Musil incluiu uma história mais longa, O melro (p.101-119).

$\mathrm{O}$ interesse de Musil na psicologia animal, ingrediente essencial de $O$ jovem Törless, fica de novo evidente em muitas dessas histórias. Um número dos esboços originais para as peças publicadas em 1936 é encontrado nos Cadernos de Anotações, e um deles, do período de seu serviço no exército, contém uma lista de títulos para o projetado "Livro de Animais". Uma história publicada pela primeira vez em 1923 - A catástrofe das lebres, é uma obra-prima de apenas duas páginas, passada em uma ilha de férias, na qual o autor descreve um encontro entre um cão fox terrier e uma jovem lebre. A dona do terrier, uma senhora elegantemente trajada, e o próprio narrador parecem pertencer a um grupo constante de hóspedes em feriados. O cão, conduzido por seus instintos, caça e mata a lebre. No espaço de poucos segundos, os espectadores humanos também são apanhados em avidez primitiva de sangue. Musil teria assim comparado o que se sucedeu à maneira como agiam os membros da classe que torturaram o menino Basini em O jovem Törless; a ilha se torna, portanto, uma selva, e nem toda a roupagem civilizada européia moderna disfarçava a natureza subjacente dos humanos.

No início de O melro, o autor explica o que um homem, que ele chama de Adois, disse a seu velho amigo Aum. Há que se lembrar, neste momento deste conto, da predileção de Musil por apresentar aspectos opostos de um personagem como de duas pessoas separadas. Adois prossegue relatando uma história em três partes, unidas pela imagem do melro. O episódio central conta que um dia, durante a [Primeira Grande] Guerra, quando lutava nas montanhas, sentiu o entusiasmo do perigo, vendo-se emplumado, com a plumagem do Pássaro da Morte. Logo em seguida, durante um ataque aéreo, escapou da morte como por milagre. A certeza da morte, combinada com sua miraculosa sobrevivência, trouxe a ele um estado de exaltação pueril. O primeiro e o último episódio mostram Adois retirando-se da vida normal, primeiramente para seguir o 
melro e sua canção mágica, ainda que isso significasse abandonar a esposa. No episódio final, ele retorna para a casa de sua família, após a morte dos pais, tornando-se cada vez mais absorvido pelos objetos redescobertos de sua infância. Um melro voa para dentro do quarto e diz ser sua mãe, e parece que Adois permanecerá lá, com ela, para sempre. Qual é o significado dessa história? O melro retira-se da vida normal para "outra condição"; mas como devemos interpretar o final? Poder-se-ia compreendê-lo como um retorno a um estado de inocência, ou como uma regressão à infância, uma retirada com culpa da responsabilidade social. "Soubesse eu o sentido e certamente não teria por que não he contar. É como ouvir um sussurro ou um simples murmúrio, sem saber distingui-los!” (p. 119)

Se O melro apresenta ao leitor um enigma, a obra, como um todo, contém significativos exemplos da arte de Musil. Contudo, a constante pressão do trabalho e preocupação exacerbavam sua tendência à depressão e à pressão arterial alta. Como estava acostumado a exercícios diários sistemáticos, esperava neutralizar essas condições com vigorosos exercícios de natação. Muito esgotado, sofreu um primeiro ataque cardíaco, em princípios de 1936. Daí em diante, teve de tomar muito cuidado.

Em março de 1937, Musil proferiu uma palestra pública em Viena, sob o título “On Stupidity". Com grande sutileza, examinou o conceito de estupidez, sob todos os ângulos, relacionando-o à vaidade, violência e sadismo, e distinguindo entre simplicidade e as atitudes mais perigosas daqueles que, no coletivo, perpetram ações proibidas ao indivíduo. Para o ouvinte desatento, tal discurso parecia nada mais que academicismo inofensivo. Porém Musil conseguiu identificar e condenar as crenças e ações dos líderes do nazismo e suas facções na Áustria e na Alemanha. Esse discurso foi repetido na semana seguinte, e o novo editor de Musil publicou o texto no mesmo ano. ${ }^{264}$

No verão de 1937, ele conseguiu com o editor Rowohlt vender os direitos de seu livro O homem sem qualidades para a editora de Bermann-Fischer, ora estabelecida em Viena. Esta última editora estava ansiosa para lembrar o público leitor da existência de Musil, e o autor concordou em publicar mais vinte capítulos do Livro Segundo, quando

${ }^{264}$ MUSIL, GW, v. 8, p. 1270-1291; PS, p.268-286. 
eles ainda estavam em prova. Contudo, decidiu retirá-los para reescrevê-los. A essa altura, Musil e seus editores foram violentados pelas arbitrariedades que se sucederam. Em março de 1938, imediatamente após a Anschluss (Anexação). Porque era judeu, BermannFischer, fugiu para a Suécia, e sua casa editora foi tomada pelo partido nazista. ${ }^{265}$ Ficou claro para Musil que sua única esperança de sobrevivência como escritor também estava na fuga. Martha Marcovaldi, sua esposa, era judia, e estava em perigo imediato. Era inconcebível que eles permanecessem na Áustria. Mas ainda que essa possibilidade tivesse passado por sua mente, um escritor de sua honesta coragem não poderia ter continuado a trabalhar sob uma ditadura nazista.

Segundo Le Rider (1993), não estaria Musil, correndo perigo de vida por causa de sua ascendência, de sua proximidade com a maioria dos intelectuais judeus e de sua nítida oposição à cultura ariana e à causa pangermanista anti-semita? Quanto a esse aspecto, vale ressaltar a tese de Le Rider sobre a crise de identidade que se abateu sobre os mais importantes intelectuais judeus austríacos e alemães durante o extenso período de antisemitismo que vinha crescendo desde a segunda metade dos anos 1800, até atingir a culminância na "solução final" (alem. Endlösung der Judenfrage), termo criado por Adolph Eichman, sentença assinada pelo ditador nazista em 20 de janeiro de 1942. Tal decreto refere-se especificamente ao extermínio oficial de todos os judeus, mas também se das consideradas "classes perigosas", homossexuais e ciganos, além de pessoas com deficiências mentais e físicas, portadores da Síndrome de Down e anomalias genéticas e físicas diversas... De acordo com as premissas expostas na Reunião de Wannsee nessa data, o mesmo tratamento envolvia "pessoas de sangue misto". Assim, era elevado o risco de vida diante do grau de comprometimento de Musil com os judeus. Ele não estaria fora do Holocausto - o maior massacre já cometido contra os judeus em toda a sua história.

Le Rider deixa margem aos pesquisadores que queiram conhecer mais detalhadamente a verdadeira origem de Musil. Ele poderia pertencer ao grupo dos judeus já assimilados há uma ou duas gerações - o que não era incomum naquele período. E ainda que não deixasse registro sobre a sua verdadeira origem, e assim o preferisse, ou que ele de fato não a soubesse, Musil freqüentava um grupo de intelectuais de indiscutível

${ }^{265}$ MUSIL, $G W$, v. 5 , p. 2047 ; TB, v. 2, p. $751-4$. 
ascendência judaica. ${ }^{266}$ Para evidenciar a reação dos próprios judeus ao anti-semitismo, Le Rider se refere ao "judeu sem qualidades" 267 , em flagrante comparação ao título dado por Musil a seu romance. Le Rider cita os ferimentos causados à identidade dos intelectuais judeus que se consideravam mais alemães ou mais austríacos do que os cidadãos "legítimos", os verdadeiros representantes da "raça ariana". Le Rider cita o depoimento do escritor Arthur Schnitzler, aqui tomado para expor a situação que leva a incerteza sobre a origem do título escolhido por Musil para $O$ homem sem qualidades:

\begin{abstract}
Já não era mais possível para o judeu, particularmente se fosse homem público, esquecer que era judeu, já que os outros não o esqueciam, nem os cristãos e nem, muito menos os judeus. Poderia-se escolher entre passar por insensível, intrometido ou arrogante, ou então por suscetível, tímido e atingido pela doença da perseguição. Mesmo no caso em que se conseguia manter, suficiente sangue frio e compostura para não assumir nenhuma dessas duas atitudes, era também impossível permanecer totalmente indiferente, como se um homem, cuja pele tivesse sido (...) anestesiada, mas que devesse observar, com os olhos bem abertos e bem acordados, como cinzéis sujos o arranhavam, o recortavam, até que o sangue jorrasse. ${ }^{268}$
\end{abstract}

Assim, ostensivamente, em agosto de 1938, Robert e Martha Musil deixaram Viena para umas férias, embora o apartamento deles, cheio de livros e manuscritos, fosse ainda mantido em seu nome. Após uma curta estada em Edolo, na Itália, mudaram-se para Zurique iniciando seu exílio.

- Inacabamento e imortalidade da obra: a morte espreita o criador

De 1938 até sua morte, em 1942, Musil e sua esposa viveram primeiramente em Zurique e, a seguir, em Genebra. Esses foram anos inseguros e perigosos para milhões de pessoas, especialmente, de muitas maneiras, para escritores, dependentes de publicações e de leitores em sua própria língua. Stefan Zweig e Carl Zuckmayer, para nomear apenas

\footnotetext{
${ }^{266}$ Le RIDER. Crises da identidade judia. In: A modernidade vienense e as crises de identidade, 1993, p. 313-489.

${ }^{267}$ Ibidem, p. 343-4.

${ }^{268}$ Ibidem, p. 335.
} 
dois, deixaram em suas biografias comoventes relatos do período. A Suíça se tornou cheia de refugiados, muitos deles sem recursos suficientes para suas necessidades. Por mais de um ano Musil recebeu ajuda regular do Comitê Suíço de Ajuda a Intelectuais Refugiados, e o secretário, Dr. Nellie Seidl, ajudou-o a encontrar outros contatos e fontes de auxílio. Um outro amigo leal foi o Pastor Robert Lejeune, de Zurique, que estava genuinamente interessado na obra de Musil e fez o máximo para providenciar-lhe uma renda mínima. Outra ajuda regular veio de um casal americano, Henry Hall Church e de sua esposa Bárbara, que Musil conhecera há algum tempo. Esses, últimos, moravam na França, e estavam empenhados em atividades literárias de várias espécies. Bárbara Church produziu a primeira tradução francesa de dois capítulos de O homem sem qualidades, em $1935 .{ }^{269}$

Após se mudar para a Suíça, Musil continuou a revisar os vinte capítulos do Livro Segundo, retirados de publicação na fase de prova; de acordo com anotações encontradas em seus papéis de trabalho, esperava tornar seu tom mais leve e restabelecer neles o equilíbrio entre teoria e ação narrativa. Por um lado, a ênfase no Livro Segundo, como um todo, está na "outra condição"; ela é a expressão para Musil se referir a sentimento e imaginação, ressaltando, em contraste, a razão e o intelecto. Por outro lado, Musil queria mostrar Ulrich e Ágata vivendo uma experiência de vida que permitisse pleno controle de sentimento e imaginação, sem restrição e supressão de considerações externas, embora ele próprio fosse cético em relação a relacionamentos amorosos duradouros, e por longo prazo de existência. Por outro lado, como verdadeiro intérprete dos seres humanos e da sociedade contemporânea, Musil continuou no Livro Segundo - assim como ele teria introduzido no Livro Primeiro-, a apontar personalidades típicas da época, em suas interações umas com as outras e com as duas figuras centrais, e especialmente, na medida em que as emoções desempenhavam uma parte vital, mas não reconhecida na vida pública e privada.

A sessão de encerramento da Ação Paralela, descrita no Livro Segundo, capítulos 34-38, apresenta a irônica, e ao mesmo tempo trágica imagem de uma cultura fragmentada, a ponto de colapso. Os ricos e os grandes, aqueles que tinham influência e aqueles que simplesmente a procuravam, estavam todos lá, mas, além deles, havia

${ }^{269}$ MUSIL, TB, v. 2, p. 782-5, 561-2, 586-8. 
representantes da lei, do exército, das altas finanças, da política, da educação, velhas e novas tendências em arte e literatura, e muito mais. Até Ulrich e sua irmã tinham sido persuadidos a comparecer. Argumentos não faltavam. O General Stumm tratava de resolver uma disputa entre um marxista e um psicanalista, para saber se os seres humanos eram mais condicionados por fatores econômicos do que por pulsões (alem. Triebe), estando o general preparado para admitir que as massas seguiriam sempre as suas pulsões, porém, não as admitindo os indivíduos. O Ministro da Guerra travava uma discussão fechada com o poeta Feuermaul, cujo princípio condutor parecia ser o de que o homem é essencialmente bom, e que todos os problemas podem ser solucionados pelo amor.

Um estudo recente tem mostrado que a figura de Feuermaul é um composto de todos aqueles escritores contemporâneos que, na opinião de Musil, alcançaram sucesso fácil e imerecido, e, por conseguinte, suscitaram nele tanto inveja como desprezo.. ${ }^{270}$ No romance, Feuermaul representa um ponto de vista que Musil já havia criticado em seu ensaio sobre Splenger e em outros lugares, uma atitude que, ao rejeitar o positivismo do século XIX, jogou fora com ele a razão e a exatidão do pensamento, escolhendo confiar, em vez disso, apenas na intuição e na emoção.

No capítulo 38 - Clarisse e seus demônios, Musil se refere ironicamente a Feuermaul, “o apóstolo do amor e da bondade", e a Hans Sepp, o campeão da "pureza e de marcante liderança". É nessa parte que eles começam a proferir insultos um ao outro, mas terminaram por formar causa comum numa resolução contra a guerra. Quando o general, grandemente alarmado, perguntou a Ulrich como isso tinha acontecido, este último expôs suas idéias sobre o descaso ameaçador, quanto à emoção, como uma força em assuntos humanos, por aqueles em posições de poder. Enquanto assuntos pertinentes à razão eram mantidos em ordem, os sentimentos irracionais, dominantes em todas as áreas, tanto da vida pública como da privada, não eram oficialmente reconhecidos como significativos e cresciam desenfreadamente. De geração a geração, o entulho de emoção fútil vinha aumentando cada vez mais. Ulrich deduziu, debochadamente: o Ministro da Guerra poderia dormir descansado - o próximo desastre coletivo era iminente.

\footnotetext{
${ }^{270}$ HICKMAN, 1991, p. 175.
} 
A essa altura, o autor comenta: "Ulrich estava profetizando o destino da Europa, embora não o compreendesse. De fato, ele não estava se ocupando de eventos reais, em absoluto; estava lutando para sua própria salvação". ${ }^{271} \mathrm{O}$ aspecto ressaltado nessa passagem faz lembrar que, ao mesmo tempo em que o romance era escrito, as atitudes descritas como fictícias para os personagens Feuermaul ou Hans Sepp, entretanto eram reais para Werfel ou para o ditador austríaco. Como verdadeiro choque entre posições rivais, tais atitudes vinham evoluindo de maneira bastante tensa já há algumas décadas.

Nos primeiros anos do século XX, o protesto da geração de Musil transparecia na obra de muitos escritores e artistas, contra a dominação exclusiva do intelecto. Tal protesto tinha sido transposto para uma concentração na alma e no homem interior. Os escritos de Freud, Jung e Adler são emblemáticos para enfatizar o significado da emoção (alem. Afekt) sobre a razão. Contudo as pesquisas e descobertas de tais autores tiveram pouco impacto sobre o pensamento de líderes políticos envolvidos com decisões de responsabilidade pública. No mesmo período, as tendências centrífugas do império austrohúngaro, bem como as políticas antiliberais estabelecidas por Bismarck, ainda sob o império alemão, tinham encorajado o crescimento de nacionalismo fervente.

Em 1918, após a derrota tanto da Áustria como da Alemanha, alguns dos expoentes do nacionalismo irracional, como Spengler e Moeller van den Bruck, encontraram uma audiência pronta. A solução politicamente instável foi exacerbada pela depressão econômica. Contudo, mesmo em 1931, Werfel, um dos principais escritores expressionistas, declarou, em um discurso, que o ideal de um novo homem era mais importante do que a solução de problemas sociais. ${ }^{272}$ Assim, Musil teria tido pouca dificuldade em achar modelos para seu retrato de atitudes contemporâneas. Ele estava tentando alertar seus leitores para os perigos de uma situação na qual a sociedade e seus líderes se comportassem como tinham sempre se comportado, enquanto as contracorrentes irracionais enfraqueciam o terreno por baixo de seus pés.

\footnotetext{
${ }^{271}$ MUSIL, GW, v. 3, cap. 38, p. 1038; HSQ, Livro Segundo, cap. 38. Prepara-se um grande acontecimento. Mas ninguém notou, p. 1094.

${ }^{272}$ HICKMAN, 1991, p.176.
} 
Se, na última reunião militar, os interesses adquirissem mais poder e a guerra estourasse, isso, como Musil sabia, por experiência pessoal, seria a reação mais irracional de todas. Em conversas com Wolfdietrich Rasch em Berlim, enquanto o Livro Segundo estava sendo escrito, o autor confirmou que ao escrever cada um dos estágios de seu romance, ele estava pensando tanto no cenário contemporâneo quanto na ficção. Porém, em 1932, ele sentiu que seu pensamento estava mais do que justificado. ${ }^{273}$ Sob esse prisma, a análise de Musil sobre as ideologias prevalentes no Livro Segundo, publicado na Alemanha justamente no momento em que o governo nazista subia ao poder, deve ser vista como um ato de considerável coragem.

Ulrich e Ágata decidiram a não mais se envolver com a Ação Paralela. A tranqüilidade de suas vidas juntas foi, contudo, perturbada pela chegada de uma carta irritada de Hagauer, marido de Ágata, acusando-a, em termos moderados, não apenas de falhar em seus deveres para com ele, mas de omissão social em todos os aspectos. Essa carta afetou-a profundamente. O entusiasmo que Ulrich sentira, durante semanas, subitamente evaporou. Sentia-se profundamente afetado em sua auto-estima e desejava que sua confiança fosse renovada. Mas Ulrich, como acontecia com freqüência, nada fez senão calar. Finalmente, Ágata não pôde suportar mais, saiu às pressas de casa e pensou em se suicidar. ${ }^{274}$ Em seu sofrimento, Ágata encontrou um homem que, diferentemente de seu irmão, parecia ansioso por ajudá-la a sair do que ele reconheceu ser uma crise. Esse estranho, que se mostra bondoso, era um professor e conferencista universitário de nome Lindner, e em diversos capítulos não publicados do Livro Segundo, o autor descreve essa figura e desenvolve brevemente o relacionamento de Ágata com ele. Lindner se via como um educador responsável. No seu conjunto, ele considerava a vida como um desafio moral. Citando Goethe a todo o momento, Lindner não se mostrava convencido de que a decadência moral de sua época era, pelo menos parcialmente, resultante de um excesso de indulgência com as buscas culturais. Ele era religioso, no sentido de que era pela religião, mas não que se sentisse nela. ${ }^{275}$ Todas essas características meritórias são, não obstante,

\footnotetext{
${ }^{273}$ HICKMAN, 1991, p.176.

${ }^{274}$ MUSIL, $G W$, v. 3, cap. 29-31, p. 945-973; HSQ, O professor Hagauer pega a pena. Livro Segundo. cap. 29, p. 996-1004. Ulrich e Ágata procuram posteriormente um motivo. cap. 30, p.1004-1013. Ágata quer se suicidar e conhece um homem. cap. 31, p. 1013-1025.

${ }^{275}$ MUSIL, GW, v. 4, cap. 56, p. 1174-1189; HSQ, Obra póstuma. O fazobém canta. cap. 56, p. 1239-1253. Convém notar que o termo Der Tugut, em alemão, ou The do-gooder, é de difícil tradução em português. Musil faz um neologismo que corresponderia, em português, a diversas conotações - um falso-virtuoso,
} 
colocadas em perspectiva por seu pedantismo e evidentes obsessões neuróticas em seus hábitos pessoais. ${ }^{276} \mathrm{O}$ ridículo desapiedado a que o autor expõe Lindner e Hagauer revela um profundo ceticismo a respeito da capacidade de pedagogos profissionais realizarem reformas adequadas e duradouras no sistema educacional. Musil tem pouca confiança nos pronunciamentos teóricos de educadores que se mostram, na vida privada, insignificantes e sem imaginação.Ambas essas figuras são contrastadas com Ágata, a personificação do sentimento e da imaginação. ${ }^{277}$

A maior parte dos outros capítulos completados do Livro Segundo descrevem a vida de Ulrich e Ágata e sua busca para compreender e experimentar a "outra condição" de emoção e misticismo. À medida que os dias passavam, uma profunda simpatia vai crescendo entre eles, de modo que cada um sentia o que o outro estava sentindo, freqüentemente sem necessidade de palavras. Às vezes, eles se moviam como se num sonho, separados e, contudo, unidos. Tudo dentro e fora deles parecia impeli-los para a união física, mas como irmão e irmã, sabiam que essa era uma barreira que não deviam cruzar. ${ }^{278}$ Numa ocasião, quando a tensão se tornou quase insuportável, Ágata decidiu visitar Lindner e pedir uma opinião sobre seu divórcio. Ela ficou intrigada com seu encontro com esse representante do outro lado do mundo, mas o reconhecimento de que Lindner era, ele próprio, vulnerável, de certa maneira, restaurou sua autoconfiança. ${ }^{279}$

Os capítulos 45 e 46 das Obras Póstumas - Começa uma série de estranhas ocorrências e Raios de luar durante o dia, respectivamente - relatam outras aventuras de Ulrich e Ágata. Em linguagem poética, o autor descreve a intensidade de sentimentos entre eles. Esse relacionamento forma o clímax para ambos os personagens, embora anteriormente eles estivessem envolvidos com parceiros do sexo oposto, apenas tinham conhecido brevemente o amor verdadeiro. Por um acordo tácito, sem palavras, eles continuaram evitando satisfação física, não tanto por respeito à convenção, mas por escolha própria. Eles começaram a tomar consciência de sua proximidade com maior e

\footnotetext{
falso moralista, falso benemérito.

${ }^{276}$ MUSIL, GW, v. 4, cap. 40, p. 1049-1056; HSQ, Obra póstuma. O fazobém. cap. 40, p. 1105-1113.

${ }^{277}$ MUSIL, TB, v. 1, p. 572-6.

${ }^{278}$ MUSIL, GW, v. 4, cap. 41, p. 1061-2; HSQ; Obra Póstuma. Os irmãos na manhã seguinte. cap. 41, p. 1113-1114.

${ }^{279}$ Ibidem, cap. 45, p. 1081.HSQ; Obras Póstumas. Começa uma série de estranhas ocorrências. cap. 45, p. 1140 .
} 
mais profunda sensibilidade. Luz e sombras, cores e muitos outros detalhes adquiriram significado não costumeiro. Primeiramente à janela, à luz do luar, mas também na manhã seguinte, tais detalhes se revelam numa atmosfera de misticismo à luz do dia. Na luz solar da primavera eles se reclinavam em espreguiçadeiras no jardim, e Ulrich descobria uma fascinação, muito nova para ele, contemplando plantas e flores como se pela primeira vez. Ágata lia, em voz alta, um livro da biblioteca dele, retirada de uma coleção das máximas de místicos, ao longo das épocas. Refletindo sobre eles, Ulrich começou a pensar em Deus e em sua própria atitude para com a religião, algo que não fazia há muito tempo.

Do capítulo $47^{280}$ em diante, o leitor tem uma escolha de versões. Em 1943, após a morte de Musil, sua viúva publicou uma seleção de textos ${ }^{281}$, declarando, em sua introdução, que o autor tinha feito mudanças importantes em alguns rascunhos de 1938, antes de sua morte. Assim, parece justificado considerar essas alterações ou capítulos melhorados, como preferidos pelo autor às provas de versões anteriores a 1938. As partes alteradas referem-se aos capítulos 47-52, na nova edição alemã de $1978 .{ }^{282}$ Esses últimos seis capítulos continuam a descrição da vida de Ulrich e Ágata, enquanto viveram juntos.

Evitando seus antigos amigos, os personagens permanecem em casa. Ocasionalmente, eles arriscam-se ir à cidade e juntar-se à multidão, contentando-se simplesmente em fazer parte da humanidade. No capítulo 51 - Grandes Mudanças, ${ }^{83}$ há o início de uma discussão acalorada, resultante de sua situação particular. Porém, Musil acaba por a estendê-la a uma crítica generalizada da psicologia da emoção. Essa discussão ocupou originalmente seis capítulos do grupo retirado em 1938. Na verdade, esta podia ser uma das principais razões da decisão de Musil para retardar a publicação, uma vez que esse material continha um tom teórico demais para um romance. Entretanto, esses capítulos referentes à discussão sobre psicologia foram republicados na edição de 1978, e mostram a evidência do contínuo interesse de Musil por esta área de conhecimento. Ele se refere especialmente ao trabalho dos psicólogos da Gestalt: Lewin, Scheler, Bleuler, Kretschmer, Wertheimer, Koffka e Köhler, que ele conhecera em Berlim. Ele tinha grande respeito pela obra de Freud, Jung e Klages, sobretudo pela sua capacidade de tornar

\footnotetext{
${ }^{280}$ MUSIL, GW, v. 4, cap. 47-58, p. 1095-1204; HSQ, Obras Póstumas. cap. 47-58, p. 1154-1268.

${ }^{281}$ Ibidem, p. 1204-1494.

${ }^{282}$ Ibidem, cap. 47-52, p. 1204-1239.
} 
possível discutir abertamente a sexualidade. Contudo, Musil não confiava plenamente nos seus métodos de trabalho e na maneira como os seguidores de Freud compreendiam a obra desse autor. Ele próprio tinha estudado psicologia experimental, mas, na qualidade de escritor, considerava os escritos de Freud como ficções não literárias. O quanto Musil conhecia e fazia uso da teoria psicanalítica tem sido discutido por Corino $(1973 ; 1974)$ e outros. $^{284}$

No decorrer desta tese, fica evidente que o conceito de a "outra condição" fascinou Musil desde o princípio de sua obra. A experiência "não-racional”, como ele a denominou, de preferência a denominá-la por "irracional" ou "inconsciente", é geralmente reconhecida por artistas, místicos, e, em todas as religiões da humanidade. O que há de peculiar em Musil é que ele estava convencido de que as nações civilizadas deveriam atribuir uma importância muito maior à "outra condição", a fim de se contrabalançar a excessiva concentração sobre as decisões que se baseiam apenas no intelecto. Em O jovem Törless, bem como nas duas peças de teatro e nos ensaios, Musil mostrara a significação desse sentimento. Porém, tal posição é bastante evidenciada em seu romance principal. Ulrich propusera uma Secretaria Mundial para a Exatidão e para a Alma, antes de se envolver em seu próprio relacionamento amoroso experimental com Ágata.

Em 1922, Musil tinha encontrado, na psicologia médica de Kretschmer, uma definição de personalidade igual à de Ulrich, igualmente dividida entre caminhos de experimentação do mundo lógico e não-racional, junto com a descrição da natureza de experiência imediata não-lógica, correspondente a sua própria idéia da "outra condição". ${ }^{285}$ Por volta do mesmo período, Musil retornou aos Ensaios de Emerson, realizando um número de excertos de Círculos ${ }^{286}$. Alguns destes trechos, com comentários de Musil, foram transcritos recentemente, e podem ser vistos como tendo desempenhado um papel vital no desenvolvimento de $O$ homem sem qualidades. Eles fazem parte de uma série de documentos identificados com a letra 'E' (= Emerson), todos concernentes a aspectos de intuição e sentimento. Diversos deles retornam ao tema de palavras ou idéias

\footnotetext{
${ }^{284}$ HICKMAN, 1991, p.178.

${ }^{285}$ Ibidem, 1991, p.179.

${ }^{286}$ MUSIL, GW, v.5, p. 1640, 1645,1648-51. Ver também: EMERSON, R. Circles, originalmente publicado em 1841. Disponível em: <http://www.rwe.org/works/Essays-1st_Series_10_Circles.htm>. Acesso em 05 de agosto de 2007.
} 
como vivo ou morto, de acordo com as circunstâncias, encontrado cada vez mais em $O$ jovem Törless e nos primeiros cadernos de anotações; as citações a Emerson são anotadas ao longo de linhas similares. A edição alemã de 1978 do romance principal reedita rascunhos da década de 1920 que descrevem tensões no relacionamento de Ulrich e Ágata e formam as bases de suas últimas conversas sobre sentimento e misticismo; nesses rascunhos, Musil lista declarações do ensaio de Emerson, junto com material relacionado de outras fontes. Muitas das declarações têm a ver com a experiência imediata, nãointelectual na religião, amor ou simplesmente comunicação humana:

\begin{abstract}
Em horas comuns, a sociedade senta-se fria e como estátuas. Nós todos ficamos de pé esperando, vazios, - sabendo, possivelmente, que podemos estar plenos, envolvidos por símbolos poderosos que não são símbolos para nós, mas prosa e bagatelas insignificantes. Então vem o deus, e converte as estátuas em homens ardentes, e por um lampejo de seus olhos queima o véu que envolvia todas as coisas, e o significado da própria mobília (...) se manifesta. Os fatos que assomavam tão amplos nas brumas de ontem (...) mudaram estranhamente suas proporções. Tudo o que supunha estabelecido vibra e se agita (...). ${ }^{287}$
\end{abstract}

Palavras vivas, idéias vivas respiram vida nova nos seres humanos, rompem velhos hábitos e atitudes fossilizadas e revelam o mundo sob uma nova luz. Musil acrescenta: "Van Gogh não pintou (...) assim?” Os ecos dessa passagem e de outras semelhantes reverberam onde quer que Musil fale de pensamento criador ou da "outra condição", tanto em $O$ homem sem qualidades, como em Enthusiasts (a play).

Um outro aspecto do mesmo ensaio que o atrai diz respeito à idéia de "moralidade dinâmica". Homens e mulheres que são verdadeiramente vivos e inventivos não se contentarão com uma sociedade na qual a história simplesmente se repete, mas procurarão mudá-la: "Nossa cultura é a predominância de uma idéia que carrega consigo (...) [o espírito] da cidade e das instituições. Levantemos uma outra idéia: elas desaparecerão.”288 Esses pontos de vista desafiantes recorrem à mudança da mente experimental de Musil, e encontram expressão no conceito de vida de Ulrich, como uma hipótese. Mesmo em suas anotações, ele é crítico do otimismo ilimitado de Emerson: a visão esperançosa da América do começo do século XIX não pode ser transferida sem alteração para uma

\footnotetext{
${ }^{287}$ HICKMAN, 1991, p. 179.

${ }^{288}$ EMERSON, Circles. Disponível em: <http://www.rwe.org/works/Essays-1st_Series_10_Circles.htm>. Acesso: 05 de agosto de 2007.
} 
Europa que está sofrendo as conseqüências traumáticas da Primeira Guerra Mundial. Não obstante, ele continua a ter fé no poder dos "pensamentos vivos", e um trecho detalhado para o Livro Segundo do romance, compilado dez anos depois de ter sido escrito, ainda contém muitas idéias de Emerson. ${ }^{289}$

O capítulo mais completo, que parece ser o final do romance, começa com uma descrição lírica do jardim, onde os raios de sol, o verde das folhas novas e o turbilhão de flores das árvores combinavam para criar uma atmosfera utópica de paz infinita. Como no dia em que Ágata lia as palavras dos místicos, Ulrich sentiu novamente que tinha atingido o milênio: o mundo parecia transfigurado. Ela reuniu todas as suas energias para se tornar merecedora da presença divina, experimentar em si o encontro da realidade interna com a externa; contudo, depois de algum tempo, descobriu que não poderia manter a necessária concentração. Daí em diante, a discussão da natureza da emoção continua até o fím do capítulo.

- Dois caminhos para experimentar a realidade

Ulrich já tinha declarado ${ }^{290}$ que havia dois caminhos para experimentar a realidade. Antes, ele tinha intuído sua própria vida irrevogavelmente dividida em duas árvores: a árvore do poder (razão) e a árvore da emoção, a que ele chama "a outra condição". Sua aparente incapacidade para reunir as metades separadas de seu ser lhe tinha então causado muito sofrimento. No ponto em que agora chegara, ele reconhecia uma dualidade básica inerente a todos os seres humanos, de maneira que sempre haveria um lado ou o outro predominando em duas espécies diferentes de pessoas. Ainda que na mesma pessoa, um lado ou o outro poderia predominar em diferentes ocasiões. Cada emoção possui dois aspectos contrastantes, um ativo e o outro mais bem descrito como "disposição". A visão ativa e a contemplativa são expostas como dualidade inerente em cada ser humano: nele há um apetite como o de uma besta voraz, mas há também algo que, livre de cobiça e

\footnotetext{
${ }^{289}$ MUSIL, $G W$, v. 5, p.1831-5, especialmente p. 1834-5.

${ }^{290}$ MUSIL, $G W$, v. 4, p. 1219 ; $H S Q$. Obra póstuma. O general Von Stumm lança uma bomba. Congresso Mundial da Paz. cap. 49, p.1173.
} 
plenitude, amadurece compassivamente como um processo natural. ${ }^{291}$ Então o autor reafirma a conexão já vista em O jovem Törless entre a imaginação animal e o lado ativo e expressivo da vida. Ulrich e Ágata concluem que os seres humanos podem experimentar a vida seja num estado de serena contemplação seja de atividade cheia de propósito. Isso significa não apenas atividade externa, mas também pensamento criativo e expressão de qualquer espécie. Freqüentemente Musil usa a fantasia animal como metáfora para se referir à esfera do inconsciente, mas, especialmente no capítulo 52 de Obras póstumas Para seu desprazer, Ágata encontra um resumo histórico da psicologia dos sentimentos; tal metáfora é ampliada para incluir os efeitos do inconsciente.

Depois das experiências místicas de Ulrich e Ágata, o primeiro fala das realizações positivas, devida a instintos (alem. Trieb) animais no homem, para contrabalançar a culpa muitas vezes vinculada a eles por seus efeitos destrutivos. Ação, criatividade e progresso na esfera artística são atribuídos a essa fonte. Ulrich não nega que os instintos animais no homem, com freqüência, conduzam à confusão e desordem, mas insiste que eles produzem muitos resultados tanto positivos como negativos, e que deveriam ser aceitos, não preconcebidamente censurados. Assim, Ulrich reconhece, finalmente, que as metades "exata" e "emocional" não precisam implicar uma ruptura esquizofrênica em sua personalidade, mas podem coexistir pacificamente, lado a lado. Essa visão de um possível equilíbrio entre as metades separadas de seu ser é compreendida junto com Ágata, quando eles aceitam que contemplação e atividade têm lugar decisivo na vida humana. Uma personalidade vigorosa ou uma vida equilibrada exigem períodos de atividade alternados a períodos contemplativos.

Esse foi o último capítulo que Musil pôde completar. O que aconteceu com o fim? De acordo com o plano descrito em 1926, a ação do romance deveria consistir de três fios condutores, desenvolvidos simultaneamente: a área mais ampla da Ação Paralela, a área pessoal: o relacionamento entre Ulrich e Ágata, e a área de insanidade e de crime na qual as figuras de Clarisse e Moosbruger eventualmente se encontram. O desejo de Musil de produzir algo de real valor nas discussões de experiência emocional entre Ulrich e Ágata

${ }^{291}$ MUSIL, GW, v. 4, cap. 52, p.1232-1239; HSQ, Obras Póstumas. cap. 52, p.1200-1209. 
levou-o a dedicar muito mais tempo a essa seção do que tinha previsto, mas o amplo esboço do plano original se manteve. ${ }^{292}$

Essas notas datam de 1936, mas, mais tarde, esse esboço é amplamente confirmado como permanecendo válido, embora em seguida é dada muito mais ênfase ao elemento pessoal e religioso. É esse aspecto que leva Ernst Kaiser e Eithne Wilkins - tradutores ingleses do romance - a interpretarem que Musil finalmente abandonara seu plano de deixar o relacionamento entre irmão e irmã naufragar, após o episódio do incesto, e fazer com que Ulrich se alistasse para a guerra. $\mathrm{Na}$ visão dos dois tradutores, Musil decidira terminar o romance com a descrição da tranqüila cena do jardim, como se a união mística de Ulrich e Ágata os tivesse afastado do mundo real. ${ }^{293}$

Contudo, em notas escritas em 1940, o autor ainda se referia ao episódio do incesto. Em uma carta de abril de 1942, alguns dias antes de sua morte, Musil descrevia o tema central da última parte do romance como a história de uma paixão incomum, cujo eventual colapso coincide com o da cultura. ${ }^{294}$ As análises de Kaiser e Wilkins esclarecem ângulos diferentes sobre o ponto de vista de Musil. Mas o tema subjacente, no qual sua obra deve ser primordialmente considerada como um esforço de curar sua própria neurose, tem um efeito que deve ser considerado discutível ou limitado. Um estudo mais recente aproxima Musil de uma perspectiva sociologizante, sustentando que seu isolamento e a resposta ao desenvolvimento político e social depois de 1918, provêem de sua própria natureza essencialmente burguesa. Hartmut Böhme (1974) sugere que o homem sem qualidades é o retrato da anomia e do estranhamento (alem. Entfremdung) do homem moderno. Ao traçar um paralelo entre a vida do personagem e a de Musil, Böhme sugere que se o escritor tivesse sido capaz de superar a desvantagem de sua formação e criação, o resultado talvez tivesse sido muito diferente. Mas nas circunstâncias ele estava impossibilitado de realizar um final satisfatório para o romance. Embora essa análise desafiante forneça juízos valiosos, corre o risco de examinar a obra de Musil, em última instância, de um ponto de vista unilateral e negativo. ${ }^{295}$

\footnotetext{
${ }^{292}$ MUSIL, GW, v. 4, cap.52, p. 1232 et seqs. $M w Q$, v. II, cap. 52, p. 1327 et seqs. Não há correlato na edição brasileira. (Tradução nossa.)

${ }^{293}$ HICKMAN, 1991, p.182.

${ }^{294}$ MUSIL, TB, v. 1, p. 1010-11; v. 2, p. 789-90. MUSIL, Carta a H.H. Church, Briefe, 1981, p. 1418-22.

${ }^{295}$ BOHME, Anomie und Entfremdung, 1974, p. 379-82.
} 
As notas para a versão final do capítulo 52 mostram que o autor esperou até um último estágio na situação política que o cercava para completar os três fios condutores do enredo. Mas é possível que ele eventualmente tenha decidido terminar de qualquer maneira e resumir seus últimos pensamentos num epílogo para Ulrich. Karl Dinklage traça o desenvolvimento de suas idéias, em estudo detalhado dos últimos manuscritos, e cita o plano para esse epílogo datado de janeiro de 1942: os temas listados incluem o futuro papel da China, o confronto entre a Rússia e o Ocidente, o renovado interesse de Musil por Dostoievski. Ele prevê a Segunda Guerra Mundial sem conhecer exatamente o seu desfecho, tal como não poderia imaginar o exato desfecho para a sua própria vida, imprimindo o seu significado para o presente e para o futuro. Finalmente, há duas áreas propostas para adicional leitura: Lao-tse e o sufismo. O epílogo planejado demonstra que com esforço se poderia encontrar um paralelo entre o que seria mais próprio ao desfecho de seu personagem e o exílio concreto imposto pelas circunstâncias históricas e políticas ao autor. Porém, tal paralelo se revela infrutífero nesta tese. Como ponto de basta, não serão examinadas as questões que opõem o homem verdadeiro, segundo a tradição do budismo, ao homem sem qualidades, que Musil denomina pela sua antítese. Tal discussão servirá a quem quiser encaminhá-la a uma outra tese.

- Musil como persona no exílio do ideal iluminista

Em Genebra, Musil e sua esposa viveram dezoito meses num apartamento térreo, situado no jardim de uma casa para mães e bebês. Ele ficava fascinado com as mudanças nas árvores e arbustos, vistos da janela de seu estúdio. Nunca, em sua vida, tivera a oportunidade de apreciar as cores, formas e o jogo de luzes sobre a natureza com em tantos detalhes. Ficava também intrigado com os vários gatos que eram vistos no jardim, cujas personalidades e relacionamentos registrava com sardônico humor. Um vizinho próximo e amigo era o escultor Wotruba, também um refugiado, que morava perto com a esposa, e algumas vezes visitava a família de Musil, propiciando-lhe contato social semanal. Os dois homens tinham se conhecido em Viena, e em 1939, Wotruba fez uma escultura de busto do autor. Em abril de 1941, Musil ficou alarmado com a perspectiva de 
vir a ter vizinhos barulhentos no apartamento acima do seu. Conseguiu encontrar uma pequena casa cercada por um jardim, na extremidade sul de Genebra, onde ele e Martha podiam viver sossegados.

A vida de Musil na Suíça somente foi possível em virtude do apoio de um número de amigos e de organizações de caridade. O músico Rolf Langnese, um membro exilado da Sociedade Vienense Musil, enviava dinheiro de tempos em tempos, e em 1939 a instituição American Guild for Cultural Freedom concedeu-lhe ajuda financeira por seis meses. O apartamento em Viena que fora abandonado em 1942 teve, supostamente, seus pertences transferidos para um guarda-móveis. Estes teriam sido destruídos por um bombardeio em 1945. No entanto, muitos anos mais tarde, tudo, como num toque de mágica, reapareceu pelas mãos de seu biógrafo Karl Corino, autor de Musil, Leben und Werk in Bildern und Texten (1989).

Além das tentativas fracassadas de conseguir a emigração de Musil para a GrãBretanha, a possibilidade de emigração para os Estados Unidos foi seriamente considerada, com o encorajamento de Hermann Broch, Albert Einstein, Thomas Mann e outros, mas deu em nada. Contudo, Musil ficou sabendo que $O$ homem sem qualidades tinha sido colocado na lista de livros banidos na Alemanha e na Áustria: embora evidência suficiente desse decreto não pudesse mais ser encontrada, ele ficou convencido dessa verdade, e as notícias deprimiram-no profundamente. Quando solicitou às autoridades policiais em Zurique uma prorrogação de sua licença residencial, Musil mostrou que nas circunstâncias era-lhe impossível voltar para sua pátria, uma vez que a proibição significava que sua única fonte de renda possível, através das vendas de sua obra, estava agora lhe sendo negada. ${ }^{296}$

Por muito tempo, a atitude de Musil para com a religião organizada tinha sido reservada. Seus pais foram ateus, e ele não via razão alguma para se envolver com a igreja ${ }^{297}$, ou pelo menos essa é a versão oficial deixada à posteridade. Contudo, durante seus últimos anos, as expressões de afeto e lealdade recebidas por parte de alguns amigos fez com que Musil refletisse sobre as bases do cristianismo. Tais reflexões se devem à

\footnotetext{
${ }^{296}$ HICKMAN, 1991, p.183.

${ }^{297}$ Ibidem, p. 183.
} 
amizade com o Pastor Lejeune, que despertou o interesse de Musil para as questões religiosas. Os escritos sobre a "outra condição" confirmavam sua visão de que a ação e crença genuínas devem ser infundidas pela emoção (alem. Affeckt) para terem qualquer valor.

Perto do fim de sua vida Musil desejava cada vez mais ver Deus como um criador que se preocupa como os seres humanos vivem. Apesar da falta de esperança de sua própria situação, no Caderno de Notas 30, ele chamou a atenção, para algo tido como imperdoável na tradição judaica: "Se Deus deseja criar e desenvolver o espírito, através dos seres humanos, se há qualquer valor na contribuição espiritual do indivíduo, então o suicídio é um pecado mortal: é desobediência para com Deus, o criador". ${ }^{298}$

Embora a saúde de Musil não fosse boa, ele esperava continuar trabalhando por muitos anos. No dia 15 de abril de 1942, passou a manhã completando a revisão final do capítulo 52 do Livro Segundo do romance, em suas diversas versões mais tarde reveladas, e então disse à sua esposa que tomaria um banho antes do almoço. Quando ela foi chamálo, ele estava deitado morto no chão, fulminado por um ataque. A princípio ela pensou que ele estivesse brincando, como fazia algumas vezes: mas dessa vez a morte era real. Dois dias após o seu falecimento, o corpo de Musil foi cremado em funeral ocorrido em Genebra. O Pastor Lejeune veio de Zurique para fazer o discurso de exéquias. Ele chamou Musil de o maior escritor de nosso tempo em língua alemã. Um outro amigo no exílio, Harald Baruschked, escolheu os três princípios básicos da vida e da obra de Musil: honestidade, veracidade e recusa em fazer concessão. Havia apenas oito pessoas acompanhando o enterro. Depois da Guerra, Martha Musil espalhou as cinzas de seu marido em um bosque perto de Genebra.

Logo depois da morte de Musil, sua viúva coletou subscrições para um volume póstumo de $O$ homem sem qualidades, que ela própria publicou em 1943. Martha Marcovaldi morreu em 1949, e seus últimos anos foram dedicados a tornar a obra de seu marido mais amplamente conhecida, permitindo que, após a sua morte, seus esforços

${ }^{298}$ HICKMAN, 1991, p. 184. 
fossem continuados. Centros de pesquisa para estudos de Musil foram estabelecidos em Klagenfurt, Saarbrücken e Viena.

- Honestidade, veracidade e recusa a fazer concessão: qualidades de um homem

Quando Musil escreveu: "Eu sou o homem sem qualidades, mas as pessoas não compreendem isso", estava fazendo a si uma injustiça. ${ }^{299}$ Ulrich, o personagem que ele criou, é, de fato, um homem aparentemente desligado da vida ao seu redor. Sob diversos aspectos, Ulrich poderá ser comparado ao Flaneur, que Walter Benjamin descreve. Em contraposição a seu personagem, Musil, o escritor, estava comprometido em interpretar para seus leitores o significado da vida. Em seus principais ensaios e conferências, foi capaz de mostrar seus pontos de vista com destemor. Porém, especialmente quando dificuldades do mundo externo o oprimiam - e finalmente o mataram, ele era tentado a pensar que poderia ter sido mais sábio evitar escritos criativos, limitando-se a obras teóricas. Mas então se lembrava de que a ironia construtiva era seu dom especial. Pelo uso incomparável desse dom, tornou-se um (i)moralista moderno, no sentido mais atual que se possa dar a esses termos.

A obra $O$ homem sem qualidades se situa entre os avanços científicos do século XIX e XX. Ela poderia ser nivelada à difusão.da teoria da evolução, de Darwin, à descoberta do inconsciente por Freud e à necessária ênfase ao papel das pulsões na vida humana. Emerson pregara que, em cada ser humano, em cada sociedade há possibilidades insuspeitadas de renovação e aperfeiçoamento. A preocupação de Musil foi sempre a de lutar pelo equilíbrio entre as emoções e a razão. Em virtude dos elementos matemáticos e filosóficos em seus primeiros estudos, ou, num nível mais profundo, pela natureza de sua própria mente, ele enxergava e apresentava idéias e pessoas em pares opostos, empenhando-se em esclarecê-las pela união de oposições. Percepção versus expressão, contemplação versus ação; ou, para reverter a ordem: intelecto versus sentimento, exatidão versus imaginação, para Musil, racionalismo e misticismo são os dois pólos de uma nova

${ }^{299}$ HICKMAN, 1991, p.185. 
era. Uma vez que Musil experimentou essas dicotomias como conflitos reais, em sua vida pessoal, ele foi capaz de apresentá-las de maneira convincente a seus leitores. Entretanto, o seu legado encontra limites como obra literária não chegando ao conhecimento e gosto do grande público.

A visão empírica do cientista mostra-se nos personagens centrais de Musil, na recusa destes em dar qualquer coisa por certa. Törless, Ulrich e Ágata não ficam satisfeitos com respostas já prontas às suas questões: eles devem testar a validade de qualquer teoria, mesmo que largamente aceita. Por sua própria situação, eles reafirmam a alternativa a esse mundo perigoso de meias-verdades.

No início de sua carreira de escritor, Musil mostrara o falso moralismo da tradicional família burguesa, subentendida como crítica a seus pais em $O$ jovem Törless. Usando idéias e palavras de outros acriticamente, como base para a própria existência, suas idéias chegam a produzir temerárias distorções. Mais tarde, num tempo em que a veracidade requereria verdadeiro gesto de coragem, Musil não receou retratar seus temores em relação ao que cruamente vivia ao seu redor.

Contudo, Musil, o escritor, sabia também que as palavras possuem propriedades mágicas, conhecidas desde os tempos antigos. A poesia e os textos criativos interpretam a vida. Assim, como devem ser reconciliadas as funções afetivas e imaginativas da linguagem? Musil expressa esse dilema e uma possível solução na passagem central de $O$ homem sem qualidades, quando Ulrich toma plena consciência da divisão entre as partes ativa e contemplativa, vendo-as como duas árvores ou dois caminhos, um à luz do dia, outra na escuridão. Nos pensamentos de Ulrich, as duas esferas do racional e do nãoracional são explicitamente vinculadas aos usos da linguagem lógica e imaginativa, e a conexão entre as duas espécies de experiências é mostrada no exemplo de uma imagem poética. O lado "exato" da vida encontra expressão no discurso lógico, o lado do sentimento, em sonhos e arte. Contudo, as palavras podem ser usadas para preencher 
ambas as funções. Elas contêm verdades e inverdades e é por meio do uso imaginativo das palavras, da fantasia, que os dois lados podem se juntar. ${ }^{300}$

Para Musil, uma metáfora contém uma verdade e uma falsidade, imbricadas em nossas emoções. Se a considerarmos como é, e a formarmos com nossos sentidos, dandolhe a forma de realidade, o que resulta são sonhos e arte. Entre essas duas condições, contudo, há uma parede de vidro. Se removermos tal parede com nosso intelecto, separando tudo o que não se harmoniza com os elementos destas duas condições, resultarão a verdade e o conhecimento, mas a emoção será destruída. Por um lado, da mesma maneira que certas espécies de bactérias dividem uma substância orgânica em duas partes, a espécie humana, de acordo com sua própria maneira de viver, divide o estado original vital da metáfora na concretude realidade-verdade. Por outro, na atmosfera vítrea da premonição, fé e artefatos, parece não haver outra possibilidade, o que Musil denominaria "outra condição".

É essa outra possibilidade, como uma síntese entre duas áreas opostas, que Ulrich procura descobrir, e Ágata o ajuda a compreender. Exatamente como as mesmas palavras podem ter duas funções diferentes, mas relacionadas, assim, Musil parece estar dizendo que os seres humanos podem alcançar entre intelecto e sentimento, exatidão e imaginação, ação e contemplação, uma verdadeira síntese para servir como base a uma vida melhor. Essa concepção de humanidade pode parecer utópica, mas cada indivíduo tem o poder de trabalhar para esse equilíbrio em si mesmo. Numa escala mais ampla, a sociedade que almeja esse objetivo liberta-se de sistemas antiquados ou ideologias rígidas. É sob tal condição que se tornará factualmente possível homens e mulheres realizarem seu verdadeiro potencial.

\footnotetext{
${ }^{300}$ MUSIL, $G W$, cap. 116, p. 579-581; HSQ. As duas árvores da vida e a exigência de um secretariado-geral da exatidão e da alma, p. 630-636.
} 
- Dilemas do engajamento intelectual

O conjunto de artigos rascunhados em 1920 reúne o julgamento sucinto de Musil sobre os efeitos da fragmentação de valores do mundo moderno. A sua descrição da Áustria é grotesca, mas apontava mais do que um corte claro a ilustrar o mundo moderno. ${ }^{301}$ Sua avaliação refere-se aos resultados políticos, sociais, morais e intelectuais da civilização européia sobre os efeitos subseqüentes da Primeira Guerra Mundial. Nesta parte de seus diários, Musil descreve uma série de tipos que apareceriam com seus maneirismos em seus futuros personagens. De maneira sarcástica, Musil faz anotações de como o mundo moderno havia fragmentado a sociedade e esta era a fábrica da civilização européia. $^{302}$

O que torna sua obra intrigante é que ele, o autor, e ela, a obra, correm na direção contrária ao clima predominante na Alemanha pós-Guerra. Em suas anotações, encontra-se a reivindicação de que tudo o que ocorreu durante e após a Guerra tinha suas raízes no período pré-Guerra, e é justamente isso que teria espantado seus contemporâneos. Esses preferiam concordar com observadores como Stefan Zweig (1964) ao ver a Guerra como um evento de proporções cataclísmicas, que abriu as portas para um mundo moderno de apetites desenfreados e violência sem sentido. Porém, na compreensão de Zweig, os eventos da Guerra não tinham conexão alguma com a velha ordem européia que fora substituída. ${ }^{303}$ É precisamente a recusa de Musil em ver na Guerra uma quebra radical entre duas épocas completamente diferentes, que constitui o principal ponto de contenda entre ele e contemporâneos, como Zweig.

A reconstrução do horizonte cultural que emoldurou a eclosão da Grande Guerra ajuda a colocar em perspectiva a avaliação de Musil. Eksteins (1989) se refere a um poderoso sentido de cansaço com a cultura ocidental do século XIX e com a humanidade que explica por que tantos alemães e europeus abraçaram, com entusiasmo, a Guerra como uma chance para a renovação. Porém, esse mesmo espírito de rejuvenescimento forneceu

\footnotetext{
${ }^{301}$ MUSIL, Diaries, 1999, p. 209.

${ }^{302}$ Ibidem, p. 207-229.

${ }^{303}$ ZWEIG, The world of yesterday: an autobiography, 1964.
} 
um suporte para os acontecimentos tenebrosos, inauditos, da Primeira Guerra Mundial. Eksteins argumenta que a maneira alemã para definir as regras tradicionais de guerra foi uma conseqüência direta de sua disposição para desafiar as normas de política, cultura e moral do Ocidente - uma disposição nutrida por uma cultura de vitalismo, primitivismo, amoralismo e purificação da força da violência. Tal como é conhecida, a Primeira Guerra Mundial alterou radicalmente a compreensão de guerra no Ocidente. A elite política e militar alemã foi responsável principalmente por mudanças nas regras de combate, instituindo comportamentos inconcebíveis, que incluiu a violação de pactos previamente estipulados de neutralidade, a introdução de gases mortíferos, o uso irrestrito de submarinos de guerra e a quebra da distinção fundamental entre combatentes e nãocombatentes. Inaugurava-se uma nova ordem jurídica que advogava o direito de suprimir a "vida indigna de ser vivida".

A brutalidade da guerra total instaurada pela Alemanha não é algo totalmente inaudito. Ela se apóia em modelos de comportamento compartilhados nas guerras e padrões que definiram o caráter civilizatório ocidental, ao longo dos séculos antecedentes. A Primeira Guerra Mundial ajudou a limpar as cinzas dos princípios de interação entre as nações soberanas. A exemplo, França e Inglaterra correram para juntar-se ao barbarismo, que eles depreciaram nos alemães, para vencê-los com os mesmos instrumentos no jogo das guerras. ${ }^{304}$

O principal ponto é que a assombrosa novidade da guerra - com a abdicação de regras fundamentais de humanidade e horrores que desafiavam a imaginação - , se tornou possível devido a um clima cultural e ideológico anterior a ela. Eksteins se refere ao clima impregnante que envolveu grupos de intelectuais e artistas engajando-os explicitamente no culto à violência, de maneira a advogarem diretamente o conflito.

O julgamento de Musil reflete uma ênfase semelhante quanto à continuidade do clima cultural dos anos anteriores à guerra e a situação criada pelas sublevações da guerra: tal evento havia acelerado e tornado perceptível a transição irreversível de uma visão realista do século XX. O período de transição era governado por uma ordem inteligível de

${ }^{304}$ EKSTEINS, Rites of spring: the great war and the birth of the Modern Age, 1989. Prefácio, p. xiii-xvi; p. $139-238$ 
significado, voltada para uma percepção da opacidade e descontrole do mundo moderno despido de pontos universais de referência ética.

Se a Primeira Grande Guerra não chegou a criar um mundo novo, ela ajudou a tornar plenamente visível a direção da mudança, na qual a ordem anterior à Guerra estava caminhando, ao expor a falência de noções ultrapassadas de personalidade, do ser, da moralidade e da comunidade. Ao mesmo tempo, a Guerra havia demonstrado a necessidade de se preencher o vazio deixado por essas noções com novos modelos de experiências individuais e coletivas.

Para Musil, estava em jogo um esforço conjunto, intelectual e espiritual, com fins à criação de uma nova "organização espiritual”. Em seus diários, Musil destaca o clima geral da energia revolucionária que existia somente nos segmentos conservadores da sociedade. De maneira direta, ele se refere à sua própria descrença sobre a exclusiva responsabilidadedas campanhas pangermânicas de incitamento ao ódio xenófobo ou racista, tal como propagado na imprensa. Estas não eram as únicas responsáveis pelo clima. Musil destaca os diferentes interesses dos segmentos sociais que confluíam para determinar a situação: juventude, burguesia, clérigos, conservadores, socialistas e ideólogos do liberalismo. Ele antecipa aspectos de transição social na construção de seus personagens de $O$ homem sem qualidades. Musil nota que após a Primeira Grande Guerra, “a sociedade está em fluxo, mas é ainda dominada por valores ultrapassados"305. De maneira inovadora, sua perspectiva oferece exemplos de coexistência social mais adequados à realidade das sociedades descentralizadas atuais. Ele também salientou outro elemento não reconhecido de continuidade com o passado: a persistência de muitos hábitos de pensamento anteriores à Guerra que haviam levado ao colapso da velha ordem. Em vez de responderem imaginativamente aos desafios dos anos pós-Guerra, seus contemporâneos estavam muito apressados em se apossar de velhas narrativas e muletas metafísicas que haviam sido desacreditadas pela Guerra, mostrando-se disfarçadas sob visões de renovação e redenção radicais.

${ }^{305}$ MUSIL, Diaries, 1999, p.275, 277. 
Rabinbach (1977) examinou os discursos apocalípticos que negociaram a ruptura histórica da Primeira Guerra Mundial na cultura alemã, reconstruindo um clima geral propenso ao confronto da catástrofe da Grande Guerra ao observar a existência de uma atitude de repúdio mundial e expectativa messiânica. ${ }^{306}$

De forma perspicaz, Musil se distanciou de tais visões apocalípticas. Diante do desejo por revolução, como perturbação do fluxo opressivo da história criada para apagar De forma perspicaz, Musil se distanciou de tais visões apocalípticas. Diante do desejo por revolução, como perturbação do fluxo opressivo da história criada para apagar por completo a experiência ordinária, e por ser fundamentado em um falso "ser", esse autor vislumbrou o sinal da marca perniciosa de idealismo que havia persistido até o período pós-guerra. Considerado como mau idealismo, este se alimentava de uma atitude regressiva determinada a projetar a existência do "exterior" messiânico à experiência, como possibilidade única de onde poderia vir a redenção.

A própria idéia da guerra como uma ruptura radical era para Musil uma ilusão que cegava muitos contemporâneos, devido ao fato de que estavam trilhando os velhos passos da destruição. Musil ressaltou fenômenos demasiadamente familiares tais como a nostalgia regressiva do desespero cultural e a compulsão humanista de se atacar questões éticas intricadas. Valendo-se de questionáveis princípios morais absolutistas associados ao culto ingênuo da irracionalidade e da negligência irresponsável da experiência, Musil destaca que tais princípios teriam maculado os experimentos estéticos agrupados sob o título de Expressionismo.

O esforço intelectual e estético de Musil, nos anos 1920, é suportado pela vontade de contribuir com a reorganização espiritual do presente que ele julgava indispensável. Esta é uma tarefa que ele perseguiu na sua série de ensaios e trabalhos de ficção, sobretudo em $O$ Homem sem Qualidades. A crise que assombrava a todos requeria a tarefa

\footnotetext{
${ }^{306}$ RABINBACH, 1997, p. 2-4. Para o fundo histórico do pessimismo cultural, ver: STERN, The politics of cultural despair: a study in the rise of the Germanic ideology, 1961; MOOSE, The crisis of German ideology: intellectual origins of the Third Reich, 1964; WOHL, The Generation of 1914, 1979. Para um exame sociopolítico e cultural da monarquia austro-húngara e da República Austríaca, veja JOHNSTON, The Austrian mind: an intellectual Social History, 1848-1938, 1972; STEINBERG, Austria as theater and ideology: The meaning of the Salzburg Festival, 2000.
} 
de passar a limpo a questão da valorização prevalente da guerra no mundo novo que esta havia presumivelmente criado.

Ao ser recrutado para a guerra, Musil foi designado para um posto em Tirol do Sul e subseqüentemente nomeado para a editoria do jornal militar. Ao fim da guerra ele se aproximou de rodas ativistas em torno de Kurt Hiller e Robert Müller. Contudo, ele se decepcionou com a ingenuidade de suas visões políticas - mais notadamente, sua autonomeação como vanguarda política chamada ao sacrifício de forma a liderar o povo (alem. Volk) não esclarecido. ${ }^{307}$ Durante a transição para o novo governo republicano que se seguiu ao desmonte da Áustria-Hungria, ele encontrou trabalho temporário na Secretaria de Exterior e no Ministério da Guerra em Viena.

Como suas negociações para retomar à sua posição editorial na revista Neue Rundschau fracassaram, e o patrimônio modesto que havia herdado de seus pais desapareceu na inflação dos anos pós-guerra, Musil lutou para se sustentar com a sua atividade como ensaísta e crítico de teatro em Viena. O respeito que havia angariado nos círculos literários levou-o a conquistar, em 1923, o posto de vice-presidente da sociedade austríaca para a Proteção aos Escritores Alemães, que era presidida pelo proeminente Hugo von Hofmannstahl. Graças em parte ao engajamento de Alfred Döblin, em 1923 ele ganhou o prêmio Kleist por seu drama Enthusiasts (alem. Die Schwärmer, 1921) ${ }^{308}$ que representou seu projeto mais ambicioso depois da narrativa monumental de $O$ homem sem qualidades. Devido a dificuldades técnicas para se montar o "Drama de conversa experimental", a peça não foi executada até 1929, quando estreou em Berlim em uma versão radicalmente abreviada e não autorizada. Amargurado pelo fracasso, por dificuldades financeiras crônicas e por enfermidades nervosas, Musil continuou a trabalhar no romance, que desde os meados de 1920 havia se tornado virtualmente o foco único de sua escrita de ficção. A aposta no romance se mostrou certeira. O primeiro volume de $O$ homem sem qualidades apareceu em 1930 e recebeu alto louvor crítico.

\footnotetext{
${ }^{307}$ Para uma discussão do rápido envolvimento de MUSIL com Müller, veja nota 249 em TB, v. II, 1983, p. $248-52$.

${ }^{308}$ Há tradução desta peça teatral para o português. Ver: MUSIL. Os visionários, drama em três actos. Lisboa: Minerva, 1989
} 
Entretanto, Musil nunca se esqueceu que ele também foi pego na euforia coletiva trazida pela guerra no verão de 1914. Em um ensaio publicado em setembro daquele ano, ele havia desautorizado sua posição apolítica anterior e assinalado o conflito como uma oportunidade épica para defender a herança cultural alemã sitiada e restaurar uma comunidade especificamente alemã (alem. Lebensgemeinschaft). Mesmo que esse texto tenha um nível mais alto de argumentação do que as proclamações truculentas, xenófobas e anti-semitas, com as quais muitos intelectuais alemães saudaram a Guerra, não é difícil imaginar a vergonha que suas posições apolíticas retrospectivamente trouxeram à Musil, cujo entusiasmo havia rapidamente se esfriado após experimentar, em primeira mão, a Guerra. Contudo, é precisamente a circunstância desconcertante de ele também ter sido sugado em uma experiência cativante, evocada obscuramente pela Guerra, que o tornou mais interessado em explorar quais os aspectos humanos camuflados a Guerra havia revelado e o que ela mostraria sobre a natureza humana.

Um diagnóstico correto dos anos precedentes à Guerra era crucial para se descobrir as raízes da crise que assombravam o período pós-guerra. Ele olhou para as duas décadas anteriores à Primeira Guerra Mundial como uma época de grande tumulto intelectual e desenvolvimento desvairado nas ciências, nutridos por uma fé no advento de uma era radicalmente nova. Seus ensaios relativos a esse período pintam um quadro irônico, mas simpático aos fermentos intelectuais daqueles anos, enfatizando a confusão e, ao mesmo tempo, a fertilidade da troca desordenada de visões mundiais conflitantes:

Tomo meus exemplos novamente da esfera literária: havia
irracionalismo junto com racionalismo. A idéia do romance
experimental, e dos autores de S. Fischer, esperando redenção
pelos sentimentos, através de um curto-circuito humano. Nietzsche
e o socialismo. A visão materialista da história e estágios iniciais
do idealismo. Humanismo e anti-semitismo (ou teoria racial).
Dessa forma, internacionalismo e nacionalismo também. Arte
européia e arte regional. A poesia da metrópole e da Igreja
Católica. Monismo, Cristandade Livre - igreja. ${ }^{309}$

Tal passagem ilustra a confusão ideológica dos anos anteriores à Guerra, inscrita na litania de opostos ideológicos que lutavam entre si na arena cultural - racionalismo e

${ }^{309}$ MUSIL, PS, 1990, p. 152. 
irracionalismo, elitismo nietzschiano e socialismo, materialismo e idealismo, humanismo e racismo, internacionalismo e nacionalismo.

Estas visões, altamente polarizadas, compartilhavam, em retrospectiva, um denominador comum: o espírito arrojado de experimentação e o senso positivo do futuro. $\mathrm{Na}$ realidade, uma "vontade de ser diferente e de fazer coisas de forma diferente do que as pessoas haviam feito no passado"(Musil, 1990, p.170). Com a eclosão da Primeira Grande Guerra, as chamadas gerais para defenestração da velha ordem pareceram encontrar uma realização radical e traumática. Enquanto Musil achava impossível exagerar a extensão do sofrimento e da devastação trazidos pela Guerra ao velho continente, ele estava também convencido de que o conflito havia ao menos provado estarem falidos os últimos vestígios ideológicos do final do século XIX.

Mas pouco havia sobrevivido do espírito de experimentação, anterior à Guerra, nas recém-fundadas repúblicas de Weimar e Áustria. Aqui o senso de desorientação produzido pelo colapso de identidades tradicionais e transição para novas ordens políticas e sociais foi exacerbado pela forte crise econômica de período imediato pós-Guerra. A distância da euforia confusa dos anos antecedentes à Guerra não poderia ser maior. A erradicação violenta de estruturas estabelecidas e pontos de referência deixou um vácuo considerado intolerável. A realidade moderna de esferas de vida especializadas foi experimentada como um "hospício babilônico" insuportável ${ }^{310}$, estraçalhado por crenças e ideologias díspares.

Em face de uma existência "desprovida de conceitos ordenadores" "311, Musil viu seus contemporâneos se afogarem em uma tradicional "necessidade de buscar um apoio" 312 , na mesma busca por pontos de referência fixos que havia sido desacreditada pela guerra. Onde o desejo anterior à guerra por renovação havia dado lugar a uma percepção geral de ruína e declínio, ele salientou "o remédio quase sempre é buscado

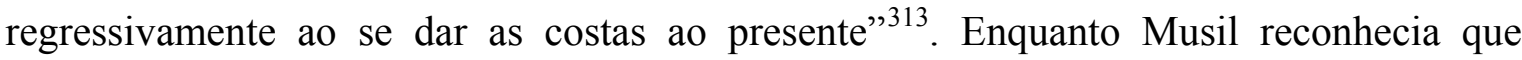
estavam em jogo fenômenos da modernidade verdadeiramente preocupantes, ele não podia deixar de denunciar a fuga de seus contemporâneos, quando se afastaram de um exame

\footnotetext{
${ }^{310}$ MUSIL, $P S, 1990$, p. 128.

311 Ibidem, p. 128.

${ }^{312}$ Ibidem, p. 127.

${ }^{313}$ Ibidem, p. 176.
} 
liberal dos problemas e suas causas. Ao invés de construir uma crítica, esta foi substituída pelo uso emocional de palavras-chave em voga - mecanização e intelectualização descuidadas do mundo moderno, dominação pela razão instrumental, capitalismo temerário e a perda da religião e de valores tradicionais.

Com desgosto, Musil notou que a correlação da retirada do presente foi uma condenação dos alegados males da modernidade, deixada a responsabilidade por conta de generalizações e simplificações envolventes. Antes de reconhecer no presente o recomeço que muitos tinham advogado antes da guerra, agora, seus contemporâneos o estavam dispensando como se tivesse ocorrido a degeneração a um estado mais desejável anterior; isto é: "a desintegração de uma condição prévia que era supostamente mais sólida", resultando em "perda de dogmas e diretrizes, dissolução de vínculos; em uma palavra: declínio". 314

O interesse de Musil por entender o clima cultural dessa época está refletido em sua confrontação com alguns dos textos fundadores do pessimismo cultural, como Chamberlain $^{315}$ e Thomas Mann ${ }^{316}$, que ele extensivamente se referiu em seus diários. Tais citações estavam contidas na mensagem culta e pessimista do declínio, e são testemunhas do escrutínio de Musil sustentado por temas chaves, desde a oposição à civilização e cultura, passando pela incompatibilidade da arte verdadeira e política moderna, aos efeitos perniciosos da racionalização, intelectualismo e materialismo. ${ }^{317}$

Sua resposta mais extensiva à constelação culta e pessimista é encontrada no ensaio sobre o declínio do Ocidente, de Oswald Spengler ${ }^{318}(1921){ }^{319}$ O tratado históricofilosófico monumental de Spengler, publicado em dois volumes, em 1918 e 1922, combinou o modelo nietzschiano de ciclos culturais com uma abordagem historiográfica

\footnotetext{
${ }^{314}$ MUSIL, $P S$, p. 163.

${ }^{315}$ CHAMBERLAIN, Foundations of the Nineteenth Century, 1988.

${ }^{316}$ MANN, Reflections of a non-political man, 1987.

${ }^{317}$ O artigo em questão é "Europeanness, War, Germanness" (alem. Europäertum, Krieg, Deutschtum) de setembro de 1914. In: MUSIL, $G W$, v. 8 , p. 1020-22. Para uma discussão do pensamento político de Musil, entre 1912 e 1922, e "Musils politische Haltung in seinen frühen Essays". Também em MUSIL, PS, Politics in Austria 1912, p. 17-21.

${ }^{318}$ SPENGLER, La decadencia de Occidente, 1976.

${ }^{319} \mathrm{O}$ artigo de Musil "Mind and experience: Notes for Readers Who Have Eluded the Decline of the West" ("Mente e Experiência: notas para os leitores que frustraram a queda do Ocidente") (Tradução nossa.) é baseado apenas no primeiro volume do trabalho de Spengler, de 1918. MUSIL, PS, p. 134-149.
} 
baseada em uma teoria que aspirava ser sugestiva para novas formas históricas. Seu apelo para a geração pós-guerra estava na reivindicação de fornecer um relato da degeneração presumivelmente inevitável da cultura ocidental na civilização - uma fase que, na morfologia histórica de Spengler, precedia imediatamente à morte da cultura, e que seus contemporâneos encontravam inscrita no cataclismo da guerra.

Apesar de Musil reconhecer o empreendimento arrojado deste autor como tentativa de fornecer um modelo, para aquela renovação intelectual e cultural que ele próprio advogava, seu ensaio visa à crítica dos defeitos na abordagem spengleriana que ele viu como sintoma de uma difundida mentalidade intelectual: "Quando se ataca Spengler, está se atacando a época da qual se advém; e que se lisonjeia, pois seus defeitos são os defeitos dele." ${ }^{320}$. O capricho metodológico da morfologia histórica do autor ora em discussão, cujo sistema analógico parecia ser fundado em pouco mais que comparações idiossincráticas, é ressaltado quando Musil busca elucidar a arbitrariedade das analogias desse historiador, oferecendo um exemplo cuidadoso de possíveis semelhanças ligando o mundo das borboletas ao da civilização chinesa:

\footnotetext{
Há borboletas amarelo-limão e há chineses [de cor] amarelo-limão. De certa forma, então, pode-se dizer que a borboleta é um chinês alado médio-europeu anão. Borboletas e chineses são ambos familiares como imagens de desejo sexual. Aqui é formulado pela primeira vez o pensamento acerca da semelhança previamente não reconhecida entre as grandes épocas da fauna lepidoptérica e a cultura chinesa. Que as borboletas tenham asas e os chineses não, este é somente um fenômeno superficial. $^{321}$
}

A ridícula justaposição das borboletas e dos chineses, dependente de como é feita uma semelhança superficial, aleatoriamente escolhida (a cor amarela), ajudou a ilustrar como a abordagem morfológica de Spengler revelava mais sobre os preconceitos culturais do observador do que sobre o objeto em investigação.

O exemplo sarcástico criado por Musil não é tanto dirigido a este autor, em si, quanto à pretensão de expor a debilidade intelectual e a ingenuidade de uma era que saudou sua teoria errática das formas com o alvorecer de um novo método historiográfico.

\footnotetext{
${ }^{320}$ MUSIL, $P S$, p. 139. (Tradução nossa.)

${ }^{321}$ MUSIL, $P S$, p. 136.
} 
Acima de tudo, Musil buscava descobrir as raízes de uma mentalidade predominante que desprezava a observação empírica e estava feliz em tolerar todas as brechas contra a convicção e a precisão.

Musil acreditava que o preconceito antiempírico e antiintelectual autorizava as inúmeras imprecisões factuais do texto de Spengler, bem como sua estratégia característica de se apossar de termos em voga nas ciências naturais, que apareciam programaticamente vazios de seu significado original, feitos para caberem nas teses pré-figuradas:

\begin{abstract}
Spengler está falando sem rigor; ele trabalha com analogias, e estas sempre estão certas de uma forma ou de outra. Se um autor está disposto a se referir a conceitos por nomes errados ou até confundi-los, pode-se eventualmente acostumar com isso. Mas algum símbolo principal, algum tipo de conexão inequívoca entre o pensamento e a palavra, deve ser sustentado. Até isto está ausente. ${ }^{322}$
\end{abstract}

Em questão, estava uma imprecisão inaceitável de pensamento e argumentação, uma tendência a negligenciar ou apagar importantes distinções para fins de um argumento sugestivo, a dependência injustificável na força de arrojadas metáforas não inspecionadas de perto, o emprego de generalizações e grandes reivindicações que não resistiam à prova do pensamento analítico. Mas Spengler foi também emblemático em seu esforço para buscar validação metodológica em alguma forma de conhecimento intuitivo, colocado convenientemente frente a um tipo de cognição intelectual alegadamente vulgar e perniciosa. Musil viu nesta estereotipia banal da razão e da intuição uma muleta cultural anterior à Guerra, que estava sendo entusiasticamente reavivada no período pós-guerra:

\footnotetext{
Mas que, por um lado, a substância inteira da intuição remonte ao fato que não se pode dizer ou tratar o que é mais importante; que se é cético ao extremo em matérias de razão (...), por outro lado, incrivelmente crédulo para tudo que aconteça surgir na mente de alguém; que se duvide da matemática e acredite em fabricações artístico-históricas da verdade como cultura e estilo; que, apesar da intuição, faz-se a mesma coisa que um empírico ao comparar e combinar fatos, só que pior, atirando com fumaça ao invés de balas: esta é a imagem clínica da mente, a mente estética do nosso tempo, suavizada pelo vício imoderado, avançado à intuição. ${ }^{323}$
}

\footnotetext{
${ }^{322}$ MUSIL, PS, p. 135.

${ }^{323}$ Ibidem, p.145-146.
} 
Ao esboçar a imagem clínica do esteta intuitivo - presumidamente a audiência preferida para os trabalhos de Spengler - Musil apontou para a desonestidade intelectual de uma ideologia cultural que alegava evitar os buracos do empiricismo estéril e do intelectualismo infrutífero. Mas estes passavam pelos mesmos domínios que o empiricista e o racionalista, enquanto se isentavam de seus padrões metodológicos.

É significativo que a seção final do ensaio sobre este autor ressalta o credo artístico do Expressionismo como corolário estético ao clima cultural que alimentou trabalhos como Decadência do Ocidente. Spengler, o esteta intuitivo e o expressionista eram para Musil sintomas reveladores de uma época que não sofria da influência excessiva da "compreensão, mas que não tem sua compreensão no lugar certo". ${ }^{324}$ Era na realidade o intelecto turvo do expressionista que o fazia parecer o protótipo do artista propenso a desperdiçar discernimentos fundamentais da arte e o condenava a emitir frases vazias; em verdade, palavras sem o peso e a checagem da realidade empírica. ${ }^{325}$

A antipatia de Musil para o expressionismo está bem documentada em numerosos comentários críticos que temperam seus ensaios e diários através dos anos de 1920 e que estão direcionados principalmente em denunciar a ideologia falha que ele vislumbrava nesta corrente estética, ao invés de atacar artistas individualmente. Ele via o expressionismo como ideologia: uma aberração que maculava as aspirações artísticas daquele tempo e estragava a prática do drama contemporâneo. As razões para seu desprezo estão mais bem ilustradas no ensaio de 1922, cujo pretexto imediato é oferecer uma revisão crítica da temporada teatral passada de Viena. ${ }^{326}$ Ao tentar relatar a qualidade limitada das peças montadas em Viena no ano anterior, Musil salientou o que ele viu como o erro fundamental da estética expressionista: a saber, sua suposição não declarada "de que um escritor não deveria pensar, mas sim sentir; que ele deveria falar imediatamente a um senso comum de sentido, contornando a atividade mental mais analítica"327.

\footnotetext{
${ }^{324}$ MUSIL, PS, p. 149.

${ }^{325}$ Ibidem.

${ }^{326}$ MUSIL, GW, v. 8, p. 1094-1103. "Sintomas de Teatro I" (“Symptomen-Theater I”) (Tradução nossa.) é o primeiro de três artigos que foram significativos para oferecer um comentário crítico de uma dramática sessão do passado.

${ }^{327}$ Ibidem, p. 1097.
} 
Em questão estava a noção não inspecionada do processo artístico predicado em noções imediatas, de sentimento e intuição, que transformavam o artista em um campeão irracional de pura emoção, presumidamente capaz de chegar a algum poço secreto da vida. Em resposta à reivindicação expressionista de ter efetuado um corte radical com as concepções passadas de arte, Musil notou como a arte, ao se revelar fonte de algum conhecimento irracional, já era parte e parcela do impressionismo. ${ }^{328}$

Musil acreditava que o motivo que levou os expressionistas a persistirem inconscientemente nos erros de seus antecessores era nada mais que seu repúdio à análise intelectual e a inabilidade relacionada para se praticar um auto-exame lúcido. Como resultado, onde os expressionistas acreditavam trazer a novidade ao destilar o sentido sintético da vida da experiência imediata, na verdade, eles não iam além da tradução de máximas banais sobre a existência humana para uma linguagem exaltada e patética. Ele se referia assim aos bons e velhos valores do humanismo remontados em uma versão diluída do socialismo. O sintoma familiar era um desejo por totalidade e síntese:

\begin{abstract}
A essência maior do Expressionismo é um método sintético em contraste com [o método] analítico. O Expressionista renuncia à análise... Portanto, tende ao dogmatismo. Ele então tenta encontrar um novo "sentimento mundial" da mesma maneira que um químico tentar encontrar borracha sintética. O que o limita é que não existe técnica puramente sintética. ${ }^{329}$
\end{abstract}

Ao perseguir a busca pela restauração da integridade da existência moderna despedaçada, o Expressionismo conseguiu uma visão sintética da vida ao se isentar de uma análise compreensiva da experiência, hipostasiando discernimentos não testados em revelações. ${ }^{330} \mathrm{O}$ que os Expressionistas acabaram por apresentar como a expressão

\footnotetext{
${ }^{328}$ MUSIL, PS, p. 1097.

${ }^{329}$ Ibidem, Diaries, p. 254-55.

${ }^{330}$ Como mostram seus diários, Musil deve este critério a Thomas Mann, que, em uma parte de Reflexões, apontou a ironia imposta na rejeição do Impressionismo dos Expressionistas. Expressionismo, como se pode ler no pequeno resumo de Musil sobre Mann, nega a realidade burguesa filistina rendida ao Impressionismo que assegura ser uma irrefutável afirmativa e, em vez de ganhar uma noção de arte baseada na imaculada e ilimitada criativa erupção do "espírito" (Geist) ou a alma do artista (MUSIL, TB, v. I, p. 483). Assim, Musil declara seguir Mann em uma avaliação dos Expressionistas. Ele parece seguir por um caminho eminentemente impressionista, sustentando as impressões e emoções como uma medida de experiência verdadeira: "Todos eles (os Expressionistas) seguem a impressão do momento, então eles são impressionistas" (MUSIL, Diaries, p. 253). Outros aspectos desenvolvidos, sobre a continuidade entre Impressionismo e Expressionismo, podem ser encontrados em outro artigo, "Toward a New Aesthetic. 1925" (Em Direção a Uma Nova Ética) (Tradução nossa.). (MUSIL, PS, p. 193-208). Aqui Musil comenta sobre as falsas doutrinas atuais, amplamente disseminadas que visam libertar o espírito humano da razão
} 
presumivelmente espontânea da alma do artista foi pouco mais que frases gastas, que não escondiam o vazio intelectual de seus trabalhos. Impiedosamente, Musil comparou esta prática ao latido de idéias,

pois realmente a invocação - com dois pontos de exclamação no lugar do ponto de interrogação - de grandes idéias da humanidade como sofrimento, amor, eternidade, bondade, ganância, mulher, sangue, caos, etc., não é mais valiosa que a expressão lírica de um cão que late para a lua. 331

Enquanto a sua rede preciosa de alusões aos mestres da literatura - Goethe, Byron, Ibsen, Maeterlinck - atestava a demonstração habilidosa de domínio literário, ele também notou que tal domínio não era suficiente para compensar a aleatoriedade de seus enredos e o vazio intelectual geral. ${ }^{332}$ As armadilhas do teatro Expressionista apontavam ainda para um problema maior que assombrava o drama, pelo menos desde o final do século XIX. Musil se dispôs a discutir este desenvolvimento histórico em dois outros grandes ensaios que também se iniciam com um comentário sobre a temporada teatral passada, com objetivo de oferecer reflexões mais abrangentes sobre o estado do teatro contemporâneo. ${ }^{26}$ Para Musil, o drama moderno havia surgido como um veículo privilegiado, voltado à propagação da noção burguesa de educação (alem. Bildung), que ele viu inscrita paradigmaticamente na idéia de Schiller: o teatro como uma "instituição moral" e o instrumento de uma educação estética devotada a transmitir virtudes aparentemente universais de humanidade. Este era um instrumento ideológico poderoso, que havia sustentado a iniciativa para a hegemonia cultural e afirmação política da burguesia, desde o Iluminismo.

[alem. Verstand] colocando-o imediatamente uma vez mais em um relacionamento com a criação. Como ele afirma, "hoje estes esforços parecem expressar um anseio que primeiro se tornou importante em conexão com os esforços relacionados ao Expressionismo. Mas se se olhar para algumas décadas no passado, podese ver esta crítica da 'razão' em nome da liberdade da 'alma', já presente naquela época; mesmo assim queria ajudar a 'alma' a conseguir uma expressão mais imediata do que um termo vazio, pego em um embaraço conceitual, permitido e conduzido pelo espírito humano de liberdade por todos os lados da estrada, não apenas pelo principal. As reais sementes desta luta por emancipação já estavam presentes no Impressionismo (...) e foram plantadas pela influência do Romantismo Alemão, de Emerson e do místico eclético Maeterlinck". MUSIL, ibidem, p. 200.

${ }^{331}$ MUSIL, $G W$, v. 8, p.1099.

${ }^{332}$ MUSIL, $G W$, v. 8, p. 1169. "Livros e Literatura" (“Bücher und Literatur”, 1926) (Tradução nossa.). 
Musil acreditava que a transição para uma etapa do capitalismo tardio havia coincidido com a exaustão do impulso ideológico inicial da burguesia, resultando na reificação e burocratização do conceito de Bildung. A erosão do imperativo edificante do drama havia levado, por um lado, à redefinição de tal estilo como uma forma previsível de entretenimento baseada no embaralhamento de algumas personagens e temas e, por outro lado, levou também ao culto de uma noção abstrata de efeito (alem. Wirkung). Associados ao impacto emocional, ambos eram perseguidos para seu próprio bem ${ }^{333}$. Na demanda contemporânea para que "um trabalho dramático... não tenha um objetivo maior que seu efeito" 334 , Musil reconheceu a tendência ao favorecimento à manipulação das afeições do público sobre a produção de conteúdo intelectual substantivo e inovador. Eram fenômenos relacionados à ênfase desproporcional à teatralidade e o culto indefensável de atores estrelas e suas atuações, que haviam substituído a apreciação das qualidades literáriasintelectuais das peças.

Para Musil, a atuação dramática do presente se exauria na evocação de humores fingidos e sentimentos artificiais, que pouco tinham a ver com o mundo emocional das pessoas reais. Ao contrário, tal tipo de atuação correspondia a um repertório banal de afeições. Era sua personagem convencional a quem o público reconhecia e com a qual se identificava, não com uma reflexão da experiência vivida:

\footnotetext{
O elemento do ator, portanto, contemporiza elementos que não existem. Realmente, estas eclosões elementares não capturam a mente. Ao contrário, capturam idéias da mente que preexistiam ao espectador e somente com o auxílio destas idéias captadas do espectador em si... O que é encenado são visões encadeadas e tradições de efeito; não paixões, mas sim atores que encenam paixões, não pessoas, mas pessoas espelhadas, e, em geral, algum indolente estado de tradição giratório. ${ }^{335}$
}

Os arroubos emocionais, presumidamente arquétipos modelados pelos atores modernos, não seguravam os espectadores através de algum impacto afetivo direto, mas sim reverberaram conceitos convencionais de como as emoções deveriam parecer. Estas haviam sido implantadas no público através da mediação de uma tradição estética, que havia sido engolida na evocação auto-referencial de significados reificados. Musil

\footnotetext{
${ }^{333}$ MUSIL, $G W$, v. 8, p. 1120.

${ }^{334}$ Ibidem.

${ }^{335}$ Ibidem, v. 8, p. 1107.
} 
censurava esta prática estética por sua inabilidade para capturar os aspectos mais intrincados da realidade contemporânea e pela propensão relacionada para oferecer uma imagem artificial e enganadora da experiência humana.

Semelhante à inclinação Expressionista para disfarçar lugares-comuns sob o manto de revelações pré-racionais, tal tendência teatral se isentava de um escrutínio sério da realidade moderna, e, portanto, se desviando do que Musil prezava como o dever fundamental da arte, a saber: oferecer novos modelos para se ser humano, baseados na observação cuidadosa da experiência presente. Em seu culto irrefletido de emoções e intuições, a humanidade estava também propensa a desperdiçar o potencial intelectual distinto da arte, consignado a uma mistura específica de intelecto e sentimento ${ }^{336}$. Era essa fonte que poderia e deveria ter sido tocada na busca por uma nova organização espiritual da era pós-guerra.

Expressionistas, como emblemáticos do renascimento de atitudes intelectuais danosas que haviam perturbado os anos anteriores à guerra: antiintelectualismo, antiempiricismo, e o culto a emoções turvas como sentimento e intuição. Ele achava irônico que os erros do período antes da guerra estavam sendo repetidos justamente naquelas áreas que se orgulhavam de serem as mais inovadoras. Ele via nelas um desejo regressivo de ancoragem da experiência individual e coletiva em modelos permanentes de interpretação que se propunham a transcender a realidade imediata e contingente.

Em reflexão similar, ele se refere à necessidade pelo inequívoco, repetível e fixo, saturada na esfera da ética e moralidade, como dominada por um furor pelo inequívoco. E à inabilidade de lida com as ambigüidades de um tempo de transição, uma compulsão de se forçar o evento único para categorias gerais de interpretação e julgamento, que não levavam em conta sua singularidade constitutiva. ${ }^{337} \mathrm{O}$ humanismo exemplificava os anacronismos do pensamento moral guiado por uma tendência à sistematização e padronização.

\footnotetext{
${ }^{336}$ MUSIL, $G W$, v. 8, p.1107.

${ }^{337}$ Ibidem, PS, 1990, p.182.
} 
Aos olhos de Musil, a exigência humanista de articular uma noção não ambivalente e universal de humanidade desejada se limitava a reunir uma seleção errática de exemplos mortos, que não tinham qualquer relação com a riqueza e singularidade da experiência específica. Ele nunca se cansava de zombar da reverência humanista por figuras sublimes como Goethe e Lessing, cujas grandes vidas, pintadas como pensadores "auto-contidos, totalidades únicas" deveriam carregar exemplos inequívocos de caráter exemplar e "valor educacional" "338. Com sarcasmo, ele indagava sobre o que aconteceria se se estendesse às ciências naturais a prática humanista de inventariar personalidades, épocas e culturas para se estabelecer modelos de moralidade. Do seu ponto de vista, se esse fosse procedimento em uma disciplina como a física, os maiores feitos não ficariam acima das biografias de Kepler e Newton. ${ }^{339}$

Ele vislumbrava assim uma ânsia análoga por circunscrever e estabilizar noções fixas de humanismo nas visões idealizadas de comunidade apresentadas por ideologias tão heterogêneas quanto o nacionalismo e o socialismo. A despeito de diferenças ideológicas, ambas as doutrinas compartilhavam de uma dependência preocupante de noções antiquadas do indivíduo autocontido, definido por uma essência imutável, que elas transformavam em pedra fundamental de várias construções moduladas da comunidade nacional. Ao fazer isso, tais doutrinas eram compelidas a ignorar a lição ensinada pela guerra sobre a manipulação fundamental e falta de forma moral dos seres humanos, que haviam provado ser capazes tanto de canibalismo quanto de produzir a Crítica da razão pura.

O nacionalismo, com sua dependência do conceito pseudocientífico de sangue e raça, e o socialismo, com sua crença ingênua na bondade fundamental da natureza humana, seu ethos abstrato de "altruísmo de fraternidade" e a noção decorrente do estado como "uma instituição para o aperfeiçoamento humano"340, baseavam-se em remédios vindos de um passado transfigurado ao invés de engajar-se em uma confrontação com o presente. Ao invocar "um falso "nós", que não corresponde à realidade" ${ }^{341}$, tais ideologias proviam a necessidade difusa para fundamentações permanentes e então refletiam um tipo

\footnotetext{
${ }^{338}$ MUSIL, $P S$, p. 132.

${ }^{339}$ Ibidem, p.132-133.

${ }^{340}$ Ibidem, p. 109.

${ }^{341}$ Ibidem, p. 111.
} 
de pensamento que era, por definição, desenhado para exceder os limites da experiência e invadir a esfera de especulação metafísica. Para Musil, esse era um posicionamento que se mostrava absolutamente inadequado para encarar o desafio do período pós-Guerra.

Convencido de que era imperativo nomear os impulsos ideológicos que uniam fenômenos tão diversos quanto o pessimismo cultural, Expressionismo e ideologias políticas quanto o nacionalismo e o socialismo, Musil traçou sua necessidade difundida por certezas absolutas, de volta a uma mentalidade cultural abrangente fundada em um tipo prejudicial de idealismo. Em questão estava o posicionamento que pretendia se responsabilizar pela experiência avaliando-a contra um conjunto de idéias e ideais localizados em uma esfera além da vida ordinária. Este era um sistema de pontos de referência fixos além da realidade aos quais era esperado que esta se conformasse.

Esse idealismo pernicioso era marcado pela fixação em noções pré-formadas sobre o modo como as coisas deveriam ser e por uma falta de preocupação em examinar as presunções latentes que ancoravam e legitimavam tais noções. Como descreveu Musil,

nós estabilizamos nossos ideais como idéias platônicas-pitagóricas,
imóveis e inalteráveis, e quando a realidade não se conforma a estes,
ficamos em posição de considerar este mesmo fato, de que a realidade é
somente sua realização "impura", como característico de sua
identidade. ${ }^{342}$

A experiência perderá quando julgada por padrões fundamentados em uma esfera estranha a ela. Inevitavelmente, este tipo de idealismo está propenso a desautorizar a realidade presente como inadequada; sua realização esta manchada por ideais de outra forma inatingíveis. Musil pensava que o clima antimoderno de condenação, o ressentimento e o escapismo rancoroso dos anos pós-Guerra nascia de um tipo de idealismo que prosperava da discrepância entre uma noção idealizada da "boa vida" e uma realidade que deixava de alcançar esta noção.

Connolly (1993) traçou esta atitude de volta à ansiedade moderna, mais incisivamente descrita por Friedrich Nietzsche. Para Conolly, a modernidade é definida

${ }^{342}$ MUSIL, PS, p. 113. 
por um dilema que retrocede longe na história do Ocidente, e tão longe quanto o despertar do Cristianismo. Por um lado, o período moderno é marcado pelo eclipse de certezas metafísicas centenárias e pontos absolutos de referência - Deus, razão, soberania, comunidade. Por outro lado, abriga a crença de que a vida se torna sem sentido sem estas certezas. A perda da possibilidade de basear a experiência do mundo em um exterior metafísico implica abrir o caminho para o niilismo. Para escapar desse dilema, os modernos encenaram tentativas de manter vivo artificialmente algum substituto daquele exterior, como uma totalidade de significado ancorada em uma dimensão que reside além da experiência alienante desse mundo. É uma operação que gera violência, pois sua busca latente por um mundo ordenado e harmonioso implica em uma vida variada opressiva e escravizante. ${ }^{343}$

Outra reação preocupante para tal dilema é o niilismo passivo: o niilista passivo admite a inabilidade para fundamentar seus valores maiores em um padrão transcendente, mas esta admissão o leva a desvalorizar e a desprezar o mundo, porque este desertou de seus ideais. Esta atitude também gera violência, desta vez como a ira do indivíduo que se julga superior, com demasiada disposição de participar da destruição de um mundo marcado pela corrupção irredimível.

Musil reconheceu que "o desejo por um "estouro metafísico"” presente ${ }^{344}$ englobava ambas as atitudes. Ele estava consciente do potencial para violência abrigada por tal nostalgia metafísica, ao enxergar claramente as conseqüências prejudiciais causadas pela tendência para formular idéias que não tinham referência alguma com a realidade de eventos históricos. Era nítida a frustração constante com o mundo à volta, deixando que muitos se conformassem ao que havia de verdade em tais eventos. A tal atitude regressiva, Musil opôs um tipo de idealismo mais frutífero, uma instância comprometida ao exame próximo do que é a vida ordinária, de modo a formular hipóteses e modelos sobre como as coisas poderiam ser feitas de outra maneira:

\footnotetext{
${ }^{343}$ CONOLLY, Political theory and modernity, 1993, p.13-14.

${ }^{344}$ MUSIL, PS, 1990, p. 129.
} 
Eu chamo de idealismo a formação da realidade de acordo com idéias (e diria que seguir idéias bem sucedidas até a próxima etapa de realização é ter atingido somente idealismo de segundo grau). Portanto, quando a vida não alcança um sistema de ideais, não sou capaz de ver muito idealismo nestes. Deveria-se finalmente perceber que não é que a vida deixa de se conformar com ideais por desobediência, como na escola, mas sim que o erro deve estar nos ideais. ${ }^{345}$

Os ideais que Musil alardeava não estavam baseados em critérios teoricamente atemporais de valor, mas deveriam ser julgados em termos de sua habilidade para transformar a realidade de acordo com padrões contingentes. Pressupunham a vontade de se encarar o presente ao colocar a maior ênfase no exame factual rigoroso, mas ainda assim liberal da experiência, seguindo o espírito sadio da experimentação científica.

Esta é a visão antiapocalíptica da condição moderna, composta por um "idealismo empírico" que guiou o relato específico de Musil do presente. Sem negar o diagnóstico corrente de "uma multiplicidade inexpressável"346, do mundo moderno infestado pelo contraste desordenado de visões mundiais conflitantes, e sem pontos de referência firmes, Musil rejeitava a avaliação prevalecente que estigmatizava o presente como uma era de declínio. Ele estava, ao contrário, determinado a olhar com novos olhos as circunstâncias históricas que haviam produzido um mundo tão caótico, começando com o tumulto da Primeira Grande Guerra.

Sob tal perspectiva a Guerra era o auge de uma crise ideológica aguda que havia molestado as sociedades do final do século XIX, revelando, em realidade, a implosão auto-induzida da ordem político-social que havia passado de seu tempo: "Este estímulo explosivo, com o qual o ser humano se liberou (...) foi a renúncia da vida de classe média, o desejo pela desordem ao invés da velha ordem." ${ }^{347}$. Por esta razão, nenhum dos valores e ideologias anteriores à guerra, se restaurados, poderiam contribuir para resolver quaisquer dos problemas correntes. A presente crise não poderia ter sido ajudada pela idealização do passado e advogar-se à volta para remédios tradicionais, tal como "fé, pensamento pré-científico, simplicidade, humanidade, altruísmo, solidariedade nacional, subordinação do cidadão ao Estado, o abandono do individualismo capitalista e seu modo

\footnotetext{
${ }^{345}$ MUSIL, $P S, 1990$, p. 113.

${ }^{346}$ Ibidem, p. 175.

${ }^{347}$ Ibidem, p. 112.
} 
de pesar" ${ }^{349}$. Era exatamente este passado que carregava as sementes de sua própria destruição.

A perspectiva que apresentava a guerra como o colapso de uma ordem social não mais viável também permitia ao observador ver o presente como tempo de transição e não como uma era de declínio. Ecoando a tese de Max Weber de uma modernidade ocidental moldada por processos de racionalização e diferenciação, Musil acreditava que as sociedades européias estavam presas em um processo irreversível de decomposição e diferenciação interna que era responsável pela proliferação de domínios especializados de experiência e discursos cognitivos. Isso significava para o indivíduo um enorme acréscimo na complexidade da vida cotidiana. Tendo que lidar com esferas da vida cada vez mais especializadas, cada uma delas governada por princípios parcialmente incomensuráveis, a pessoa mediana acabaria por se tornar sobrecarregada com questões que não poderia dominar. A indisposição corrente vis-à-vis da civilização moderna nada mais era que um código secreto para

o sobrecarregar dos indivíduos com questões cujas próprias palavras quase não compreendiam (testemunhar a democracia política, ou os jornais). É natural que o indivíduo reaja de uma forma completamente patológica: hoje em dia esperamos que o homem de negócios típico tome decisões intelectuais cuja deliberação conscienciosa embaralharia a mente de um Leibniz! $!^{349}$

Era a complexidade aumentada da vida trazida por avanços modernos como a democracia de massa, e seus fenômenos auxiliares tal como a média de massa que fizeram a realidade moderna parecer opaca e fora de controle. A própria identidade do indivíduo havia se tornado o terreno contestado em que instituições e formações sociais disparatadas encenavam suas lutas: "Estado, nação, Igreja, profissão, classe, sexo, etc. O indivíduo não pode pertencer por completo a qualquer desses grupos, pois estes estão em conflito uns com os outros. Aqui também, a questão é uma das lutas ente aparatos de diferentes tipos". 350

\footnotetext{
${ }^{349}$ MUSIL, PS, 1990, p. 130.

${ }^{349}$ Ibidem, p. 130.

${ }^{350}$ MUSIL, $P S$, p. 170.
} 
Era compreensível que a pessoa mediana se sentisse impressionada e reagisse de forma patológica - isto é, rejeitando o presente e desejando o retorno a um passado idílico, idealizado em um ritmo de vida mais manejável. Tanto quanto Musil reconhecia o apuro do indivíduo preso entre reivindicações que competiam entre si, de instituições baseadas em ideologias disparatadas, ele não acreditava que a estrutura diferenciada da modernidade poderia ser desfeita. Era imperativo reconhecer o presente como uma nova condição ainda não reconhecida ao invés de uma pressuposta degeneração do estado de fatos mais desejável. As divisões e fragmentações correntes então finalmente apareceriam como a propriedade distinta de nova ordem: "Diversidade como uma qualidade do futuro" ${ }^{351}$. Musil estava convencido que afirmar a múltipla variedade e a descentralização das sociedades modernas era a chave para reconhecer e explorar o potencial construtivo da modernidade. $\mathrm{O}$ exame liberal do presente então mostraria como a condição moderna havia tornado possível a realização de alguns dos sonhos antigos da humanidade:

\footnotetext{
no porão deste hospício ouvimos soar o desejo [...] para se criar; os sonhos arquetípicos da humanidade estão se realizando, como o vôo, nossa bota de sete léguas; enxergar através de corpos sólidos, e uma riqueza incrível de fantasias que em séculos passados eram a magia feliz de sonhos. ${ }^{352}$
}

De forma semelhante, era importante confrontar e reinterpretar aquele "senso de contingência" 353 em relação à experiência individual e coletiva, que estava entre os legados mais perturbadores da guerra. A pura falta de sentido da guerra havia tornado visível, em escala histórico-mundial, a falta de necessidade imanente de sentido de tal evento na história humana. Fornecendo uma realização traumática do apelo nietzschiano para se descartar a categoria confiável do desdobramento teológico tão crucial para a tradição metafísica ocidental, Musil afirma: “é quase como se os eventos por si não fossem nem um pouco necessários, mas se constituíssem somente em necessidade acomodada após o fato" ${ }^{354}$. Relegar a noção de necessidade tinha, assim, implicações inquietantes.

\footnotetext{
${ }^{351}$ MUSIL, PS, p. 176.

352 Ibidem, p. 128.

${ }^{353}$ Ibidem, p. 118.

${ }^{354}$ Ibidem.
} 
Se a história não tinha nenhum sentido, além dos relatos extrínsecos dados em retrospectiva, então não há diretrizes transcendentes que permitissem aos humanos prever e moldar o futuro. No entanto, Musil também enfatizou o otimismo implícito na defenestração de noções tradicionais da história como destino ou processo legal em favor de relatos que retratam a existência individual e coletiva como uma continuação de situações que não obedecem a nenhuma lei de necessidade. Para Musil aspessoas não são capazes de mudar leis; mas podem mudar situações, não importando quantas leis imanentes possam ter contribuído para tais situações. Essa era, então, a visão da história: uma continuação de situações que poderiam dar poder aos humanos para espalhar relatos normativos de experiência. Captar e lidar com tal liberdade significava ficar à altura do verdadeiro legado do Iluminismo, um legado que precisava ser clamado pelo presente: "pois se resultar que nosso ser interior não está dependurado pelas cordas de marionete de alguma criatura do destino, mas pelo contrário, que estamos entre as dobras de uma multidão de pequenos pesos aleatoriamente ligados, então nós mesmos podemos equilibrar a balança". 355

A perspectiva que tratava da contingência da experiência como consciência liberadora, ao invés de frustrante, era também a mais adequada para se lidar com novos e desconcertantes discernimentos da natureza humana concebidos pela guerra. Musil descobriu que a guerra havia finalmente passado a limpo a noção humanista de comunidade européia, cuja humanidade essencial estava inscrita em valores presumivelmente inatos, que transcendiam fronteiras nacionais. Os excessos da guerra haviam ensinado aos contemporâneos uma lição bem diferente que precisava ser confrontada sem moralismo nostálgico, e sem ser voltada a motivações de cunho pessoal:

Eu colocaria por alto como se segue: as pessoas são uma enorme massa indolente em toda questão moral... eu vejo as degenerações monstruosas que a guerra levou a brotarem como cogumelos. O egoísmo implacável do lucro, dos camponeses, de comerciantes legítimos, a presunção pomposa da casta-mestre com seu Pessoal do Exército Geral, a compostura de carrasco com a qual os guardiões de uma nova ordem alemã procederam contra tudo que fosse estranho ao seu espírito, o regozijo com o qual as pessoas da Entente celebraram sua vitória troiana (Wilson como o cavalo)... E chego à conclusão que eu havia colocado antes do início da guerra - um dos poucos alemães a fazer tal [coisa] — que em termos morais, um ser humano é uma coisa disforme, uma

${ }^{355}$ MUSIL, PS, p. 122. 
substância coloidal que se aconchega às outras formas ao invés de se moldar. ${ }^{356}$

De acordo com Musil, a experiência da guerra havia confirmado a visão de ética anterior a esta, expondo a qualidade ilusória de uma visão de moralidade predicada na ficção de categorias e valores imutáveis, e incluindo a noção de um sujeito auto-idêntico endossado com o livre arbítrio.

A facilidade com a qual a guerra havia transformado cidadãos respeitosos em criminosos implacáveis havia demonstrado a deformidade fundamental da natureza humana, sugerindo que os humanos padecem de qualquer essência estável ou atributos essenciais e que são, ao contrário, moldados em uma troca constante entre indivíduo e ambiente. O "teorema da deformidade humana" "357 não levava necessariamente à uma visão niilista de subjetividade e individualidade, acreditava Musil. Ao contrário, clamava por se mudar da perspectiva de uma essência imutável para uma análise concreta da interação do indivíduo com seu ambiente. ${ }^{358}$

Aceitar o teorema de uma humanidade disforme iria, por sua vez, ajudar a lançar uma luz diferente sob o papel de várias ideologias, cuja proliferação desordenada estava entre os fenômenos mais perturbadores do presente. Musil tinha pouca simpatia por aqueles que deploravam a influência corrupta de ideologias conflitantes. Em seu lugar enfatizava como as ideologias forneciam direção espiritual e intelectual, necessitadas há muito, para criar um horizonte de significados voltados a uma existência fundada em coordenadas contingentes: "Ideologia é a alma da vida, mesmo da vida cotidiana. Não somente revela o caráter dessa vida, mas a forma também... Ideologia é: o ordenamento intelectual de sentimentos; uma conexão objetiva que torna a conexão subjetiva, mas fácil." ${ }^{, 359}$ As ideologias eram para Musil moldes espirituais contingentes dentro dos quais a própria vida se jogava para adquirir forma. Moldavam tanto formas de vida quanto eram formadas por elas, fornecendo aos indivíduos modernos um crivo intelectual preciso para se ordenar um mundo emocional, de outra forma amorfo.

\footnotetext{
${ }^{356}$ MUSIL, Diaries, 1999, p. 267-268.

${ }^{357}$ Ibidem, PS, p. 167.

${ }^{358}$ Ibidem, p. 178.

${ }^{359}$ MUSIL, $P S$, p.173-174.
} 
O crescimento de ideologias disparatadas no presente também representava um meio para se lidar com a onda de complexidade da vida moderna; na verdade, era um subproduto da necessidade pelo domínio de esferas cada vez mais especializadas da experiência. Especialmente importante era reconhecer a proliferação corrente de ideologias como desenvolvimento irrevogável, porque o processo de diferenciação que havia disparado a expansão desordenada de credos e sistemas de valores não podia ser revertido: "Nunca mais uma ideologia homogênea, uma 'cultura' surgirá por si só em nossa sociedade ocidental. Mesmo se existiu alguma vez em um passado distante (apesar de provavelmente a imaginarmos como perfeita demais), a água escorre para baixo, e não para cima" 360 .

Musil se indagava se as civilizações saudosamente invocadas de eras passadas eram a expressão da verdadeira harmonia cultural, ou se elas eram apenas a ilusão produzida por um olhar embelezador, voltado ao passado. Ele também se indagava sobre os constantes apelos por uma unidade cultural ou pelo advento da ideologia que poderia prevalecer sobre todas as outras, em virtude de sua superioridade intrínseca. Em seu lugar, eram necessários esforços para se criar "condições sociais que salvaguardem a estabilidade e profundidade de esforços ideológicos em geral" ${ }^{\text {361 }}$, exigindo formas de se promover a confrontação e interação de formas ideológicas ao invés de abandoná-las ao acaso.

Há uma abstração característica nas propostas de Musil, que em certos momentos parecem vagas e pouco práticas. Pode-se perguntar, por exemplo, que medidas concretas ele viu na tarefa de cuidar daquela troca produtiva entre ideologias advogadas tão ardentemente. Ao mesmo tempo em que suas sugestões parecem vagas, sua posição sobre assuntos específicos ou posicionamentos ideológicos parece crítica ao extremo, uma crítica que não poupava mesmo pontos de vista com quais ele simpatizava, como o socialismo.

A leitura pormenorizada de seus ensaios e diários dá a impressão de que a sagacidade de suas observações impediam que Musil se comprometesse por inteiro a uma

\footnotetext{
${ }^{360}$ Ibidem, p. 130.

${ }^{361}$ MUSIL, PS, p. 130.
} 
causa. Isso poderia relegá-lo a uma posição de observador interessado, mas no fim desengajado. Nesses fundamentos, Musil tem sido visto como uma encarnação do intelectual mandarim - a corporificação paradigmática das contradições do elitismo do alto modernismo e falta de engajamento político. ${ }^{362}$ Antes de se tirar tais conclusões, contudo, deve-se considerar a que grau esta posição foi refletida conscientemente por Musil. Musil estava ciente de que faltava nele uma dose saudável de cinismo e pragmatismo egoísta necessário para o político profissional. Também faltava nele a habilidade do ativista de tomar partido e defendê-lo intransigentemente enquanto nega ou concorda com suas fraquezas e pontos cegos. ${ }^{363}$

Contudo, Musil estava convencido de que havia uma diferença qualitativa entre a esfera da política e aquela da reflexão intelectual. Enquanto ambas cumpriam

\footnotetext{
${ }^{362}$ Veja por exemplo, Böhme (1974) sobre o início dos estudos de MUSIL como um emblema de anomia do burguês intelectual, já no período capitalista avançado: BÖHME, Anomie und Entfremdung: Literatursoziologishche Untersuchungen zu den Essays Robert MUSILs und seinem Roman "Der Mann ohne Eigenschaften",1974. Veja também Luft: a caracterização de MUSIL como representante do mandarim intelectual grupo da sua época na introdução de sua monografia. LUFT, Robert Musil and the crisis of European Culture, 1880-1942, 1980.

${ }^{363} \mathrm{O}$ político profissional e o ativista representaram para MUSIL as duas formas principais de compromisso político. Ele via as duas com um conteúdo débil. A seus olhos, o político captura a essência política como “a) representação de interesses, b) relação de ideologias para interesses" (MUSIL. The man without qualities, v. II, p.1856). Isto é, ele manipula o elemento de ideologias existentes para assegurar o interesse de seu eleitorado e manter o poder próprio. $\mathrm{O}$ ativista é, ao invés disso, instigado por puro zelo ideológico, e não é dirigido por uma consciência calculista de auto-interesse. Em um trecho do diário de 1920, Musil reúne dadaístas, expressionistas, anarquistas, niilistas, comunistas, monarquistas, novos católicos, e sionistas como exemplos de ativismo. O que todos eles têm em comum, ele e argumenta: é um ardor ascético o obstinado compromisso com uma causa, uma posição redentora e apocalíptica que relembra a paixão dos primeiros mártires cristãos. Exceto, como Musil ironicamente declara, que o sacrifício de um mártir é agora substituído por uma menos truculenta discussão, que se desenrola em uma atmosfera nebulosa de jornais e revistas. MUSIL, TB, v. I, p. 382-83. O fanatismo do ativista culmina para Musil em um descompromissado fervor do revolucionário, que representa um tipo ainda maior de perigo. A maldade revolucionária encontrase em sua atitude de tudo ou nada, e na determinação para sempre tomar o caminho mais alto. Isto se traduz em um desejo fanático de realizar ideais abstratos sem levar em conta a confusão de sua implementação: "Ele voa, ainda assim não pode andar; ele nada sob as águas, mas não pode respirar. Aquilo que para uma pessoa importante é um fato pessoal, um caminho marcado com dificuldade através de objeções que ele colocou para si mesmo, é para ele, estilo. A pessoa criativa é - como artigo da vida e morte, tão bem constituída, que ambas as escalas estão muito pesadas e apenas um excesso de peso que ultrapassou é necessário para dar equilíbrio, o "ultra" é tanto radiante para a inviolabilidade de cada cabelo humano contado, ou milhares condenados por ele para a destruição com um derrame cerebral" (MUSIL, Diaries, p. 270). A determinação para assegurar uma demanda absoluta e nunca entrar em compromisso é formal e se torna um gesto vazio, porque falha em se submeter a ponderar conseqüências das ações revolucionárias em certa situação. Psicologicamente o outro lado do caminho abstrato revolucionário é um conteúdo autojustificado para as necessidades de pessoas reais que possam estar no caminho da realização do ideal. O caminho revolucionário, embora envolvido com uma política radical, respira violência e destruição. De qualquer forma tal argumentação prova inabilidade para levantar alternativas construtivas para a qual Musil está lutando. Veja também o comentário de MUSIL sobre a relação de Ulrich com a política. MUSIL, $M w Q$. ${ }^{364}$ MUSIL, Diaries, 1999, p. 257.
} 
importantes tarefas no presente, seus objetivos diferentes também tornavam suas estratégias e metas de muitos modos incompatíveis. $\mathrm{O}$ ativismo político era sobre advogar inequivocamente a ideologia presumivelmente verdadeira que iria, de uma vez por todas, fechar as cicatrizes do presente. Em contraste, o pensador que escolheu delinear uma estrutura intelectual ampla, adequada à reorganização espiritual do presente, teria que proceder de outra forma. Ele era compelido a praticar a virtude da reflexão ensaística, daquela exploração liberal e descompromissada, de uma questão vista por vários ângulos.

Alguns dos comentários de Musil sobre o socialismo podem servir como ilustração para o tipo de reflexão que ele advogava e praticava. Ele era bastante crítico do socialismo como ideologia, não porque simpatizasse com seus oponentes sobre o direito, mas porque achava alguns de seus dogmas psicologicamente inviáveis e fadados ao fracasso.

Assim, os dois principais preceitos no cerne do socialismo, notadamente, a afirmação da igualdade de todos os indivíduos e o imperativo de amar o seu próximo como a si mesmo tinham pouca ancoragem na psicologia humana e não poderiam de forma alguma fornecer a fundação para a vida coletiva. ${ }^{364}$ Ele achava ainda mais irônico que precisamente estes dois preceitos representassem o ponto de contato do socialismo com o cristianismo, um de seus oponentes ideológicos principais.

Em outra anotação de seu diário, ele comparou as reivindicações do "socialista cristão" com o "socialista vermelho". Enquanto o primeiro pregava obediência incondicional à comunidade como forma de se afastar dos prazeres da carne, ficando, desta forma, mais próximo de Deus, o segundo pregava, de acordo com o imperativo espiritual cristão, o meio de perpetrar a exploração material das massas. A despeito de suas diferenças, Musil viu que os dois antagonistas compartilhavam o mesmo postulado 
fundamental, notadamente, "que o bem-estar da sociedade... representa o maior dos bens éticos"365. Era o bem-estar da comunidade, acima do bem-estar individual, que fazia a ambos socialistas. Precisamente este dogma mereceu um escrutínio mais detalhado.

Musil achava que o individualismo, cerne do capitalismo, era psicologicamente mais sustentável do que o comunitarismo sonhador do socialismo, por ser fundamentado em uma avaliação mais realista da natureza humana. Uma anotação no diário do período entre 1920 a 1926 levanta este ponto enquanto avalia as dificuldades ideológicas do socialismo em sua competição com o capitalismo. O que tornava o capitalismo praticamente irresistível era seu postulado simples de que "cada gasto de dinheiro ou esforço" requer "algo imediatamente em troca", pois este postulado alcança uma inclinação fundamental da natureza humana. Como conseqüência: A questão [do socialismo] não é como se educar novas pessoas que, porque vêem as coisas por uma perspectiva mais ampla, assume voluntariamente tarefas desagradáveis; ao contrário consiste em encontrar o retorno compensador e considerar a natureza humana. ${ }^{366}$

O socialismo foi bem aconselhado para considerar a natureza humana e repensar as relações humanas em termos de uma troca interessada, isto é, se fosse vencer a sua luta contra o capitalismo. As passagens selecionadas, documentando a posição política de Musil quanto ao socialismo, mostram como a reflexão ensaística permitiram que ele pusesse o dedo na ferida psicológica da ideologia de uma perspectiva não dogmática, que reconhecia prosperamente a crítica, mas também as premissas compartilhadas dos opositores ideológicos do socialismo. Era esse tipo de reflexão fluída e corajosamente mutável que tornou possível a navegação pelo arquipélago de estranhas alianças e disputas cáusticas entre ideologias disparatadas.

Para Musil, o estado mental intelectual do ensaísmo permitia ao observador evitar se prender demasiado em única crítica minuciosa ideológica; ao contrário, tornava possível vislumbrar as forças e falhas compartilhadas por posições ideológicas antagonistas. O objetivo era atingir uma perspectiva intelectual maior do que a de qualquer ideologia e ainda colocar o dedo sobre os erros intelectuais de sua era, como

\footnotetext{
${ }^{365}$ MUSIL, TB, v. I, 1983, p. 575.

${ }^{366}$ MUSIL, Diaries, 1999, p. 306.
} 
Musil havia feito com sua denúncia ao mau idealismo de seu tempo. O objetivo final era obter discernimento para mecanismos mais amplos de troca ideológica, de forma a articular alguma direção desejável de mudança. Como o próprio Musil definiu a tarefa em mãos: "uma vida sem se sistematizar, não obstante, com ordem. Ordem autocriativa. Ordem geradora. Uma organização que não seja determinada de $a$ a $z$, mas uma que proceda de $n$ a $n+\Gamma^{367}$.

A ordem prevista por Musil não dizia respeito à formulação de prescrições normativas, mas sim guiar o intercâmbio de ideologias de uma forma que o deixaria constantemente aberto para negociações. O que permitia ao intelectual cumprir esta tarefa não era o fato dele habitar um ponto de vantagem superior localizado acima ou fora da troca das ideologias e jogos de linguagem da modernidade, de acordo com a perspectiva privilegiada do "intelectual solto" de Mannheim ${ }^{368}$. Era na verdade o compromisso do intelectual com a observação empírica que seu uso flexível da razão, virtudes potencialmente disponíveis à qualquer um, que o assistiam na tarefa de articular algum tipo de visão geral sintética, enquanto afirma a impossibilidade de alguma vez vir a habitar uma perspectiva absoluta que englobe tudo.

A visão da modernidade estava moldada por uma convicção de que era imperativo reconhecer a realidade devastada dos anos pós-guerra e de se articular síntese espiritual contingente que extrairia o potencial positivo do período moderno. As dificuldades presentes nesta tarefa são reconhecidas em sua peça de 1921 Os visionários ${ }^{369}$ (alem. Die Schwärmer), que encena a idéia de Musil da literatura como um laboratório para explorar novos modos de se "ser humano".

O texto se oferece como um perfil de seus personagens principais, quatro amigos antigos que se esforçaram para abraçarem o discernimento da contingência da existência e a abertura em que implica. Só que suas vidas adultas ficaram reificadas em uma rotina cotidiana vazia, apenas intermitentemente assombrada pela memória das visões extáticas de sua juventude. Thomas, um professor universitário, passou a desconfiar e reprimir seu

\footnotetext{
${ }^{367}$ MUSIL, Diaries, 1999, p. 318. Grifos nossos.

${ }^{368}$ MANNHEIM, Ideology and utopia, 1968.

${ }^{369}$ MUSIL, Os visionários, 1989.
} 
lado emocional, retirando-se para um intelectualismo desengajado. Ele encontra seu ideal ego em Anselm que, ao desistir da carreira universitária, que também era sua meta, ficou preso em uma busca por uma condição emocional extática que ele procura convocar em discursos patéticos e comportamento errático, irresponsável. Anselm é o amante de Regine, que também tem perseguido em uma série de relações extramaritais uma emoção extática que ela havia experimentado uma vez com seu primeiro marido falecido. Em contraste sua irmã Maria, esposa de Thomas, fez de sua natureza quieta e confiante uma virtude de bondade que é tão insatisfatória quanto é insípida. Uma série de eventos reúne os amigos, oferecendo a eles uma chance de avaliar suas vidas. Eles se esforçam para entender como foi possível a paixão intuída de sua juventude ter se tornado um caminho para a auto-ilusão, que levou à esterilidade espiritual e, no caso de Regine e Anselm, à conduta indefensável. Principalmente Regine e Anselm têm que confrontar a questão do que é a vida produzida por um ethos cuja verdade reside em sua mutabilidade e contingência.

Como se deve avaliar tal ethos, que todos os personagens perseguiram de uma forma ou outra em suas visões juvenis, se não há critérios firmes para o comportamento honesto ou desejável? Não há soluções apresentadas no final, exceto que ocorre um embaralhamento dos dois casais. A equilibrada Maria escolhe seguir o Anselm guiado pela emoção, deixando para trás o cerebral Thomas e a instintiva Regine como um casal heterogêneo.

Enquanto, por um lado, o texto tem sido interpretado como sugestão à necessidade de uma melhor integração do sentimento e intelecto em cada personagem ${ }^{370}$, por outro lado, permanecem obscuras como as novas relações estabelecidas entre os quatro amigos ajudarão cada um a atingir uma relação mais equilibrada de ambos os lados.

Essa peça de Musil contém o diagnóstico para uma condição existencial que ele primeiro descreveu em $O$ jovem Törless. Oferece uma dramatização densa dessa condição, que faz poucas concessões sobre a necessidade por desenvolvimento dramático

\footnotetext{
${ }^{370}$ HICKMAN, 1991, p. 102-103.
} 
ou por contextualizar questões e temas psicossociais específicos. Em sua densidade e complexidade intelectual, o texto representa a resposta de Musil para o vazio e vácuo intelectual patológico que ele associava com o drama social contemporâneo. Musil estava plenamente consciente de que seu mais ambicioso experimento de pensamento, $O$ homem sem qualidades, exigia um comprometimento extraordinário de seu público. ${ }^{371}$

Musil considerava esse romance uma oportunidade para se especificar e historiar a visão ética que ele havia articulado antes da Primeira Guerra. Ele pretendia mostrar que a experiência mística de despojamento, ligado à religião e à arte, não apontava para a existência de um exterior ético da experiência, mas sim para uma relação diferente entre sentimento e intelecto, compatível com a existência imanente e finita. Essa investigação a funda um modelo de ética que relega o desejo por princípios absolutos em favor de coordenadas contingentes mais adequadas para lidar com uma modernidade definida pela descentralização e desprovida de um exterior metafísico.

Musil se apropriou de imagens-chave da Crítica da faculdade do juízo de Kant para explicar a configuração do intelecto e do sentimento. Sua visão inicial da arte como abrangendo dois territórios distintos, conhecimento e ética, "racióide" e "não-racióide", envolvida em uma noção da experiência estética, conectando dois modos distintos de experiência; a "outra condição", ordinária e inconcebível, torna cada um desses estados fundamentado em outros estados mentais incomensuráveis.

As ramificações éticas dessa visão foram auto-referenciais, colocadas à prova em O homem sem qualidades. Quando considerada nessa perspectiva, a dívida de Musil para com Kant fornece uma chave para o quebra-cabeça articulado por esta tese. O que exigiu esforço não somente para compreender o projeto estético do romance, mas também para se apreender a qualidade peculiar da visão modernista de Musil, que, de acordo com a

\footnotetext{
${ }^{371}$ Veja a retrospectiva dissertação de Musil e, TB, v. I, p. 960, de acordo com os quais o teatro representa uma forma dramática inovada, que se poderia ter imaginativamente criado (alem. Gedichtet ) tanto quanto seus atores. A peça de teatro escrita por Musil foi bem recebida quando apareceu impressa em 1921. Após o seu lançamento, Musil foi premiado com o Troféu Kleist em 1923. Ao mesmo tempo, o texto foi imediatamente reconhecido como de difícil interpretação. Foi uma imensa decepção o humilhante fracasso de sua única produção, durante toda a vida de Musil, em Berlim de 1929. Musil nunca cessou de refletir sobre as razões para o infortúnio de um texto em que ele lançava tanta esperança.
} 
perspectiva que lhe dá esta tese, girava em torno de uma demanda social para abraçar o vazio moderno da ética.

Confirma-se, assim, a hipótese, segundo a qual a constituição da identidade narrativa individual ou sócio-histórica é o lugar procurado da fusão entre história e ficção. A construção que visava a um paralelo entre os aspectos biográficos da vida de Musil, o autor, a composição dos elementos que compuseram o personagem Ulrich, o homem sem qualidades, a descrição do Zeitgeist que compõe a trama da obra $O$ homem sem qualidades é uma resposta à pré-compreensão intuitiva de como se tornam as vidas humanas mais legíveis quando interpretadas em função das histórias que as pessoas contam a seu respeito. Essas histórias da vida são mais inteligíveis quando lhes são aplicados modelos narrativos extraídos da história e da ficção, drama ou romance.

O estatuto epistemológico da obra literária de Musil, cujo objeto privilegiado foi o homem sem qualidades - como artifício autobiográfico - confirma tal intuição. É, portanto, plausível ter como válida a cadeia de asserções que dá conclusão a esta tese: o conhecimento de si próprio é uma interpretação que encontra, na narrativa, entre signos e símbolos, uma mediação privilegiada; esta serve-se tanto da história como da ficção. E faz da história de uma vida uma história fictícia, uma ficção histórica comparável às biografias dos grandes homens, dos homems com qualidades, em que se misturam a história e a ficção. O problema da identidade pessoal, tal como revelado pelo personagem central de $O$ homem sem qualidades e pela própria vida de Musil, suscita uma clara compreensão do que está em jogo na própria questão da identidade quando aplicada a pessoas ou a comunidades. A tese atesta que a obra, como superação das dificuldades relativas à noção de identidade pessoal, expõe os conflitos que subjazem à idéia de identidade como mesmidade e as diversas relações operadas neste nível. O homem sem qualidades deixa transparecer o aspecto de que a identidade tem sentido numérico: Musil é também Ulrich em duas ocorrências, não se constituindo, porém, em uma só e mesma coisa; se há identidade entre criador e criatura, entre autor e personagem, ela não signfica unicidade, ela é comutativa: o seu contrário é a pluralidade, não uma identidade, mas duas ou várias identidades, e é neste sentido que o homem sem qualidades pode ser 
compreendido como um processo de reidentificação do autor projetado em seu personagem.

A estrutura do romance mostra fatos de tal forma semelhantes que são intercambiáveis, embora não sejam contrários e conservem, cada um, sua identidade com estatuto de acontecimento 


\section{CONSIDERAÇÕES FINAIS - CONCLUSÃO}

- A ética indutiva do homem sem qualidades

Esta tese se apóia na hipótese relativa à indagação de Ulrich, o personagem central de $O$ homem sem qualidades, sobre o que é o Bem. O mundo da vida (alem. Lebenswelt) constitui a estrutura principal de referência para a resposta. A abrangência de sua resposta não se encontra apenas na perspectiva caleidoscópica que lhe dá $O$ homem sem qualidades. Ela pode ser encontrada também na biografia de Musil como a procura da ética voltada para a conduta de sua própria vida, traduzida nas indagações dirigidas para a cultura de sua época e transposta em seus ensaios, diários e anotações - enfim, em toda a sua obra. As discussões dirigidas a tais questões, tanto em seus textos de ficção como em outros, foram guiadas pela presunção de que elas articulavam uma hipótese específica sobre a natureza da ética e sua relação com a arte no período moderno. Musil já tinha resumido essas questões em seus escritos no período pré-Guerra, mas desenvolveu-as de forma mais extensa, tentando encontrar respostas aos desafios culturais e políticos que culminam no período durante a Primeira Guerra. Musil descreveu a ética combinando critérios obtidos das teorias psicológicas contemporâneas, dentro de uma rede de imagens kantianas, nos termos de uma modalidade emocional alternativa, incompatível com a ética comum. A perspectiva traçada é intermitente e superficial dentro da experiência da arte.

O homem sem qualidades configura-se como experimento planejado visando testar a inter-relação entre arte e ética. $\mathrm{O}$ romance mostra o que acontece quando se tenta entender uma vida voltada para a moralidade no esforço para atravessar a cisão entre as duas modalidades distintas que separam os reinos comuns e éticos da experiência sensível. Ao especular sobre dois discernimentos, cada um com a intenção de reduzir um dos reinos à categoria experimental do outro, Musil esperava que a demonstração das conseqüências complexas de experimentos ajudaria a liquidar o sonho de uma vida moral, reconciliada. 
Sob o foco que contempla a ética, $O$ homem sem qualidades revelou as propriedades de um experimento científico. A natureza experimental da ética musiliana empenhou-se em investir, até as últimas conseqüências, no que poderia advir da relação incestuosa entre Ulrich e Ágata, como ato simbólico de transgressão aos ditames da cultura humana. $\mathrm{O}$ autor deixa a critério do leitor o julgamento daquilo que notadamente rompe com as bases da cultura, de tal maneira como se ele expusesse o oposto do tabu do incesto, atribuindo-lhe valência positiva.

O homem sem qualidades cria, assim, na ficção, a situação extrema de infração ao incesto produzindo, no experimento proibido, o enfrentamento solitário do indivíduo ao fundamento da cultura. Musil não chega a concluir se o seu experimento terá sucesso ou se falhará. A questão deixada pelo autor é que, se há falha ética na cultura, e se ela se apóia sobre um fundamento, ato da própria transgressão, ela é parte de um procedimento integral que deve ser experimental. Em outras palavras, o romance pode assim ser lido como experimento de transgressão a ser simbolicamente repetido por cada leitor. Entretanto, pelo seu caráter inacabado, não se trata de um experimento trágico. Musil promove um palco no qual não se produz catarse no leitor. Nesse aspecto, o raciocínio musiliano se assemelha à conhecida metáfora de Wittgenstein no Tratado lógico-filosófico (Wittgenstein, 1987), quando esse filósofo se refere à escalada do conhecimento: esta deve ser completamente empreendida por cada indivíduo que procura encontrar as possibilidades e limitações lógicas da linguagem que distingue o homem como tal. Nesse caso, a factual impossibilidade de conclusão ou acabamento de $O$ homem sem qualidades encontra ressonância na proposição de Wittgenstein: "o que é de todo exprimível, é exprimível claramente; e aquilo de que não se pode falar, guarda-se em silêncio" (Witgenstein, 1987, p. 27). No caso de Musil, o experimento de infração ao incesto é projetado para testar o potencial e as limitações da arte, no caso, na sua expressão literária, tanto quanto para testar o potencial e limitações da ética da cultura na modernidade tardia. Junto à imagem wittgensteiniana de que "fazemo-nos imagens dos fatos" "384, e se "a imagem é um fato" ${ }^{385}$, o leitor é ipso facto levado a se enxergar na imagem que o romance projeta à sua compreensão. A tal raciocínio, poder-se-ia acrescentar

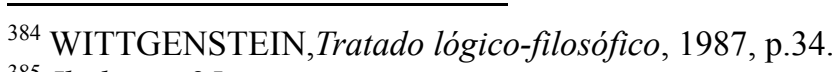

${ }^{385}$ Ibidem, p. 35 .
} 
Ou uma coisa tem propriedades que nenhuma outra tem, e pode-se então sem mais, distingui-la das outras através de uma descrição, e referi-la; ou então há diversas coisas, que têm em comum as suas próprias propriedades, e é de todo impossível mostrar uma delas. Se nada distingue uma coisa não posso distingui-la, porque senão fica distinta. [...] A configuração dos objetos forma o estado das coisas. ${ }^{372}$

O que se depreende de tal citação é que deixar $O$ homem sem qualidades concluído descartaria a escada do romance ao leitor, depois de tê-la escalado. Desse modo, Musil considerou a possibilidade de enviar seu personagem principal para morrer na Primeira Grande Guerra após Ulrich ter reconhecido suas falhas. ${ }^{373}$ Porém, ele não chegou a decidir por essa saída. Ulrich não terá no romance de Musil a mesma alternativa encontrada por Sófocles para o Édipo. Uma vez conhecida a verdade que ele procura em suas origens, e em posse da consciência, Édipo escolhe a cegueira e, destronado, apartado da sociedade que o alijaria, parte para o ostracismo no Bosque das Eumênides.

A morte anunciada do personagem Ulrich de Musil é diferente. Contudo, ela não pode ser imediatamente interpretada como se $O$ homem sem qualidades estivesse para ser destruído na Guerra, junto com a velha ordem à qual ele pertence. A mensagem construtiva legada pelo romance não foi encontrada no destino de Ulrich, o herói burguês. Ao contrário, a sua saída se encontrará nas lições positivas a serem tiradas de suas falhas pelo próprio leitor.

Caberia indagar o que são e em que se constituem tais falhas, então? Depois da imensa construção do romance, a ética se revela um vazio cognitivo inexplicável. A ética é o vazio palpável que preenche o círculo descrito pelo personagem Clarisse. O leitor pode querer saber como a "questão de uma vida justa", posta como indagação crucial de Ulrich, pode ser respondida se a passagem entre as modalidades emocionais básicas da vida comum e da ética permanece intransponível. Uma vez preenchida tal passagem, sua obstrução não invalidaria a busca de uma pessoa por uma vida melhor? Os registros não publicados de Musil mostram que a última mensagem do romance se constituiria em alguma forma de niilismo ético. O colapso da utopia da outra condição era justamente causado por abrir o caminho para a utopia de uma ética indutiva. Nos próprios termos de

\footnotetext{
372 Ibidem, p.33.

${ }^{373}$ Sobre isso, ver o esquema montado pela edição inglesa, intitulado "Concluding Section" (alem. SchluBteil), semelhante ao que constitui os escritos rascunhados por Musil depois de 1934.
} 
Musil, esta era a utopia de uma vida real, diferente da busca pela outra condição, dirigida pela negação da vida de Ulrich. A ética indutiva tencionava oferecer um local para conhecer e promover a visão exata da realidade do mundo moderno. A versão mais madura da utopia, inexatidão e dissertação adotadas por Ulrich no Livro Primeiro ${ }^{374}$ servia para representar a ética adequada para aquela era indutiva introduzida pelo colapso da velha ordem da Primeira Guerra Mundial.

Baseado na obrigação pragmática de formular uma vida comum sistemática, Musil descreve uma psico-tecnologia de coletivos, que serve para confrontar a tarefa de articular as coordenadas, visando à vida individual e coletiva. Porém tal experiência revelava a ampla perspectiva da charlatanice indutiva, capaz de operar de acordo com a distinção fundamental entre o reino coletivo e a vida individual.

Regulado pela "moralidade racional de uma sociedade tecnológica" e também pela visão tecnocrata que abrange os ideais de paz, justiça, estado de ser geral, e o domínio particular da verdadeira experiência ética, Musil revela que esse era "um reino excepcional de criatividade e gênio" 375 .

Tais observações levam a compreender que Musil não possuía uma sólida visão utopista, mas estava explorando suas ramificações, enquanto ia produzindo sua obra. Sua reflexão sobre utopia, do foco de uma problemática elitista, surge na questão de como

\footnotetext{
${ }^{374}$ MUSIL, Nachtrag: Vgl. Aber zu Us. Persönlicher Krise 238/99, Utopie der induktiven Gesinnung, Nachträge u. Weiterbildung. $G W$, v.5, p. 1882-1883.

${ }^{375}$ A este respeito Musil argumenta, muito misteriosamente, para a "redução da moralidade para momentos de genialidade". ( $G W$, v.5, p. 1882). A interpretação voltada para compreender tal proposição como se a experiência ética genuína permanecesse consignada ao reino particular do "gênio de moralidade" serve pouco para especificar esta visão. Musil havia planejado tal discussão, em uma importante parte do segundo volume, como é atestado pelos rascunhos do material não publicado. Escritos entre 1939 e 1941, tais capítulos são referidos nas partes 48: "Uma mentalidade direcionada em direção ao significante, e o começo de uma conversa sobre o sujeito (Ibidem, II, p. 1335-41); 49: "Sobre o gênio do General von Stumm" (Ibidem, II, 1341-49); e 50, "Gênio, um problema" (Ibidem, II, 1349-52). Os principais obstáculos com os quais Musil estava lutando em sua linha de reflexão são iluminados pela questão da autocrítica: "Que tal a objeção concernente ao critério da criação, do gênio, do espírito [des Geistes]?”(Ibidem, II, 1883). Musil entendeu que definindo a verdadeira experiência ética como "gênio" estava simplesmente reestruturando o problema sem prover uma solução. De fato, estava meramente mudando o assunto crucial da articulação de um critério para identificar o reino ilusório da moralidade genuína, transferindo-o do reino da ética para o horizonte estético da criatividade espontânea e das iluminações prodigiosas que fazem um "gênio".
} 
estender a moralidade articulada por indivíduos como Ulrich, um homem sem qualidades, ao resto da humanidade.

Mais do que se debruçar sobre reflexões éticas, os indivíduos estão voltados para a luta cotidiana e buscam satisfazer as necessidades materiais mais imediatas. Musil sente-se forçado a distinguir entre uma ética indutiva para as multidões, na qual a moralidade se concentra em ter acesso regular à comida, abrigo e trabalho, e a ética para poucos que, dispensados de tal preocupação existencial, podem se concentrar nas visões mais altas. $\mathrm{O}$ foco de algumas suposições voltadas para uma ética maior, além das satisfações mais imediatas da vida cotidiana, é referido com os termos "uma genial modalidade", e sugere que Musil encontrava problemas desligando-se de algumas suposições éticas relativas à mesma ideologia do individualismo, que ele julgava obsoleta.

Embora permaneça a tentativa de prover qualquer indicação concreta do que Musil atribuiria à ética cotidiana, a idéia crítica de uma ética indutiva abre importantes focos de investigação na conclusão desta tese. Enquanto a discussão não dispensa a realidade da experiência ética, a atitude indutiva reconhece que a ética não pode prover uma visão unidimensional como o horizonte inteligível de significados para a vida comum. Tal discussão se encaminha à renúncia dos sonhos por uma vida totalmente moral e reconciliada, transcendente à complexa ambivalência da experiência do momento inaugural da modernidade a seu desenvolvimento tardio. Em vez disso, a discussão se encaminha para aceitar como irreversível a condição definida pela separação da consciência individual e a descentralização característica da sociedade moderna. A discussão inaugurada por Musil convoca o conhecimento e o entendimento do potencial libertado, inerente à condição moderna, doravante definida pela nova conjunção da ética, o que se buscou fazer nesta tese.

$\mathrm{Na}$ análise final do romance, a ética de Musil é levada pela compreensão de que, na modernidade, a questão da vida melhor - uma das coordenadas para organizar e direcionar a existência individual e coletiva - não pode ser confrontada pelo suposto marco inicial, puramente ético. Para se compreender a ética em sua extensão, esta deve se misturar com o hospedeiro de considerações práticas e pragmáticas que ela contém. O que 
guia a ética indutiva não é a pureza de uma reconhecível moral imperativa, mas a realidade híbrida de reclamações conflitantes e de perspectivas das diferentes esferas no mundo moderno.

Este pragmatismo empírico é geralmente incerto e rejuvenescido pelo movimento subversivo da imaginação estética. A arte - e a literatura em particular - , desafia o status quo, apresentando alternativas imaginárias ao que é dado. A autoridade do modelo único - sua exemplaridade, para usar o termo que Musil apropriou de Kant — deriva da habilidade da arte de superar a moralidade ético-emocional. Tal posição é, em si mesma, o local para um julgamento ético, que está consignado à interpretação do sentimento e do intelecto em especial. É um tipo de julgamento que pode produzir um comportamento proposital na ausência de princípios gerais de conduta. O apelo de Musil, hoje, conduz a um tipo de modernismo bastante diferente: ele se encontra precisamente na interminável qualidade normativa da ética e das visões éticas.

O exame pormenorizado da obra de Musil permitiu refletir sobre o problema da identidade pessoal e da identidade narrativa como crucial à compreensão dos efeitos da modernidade sobre o curso histórico atual. A questão do si suscita remanejamentos consideráveis no próprio plano do agir humano. A identidade pessoal só é possível de se articular na dimensão temporal da existência.

A compreensão de si é uma interpretação que se encontra na narrativa, entre outros signos e símbolos e, de tal maneira, que se torna uma mediação privilegiada. Tal compreensão se deve ao último empréstimo à história e à ficção, fazendo da história de uma vida uma história fictícia ou uma ficção histórica, e entrecruzando o estilo historiográfico da biografia com o estilo romanesco da autobiografia imaginária. Faltava a essa apreensão intuitiva do problema da identidade narrativa uma clara compreensão do que está em jogo na própria questão da identidade aplicada às pessoas ou às comunidades. A questão do entrecruzamento entre história e ficção, de algum modo, desviava a atenção das dificuldades consideradas ligadas à questão da identidade como tal. 
A teoria narrativa encontra uma de suas principais justificativas no papel que exerce entre o ponto de vista descritivo e a ação. É possível descrever a tríade que consiste em descrever, narrar e prescrever, e, a cada momento, a ação implica uma relação específica sobre a constituição do si. Em muitas narrativas, é pela escala de uma vida inteira que o si procura sua identidade entre ações curtas. A literatura mostrou-se, assim, ser um vasto laboratório onde são testadas estimativas, avaliações, julgamentos de aprovação e de condenação pelos quais a narrativa serve de propedêutica à ética.

Há uma fraqueza do critério de similitude, no caso de uma grande distância no tempo, do qual depende uma das componentes da noção de identidade: a continuidade ininterrupta entre o primeiro e o último estágio de desenvolvimento para o mesmo indivíduo. Tal critério prevalece em todos os casos em que o desenvolvimento do indivíduo pressupõe o crescimento e o envelhecimento. Estes operam como fatores de dessemelhança e, por implicação, de diversidade numérica. A demonstração dessa continuidade funciona como critério anexo ou substitutivo da similitude; ela repousa na série ordenada de mudanças fracas que, tomadas uma a uma, ameaçam a semelhança sem destruí-la.

A idéia de estrutura, posta em contraste com a noção de acontecimento, responde ao critério de identidade. Ela confirma o caráter relacional da identidade que não aparecia na antiga formulação da substância. Kant a teria restabelecido ao classificar a substância entre as categorias da relação como condição de possibilidade para pensar a mudança. As sucessivas transformações chegariam a algo que não muda, pelo menos no momento da atribuição do acidente à substância. A permanência no tempo torna-se assim o aspecto transcendental da identidade numérica.

A questão desafiadora posta por $O$ homem sem qualidades é a ipseidade do si, no tanto em que ela implica uma forma de permanência no tempo que não seja redutível à determinação de um substrato de identidade. Tal questão permite encaminhar a investigação do protagonista acerca de uma forma de permanência no tempo que constitua uma resposta à pergunta: “Quem sou eu?”. 
O autor aponta para dois modelos de permanência no tempo, um descritivo e outro emblemático, respectivamente, o caráter e a palavra considerada. Sua hipótese é que a polaridade entre os dois modelos de permanência exprime a ação de recobrir quase completamente as noções do idem e da ipse, enquanto a fidelidade a si na manutenção da palavra marca o afastamento extremo entre a permanência do si e a do mesmo. Tal operação atesta a irredutibilidade dos problemas entre os dois modelos.

Pela instabilidade emprestada dos hábitos e das identificações adquiridas - isso que se nomeia como disposição ou qualidades - o caráter assegura ao mesmo tempo a identidade qualitativa, a continuidade ininterrupta na mudança. Finalmente, a permanência no tempo é que define a condição de mesmidade. O caráter é verdadeiramente "o quê" do "quem". O caráter tem uma história, contraída, no duplo sentido da palavra "contração". A dialética da inovação e da sedimentação subjacente ao processo de identificação o atestam.

É possível, assim, opor regularmente as aporias de uma identidade suspensa apenas pelo testemunho da memória; isto é: as aporias psicológicas concernentes aos limites, as intermitências durante o sono, as perdas da memória, mas também as aporias mais propriamente ontológicas no que dizem respeito ao caráter - o si sob a aparência da mesmidade.

Ao encerrar esta tese, pretende-se que a identidade narrativa tenha sido compreendida de uma maneira construtiva e não mais polêmica ou defensiva. Duas tarefas positivas restam por serem cumpridas: a primeira é levar ao seu mais alto grau a dialética da mesmidade e da ipseidade implícita na noção de identidade narrativa. A segunda é completar esta investigação do si relatado, pela exploração das mediações que a teoria da narrativa pode operar entre teoria da ação e teoria moral, e esta segunda tarefa terá duas vertentes. Voltando à tríade - descrever, relatar, prescrever - pergunta-se como a extensão do campo prático suscita a função narrativa, se a ação descrita deve poder igualar-se à ação relatada. Ao se examinar de que maneira a narração mostra-se como o primeiro laboratório do julgamento moral, verifica-se que ela nunca é eticamente neutra. As duas vertentes da teoria narrativa, prática e ética, permitem a constituição da ação e do si. 
O modelo específico de conexão entre acontecimentos, que constitui a intriga, permite se integrar à permanência no tempo. Porém, tal conexão expõe o seu negativo sob o regime da identidade-mesmidade, a saber, a diversidade, a variabilidade, a descontinuidade, a instabilidade, tal como se dá o processo da formação das identidades híbridas da modernidade tardia. A noção de intriga, transposta da ação para os personagens da narração, gera, assim, a dialética do personagem que é uma dialética da mesmidade e da ipseidade.

O passo decisivo para uma concepção narrativa da identidade pessoal é dado quando se passa da ação ao personagem, sabendo-se que o personagem é aquele que faz a ação na narrativa. A categoria do personagem é ela própria uma categoria narrativa: seu papel na narração depende da própria inteligência narrativa que a intriga contém em si mesma.

Longe de confirmar a identidade ética figurada pela manutenção de si, o personagem parece retirar-lhe todo o ponto de apoio. Em O homem sem qualidades, cabe indagar: por que, efetivamente, Musil consegue fazer o leitor se interessar pelo drama da dissolução da identidade de seu personagem? Tal indagação leva o leitor à mesma perplexidade do personagem: como poderia haver o não-sujeito se ele não permanecesse uma figura do sujeito, mesmo que fosse sobre o modo negativo?, dado que um sujeito verdadeiro é nada. A ficção literária começa a mudar para seu contrário quando a ficção se volta para a vida. À procura da identidade, o leitor se encontra diante da hipótese de sua própria perda de identidade. Esse foi o tormento de Musil e o efeito de sentido cultivado pela imensidade de sua obra. O si representado pela narrativa é, na realidade, confrontado com a hipótese de seu próprio nada. Esse nada não quer dizer que não se tenha nada o que dizer, pelo contrário, há muito o que se dizer, e é essa a motivação da imensidade de uma obra como O homem sem qualidades. A frase "Eu não sou nada" deve conservar sua forma paradoxal: "nada" já não significaria nada, se nada não fosse, com efeito, atribuído ao $e u$. Mas quem é ainda $e u$ quando o sujeito diz que é nada? Um si privado do auxílio da mesmidade. 
O exame de casos-limite, tal como Musil expõe o seu personagem, revela que eles são gerados pela imaginação narrativa, sugerindo uma dialética da posse e da espoliação, da preocupação e da despreocupação, da afirmação de si e do desaparecimento de si. Assim o nada imaginado do si torna-se crise existencial do si na transição dos tempos da modernidade, configurando um novo devir.

- Ética e subjetivação em Musil

A obra de Musil revela a urgência da tarefa intelectual: propiciar um tipo de relação do indivíduo para consigo mesmo que rechace e denuncie a pressuposta universalidade de todo o fundamento. Tal expectativa evitaria que as relações de poder se cristalizassem em estados de dominação. O advento de uma nova era moderna seria marcado por critérios de verdade que se apoiariam sobre índices quantitativos. Sem que tais critérios recorressem a um estado interior, dado de antemão ao conhecimento e à experiência, ou arraigado em uma profundidade íntima e inacessível, Musil revela, com $O$ homem sem qualidades, o lugar do sujeito deslocado do centro de reflexão. Na nova modernidade, o sujeito estaria liberado dos atributos que lhe foram dados pelo saber e pelo poder disciplinar normalizador, de maneira que a sua conduta não seria determinada por qualquer moral orientada para o código de costumes, mas isso constitui uma utopia.

O estudo da moral greco-latina, assim como o estudo de algumas tecnologias do eu, nas quais se encontram os traços que ainda permanecem na moral moderna, conduzem Musil a pensar na matriz de uma moral orientada para a ética, que não pode, nem deve ser uma cópia da moral pagã. Se há uma filosofia propriamente musiliana, ela não pretende oferecer um programa acabado ou traçar um desenho completo do ideário contrário às bases do pensamento ocidental clássico. Talvez, de maneira menos ambiciosa, ou mais limitada, ela revele a possibilidade de orientar os esforços de pensamento e ação para a constituição daquilo que poderia ser alcançado como uma estética da existência. 
A idéia de uma moral como obediência a um código de regras se revela no romance $O$ homem sem qualidades como o processo de seu desaparecimento. À ausência de moral deve corresponder uma busca de uma estética da existência. Tal proposição revela a postura crítica do intelectual engajado diante das tentativas contemporâneas de encontrar o fundamento para uma moral universal de caráter normativo. Seus personagens compõem estilos de existência tão diferentes uns dos outros que já não é possível encontrar neles pontos de definição. Neles não há uma caracterologia psicológica, tal como previa a investigação nos primórdios de uma psicologia inaugurada no início do século XX. Seus personagens não são indivíduos passíveis de serem compreendidos em grupos singulares. A busca de uma forma de moral única a orientar os comportamentos, antes aceitável para todos - no sentido de que todos deveriam submeter-se a ela - parece catastrófica a Musil. Para o homem sem qualidades, a ética é um modo de relacionamento do indivíduo consigo mesmo, e se coloca de maneira eminentemente prática. A ética musiliana não trata de investigar o quê, de propor um fundamento que volte a legitimar um código, ainda que mínimo. Ela trata de indagar pelo como, de como se constitui o indivíduo como sujeito moral de suas ações. O como introduz a variabilidade, a transformação possível, a diversidade. Investigar o como conduz a encontrar o fundamento móvel e altamente transformável em relação à constituição do indivíduo como sujeito de suas ações. Supõe ainda aceitar a variabilidade e a diversidade, pensar a ética como criação de e a partir da liberdade e pensar o sujeito como obra de si mesmo, tal como é uma obra de arte.

Ao revelar a desconstrução da moral greco-romana remanescente na tradição do império austro-húngaro, Musil propõe um novo tipo de relação do homem consigo mesmo: esta não se baseia nem na universalidade de um fundamento nem numa reflexão sistemática sobre o sujeito como algo preexistente, como um dado prévio à experiência e à ação. Na moral grega, respeita-se o caráter individual da conduta sem que haja um ego: a escolha do modo de vida é uma questão pessoal e a elaboração, o trabalho sobre a própria vida, apóia-se em uma série de técnicas que não tem caráter normativo nem pretende se organizar na forma de código. O elemento sobre o qual descansa a moral antiga é o trabalho sobre si: a ascese do espírito é elevada à categoria de matriz constitutiva do ethos, 
onde ethos implica relação do indivíduo consigo mesmo, com os outros e em relação com a verdade.

O que chama a atenção na concepção de ruptura com a moral antiga, e com o que Musil mostra ter afinidade, é precisamente o papel do trabalho sobre si mesmo, o papel de uma estetização do sujeito moral. Da afinidade para com tal princípio, várias vezes expressa, nasce a proposta: basear a moral na escolha pessoal do indivíduo, entender o sujeito como forma, que cada um deve elaborar, trabalhar e constituir segundo critérios de estilo e por meio de tecnologias. Este seria, resumidamente, o esquema de uma estética da existência, ausente em sociedades como aquela com que ele se defronta. $\mathrm{O}$ que o surpreende é o fato de que, na nova modernidade, a sociedade, a arte tenha se transformado em algo relacionado apenas a objetos e não a indivíduos ou à vida. $\mathrm{O}$ cerne de sua posição se refletiria nas posições defendidas por Hegel: não poderia a sociedade se transformar numa obra de arte? A arte, entendida como um conjunto aberto e variável de técnicas de construção e criação se deveria deslocar do mero âmbito dos objetos para o âmbito da vida. A aposta utópica musiliana poderia ser assim traduzida: colocar o conjunto de técnicas nas mãos de cada indivíduo, para que ele mesmo produza sua própria vida e gerencie sua própria liberdade e não só a partir das bases de uma moral. A tradição grega não seria reconstituída segundo tais critérios, mas ela se daria como reflexão sobre um dos textos mais importantes da modernidade: o texto de Kant sobre as categorias do entendimento (Crítica da razão pura, 1984, segunda parte, p. 102-173). Neste texto, Kant define o Iluminismo como a saída do homem de sua culpável incapacidade, como imaturidade para tomar e assumir as próprias decisões sem recorrer ao dogma ou à autoridade. A decisão mais importante é a que afeta o estilo de vida de cada indivíduo, na qual se vejam implicadas as relações que este mantém consigo e com os outros. Assumir radicalmente o princípio governante da modernidade significa, a partir desta perspectiva, colocar as condições para que o indivíduo seja artista ou artífice do seu próprio ethos. E se essa modernidade apontada por Kant, nesse ambiente de maturidade, se inaugurou com um trabalho crítico, isto é, com uma reflexão sobre os limites do conhecimento e da ação, o estabelecimento da crítica, na visão de Musil, consiste em trabalhar e refletir sobre os limites para uma nova condição humana. Mas não com a intenção de legitimar sua 
condição de estruturas transcendentais, dadas a priori, e conseqüentemente invariáveis, mas com o propósito de mostrar sua historicidade, sua contingência, com o objetivo de tornar possível a transformação de tal condição.

Algumas das mais fortes características da fase do pensamento de Musil, durante os quase trinta anos em que elaborou $O$ homem sem qualidades, encontram-se sob nova perspectiva do acima referido texto de Kant. Tais características podem ser situadas em três pontos, a saber:

1. Mostrar a imanência daquilo que pensamos como transcendental. Isto é: tanto o conhecimento como a ação encontram suas condições de desenvolvimento nos sistemas de ordenamentos. Dispositivos e episteme são totalmente históricos - e como tais, contingentes e possivelmente superáveis. Tais sistemas organizam o espaço do saber e do poder. Isto é, eles respondem às perguntas "O que podemos saber?" e "O que devemos fazer?" para um momento dado. Esses sistemas se apresentariam como condições históricas da realidade.

2. Substituir o fundamento pela experiência. A partir daqui, a investigação musiliana assume a forma sistemática que obriga a perguntar, não pelo fundamento quando este não é entendido como substância invariável ou como forma transcendental, mas pela forma histórico-crítica que tem como objeto a descrição das distintas experiências e relações entre domínios de saber, tipos de normatividade e formas de subjetividade. O propósito da tarefa musiliana, revelada pelo homem sem qualidades, é mostrar que nem os limites do conhecimento, nem as divisões normativas, nem as posições que o sujeito adquire, respondem a um fundamento ou necessidade, mas têm caráter de acontecimento histórico, e ainda que tal perspectiva de acontecimento histórico seja anacrônica.

3. Colocar o sujeito no espaço da experiência, não como norma constituinte, mas como forma constituída de maneira incompleta. $\mathrm{O}$ homem sem qualidades não é uma invariante, nele não há uma essência fixa, acabada e idêntica a si mesma, mesmo quando ela é uma forma constituída com e pelas experiências históricas. Falar de sujeito é falar das complexas relações que os indivíduos mantêm consigo mesmos, com os outros e com a 
verdade. $\mathrm{O}$ sujeito se constitui na experiência e mediante práticas e tecnologias de saber, de poder, de si.

A proposta de uma estética da existência encontra sua possibilidade em um triplo deslocamento. Se os limites do conhecimento e da ação carecem de suporte transcendental, não cabe ao sujeito se submeter ao ditame de algum fundamento e se, sobretudo, o sujeito não é dado, só resta uma conseqüência prática: criar a si mesmo como uma obra de arte.

A conseqüência de tal raciocínio se assenta sobre o desligamento de qualquer tipo de esteticismo fantasioso e inconseqüente tal como era a proposta do expressionismo. Ao contrário, a escolha pessoal da própria forma de vida, que se situa na base da estética da existência, não se produzia em um espaço vazio, mas no âmbito da experiência que gera um desenho no qual algumas escolhas são possíveis e outras, não. Musil revela que o campo de uma escolha totalmente deliberada, que ignora os movimentos do tecido social, só é possível como ficção.

A tradição clássica pretendia dar um estilo à vida, utilizando técnicas para estilizar a conduta. Tal tradição realizava um constante trabalho sobre si e uma constante reflexão sobre esse mesmo trabalho. Tal trabalho envolvia os cidadãos e a verdade: sua ética era fundamentalmente uma estética do eu. Mas a constituição do indivíduo como sujeito, a escolha do estilo, realizava-se em um marco regido por princípios, cercado por limites que se impunham como condições: princípios e limites, ainda que não sendo eternos, não podiam também ser mudados de qualquer forma e a qualquer momento; limites que, por outro lado, não se dão completamente à consciência, posto que constituem o impensado do pensamento.

Uma estética da existência, tal como Musil a propõe, possibilitaria maior possibilidade de escolhas pessoais. Considerando a própria vida uma obra de arte, Musil propõe uma ética sem estilo, o que se acha possibilitado e limitado pelos domínios do saber e pelas construções normativas que constituem o indivíduo como sujeito e objeto de determinados conhecimentos e poderes. A escolha é possível, porém ela tem como pano 
de fundo o sistema, os jogos de verdade e os dispositivos de poder. Tal constatação converte a estética da existência em um modo de ver a ética, que tem como características a crítica e a experimentação.

Enquanto modo crítico, a estética da existência encontra em sua base os domínios de saber e os dispositivos de poder que condicionam a experiência e desenham a margem de possibilidades de uma época. Entretanto tais domínios não são necessários nem imutáveis. Isso quer dizer que os limites impostos se evidenciam como tantos outros lugares de transgressão possíveis, devendo ser pensados com atenção, tendo em conta sua radical contingência. $\mathrm{O}$ que a experiência histórica mostra com a leitura de $O$ homem sem qualidades é como os limites são variáveis, e os fundamentos, mutáveis. A escolha do estilo deve questionar a experiência que constitui o atual sistema de relações. $O$ homem sem qualidades muda totalmente o modo de ser, a relação com os outros, com as coisas, com a eternidade, com Deus etc. Ele produzirá uma verdadeira revolução sob as condições dessa mudança radical de experiência. Revelando com suas ações, aparentemente desconexas, uma moral do estilo, ele redescobre no retiro solipsista uma individualidade isolada e auto-suficiente. A cena final do incesto só poderia ocorrer sob tais condições. Entretanto, o caráter desconexo ou caótico das ações do homem sem qualidades revela dimensões epistemológicas ligadas a um saber compartilhado. Como dimensão política, suas ações estão ligadas a um contato imerso nas relações de poder paralelo com/sobre/sob os outros. A partir da perspectiva musiliana, o indivíduo não pode mudar seu modo de ser sem mudar simultaneamente as relações para consigo, as relações com os outros e as relações com a verdade.

Enquanto modo de experimentação, a estética da existência propõe colocar à prova tanto os limites impostos à experiência, como a condição de sujeito que os seus próprios limites constroem. A crítica permanente de época histórica, o Zeigeist, e do próprio eu se apresenta ao mesmo tempo como um deslocamento de limites e como práticas de si. Ao enfatizar o caráter de prática da ética, o ethos como uma prática que se revela em transgressão e liberdade, o sujeito há de ser não somente visualizado, mas configurado segundo escolhas individuais e critérios de estilo. 
No centro da estética da existência, situa-se a questão da liberdade. A crítica como componente da estética da existência tem como tarefa levar tão longe quanto possível o trabalho da liberdade. Com relação à ética, a liberdade é condição e objeto, pois a liberdade é condição ontológica da ética, e a ética é a forma reflexiva que adota a liberdade. Sobre essa temática, Marcuse tem muito a dizer quando afirma "nascemos e morremos racional e produtivamente". Ele expõe o duplo significado do termo racionalização quando prevê que a destruição é o preço do progresso, como a morte é o preço da vida, que a renúncia e a labuta são os requisitos para a satisfação e o prazer, que os negócios devem prosseguir e que, se há alternativas, estas são uma utopia. Essa ideologia pertence ao aparato social estabelecido; é um requisito para o seu funcionamento contínuo e parte de sua racionalidade. Porém o aparato derrota o seu próprio objetivo, se este é criar uma existência humana com base numa natureza humanizada. E, se esse não é o seu propósito, a racionalidade, em si, se torna suspeita. A racionalidade é ainda lógica porque, de início, o negativo está no positivo, o desumano está na humanização, a escravidão, na libertação. Essa dinâmica pertence à realidade e não é inerente ao psiquismo; ela advém de uma realidade na qual o cientificismo teve papel decisivo em unir a razão teórica e prática. (Marcuse, 1967, p; 143)

Que a liberdade seja objeto de uma construção transgressiva à ordem e inacabada em sua ação é algo que, em certa medida, contrasta poderosamente com boa parte do pensamento estabelecido e vigente que serve de base tanto para as opiniões quanto para a ação individual e coletiva na nova modernidade. Pensar a liberdade como um direito, como algo que, em qualquer caso, se tem ou não se tem, perde-se ou se conquista, implica um processo complexo engendrado pela reflexão, prática e atitude. $\mathrm{O}$ objeto ao qual se aplicam a reflexão, a prática e a atitude é o sujeito: nós mesmos como seres historicamente determinados, em parte por relações de poder-saber, mas, ao mesmo tempo, sujeitos a transformações, capazes de enfraquecer as fronteiras, os limites que nos constituem por meio de um trabalho sobre nós mesmos, em exercício prático-crítico. É a tal objeto que se endereça uma estética da existência. O que se pode dizer do sujeito - uma vez colocandoo em um marco moral, epistemológico e político - é que ele se constitui segundo alguns limites que, em sua contingência, enunciam a sua capacidade e possibilidade de transformação. Compreende-se, assim, que a concepção de pensamento que se situa na 
base de $O$ homem sem qualidades exclua o refúgio da identidade contra as armadilhas do fundamento: desprender-se de si mesmo é o exercício prático e crítico que corrói os limites e desloca o fundamento do conceito de identidade na nova modernidade, conforme se queria demonstrar.

Não é estranho que o pensamento de Musil acabasse chegando a um ethos, entendido como conjunção de atitude e exercício: um modo de relação com respeito à atualidade, escolha voluntária de uma forma de ser ou tipo de relação consigo, com os outros e com a verdade. Esse ethos distinguirá o pensamento inovador de Musil. Esse ethos consiste em uma crítica do que se diz, pensa e faz, por meio de uma ontologia histórica e ao mesmo tempo anacrônica de nós mesmos. O homem sem qualidades caracteriza-se por duas atitudes fundamentais, e estas se revelam em limites e experimentação.

A contribuição desta tese revela que a atitude-limite implica uma relação de análise dos parâmetros que constituem o homem moderno, se se pode conceituar a modernidade, sob a égide da ética clássica. Trata-se de saber o que há de singular, contingente e arbitrário naquilo que tem sido legado como universal, necessário e obrigatório. Em suma, trata-se de transformar a crítica exercida sob a forma de limitação necessária, em uma crítica prática, e esta se dá sob a forma de uma transgressão possível. Para isso, é preciso empreender uma análise, não de estruturas formais com valor universal, mas dos conjuntos históricos que conduziram os homens a se reconhecerem como sujeitos de seus pensamentos e ações. Longe de assegurar a legitimidade e a pretensão universalista de qualquer fundamento, Musil trata tanto os discursos que articulam o que se pensa, diz e faz como os acontecimentos históricos. Estes não são concomitantes, mas paralelos. Por meio dessa análise, a contingência nos faz ser o que somos e, a partir dela, a possibilidade de não ser, fazer ou pensar o que somos, pensamos e fazemos.

A atitude, denominada experimental, ou uma "outra condição" pretende complementar a crítica dos limites com um trabalho de transformação prática, precisa e constante da contingência que nos constitui, por meio de um exame histórico-crítico dos limites que se pode transpor, portanto com o trabalho sobre nós mesmos como seres livres. 
De fato, o próprio exercício da travessia como transgressão, que busca estender o possível, além do supostamente necessário, é entendido como exercício de liberdade.

A analítica musiliana começa por um estudo dos domínios ou eixos nos quais o sujeito se constitui: o poder, o saber e a ética; em outras palavras, ela abrange as relações com os outros, com a verdade e consigo mesmo. Musil entende que, nesses domínios, exercem-se práticas de dominação e de liberdade. O estudo de tais práticas - a ontologia histórica de nós mesmos — indica como fomos constituídos como sujeitos que exercem e sofrem relações de poder. Tal estudo indica ainda como nos constituímos como sujeitos morais de nossas ações. Essa ontologia de nós mesmos não pode ser considerada uma teoria ou doutrina, nem mesmo um corpo de saberes. Ela é mais propriamente um ethos, uma vida filosófica em que a crítica do que somos é simultaneamente análise histórica dos limites que nos são colocados e a prova de sua transgressão possível.

Para essa filosofia entendida como ethos, a liberdade é simultaneamente condição, objeto e objetivo. Entendida como prática, o presente é contingência que configura um campo de ações, mas é também possibilidade de transgressão. O trabalho ascético do indivíduo sobre ele mesmo, que transforma suas relações com os outros e com a verdade, é um exercício de liberdade que transgride os limites da contingência, um exercício por meio do qual o sujeito se desprende de si. Musil está convencido de que, no presente, existem mais liberdades possíveis, mais possibilidades de recriar o futuro do que se possa imaginar.

Completado o arco do século XX, esta tese contribui para enfatizar a necessidade imperativa de não destruir as qualidades do homem; não sem ressaltar que estas estão sendo destruídas pela voracidade que envolve a sociedade tecnológica no capitalismo tardio. Reintroduzir as qualidades humanas no mundo das qualidades cada vez mais inumanas é, contudo, enfrentar um paradoxo; e este é grande desafio que resta à tarefa das práticas sociais voltas à reflexão ética. Tal paradoxo expressa um desafio que aponta um limite à cultura nomeada pós-moderna; se esta é capaz de se desdobrar no vazio, contra o qual a personificação de homens sem qualidades protege e dissimula a busca de verdadeiras virtudes. Fica assim tal tarefa legada às novas gerações influenciadas pelas 
ilusões do individualismo, das crenças na auto-suficiência, na busca de realização das possibilidades pessoais sem que estas compreendam uma visão social do todo. A perspectiva que se delineia para o cumprimento de tais possibilidades, com igualdade de condições a todos, e diante do eminente esgotamento de recursos da Terra, é demasiado predatória e destruidora, fazendo com que já se enxergue um grande incêndio na linha do horizonte. É possível que não se possa avançar muito mais sob um sistema filosófico musiliano. O inacabamento forçado de seu trabalho, o fato de que sua morte não tenha legado uma conclusão a diversas questões deixadas em aberto, obrigou esta tese apenas a construir hipóteses sobre seu trabalho. A obra de Musil não se fecha assim sobre si mesma, não adquirindo a forma fechada de um sistema. Insinua-se nela, pelo contrário, uma abertura, uma brecha, na qual é possível seguir pensando de outros modos, com um objetivo: construir a liberdade, antes que ela se transformasse na versão monstruosa das guerras que marcariam a nova modernidade no século XX em diante. 


\section{REFERÊNCIAS BIBLIOGRÁFICAS}

\section{Básica}

MARCUSE, H. L'homme unidimensionnel: essai sur l' idéologie de la société industrielle avancée. Trad. M. Wittig; H. Marcuse. Paris: Minuit, 1969. (Arguments, 34).

MARCUSE, H. A ideologia da sociedade industrial. Trad. G. Rebua. Rio de Janeiro: Zahar, 1967.

MARCUSE, H. One-dimensional man: studies in the advanced industrial society. Boston: Beacon Press, 1964.

MUSIL, R. O homem sem qualidades. Trad. Lya Luft; C. Abbenseth. Rio de Janeiro: Nova Fronteira, 2006. (40 Anos, 40 Livros).

MUSIL, R. O jovem Törless. Trad. Lya Luft. Rio de Janeiro: O Globo; São Paulo: Folha de São Paulo, 2003.

MUSIL, R. The confusions of Young Törless. Trad. S. Whiteside. New York: Penguin, 2001.

MUSIL, R. Diaries 1899-1941. Selec., trad., anot., pref. Philip Payne. New York: Basic Books, 1999..

MUSIL, R. O melro e outros escritos de obra póstuma publicada em vida. Trad. Nicolino de S. Neto. São Paulo: Nova Alexandria, 1996.

MUSIL, R. The man without qualities. Trad. S. Wilkins. New York: Vintage, 1996. 2 v.

MUSIL, R. Precision and Soul: essays and addresses. Ed. e trad. B. Pike e D. S. Luft. Chicago: University of Chicago, 1994.

MUSIL, R. Os visionários, drama em três actos. Trad. L. Scheidl. Lisboa: Minerva, 1989.

MUSIL, R. Les exaltés. Trad. P. Jacottet. Paris: Seuil, 1985.

MUSIL, R. Tagebücher. 2 ed. Ed. Adolf Frisé. Reinbek bei Hamburg: Rowohlt, 1983. 2 v.

MUSIL, R. The enthusiasts. Trad. A. Simon. New York: Performing Arts Journal Publications, 1983.

MUSIL, R. Beitrag zur Beurteilung der Lehren Machs, Berlin, 1908. Reprint. Adolf Frisé (Ed.). Reinbek, 1980.

MUSIL, R. Briefe 1901-1942. Adolf Frisé; Murray G. Hall (Ed.).Reinbeck bei Hamburg, 1980. 2 v. 
MUSIL, R. Der Mann ohne Eigenschaften. Gesammelte werke, in neum Bänden. Reinbeck bei Hamburg: Rowohlt, 1978. v. 1-5. 9 v.

MUSIL, R. Gesammelte werke, in neum Bänden. Ed. Adolf Frisé. Reinbeck bei Hamburg: Rowohlt, 1978. 9 v.

MUSIL, R. Três novelistas contemporâneos. Trad. M. S. Almeida et al. Lisboa, Presença, 1966. 


\section{Bibliografia}

ABBAGnAnO, N. Dicionário de filosofia. Trad. coord. A. Bosi et al. 2. ed. São Paulo: Mestre Jou, 1982.

ADORNO, T. W. Notas de literatura I. Trad. J. de Almeida. São Paulo: Duas Cidades; Ed. 34, 2003.

ADORNO, T. W. Notas de literatura I. Trad. J. de Almeida. São Paulo: Livraria Duas Cidades, Editora 34, 2003. (Coleção Espírito Crítico).

ADORNO, T. W. A indústria cultural - o iluminismo como mistificação das massas. In: Indústria cultural e sociedade. Trad. J. E. Lévy. São Paulo: Paz e Terra, 2002..

ADORNO, T.W. et al. Teoria da cultura de massa. São Paulo: Paz e Terra, 2000. [s. r. c.].

ADORNO, T. W. Progresso. In: Palavras e sinais: modelos críticos 2. Trad. M. H.

Ruschel. Petrópolis: Vozes, 1995.

ADORNO, T. W. Teoria estética. Trad. A. Morão. Lisboa: Edições 70, 1993. (Arte \& Comunicação).

ADORNO, T. W. Mínima moralia: reflexões a partir da vida danificada. 2. ed. Trad. L. E. Bicca. São Paulo: Ática, 1993. (Série Temas, Estudos filosóficos, 30).

ADORNO, T. W. Notas de literatura. 2. ed. Trad. C. A. Galeão; I. A. da Silva. Rio de Janeiro: Tempo Brasileiro, 1991. (Biblioteca Tempo Universitário - Séries Estudos Alemães).

ADORNO, T. W. Dialética do esclarecimento: fragmentos filosóficos. Trad. Guido de Almeida. Rio de Janeiro: Zahar, 1985.

AGAMBEN, G. Estâncias: a palavra e o fantasma na cultura ocidental. Trad. S. J. Asmann. Belo Horizonte: Ed. UFMG, 2007. 263 p. (Coleção Humanitas).

AGAMBEN, G. A linguagem e a morte: um seminário sobre o lugar da negatividade. Trad. H. Burigo. Belo Horizonte: Ed. UFMG, 2006. (Coleção Humanitas).

AGAMBEN, G. Estado de exceção. Trad. I. D. Poleti. São Paulo: Boitempo, 2004. (Coleção 
Estado de Sítio).

AGAMBEN, G. O poder soberano e a vida nua: Homo saccer. Trad. A. Guerreiro. Lisboa: Presença, 1998.

AGAMBEN, G. Quel che resta di Auschwitz.L' archivio e il testimone. Torino: Bollati Boringhieri, 1998.

ALBOUY, F.-X. Le temps des catastrophes. Paris: Descartes \& Cie, 2002.

ALTHUSSER, L. Filosofia e filosofia espontânea dos cientistas. Trad. E. Bacelar. Lisboa: Presença; São Paulo: Martins Fontes, 1974.

ARENDT, H. Entre o passado e o futuro. 5. ed. 1. reimpr. Trad. M. W. Barbosa de Almeida. São Paulo: Perspectiva, 2001. (Coleção Debates).

ARENDT, H. A condição humana. 10. ed. Trad. R. Raposo. Pós-fácio de Celso Lafer. Rio de Janeiro: Forense Universitária, 2000.

ARENDT, H. Origens do totalitarismo: anti-semitismo, imperialismo, totalitarismo. 4. reimpr. Trad. R. Raposo. São Paulo: Companhia das Letras, 2000.

ARENDT, H. Homens em tempos sombrios. 2. reimpr. Trad. D. Bottmann. São Paulo: Companhia das Letras, 1999.

ARENDT, H. On violence. New York: Harcourt Brace \& Company Book, 1970.

ARENS, K. Functionalism and Fin-de-Siècle: Fritz Mauthner's Critique of Language. New York: Lang. 1984.

ARISTOTLE. Complete works of Aristotle. Trad. J. Barne (Ed.) New Jersey: Princeton University Press, LXXI, 1961. 2v.

ARON, R. Progresso y desilusión: la dialéctica de la sociedad moderna. Trad. J. Sucre. Venezuela: Monte Avila, 1969.

ARRIGHI, G. $O$ longo século $X X$. Dinheiro, poder e as origens de nosso tempo. Trad. V. Ribeiro. 5. reimp. São Paulo: Contraponto, UNESP, 1996. 
ASHHEIM, S. E. The Nietzsche legacy in Germany, 1890-1990. Berkeley: Califórnia University Press, 1992.

AUGÉ. M. Não-lugares: introdução a uma antropologia da supermodernidade. 4. ed. Trad. M. L. Pereira. São Paulo: Papirus, 1994. (Travessia do século).

BAGEHOT, W. Physic and politics: or thoughts on the application of principles of "natural selection" and "inheritance" to political society. Boston: Beacon paperbacks, 1956.

BAHR, H. Zur Überwindung des Naturalismus. Theoretische Schriften 1887-1904. Stuttgart: Kohlhammer, 1968.

BAHR, H. Dialog vom Tragischen. Berlin: Fischer, 1904.

BAKHTIN, M. Questões de literatura e estética: a teoria do romance. Trad. J. M. de Macedo. São Paulo: Ed. 34, 2000.

BAMBACH, C. R. Heidegger, Dilthey, and the crisis of Historicism. Ithaca: Cornell University Press, 1995.

BARNOUW, D. Weimar intellectuals and the threat of Modernism. Bloomington: Indiana University Press, 1988.

BARTHES, R. A preparação do romance. I - Da vida à obra. Trad. L. Perrone-Moisés. São Paulo: Martins Fontes, 2005. v. I.

BARTHES, R. A preparação do romance. II - A obra como Vontade. Trad. L. Perrone-Moisés. São Paulo: Martins Fontes, 2005. v. II.

BATHRICK, D.; HUYSSEN, A. (Ed.). Modernity and the text: Revisions of German Modernism. New York: Columbia University Press, 1989.

BAUER, O.; MARCUSE, H.; ROSENBERG, A. et al. Fascismo y capitalismo. Trad. J. A. Bravo. Barcelona: Martinez Roca, 1972.

BAUMAN, Z. La sociedad individualizada. Trad. M. Condor. 2. ed. Madrid: Catedra, 2007.

BAUMAN, Z. Europa: uma aventura inacabada. Trad. C. A. Medeiros. Rio de Janeiro: Jorge Zahar Ed., 2006. 
BAUMAN, Z. Identidade. Entrevista a Benedetto Vecchi.. Trad. C. A. Medeiros. Rio de Janeiro: Jorge Zahar Ed., 2005.

BAUMAN, Z. Comunidade. A busca por segurança no mundo atual. Trad. P. Dentzien. Rio de Janeiro: Jorge Zahar Ed., 2003.

BAUMAN, Z. Modernidade líquida. Trad. P. Dentzien. Rio de Janeiro: Jorge Zahar Ed., 2000.

BAUMAN, Z. Modernidade e ambivalência. Trad. M. Penchel. Rio de Janeiro: Jorge Zahar Ed., 1999.

BAUMAN, Z. Globalização: as conseqüências humanas. Trad. M. Penchel. Rio de Janeiro: Jorge Zahar Ed., 1998.

BAUMAN, Z. O mal-estar da pós-modernidade. Trad. M. Gama; C. M. Gama. Rio de Janeiro: Jorge Zahar Ed., 1998.

BAUMAN, Z. Ética pós-moderna. Trad. J. R. Costa. São Paulo: Paulus, 1997. (Coleção Critérios Éticos).

BAUMAN, Z. Modernidade e holocausto. Trad. M. Penchel. Rio de Janeiro: Jorge Zahar Ed., 1989.

BAUMAN, Z. Legislators and interpreters: On modernity, postmodernity and intellectuals. Ithaca: Cornell University Press, 1987.

BECK, U. O que é globalização? Equívocos do globalismo, respostas à globalização. Trad. A. Carone. São Paulo: Paz e Terra, 1999.

BECK, U. La sociedad del riesgo. Hacia una nueva modernidad. Trad. J. Navarro; D. Jiménez; M. R. Borrrás. Barcelona: Paidós, 1998.

BECK, U. Modernização reflexiva: política, tradição e estética na ordem social moderna. Trad. M. Lopes. São Paulo: Ed. da Universidade Estadual Paulista, 1997. (Biblioteca Básica).

BECK, U. Ecological enlightenment: essays on the politics of the risk society. New Jersey: Humanities Press, 1995. 
BECK, U.; BECK-GERNSHEIM, E. La individualización: el individualismo institucionalizado y sus consecuencias sociales y políticas. Trad. B. Moreno. Barcelona: Paidós, 2003.

BECKETT, S. Esperando Godot. Trad. F. Rangel. São Paulo: Abril, 1976.

BELL, D. Risk society: towards a new modernity. London: Sage Publ., 1992.

BELL, D. The end of ideology. New York: Free Press, 1962.

BENJAMIN, W. O conceito de arte no romantismo alemão. Trad. e prefácio M. S. Silva. São Paulo: Iluminuras, 2002.

BENJAMIN, W. A obra de arte na época de sua reprodutibilidade técnica. Trad. C. N. Coutinho. In: MOLES, A. et al. Teoria da cultura de massa. 6. ed. Introdução, comentários e seleção de L. C. Lima. São Paulo: Paz e Terra, 2000.

BENJAMIN, W. et al. Textos escolhidos. Seleção de Z. Loparic e O. B. F. Arantes. Trad. J. L. Grünnewald et al. São Paulo: Abril Cultural, 1983. (Os Pensadores, 48).

BERGE, P.; POMEAU, Y; VIDAL, C. L'ordre dans le chaos: vers une approche deterministe de la turbulence. Paris: Hermann, 1984.

BERGER, P. L; HUNTINGTON, S, P. Many globalizations: cultural diversity in the contemporary world. New York: Oxford University Press, 2003.

BERGER, P. L.; LUCKMAN, T. A construção social da realidade. Tratado de sociologia do conhecimento. Trad. F. de S. Fernandes. 5. ed. Petrópolis: Vozes, 1983.

BERLIN, I. Estudos sobre a humanidade: uma antologia de ensaios. Trad. R. Eichenberg. São Paulo: Companhia das letras, 2002.

BERMAN, A. Preface to Modernism. Urbana: University of Illinois Press, 1994.

BERNSTEIN, M. A. Five portraits: modernity and the imagination in Twentieth-century German Writing. Evanston: Northwestern University Press, 2000.

BHABHA, H. K. O local da cultura. Trad. M. Ávila et al. 3. reimpr. Belo Horizonte: Ed. UFMG, 
2005. (Coleção Humanitas).

BITHELL, J. Modern German literature 1880-1950. London: Methuen, 1959.

BLANCHOT, M. Le livre à venir. Paris: Gallimard, 1959.

BOAVENTURA, S. S. (Org.). A globalização e as ciências sociais. 2. ed. São Paulo: Cortez, 2002.

BOBbiO, N.; METTEUCCI, N.; PASQUINO, G. Dicionário de política. 5. ed. Trad. C. C. Varrialle et al. Pref. F. H. Cardoso. Brasília: UNB; São Paulo: Imprensa Oficial, 2004. 2 v.

BOBBIO, N. A era dos direitos. 4. tir. Trad. R. Lyra. Apresentação Celso Lafer. Rio de Janeiro: Campus, Elsevier, 1992.

BOBBIO, N. Os intelectuais e o poder: dúvidas e opções dos homens de cultura na sociedade contemporânea. Trad. M. A. Nogueira. São Paulo: UNESP, 1997. (Biblioteca básica).

BOBBIO, N. O problema da guerra e as vias da paz. Trad. A. Lorencini. São Paulo: UNESP, 2003.

BOBBIO, N. O futuro da democracia. Trad. M. A. Nogueira. São Paulo: Paz e terra, 2000. (Pensamento crítico, 63).

BOÉTIE, E. de la. Discurso da servidão voluntária. 2. reimp. Trad. L. Garcia dos Santos. São Paulo: Brasiliense, 2001.

BOHME, H. Anomie und Entfremdung. Literatursoziologische Untersuchungen zu den Essays Robert Musils und seinem Roman "Der Mann ohne Eigenschaften". Kronberg: Skripten Literaturwissenschaft, 1974.

BORDIEU, P. Os usos sociais da ciência: por uma sociologia clínica do campo científico. Trad. D. B. Catani. São Paulo: Ed. UNESP, 2004.

BORDIEU, P. A institucionalização da anomia. In: . O poder simbólico. 6. ed. Trad. F. Tomaz. Rio de Janeiro: Bertrand Brasil, 2003. p. 255-279.

BORDIEU, P. (Coord.). A miséria do mundo. 5. ed. Trad. M. S. S. Azevedo et al. Petrópolis: Vozes, 1997. 
BOSI, A. Literatura e resistência. São Paulo: Companhia das letras, 2002.

BOSI, A. Fenomenologia do olhar. In: NOVAES, A. (Org.). O olhar. São Paulo: Companhia das Letras, 1988. p. 65-87.

BOSI, E. Memória e sociedade. Lembranças de velhos. 12. ed. São Paulo: Companhia das Letras, 1994.

BOSI, E. O tempo vivo da memória: ensaios de psicologia social. 2. ed. São Paulo: Ateliê Editorial, 2003.

BOUVERESSE, J. et al. $O$ século $X X$. Trad. J. A. Furtado. Lisboa: Publicações Dom Quixote, 1983. (Coleção História da Filosofia).

BRAIT, B. (Org.). Bakhtin, dialogismo e construção do sentido. 2. ed. Campinas: Ed. UNICAMP, 2005.

BRANCO, L. C.; BRANDÃO, R. S. (Org.). A força da letra: estilo, escrita, representação. Belo Horizonte: Ed. UFMG, 2000.

BRANDÃO, R. S. A vida escrita. Rio de Janeiro: 7 Letras, 2006. (Coleção Sete Faces).

BRANDÃO, R. S. Literatura e psicanálise. Porto Alegre: Editora da UFRGS, 1996. (Síntese Universitária, 45-46).

BRAUDEL, F. Escritos sobre a história. Trad. J. Guinsburg; T. C. Silveira da Mota. São Paulo: Perspectiva, 1994.

BRAUN, W. The confusions of young Törless, The Germanic Review 40 (1965), p. 116131.

BRAUN, W. The temptation of Ulrich: the problem of true and false unity in Musil's Der Mann ohne Eigenschaften, The German Quarterly 29 (1956), p. 29-77.

BROCH, H. Geist and Zeitgeist: the spirit in an unspiritual age. Six essays by Hermann Broch. Trad. J. Hargraves. New York: Counterpoint, 2002.

BROCH, H. Os sonâmbulos. Trad. M. A. Ferreira; J. Camacho. Lisboa: Edições 70, 19881989. $3 \mathrm{v}$. 
BROCH, H. Création littéraire et connaissance. Trad. A. Kohn. Paris: Gallimard, 1966. (Biblioteque des idées).

BURITY, J. A. (Org.). Cultura e identidade: perspectivas interdisciplinares. Rio de Janeiro: DP \&A Editora, 2002.

BURKE, P. Variedades de história cultural. 2. ed. Trad. A. Porto. Rio de Janeiro: Civilização Brasileira, 2006.

BURKE, P. O que é história cultural? Trad. S. G. de Paula. Rio de Janeiro: Jorge Zahar Ed., 2005.

BURKE, P. Hibridismo cultural. Trad. L. S. Mendes. São Leopoldo: Ed. UNISINOS, 2003.

BURKE, P. História e teoria social. Trad. K. B. Gerhardt; R. V. Majer. São Paulo: Ed. UNESP, 2002.

CAMPOS, M. T. C. de. Marcuse: realidade e utopia. São Paulo: Annablume, 2004.

CANDIDO, A. et. al. A personagem de ficção. São Paulo: Perspectiva, 2007. (Col. Debates).

CANETTI, E. Massa e poder. Trad. S. Tellaroli. São Paulo: Companhia das Letras, 2005.

CANETTI, E. O jogo dos olhos. História de uma vida /1931-1937. Trad. S. Tellaroli. São Paulo: Companhia das Letras, 1990.

CASSIRER, E. O mito do estado. Trad. A. Cabral. São Paulo: Códex, 2003.

CASTEL, R. A insegurança social: o que é ser protegido? Trad. L. M. E. Orth. Petrópolis: Vozes, 2005.

CASTEL, R. As metamorfoses das questão social. Uma crônica do salário. 5. ed. Trad. I. D. Poleti. Petrópolis: Vozes, 2005.

CASTEL, R. Entrevista concedida a DIDIER E. Em 29 de junho de 1980. In: ENTREVISTAS do Le Monde. Sociedade. Trad. S. Flaksman. São Paulo: Ática, 1989. p. 35-39.

CASTELlO BRANCO, L.; BRANDÃO, R. S. (Org.). A força da letra. Estilo, escrita, representação. Belo Horizonte: Ed. UFMG, 2000.

CASTORIADIS, C. Sujeito e verdade no mundo social-histórico. Seminários 1986-1987: a criação 
humana I. Trad. E. Aguiar. Rio de Janeiro: Civilização Brasileira, 2007.

CASTORIADIS, C. Uma sociedade à deriva. Entrevistas e debates 1974-1997. Trad. C. Berliner. Aparecida: Idéias \& Letras, 2006.

CASTORIADIS, C. As encruzilhadas do labirinto VI. Figuras do pensável. Trad. E. Aguiar. Rio de Janeiro: Civilização Brasileira, 2004.

CASTORIADIS, C. As encruzilhadas do labirinto IV. A ascensão da insignificância. Trad. R. Vasconcellos. São Paulo: Paz e Terra, 2002.

CASTORIADIS, C. As encruzilhadas do labirinto II. Os domínios do homem. 5. ed. Trad. G. Reynaud. Rio de Janeiro: Paz e Terra, 2000.

CASTORIADIS, C. A instituição imaginária da sociedade. 5. ed. Trad. G. Reynaud. Rio de Janeiro: Paz e Terra, 2000. (Rumos da cultura moderna, 52).

CASTORIADIS, C. As encruzilhadas do labirinto $V$. Feito e a ser feito. Trad. Lílian do Valle. Rio de Janeiro: DP\&A, 1999.

CASTORIADIS, C. As encruzilhadas do labirinto I. 2. ed. Trad. C. S. Guedes; R. M. Boaventura. Rio de Janeiro: Paz e Terra, 1997. (Rumos da cultura moderna, 53).

CASTORIADIS, C. As encruzilhadas do labirinto III. O mundo fragmentado. Trad. R. M. Boaventura. Rio de Janeiro: Paz e Terra, 1992.

CAULFIELD, H. The conservation and environmental movements: an historical analysis. In: LESTER, J. (Ed.). Environmental politics and policy: theories and evidence. Durham, London: Duke University Press, 1992. p. 13-56.

CAVENACCI, M. Sincretismos. Uma exploração das hibridações culturais. São Paulo: Studio Nobel, 1966.

CHAMBERLAIN, H. S. Foundations of the Nineteenth Century. New Orleans: Flanders Hall, 1988. 2v.

CHANGEUX, J.-P.; RICOEUR, P. La natureza y la norma. Lo que nos hace pensar. Trad. C. A. Flores. México: Fondo de Cultura Economica, 2001. 318p. 
CHÂTELET, F. Reler Marcuse para não viver como porcos. Folha de S. Paulo, São Paulo, 9 ago. 1999. Caderno Mais!

CHÂTELET, F. (Org.). A filosofia das ciências sociais de 1860 aos nossos dias. Lisboa: Dom Quixote, 1983. (História da Filosofia, 7).

CHÂTELET, F. (Org.). O século XX. Trad. J. A. Furtado. Lisboa: Dom Quixote, 1983. (História da Filosofia, 8).

CHÂTELET, F. (Org.). A filosofia do mundo cientifico e industrial 1860-1940. Lisboa: Dom Quixote, 1983. (História da Filosofia, 6).

CHÂTELET, F. (Org.). A filosofia do mundo novo séc. XVI e séc. XVII. Lisboa: Publicações Dom Quixote, 1983. (História da Filosofia, 3).

CHÂTELET, F. (Org.). A filosofia de Kant a Husserl. Lisboa: Dom Quixote, 1983. (História da Filosofia, 3).

COMPAGNON, A. O trabalho da citação. Trad. C. P. B. Mourão. Belo Horizonte: Ed. UFMG, 2007.

COMTE-SPONVILLE, A. O capitalismo é moral? Trad. E. Brandão. São Paulo: Martins Fontes, 2005.

CONNOLLY, W. E. Political theory and Modernity. Ithaca: Cornell University Press, 1993.

COOPER, D. (Org.). Dialética da libertação. Trad. E. Jorge. Rio de Janeiro: Zahar, 1968.

COSTA, J. F. A ética e o espelho da cultura. 3. ed. Rio de Janeiro: Rocco, 2000.

COUTINHO, E. F.; CARVALHAL, T. F. Literatura comparada: textos fundadores. Rio de Janeiro: Rocco, 1994a.

CORINO, K. Robert Musil: Eine Biographie. Reinbek bei Hamburg: Rowohlt, 1989.

CORINO, K. Robert Musil. Leben und Werk in Bildern und Texten. Reinbek bei Hamburg: Rowohlt, 1988.

CORINO, K. Robert Musil und Alfred Kerr. Der Dichter und sein Kritiker. In: DINKLAGE, 
E.; ALBERTSEN, E.; CORINO, K. Robert Musil. Studien zu seinem Werk. Reinbek bei Hamburg: Rowohlt, 1970. p. 236-83.

CORNGOLD, S. Complex pleasure. Forms of feeling in German Literature. Palo Alto: Stanford University Press, 1998.

COSTA LIMA, L. Teoria da literatura em suas fontes. 2. ed. Rio de Janeiro: Francisco Alves, 1975. v. II.

CRITIQUE. Vienne, début d'un siècle. Paris, t. XXXI, n. 339-340, 1975.

DARWIN, C. A origem do homem e a seleção natural. Trad. A. C.; E. N. Fonseca. São Paulo: Hemus-Livraria, 1974.

DAWIDOWSKI, C. Die geschwächte Moderne: Robert Musils episches Frühwerk im Spiegel der Epochendebatte. Frankfurt a. M.: Lang, 2000.

DE CERTEAU, M. A invenção do cotidiano. Artes de fazer. 10. ed. Trad. E. F. Alves. Petrópolis: Vozes, 2004.

DELEUZE, G. Empirismo e subjetividade. Ensaio sobre a natureza humana segundo Hume. Trad. L. Orlandi. São Paulo; Ed. 34, 2001.

DELEUZE, G. Diferença e repetição. Trad. L. Orlandi; R. Machado. Rio de Janeiro: Graal, 1988.

DELEUZE, G. Nietzsche e a filosofia. Trad. E. F. Dias; R. J. Dias. Rio de Janeiro: Ed. Rio, 1976. (Coleção Semeion).

DELEUZE, G.; GUATTARI, F. O anti-édipo: capitalismo e esquizofrenia. Trad. G. Lamazière. Rio de Janeiro: Imago, 1976b. (Série Logoteca).

DELEUZE, G. Lógica do sentido. Trad. L. R. Salinas. 2. ed. São Paulo: Perspectiva, 1974. (Coleção Estudos).

DELEUZE, G.; GUATTARI, F. Mil platôs. Capitalismo e esquizofrenia. 2. reimpr. Trad. S. Rolnik. São Paulo: Ed. 34, 2005. (Coleção TRANS, v. 4)

DERRIDA, J.; ROUDINESCO, E. De que amanhãa: diálogo. Trad. A. Telles. Rio de Janeiro: Jorge Zahar Ed., 2004. 
DERRIDA, J. Fuerza de ley: el "fundamento místico de la autoridad”. Trad. A. Barberá; P. P. Gómez. Madrid: Tecnos, 2002.

DESCAMPS, C. Novas fronteiras da ciência: novas interrogações das ciências humanas. In: ENTREVISTAS do Le Monde. Idéias contemporâneas. Trad. M. L. Blumer. São Paulo: Ática, 1989. p. 7-14.

DIEGUES, A. O mito do paraíso desabitado: as áreas naturais protegidas. In: FERREIRA, L.; VIOLA, E. (Org.). Incertezas de sustentabilidade na globalização. Campinas: Ed. UNICAMP, 1996. p. 279-318.

DILTHEY, W. Introducción a las ciencias del espiritu. Ensayo de una fundamentación del estudio de la sociedad y de la historia. 2. ed. Madri: Selecta de Revista de Ocidente, 1966.

DOMENACH, J-M.; CLAIR, A.; CHIRPAZ, F. Marcuse: contestação, filosofia e utopia. Trad. J. Perestrello. Lisboa: Moraes Editores, 1970.

DOMINGUES, I. (Org.). Conhecimento e transdiciplinaridade: aspectos metodológicos. Belo Horizonte: Ed. UFMG, 2005. v.2.

DOSSE, F. A história. Trad. M. E. O. Assumpção. Bauru: EDUSC, 2003. (Coleção História).

DOSSE, F. O império do sentido. A humanização das Ciências Humanas. Trad. I. S. Cohen. Bauru: EDUSC, 2003. (Coleção História).

DUARTE, R. Teoria crítica da indústria cultural. Belo Horizonte: Ed. UFMG, 2003. (Coleção Humanitas).

DUARTE, R. Adorno/Horkheimer \& a dialética do esclarecimento. Belo Horizonte: Jorge Zahar Ed., 2002. (Filosofia Passo-a-Passo).

DUBY, G. Entrevista concedida a PESSIS-PASTERNAK, G. em 24 de maio de 1989. In: ENTREVISTAS do Le Monde. Idéias contemporâneas. Trad. M. L. Blumer. São Paulo: Ática, 1989. p. $90-98$.

DURKHEIM, E. Da divisão do trabalho social. Trad. J. A. Giannotti. São Paulo: Abril Cultural, 1973. p. 303-372. (Os Pensadores, 33). 
EAGLETON, T. Teoria da literatura: uma introdução. Trad. W. Dutra. São Paulo: Martins Fontes, 2006.

EAGLETON, T. A idéia de cultura. Trad. S. Castelo Branco. São Paulo: UNESP, 2003.

EAGLETON, T. A ideologia da estética. Trad. M. S. R. Costa. Rio de Janeiro: Jorge Zahar, 1993.

ECKERSLEY, R. Environmental and political theory: toward an egocentric approach. Albany: State University of New York Press, 1992.

ECO, U. Quase a mesma coisa. Trad. E. Aguiar. Rio de Janeiro, São Paulo: Record, 2007.

ECO, U. Apocalípticos e integrados. Trad. Pérola de Carvalho. São Paulo: Record, 2004.

ECO, U. Sobre a literatura. Trad. E. Aguiar. Rio de Janeiro: Record, 2003.

ECO, U. A obsessão laica pelo novo Apocalipse. In: ECO, U.; MARTINI, C. M. Em que crêem os que não crêem? 6. ed. Trad. E. Aguiar. Rio de Janeiro: Record, 2001.

ECO, U. Cinco escritos morais. 2.ed. Trad. E. Aguiar. Rio de Janeiro: Record, 1997.

ECO, U. Leitura do texto literário: lector in fabula. Trad. M. Brito. Lisboa: Presença ,1983.

EDER, K. The "new social movements": moral crusades, political pressure groups, or social movements? Social Research, v. 52, n. 4, p. 869-890, 1985.

EKSTEINS, M. Rites of spring: The Great War and the birth of the modern age. New York: Houghton Mifflin, 1989.

ELIAS, N. Envolvimento e alienação. Trad. Álvaro de Sá. Rio de Janeiro: Bertrand Brasil, 1998.

ELIAS, N. A sociedade dos indivíduos. Org. Michael Schröter. Trad. V. Ribeiro. Rio de Janeiro: Jorge Zahar Ed., 1994.

ELIAS, N. O processo civilizador. Formação do estado e civilização. Trad. R. Jungman. Rio de Janeiro: Jorge Zahar Ed., 1993. v.2.

ELIAS, N.; SCOTSON, J. L. Os estabelecidos e os outsiders. Sociologia das relações de poder a partir de uma pequena comunidade. Trad. V. Ribeiro. Rio de Janeiro: J. Zahar Editor, 2000. 
EMERSON, W. R. Circles. Essay X. In: __.Esssays. Disponível em: http://www.rwe.org/works/Essays-1st Series 10 Circles.htm. Acesso em 27/04/2007.

ENTREVISTAS do Le Monde. Idéias contemporâneas. Trad. M. L. Blumer. São Paulo: Ática, 1989.

ENTREVISTAS do Le Monde. A sociedade. Trad. S. Flaksman. São Paulo: Ática, 1989.

ENTREVISTAS do Le Monde. O indivíduo. Trad. S. Flaksman. São Paulo: Ática, 1989.

ERIKSON, E. Identity: youth and crisis. New York: Norton, 1968.

ÉSQUILO. Agamênon. Trad. e estudo J. Torrano. São Paulo: Iluminuras, FAPESP, 2004. (Coleção Dionisias) (Orestéia, I).

ÉSQUILO. Coéforas. Trad. e estudo J. Torrano. São Paulo: Iluminuras, FAPESP, 2004. (Coleção Dionisias) (Orestéia, II).

ÉSQUILO. Eumênides. Trad. e estudo J. Torrano. São Paulo: Iluminuras, FAPESP, 2004. (Coleção Dionisias) (Orestéia, III).

EVERDELL, W. R. The first moderns: profiles in the origin of Twentieth-Century thought. Chicago: University of Chicago Press, 1997.

FERREIRA, A. B. de H. Novo dicionário Aurélio da língua portuguesa. 2. ed. 32. reimpr.. Rio de Janeiro: Nova Fronteira, 1986.

FEYERABEND, P. Contra o método. Trad. C. A. Mortari. São Paulo: UNESP, 2003.

FEYERABEND, P. Adeus à razão. Trad. M. G. Segurado. Lisboa: Rio de Janeiro: Edições 70, 1991. (Bilioteca de Filosofia Contemporânea).

FEYERABEND, P. Entrevista concedida a PESSIS-PASTERNAK, G. em 28 de fevereiro de 1982. In: ENTREVISTAS do Le Monde. Idéias contemporâneas. Trad. M. L. Blumer. São Paulo: Ática, 1989. p. 26-32.

FICHTE, G. J.; SCHELLING, F. V. Escritos filosóficos. Trad. R. Torres Filho. São Paulo, Abril, 1973. (Os Pensadores) 
FIORIN, L. J. et al. Dialogismo, polifonia, intertextualidade. São Paulo: EDUSP, 2003.

FOUCAUlT, M. A ordem do discurso. Trad. L. F. de Almeida Sampaio. 16. ed. São Paulo: Edições Loyola, 2008. (Leituras Filosóficas).

FOUCAULT, M. Em defesa da sociedade. Trad. M. E. Galvão. São Paulo: Martins Fontes, 2008.

FOUCAULT, M. Segurança, território, população. Trad. E. Brandão. São Paulo: Martins Fontes, 2008.

FOUCAULT, M. Problematização do sujeito: psicologia, psiquiatria e psicanálise. Trad. V. L. A. Ribeiro. 2. ed. Rio de Janeiro: Forense Universitária, 2006. (Coleção Ditos \& Escritos, I).

FOUCAULT, M. Estética: literatura e pintura, música e cinema. 2. ed. Manoel de Bastos (Org.). Trad. I. A. D. Barbosa. Rio de Janeiro: Forense universitária, 2006. (Ditos e escritos III).

FOUCAULT, M. A hermenêutica do sujeito. Trad. M. A. da Fonseca; S. T. Muchail. São Paulo: Martins Fontes, 2004. (Coleção Tópicos).

FOUCAULT, M. Nietzsche, Freud e Marx: theatrum philosoficum. 4. ed. Trad. J. L. Barreto. São Paulo: Princípio, 1987.

FOUREZ, G. A construção das ciências. Introdução à filosofia e à ética das ciências. Trad. L. P. Rouanet. São Paulo: UNESP, 1995.

FREUD, S. Análise terminável e interminável (1937). In: Moisés e o monoteísmo. Rio de Janeiro: Imago, 1975. p. 247-290. (Edição standard brasileira das obras psicológicas completas de Sigmund Freud, XXIII).

FREUD, S.; EINSTEIN, A. Por que a guerra? (1932). In: Novas conferências introdutórias sobre psicanálise e outros trabalhos, 1976, p. 241-259. (Edição standard brasileira das obras psicológicas completas de Sigmund Freud, XXII).

FREUD, S. Conferência XXXI: A dissecção da personalidade psíquica (1933 [1932]). In: .Novas conferências introdutórias sobre psicanálise e outros trabalhos, 1976. p. 75-102 (Edição standard brasileira das obras psicológicas completas de Sigmund Freud, XXII). 
FREUD, S. Psicologia de grupo e a análise do ego (1921). In: Além do princípio de prazer. Rio de Janeiro: Imago, 1976. p. 91-184. (Edição standard brasileira das obras psicológicas completas de Sigmund Freud, XVIII).

FREUD, S. O ego e o id (1923). In: . O ego e o id. Rio de Janeiro: Imago, 1976. p. 23-90. (Edição standard brasileira das obras psicológicas completas de Sigmund Freud, XIX).

FREUD, S. O ‘estranho’ [1917-1919]. In: .Uma neurose infantil e outros trabalhos. Rio de Janeiro: Imago, 1976. p. 273-318. (Edição standard brasileira das obras psicológicas completas de Sigmund Freud, XVII).

FREUD, S. O mal-estar na civilização (1930 [1929]). In: O futuro de uma ilusão. Rio de Janeiro: Imago, 1974. p. 81-178. (Edição standard brasileira das obras psicológicas completas de Sigmund Freud, XXI).

FREUD, S. O futuro de uma ilusão (1927). In: O futuro de uma ilusão. Rio de Janeiro: Imago, 1974. p. 15-80. (Edição standard brasileira das obras psicológicas completas de Sigmund Freud, XXI).

FREUD, S. Totem e tabu (1913 [1912-13]). In: Totem e tabu e outros trabalhos. Rio de Janeiro: Imago, 1974. p.17-198. (Edição standard brasileira das obras psicológicas completas de Sigmund Freud, XIII).

FROMM, E. Conceito marxista de homem. Trad. O. A. Velho. Rio de Janeiro: Zahar Editores, 1962. Versão inglesa dos Manuscritos econômicos e filosóficos [Primeiro manuscrito] de Karl Marx por: T. B. Bottomore do original alemão. p. 93-196.

FUKUYAMA, F. A grande ruptura: a natureza humana e a reconstituição da ordem social. Trad. N. Montingelli Jr. Rio de Janeiro: Rocco, 2000. (Coleção Administração \& Negócios).

FUKUYAMA, F. The end of history and the last man. New York: Avon, 1993.

GABRIEL, Y. Freud e a sociedade. Trad. V. Ribeiro. Rio de Janeiro: Imago, 1988.

GAGNEBIN, J. M. Lembrar escrever esquecer. 2. ed. São Paulo: São Paulo, Ed. 34, 2006.

GAGNEBIN, J. M. História e narração em Walter Benjamin. 2. ed. São Paulo: Perspectiva, 2004. 
GALBRAITH, J. K. A era da incerteza. Trad. F. R. N. Pellegrini. 9. ed. São Paulo: Pioneira, 1998. (Novos Umbrais).

GARCIA CANCLINI, N. Culturas híbridas. Buenos Aires: Editorial Sudamericana, 1992.

GARCÍA PONCE, J. La errancia sin fin: Musil, Borges, Kosowski. 2. ed. Barcelona: Anagrama, 2001.

GAUSSEN, F. O campo da liberdade. In: ENTREVISTAS do Le Monde. Sociedade. Trad. S. Flaksman. São Paulo: Ática, 1989.

GAY, P. A experiência burguesa da Rainha Vitória a Freud: a educação dos sentidos. Trad.

P. Salter. São Paulo: Companhia das Letras, 1988. v. 1.

GAY, P. A experiência burguesa da Rainha Vitória a Freud: o cultivo do ódio. Trad. S. G.

Paula; V. de Lamare Noronha. São Paulo: Companhia das Letras, 1988. v. 3.

GAY, P. Weimar culture: the outsider as insider. New York: Harper \& Row, 1968.

GELLNER, E. Condições da liberdade: a sociedade civil e seus rivais. Trad. L. Magalhães. Rio de Janeiro: Jorge Zahar, 1996.

GERTH, H. H; MILLS, C. W. From Max Weber. Essays in sociology. New York: Routledge, 1991.

GOLDMANN, L. La creación cultural en la sociedad moderna. Trad. F. Cusó. Barcelona: Editorial Fontamara, 1980.

GOLDMANN, L. Pour une sociologie du romain. Paris: Gallimard, 1964.

GORZ, A. Capitalisme, socialisme, écologie: désorientation, orientation. Paris: Galilée, 1991.

GRANGER, G. G. O irracional. Trad. A. Lorencini. São Paulo: UNESP, 2002.

GROSS, P.; LEVITT, N. Higher superstition: the academic quarrels with science. 2. ed. Baltimore: John Hopkins, 1998.

GIDDENS, A. A constituição da sociedade. Trad. A. Cabral. São Paulo: Martins Fontes, 2003.

GIDDENS, A. Modernidade e identidade. Trad. P. Dentzien. Rio de Janeiro: Zahar, 2002. 
GIDDENS, A.; BECK, U.; LASH, S. Modernização reflexiva: política, tradição e estética na ordem social moderna. Trad. M. Lopes. São Paulo: Ed. UNESP, 1997. (Col. Biblioteca Básica).

GIDDENS, A. A transformação da intimidade: sexualidade, amor e erotismo nas sociedades modernas. Trad. M. Lopes. São Paulo: Ed. UNESP, 1992. 228p.

GIDDENS, A. As conseqüências da modernidade. Trad. R. Fiker. São Paulo: Ed. UNESP, 1991.

GUATTARI, F. Caosmose: um novo paradigma estético. Trad. A. L. de Oliveira; L. C. Leão. São Paulo: Ed. 34, 1992. (Coleção TRANS).

GOFFMAN, E. Estigma: notas sobre a manipulação da identidade deteriorada. 4. ed. Trad. M. B. M.L. Nunes. Rio de Janeiro: LTC, 1988.

GUINSBURG, J. (Org.). A paz perpétua: um projeto para hoje. Trad. J. Guinsburg. São Paulo: Perspectiva, 2004. (Coleção Elos).

GOLDMANN, L. Sociologia do romance. 3. ed. Trad. A. Cabral. Rio de Janeiro: Paz e Terra, 1990. (Coleção Literatura e Teoria Literária).

GUMPLOWICZ, L. Sociologie et politique. 5. reimpr. Pref. René Worms. Paris: Giard \& Brière, [1898]. (Bibliotèque Sociologique Internationale,12).

HABERMAS, J. O Ocidente dividido. Trad. L. Villas Bôas. Rio de Janeiro: Tempo Brasileiro, 2006. (Biblioteca Colégio do Brasil; 13).

HABERMAS, J. O futuro da natureza humana: a caminho de uma eugenia liberal? Trad. K. Jannini. São Paulo: Martins Fontes, 2004. (Coleção Tópicos).

HABERMAS, J. Era das transições. Trad. e introd. F. B. Siebeneichler. Rio de Janeiro: Tempo Brasileiro, 2003.

HABERMAS, J. A crise de legitimação no capitalismo tardio. 2. ed. Trad. V. Chacon. Rio de Janeiro: Edições Tempo Brasileiro, 2002. (Biblioteca Tempo Universitário - Séries Estudos Alemães).

HABERMAS, J. A inclusão do outro: estudos de teoria política. Trad. G. Sperber; P. A. Soethe. São Paulo: Edições Loyola, 2002. (Coleção Humanística). 
HABERMAS, J. Textos e contextos. Trad. S. L. Vieira. Lisboa: Instituto Piaget, 2001. (Coleção Pensamento e Filosofia).

HABERMAS, J. Comentários à ética do discurso. Trad. G. L. Encarnação. Lisboa: Instituto Piaget, 1991. (Coleção Pensamento e Filosofia).

HABERMAS, J. O discurso filosófico da modernidade. Trad. A. M. Bernardo et al. Lisboa: Publicações Dom Quixote, 1990. (Nova Enciclópedia).

HABERMAS. Modernity versus Postmodernity [1979], New German Critique 22, 1981.

HABERMAS, J. et al. Conversaciones con Herbert Marcuse. Trad. G. Muñoz. Barcelona: Gedisa, 1980. (Col. Libertad y Cambio; Serie Conversaciones).

HABERMAS, J. Trabalho e interação. Técnica e ciência como “ideologia". Lisboa: Ed. 70, 1968.

HALL, S. Da diáspora: identidades e mediações culturais. Liv Sovik (Org.). Trad. A. La Guardia Resende et al. Belo Horizonte: UFMG, 2006

HALL, S. A identidade cultural na pós-modernidade. 8 ed. Trad. T. T. da Silva; G. L. Louro. Rio de Janeiro: DP \& A, 2003.

HANKE, M. A qualidade do homem sem qualidades. Trad. G. Otte. Revista Alceu, v. 4, n. 8, p. 128-140, jan./jun. 2004.

HARDT, M.; NEGRI, A. Multidão: guerra e democracia na era do império. Trad. C. Marques. Rio de Janeiro: Record, 2005.

HARVEY, D. Condição pós-moderna: uma pesquisa sobre as origens da mudança cultural. 13. ed. Trad. A. U. Sobral et al. São Paulo: Loyola, 2003.

HEELAS, P. The new age movement: the celebration of the self and the sacralization of modernity. Cambridge: Blackwell Publishers, 1996.

HEGEL, G. W. F. Fenomenologia do espirito. Trad. P. Menezes e K.-H. Efken. Apresentação H. Vaz. Petrópolis: Vozes, 1992a. Parte 1. (Col. Pensamento humano). 
HEGEL, G. W. F. A fenomenologia do espirito. Estética. A idéia e o ideal. Estética. O belo artístico e o ideal. Introdução à história da filosofia. Trad. Guimarães editores; A. Amado. São Paulo: Abril, 1974. (Os Pensadores, XXX).

HEIDEGGER, M. Todos nós... ninguém: um enfoque fenomenológico do social. Trad. e comentário D. M. Critelli. São Paulo: Moraes, 1981.

HELLER, A.; FEHÉR, F. A condição política pós-moderna. 2. ed. Trad. M. Santarrita. Rio de Janeiro: Civilização Brasileira, 2002.

HENDERSON, L.D. Die moderne Kunst und das Unsichtbare: Die verborgenen Wellen und Dimensionen des Okkultismus und der Wissenschaften. In: SEEMANN, H.; LOERS, V. (Ed.). Okkultismus und Avantgarde. Von Munch bis Mondrian 1900-1915.Frankfurt: Tertium, 1995. p. 13-31.

HENNINGER, P. Der Buchstabe und der Geist: Unbewußte Determinierung im Schreiben Robert Musils. Frankfurt a.M.: Lang, 1980.

HERRMANN, F.; LOWENKRON, T (Org.). Pesquisando com o método psicanalítico. São Paulo: Casa do Psicólogo, 2004.

HICKMAN, H. Robert Musil and the culture of Vienna. La Salle: Open Court, 1991.

HIRSCHMAN, A. O. A retórica da intransigência: perversidade, futilidade, ameaça. Trad. T. R. Bueno. São Paulo: Companhia das Letras, 1992.

HOBBES, T. Leviatã : ou matéria, forma e poder de um estado eclesiástico e civil. Trad. A. Marins. São Paulo: Martin Claret, 2002.

HOBBES, T. Do cidadão. Trad. R. J. Ribeiro. São Paulo: Martins Fontes, 1998.

HOBSBAWM, E. O novo século: entrevista a Antonio Polito. Trad. A. Cameron; C. Marcondes. São Paulo: Companhia das Letras, 2000.

HOBSBAWM, E. Sobre a história. 4. reimp. Trad. C. Knipel. São Paulo: Companhia das Letras, 1997.

HOBSBAWM, E. Era dos extremos: o breve século XX: 1914-1991. 2. ed. Trad. M. Santarrita. São Paulo: Companhia das Letras, 1995. 
HOFMANNSTHAL, H. Reden und Aufsätze I, 1891-1913, Frankfurt a.M.: Fischer: Bernd Schoeller, 1979.

HOFSTADTER, R. The paranoid style in America politics and other essays. New York: New York: Random House, 1967.

HOHENDAHL, P. U. The Scholar, the Intellectual, and the Essay: Weber, Lukács, Adorno, and Postwar Germany, The German Quartely 70.3, Verão de 1997.

HORKHEIMER, M. Teoria crítica: uma documentação. Trad. H. Cohn. São Paulo: Perspectiva, 2006.

HORKHEIMER, M. Eclipse da razão. Trad. S. U. Leite. São Paulo: Centauro, 2003.

HORKHEIMER, M. Dialética do esclarecimento: fragmentos filosóficos. Trad. G. A. de Almeida. Rio de Janeiro: Jorge Zahar Ed., 1985.

HUCK, R. Die Blütezeit der Romantik. Leipzig: Haessel, 1905.

HUME, D. Tratado da natureza humana: uma tentativa de introduzir o método experimental de raciocínio nos assuntos morais. Trad. D. Danowski. São Paulo: UNESP, 2000.

HUME, D. Uma investigação sobre os princípios da moral. Trad. J. O. A. Marques. Campinas: Editora da UNICAMP, 1995.

HUTTON, W.; GIDDENS, A. (Org.). No limite da racionalidade: convivendo com o capitalismo global. Trad. M. B. de Medina. Rio de Janeiro: Record, 2004.

HUXLEY, A. Admirável mundo novo. Trad. F. Albuquerque. São Paulo: Abril, 1980.

HYPPOLITE, J. Ensaios de psicanálise e filosofia. Trad. e introdução de J. Birman. Rio de Janeiro: Taurus-Timbre Editores, 1989.

IMBRIZI, J. M. A formação do indivíduo no capitalismo tardio: uma análise de estudos que vinculam a esfera subjetiva ao mundo do trabalho. São Paulo: Hucitec, 2005. 326p. (Saúde loucura, Textos;17).

INSTITUTO Antônio Houaiss. Dicionário Houaiss da língua portuguesa. 2. reimp. Rio de Janeiro: Objetiva, 2007. 
ISER, W. O ato de leitura: uma teoria do efeito estético. Trad. J. Kretschmer. São Paulo: Ed. 34, 1996. (Coleção Teoria, 1).

JACÓ-VILELA, A.; MANCEBO, D. (Org.). Psicologia social. Abordagens sócio-históricas e desafios contemporâneos. Rio de Janeiro, E. UERJ, 1999.

JACOBY, R. O fim da utopia: política e cultura na era da apatia. Trad. C. Marques. Rio de Janeiro, São Paulo: Record, 2001.

JAMESON, F. As sementes do tempo. Trad. J. R. Siqueira. São Paulo: Ática, 1997. (Série Temas).

JAMESON, F. Pós-modernismo: a lógica cultural do capitalismo tardio. Trad. M. E. Cevasco. São Paulo: Ática, 1996. (Série Temas).

JAMESON, F. Marcas do visivel. Trad. A. L. de A. Gazolla et al. Rio de Janeiro: Graal, 1995.

JAMESON, F. O inconsciente político. A narrativa como ato socialmente simbólico. Trad. V. L. Siqueira. São Paulo: Ática, 1992.

JASMIN, G. M. Aléxis de Tocqueville: a historiografia como ciência da política. 2. ed. Belo Horizonte: Ed. UFMG/ IUPERJ, 2005.

JANICK, A.; TOULMIN, S. Wittgenstein Vienna. New York: Simon \& Schuster, 1983.

JAUSS, R. H. et al. A literatura e o leitor: textos de estética da recepção. Seleção, trad. e introdução Luiz Costa Lima. Rio de Janeiro: Paz e Terra, 1979. (Literatura e teoria literária, 36).

JEUDY, H.-P. Espelho das cidades. Trad. R. Janowitzer. Rio de Janeiro: Casa da Palavra, 2005.

JONSSON, S. Subject without nation: Robert Musil and the history of modern identity. Durham: Duke University Press, 2000.

KANDINSKY, W.; MARC, F. On the question of form. New York: DaCapo, 1989.

KANDINSKY, W. Concerning the spiritual in art. Trad. M.T.H. Sadler. New York: Dover, 1977. 
KANGUSSU, I. M. G. Leis da liberdade: a relação entre estética e política na obra de Herbert Marcuse. 2001. 314 f. Tese (Doutorado em Estética e Filosofia da Arte) - Faculdade de Filosofia e Ciências Humanas, Universidade Federal de Minas Gerais, Belo Horizonte, 2001.

KANT, I. Crítica da razão prática. Trad. R. Schaefer. São Paulo: Martin Claret, 2003. (Coleção Obra-prima de cada autor).

KANT, I. Crítica da faculdade do juizo. 2. ed. Trad. V. Rohden; A. Marques. Rio de Janeiro: Forense Universitária, 1995.

KANT, I. Crítica da razão pura. 2. ed. Trad. M. P. dos Santos et. al. Lisboa: Fundação Calouste Gulbenkian, 1989.

KANT, I. Resposta à pergunta: O que é "Esclarecimento"? In: Textos seletos. Petrópolis: Vozes, 1974. p. 100-17.

KAUFMAN, M. (Ed.). Basic writtings of Nietzsche. New York: Random House, 2000. (Modern library classics).

KELLNER, D. A cultura da mídia - estudos culturais: identidade e política entre o moderno e o pós-moderno. Trad. I. C. Benedetti. Bauru: EDUSC, 2001. (Coleção Verbum).

KLEIN, M. Developments in theory and practise. E. Bott Spilles (Ed.) London; New York: Routledge, 1988.

KOESTLER, A. Jano. Trad. N. Deola; A. Deola. São Paulo: Melhoramentos, 1981.

KOESTlER, A. O fantasma da máquina. Trad. C. M. Oiticica; H. de Queiroz Facó. Rio de Janeiro: Zahar Editores, 1969.

KORNHAUSER, W. The politics of Mass Society. Chicago: Free Press, 1959.

KRISTEVA, J. Estrangeiros para nós mesmos. Trad. M. C. C. Gomes. Rio de Janeiro: Rocco, 1994.

KRYSINSKI, W. Dialética da transgressão. O novo e o moderno na literatura do século XX. Trad. I. A. Neis. Rio de Janeiro: Perspectiva, 2007. 
KYMLICKA, W. Ciudadanía multicultural. Barcelona: Paidós, 1996.

LA BOÉTIE, E. et al. Discurso da servidão voluntária. Trad. L. G. dos Santos. São Paulo: Brasiliense, 1999. (Elogio da filosofia).

LACAN, J. O seminário - livro 16: de um Outro ao outro. Trad. V. Ribeiro. Rio de Janeiro: Jorge Zahar, 2006

LACAN, J. Nomes-do-pai. Trad. A. Telles. Rio de Janeiro: Jorge Zahar Editor, 2005.

LACAN, J. O seminário - livro 2: o eu na teoria de Freud e na técnica de psicanálise. Trad. M. C. L. Penot; A. Quinet. Rio de Janeiro: Jorge Zahar Ed., 2005.

LaCAPRA, D. Trauma, absence, loss, Critical Inquiry, 25, p. 696-727, 1999.

LALANDE, A. Vocabulário técnico e crítico da filosofia. Trad. F. S. Correia et al. São Paulo: Martins Fontes, 1993.

LAPLANCHE, J.; PONTALIS, J.-B. Vocabulário da psicanálise. 2. ed. Trad. P. Tamen. São Paulo: Martins Fontes, 1994.

LASCH, C. O mínimo eu: sobrevivência psíquico em tempos difíceis. 4. ed. Trad. J. R. M. Filho. São Paulo: Brasiliense, 1987.

LASCH, C. A cultura do narcisismo: a vida americana numa era de esperanças em declínio. Trad. E. P. Moura. Rio de Janeiro: Imago, 1983.

LASCH, C. The revival of political controversy in the sixties. In: The agony of American left. New York: Vintage, 1969.

LATOUR. Jamais fomos modernos: ensaio de antropologia simétrica. Trad. Carlos I. da Costa. Rio de Janeiro: Ed. 34, 2005. (Coleção TRANS).

LATOUR, B. O exótico homem das cidades. Folha de S. Paulo, São Paulo, 12 abr. 1998. Caderno Mais!.

LATOUCHE, S. A ocidentalização do mundo: ensaio sobre a significação, o alcance e os limites da uniformização planetária. Trad. C. M. Pacionick. Petrópolis: Vozes, 1994 (Coleção horizontes da globalização). 
LEFEBVRE, H. A revolução urbana. $2^{\mathrm{a}}$. reimp. Trad. S. Martins. Belo Horizonte: Ed. UFMG, 2004.

LE GOFF, J. A história nova. 5. ed. Trad. E. Brandão. São Paulo: Martins Fontes, 2005.

LE GOFF, J. História e memória. 5. ed. Trad. B. Leitão et al. Campinas: Ed. Unicamp, 2003.

LEIBNIZ, G. W. Novos ensaios sobre o entendimento humano. Trad. L. J. Baraúna. São Paulo: Nova Cultural, 1999.

LEPENIES, W. Between literature and science: The rise of Sociology, 1985. Trad. R. J. Hollingdale. Cambridge: Cambridge University Press, 1988.

Le RIDER, J. A modernidade vienense e as crises de identidade. Trad. E. Gaidano. Rio de Janeiro: Civilização Brasileira, 1993.

Le RIDER, J. et al. Em torno de O mal-estar na cultura, de Freud. Trad. C. L. M. Valladares de Oliveira; C. Koltai. São Paulo: Escuta, 2002.

LÉVI-STRAUSS, C. O pensamento selvagem. 5. ed. Trad. T. Pellegrini. Campinas: Papirus, 2004.

LICHTENSTEIN, H. The dilemma of human identity. New York: Jason Aronson, 1977.

LIMA, C. L (Sel.). A literatura e o leitor. Textos de estética da recepção. Trad. L. C. Lima. Rio de Janeiro: Paz e Terra, 1979.

LINDNER, M. Leben in der Krise. Zeitromane der neuen Sachlichkeit und die intellektuelle Mentalität der klassischen Moderne. Stuttgart: Metzler, 1994.

LIPOVETSKY, G. A felicidade paradoxal: ensaio sobre a sociedade de hiperconsumo. Trad. M. L. Machado. São Paulo: Companhia das Letras, 2007.

LIPOVETSKY, G. A sociedade pós-moralista: o crepúsculo do dever e a ética indolor dos novos tempos democráticos. Trad. A. B. Ara Barueri: Manole, 2005.

LIPOVETSKY, G. Metamorfoses da cultura liberal: ética, mídia, empresa. Trad. J. M. da Silva. Porto Alegre: Meridional, 2004. 
LIPOVETSKY, G; CHARLES, S. Os tempos hipermodernos. Trad. M. Vilela. São Paulo: Barcarolla, 2004.

LIPOVETSKY, G. A era do vazio. Ensaio sobre o individualismo contemporâneo. Trad. M. S. Pereira; A. L. Faria. Lisboa: Relógio D’água, 1989.

LLOYD, D. A idéia de lei. 2. ed. Trad. A. Cabral. São Paulo: Martins Fontes, 1998. (Coleção Justiça e Direito).

LOCKE, J. Ensaio acerca do entendimento humano. Trad. A. Aiex. São Paulo: Nova Cultural, 2005.

LORENZ, K. A demolição do homem: crítica à falsa religião do progresso. Trad. H. Wertig. São Paulo: Ed. Brasiliense, 1986.

LOWEN, A. Narcisismo. Negação do verdadeiro self. Trad. A. Cabral. São Paulo: Cultrix, 1993.

LÖWY, M. Walter Benjamin, aviso de incêndio: uma leitura das teses Sobre o conceito de história. Trad. W. C. Brant; J. M. Gagnebin; L. Muller. São Paulo: Boitempo, 2005.

LUFT, D. S. Robert Musil and the crisis of European culture, 1880-1942. Berkkeley: University of California Press, 1980.

LUKÁCS, G. História e consciência de classe: estudos sobre a dialética marxista. Trad. R. Nascimento. São Paulo: Martins Fontes, 2003. (Coleção Tópicos).

LUKÁCS, G. A teoria do romance: um ensaio histórico-filosófico sobre as formas da grande épica. Trad. J. M. M. de Macedo. São Paulo: Duas Cidades, Ed. 34, 2000. (Coleção Espírito Crítico).

LYOTARD, J.-F. A condição pós-moderna. 9. ed. Trad. R. C. Barbosa. Posfácio Silviano Santiago. Rio de Janeiro: José Olympio, 2006.

LYOTARD, J.-F. O inumano. Considerações sobre o tempo. Trad. A. C. Seabra; E. Alexandre. 2. ed. Lisboa: Editorial Estampa, 1997.

LYOTARD, J.-F. O pós-moderno. 9. ed. Trad. R. C. Barbosa. Rio de Janeiro: José Olympio, 1986. 
MACH, E. The analysis of sensations and the relation of the physical to the psychical. Trad. C. M. Williams. New York: Dover, 1959.

MACINTYRE, A. As idéias de Marcuse. Trad. J. Martins. São Paulo: Cultrix, 1973.

MAFFESOLI, M. O tempo das tribos. O declínio do individualismo nas sociedades de massa. 4. ed. Trad. M. L. Menezes; D. C. Barros. Rio de Janeiro: Forense, 2006.

MAFFESOLI, M. Notas sobre a pós-modernidade: o lugar faz o elo. Trad. V. Ribeiro. Rio de Janeiro: Atlântica Ed., 2004.

MAGRIS, C. L'anello di Clarice: grandestile e nichilismo nella letteratura moderna. Milan: Giulio Einaudi Editore, 1984.

MALLARD, L. Literatura e dissidência politica. Belo Horizonte, Ed. UFMG, 2006.

MANN, T. Reflections of a non-political man. Trad. W. D. Morris. New York: Ungar, 1987.

MANN, T. A montanha mágica. Trad. H. Caro. Rio de Janeiro: Nova Fronteira, 1980.

MANNHEIM, K. Ideology and utopia. An introduction to the sociology of knowledge. Trad. L. W; E. Shils. New York: Harcourt, Brace \& World, 1968.

MANNONI, M. A teoria como ficção: Freud, Grodeck, Winnicott, Lacan. Trad. R.. C. Lacerda; W. Dutra. Rio de Janeiro: Campus, 1982. (Textos contemporâneos em psicologia, psicanálise e psiquiatria, 7).

MARCUSE, H. Eros e civilização: uma interpretação filosófica do pensamento de Freud. 8. ed. Trad. Á. Cabral. Rio de Janeiro: Guanabara, [s.d.].

MARCUSE, H. Cultura e psicanálise. Seleção Isabel Loureiro. Trad. Wolfgang Leo Maar, Robespierre de Oliveira e Isabel Loureiro. São Paulo: Paz e Terra, 2001. (Col. Leitura).

MARCUSE, H. Comentários para uma redefinição da cultura. Trad. R. Oliveira. In: . Cultura e psicanálise. São Paulo: Paz e Terra, 2001.p. 78-111.

MARCUSE, H. A noção de progresso à luz da psicanálise. In: . Cultura e psicanálise. São Paulo: Paz e Terra, 2001. p. 112-138. 
MARCUSE, H. Sobre o caráter afirmativo da cultura. Trad. W. L. Maar. In: Cultura e psicanálise. São Paulo: Paz e Terra, 2001. p. 7-77.

MARCUSE, H. A sociedade como obra de arte. Trad. R. C. Barbosa. Novos Estudos CEBRAP, n. 60, p. 45-52, jul. 2001.

MARCUSE, H. A grande recusa hoje. Trad. I. Loureiro; R. de Oliveira. Petrópolis: Vozes, 1999.

MARCUSE, H. Tecnologia, guerra e fascismo. KELLNER, D. (Ed.). Trad. M. C. V. Borba. São Paulo: UNESP, 1999.( Biblioteca Básica).

MARCUSE, H. A obsolescência da psicanálise. In: . Cultura e sociedade. Trad. I. Loureiro.

São Paulo: Paz e Terra, 1998. v. 2.

MARCUSE, H. Teoria y politica. Trad. M. J. Redondo. Valencia: Revista Teorema, 1980.

MARCUSE, H. Razão e revolução: Hegel e o advento da teoria social. 3. ed. Trad. M. Barroso. Rio de Janeiro: Paz e Terra, 1978. (O Mundo Hoje, 28).

MARCUSE, H. Un nouvel ordre, Le Monde Diplomatique, n. 268, jun.1976.

MARCUSE, H. et al. Ecología y revolución. Buenos Aires: Nueva Visión, 1975. (Coleção Fichas, $45)$.

MARCUSE, H. et al. La sociedad industrial contemporanea. 8. ed. Trad. M. S. Prieto; J. Campos. México: Siglo Veintiuno Editores, 1974.

MARCUSE, H. Contra-revolução e revolta. Trad. A. Cabral. Rio de Janeiro: Zahar Editores, 1973.

MARCUSE, H. Idéias sobre uma teoria crítica da sociedade. Trad. F. Guimarães. Rio de Janeiro: Zahar Editores, 1972.

MARCUSE, H. O fim de uma utopia. Trad. C. N. Coutinho. Rio de Janeiro: Paz e Terra, 1969.

MARCUSE, H. Liberdade e agressão na sociedade tecnológica. Trad. A. Vasconcellos. Revista Civilização Brasileira, v.3, n.18, mar./abr.1968. 
MARX, K. First Manuscript: Alienated. In: FROMM, E.; BOTTOMORE, B.T. Economic and philosophical manuscripts, Karl Marx. Trad. T. B. Bottomore. London: The Tower Building, 2004.

MARX, K. Manuscritos econômico-filosóficos e outros textos escolhidos. Trad. publicada sob licença da Ed. Paz e Terra. São Paulo: Abril, 1972.

MARX, K. Manuscritos econômicos: excertos de ideologia alemã. In: FROMM, E. Conceito marxista de homem. Rio de Janeiro: Zahar, 1961.[s.r.c.]

MATOS, O. Discretas esperanças. São Paulo: Ed. Nova Alexandria, 2006.

MATTICK, P. Crítica de Marcuse: el hombre unidimensional en la sociedad de clases.

Trad. A. Pérez. Barcelona: Ediciones Grijalbo, 1974.

MAUTHNER, F. Beiträge zu einer Kritik der Sprache. 1901-2. Hildesheim: Olms, 1967.

MAUTHNER, F. Gottlose Mystik. Dresden: Carl Reissnner, 1924.

McBRIDE, P. C. The void of ethics: Robert Musil and the experience of modernity. Evanston: Northwestern University Press, 2006.

McCORMICK, J. P. Confronting mass democracy and industrial technology: political and society theory from Nietszche to Habermas. Durham: Duke University Press, 2002.

MERLEAU-PONTY, M. A natureza. Curso do Collège de France. Trad. A. Cabral. São Paulo: Martins Fontes, 2000.

MEZAN, R. A vingança da esfinge. Ensaios de psicanálise. São Paulo: Brasiliense, 1988.

MEZAN, R. Freud, pensador de cultura. São Paulo: Brasiliense; Brasília: CNPq, 1985.

MILLER, J-A. L'ére de l'homme sans qualités, La Cause Freudienne, Paris, n. 57, p. 73-97, juin 2004. (Politique Psy).

MOLES, A et al. Teoria da cultura de massa. Introdução, comentários e seleção de Luiz Costa Lima. 6. ed. São Paulo: Paz e Terra, 2000. 
MOMMSEN, W. J. Imperial Germany 1867-1918: Politics, culture and society in an authoritarian state. Trad. R. Deveson. Londres: Arnold, 1995.

MONTI. Musil. La metafora della scienza. Napoli: Pironti, 1983.

MORA, J. F. Dicionário de filosofia. Ed. abrev. Preparada por E. G. Belsunce; E. de Olaso. Lisboa: Publicações Dom Quixote, 1982.

MORIN, E. Cultura de massas no século XX (O espírito do tempo). 2. ed. Trad. M. R. Sardinha. São Paulo: Forense, 1969.

MORUS, T. A utopia. Trad. P. Neves. Porto Alegre: LP\&M, 1997.

MOSCOVICCI, S. Representações sociais: investigações em psicologia social. 3. ed. Trad. P. Guareschi. Petrópolis: Vozes, 2003.

MUNFORD, L. A condição do homem: uma análise dos propósitos e fins do desenvolvimento humano. Trad. V. de Miranda Reis. Porto Alegre: Globo, 1952.

NEUMANN, F. Estado democrático e estado autoritário. Trad. L. Corção. Rio de Janeiro: Zahar Editores, 1969.

NIETZSCHE, F. A vontade de poder. Trad. M. S. P. Fernandes; F. J. Dias de Moraes. Rio de Janeiro: Contraponto, 2008.

NIETZSCHE, F. O nascimento da tragédia ou helenismo e pessimismo. Trad. J. Guinsburg. São Paulo: Companhia das letras, 2007.

NIETZSCHE, F. Sabedoria para depois de amanhã. Trad. K. Jannini. São Paulo: Martins Fontes, 2005.

NIETZSCHE, F. Humano, demasiado humano: um livro para espíritos livre. Trad. P. César de Souza. São Paulo: Companhia das letras, 2000.

NIETZSCHE, F. Genealogia da moral: uma polêmica. Trad. P. César de Souza. São Paulo: Companhia das letras, 1999.

NIETZSCHE, F. Além do bem e do mal: prelúdio a uma filosofia do futuro. 2. ed. Trad. P. César de Souza. São Paulo: Companhia das Letras, 1998. 
NIETZSCHE, F. Unfashionable observations. In: Complete works of Friedrich Nietzsche.

Trad. R. T. Gray. Paulo Alto: Stanford University Press, 1995. v.2.

NOVAES, A. (Org.) et al. Civilização e barbárie. São Paulo: Companhia das Letras, 2004.

NOVAES, A. (Org.) et al. O avesso da liberdade. São Paulo: Companhia das Letras, 2002.

NOVAES, A. (Org.) et al. A outra margem do ocidente. São Paulo: Companhia das Letras, 1999.

NOVAES, A. (Org.) et al. A crise da razão. São Paulo: Companhia das Letras, 1996.

NOVAES, A. (Org.) et al. O olhar. São Paulo: Companhia das Letras, 1988.

OFFE, C. The utopia of the zero-option modernity and modernization as normative political criteria. Praxis International, v. 7, n. 1, p.1-24, 1987.

OFFE, C. New social movements: challenging the boundaries of institutional politics. Social Research, v. 52, n.4, p. 817-68, 1985.

OFFE, C. Problemas estruturais do Estado capitalista. Trad. B. Freitag. Rio de Janeiro:

Tempo Brasileiro, 1984. (Biblioteca Tempo Universitário - Série Estudos Alemães).

ORTEGA Y GASSET. A rebelião das massas. Trad. M. P. Michael. 2. ed. São Paulo: Martins Fontes, 2002. (Tópicos).

ORWELL, G. 1984. Trad. W. Velloso. 16. ed. São Paulo: Nacional, 1983. (Biblioteca do Espírito Moderno, série 4, Literatura, 24).

OUTHWAITE, W.; BOTTOMORE, T. (Ed.). Dicionário do pensamento social do século XX. Rio de Janeiro: Jorge Zahar Ed., 1996.

PAHL, R. Depois do sucesso. Ansiedade e identidade Fin-de-Siècle. Trad. G. C. Cardoso de Sousa. São Paulo: Editora UNESP, 1997.

PAREYSON, L. Os problemas da estética. Trad. M. H. Nery Garcez. São Paulo: Martins Fontes, 2001.

PARFIT, D. Reasons and persons. New York: Oxford University Press, 1986. 
PAYNE, P. Robert Musil's works, 1906 -1924: a critical introduction. 2.ed. rev. Frankfurt am Main: Peter Lang, 1989.

PAZ, F. M. et al. Utopia e modernidade. Curitiba: Ed. UFPR, 1994. 245 p. (Série Pesquisa).

PESSIS-PASTERNACK, G. Do caos à inteligência artificial; quando os cientistas se interrogam. 2. reimp. Trad. L. P. Rouanet. São Paulo: Ed. UNESP, 1993. (Biblioteca básica).

PEYRET, Jean-François. 'Musil ou les contraditions de la modernité'. Critique: Vienne, début d'un siècle. Aout-septembre. Tome XXXI, n. 339-340. Paris: Minuit, 1975, p. 846-863.

PIKE, B. Robert Musil: An introduction to his Work. New York: Cornell University Press, 1961.

PLATÃO. Apologia de Sócrates. Banquete. Trad. J. Melville. São Paulo: Martin Claret, 2006. (Coleção A Obra-Prima de Cada Autor).

PONCE, J. G. La errancia sin fin: Musil, Borges, Klossowski. Barcelona: Editorial Anagrama, 2001.

POPPER, K. R. A lógica das ciências sociais. 3. ed. Trad. E. de R. Martins et al. Rio de Janeiro: Tempo Brasileiro, 2004.

POPPER, K. A sociedade aberta e seus inimigos. 3. ed. Trad. M. Amado. Belo Horizonte: Itatiaia; São Paulo: EDUSP, 1987. Tomo 2. (Biblioteca de Cultura Humanista).

POPPER, K. R. A lógica da pesquisa científica. Trad. L. Hegenberg; S. da Mota. São Paulo: Cultrix, 1978.

PRIGOGINE, I. Leis do caos. Trad. R. L. Ferreira. São Paulo: Ed. UNESP, 2002.

PRIGOGINE, I.; STENGERS, I. A nova aliança: metamorfose da ciência. Trad. M. Faria; M. J. M. Trincheira. Brasília: Ed. UNB, 1991.

RABINBACH, A. In the shadow of catastrophe. German intellectuals between Apocalipse and Enlightenment. Berkley: University of California Press, 1997.

RAMONET, I. Guerras do século XXI: novos temores e novas ameaças. Trad. L. Magalhães. Petrópolis: Vozes, 2003. 
RAMONET, I. Geopolítica do caos. 4. ed. Trad. G. J. de F. Teixeira. Petrópolis: Ed. Vozes, 1998. (Coleção Zero à esquerda).

RANCIÈRE, J. A partilha do sensivel: estética e política. Trad. M. C. Netto. São Paulo: Ed. 34, 2005.

RANCIÈRE, J. O desentendimento: política e filosofia. Trad. A. L. Lopes. São Paulo: Ed. 34, 1996. (Col. TRANS).

RATZENHOFER, G. Sociological knowledge: the positive philosophy of social life. London: Ayer Co., 1975. (European sociology series).

RAWLS, J. Justiça como eqüidade: uma reformulação. Trad. C. Berliner. São Paulo: Martins Fontes, 2003. (Coleção Justiça e Direito).

RAWLS, J. Justiça e democracia. Trad. I. A. Paternot. São Paulo: Martins Fontes, 2000.

REALE, G.; ANTISERI, D. História da filosofia: do romantismo até nossos dias. Trad. A. Cunha. São Paulo: Paulus, 1991. 3 v.

RENAULT, A. O indivíduo. Reflexão acerca da filosofia do sujeito. Trad. E. Gaidano. 2. ed. Rio de Janeiro: Difel, 2004. (Coleção Enfoques, Filosofia).

RIBEIRO, R. J. A marca do Leviatã : linguagem e poder em Hobbes. São Paulo: Ateliê Editorial, 2003.

RICOEUR, P. O tempo e narrativa. Trad. R. L. Fereira. Campinas: Papirus, 1997. t. III.

RICOEUR, P. O si-mesmo como um outro. Trad. L. M. César. Campinas: Papirus, 1991.

RIECKMANN, J. Aufbruch in die Moderne. Die Anfänge des Jungen Wien. Königstein/Taunus: Athenäum, 1985.

RIESMAN, D. A multidão solitária: um estudo da mudança do caráter americano. 2. ed. Trad. R. R. Krausz; J. Guinsburg. São Paulo: Perspectiva, 1995. (Coleção Debates).

ROCHE, S. La société incivile: qu' est-de que l' insécurité? Paris: Seuil, 1996.

ROGOWSKI, C. Distinguished outsider: Robert Musil and his critics. Columbia: Camden, 1994. 
RORTY, R. A filosofia e o espelho da natureza. Trad. A. Trânsito. Rio de Janeiro: RelumeDumará, 1994.

RYAN, J. The vanishing subject: early psychology and literary modernism. Chicago: University of Chicago Press, 1991.

RUSHDIE, S. Imaginary homelands: essays and criticism. London: Granta Books; New York: Penguin, 1991.

SAER, J. J. Genealogia do homem sem qualidades. Disponível em http://biblioteca.folha.com.br./1/27/2001052001.html. Acesso em 15/04/2007.

SAFOUAN. Estudos sobre o Édipo: introdução a uma teoria do sujeito. Trad. A. S. Stysei. Rio de Janeiro: Jorge Zahar Ed., 1979.

SAnTO AGOStinHO. Confissões. Trad. J. O. Santos; A. A. de Pina. São Paulo, Nova Cultural, 1999.

SARTRE, J.-P. Que é a literatura? Trad. C. F. Moisés. 3. ed. São Paulo: Ática, 2004.

SARTRE, J.-P. O ser e o nada: ensaio de ontologia fenomenológica. 12. ed. Trad. P. Perdigão. Petrópolis: Vozes, 2003

SARTRE, J.-P. Em defesa dos intelectuais. Trad. S. G. de Paula. São Paulo: Ática, 1994. (Ponto de Vista).

SCHNEIDERS, W. Deutsche Philosophie im 20. Jahrhundert. Munich: Beck, 1998.

SCHÖPKE, R. Por uma filosofia da diferença: Gilles Deleuze, o pensador nômade. Rio de Janeiro: Contraponto, São Paulo: EDUSP, 2004.

SCHORSKE, C. E. Pensando com a história: indagações na passagem para o modernismo.

Trad. P. M. Soares. São Paulo: Companhia das Letras, 2000.

SCHORSKE, C. E. Viena fin-de-siècle: política e cultura. Trad. D. Bottmann. São Paulo: Companhia das Letras; Campinas: Ed. Unicamp, 1988.

SCHULTE-SASSE, J. Foreword: Theory of Modernism Versus Theory of the Avant-Garde. In: BURGER. Theory of the Avant-Garde. Trad. M. Shaw. Minneapolis: University of Minnesota Press, 1984. 
SCHULTZ, A. El problema de la realidad social. Trad. N. Míguez. Buenos Aires: Amorrortu editores, 1974.

SELIGMAN-SILVA, M. (Org.). História, memória, literatura: o testemunho na era das catástrofes. Campinas: Ed. UNICAMP, 2003.

SENNETT, R. A cultura do novo capitalismo. Trad. C. Marques. Rio de Janeiro, São Paulo: Record, 2006.

SENNET, R. A corrosão do caráter: conseqüências pessoais do trabalho no novo capitalismo. Trad. M. Santarrita. Rio de Janeiro: Record, 1999.

SERRES, M. O contrato natural. Rio de Janeiro: Nova Fronteira, 1991.

STERN, F. The politics of cultural despair: a study in the rise of the Germanic ideology. Berkeley: University of California Press, 1961.

SIDEKUM, A. (Org.). Alteridade e multiculturalismo. Ijuí: Ed. UNIJUÍ, 2003.

SILVA, T. T. da. (Org.). Nunca fomos humanos. Nos rastros do sujeito. Trad. T. T. da Silva. Belo Horizonte: Autêntica, 2001.

SILVA, V. A. Psicanálise da criação literária: as neuroses dos grandes escritores. Rio de Janeiro: Achiamé, 1984.

SIMMEL, G. Questões fundamentais da sociologia. Indivíduo e sociedade. Trad. P. Caldas. Rio de Janeiro: Jorge Zahar Ed., 2006.

SIMMONS, I. G. Humanidade e meio ambiente: uma ecologia cultural. Trad. L. Teopisto. Lisboa: Instituto Piaget, 2001. (Perspectivas Ecológicas).

SÓFOCLES. Édipo Rei. Trad. Donaldo Schüler. Rio de Janeiro: Lamparina Ed., 2004. (Coleção Cena Viva).

SONTAG, S. Diante da dor dos outros. Trad. R. Figueiredo. São Paulo: Companhia das Letras, 2003.

SORRENTINO, M. (Coord.). Ambientalismo e participação na contemporaneidade. São Paulo: EDUC, FAPESP, 2001. 
SPENGLER, O. La decadencia de Occidente: bosquejo de una morfologia de la historia universal. Trad. M. G. Morente. Madrid: Espasa Calpe, 1976. 2 v.

SPÖRL, U. Gottlose Mystik in der deutschen Literatur um die Jahrhundertwende. Paderborn: Schöningh, 1997.

STAROBINSKI, J. As máscaras da civilização. Trad. M. L. Machado. São Paulo: Companhia das Letras, 2001.

STEGMÜLLER, W. A filosofia contemporânea. Introdução crítica. Trad. Hauptströmungen der Gegenwartsphilosophie. São Paulo: EPU, 1977. v. 1.

STEIN, C. As erínias de uma mãe: ensaio sobre o ódio. Trad. N. da Silva Jr. São Paulo: Escuta, 1998.

STEIN, C. O psicanalista e seu ofício. Trad. N. da Silva Jr. São Paulo: Escuta, 1988.

STEIN, C. As erínias de uma mãe: ensaio sobre o ódio. Trad. N. da Silva Jr. Pref.. Renato Mezan. São Paulo: Escuta, 1988b.

STEIN, C. La mort d'Oedipe. Paris: Deöel, 1959.

STEINBERG, M. P. Austria as theater and ideology. The meaning of the Salzburg Festival. 2 ed. Ithaca: Cornell University Press, 2000.

STEINER, G. Gramáticas da criação. Trad. S. A. de Andrade. São Paulo: Globo, 2003.

STENGERS, I. A invenção das ciências modernas. Trad. M. Altman. São Paulo: Ed. 34, 2002. (TRANS).

STERN, F. The politics of cultural despair: a study in the rise of Germanic ideology. Berkeley: University of California Press, 1961.

STRUTZ, J.; STRUTZ, J. (Ed.) Robert Musil: Theater, Bildung, Kritik. Munich: Fink, 1985.

TASSARA, E. T. O. (Org.). Psicologia USP, São Paulo, v. 16, n. 1/2, 2005.

TASSARA, E. T. O.; RABINOVICH, E. P.; GUEDES, M. C. (Ed.). Psicologia e ambiente. São Paulo: EDUC, 2004. 
TASSARA, E. T. O. (Org.). Panoramas interdisciplinares para uma psicologia do urbano. São Paulo: EDUC-FAPESP, 2001.

TOCQUEVILLE, A. de. $O$ antigo regime e a revolução. 4. ed. Trad. Y. Jean. Brasília: Ed. UnB, 1997.

TOCQUEVILle, A. de. A democracia na América. 3. ed. Trad. e notas Neil Ribeiro da Silva. Belo Horizonte: Itatiaia, 1987.

TODOROV, T. Memória do mal, tentação do bem: indagações sobre o século XX. Trad. J. A. D'Avila. São Paulo: ARX, 2002.

TODOROV, T. O homem desenraizado. Trad. C. Cabo. Rio de Janeiro: Record, 1999.

TORRANO, J. Sacralidade e violência, estudo de Agamêmnon. In: ÉSQUILO. Agamêmnon. Orestéia 1. Estudo e Trad. J. Torrano. São Paulo: Iluminuras FAPESP, 2006. p. 17-100.

TORRANO, J. Herói e honras heróicas, estudo de Coéforas. In: ÉSQUILO. Coéforas. Orestéia II. Estudo e Trad. J. Torrano. São Paulo: Iluminuras FAPESP, 2006. p. 15-69.

TORRANO, J. Teologia trágica, estudo de Eumênides. In: ÉSQUILO. Eumênides. Orestéia III. Estudo e trad. J. Torrano. São Paulo: Iluminuras FAPESP, 2006. p. 15-67.

TOULMIN, S. Cosmopolis: the hidden agenda of modernity. Chicago: University of Chicago Press, 1999.

TOURAINE, A. Igualdade e diversidade. O sujeito democrático. Trad. M. Florenzano. Bauru: EDUSC, 1998.

TOURAINE, A. O retorno do actor. Ensaio sobre sociologia. Trad. A. P. da Silva. Lisboa: Instituto Piaget, 1996.

TURNER, T. Antropology and multiculturalism: what is antropology that multiculturalism should be mindful to it? In: GOLDBERG, D. T. Multiculturalism. A critical reader. London: Oxford, Blackwell, 1994.

VARSAVA, J. A. Törless at the Limits of Language: a revised reading, Seminar: a Journal of Germanic Studies 20.3 Sept. 1984, p. 188-204. 
VATTIMO, G. O fim da modernidade: niilismo e hermenêutica na cultura pós-moderna. Trad. E. Brandão. São Paulo: Martins Fontes, 1996. (Coleção Tópicos).

VATTIMO, G. As aventuras da diferença. O que significa pensar depois de Heidegger e Nietzsche. Trad. J. E. Rodil. Lisboa: Ed. 70, 1988.

VEYNE, P. et al. Indivíduo e poder. Lisboa: Ed. 70, 1988. (Perspectivas do homem).

VICO, G. Princípios de (uma) ciência nova. (Acerca da natureza comum das nações). Trad. A. L. A. Prado. São Paulo, Abril, 1974.

WAISBERG. Pensamento engajado em Marcuse: Homens sem qualidades e a estética predatória do capitalismo tardio. Belo Horizonte: UFMG-ABRAE -Associação Brasileira de Estética, 2006. In: DUARTE, R. (Org.) et al. Herbert Marcuse, dimensão estética: homenagem aos 50 anos de Eros e Civilização. 1 CD-ROM, digital, estéreo.

WAISBERG, M. T. O esquecimento de sonhos e as ilusões da consciência: Freud e o último caráter da hermenêutica. Pref. Eda T. de O. Tassara. Belo Horizonte: C/Arte, 2006. (Col. C/Saúde).

WALZER, M. Guerras justas e injustas: uma argumentação moral com exemplos históricos. Trad. W. Barcellos. São Paulo: Martins Fontes, 2003.

WALZER, M. Da tolerância. Trad. A. Pisetta. São Paulo: Martins Fontes, 1999.

WEBBER, A. Sense and Sensuality in Musil's Törless, German Life and Letters 41.2, 1988, p. 106-30.

WEBER, M. Metodologia das ciências sociais. Trad. A. Wernet. 4. ed. São Paulo: Cortez Editora, Campinas: UNICAMP, 2001. Parte 1.

WEBER, M. Metodologia das ciências sociais. Trad. A. Wernet. 3. ed. São Paulo: Cortez Editora, Campinas: UNICAMP, 2001. Parte 2.

WEIL, S. O enraizamento. Trad. M. L. Loureiro. Bauru: EDUSC, 2001.

WEININGER, O. Geschlecht und Charakter. Eine prinzipielle Untersuchung. München: Matthes \& Seitz, 1980. 
WIEVIORKA, M. Em que mundo viveremos? Trad. E. Landa; F. Landa. São Paulo: Perspectiva, 2006. 303 p. (Coleção Estudos).

WIGGERSHAUS, R. A Escola de Frankfurt. História, desenvolvimento teórico, significação política. Trad. L. Deroche-Gurgel; V. A. Harvey. Rio de Janeiro, 2002.

WITTGENSTEIN, L. Tratado lógico-filosófico. Investigações filosóficas. Trad. M. S. Lourenço. Lisboa: Fundação Calouste Gulbenkian, 1987.

WOHL, R. The generation of 1914. Cambridge: Harvard University Press, 1979.

WOLFF, R. P.; MOORE JR., B.; MARCUSE, H. Crítica da tolerância pura. Trad. R. Jungmann. Rio de Janeiro: Zahar Editores, 1970.

WOOLF, V. O leitor comum. Trad. L. Viégas. Rio de Janeiro: Graphia, 2007.

YÚDICE, G. A conveniência da cultura: usos da cultura na era global. Trad. M.-A. Kremer. Belo Horizonte: Ed. UFMG, 2004.

ZìZEK, S. Multiculturalismo, o la logica cultural del capitalismo multinacional. In: JAMESON. Estudios culturales. Reflexiones sobre el multiculturalismo. Barcelona: Paidós, 1998.

ZWEIG, S. The world of yesterday. An autobiography. Nebraska: University of Nebraska Press, 1964. 